\title{
Hajdú Dóra
}

\section{A törvény által elő́rt közös jogkezelés a magyar és francia szerzői jogban}

A kézirat lezárásának időpontja: 2015. november 30.

$\mathrm{PhD}$ értekezés

Témavezetők:

Dr. Mezei Péter

Prof. Antoine Latreille

egyetemi docens

egyetemi tanár

Szeged 


\section{Az értekezés vázlata}

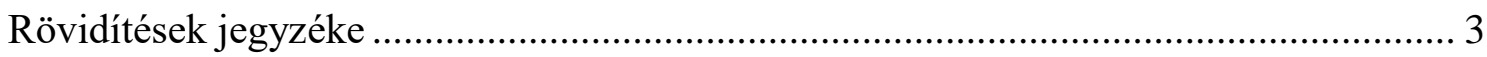

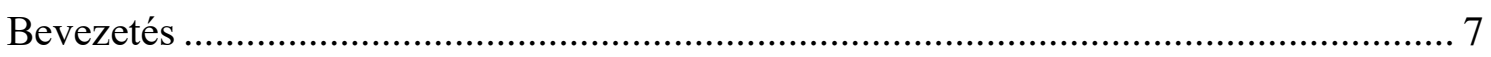

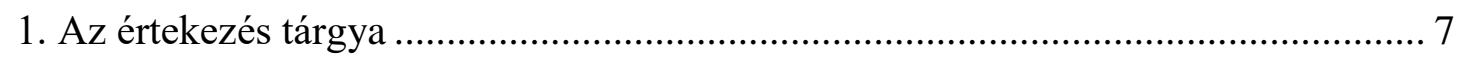

2. A vizsgálati módszer és az értekezés felépítése .................................................. 19

I. rész Fogalmi és elméleti keretek - a közös jogkezelés két eltérő felfogása................ 21

I. fejezet A szerzői jog korlátai, korlátozása ......................................................... 22

II. fejezet A közös jogkezelés fogalma és szervezeti háttere .................................... 34

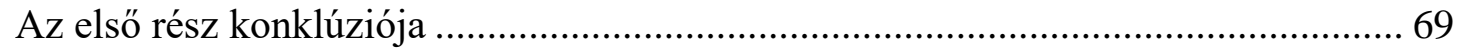

II. rész A törvény által elöírt közös jogkezelés, mint a kizárólagos jog korlátja ............. 71

I. fejezet A jog gyakorlásának korlátozása a közös jogkezelés előírásával ................ 73

II. fejezet A kizárólagos jog díjigényre korlátozása révén bevezetett közös

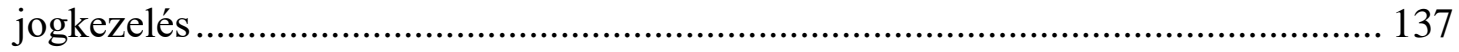

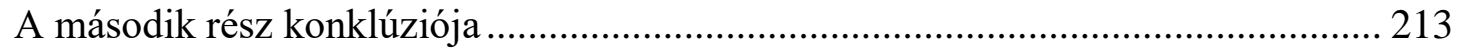

III. rész A törvény által előírt közös jogkezelés, mint a joggyakorlás módja................ 216

I. fejezet $\mathrm{Az}$ engedélyezési jog gyakorlása kilépést engedő közös jogkezelés

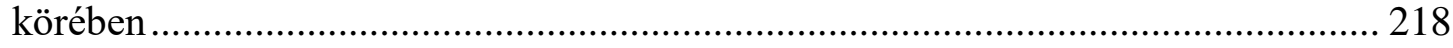

II. fejezet Közös jogkezelés a hatékonyság szolgálatában.................................... 251

A harmadik rész konklúziója ........................................................................... 291

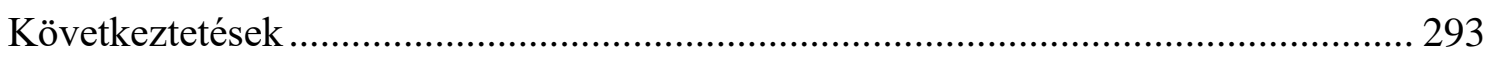

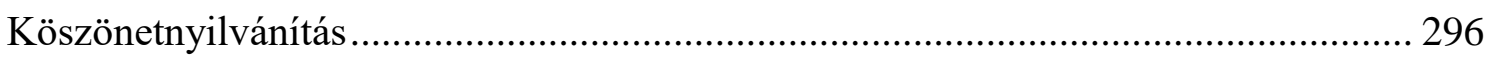

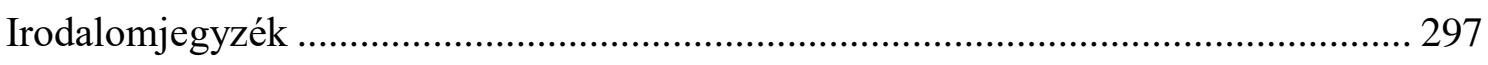

Hivatkozott jogszabályok és jogesetek jegyzéke .................................................. 315

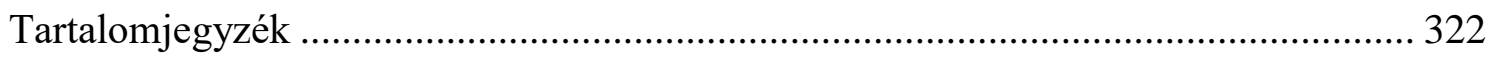

Függelék - Résumé substantiel de la thèse de doctorat ..............................................329 
Rövidítések jegyzéke

1957. évi törvény

1985. évi törvény

1995. évi törvény

Adatbázis-irányelv

ARTISJUS

bek.

Bérlet-irányelv

BNF

BUE

Bull. civ.

c/

CA

CCIP

CFC

CMO

Cnytv.

Comm. com. électr.

CPI

D.

DADVSI-törvény

Ectv.

EIPR

EJI
Loi n57-298 du 11 mars 1957 sur la propriété littéraire et artistique

Loi $\mathrm{n}^{\circ}$ 85-660 du 3 juillet 1985 relative aux droits d'auteur et aux droits des artistes-interprètes, des producteurs de phonogrammes et de vidéogrammes et des entreprises de communication audiovisuelle

Loi n ${ }^{\circ}$ 95-4 du 3 janvier 1995 sur la reprographie

Az adatbázisok jogi védelméről szóló 1996. március 11-i 96/9/EK európai parlamenti és tanácsi irányelv

ARTISJUS Magyar Szerzői Jogvédő Iroda Egyesület bekezdés

Az Európai Parlament és a Tanács 2006/115/EK irányelve (2006. december 12.) a bérleti jogról és a haszonkölcsönzési jogról, valamint a szellemi tulajdon területén a szerzői joggal szomszédos bizonyos jogokról (kodifikált változat)

Bibliothèque Nationale de France

Berni Uniós Egyezmény, az irodalmi és a művészeti művek védelméről szóló 1886. szeptember 9-i Berni Egyezmény Párizsban, az 1971. évi július hó 24. napján felülvizsgált szövege

Bulletin du droit civil

contre

Cour d'appel

Chambre de commerce et d'industrie de région Paris - Île-deFrance

Centre française d'exploitation du droit de copie

Collective management organization

2011. évi CLXXXI. tv. a civil szervezetek bírósági nyilvántartásáról és az ezzel összefüggő eljárási szabályokról

Communication, commerce électronique

Code de la Propriété Intellectuelle

Recueil Dalloz

Loi $\mathrm{n}^{\circ}$ 2006-961 du 1 août 2006 relative au droit d'auteur et aux droits voisins dans la société de l'information

2011. évi CLXXV. tv. az egyesülési jogról, a közhasznú jogállásról, valamint a civil szervezetek müködésérool és támogatásáról

Europen Intellectual Property Review

Előadóművészi Jogvédő Iroda 


\begin{tabular}{|c|c|}
\hline $\mathbf{E U}$ & Európai Unió \\
\hline EuB & Európai Unió Bírósága \\
\hline Fasc. & Fascicule \\
\hline FILMJUS & $\begin{array}{l}\text { FILMJUS Filmszerzők és Előállítók Szerzői Jogvédő } \\
\text { Egyesülete }\end{array}$ \\
\hline Gaz. Pal. & La Gazette du Palais \\
\hline HUNGART & $\begin{array}{l}\text { HUNGART Vizuális Mủvészek Közös Jogkezelő Társasága } \\
\text { Egyesület }\end{array}$ \\
\hline IIC & $\begin{array}{l}\text { International Review of Intellectual Property and Competition } \\
\text { Law }\end{array}$ \\
\hline InfoSoc-irányelv & $\begin{array}{l}\text { Az Európai Parlament és a Tanács 2001/29/EK irányelve } \\
\text { (2001. május 22.) az információs társadalomban a szerzői és } \\
\text { szomszédos jogok egyes vonatkozásainak összehangolásáról }\end{array}$ \\
\hline ISZJSZ & Iparjogvédelmi és Szerzői Jogi Szemle \\
\hline JCl. & Juris Classeur \\
\hline JCP G & La semaine juridique - Édition générale \\
\hline JIPITEC & $\begin{array}{l}\text { Journal of Intellectual Property, Information Technology and } \\
\text { Electronic Commerce Law }\end{array}$ \\
\hline KJK & Közös jogkezelő \\
\hline KJK-irányelv & $\begin{array}{l}\text { Az Európai Parlament és a Tanács } 2014 / 26 / E U \text { irányelve } \\
\text { (2014. február 26.) a szerzői és szomszédos jogokra vonatkozó } \\
\text { közös jogkezelésröl és a zenemüvek belső piacon történő } \\
\text { online felhasználásának több területre kiterjedő hatályú } \\
\text { engedélyezéséről }\end{array}$ \\
\hline Követő jogi irányelv & $\begin{array}{l}\text { Az Európai Parlament és a Tanács 2001/84/EK irányelve } \\
\text { (2001. szeptember 27.) az eredeti müalkotás szerzőjét megillető } \\
\text { követő jogról }\end{array}$ \\
\hline MAHASZ & Magyar Hangfelvétel-kiadók Szövetsége \\
\hline Műhold-irányelv & $\begin{array}{l}\text { A Tanács 93/83/EGK irányelve (1993. szeptember 27.) a } \\
\text { müholdas müsorsugárzásra és a vezetékes továbbközvetítésre } \\
\text { alkalmazandó egyes szerzői és szomszédos jogi szabályok } \\
\text { összehangolásáról }\end{array}$ \\
\hline NIR & Nordiskt Immateriellt Rättsskydd \\
\hline NKA & Nemzeti Kulturális Alap \\
\hline $\begin{array}{l}\text { OMPI } \\
\text { pma }\end{array}$ & $\begin{array}{l}\text { Organisation Mondiale de la Propriété Intellectuelle } \\
\text { post mortem auctoris }\end{array}$ \\
\hline Propr. intell. & Propriétés intellectuelles \\
\hline Propr. intell. & Propriétés intellectuelles \\
\hline Ptk. & 2013. évi V. törvény a Polgári Törvénykönyvröl \\
\hline PUAM & Presses universitaires d'Aix-Marseille \\
\hline RIDA & Revue internationale du droit d'auteur \\
\hline RIDC & Revue internationale de droit comparé \\
\hline RLDI & Revue Lamy droit de l'immatériel \\
\hline RTD Com. & Revue trimestrielle de droit commercial \\
\hline
\end{tabular}


S.

SGDL

SOFIA

szerk.

SZJSZT

Szjt.

Szoftver-irányelv

SZTNH

TGI

tv.

Védelmi idő irányelv

WIPO
Sirey

Société des Gens de Lettres

Société française des intérêts des auteurs de l'écrit

szerkesztette

Szerzői Jogi Szakértő Testület

A szerzői jogról szóló 1999. évi LXXVI. tv.

Az Európai Parlament és a Tanács 2009/24/EK irányelve (2009. április 23.) a számítógépi programok jogi védelméről (kodifikált változat)

Szellemi Tulajdon Nemzeti Hivatala

Tribunal de Grande Instance

törvény

Az Európai Parlament és a Tanács 2006/116/EK irányelve (2006. december 12.) a szerzői jog és egyes szomszédos jogok védelmi idejéről (kodifikált változat)

versus

World Intellectual Property Organization 


\section{Bevezetés}

\section{Az értekezés tárgya}

Napjaink szerzői jogában újra és újra előbukkanó kérdés, hogy a szerzői jog reformra szorul-e. ${ }^{1}$ Ez az igény alapvetően a szerzői jog és a technológiai fejlődés kapcsolatára vezethető vissza: több olyan jelenség is megfigyelhető a felhasználási szokásokban, amelyek a digitalizáció elterjedésének köszönhetőek, és amelyek miatt egyesek a szerzői jog strukturális reformjának szükségességét hangsúlyozzák. Ez nem új keletü folyamat, ugyanis a szerzői jog a születésétől fogva a technológiával szimbiózisban fejlődik, alakul. ${ }^{2}$ Ami az újdonság erejével hat, az egyfelől ezeknek a változásoknak a gyorsasága, illetve az, hogy ezáltal a szerzői müvek alkotása és felhasználása is a korábbiaktól eltérö képet mutat.

A szerzői jog alapvetően arra a természetes gazdasági szükségletre reflektál, amelyben a szerző alkotóként a műve felhasználásából származó jövedelemből kíván megélni, ${ }^{3}$ vagyis eredendően a szerző és a professzionális felhasználók (elsősorban a kiadók) közötti viszonyt kívánta rendezni ${ }^{4}$ olyan keretek között, amelyekben a művek viszonylag ritkák voltak, és emiatt különös értéket képviseltek. ${ }^{5}$ A szerzői jog így arra a

\footnotetext{
${ }^{1}$ A témával kapcsolatosan legutóbb lásd például: SÁR (2007) p. 34-41. PoGÁCSÁS (2012) p. 131-137. UJHELYI (2013) p. 69-107. Érdemes már itt kiemelni azt is, hogy az Európai Unióban jelenleg is zajlik az InfoSoc-irányelvnek, az uniós szerzői jogi harmonizáció egyik alappillérének reformja. A téma Európai Parlamenti képviselő rapportőre, a Kalózpárti német Julia REDA 2015 elején hozta nyilvánosságra ezzel kapcsolatos jelentését, amelyet az Európai Parlament 2015. július 9-én az eredeti elöterjesztéstől gyökeresen eltérö tartalommal fogadott el. Projet de rapport sur la mise en ouvre de la directive 2001/29/CE du Parlement européen et du Conseil du 22 mai 2001 sur l'harmonisation de certains aspects du droit d'auteur et des droits voisins dans la société de l'information (2014/2256 (INI)) (http://www.europarl.europa.eu/sides/getDoc.do?pubRef=-//EP//NONSGML+COMPARL+PE-

546.580+02+DOC+PDF+V0//FR\&language=FR); Az Európai Parlament 2015. július 9-i állásfoglalása az információs társadalomban a szerzői és szomszédos jogok egyes vonatkozásainak összehangolásáról szóló, 2001. május 22-i 2001/29/EK európai parlamenti és a tanácsi irányelv végrehajtásáról (2014/2256(INI)) (http://www.europarl.europa.eu/sides/getDoc.do?pubRef=-//EP//NONSGML+TA+P8$\mathrm{TA}-2015-0273+0+\mathrm{DOC}+\mathrm{PDF}+\mathrm{V} 0 / / \mathrm{HU})$.

${ }^{2}$ MEZEI (2012a). 197-208.

${ }^{3}$ Arról, hogy a szerzői jog fejlődése során alapvetően nem ez a koncepció dominált: PoGÁCSÁS (2014) p. 149-162.

${ }^{4}$ GERVAIS (2012) p. 91.

5 Nem véletlen, hogy a szerzői jog elődje a privilégiumok rendszere volt, amelyekben a szuverén föhatalom biztosított monopoljogot egy-egy mü kinyomtatására és terjesztésére. Ez is arra az üzleti koncepcióra épül, hogy a szerző és közönsége közé beékelődik egy, a mü minél szélesebb körben ismertté tételében érdekelt, és így anyagi hasznot szerző kiadó. A szerzői jogi szabályok létrejötte így elsősorban a szerzők védelmére hivatott a kiadók túlzott erőfölényével szemben annak figyelembe vételével, hogy a kiadók oldaláról is kiegyensúlyozottá váljon a kulturális javak előállításában való részvétel. A szerzői jog történetéről, különösen a privilégiumok rendszeréről lásd: MEZEI (2004), BoDÓ (2011). HAJDÚ (2014b),
} 
logikára épült, hogy a szerző átruházza az őt megillető jogokat a kiadóra, vagy azok gyakorlását neki átengedi, vagyis a kiadó belép a szerző helyébe a mü további hasznosítása során. A kiadó számára tehát biztosítani kellett azokat a jogi eszközöket, amelyek segítségével profitot termelhet a mü felhasználásából. ${ }^{6}$ Másrészt pedig olyan fékeket kellett beépíteni, amelyek megakadályozták, hogy a professzionális szervezetek túlságosan kihasználják a szerzőket, vagyis biztosítani kellett azokat a feltételeket, amelyekben a kreatív alkotó elme kiteljesedhetett. Ehhez képest napjainkban az figyelhető meg, hogy „a mai szerző egyre inkább előre megszervezett vállalkozóimüszaki keretben alkot." ${ }^{, 7}$ A szerzői művek előállítása tömegessé válik, ${ }^{8}$ olybá tűnik, mintha a különböző irányzatok gyakori változásával a müvek hasznosításának élettartama is lerövidülne. Az aktuális stílusirányzatok követésének igényével, illetve a kulturális ipar koncentrálódásával pedig egyes műfajokban talán még a münek az alkotó személyiségvonásaihoz való kapcsolódása is gyengül (amellett persze, hogy továbbra is szerzői jogi védelmet élvező, egyéni, eredeti jellegü alkotások születnek), amennyiben az alkotók törekszenek ezek követésére.

A tömegesség nem egyedül a művek létrehozása kapcsán érhető tetten, hanem azok fogyasztása is nagyságrendekkel nagyobb méreteket öltött, mint valaha. Míg korábban a szerzői művek élvezete jól körülhatárolható keretek között zajlott, mára ezek a határok egyre elmosódottabbá váltak. ${ }^{9}$ Manapság az információ a világ bármely pontjáról gyakorlatilag azonnal hozzáférhető, naponta rengeteg új tartalom, potenciálisan egyéni, eredeti jellegű szerzői mű születik, amelyek a világhálóra kerülve azonnal széles közönséghez jutnak el. ${ }^{10} \mathrm{~A}$ szerzői jog ráadásul olybá tünik, hogy nincsen felkészülve ezekre a tömeges, nem professzionális felhasználók általi felhasználásokra. ${ }^{11}$ Legalábbis a szerzői jog eredeti rendeltetésével ellentétesnek tűnik,

DeAZley - KRETSCHMER - Bently (2010), PFister, Laurent: Histoire du droit d'auteur, J.Cl Propriété littéraire et artistique, Fasc. 1110

${ }^{6}$ ESCARRA - RAULT - HEPP (1937) p. 21-22.

${ }^{7}$ GYERTYÁNFY ( 2001) p. 342.

${ }^{8}$ Meg kell jegyezni azt is, hogy közgazdasági szempontú megközelítéssel a kulturális javak termelésének elősegítésére nem feltétlenül a szerzői jog a leghatékonyabb mód. AlCARAS (2007) p. 55-74.

${ }^{9}$ GYERTYÁNFY (1995) p. 456.

10 Marco RiCOLFI szerint ezt a kapcsolatot az alábbi három szóval lehet a legjobban jellemezni: „, anywhere, anytime and perfect”. Vagyis a tartalom a világ bármely pontjáról, bármikor, minőségromlás nélkül elérhetö. RICOLFI (2007) p. 286-287.

${ }^{11}$ Az ehhez kötődő egyik legvitatottabb kérdést, a digitális magáncélú másolatok kérdését jelen dolgozat keretei között is elemezzük. E helyütt érdemes azonban legalább említés szintjén foglalkozni a tömeges, nem professzionális felhasználásokhoz kötődő másik problémakörről, nevezetesen a felhasználók által készített majd megosztott, ún. „user generated content” (UGC) kérdésköréről. Ezzel kapcsolatban lásd: $A$ Szerzői Jogi Szakértő Testület tanulmányai a szerzői jog digitális világhoz való alkalmazkodásáról - A 
és társadalmi feszültségekhez vezet az, ha a szerzői jog az amatőr felhasználásokat a professzionális felhasználásokhoz hasonlóan kezeli. ${ }^{12}$ A fennálló szerzői jogi keretek rugalmasabbá tétele ${ }^{13}$ a szerzői jog alapelveinek és alapvető funkcióinak megtartása mellett ebből a szempontból fontos. A cél ugyanis az lenne, hogy a szerzői jog továbbra is be tudja tölteni legalapvetőbb funkcióját, nevezetesen azt, hogy a kreatív információ előllítását és az abba való befektetést oly módon ösztönözzék, hogy közben az ehhez való hozzáférést a lehető legszélesebb mértékben biztosítsák, ennek következményeként pedig az alkotó ebbéli minőségének feltüntetésével anyagi kompenzációban részesüljön müve felhasználása után. ${ }^{14}$

Az érvényes, univerzális paradigma (legyen szó akár a copyright, akár a droit d'auteur típusú megközelítésről, ideértve azt is, hogy a német és a francia hagyományok eltérnek egymástól) ${ }^{15}$ a szerzői jog több mint háromszáz éves fennállása alatt egyfajta egyensúlyozó szerepet töltött és tölt be. A szerző és a társadalom (értve ez alatt a felhasználókon kívül a többi alkotót, illetve a szerzői művek közönséghez juttatásában szerepet vállalókat) egymással szembenálló érdekei közötti összhang megteremtése maga a szerzői jog. Ez az egyensúlykeresés akkor is igaz, ha figyelembe vesszük, hogy a kontinentális (főleg francia és az ezt követő) szerzői jog központja a szerző, és a szerzői jogi szabályozás az ő személye köré épül fel, elsősorban az ő érdekeit kívánva védelmezni. ${ }^{16}$ Ennek megfelelően a kontinentális szerzői jog a véleménynyilvánítás szabadságából is eredeztethetően ${ }^{17}$ szerzőt megillető személyhez

Szerzői Jogi Szakértő Testület UGC-munkacsoportjának beszámolója a felhasználók által generált tartalom szerzöi jogi kérdéseivel kapcsolatban, ISZJSZ, 2014/4. p. 93-153.

12 CARON (2012b) p. 21. Erre példaként szintén a magáncélú másolatra tekintettel díjakat érdemes felhozni. Az átalánydíjas rendszer lényege abban áll, hogy a díjazás megfizetése mellett a szerzői jog nem avatkozik be a magánszemélyek általi felhasználásokba. Teoretikusan még a díjazást sem a végfelhasználóktól kell beszedni, azt ugyanis sok esetben a gyártóra vagy importőrre telepíteti a jogalkotó, amely azt csak továbbhárítja a fogyasztókra. Lásd ezzel kapcsolatban a dolgozat III. részének II. fejezetét.

${ }^{13} \mathrm{Az}$ értelmezési keretek rugalmasabbá tételét célozza az a nyilatkozat is, amelyben a kontinentális szerzői jogban jártas elismert jogtudósok a szerzői jogi korlátozások sarokkövének, a háromlépcsős tesztnek az értelmezési kereteit kívánják újragondolni. GEIGER - HILTY - GRIFFITHS -SUTHERSANEN: (2010) p. 119-122.

${ }^{14}$ GERVAIS (2012) p. 91-92.

${ }^{15}$ A dolgozat nem kíván részletesen foglalkozni az angolszász és kontinentális szerzői jogi gondolkodás különbségeivel. Erre vonatkozó külön utalás hiányában általános értelemben használva a szerzői jog alatt a kontinentális szerzői jogot értjük. A két szerzői jogi struktúra közötti eltérések részletes elemzéséhez lásd pl. BENHAMOU - FARCHY (2009).

${ }^{16}$ BERNAUlT - Clavier (2015), Balance des intérêts” szócikk, p. 43.

${ }^{17}$ FALUDI Gábor ezt így fogalmazza meg találóan: „A szerzői jog - talán elsősorban - az egyedi szellemi alkotásban megformált véleménynyilvánitási jog motorja. E motor hajtóanyaga a tulajodnszerü, de személyiségi elemekkel összefonódott kizárólagos jogba átírt szabadság, amely lehetővé teszi, hogy a 
füződő és vagyoni jogok összessége, amelyek a tulajdonjoghoz hasonlóan alapvetően kizárólagos (de nem korlátlan) rendelkezési jogot biztosítanak az alkotónak a mủve felett. Az angolszász megközelítés ezzel szemben sokkal inkább utilitárius, az alkotóval szemben az alkotásra helyez nagyobb hangsúlyt. ${ }^{18}$

Ez a több szinten jelen lévő Janus-arcúság érdekfeszítő vitákat generál a szerzői jog valódi természetéről, céljáról és funkcióiról. ${ }^{19} \mathrm{Az}$ azonban kétségtelen, hogy a hangsúly a szerzőn, mint individuumon van. Nem elvitatva a személyhez füződő jogok fontosságát, ${ }^{20}$ a gazdasági forgalomban a vagyoni jogok kiemelt szereppel bírnak. Ezek biztosítják ugyanis azt, hogy az alkotó a maga mủvét felhasználhatja, illetve másoknak a felhasználást engedélyezheti, vagy megtilthatja. A szerző tehát monopóliummal rendelkezik a műve hasznosítása tekintetében. A francia jogban található megfogalmazás szerint (és ebben ismét csak utalás történik a szerzői jog céljára is), a felhasználáshoz, a mü kiaknázásához füződő jog (droit de l'exploitation) abban áll, hogy a jogosult a müvet minden lehetséges módon eljuttahatja a közönséghez, vagyis minden ilyen kihasználáshoz füződik kizárólagos jog. ${ }^{21} \mathrm{Ez}$ a megközelítés annak ellenére alapvetően meghatározza a szerzői jog fejlődését az első szerzői jogi törvények ${ }^{22}$ elfogadása óta, hogy felvetődött (és elutasításra került) az is, vajon egy másfajta, az anyagi kompenzációra nagyobb hangsúlyt fektető, az engedélyezési jogot visszaszorító struktúra nem biztosítaná-e megfelelőbb módon a

szerzö - ha úgy tetszik az eredeti jogosult - jogi, gazdasági autonómiájára építve gyakorolhassa a véleménynyilvánitás jogát, ebbe beleértve a müve szabad piaci értékesitését is." FALUDI (2008) p. 10.

${ }^{18}$ Ezt az Amerikai Egyesült Államok Alkotmányának szabadalmi és szerzői jogi klauzulája [I. cikk (8) bek. 8. pont] is csak a ,hasznos müvészetek” előmozdítása érdekében ismeri el az oltalmat.

${ }^{19} \mathrm{Ez}$ a Janus-arcúság több szinten is érdekes problémákat vet fel. Szűkebb értelemben a személyhez füződő jogok helyét elemző monista és dualista felfogások a szerzői jog dogmatikai rendszerén belül jelenítik meg a kétarcúságot. Vagyis kérdés az, hogy a szerzői jog, bevett francia nevével irodalmi és müvészeti tulajdon (propriété littéraire et artistique) a tulajdon egy formájának tekinthetö-e. PFISTER (2005) p. 117-209. ALMA-DELETTRE (2007) p. 25-37. Franciaország egyébként a személyhez füződő és vagyoni jogok elkülönítésének dualista megoldását követi. FRANÇON (1999) p. 216. A magyar szerzői jog kapcsán lásd: FALUDI (1995) p. 146-156. GYENGE (2003). p. 649-657. Tágabb értelemben pedig a szerzői jog különböző érdekek közötti puffer szerepe is ide tartozik, amelyik a jogterület végső célja (csak a legfontosabbakat kiemelve: a szerző érdekeinek mindenek felett álló védelme, a további alkotás ösztönzése, vagy épp a müvek minél szélesebb közönséghez juttatása) elemzésének sokkal inkább filozofikus jellegü meghatározását jelenti. ALLEAUME (2010) p. 423-445.

${ }^{20}$ A személyhez füződő jogok közgazdaságtani vonzataival kapcsolatban lásd: GREFFE (2005) p. 43-55.

${ }^{21}$ GAUDRAT - SARDAIN (2005) p. 10.. Ez a megközelítés érdekes eredményre vezet a szerzői jog határainak, az az alóli kivételek körének meghatározásában. Ezt a nézetet elfogadva például a szük családi körben történő előadás közönség, nyilvánosság hiányában eleve nem a szerzői jog hatálya alá tartozó felhasználás, nem pedig kivétel. CARON (2012b) p.20-21.

${ }^{22}$ A világ első szerzői jogi törvénye Anna királynő 1709-es statútuma. Franciaországban az első szerzői jogi törvényt 1793-ban, Magyarországon pedig 1884-ben fogadták el. GINSBURG (1991) p. 124-289. OCHOA (2007) p. 142-143. 
szerző érdekeit? ${ }^{23}$ Alkotások ugyanis a szerzői jog megszületése előtt is léteztek, a kreatív emberi önkifejezési formák a barlangrajzok óta részei az emberiség történetének, a kiemelkedő mủvészek pedig mecénásaik révén meg tudtak élni önmagában az alkotótevékenységből is. A válasz viszont egyelőre változatlan maradt: abszolút szerkezetü, negatív tartalmú jogviszony alanyaként továbbra is a szerző az, aki egy személyben $^{24}$ rendelkezik a müve felett, ez biztosítja ugyanis számára a leghatékonyabb védelmet.

A jogviszony közvetett tárgya maga a szerzői mü, amely egy elvont kategória, lényege az immaterialitásában, hordozótól való függetlenségében rejlik. Éppen ez a jellemző nehezíti meg a kényes egyensúlynak a megtalálását: a szerzői mủ ugyanis másolható. ${ }^{25}$ Amint egyszer eljutott a közönséghez, nem lehet kizárni annak lehetőségét, hogy a müvet valaki reprodukálja. Vagyis a szerző a mü alapvető eszmei jellege miatt nincs abban a helyzetben, hogy minden egyes felhasználást egyedileg engedélyezzen. Az olyan mütípusok esetében, amelyek körében gyakori az ismételt felhasználás (tipikusan ilyenek a zenemüvek), a szerzők még kevésbé tudnak a mü sorsának urai maradni. Viszonylag korán nyilvánvalóvá vált az is, hogy az alkotók egymaguk nem tudják a nekik biztosított jogokat hatékonyan egyedileg gyakorolni (különösen a zenemüvek nyilvános előadásának körében), ${ }^{26}$ nem tudnak ugyanis minden egyes felhasználást követni, és ezeket engedélyezni. Felismerték, hogy az egyéni joggyakorlás nehézségei leküzdésének hatékony módja, ha a szerzők a joggyakorlásra külön szervezetet hoznak létre. ${ }^{27}$ Alapvetően ez az igény vezetett a közös jogkezelés jogintézményének létrejöttéhez Franciaországban, majd kiterjedéséhez Németországban, és alapozza meg müködésének legitimitását mind a mai napig a kontinentális jogi hagyományokkal rendelkező országokban, így Magyarországon is ${ }^{28} \mathrm{~A}$ technológiai fejlödés tehát nem az elsödleges indoka a közös jogkezelés fejlödésnek, bár

\footnotetext{
${ }^{23}$ Az elemzés azzal foglalkozik, hogy a szerzők számára előnyösebb lenne-e, ha a művük feletti rendelkezést biztosító kizárólagos jog helyett mindössze díjazáshoz való jogként definiálnánk a szerzői jogot. GINSBURG (2009) p. 7-10. Hasonlóképpen: CARON (2007) p. 105-116.

${ }^{24}$ Több szerző esetén a jogok gyakorlása a létrehozott mü típusától is függ. Szjt. 5-7. §. CPI L. 113-2, L. 113-3, L. 113-4, L. 113-5 cikkek.

${ }^{25} \mathrm{Az}$ angolszász copyright elnevezés is erre a jellemzőre utal.

${ }^{26}$ FICSOR (1985) p. 299.

${ }^{27}$ Erről a folyamatról, amelynek az első közös jogkezelő szervezet megalakításán kívül az első francia szerzői jogi törvények megszületéséig vezetett, lásd: HAJDÚ (megjelenésre elfogadva).

${ }^{28}$ GYENGE - SARKADY (2013) p. 22-26.
} 
kétség kívül ennek katalizátora - tekintettel arra, hogy ennek köszönhetően keletkeznek olyan újabbnál újabb platformok, amelyek a tömeges müélvezetet lehetővé teszik. ${ }^{29}$

A közös jogkezelés viszont a jogok gyakorlásán túl egy másik dimenzióba helyezve is vizsgálható. A kizárólagos jog biztosítása ugyanis éppen az érdekkiegyensúlyozás szükségessége miatt nem jelenti, nem jelentheti egyben azt is, hogy ez a jogosultság ne lenne korlátok közé szorítható. Pusztán a szerző érdekeinek figyelembe vétele ugyanis megbéníthatná azt, hogy a kreatív alkotótevékenység révén létrejött müvekhez a közönség minél szélesebb köre juthasson hozzá, ami pedig az újabb alkotófolyamat gátját is jelentené. Ez nem jelenti azt, hogy a szerzői jogot el kellene törölni, és elsődlegesen a felhasználók, a társadalom érdekeit kellene középpontba helyezni. ${ }^{30}$ Épp ellenkezőleg: a jelenlegi struktúra azon az elven nyugszik, hogy a kizárólagos jog ésszerü korlátainak megtalálásával kell az ideális egyensúlyi állapotot fenntartani. Ezeknek a korlátoknak a megvonása viszont semmiképpen sem történhet ad hoc módon. Amennyiben a jogalkotó úgy dönt, hogy az érdekkiegyensúlyozást a szerzői jogon belüli eszközökkel kívánja megvalósítani, akkor annak nemzetközi és az uniós szerzői jog által meghúzott kereteken belül kell megtörténnie, hiszen a „szerzői jog jogalkotói »újragondolása« nem történhet a sokoldalú nemzetközi egyezményes és az európai uniós kötelezettségek (irányelvek és elvállalt egyezményi tagság) figyelmen kívül hagyásával, egyetlen országon belül." 31 Természetesen annak sincsen akadálya, hogy ezeket a korlátokat a szerzői jogon kívüli eszközökkel érje el a jogalkotó. A jelenlegi szabályozási környezetben is található példa arra, hogy az egyensúly más jogterület által biztosított lehetőségeken keresztül érvényesül, nem egyedülálló például a versenyjog alkalmazása a szerzői jog területén, ${ }^{32}$ sőt a közös jogkezelés kizárólag üzleti modellként való megközelítése kizárólagos versenyjogi kontrollt eredményez. ${ }^{33}$

\footnotetext{
${ }^{29}$ Ennek legszemléletesebb példája a magáncélú másolatra tekintettel fizetett díjak fejlődésvázlata: a háztartásokba beszivárgó, rögzítésre alkalmas magnetofonok tették lehetővé, nélkülözhetetlenné a jogalkotó számára a kérdés rendezését. HuGENHOLTZ (2012) p. 179-196.

${ }^{30}$ MEZEI (2014a) p. 407-423.

${ }^{31}$ GYERTYÁNFY (2006a). p. 450.

${ }^{32}$ Jóllehet a versenyjog kapcsolata a szellemi tulajdonvédelem egyes kérdéseivel sokkal jelentősebb az iparjogvédelem területén, a jogterületnek a szerzöi joggal is van közös pontja. A közös jogkezelés kifejezetten egy ilyen metszéspontot képvisel, különös tekintettel az Európai Unió Bizottságának és Bíróságának vonatkozó döntéseire.

${ }^{33}$ FALUDI (2009b) p. 64-92.
} 
A szerzői jogot érintő korlátozások, a fogalmat a legtágabb értelemben véve, egy sokszínű palettát alkotnak, hiszen a szerzői jogon belül alkalmazott ilyen eszközök is változatosak. Vannak közöttük olyanok, amelyek a szerzői jog fennállásának kérdésével kapcsolatban tartalmaznak megszorításokat (például a védelmi idő intézménye). ${ }^{34}$ Mások a szerző számára biztosított monopólium alól tartalmaznak kivételeket (például az idézés). ${ }^{35}$ Ebbe a körbe sorolhatóak azok a törvényi rendelkezések is, amelyek a szerző rendelkezési jogát olyan módon csorbítják, hogy a jog gyakorlásának módját határozzák meg. Ebbe a körbe alapvetően két fajta jogintézmény sorolható. Az egyik, a szerzői jog természetétől idegen, az iparjogvédelemmel szorosabb kapcsolódási pontot mutató kényszerengedély. ${ }^{36} \mathrm{~A}$ másik pedig a közös jogkezelés, amennyiben az nem a jogosultak önkéntes elhatározásán, hanem a jogalkotói akaraton alapul. Több esetben ugyanis a felhasználások tömegességére való tekintettel a jogalkotó (ideértve az uniós jogalkotót is) felismerte ennek hatékonyságát és szükségességét, így ezt a joggyakorlási módot előírta a jogosultak számára. ${ }^{37}$

\footnotetext{
${ }^{34}$ A védelmi idő az első szerzői jogi törvény óta szerves részét képezi a szerzői jognak. Anna királynő statútumában ez az idő 14 év volt, mely egyszer újabb 14 évre megújítható volt. Az első francia szerzői jogi törvényben 10, az első magyar szerzői jogi törvényben pedig pma 50 évben lett meghatározva. A védelmi idő azóta folyamatosan emelkedett, a BUE pma 50 éves védelmi időt ír elő a részes államok számára. Az Európai Unió harmonizálta a kérdést, és a Védelmi idő irányelvben pma 70 évben állapította meg a védelmi idő határait. A szomszédos vagy kapcsolódó jogi jogosultságok esetén hasonló tendencia figyelhető meg. Lásd ezzel kapcsolatban különösen a védelmi idő irányelv módosítását: az Európai Parlament és a Tanács 2011/77/EU irányelve (2011. szeptember 27.) a szerzői jog és egyes szomszédos jogok védelmi idejéről szóló 2006/116/EK irányelv módosításáról.

${ }^{35}$ Az idézés az egyik legklasszikusabb példája a szerzői jog korlátozásának. Különösen a szöveges művek esetében jelentős az alkalmazása, mivel a mü rövid részletének a forrás és a szerző nevének feltüntetésével történő ingyenes, a szerző engedélyéhez nem kötött felhasználását jelenti. Bevezetését mind a BUE (10. cikk), mind az InfoSoc-irányelv [5. cikk (3) bek. d) pont] lehetővé teszi, így megjelenik a nemzeti szerzöi jogokban is [Szjt. 34. § (1) bek., CPI L. 122-5-3 a) cikk].

${ }^{36}$ Kényszerengedély alatt azokat az eseteket értjük, amikor a jogosultnak nincsen választási lehetősége a felhasználási engedély megadását illetően. Jellemzője viszont, hogy a felhasználást egyedileg engedélyeztetni kell, az nem automatikusan a törvény által garantált. Az engedélyezési jog gyakorlását a törvény általában a jogosulttól elvonja, és harmadik személy kezébe helyezi. (Alkalmazása egyébként gyakoribb az iparjogvédelem körében.) Az Szjt. 2009. február 1. előtt hatályos 19. § (1) bekezdése tartalmazott ilyen rendelkezést. A törvény akként fogalmazott, hogy „A hangfelvétel-elöállitó, valamint a multimédia mü létrehozója és az elektronikus adatbázis összeállitója követelheti, hogy a már nyilvánosságra hozott nem színpadi zenemüveknek és zeneszövegeknek, valamint az ilyen színpadi zenemüvekböl vett részleteknek hangfelvételen, videofelvételen, digitális hordozón terjesztett multimédia müben vagy elektronikus adatbázisban való újabb többszörözését és példányonkénti terjesztését megfelelö dijazás ellenében számára is engedélyezzék." Lásd még: WIPO Guide to the Copyright and Related Right Treaties Administered by WIPO and Glossary of Copyright and Related Right Terms, 2003 (http://www.wipo.int/edocs/pubdocs/en/copyright/891/wipo_pub_891.pdf), p. 277. „Compulsory license".

${ }^{37}$ DIETZ (1976) p.32.
} 
Bár szervezetüket, jogi helyzetüket, a nyilvántartásba vételüket és felügyeletüket tekintve az európai országokban működő közös jogkezelő szervezetek ${ }^{38}$ igen nagymértékü diverzitást mutatnak, alapvonásaikban sok hasonlóság található. $A$ jogintézmény logikája ugyanis a jogosultak önkéntes alapon megvalósuló önkorlátozása mentén épül fel, vagyis az önkéntes közös jogkezelés tekinthető a jogintézmény archetípusának. ${ }^{39}$ A közös jogkezelés ilyen módon a szerzőt a műve feletti rendelkezési jog keretében megillető szerződési szabadság kiteljesedésének is tekinthető. A szerző szabadon dönthet ugyanis arról, hogy az engedélyezési jog gyakorlását nem egymaga kívánja gyakorolni, hanem a hasonló alkotókkal közösen létrehozott szervezet útján. ${ }^{40}$ Mivel ez a közös jogkezelő szervezetnek adott önkéntes megbízáson alapul, egyben általában azt is jelenti, hogy a szerzőnek mindenkor jogában áll művét kiaknázatlanul hagyni vagy az erre vonatkozó jogokat egyénileg gyakorolni. ${ }^{41}$

A közös jogkezelés keretében történő joggyakorlás gyakorlati előnye egyértelmü, legyen szó akár önkéntes, akár törvény által elöírt verzióról. Az engedélyezési jog gyakorlásával szükségképpen együtt járó adminisztratív és egyéb jellegü terheket a közös jogkezelő szervezet leveszi a szerző válláról, aki így energiáit további művek megalkotására fordíthatja. Természetesen fontos annak vizsgálata, hogy milyen jogi keretek között, milyen formában jönnek létre ezek a szervezetek, milyen jogviszony van a jogosultak és a szervezet, illetve a szervezet és a felhasználók között, vagyis mi alapozza meg azt, hogy a szerzők nevében és helyett eljárva engedélyt adjanak a müvek felhasználására (ideértve a közös jogkezelési tevékenység versenyjogi ex post szabályozását is). ${ }^{42}$

A törvény által előírt közös jogkezelési esetkörök vizsgálata is figyelmet érdemel. ${ }^{43}$ Ezekben az esetekben ugyanis a jogalkotó határozza meg, hogy a szerző milyen keretek között gyakorolhatja a rendelkezési jogát, ily módon ezek az esetek nem

\footnotetext{
${ }^{38}$ Az amerikai közös jogkezelés müködéséröl lásd például: DIRINGER (2010) p. 4-279.

${ }^{39}$ SIIRIAINEN (1999).

${ }^{40}$ Ehhez lásd: FLORENSON (2003) p. 3-125.

${ }^{41}$ GYERTYÁNFY (1997b) p. 261.

42 Áttekintő szakirodalomként lásd: SIIRIAINEN (1999), NÉRISSON (2013), DIRINGER (2011), BORONKAY - BOYTHA - CSEPELY-KNORR - SZILÁGYI (2008), LÁNCHIDI (2010), GRAD-GYENGE - SARKADY (2014), FALUDI (2009a) p. 126-135.

43 A jogtudomány eddig kevés figyelmet szentelt kifejezetten ennek a kérdéskörnek a vizsgálatára. Két ezzel foglalkozó tanulmányról van tudomásunk, illetve elismerjük, hogy helyenként a témakör megjelenik a korlátozások átfogó vizsgálata kapcsán. FICSOR (2003), VON LEWINSKI (2004).
} 
tekinthetőek sem a jogosult önkorlátozásának, sem pedig pusztán üzleti modellnek. ${ }^{44}$ Más nézőpontból viszont ez a feltétel jelenti bizonyos jogok esetében a joggyakorlás egyetlen lehetséges módját. Sőt, adott esetben az is elképzelhető, hogy a kötelező közös jogkezelés elöírása azzal a megkötéssel, hogy a jogdíjkövetelés annak névre szóló felosztásáig nem ruházható át, sokkal inkább a szerzők javát szolgálja, mint egy voltaképpen érvényesíthetetlen egyéni engedélyezési jog fenntartása. Különösen annak figyelembe vételével érdekes ez a felvetés, ha a jogkezelést aszerint kategorizáljuk, hogy ki gyakorolja a jogokat. Jean-Loup TOURNIER úgy érvelt, hogy egyéni jogkezelés alatt tulajdonképpen a szerző saját maga által végzett jogkezelést kell érteni. Amennyiben ebbe a folyamatba akár kiadó, mint felhasználó, akár egyéb kapcsolódó jogi jogosult belép, többet már nem beszélhetünk egyéni jogkezelésről a szó klasszikus értelmében. Ráadásul ezeknek a piaci szereplőknek az érdeke sok esetben ellentétes lehet a szerzőkével. Ilyen körülmények között a közös jogkezelés, mivel szervezetileg a szerzőket tömörítő szervezetek végzik, ${ }^{45}$ paradox módon inkább megfelel az egyéni jogkezelés sajátosságainak, mint ez a kereskedelmi típusú, helyettesítő jogkezelés. ${ }^{46}$ Maguk a jogok is változatosak lehetnek, ugyanis bizonyos esetekben a közös jogkezelés jelenti a joggyakorlás egyetlen lehetséges, hatékony módját.

Nélkülözhetetlennek tünik éppen ezért állást foglalni a törvény által előírt közös jogkezelés valódi természetéröl, vagyis arról, hogy ezek az esetek valójában szerzői jogi korlátozásnak tekinthetőek-e. Amennyiben igen, akkor milyen természetü és mértékü korlátozásnak minősülnek. Vagy épp ellenkezöleg, a joggyakorlás egyetlen lehetséges módját határozzák-e meg. Paradox eredményre vezetne annak kimondása, hogy a közös jogkezelés a szerzői jogok korlátját jelenti olyan esetekben, amikor a jog gyakorlására más mód objektív módon nem áll a szerzők rendelkezésére, ${ }^{47}$ viszont ez nem feltétlenül érvényesül minden kötelező közös jogkezelésben kezelt jog esetében. Vagyis előfordulhat, hogy a jogalkotó más megfontolások szem előtt tartásával rendelkezett a közös jogkezelés elöírásáról. Fontos azt is tisztázni, hogy a nemzetközi és uniós szerzői jog milyen esetekben és milyen feltételekkel teszi lehetővé (ha egyáltalán) ilyen jogintézmények bevezetését.

\footnotetext{
${ }^{44}$ Ezzel ellentétesen: GYENGE (2008) p. 198.

45 Több esetben előfordul, hogy kapcsolódó jogi jogosultak, sőt akár kiadók is (mint származékos díjrészesedési jog vagy vagyoni jogi jogosultak) a közös jogkezelő szervezet tagjai. A francia SOFIA például az írókat és a kiadókat tömöríti, de az Artisjus tagja is lehet a zenemükiadó.

46 TOURNIER (1996) p. 97.

${ }^{47}$ VON LEWINSKI (2004a) p. 251.
} 
Ez utóbbi körülmény annak fényében különösen izgalmas, mert úgy tünik, hogy a szerzői jogban manapság divatos problémák megoldásaként valamilyen törvény által elöírt közös jogkezelési rezsimet vizionál a jogalkotó, de ez az igény a jogirodalomban is felvetődik az internetes felhasználások kapcsán. ${ }^{48}$ Daniel GERVAIS egyenesen úgy fogalmaz, hogy ezen felhasználásokhoz kötött engedélyek többségét közös jogkezelés alá kell vonni. ${ }^{49}$ A jogalkotói aktivizmus egyik legszemléletesebb példája a francia parlament által 2012-ben elfogadott törvény, ${ }^{50}$ amely a kereskedelmi forgalomban nem kapható könyvek digitalizálását egy speciális, a jogosultak kilépését engedő rezsimen keresztül kívánja rendezni. De az árva művekkel kapcsolatos jelenlegi szerzői jogi diskurzusban is kiemelt szerepet játszik a probléma közös jogkezelés útján való kezelése. ${ }^{51}$

Másodsorban a törvény által elöírt közös jogkezelési esetkörök kritikája sok esetben összemosódik a szerzői jog rendszere egészének bírálatával. ${ }^{52}$ Ez a tendencia kiválóan megfigyelhető a magáncélú másolatra tekintettel fizetett díjak kapcsán. A fájlcserélésen kívül ez tekinthető olyan témának, amely rendszeresen sajtónyilvánosságot kap, így az ,átlagfelhasználónak” is van róla véleménye. Sőt a felhasználók rendszerint azzal is tisztában vannak, hogy ez a díj közös jogkezelő szervezetek kezelésében áll. A díjazást érő, szakmai, de leginkább a társadalom felől érkező kritika könnyen a szerzői jog megkérdőjelezéséhez vezethet. Ez a társadalom, a felhasználók részéről érzékelhető elutasítás többször annak is köszönhető, hogy a közös jogkezelő szervezetek infrastruktúrájuk és apparátusuk révén fáradhatatlanul küzdenek az újabb felhasználási módok kapcsán járó (jog)díjigények érvényesítéséért. ${ }^{53}$ Másrészröl viszont a sokszor - az átlagos felhasználó számára - átláthatatlan müködés,

\footnotetext{
${ }^{48}$ Ez a jogalkotói aktivizmus viszont ellentétben állhat azzal az igénnyel, amely az egyéni joggyakorlás elsőbbségének megtartása mellett foglal állást. FICSOR (2003a) p. 3-4.

${ }^{49}$ GERVAIS (2012) p. 94.

${ }^{50}$ Loi n ${ }^{\circ}$ 2012-287 du 1er mars 2012 relative à l'exploitation numérique des livres indisponibles du XXe siècle.

${ }^{51}$ A kereskedelmi forgalomban nem kapható könyvekröl szóló törvény elemzését lásd: HAJDÚ (2013) p. 53-59., TARR (2013) p. 108-134. A teljesség igénye nélkül lásd például az árva művekre vonatkozóan: GYENGE (2009) p. 160-172., GYENGE (2011) p. 119-124., LEGEZA (2012) p. 23-58., GROFFE (2012) p. 112-118, PIRIOU (2012) étude 14,. MeZEI (2014b) p. 940-952. Megjegyzendő még, hogy a Google Books projektben is lényegében egy közös jogkezeléshez nagyon hasonló modell felállítását tervezte a cég. Erröl a projektről lásd többek között: MEZEI (2011) p.5-47., illetve EFRONI - GEBERT (2011) p. 532., STROWEL (2010) p. 1-7., CARRE - VERCKEN (2014) p. 119-138.

${ }_{53}^{52}$ NÉRISSON (2014) p. 146.

${ }^{53}$ Történelmi példa ennek kapcsán a német közös jogkezelö szervezetek tevékenysége a követő jogi, vagy éppen a reprográfiai díjak tekintetében. NORDEMANN (1988) p.37-41.
} 
illetve a megfelelő ismeretek hiánya az, amely miatt tévesen adóként, egyfajta ,állami sarcként” tekintenek a szerzői (jog)díjakra. ${ }^{54}$

A törvény által elöírt közös jogkezelési esetkörök nem képeznek homogén csoportot. Egyfelöl még a kontinentális szerzői jogon belül is különbségek fedezhetőek fel a közös jogkezelés helyéről és szerepéről alkotott elképzelések között. Ezt jól tükrözi a francia és német, ${ }^{55}$ illetve ez utóbbihoz közel álló magyar szerzői jogi gondolkodás közötti különbség. Ez nem elhanyagolható befolyással bír arra, hogy a törvény által elöírt közös jogkezelési esetkörök mennyire mélyen vannak beágyazódva egy nemzeti szerzői jog hagyományába. Ugyanilyen diverzitást mutatnak a törvény által elöírt közös jogkezelési esetkörök nemzeti szerzői jogban megjelenő formái is. Nincs egy olyan egységes sablon, amellyel a közös jogkezeléssel érintett jogok (és díjigények) leírhatóak lennének. Ez következik egyébként abból is, hogy a közös jogkezelés körébe tartozó vagyoni jogokra vonatkozó szabályok speciális követelményeket tartalmaznak a vagyoni jogok gyakorlására, illetve a felhasználási szerződésekre vonatkozó általános szabályokhoz képest. ${ }^{56}$

Ezen indokok miatt álláspontunk szerint a törvény által elöírt egyes közös jogkezelési esetköröket (ideértve az engedélyezési jogok gyakorlását és a díjigények érvényesítését is) külön-külön érdemes vizsgálat alá vonni. Különös figyelmet érdemel annak elemzése, hogy miért pont az adott kizárólagos jog (vagy díjigény) az, amelyre a jogalkotó a közös jogkezelés alá vonásról rendelkezett; ahogyan az is, hogy hogyan valósul meg a közös joggyakorlás. Az előbbi vizsgálati szempont jelentősége nemcsak abban áll, hogy a jog kollektív természetéröl véleményt formálhassunk, hanem annak alátámasztására is, hogy a jogalkotó mennyire tágan vagy szüken értelmezte az adott vagyoni jog gyakorlásának kereteit. A közös joggyakorlás módja pedig értelemszerủen az engedélyezési jog gyakorlásának vagy a díjigény érvényesítésének és a beszedett (jog)díjak felosztásának anomáliáira világít rá. Annak megvizsgálása, hogy a törvény által előírt közös jogkezelés bizonyulhat-e egyes szerzői jogi problémák megfelelő kezelésének, a szerzői jog fejlődési irányával kapcsolatos utat is kijelölheti.

\footnotetext{
${ }^{54}$ Hasonlóan lásd: TOURNIER (1996) p. 97.

55 Ennek a közös jogkezelés körében megfigyelhető jelentőségéről: NÉRISSON (2013).

${ }^{56}$ FALUDI (2004) p. 87. Ez a lex speciali derogat legi generali elv alkalmazandó álláspontunk szerint a CPI vonatkozásában is.
} 
A dolgozat ennek megfelelöen a kötelezö közös jogkezelés jogintézményét egy korábban nem, vagy csak kevésbé vizsgált szempontból, a szerzői jogi korlátozásrendszer szemszögéböl elemzi, és emiatt külön figyelmet fordít az egyes vagyoni jogok elemzésére is. Ennek a szempontnak a hangsúlyozását a miatt is fontosnak tartjuk, mivel a közös jogkezelés alapvetően nem a szerzői jogok korlátozásának jogpolitikai célját szolgálja, azonban kétségtelenül betölt ilyen szerepet is.

Bár a közös jogkezelés jelentős szerepet játszik a kapcsolódó jogok (droits voisins) kezelésében is, ${ }^{57}$ ezek elemzésére a dolgozat csak érintőlegesen tér ki. Ennek oka a kapcsolódó jogok eltérő, a szerzőt megilletőnél szükebb terjedelmü természetében rejlik, ${ }^{58}$ másrészt pedig a jogkezelés természete is eltérö lehet, hiszen más jellegü tevékenység szükséges a szerzőkhöz hasonlóan gyenge tárgyalási pozícióban lévő előadóművészek, illetve az eleve erősebb félként számon tartott hangfelvétel-előállítók esetében, amely utóbbi esetben az engedélyezési jogok gyakorlása - hacsak a törvény nem írja elő - jellemzően ritkán történik közös jogkezelés keretében. ${ }^{59}$ A szerzői jog korlátozásának szempontjából tehát ezeknek a jogoknak a vizsgálata irreleváns. A müködési elv, a szervezetrendszer természetesen azonos lehet mindkét jogtípus esetében, illetve bizonyos díjigényekből a kapcsolódó jogi jogosultak is részesednek. Ez indokolja a kapcsolódó jogok közös kezelésének érintőleges felbukkanását azokban a fejezetekben, amelyekben ez nélkülözhetetlen az elemzés teljessé tételéhez.

A szakirodalomban sokszor éles különbségként megjelenő elválasztás a díjigények és az engedélyezési jogok gyakorlása között ${ }^{60}$ szintén megjelenik a dolgozatban. Elismerjük, hogy a vagyoni jogok természete (és kezelési módja és érvényesítése) között eltérés mutatkozhat a szerint, hogy engedélyezési jogról vagy díjigényről van-e szó, viszont ez a distinkció magáról a közös jogkezelésről és annak a korlátozásokkal kapcsolatban betöltött szerepéről keveset árul el. A különbségtétel sokkal inkább használható a vagyoni jogok általános jellemzésénél, illetve a vagyoni

\footnotetext{
${ }^{57}$ Elsősorban az előadóművészi jogok közös kezelése bír jelentőséggel, hiszen a hangfelvétel-előállítók esetében csak kiegészítő szereppel bír, a rádió-és televízió-szervezeket esetében alig fordul elő, az adatbázis előállítókat megillető védelem pedig csak egyéni jogként létezik.

${ }^{58}$ A kapcsolódó jogokra vonatkozó szabályokkal az Szjt. Harmadik része foglalkozik (73-84/A. §). A CPI Második könyvében találhatóak meg a francia szabályok (L. 211-1 cikktől L. 217-3. cikkig).

${ }^{59}$ SIIRIAINEN, Fabrice: Théorie générale de la gestion collective - Logique du droit exclusif de la gestion collective. J. Cl. Propriété littéraire et artistique, Fasc. 1550. 2. pont.

${ }^{60}$ Lásd. pl. SIIRIAINEN (Fasc. 1550) 3. pont.
} 
jogok általános korlátozhatóságánál. A disszertáció vezérlő elvének tehát ezen koordináta-rendszer mentén is azt kell tekinteni, hogy a közös jogkezelés elöírása mely esetekben tekinthető inkább korlátozásnak, és mely esetekben jelenik meg egyszerü joggyakorlási módként.

A dolgozat ennek keretében két nemzeti szabályozást vesz figyelembe: tárgyát alapvetően a magyar és a francia nemzeti szerzői jog elemzése adja. A vizsgálat körének ilyen irányú szűkítését gyakorlati és elméleti szempontok támasztják alá. Elméleti indoka a témaválasztás szúkítésének az, hogy a magyar és francia szerzői jog a kontinentális szerzői jogon belül is bizonyos tekintetben két eltérő pólust képvisel, tekintettel arra, hogy a magyar szerzői jog megoldásait sok esetben a német jogban kimunkált elvek inspirálták. Így a disszertáció bemutatja azt is, hogy a szerzői jogról alkotott alapvető elképzelések különbözősége mennyiben van hatással a törvény által elöírt közös jogkezelési esetkörök szerzői jogi beágyazottságára. A témaválasztást gyakorlati szempontból pedig egyfelől a szerző nyelvtudása határozza meg, másfelől az a körülmény, hogy a dolgozat magyar-francia közös témavezetésủ doktori disszertáció keretében készült el. A dolgozat részletes francia nyelvü összefoglalója függellékként a dolgozat részét képezi.

\section{A vizsgálati módszer és az értekezés felépítése}

A kötelező közös jogkezelési esetkörök diverzitása okán a disszertáció elsősorban arra törekszik, hogy ezeket rendszerben elhelyezve megvizsgálja, hogy melyik eset milyen módon képezheti a szerzői jogok korlátját. A dolgozat a törvény által elöírt közös jogkezelési esetkörök jogi szabályozására koncentrál, de a joggyakorlat (különösen a bírói gyakorlat, illetve az SZJSZT szakvéleményei) elemzése is indokolt terjedelemben megjelenik. Törekedtünk a föbb szakirodalmi álláspontok, soft law jellegű dokumentumok megállapításának kiemelésére és kritikájára is.

A disszertáció, igazodva ahhoz, hogy magyar-francia közös témavezetésü doktori képzés keretében készült el, két választott nemzeti jog, a magyar és a francia szabályozás elemzésére fókuszál. Célja annak érzékeltetése, hogy az eltérő kulturális, gazdasági, társadalmi, jogi hagyományokkal rendelkező államokban (mára már azonos nemzetközi és uniós jogi háttérrel) milyen eltérő felfogással közelítenek a törvény által elöírt közös jogkezelés kérdéséhez. Ez azt is lehetővé teszi, hogy a különböző jogi 
megoldások tanulságait levonva azok mutatis mutandis nemzeti szerzői jogba való beépítésének kérdését felvessük.

Ennek szem elött tartásával született meg az az igény, hogy szerkezetét tekintve a dolgozat egészét a francia módszertan hassa át. Jogi témájú írások esetén a bevett gyakorlat alapján az érvelést két förészre, és ezeken belül két alrészre illik felosztani, amelyek egymással szoros logikai kapcsolatban állnak. Bár nem vettük át teljes egészében a francia metódust, a dolgozat ugyanis három fő részre tagolódik, a részek belső szerkezetének kialakításánál törekedtünk a szimmetriára és arra, hogy két fejezetből, valamint két alfejezetből álljanak.

A dolgozat első része adja meg a fogalmi és elméleti hátteret. Ebben kerül általánosságban bemutatásra a közös jogkezelés rendszere, szervezeti felépítése, valamint a szerzői jog korlátozásának és a közös jogkezelésnek a lehetséges metszéspontjai. A speciális kérdéseket igyekeztünk az egyes vagyoni jogok keretében tárgyalni. Így például a háromlépcsős teszt részletes elemzésére sem térünk ki ebben a fejezetben. Helyette a magáncélú többszörözésnek szentelt oldalak foglalkoznak a teszt alkalmazásával ebben a speciális kérdésben. A dolgozat második része foglalkozik azokkal az esetekkel, amelyek kapcsán felmerülhet, hogy a törvény által elöírt közös jogkezelés a szerzői jog korlátját képezi. A két fejezetben szó lesz azokról az esetekről, amelyekben a közös jogkezelés a szerzői jog törvényben meghatározott korlátjához kötődik (II. fejezet), illetve bemutatásra kerül, hogy ez a joggyakorlásnak milyen korlátját képezi (I. fejezet).

A harmadik részt azoknak az eseteknek az elemzésére szenteljük, amelyekben a közös jogkezelés túlmutat a korlátozó funkción. Ez jelentheti egy olyan rugalmas rendszer bevezetését, amelyben a szerzőknek lehetőségük van a rezsimből történő kilépésre (I. fejezet), illetve azokat az eseteket is ide soroljuk, amelyekben a közös jogkezelés valamely speciális jogpolitikai cél megvalósításának eszközeként jelenik meg (II. fejezet) 


\section{I. rész Fogalmi és elméleti keretek - a közös jogkezelés két eltérö felfogása}

A dolgozat a szerzői jogi korlátozások szemüvegén keresztül mutatja be a törvény által elöírt közös jogkezelési eseteket. Korlátozás alatt nem csak a CPI-ben felsorolt, ${ }^{61}$ a szakirodalom által kivételekként (exceptions) emlegetett csoportot, és nem is csak az Szjt-ben szabad felhasználás és a szerzői jog egyéb korlátai cím alatt tárgyalt rendelkezéseket értjük. Általánosságban idetartozónak tekintünk minden olyan törvényi előírást, amely a szerzői monopóliumot valamilyen módon csorbítja: legyen az akár a jog fennállása kapcsán elfogadott kivétel, akár annak díjigényre való korlátozása, akár a gyakorlásának módját meghatározó rendelkezés. Mivel álláspontunk szerint a közös jogkezelés is ilyen korlátozásként azonosítható, fontosnak tartjuk vázlatosan ismertetni mindkét témakört azzal a fenntartással, hogy e rövid bevezetés célja nem a korlátozások monografikus szintű ismertetése, ${ }^{62}$ hanem azoknak a paramétereknek az azonosítása, amelyek mentén a közös jogkezelés jogintézménye elhelyezhető a korlátozások koordinátarendszerében (I. fejezet). Hasonlóképp, bár nem foglalkozunk részletesen a közös jogkezelés szervezeti felépítésével, vázlatosan (elsősorban a közös jogkezelésről alkotott felfogásbeli különbségek érzékeltetése miatt) ez is bemutatásra kerül (II. fejezet). A közös jogkezelés ugyanis, bár a szerzői jog részét képezi, több jogterület metszéspontjában áll, és önmagában, az önkéntes közös jogkezelés jellegét tekintve is diverz jogintézmény. ${ }^{63}$ A törvény által elöírt közös jogkezelés jellemzőinek vizsgálatához, mivel az önkéntes közös jogkezelés kapcsán kialakult elvekre épül rá, mindenképpen szükséges ennek a generális szervezeti és müködési struktúrának az ismerete.

\footnotetext{
${ }^{61}$ CPI L. 122-5. cikk.

${ }^{62}$ Erre lásd például: Gyenge (2010), SenfflLeben (2004), Guibault (2002), LUCAS - SiRinELLi BENSAMOUN (2012).

${ }^{63}$ Lásd például a szerzői jogok és kapcsolódó jogi jogosultak jogait kezelő szervezetek szervezete és múködése közötti eltéréséket. A hangfelvétel-elöállítókat tömörítő KJK-k esetében például a szolidaritáson alapuló kulturális és szociális felhasználás sokkal kevésbé jellemző.
} 


\section{I. fejezet A szerzői jog korlátai, korlátozása}

A szerzői jog korlátozása alatt átfogóan minden olyan törvényi rendelkezést értünk, amelyek a müvön fennálló szerzői kizárólagos jogot szükítik azzal a céllal, hogy az alkotók és a társadalom ellentétes érdekei között fennálló feszültséget valamilyen módon tompítsák. A korlátozások tehát a szerzői jogi érdekkiegyensúlyozás eszközei. A kizárólagos jogok és korlátozások kölcsönhatását, a kényes egyensúly fenntartásának szükségességét FICSOR Mihály fogalmazza meg találóan. Azt állítja, hogy minél nagyvonalúbb a jogi oltalom, minél általánosabb és szélesebb jogokat biztosít, annál inkább szükség van valamilyen kivételre vagy korlátozásra, és fordítva. ${ }^{64}$

Ebböl a felfogásból az is következik, hogy a korlátozásokat nem lehet pusztán a szerzői jogi jogszabályokban kivétel vagy korlátozás címszó alatt felsorolt rendelkezésekkel azonosítani. A közös jogkezelés esetében nem is lehetne ilyenről szó, hiszen nincsen olyan törvényi vagy irányelvi rendelkezés, amely ezt a besorolást elvégezné. A korlátozásokat tehát sokkal inkább egy színes palettaként értékeljük. Ebbe pedig az is belefér, hogy ne csak a jog fennállását, hanem annak egyéni gyakorlását csorbító törvényi rendelkezéseket is korlátozásnak tekintsük. ${ }^{65}$ Ennek indoka abban rejlik, hogy a jog gyakorlása módjára vonatkozó elöírások ténylegesen alkalmasak lehetnek arra, hogy a jog fennállását korlátozó intézkedésekkel azonos hatást váltsanak ki. ${ }^{66}$ Másrészről a jog fennállásának és gyakorlásának egysége képezi a szerzői monopóliumot, mint egy érme két oldala. Emiatt túlságosan szúkítő értelmezést jelentene annak kimondása, hogy korlátozásként csak ez előbbit érintő rendelkezések értelmezendőek. Persze ez nem jelenti azt, hogy a kategóriát ne lehetne külön, összefoglalóan is névvel illetni, illetve elemezni. Harmadrészt pedig a BUE aprólékosan kidolgozott korlátozásrendszere is a monopólium részleges megszüntetésére éppúgy tartalmaz példát, mint a joggyakorlás módjának elöírására vonatkozóan.

A közös jogkezeléssel való ütköztetés során két szempontból érdemes a korlátozásokat megvizsgálni. Az első a korlátozások jogpolitikai indokainak azonosítása (1. pont), hiszen a törvény által elöírt közös jogkezelés bevezetése mellett is hasonló érvek szólhatnak, alátámasztva a közös jogkezelés korlátozásként való értelmezésének

\footnotetext{
${ }^{64}$ FICSOR (2002). p. 259.

${ }^{65}$ Ezzel ellentétesen: GALOPIN (2012) p. 16.

${ }^{66}$ Alma-DeletTRE (2007) p. 36.
} 
lehetőségét. A második szempont pedig azoknak a kategóriáknak a bemutatása, amelyek a nemzetközi, uniós és nemzeti szerzői jog alapján klasszikusan a szerzői jog korlátait képezik. (2. pont). Ennek az elemzésnek a fontossága a közös jogkezelés diverzitásában keresendő: az egyes esetek ugyanis az egyezmények és az uniós jog másmás rendelkezésihez kapcsolódnak. Emellett pedig a további jogok közös jogkezelés alá vonásának általános kereteit szabják meg.

\section{A korlátozások indokai}

A korlátozások érdekkiegyensúlyozó szerepe mögött többféle indok és érdek húzódik meg. Mindenekelőtt megjelenik a kulturális és információs közérdek, nevezetesen az, hogy a művekhez való hozzáférés minél szélesebb körben legyen biztosítva. Emellett pedig a felhasználók magánszférájának védelme is kiemelten fontos szempont, a szerzői jog ugyanis nem hivatott arra, hogy ebbe beavatkozzon. ${ }^{67}$

Ezeket az érdekeket jobban körülírva, a korlátozások bevezetését megalapozhatja az, hogy a szerzői jog, mint nemzetközi emberi jogi források által elismert emberi jog összeütközésbe kerül egy másik elismert emberi joggal. Ilyen módon tehát a szerzői jog klasszikus korlátai beazonosíthatóak egy-egy emberi jog szerzői jogi vetületének is. Konkrét példa erre a gondolatmenetre az idézés esete, amely a véleménynyilvánítás jogának szabadságából eredeztethető szerzői jogi korlátozás. Mivel maga a szerzői jog is a véleménynyilvánítás szabadságából eredeztethető, ezekben az esetekben voltaképpen a lényegét tekintve két azonos emberi jog ütközése miatt kell biztosítani azt, hogy a jogot az adott szerzőn kívül mások is (tipikusan szintén szerzők) gyakorolhassák. Ezt a konfliktust talán még szemléletesebben érzékelteti a paródia célú felhasználások monopoljog alóli kivételével történő lehetővé tétele. ${ }^{68}$

A közös jogkezelés gyökerei az emberi jogi vetület tekintetében az önrendelkezési jogban gyökerező egyesülési jogban, illetve ez emberi méltósághoz kötődő autonóm emberi cselekvési szabadságban gyökerező szerződési szabadságban ${ }^{69}$

\footnotetext{
${ }^{67}$ LINANT DE BELLEFONDS (2004) p. 203.

${ }^{68}$ A paródia kivételét az InfoSoc-irányelv 5. cikk (3) bekezdés k) pontja teszi lehetővé. A CPI-ben ez a kivétel az L. 122-5 $4^{\circ}$ cikkben található. A magyar szerzői jogi törvény viszont szöveg szerint nem ismeri a paródia célú szabad felhasználást. Ennek elemzésére a magyar szakirodalomban lásd GYENGE (2010) p. 222-225, illetve FALUDI (2015) p. 94-120.

69 8/2014. (III. 20.) AB határozat a devizahitelszerződések jogszabállyal történő módosításával kapcsolatban. Illetve a korábbi Alkotmány alapján a szerződési szabadság a piacgazdaságból levezethető
} 
keresendők. Az engedélyezési jog kötelező, kilépést nem engedő változatának elöírását tehát ebből a szempontból lehet vizsgálni. Ezért kell külön figyelmet fordítani arra, hogy ilyen esetekben a jogalkotó kötelezővé teszi-e a csatlakozást a közös jogkezelő szervezetekhez. Illetve ennek hiányában a nem tag jogosultak képviselete megfelelő garanciákkal kerül-e körülbástyázásra. ${ }^{70}$

A magánszféra, mint védendö érték a magáncélú felhasználások mögött meghúzódó legfontosabb indok. Az egyik ilyen kivétel a francia jog alapján a művek szük családi körben történő előadását jelenti. ${ }^{71}$ A másik, általánosabb és a közös jogkezeléssel közvetlenül összefüggésben álló példa a magáncélú többszörözés. A kizárólagos jog díjigényre korlátozásának, és ebből következően a közös jogkezelés törvény általi előírásának egyik indoka ugyanis éppen abban rejlik, hogy a szerzői jog ne avatkozzon bele a felhasználók magánéletébe azzal, hogy az ilyen jellegü többszörözéseket is engedély megszerzéséhez kösse. ${ }^{72}$ A felhasználások tömegessége és követhetetlensége pedig szükségképpen magával vonja a közös jogkezelés előírását is.

A kultúrához, oktatáshoz való hozzáférés alapozza meg az oktatási és kulturális intézmények számára biztosított kivételeket, ${ }^{73}$ hasonlóképpen a fogyatékkal élők javára biztosított $^{74}$ korlátozásokhoz. A jogalkotó által a közös jogkezelő szervezetek kezelésébe utalt könyvtári haszonkölcsönzési díjak is éppen e miatt az elv miatt a

önálló alkotmányos jog [13/1990. (VI. 18.) AB határozat, 29/1993. (V. 6.) AB határozat], illetve az ember általános cselekvési szabadságának megnyilvánulási formájaként az emberi méltóságból levezethető [24/1996. (VI. 25.) AB határozat].

${ }^{70}$ Ezt az elemzést részletesen a II. rész I. fejezetében, illetve a III. rész II. fejezetében végezzük el.

${ }^{71}$ A szük családi körben való előadás (représentation dans le cadre du cercle de famille) kivételét a CPI L. 122-5 $1^{\circ}$ cikke szabályozza. Christophe CARON elemzése szerint viszont nyilvánosság hiányában ez a felhasználás per definitionem kiesik a szerzői jog hatálya alól. Emiatt tulajdonképpen ez a rendelkezés nem is tekinthető kivételnek. CARON (2012b) p. 20-21. Az érvelést megerösíti egyébként egy bírósági döntés is. CA Paris, 12 sept. 2008, SAIF et al. c/ SARL Maïa Films et al. RTD Com, 2009, p.137 (obs. F. Pollaud-Dulian, Comm. com. électr. 2008, étude 23, note P.-Y. Gautier, Légipresse 2008, $\mathrm{n}^{\circ} 257$, III, p. 238, note P. Boiron et E. Mirat; RLDI 2008/11, n 1429, note B. Khalvdijan). Az Szjt. megoldása is ezt az utóbbi logikát követi. A törvény a nyilvánosságot határozza meg úgy, hogy az a felhasználó családján és annak társasági, ismerősi körén kívüli személyek körét jelenti [Szjt. 24. § (3) bek.]. Illetve tartalmaz egy kifejezetten a magánhasználatra, illetve alkalomszerüen tartott zártkörü összejövetelen elöadott mủvekre vonatkozó szabad felhasználási kategóriát is [Szjt. 38. § (1) bek. f) pont].

${ }^{72}$ Részletesen a dolgozat II. részének II. fejezetében kerül kifejtésre.

${ }^{73}$ InfoSoc-irányelv 5. cikk (2) bek. c) pont, 5. cikk (3) bek. a) pont, Szjt. 34. § (2) bek., 34. § (4) bek., 35. $\S(4)$ bek., 35. $\S(5)$ bek., 38. $\S(1)$ bek. b) pont, 38. $\S(5)$ bek. CPI L. $122-53^{\circ}$ e) és L. 122-5 8 cikkek.

${ }_{74}$ InfoSoc-irányelv 5. cikk (3) bek. b) pont, Szjt. 41. § (1) bek., CPI L. 122-5 $7^{\circ}$ cikk. Illetve fontos kiemelni a vakok, látáskárosultak vagy egyéb okból látási képességükben korlátozott személyek nyomtatott müvekhez való hozzáférését elősegítő Marrakeshi Szerződés elfogadását. (Marrakesh Treaty to Facilitate Access to Published Works for Persons Who Are Bind, Visually Impaired, or Otherwise Print Disabled). 
tipikusan haszonkölcsönzés keretében terjesztett mütípusok esetében nem engedélyezési jogként kerültek meghatározásra. A felhasználási engedélyek fejében fizetett jogdíjak a jellemzően állami fenntartású könyvtárakra túl nagy terhet rónának, míg az olvasókra történő továbbhárításuk megnehezítené a kultúrához való hozzáférést. ${ }^{75}$ Mind a francia, mind a magyar jogalkotó közös jogkezelésen alapuló köztes megoldást választott a díjak beszedésére és felosztására.

Nem kizárólag ezek az általános emberi jogi megfontolások húzódhatnak meg azonban a szerzői jogi korlátozások bevezetése mögött. A monopoljoggal szükségképpen összeütközésbe kerülhetnek versenyjogi és piaci megfontolások, amelyek szintén a szerzői jog korlátozásához vezethetnek. Ezek az érdekek jelennek meg a szoftverekre vonatkozó, a szerzői jog főszabályától eltérő rezsim mögött is, ${ }^{76} \mathrm{de}$ az adatbázis irányelvben is. ${ }^{77} \mathrm{~A}$ piaci megfontolások játszanak kiemelkedő szerepet a vezetékes továbbközvetítési jog kizárólagos engedélyezési jogának kötelező közös jogkezelés alá utalásában is. A továbbközvetítést végző szervezet ugyanis a továbbközvetítés technikai jellemzői miatt nincsen abban a helyzetben, hogy egyedi engedélyeket szerezzen. A jogosítás megkönnyítésé érdekében döntött úgy az uniós jogalkotó, hogy a tagállamok számára előírja a kötelező közös jogkezelés bevezetését. ${ }^{78}$ Megjegyzendő, hogy emellett a kulturális cél is megjelenik, hiszen sem a földfelszíni, sem a müholdas sugárzás a jelek kódoltságától, illetve a terepviszonyoktól függően nem képes mindenhova eljutni. A vezetékes továbbközvetítés a probléma áthidalásával ezt a kulturális célt valósítja meg.

Az is előfordulhat, hogy a felhasználásra járulékos, másodlagos felhasználási piac épül ki. Ezekben az esetekben a szerzőt megillető kizárólagos jog korlátozottságát a piac kiépülésének és müködésének elősegítése, a piaci sajátosságok indokolják. Ezekben az esetekben a korlátozottság viszont nem jelent egyben ingyenességet is, a

\footnotetext{
${ }^{75}$ Erről részletesen lásd a III. rész II. fejezetét.

${ }^{76}$ Ezek a megfontolások nem csak kifejezetten a kivételek körében érhetők tetten, hanem a szoftverekre vonatkozó általános szerzői jogi rezsimben. A kivételek körében éppen a kivétel kizárása hívható fel példaként. Szoftverről ugyanis, általánosságban a szerzői müvekhez képest magáncélra sem lehet másolatot készíteni a jogosult engedélye nélkül. Engedélykérés nélküli másolat kizárólag a biztonsági másolat lehet, amennyiben az a felhasználáshoz szükséges. Szoftver-irányelv 5. cikk (1)-(2) bek., Szjt. 35. $\S(1)$ bek., 59 § (1)-(2) bek., CPI L. 122-5 $2^{\circ}$ cikk.

77 Az Európai Parlament és a Tanács 96/9/EK irányelve az adatbázisok jogi védelméről. A szoftver és az adatbázis kapcsán bevezetett speciális rendelkezések utalnak a funkcionális müvek eltérő természetére.

${ }^{78}$ Részletes elemzést lásd a II. rész I. fejezetében.
} 
másodlagos piacokon többnyire díjfizetés ellenében lehetséges a felhasználás. ${ }^{79}$ Erre szintén a magáncélú másolat jelent kitünő példát, a felhasználások tömegessége, ezek egyedi beazonosíthatatlansága igazolja a kizárólagos jog helyett a díjigény bevezetését, illetve az ezzel szorosan összefüggő közös jogkezelést. A piacot a másolatok elkészítéséhez használt eszközök, üres hordozók jelentik, amelyekre vonatkozóan a jogalkotó a többszörözési cselekményre tekintettel díj fizetését írja elö. ${ }^{80}$

Illetve bizonyos esetekben gyakorlati, praktikus okok szolgáltatatnak alapot a korlátozás bevezetéséhez. Ez alapvetően megmutatkozik abban az esetben, ha az engedélyezési jog gyakorlása nehézségekbe ütközik, vagy aránytalanul magas költségekkel járna. A reprográfia útján történő többszörözés Franciaországban megmaradt a szerzőt megillető kizárólagos engedélyezési jog keretei között. Hatékony gyakorlása érdekében viszont a jogalkotó kötelező közös jogkezelés keretébe utalta a kizárólagos jogot, különösen figyelembe véve azt, hogy a fénymásolás jellemzően oktatási intézmények falai között zajlik, vagy egyébként általában szakmai célokat szolgál. ${ }^{81}$

\section{A korlátozások megjelenési formái}

Sem a magyar, sem a francia, sem pedig az uniós és nemzetközi szerzői jogban nincsen a korlátozásnak egységesen elfogadott definíciója. A magyar törvény terminológiáját is figyelembe véve három bevett kifejezéssel találkozhatunk: kivétel, korlátozás és szabad felhasználás. A fogalmi változatossággal kapcsolatban ehelyütt csak annyit kell leszögezni, hogy az Szjt.-ben a „szabad felhasználás és a szerzői jog más korlátjai" kifejezés szerepel. ${ }^{82}$ A CPI-ben ezzel szemben nem található meg egyik kifejezés sem, ${ }^{83}$ a jogtudomány viszont következetesen a kivétel (exception) kifejezést alkalmazza. A nemzetközi és uniós jogi terminológiában párhuzamosan, egymás mellett létezik a kivétel és korlátozás (exception és limitation) szakkifejezés anélkül, hogy maguk a szerzői jogi egyezmények, vagy az irányelvek, különösen az InfoSoc-

\footnotetext{
${ }^{79}$ GYENGE (2011) p. 72-73.

${ }^{80}$ Részletesen lásd a II. rész I. fejezetét.

${ }^{81}$ Részletes elemzését lásd a II. rész I. fejezetében.

${ }^{82}$ Ez az Szjt. IV. fejezetének címe (33-41. §).

${ }^{83}$ Hagyományosan a CPI L. 122-5 cikkében foglalt felsorolást szokták a szerzői jogi kivételeknek tekinteni. Ez a cikk a „szerzö nem tilthatja meg” (,l'auteur ne peut interdire”) fordulattal vezeti be ezeket az esetköröket.
} 
irányelv ${ }^{84}$ elhatárolná őket egymástól. Lehetséges magyarázat erre az anomáliára, hogy az angolszász és a kontinentális szerzői jogi hagyományokkal rendelkező országok is be tudják vezetni belső jogukba a nemzetközi és uniós jogi kötelezettségeket. ${ }^{85} \mathrm{~A}$ jogtudományban fellelhető, alább ismertetésre kerülő más vélemények szerint viszont az eltérő megnevezések mögött eltérő tartalom húzódik meg. A jogtudomány tehát ennek fényében tesz kísérletet a probléma feloldására: minden korlátozásokkal foglalkozó szakirodalom igyekszik a maga koordináta-rendszerében elhelyezni ezeket a fogalmakat.

Silke VON LEWINSKI kivételként egyértelmüen azokat az eseteket nevesíti, ahol a jogosult oldaláról szemlélve sem a kizárólagos jog, sem pedig jogdíjfizetés nem illeti öt meg. Másrészt viszont korlátozásként definiálja azokat a tényállásokat, ahol a jogosultat díjazáshoz való jog megilleti ugyan, a kizárólagos jogát viszont nem gyakorolhatja. Ennek két fajtája szerinte a törvényi engedély és a kényszerengedély. ${ }^{86}$ FICSOR Mihály is ezt a csoportosítást alkalmazza, vagyis kivételként definiálja az ingyenes és nem engedélyköteles felhasználásokat. ${ }^{87}$

Lucie GuIBAULT ezzel szemben a korlátozások szót használja általános értelemben, mivel ezt egy semleges kifejezésnek tekinti, amely az összes szerzői jogi kivétel és korlátozás gyüjtőfogalmául szolgálhat. ${ }^{88}$ Ö a korlátozás fogalmán belül különít el négy kategóriát: nevezetesen elsőként a kivételeket, ahol a jogosult kizárólagos joga és jogdíjigénye sem marad meg. Ezt követik a törvényi engedélyek, ahol a kizárólagos jog elvész, de a jogdíjigény megmarad, majd a kényszerengedélyek, ahol bár mindkét jogosultság megvan, a jogosultnak a törvényben meghatározott feltételek szerint kell megadnia a felhasználási engedélyt. ${ }^{89}$ Végül pedig a kötelező közös jogkezelési esetköröket tekinti a korlátozások utolsó típusának, ami a joggyakorlás módjára vonatkozik. ${ }^{90}$

\footnotetext{
${ }^{84}$ InfoSoc-irányelv 5. cikk.

${ }^{85}$ GEIGER - MACREZ - BOUVL - CARRE - HASSLER - SCHMIDT (2009) p. 232.

${ }^{86}$ VON LEWINSKI (2008) p. 152.

87 FICSOR (2002) 5.04. pont. FICSOR Mihály egyébként több helyen is kifejti azt a nézetét, mely kivételként az ingyenes és engedélyhez nem kötött felhasználási cselekményeket, korlátozásként pedig kizárólagos jog más módon történő megcsorbítását érti. FICSOR (2012b) p. 2.

${ }^{88}$ Guibault (2002) p. 16.

${ }^{89}$ A szerzői jog területén ezek ritkák, Lucie GUIBAULT a Berni Uniós Egyezmény 11bis cikkének (2) bekezdését, illetve a 13. cikk (1) bekezdését hozza példának. Lásd: GUILBAULT (2002) p. 25.

${ }^{90}$ Guibault (2002). p. 20-21.
} 
A magunk részéről csatlakozunk a WIPO szerzői jogi szószedetében foglaltakhoz, amely azt a megállapítást teszi, hogy a nemzetközi dokumentumokban a „kivételek és korlátozások” lefednek minden szabad felhasználási esetkört, nem önkéntes engedélyt, és minden egyéb lehetséges korlátozást (mint amilyen a kötelező közös jogkezelés elrendelése is). ${ }^{91}$

Annyi megszorítást füzünk a fent elhangzottakhoz, hogy a dolgozatban egységesen a korlátozás kifejezést használjuk, mivel ezt tartjuk egy olyan tág, értéksemleges $^{92}$ kategóriának, amely alkalmas arra, hogy az érdekkiegyensúlyozó szerep sokféleségét átfogja, keretbe foglalja. Ebbe természetesen beleértjük az egyébként sok helyen „kivételként” aposztrofált tényállásokat is. ${ }^{93}$ Ezzel a fogalomhasználattal egyúttal tudatosan eltérünk a nemzeti törvényekben megtalálható kifejezésektől, egy általánosabb szintre emelve ez által a kutatás tárgyát.

A korlátozások mértékük szerint eltérő szinteken állapíthatóak meg. A tulajdonjogi szemlélethez köthető korlátozásokban a rangsor az alábbiak szerint állapítható meg. A kivételek jelenthetik azokat az eseteket, amikor a felhasználás ingyenes, és nem szükséges hozzá a szerző engedélye. A díjigény ehhez képest abban hoz változást, hogy a felhasználáshoz, bár nem kell a szerző engedélyét kérni, azonban mégis díjazás illeti őt meg. A kényszerengedély esetében a teoretikusan a kizárólagos jog mindkét eleme, a díjazáshoz való jog és az engedélyezés is megilleti a jogosultat, ennek gyakorlását azonban a jogszabály elvonja a szerzőtől, és valamely más

91 WIPO Guide to the Copyright and Related Right Treaties Administered by WIPO and Glossary of

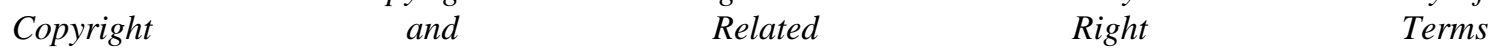
(http://www.wipo.int/edocs/pubdocs/en/copyright/891/wipo_pub_891.pdf), 2003.p. 286-287.

92 A korlátozásnak ezt a természetét emeli ki Christophe GEIGER is. GEIGER (2004) p. 887.

93 Úgy véljük, hogy ezzel a meghatározással nem ellentétes az, hogy a VG Wort-ügyben az EuB a kivételeket és korlátozásokat [az InfoSoc-irányelv 5. cikk (2) bekezdés b) pontjában foglalt magáncélú többszörözéssel összefüggésben] külön kezelte, arra élezve ki az elhatározást, hogy a jogosult rendelkezési joga fennáll-e. Ez tehát összecseng az általunk is használt fogalommal, ugyanis a közös jogkezelés önmagában nem jelenti azt, hogy a szerzőt megillető kizárólagos jog megszűnne létezni. Másrészt viszont ez tekinthető úgy is, hogy a kivétel olyan megoldás, amely az engedélyezési jogot teljes egészében korlátozza, vagyis ez utóbbi általánosabban használható fogalomként tekinthető.

A kivétel ugyanis a Bíróság értelmezésében annyit jelent, hogy a jogosult nem rendelkezhet többé kizárólagos engedélyezési jogával, az általa adott bárminemű engedély semmisnek tekinthető. Ha a tagállam korlátozásként vezette viszont be a magáncélú többszörözést, akkor is annak vizsgálata a döntő, hogy a jogosultat megillető jog fennáll-e. Ha ugyanis a többszörözési jogot a jogosult számára fenntartotta a tagállami jogalkotó, abban az esetben a méltányos díjazásra vonatkozó rendelkezések nem alkalmazhatóak, lévén, hogy nem keletkezik olyan sérelem, amit ellentételezni kellene. Amennyiben viszont a többszörözési jogot nem tartották fenn, az engedélyezési cselekménynek nincs semmilyen kihatása a szerzőket ért sérelemre. Lásd a C-457/11-C-460/11. sz. VG Wort egyesített ügyekben 2013. június 27-én hozott ítéletet, különösen annak 37. és 39. pontjait. 
személyre, tipikusan hatóságra telepíti. ${ }^{94}$ A kötelező közös jogkezelés, amennyiben a kizárólagos engedélyezési jogot érinti, a tulajdonkorlátozás legenyhébb formájának tekinthető. E mellett pedig megjelenik a szerző szerződési szabadságának korlátozása is a közös jogkezelés a kilépést engedő, de törvény által elöírt közös jogkezelés esetében, valamint az önkéntes jogkezelésnél akkor, ha a csatlakozás egyébként gazdasági kényszer eredménye.

A korlátozások nemzeti jogba beágyazottságát nagymértékben meghatározzák a nemzetközi és uniós jogi követelmények. ${ }^{95}$ Mindenekelőtt a BUE korlátozásrendszerét kell ehelyütt figyelembe venni. ${ }^{96}$ A nemzetközi szerzői jogi egyezmény ugyanis pontosan körülhatárolja a részes felek lehetőségeit a szerzői jog korlátozása kapcsán. A BUE alapvetően a korlátozásoknak kétféle típusát ismeri el: a díjazással kompenzált korlátozásokat (ezek a törvényi engedélyek, illetve a mechanikai többszörözési jog kapcsán a kényszerengedély) és a díjazással nem járó korlátozásokat. Ez utóbbiak vagy olyan csekély jelentőségü felhasználások lehetnek, amelyek nem tartoznak a szerző monopoljogába, vagy pedig olyan felhasználások, amelyek a tranzakciós költségek túlzottan magas volta miatt maradnak ingyenesek. ${ }^{97}$ Más megközelítést alkalmazva az egyezmény bizonyos esetekben maga határozza meg azoknak a felhasználásoknak a körét, amelyek kivételeket jelentenek az általa biztosított kizárólagos jog alól. ${ }^{98}$ Más

\footnotetext{
${ }^{94} \mathrm{Az}$ árva művek engedélyezése kapcsán a hatályos Szjt.-ben foglalt rezsim tekinthető szerzői jogi kényszerengedélynek. A törvény 41/B. § (1) bekezdése értelmében az SZTNH a felhasználás mértékéhez és módjához igazodó díj megállapítása mellett engedélyt ad a felhasználásra. Kényszerengedélynek tekinthető az Szjt. korábban hatályos szövegében a mechanikai többszörözési jogra vonatkozó 19. §, amelyet részletesen a dolgozat II. rész I. fejezetében elemzünk. A kényszerengedély egyébként az iparjogvédelmi oltalmi formák sajátja, a szabadalmi jogban a találmány hasznosítását teszi lehetővé, a szabadalomról szóló 1995. évi XXXIII. törvény a hasznosítás elmulasztása miatt, illetve a szabadalmak függősége miatt teszi lehetővé a megadását. A törvény mindkét esetben azt a feltételt támasztja egyébként az engedély megadásához, hogy a szabadalmas megfelelö feltételek mellett ésszerü időn belül sem volt hajlandó engedélyt adni, és a kényszerengedélyt kérő a találmányt megfelelő mértékben hasznosítani tudja [33. § (1) bek.].

95 Érdekes módon a nemzeti jogoknak a nemzetközi és uniós sztenderdeknek való megfelelését szokás vizsgálni. Olyan átfogó elemzésről nem tudunk, amely az uniós szerzői jogban előírt közös jogkezelésnek a BUE-hoz való viszonyát vizsgálná. AXHAMN (2013) p. 179-180.

${ }^{96}$ A BUE elemzésénél egyrészt az egyezményt Magyarországon kihirdető jogszabályt (1975. évi 4. törvényerejű rendelet) vettük figyelembe. Másrészt pedig a WIPO honlapjáról elérhető francia nyelvü szövegváltozatot. Franciaország alapvetően a monizmus elvét követi, így a nemzetközi szerződéseknek nincsen külön kihirdető jogszabályuk. Ezt az Alkotmány is deklrálja 55. cikkében: „Les traités ou accords régulièrement ratifiés ou approuvés ont, dès leur publication, une autorité supérieure à celle des lois, sous réserve, pour chaque accord ou traité, de son application par l'autre partie." DuPUY KERBRAT (2014) p. 454-455.

${ }^{97}$ GOLDSTEIN - HUGENHOLTZ (2013) p. 372.

${ }^{98}$ Ilyen például a BUE 10. cikk (1) bekezdésében biztosított idézés.
} 
helyeken pedig lehetőséget biztosít az unióban részes államok számára ilyen korlátozások bevezetésére. ${ }^{99}$

Ez a megközelítési mód nem ismeretlen az uniós jogban sem, mivel hasonló technikával él a Bérlet-irányelv is a nyilvános haszonkölcsönzési jog vonatkozásában. ${ }^{100} \mathrm{~A}$ nyilvános haszonkölcsönzés joga egy nemzetközi szerzői jogi egyezmények által külön nem nevesített, nem elismert kizárólagos jog, amelyet a tagállamok az irányelv elöírásai alapján kötelesek biztosítani. ${ }^{101}$ Tekintettel viszont arra, hogy a haszonkölcsönzési jog ezer szállal kötődik a nemzeti kultúrpolitikához, maga az irányelv teszi lehetővé azt, hogy a jogot ne engedélyezési jogként, hanem díjigényként implementálják a tagállami szerzői jogok. ${ }^{102}$ Általános értelemben véve az InfoSocirányelv is ezt a jogtechnikai megoldást alkalmazza. Egy gyakorlatilag zárt (a de minimis kivétel ${ }^{103}$ miatt mégsem az) listát tartalmaz, amely bár arra hivatott, hogy az analóg világban létező kivételeket átültesse a digitális korba, ${ }^{104}$ nem tesz mást, mint összefoglalja a tagállamokban létező kivételeket, mintegy pillanatfelvételt adva a 20. század végére kialakult korlátozásformáknak. ${ }^{105}$ A nemzeti szerzői jogokba a felsoroltakon túli kivételek bevezetése emiatt nem felel meg az uniós jog előírásainak. Részben elörebocsátva tehát a dolgozat konklúzióját, ebből az következik, hogy a közös jogkezelés kivétellé vagy korlátozássá minősítése megsértené az irányelvből fakadó tagállami kötelezettségeket. Ez tehát egy jelentős formai érv a jogtudományban a két kategória különválasztására, amely merev elválasztás feloldására törekszünk a dolgozatban.

A törvény által elöírt közös jogkezelés esetében tehát mindenekelőtt azt kell megvizsgálni, hogy megfelelnek-e ezeknek, az egyes vagyoni jogok esetében

\footnotetext{
99 A BUE 10. cikk (2) bekezdése az oktatási célú felhasználásokról például egy ilyen felhatalmazást tartalmaz.

${ }^{100}$ Bérlet-irányelv, 6. cikk (1) bek.

${ }^{101}$ A nyilvános haszonkölcsönzési jog eredőjeként a bérleti jog viszont a TRIPS-egyezmény, a WCT és a WPPT, Pekingi Egyezményben is biztosított.

${ }^{102}$ Elemzését lásd a III. rész II. fejezetében.

103 A rendelkezés InfoSoc-irányelv 5. cikk (3) bekezdésének o) pontjában található az alábbi megfogalmazásban: „más kisebb jelentőségü felhasználás, amennyiben a nemzeti jogban már léteznek kivételek, illetve korlátozások, feltéve, hogy azok kizárólag analóg felhasználásra vonatkoznak, és nem érintik az áruk és szolgáltatások Közösségen belüli szabad mozgását, az e cikkben szereplö egyéb kivételek és korlátozások sérelme nélkül."

104 TREPPOZ (2010) p. 7.

$105 \mathrm{Az}$ irányelvet a megközelítés miatt sok kritika érte, mivel nem biztosítja a rendszer kellő rugalmasságát a technológiai változások miatti új igények kielégítésére. A helyzetet pedig a lista további bővítése nem oldaná meg. JANSSENS (2009) p. 337.
} 
megengedett korlátozásoknak. Tágabban véve a korlátozások fogalmát, elemezni kell annak a lehetőségét is, hogy a kötelező közös jogkezelés nem megengedett alakszerüségi követelménynek minősül-e, illetve, hogy megfelel-e az egyezményben foglalt egyenlő elbánás elvének.

Az első kérdés, hogy a törvény által elöírt közös jogkezelés tekinthetö-e a BUE 5. cikk (2) bekezdésében foglalt alakszerüségi kritériumnak. Ez a cikk kimondja azt, hogy a szerzők részére biztosított jogok élvezete és gyakorlása nincs kötve semmiféle alakszerüséghez és független attól, hogy a mü a származásának országában védelem alatt áll-e. Az alakszerüség a BUE szóhasználatában annyit tesz, hogy ez a jog érvényességéhez szükséges feltétel, amelyek tipikusan olyan adminisztratív követelmények elöírásában testesül meg, amelyek nem teljesítése esetén a szerző elesik az öt megillető jogoktól, vagy a védelemtől. Azt azonban maga a BUE kommentárja is elismeri, hogy ezeknek a feltételeknek a jogok keletkezését kell befolyásolniuk, és nem érintik a jogok gyakorlása kapcsán elöírt feltételeket. ${ }^{106}$ Ennélfogva általánosságban elmondható, hogy a törvény által elöírt közös jogkezelést, mivel a jog fennállását nem érinti, nem lehet a BUE által előírt alakszerűségi követelménynek tekinteni.

A BUE néhány vagyoni jog esetében lehetővé teszi, hogy a jog gyakorlásának módjára nézve a részes államok feltéteket támasszanak, amely tipikusan a közös jogkezelés bevezetésében manifesztálódik. Ilyen a BUE 11bis cikk (1) bekezdésében biztosított sugárzási, és ehhez kötődő egyéb jogok tekintetében a joggyakorlás feltételeinek megszabására vonatkozó lehetőség biztosítása a cikk (2) bekezdésében. Másrészt pedig a 14ter cikkben foglalt követő jog, vagy közismert francia nevén a droit de suite esetében teszi lehetővé azt, hogy a szerzőt megillető díjazás mértékét és beszedésének módját a részes államok maguk határozzák meg. Harmadrészt pedig a mechanikai többszörözés esetében a BUE 13. cikk (1) bekezdése biztosítja fenntartások és feltételek bevezetését. Ilyen esetekben tehát a jogok gyakorlásának korlátozását maga a nemzetközi egyezmény biztosítja, a kérdés vizsgálata tehát elsősorban arra vonatkozik, hogy a jogalkotó ezt milyen mértékben írja elö. Ehhez hozzá kell füzni azt is, hogy a jogok korlátozásának biztosítását uniós dokumentumokban is megtalálhatjuk, részben élve a BUE által biztosított lehetőséggel, részben pedig azon túlterjeszkedve, szigorúbb feltételeket állítva. Így a Műhold-irányelv előírja a tagállamok számára a

${ }^{106}$ MASOUYÉ (1978) p. 35. 
rádió-és televízió-szervezet jogának kivételével a vezetékes továbbközvetítési jog kötelező közös jogkezelés körében történő gyakorlásának bevezetését. ${ }^{107}$ A követő jog tekintetében a Követő jog irányelv lehetőséget biztosít a közös joggyakorlás előírására. ${ }^{108}$ Ennek megfelelően tehát az egyes vagyoni jogok elemzésénél részletesen kitérünk majd a BUE-ban foglalt keretekre, és azok nemzeti megjelenési formáira.

A nemzeti elbánás elve a harmadik olyan tágabb értelemben vett korlát, amelyet a közös jogkezelés tekintetében figyelembe kell venni, mind a BUE, mind pedig az uniós jog által támasztott követelmények szerint. A közös jogkezelés (kifejezetten pedig a kiterjesztett hatályú közös jogkezelés) természeténél fogva kiindulópontja az ilyen irányú vizsgálódásoknak. A tömeges felhasználások ugyanis jellemzően nem válogatnak a szerző nemzetisége szerint, másik oldalról pedig a külföldi szerzőknek is biztosítani kell a belföldiekkel azonos elbánást.

A szerzői jogok korlátozhatóságának kereteit (általánosságban véve) ${ }^{109}$ a háromlépcsős teszt jelöli ki. A BUE a többszörözés joga kapcsán teszi általános mércévé a tesztet ${ }^{110}$ azáltal, hogy speciális kivételek helyett azokat a szabályokat rögzíti, amelyek mentén a kitárólagos jog korlátozható. ${ }^{111}$ Az előírást később a többi nemzetközi szerzői jogi egyezmény is átvette, illetve különleges helyet foglal el az InfoSoc-irányelv korlátozási rendszerében is. ${ }^{112}$ Alkalmazási köre így fokozatosan bővülve mára valóban a korlátozások bevezetésének viszonyítási pontjává tette. Bár az egyes szövegváltozatok között akadnak eltérések, a teszt lényege minden esetben abban áll, hogy a kizárólagos jogok korlátozásának különleges esetekre kell vonatkoznia, nem lehet sérelmes a mü rendes felhasználására és indokolatlanul nem károsíthatja a szerző jogos érdekeit. A közös jogkezeléssel összefüggésben a teszt alkalmazása két szempontból bír jelentőséggel. A legkézenfekvőbb azokban az esetekben, amikor a jogalkotó díjigénnyé szorítja le a kizárólagos jogot, és a díjigény kezelését pedig közös

\footnotetext{
${ }^{107}$ Ennek elemzését lásd a II. rész I. fejezetében.

${ }^{108}$ Elemzését lásd a III. rész II. fejezetében.

${ }^{109}$ A megfogalmazás generális, a teszt napjainkban a nemzeti szerzői jogkokban betöltött szerepére utal. Az egyes szövegváltozatainak elemzését, a szerepének változását részletesen a II. rész II. fejezetében ismertetjük.

${ }^{110}$ BUE 9. cikk (2) bek.

${ }^{111}$ FICSOR (2002) p. 280

112 Lásd: InfoSoc-irányelv 5. cikk (5) bek. A teszt különböző szövegváltozatokban és funkciókban szerepel egyébként több más, szerzői joggal kapcsolatos irányelv szövegében is, lásd: Szoftver-irányelv 6. cikk (3) bek., Bérlet-irányelv 10. cikk (3) bek., Adatbázis-irányelv 6. cikk (3) bek., Árva mü-irányelv (20) preambulumbekezdés. A teszt az Infosoc-irányelvben érintett vagyoni jogokra vonatkozó horizontális jellege miatt jut kiemelt szerephez. GYENGE (2010) p. 108-145.
} 
jogkezelő szervezetekre bízza. Ez történik tipikusan a magáncélú másolatokra tekintettel fizetett díjak esetében. ${ }^{113}$ Másrészt pedig a teszt alkalmazása indokolt lehet azokban az esetekben, ahol a nemzetközi és uniós jogi dokumentumok nem utalnak a jog gyakorlása módjának meghatározására, viszont a nemzeti jogalkotó mégis a közös jogkezelés előírásáról határozott. Ezért ezeknek a törvényi előírásoknak a teszttel való összhangjának vizsgálata elengedhetetlen a kilépést engedő és kiterjesztett közös jogkezelési esetekben. ${ }^{114}$ Mindezt a vizsgálatot természetesen annak tudatában érdemes elvégezni, hogy az engedélyezési jogok kötelező közös kezelése (elvi szinten legalábbis) kevésbé hátrányos a szerzői jog bevett elveire, hiszen a jog magva érintetlen marad, többnyire csak a gyakorlásának módjában jelent változást. Ebben a megközelítésben tehát a (kötelező) közös jogkezelés egyfajta köztes területet jelent az egyénileg kezelt engedélyezési jogok és a korlátozások között, és mint ilyen, elsőbbséget kell élveznie a korlátozásokkal szemben. ${ }^{115}$ Ahogyan viszont jelen dolgozat is tükrözi, sok esetben a kötelező közös jogkezelés éppen a kizárólagos jog korlátjaként meghatározott díjazási igényhez kötődik, a szerzői jog három nagy pillérének ${ }^{116}$ összefonódása, és a közöttük lévő viszony meghatározása indokolt.

\footnotetext{
${ }^{113}$ Elemzését lásd a II. rész II. fejezetében.

${ }^{114}$ Elemzését lásd a III. rész I. fejezetében.

115 AXHAMN (2013) p. 185-186.

${ }^{116}$ REINBOTHE (2002).
} 


\section{II. fejezet A közös jogkezelés fogalma és szervezeti háttere}

A közös jogkezelés, a korlátozásokhoz hasonlóan, ezer szállal kötődik a különböző kulturális, oktatási és szociális célok megvalósításához, illetve a szervezetek létrehozásával, müködésével és felügyeletével kapcsolatos nemzeti szabályokhoz. Emiatt nem egyszerü feladat a közös jogkezelési tevékenység nemzetközi harmonizációja sem. Nem meglepő tehát, hogy nincsen a közös jogkezelésre vonatkozó egyezmény, illetve az sem, hogy a KJK-irányelv elfogadását is hosszas előkészítő munka előzte meg. Ezek a felfogásbeli, illetve a szervezeti kérdésekben megjelenő különbségek önmagukban is a korlátozásokkal kapcsolatos választást hordoznak, hiszen a kollektivizáció mértékének és módjának meghatározásában a jogalkotói beavatkozás megmutatja, hogy a jogalkotó mekkora teret enged a jogosultak rendelkezési jogának közös jogkezelés keretében történő megvalósítására.

Mivel a dolgozat tárgya a közös jogkezelés vizsgálata, ezért nélkülözhetetlennek tartjuk azonosítani azokat a tevékenységi köröket, illetve tipizálási szempontokat, amelyek meghatározóak a közös jogkezelés szempontjából (1. fejezet). Másrészt pedig röviden utalni kell a szervezeti felépítés különbözőségeire, ez ugyanis hatással lehet az egyes jogok gyakorlásának ilyen módon történő gyakorlására is (2. fejezet).

\section{A közös jogkezelés fogalma}

A közös jogkezelésnek nincsen általánosan elfogadott, jogi kötőerővel rendelkező fogalma nemzetközi dokumentumokban. Az sem magától értetődő, hogy a nemzeti szerzői jogi törvénynek egyébként tartalmaznia kell-e egy ilyen definíciót, vagy, hogy milyen elnevezéssel kell illetni a közös jogkezelést. (§1. pont). A jogtudomány viszont igyekezett a tevékenység leglényegesebb elemeit összefoglalni, és mind uniós, mind nemzeti szinten létezik elfogadott meghatározás (§2. pont).

\section{§1. A fogalom meghatározásának elutasítása}

A szerzői jog alanya, tárgya és tartalma kapcsán kialakított nemzetközi minimum sztenderdek ${ }^{117}$ elfogadása sem egyszerü az eltérő szerzői jogi rendszerek

${ }^{117}$ GYERTYÁNFY - FALUDI - KABAI - SZINGER - TÓTH (2004) p. 707. 
közös gyökerei azonosításának nehézségei miatt, ${ }^{118}$ ez hatványozottan érvényes a közös jogkezelés területére. A WIPO berkein belül az 1970-es évektől kezdve folyamatosan napirenden volt a témakör vizsgálata, ezek a tárgyalások azonban nem jutottak túl az előkészítés fázisán. Az előkészítő dokumentumok viszont hasznos segítséget nyújtanak a közös jogkezelés általános jellemzőinek megállapításához. ${ }^{119}$

Hasonlóképpen a CPI sem tartalmaz jogi kötőerővel rendelkező meghatározást. A kódex még a közös jogkezelés, közös jogkezelő szervezet kifejezéseket sem használja, helyette a ,jogdíjak beszedésével és felosztásával foglalkozó társaságok” (sociétés de perception et de répartition des droits) címü fejezetben tartalmazza a társaságokra vonatkozó általános szabályokat. A kifejezés ugyan pontos, mivel tartalmazza a közös jogkezelési tevékenység legfontosabb elemeit, viszont torzítóan szükítő értelmü is. Nem veszi figyelembe azokat az egyéb feladatokat (pl. a szociális és kulturális tevékenységet, a kötegben való engedélyezést és a kollektív, normatív felosztást), amelyek megkülönböztetik a közös jogkezelő szervezeteket a jogkezelést egyéb, üzleti alapon megvalósító szervezetektől. ${ }^{120}$ A definíció hiánya viszont beleillik abba a koncepcióba, amely a közös jogkezelést egy szerződéses konstrukcióként fogja fel. Ilyen értelemben véve a törvénynek valóban nincsen más szerepe azon túl, hogy az ellátott tevékenység központi tartalmi elemeit meghatározza, a jogosultak döntési szabadsága körébe utalva azt, hogy ezen kívül milyen egyéb tevékenységek közös végzésére szerződnek.

A CPI másik következetlensége, hogy a ,jogdíjak beszedésével és felosztásával foglalkozó társaságok” kifejezés mellett használja a „szerzők szakmai szervezetei”121 kifejezést is, amely az 1957. évi szerzői jogi törvényben bukkant fel, mintegy a közös jogkezelés előzményeként. ${ }^{122} \mathrm{~A}$ jogtudomány álláspontja, hogy a két kifejezés a konkrét rendelkezés kapcsán azonos szervezetet, a közös jogkezelő szervezeteket jelöli. ${ }^{123}$ Ezzel

\footnotetext{
${ }^{118}$ Ezekről a közös alapelvekről lásd: COLOMBET (1992).

${ }^{119}$ FICSOR (2002) p. 25-36.

${ }^{120}$ Mint ahogyan később ismertetésre kerül, ez az elhatárolás a KJK-irányelv lényeges részét is képezi.

121 Lásd pl. CPI L. 132-18. cikk, amely az általános előadási szerződések (contrats généraux de représentation) megkötésének módjáról rendelkezik.

122 1957. évi szerzői jogi törvény 43. cikk.

${ }^{123}$ SCHMIDT (1971).
} 
szemben viszont a jogsértéssel szembeni fellépések kapcsán a CPI határozottan különbséget tesz a két szervezet között. ${ }^{124}$

A fogalmi elemek körülírásának szükségessége tehát alapvetően a jogtudományban vetődött fel azért, hogy a tevékenységet tudományosan elfogadott módszerekkel vizsgálni lehessen.

\section{§2. A definíció megalkotása}

A tudományos szempontokon túl bizonyos esetekben a tételes jogban is szükséges rögzíteni a tevékenység alapjait. Bár nemzetközi szinten nehéz a közös viszonyítási pontokat megtalálni, regionális szinten ez sikeresebb feladat lehet, amit a KJK-irányelv közelmúltbeli elfogadása is bizonyít. Az sem elképzelhetetlen, hogy a közös jogkezelés fogalmát nemzeti szerzői jogi törvénybe foglalja a jogalkotó, ahogyan azt a magyar példa mutatja.

\section{A) Jogforrásokban}

A harmonizáció egyik legfontosabb eleme annak biztosítása, hogy a fogalmakat azonos jelentéssel ruházzuk fel. Ennek fényében érthető az, hogy uniós jogforrásokban miért szükséges mégis a közös jogkezelés definiálása. Az uniós jogalkotó a szerzői jogi harmonizáció ${ }^{125}$ során felismerte, hogy bizonyos részkérdések rendezésénél a közös jogkezelés is felmerülhet, a tevékenység ugyanis mélyen gyökerezik a tagállami szerzői jogokban, és bizonyos esetekben, a technológiai fejlődés eredményeként hatást gyakorol a belső piac müködésére (pl. a televíziós adások határokon átnyúló közvetítése esetén). Ezek a szabályok azonban csak elszórtan jelentek meg az elfogadott irányelvekben, a közös jogkezelésre vonatkozó uniós elvek kimunkálásának terepe hosszú éveken keresztül a Bizottság és a Bíróság volt, majd pedig soft law jellegü dokumentumokban találhattuk meg a jogintézményre vonatkozó legfontosabb elveket. Ezek azonban a szervezetek felépítésére vagy az általuk végzett tevékenységre vonatkozó átfogó jellegü meghatározást nem adtak, többnyire a multiterritoriális engedélyezés kérdésével foglalkoztak annak belső piacra gyakorolt

\footnotetext{
${ }^{124}$ NÉRISSON (2013) p. 356. Lásd a CPI L. 331-2. és L. 331-24. cikkeit.

${ }^{125} \mathrm{Az}$ uniós szerzői jogi harmonizáció folyamata önmagában is egy monográfia tárgyát képez(het)i. A témában megjelent magyar tanulmányok közül lásd pl. GYERTYÁNFY (1991a-c), GYERTYÁNFY (2002) p. 271-283. BOYTHA (2003) p. 335-438. Francia nyelven pedig: BÉNABOU (1998). BÉCOURT (1995b-d).
} 
közvetlen hatása miatt. A dokumentumok, ${ }^{126}$ bár kísérletet tesznek a közös jogkezelés meghatározására is, jellemzően a közös jogkezelés formai definícióját tartalmazzák: közös jogkezelésnek tekintenek minden olyan tevékenységet, amelyet az uniós jog alapján közös jogkezelő szervezetnek minősíthető szervezet végez. Éppen ezért a legtöbb általános meghatározás a közös jogkezelő szervezet fogalmát igyekszik tisztázni, a közös jogkezelési tevékenység egyes elemei pedig adott esetben csak utalás szintjén történnek meg.

A KJK-irányelv az első olyan jogforrás, amelyben a közös jogkezelés nem csak érintőlegesen jut szerephez. Az irányelv a közös jogkezelés fogalmának meghatározásával kapcsolatban nem tér el jelentősen a korábbi dokumentumoktól: a meghatározás a közös jogkezelő szervezet fogalmának leírására terjed ki, anélkül, hogy a közös jogkezelési tevékenység meghatározó tartalmi elemeire nézve lényegi eligazítást adna - azon túl persze, hogy a közös jogkezelő szervezet kezeli a szerzői és szomszédos jogi jogokat. Az irányelv alkalmazásában közös jogkezelő szervezet minden olyan szervezet, amely egynél több jogosult érdekében és közös javára kizárólagos vagy fő céljaként szerzői és szomszédos jogokat kezel jogszabály, jog, átruházás, felhasználási engedély vagy más szerződéses megállapodás alapján, és amely

\footnotetext{
${ }^{126} \mathrm{Az}$ alábbi irányelvek tartalmaznak elszórtan rendelkezéseket a közös jogkezelésre vonatkozóan: Mühold-irányelv 1. cikk (4) bekezdés, 13. cikk; Bérleti irányelv 5. cikk; Követő jogi irányelv 6. cikk. A területet érintő előkészítő és soft law jellegü dokumentumok közül pedig az alábbiak a legfontosabbak: Livre Vert Le droit d'auteur et les droits voisins dans la Société de l'Information, COM(95) 382 final, le 09 juillet 1995; Follow-Up to the Green Paper on copyright and related rights in the Information Society, Communication from the Commission, 20 November 1996; Rapport du Parlement européen sur un cadre communautaire pour les sociétés de gestion collective du droit d'auteur, A5-0478/2003, le 11 décembre 2003; Proposition de résolution du Parlement européen sur un cadre communautaire pour les sociétés de gestion collective du droit d'auteur (2002/2274(INI)), le 11 décembre 2003; Communication de la Commission au Conseil, au Parlement européen et au Comité économique et social européen - La gestion du droit d'auteur et des droits voisins au sein du marché intérieur COM(2004) 261 final, 16 avril 2004; Commission Staff Working Document: Study on a Community Initiative on the Cross-border Collective Management of Copyright, 07/07/2005; Parlement européen Commission des affaires juridiques, Document de travail sur la recommandation de la Commission du 18 octobre 2005 relative à la gestion collective transfrontière du droit d'auteur et des droits voisins dans le domaine des services licites de musique en ligne, 23/08/2006; Rapport du Parlement européen sur la recommandation de la Commission du 18 octobre 2005 relative à la gestion collective transfrontière du droit d'auteur et des droits voisins dans le domaine des services licites de musique en ligne (2005/737/CE), A6-0053/2007 final; 2005/737/CE Recommandation de la Commission du 18 mai 2005 relative à la gestion transfrontière du droit d'auteur et des droits voisins dans le domaine des services licites de musique en ligne. Az ajánlást követő legfontosabb hatástanulmányok, egyéb dokumentumok az alábbiak: European Commission Monitoring of the 2005 Online Recommendation, Communication de la Commission au Parlement européen, au Conseil, au Comité économique et social européen et au Comité des régions sur les contenus créatifs en ligne dans le marché unique, $\operatorname{COM(2007)} 836$ final; Résolution du Parlement européen du 25 septembre 2008 sur la gestion collective transfrontière du droit d'auteur et des droits voisins dans le domaine des services licites de musique en ligne, P6_TA(2008)0462.
} 
legalább tagjai tulajdonában vagy ellenőrzése alatt áll, vagy nonprofit szervezetként müködik. ${ }^{127}$ Természetesen az irányelv értelmében mindkét utóbbi feltételt teljesítő szervezet is közös jogkezelő szervezetnek minősül. ${ }^{128}$

A közös jogkezelési tevékenység egzakt meghatározásának hiányában is az irányelv azon rendelkezéseiből, amelyek a közös jogkezelő szervezetek müködésére, illetve felügyeletére vonatkoznak, ${ }^{129}$ leszürhető, hogy az uniós jogalkotó mit tekint a közös jogkezelési tevékenység föbb tartalmi elemeinek. A közös jogkezelő szervezet ezek alapján bármely honosságú jogosult által megválasztott vagyoni jog gyakorlását végzi az adott tagállami jog alapján biztosított jogcímmel szerzett képviseleti jog alapján, illetve kölcsönös képviseleti szerződések révén képviseli a külföldi jogosultakat is. Ennek érdekében demokratikus döntéshozatali rend alapján a szervezet meghatározza és hozzáférhetővé teszi a felhasználás és a díjfizetés feltételeit, valamint a beszedett jogdíjak felosztásának rendjét, ideértve a kezelési költségekről, és az egyéb, kulturális, szociális és oktatási célú levonásokról való rendelkezést is. A definíció nem utal viszont a közös jogkezelési tevékenység legfontosabb tartalmi elemeire, vagyis a kötegben való engedélyezésre, a normatív felosztásra és a jogkezelés díjának (költségeinek) tulajdonosi meghatározására.

Az irányelv tehát láthatóan törekszik a tevékenységek minél átfogóbb meghatározására. A KJK szervezet a kizárólagos jogok és díjigények gyakorlását végzi,

\footnotetext{
${ }^{127}$ KJK-irányelv, 3. cikk. a) pont. Az irányelvnek a Hivatalos Lapban megjelent magyar nyelvủ változatát használtuk a dolgozat elkészítésekor. Megjegyezzük azonban, hogy a magyar fordítás nem mindenhol alkalmaz szabatos kifejezéseket. Az újrafordítástól azonban eltekintünk azon oknál fogva, hogy nem az irányelv elemzése képezi a dolgozat tárgyát.

${ }_{128}$ Kiemelendő, hogy az irányelv egyes rendelkezései a független jogkezelő szervezetekre is vonatkoznak. Ezek alapvetően olyan szervezetek, amelyek szerzői vagy szomszédos jogokat kezelnek, azonban profitorientált módon müködnek, és nem állnak a jogosultak közvetett vagy közvetlen tulajdonában vagy ellenőrzése alatt. (3. cikk b) pont) Mivel azonban ezek nem tartoznak a közös jogkezelés klasszikus értelemben vett fogalma alá, tevékenységük elemzésétől ehelyütt eltekintünk. Azt azonban meg kell jegyezni, hogy a definíció beépítése az irányelvbe is azt mutatja, hogy a szerzői és szomszédos jogok gyakorlását nem csak a klasszikus értelemben vett közös jogkezelő szervezetek végezhetik. A közös jogkezelés ennél sokkal tágabb értelemben is felfogható, amennyiben ide tartozónak tekintjük mindazokat a szervezeteket, akik repertoárok kezelését végzik. A legfontosabb elhatárolási szempontokat az irányelv is felsorolja: ezek a szervezetek ugyanis jellemzöen profitorientált tevékenységet végeznek, és a jogosultak és a szervezet között teljesen más jellegü jogviszony fedezhető fel, mint a klasszikus értelembe vett közös jogkezelö szervezetek esetében: a jogosultak ugyanis ezekben az eseteken nem rendelkeznek a szervezet müködésére olyan befolyással, mint amit egyébként a tagsági, tulajdonosi jogosultság biztosít számukra a közös jogkezelő szervezetekben. További különbséget jelent, hogy ezek a szervezetek jellemzően nem látnak el olyan kulturális, szociális, és oktató tevékenységet, mint amit a klasszikus értelemben vett közös jogkezelő szervezetek igen. Ezeket a szervezeteket FICSOR sem tekinti a közös jogkezelés körébe tartozó szervezeteknek. FICSOR (2002) p. 16.

${ }^{129}$ KJK-irányelv 5-22. cikkek.
} 
ehhez kötődően monitorozza a felhasználásokat és fellép a szerzői jog olyan tömeges megsértése ellen, amely a repertoárjába tartozó müvek és teljesítmények engedély nélküli vagy „alulengedélyezett” felhasználásában, díjigény esetén a díj meg nem fizetésében vagy az adatszolgáltatás elmulasztásában áll. A szakirodalom a szerzői jogi jogalkotásban, illetve a szerzői jogi ismeretek közvetítésében végzett szerepüket is elismeri csakúgy, mint a jogosultaknak biztosított jogsegély-szolgáltatást. ${ }^{130}$ Mivel ezen utóbbi tevékenységek lazábban kapcsolódnak a közös jogkezelő szervezetek klasszikus feladataihoz, és a digitális belső piac működését ezek a kiegészítő tevékenységek nem befolyásolják, nem meglepő, hogy az irányelv nem tartalmaz ezek harmonizációjára vonatkozó rendelkezéseket. Nem elvitatva a közös jogkezelő szervezetek tagállami kultúrpolitikában játszott szerepét, azt is figyelembe kell venni, hogy a közös jogkezelés nem elsősorban kultúrpolitikai eszköz, ${ }^{131}$ az uniós harmonizáció tehát értelemszerüen a tevékenység szűk keresztmetszetére terjedhet csak ki, annak ellenére, hogy maga a KJK-irányelv is hivatkozik az EUMSZ kultúrára vonatkozó 167. cikkére. ${ }^{132} \mathrm{~A}$ harmonizációs célokból adódó tág fogalom viszont a jogszabály tagállami átültetése során nehézségekbe ütközhet, ahogyan azt az SZTNH által nyilvánosságra hozott részletes koncepció is tükrözi. Azok a tagállamok, így köztük Magyarország, ahol az irányelvben foglaltnál szorosabb fogalmi keretek közé szorítják a közös jogkezelést, joggal tarthatnak a tevékenység felhígulásától a tágabb fogalom átvételével. ${ }^{133}$

Nemzeti jogszabályokban is előfordulhat a közös jogkezelés definiálása, az Szjt. például a francia kódexszel ellentétben tartalmazza a közös jogkezelés definícióját. Ez alapján „közös jogkezelés a felhasználás jellege, illetve körülményei miatt egyedileg nem gyakorolható szerzői jogok és a szerzői joghoz kapcsolódó ilyen jogok

\footnotetext{
${ }^{130}$ GYERTYÁNFY (2005-2006) p. 73-74.

${ }^{131}$ GYENGE (2008) p. 198 A közös jogkezelő szervezetek kultúrpolitikai szerepét más megvilágításba helyezheti az, hogy a KJK-irányelv az zenei jogok online kezelése kapcsán az európai kulturális sokszínűség ellen hat. DIETZ (2014) p. 237-249. Hasonló folyamat figyelhető meg egyébként a könyvtári haszonkölcsönzési jog tekintetében a Bizottság által indított kötelezettségszegési eljárások kapcsán. Bár a Bizottság alapvetően egyes skandináv államok diszkriminatív gyakorlatát vitatta a díjazás felosztása kapcsán, a célzottan nemzeti kultúrát támogató felosztási rendszer teljes eltörlése szintén a kulturális sokszínüség ellen hat.

${ }^{132}$ KJK-irányelv (3) preambulumbekezdés.

${ }^{133}$ Szellemi Tulajdon Nemzeti Hivatala Részletes koncepció a szerzői és szomszédos jogokra vonatkozó közös jogkezelésről és a zeneművek belső piacon történő online felhasználásának több területre kiterjedő hatályú engedélyezéséröl szóló 2014/26/EU irányelv átültetéséhez megalkotandó magyar jogi szabályozás föbb tartalmi kérdéseivel kapcsolatban, (http://www.sztnh.gov.hu/sites/default/files/20150710_kjk_ire_reszletes_atultetesi_koncepcio_konzultaci ora_0.pdf), p. 4-6.
} 
érvényesitése a jogosultak által erre létrehozott szervezet útján, függetlenül attól, hogy azt a törvény írja elö vagy az a jogosultak elhatározásán alapul."134

A meghatározást talán szerencsésebb lett volna úgy megfogalmazni, hogy egyedileg nehezen (vagy tipikus esetben egyedileg nem) gyakorolható jogok tartoznak a közös jogkezelés alá, hiszen így a hatályos megfogalmazás nyelvtani értelmezéséből az következik, hogy azokban az esetekben, ahol a jogalkotó vagy a jogosultak a jogok közös jogkezelés útján történő gyakorlásáról rendelkezett, az egyéni joggyakorlásra nincsen tovább mód. A hatályos törvényi rendelkezés ugyanis látszólag a jogosultaknak azt az önkéntes elhatározását, szabad belátását kérdőjelezi meg, amelyek alapján jogaikat közös jogkezelő szervezet útján kívánják gyakorolni. Az egyesülési jog szabadságánál fogva a jogosult főszabály szerint maga dönthet arról, hogy tagként csatlakozni kíván-e a közös jogkezelő szervezethez vagy egyébként megbízást ad a képviseletre; vagy ebböl teljesen kimaradva egyénileg gyakorolná rendelkezési jogát. A tételes jogi rendelkezések szintjére konkretizálva ez a törvény által elöírt, kilépést engedő közös jogkezelés megalapozottságának megkérdőjelezését is jelenti. Ennek a konstrukciónak ugyanis, a nevéböl is adódóan, az egyik legfontosabb eleme a jogosult számára biztosított azon lehetőség, amely alapján írásbeli nyilatkozatával kiléphet a közös jogkezelés alól. ${ }^{135} \mathrm{Az}$ általános definíciót figyelembe véve viszont erre sem lenne lehetősége a jogosultnak, mivel az az egyedileg nem gyakorolható jogokat általánosságban tekinti közös jogkezelés alá tartozónak. ${ }^{136}$

A törvényi rendelkezés ezen kívül utal arra is, hogy mit tekint a közös jogkezelési tevékenység tartalmi elemeinek. Nevezetesen a felhasználás engedélyezése vagy a díjigény érvényesítése érdekében a közös jogkezelő szervezet megállapítja a jogdíjakat és a felhasználás egyéb feltételeit; figyelemmel kíséri a müvek és kapcsolódó jogi teljesítmények felhasználását; beszedi és felosztja vagy felosztás céljára más közös jogkezelő szervezetnek átadja a jogdíjakat; valamint fellép a szerzői jog vagy kapcsolódó jog megsértésével szemben. ${ }^{137}$ Az Szjt. 2011. évi módosítása ${ }^{138}$ nyilvánvalóvá teszi a közös jogkezelési tevékenység minimum elemeit is. A hatályos

\footnotetext{
${ }^{134}$ Szjt. $85 . \S$

${ }^{135}$ Lásd: Szjt. 87. § (3) bek.

${ }^{136}$ GRAD-GYENGE - SARKADY (2014) p. 115-116.

${ }^{137}$ Szjt. 85. §.

138 2011. évi CLXXIII. törvény a szellemi tulajdonra vonatkozó egyes törvények módosításáról.
} 
89. § értelmében ugyanis a közös jogkezelő szervezetnek legalább kétfajta tevékenységet kell ellátnia: egyrészt a jogdíjak és a felhasználás egyéb feltételeinek megállapítását (vagy az abban való részvételt), másrészt a jogdíjak felosztását (vagy ehelyett - a jogdíjak beszedését és felosztás céljára más közös jogkezelő szervezetnek történő átadását). Vagyis a magyar jogalkotó, hasonlóan ahhoz, ahogyan a CPI utal a szervezetekre, egy vázáig lecsupaszított definíciót tekint a közös jogkezelési tevékenység lényegének. Ehhez képest a müvek felhasználásának figyelemmel kísérése és a jogsértésekkel kapcsolatos fellépés úgy tünik, mintha csak másodlagos feladata lenne a közös jogkezelő szervezeteknek.

\section{B) A jogtudományban}

A jogszabályi definíció teljes hiányában, vagy annak szükszavúsága miatt a jogtudomány igyekszik egy általánosabb definíciót kimunkálni, vagy legalább törekedni arra, hogy a közös jogkezeléssel kapcsolatos legfontosabb ismérveket összegyüjtse. A francia jogirodalomban elfogadott, legtöbb helyen idézett definíciót Fabrice SIIRIAINEN alkotta meg. Ez alapján a közös jogkezelés egy jogi személy által végzett tevékenység, amelynek fó célja tagjainak vagy azok jogutódainak a szerzői és/vagy kapcsolódó jogainak kezelése az ő javukra. A jogkezelés szükség szerint a felhasználási feltételek meghatározásában és a felhasználási engedélyek megadásában, és a felhasználás ellenértékeként meghatározott díjazás ellenőrzésében, beszedésében, és felosztásában áll. A közös jogkezelő társaságok tagjai csak szerzők, előadóművészek, hangfelvételvagy videofelvétel-elöállítók, kiadók, vagy az ő jogutódaik lehetnek. A közös jogkezelés előmozdítja továbbá azon jogosultak személyhez füződő és vagyoni érdekeit, akiknek a jogaira a közös jogkezelés kiterjed, különösen kulturális, sőt, szociális tevékenység révén. ${ }^{139}$

A magunk részéről a közös jogkezelési tevékenységnek egy még általánosabb értelmet kívánunk tulajdonítani, ami kellően absztrakt ahhoz, hogy mind a francia, mind

\footnotetext{
139 „Il s'agit de l'activité d'une personne morale qui a pour objet principal l'exercice des droits d'auteur et/ou des droits voisins de ses membres ou d'ayants droit, pour le compte de ceux-ci-c'est-à-dire dans un cadre fiduciaire. L'exercice de ces droits consiste, le cas échéant, dans la fixation des conditions et délivrance des autorisations d'exploitation, dans le contrôle, la perception et la répartition des rémunérations dues en contrepartie de l'exploitation des droits. Les membres des sociétés de gestion collective sont obligatoirement des auteurs, des artistes-interprètes, des producteurs de phonogrammes ou de vidéogrammes, des éditeurs, ou leurs ayants droit. La gestion collective poursuit également la promotion des intérêts moraux et matériels de ceux dont les droits sont ainsi exercés, notamment dans le cadre d'une action culturelle, voire sociale." SIIRIAINEN (1999) p. 15.
} 
pedig a magyar szerzői jog elemzésekor alkalmazni lehessen. Vagyis a szerzői kizárólagos jogok és díjigényeknek a szerzők által erre a célra létrehozott szervezeteken keresztüli, ${ }^{140}$ a jogosultak javára történő (vagyis egyfajta speciális bizomány keretei között megvalósuló) közös kezelését értjük a fogalom alatt. A jogkezelés alapvetően közös, mert nem ügynöki rendszeren keresztül müködik, vagyis célja nem az, hogy az egyes szerzők egyes jogait kezelési költség fejében kezelje. Ráadásul a szervezet a tevékenységét a saját nevében, de a jogosultak javára végzi, amely miatt gyakorlatilag csak non-profit tevékenységként végezhető, a hatékonyság és átláthatóság kritériumainak figyelembevételével. Megjelenik a kollektivizáció, és bizonyos tekintetben a szociális érdek is, ugyanis a díjak felosztásáról a szervezet belső müködési szabályai szerint dönt, vagyis szükségképpen megjelenik valamilyen általánosítási, egységesítési faktor. Másrészt pedig ezeknek a díjaknak egy része a törvény értelmében vagy a jogosultak döntése alapján az ő javukra szociális és kulturális célra is felhasználható. A jogkezelés pedig kiterjed a díjazás mértékének, illetve a felhasználás egyéb feltételeinek meghatározására, a díjak beszedésére, felosztására, a kezelt jogok körében a jogérvényesítésre. Vagyis a klasszikus szerzői jogi jogkezelés körén kívül maradnak a közös jogkezelők által adott esetben ellátott egyéb tevékenységek, mint a szerzői jogi jogtudatosság előmozdítását segítő oktató tevékenység.

Mivel a közös jogkezelés sokszínű formában megjelenő tevékenységet takar, még a fogalmi elemek meghatározása mellett is felállíthatóak olyan kritériumok, amelyek a közös jogkezelés további tipizálása teszik lehetővé. ${ }^{141}$ Erre azért is szükség van, mert ezek a szerzői jog korlátozása meghatározásához is támpontot adnak azokban az esetekben, amikor a törvény elöírja az engedélyezési jogok gyakorlásának módját. Az első szempont a kollektivizáció mértéke, amely alapján három csoport különíthető el: a) közös képviselet, egyediesített engedélyezés, jogdíjak közvetlen felosztása b) teljes közös jogkezelés, általános jogosítás, a felosztás normatív alapon, korrekciós elvek mentén történik c) a jogok közös védelme, általános jogosítás, az egyéni jogosultak között nincsen felosztás. A kollektivizáció mértéke mind az engedélyezési jogok, mind a díjigények vonatkozásában jelentőséggel bírhat, ugyanis a törvény mindkét esetben tartalmazhat elöírásokat bizonyos összegek speciális elvek mentén

\footnotetext{
140 Megjegyzendő, hogy egyes díjigények gyakorlása esetén alapítványi, illetve állami beleszólású alapítványi konstrukciók is létezhetnek.

${ }^{141}$ FICSOR (1985) p. 299-300.
} 
történő felhasználására (pl. a kulturális és szociális célú felhasználások), amelyek természetszerüleg megtörik az egyéniesített jogdíjfelosztás elvét.

A jogosultak választási szabadsága szerint, vagyis a közös jogkezelés önkéntessége alapján szintén három csoportba sorolhatók a szervezetek. Ezek alapján a legszabadabb eset, amikor a jogosultak szabadon választhatnak, hogy egyénileg vagy csoportosan kívánják-e a jogaikat gyakorolni; ezt követi az az eset, amikor a törvény előírja a közös jogkezelést; a legszigorúbb pedig értelemszerüen az a verzió, amikor a törvény kijelöli azt az egyetlen szervezetet, amely jogosult az adott jog közös kezelésére. A törvény által elöírt közös jogkezelés megvalósítási formája szerint tehát ebbe a két utóbbi kategóriába tartozhat.

A közös jogkezelő szervezet és jogosultak viszonyának egy másik mutatója, a kiterjesztett közös jogkezelés elvének bemutatása. Ezek alapján az első eset, amikor a szervezet csak a tagjai jogait kezelheti, ezt követi az a megoldás, amelyben a törvényben kijelölt esetekben a szervezet tevékenysége kiterjed a nem tagok jogainak kezelésére is, ezek azonban kiléphetnek a közös jogkezelés alól. ${ }^{142}$ A harmadik esetet pedig a kilépést nem engedő kiterjesztett közös jogkezelés jelenti.

A negyedik tipizálási szempont pedig a közös jogkezelő szervezetnek a jogdíjak megállapítása kapcsán fellelhető szabadságára vonatkozik. A legszabadabb természetesen az, amelyben a felhasználási feltételek megállapítása szabad tárgyalások útján alakul ki, az ebből eredő vitákat pedig a bíróság dönti el. Megszorítást tartalmaz az olyan törvényi elöírás, amely ugyan meghagyja a szabad tárgyalás lehetőségét a jogosultaknak, ám a megállapodás alkalmazásának előfeltétele az illetékes hatóság általi jóváhagyás. A leginkább megszorító pedig az az értelmezés, amelyben a felhasználási feltételeket a jogalkotó szabja meg. Ez a gyakorlatban nehezen elképzelhető, általában díjigények esetén a fizetendő díj meghatározását, vagy a felhasználási szerződés díjfeltételét írja elő a jogalkotó.

A közös jogkezelés szervezeti hátterének leírásánál, illetve az egyes jogok gyakorlásának elemzésénél ezekre a szempontokra külön figyelmet fordítunk.

${ }^{142}$ Ennek megvalósítása a gyakorlatban történhet a kiterjesztett hatály vélelmének alkalmazásával [lásd. Szjt. 87. § (1) bek.], de ezzel azonos hatással bír, ha az engedélyezésre jogosult közös jogkezelő szervezet javára törvényi és/vagy bírói vélelem áll fenn, amely szerint a közös jogkezelő a nem csatlakozott jogosultakat is képviseli az ellenkező bizonyításáig. 


\section{A közös jogkezelés szervezeti háttere}

A dolgozatban a közös jogkezelö szervezetként hivatkozunk ezekre a társaságokra (Franciaország), illetve egyesületekre (Magyarország), tekintet nélkül arra, hogy egyébként milyen jogi formában müködnek, ${ }^{143}$ illetve hogy a törvény milyen névvel illeti őket. A szóhasználat indoka egyfelől a fentebb elemzett szükítő értelmezés elkerülése. Másrészt pedig annak feltételezése, hogy a társaság kifejezés használata a magyar nyelvü olvasó számára a közös jogkezelést végző egyesületek jogi formájáról félrevezető információval szolgáltatna. A szervezet szó viszont a magyar használatban kellően általános kifejezés ahhoz, hogy magába foglalja a jogi személyiséggel rendelkező polgári társasági formában (société civile) müködő francia közös jogkezelöket is. Másrészt pedig ez a magyar Szjt. bevett szóhasználata is, az egyesületre, mint jogi formára való kifejezett utalás a törvény 91-92. §-aiban található meg, a nyilvántartásba vétel egyes követelményeinek meghatározásánál. Ráadásul a nemzetközi terminológiában is a „,collective management organizations” az általánosan használt elnevezés, ${ }^{144}$ amely nem tartalmaz utalást a szervezetek jogi formájára.

Bár a dolgozat alapvetően nem a közös jogkezelő szervezetek jogi felépítését, az ezt meghatározó kereteket tartja elsődleges vizsgálati tárgyának, mégis fontosnak tartjuk röviden bemutatni, hogy a két vizsgált országban ezek hogyan valósulnak meg. Ennek oka egyfelől abban áll, hogy a törvény által elöírt közös jogkezelés minden esetben ezekre a már létező szervezeti struktúrákra települ rá. Másrészt pedig bizonyos esetekben szükség van arra, hogy a tag és a nem tag jogosultak jogállása közötti különbség megfelelően tisztázásra kerüljön, amelyhez elengedhetetlenek az alapvető strukturális ismeretek. Harmadrészt az sem elhanyagolható szempont, hogy a közös jogkezelés szervezeti felépítése, felügyelete kölcsönhatásban áll a közös jogkezelés jogintézményének természetéről vallott felfogással. Ez kitűnően megmutatkozik abban a kettősségben, hogy a francia szabályok a közös jogkezelés szerzödéses jellegére és önkéntességre helyezik a hangsúlyt, ennek megfelelően szigorúbb felügyeletet csak a

\footnotetext{
${ }^{143}$ A változatos jogi formákról, felügyeleti és müködési szabályokról egyébként több összehasonlító jellegü munka is született. Az egyik ilyen a francia Szenátus számára készített munkaanyag, amely hét állam (Németország, Dánia, Spanyolország, Olaszország, Hollandia, Egyesült Királyság, USA) megoldásait járja körül. La gestion collective des droits d'auteur et des droits voisins, Les documents de travail de Sénat, novembre 1997. A másik pedig a Daniel GERVAIS által szerkesztett kötet: GERVAIS, (2010).

${ }^{144}$ Ehhez lásd a WIPO honlapját. http://www.wipo.int/copyright/en/management/
} 
törvény által elöírt esetekben támaszt a jogalkotó. Ezzel szemben Magyarországon megfordult a kiindulási pont: a jogalkotó a tipikusan közös jogkezelés keretében gyakorolt jogokat valamilyen módon közös jogkezelés alá rendelte, így az önkéntes közös jogkezelés vált kivétellé. ${ }^{145}$ Ennek oka az Szjt. vagyoni jogok részletes, modern generálklauzulára, illetve az egyes jogok szabályozására épülő megoldásában keresendő. A jogalkotó az új Szjt. elfogadásakor a már korábban is közösen kezelt, és hagyományosan egyedileg nem gyakorolható jogokhoz a közös jogkezelés jól kialakult rendjének a privatizáció melletti megőrzése céljából rendelte ezt a joggyakorlási módot. Ehhez társul az is, hogy a nyilvántartásba vétel és a müködés tekintetében rendkívül részletes szabályokat állapított meg a jogalkotó. ${ }^{146}$

A francia kódexbe viszonylag későn, a törvénykönyv 1985. évi módosításával kerültek be a közös jogkezelés müködésére vonatkozó szabályok - ez különösen ahhoz képest tünik megkésettnek, hogy az első közös jogkezelő társaságok ebben az országban alakultak. A müködésre vonatkozó legjelentősebb reformot a müködésüket felügyelő állandó bizottság bevezetése jelentette az ezredfordulón, ${ }^{147}$ egyébként kisebb finomhangolásoktól eltekintve a rendszer lényege érintetlen maradt.

Magyarországon a közös jogkezelés gyökereit a régi Szjt. idejében a Szerzői Jogvédő Hivatal müködése jelentette, azonban az első ilyen jellegü tevékenységet végző

\footnotetext{
145 Ez tükröződik az SZTNH által vezetett nyilvántartásban is. A kezelt jogok alapján történő csoportosítás szerint lekérve az adatokat látható, hogy önkéntes közös jogkezelés körébe a gyakorolt jogok kisebbsége tartozik (http://kjk.sztnh.gov.hu/jogok-listanezet).

${ }^{146}$ A KJK-irányelv egyik célja éppen a közös jogkezelők szervezetére, müködésére vonatkozó alapvető kívánalmak rögzítése. Az irányelv átültetésére 2016. április 10-ig van idejük a tagállamoknak. Magyarországon az átültetés koncepciójáról szóló konzultáció 2015. elején zajlott le. A koncepció anyaga elérhető az alábbi linken: Javaslat a szerzői és szomszédos jogokra vonatkozó közös jogkezelésröl és a zenemüvek belső piacon történő online felhasználásának több területre kiterjedö hatályú engedélyezéséröl szóló 2014/26/EU irányelv magyar jogba történö átültetésének koncepciójára (http://hu.scribd.com/doc/252881981/KJK-iranyelv-atultetesi-koncepcioja\#scribd). Ennek lezárásaként 2015. júliusában került nyilvánosságra az SZTNH által elkészített Részletes koncepció. (Részletes koncepció a szerzői és szomszédos jogokra vonatkozó közös jogkezelésről és a zenemüvek belső piacon történő online felhasználásának több területre kiterjedő hatályú engedélyezéséről szóló 2014/26/EU irányelv átültetéséhez megalkotandó magyar jogi szabályozás főbb tartalmi kérdéseivel kapcsolatban, (http://www.sztnh.gov.hu/sites/default/files/20150710_kjk_ire_reszletes_atultetesi_koncepcio_konzultaci ora_0.pdf) Az irányelv egyébként annak a folyamatnak egy fontos állomása, amely a KJK tekintetében a versenyjogi felügyelettől fokozatosan eltávolodva a szerzői jog természetéhez közelebb álló eszközökre helyezi a hangsúlyt. GYERTYÁNFY (1991) p. 597.

${ }^{147}$ Loi no 2000-719 du 1er août 2000 modifiant la loi $n^{\circ} 86-1067$ du 30 septembre 1986 relative à la liberté de communication.
} 
szervezet már 1907-ben megalakult. ${ }^{148}$ Majd pedig 1996-ban az állami közös jogkezelés privatizációját követően (a folytonosság biztosítása mellett) kormányrendeletben kerültek tisztázásra a legfontosabb kérdések. Az új Szjt. három évvel később gyakorlatilag szó szerint átemelte ezeket a rendelkezéseket, jelezve azt, hogy alapvetően egy modern, a tevékenység feltételeit megfelelő módon körülhatároló jogforrásról volt szó. A közös jogkezelés szervezeti és müködési kereteit érintően két reformról beszélhetünk. Az első a 2003. évi CII. törvény, amely finomhangolást jelentett a korábbi rendszerben. A második jelentős módosítás pedig a 2011. évi CLXXIII. törvénnyel bevezetett közös jogkezelési tevékenység liberalizációja, illetve ezzel összefüggésben a felügyeleti szabályok teljes újraírása. A témakört érintően a következő nagyobb változás mindkét országban a KJK-irányelv implementációja során fog bekövetkezni, az átültetés határideje 2016-ban jár majd le. A szervezeti háttér bemutatása során két témakört kell részletesen érinteni. Mindenekelőtt szólni kell arról, hogy a jogosultak önrendelkezési joga milyen módon jelenik meg a szervezetek létrehozása során (A pont). Ezen kívül pedig azt kell szem előtt tartani, hogy a jogalkotó ezt a szabadságot hogyan korlátozza a felügyeleti szabályok elöírásával (B pont). Bár ebben a második szempontban a versenyfelügyeleti szabályok is szerepet kaphatnának, mivel a dolgozat témája szempontjából kevés jelentőséggel bírnak, ezek ismertetésétől eltekintünk.

\section{§1. A jogosultak önkorlátozása}

A közös jogkezelő szervezetek létrehozása a jogosultak önkéntes elhatározásán alapszik. Mivel a szervezet a tevékenységet a tagjai javára és érdekében végzi, alapvető fontosságú az is, hogy a müködéssel kapcsolatos alapvető döntések meghozatalában a jogosultak is részt vegyenek. Ez az a két meghatározó tényező, ami a közös jogkezelő szervezeteket megkülönbözteti az üzleti alapon végzett jogkezeléstől - nem véletlen tehát, hogy hangsúlyozottan kiemelésre kerülnek a közös jogkezelés egyes definícióiban is, illetve hogy a KJK-irányelv is ezeknek a szempontoknak a szem előtt tartásával határozza meg a szervezeti szabályokat. ${ }^{149}$

\footnotetext{
148 Ez az úgynevezett „MARS”, a Magyar Szövegírók, Zeneszerzők és Zeneműkiadók Szövetkezete, amely a zeneművek nyilvános előadásának védelmét látta el. ALFÖLDY (1936) p. 57-58. Az Artisjus történetéről lásd: GÉRA - CSATÁRI (2007).

${ }^{149}$ A Bizottság a KJK-irányelv javaslatának egyik célját az alábbiak szerint foglalta össze: „a közös jogkezelő szervezetek irányitására és átláthatóságára vonatkozó követelmények fejlesztése annak
} 
Ez a jellemző tükröződik a kereskedelmi társasági, profitorientált jogi személyi forma elutasításában is. Magyarországon ennek megfelelően egyesületi formában [A] pont], míg Franciaországban polgári társasági formában [B) pont] müködnek. A formaválasztás egyébként igazodik a szerzői vagyoni jogok státusával összefüggő eltérő megközelítési módokhoz is. Míg ezek Franciaországban átruházhatóak, és így a szervezet a csatlakozás során megszerzi őket (vagy a törvény eleve ezek átszállásáról rendelkezik), addig Magyarországon az egyesületi tagok a belépés során megbízást adnak a szervezetnek az érintett vagyoni jogok gyakorlására.

\section{A) Egyesületi forma}

A közös jogkezelő szervezetek müködésére vonatkozó hatályos szabályokat az Szjt.-t módosító 2011. évi CLXXIII. törvény iktatta be. A törvény a közös jogkezelési tevékenység liberalizációjának megteremtésével párhuzamosan jelentősen átírta a korábbi működési és felügyeleti szabályokat. A lényeg azonban változatlan maradt: a közös jogkezelés nyilvántartásba vételhez kötött tevékenység, ${ }^{150}$ amelyet az itt letelepedett közös jogkezelő szervezetek egyesületi formában látnak el. ${ }^{151}$

A közös jogkezelés szervezete kapcsán külön utalni kell az Szjt. és a Ptk. viszonyára, nem szabad ugyanis megfeledkezni arról, hogy háttérjogszabályként az Szjt. mögött meghúzódnak a Ptk. egyesületekre vonatkozó általános szabályai, ${ }^{152}$ illetve a Cnytv. és Ectv. egyesületekkel kapcsolatos rendelkezései ${ }^{153}$ is. Ezek viszonyának meghatározásában segítséget nyújt a ,lex specialis derogat legi generali” latin maxima, amely alapján a speciális szabályok élveznek elsőbbséget az általánossal szemben. Ez a viszony egyébként az egyes törvényekben is pontosításra kerül. A Ptk. az Szjt. 3. §-ában található utaló szabálya értelmében általános háttérjogszabálya a szerzői jogi törvénynek. Az Ectv. rendelkezéseitől való eltérés lehetőségére vonatkozó felhatalmazást a törvény 4. § (1) bekezdésében találjuk. Ez azt mondja ki, hogy a külön

érdekében, hogy a jogtulajdonosok képesek legyenek hatékonyabb ellenörzést gyakorolni ezek felett és elösegiteni a vezetési hatékonyságuk javitását". Javaslat az Európai Parlament és a Tanács irányelve a szerzői és szomszédos jogokra vonatkozó közös jogkezelésről és a zenemüvek jogainak belső piacon történő online felhasználásra szóló, több területre érvényes engedélyezéséröl, COM(2012) 372 final, p. 3.

${ }^{150}$ Szjt. 86. § (1) bek.

${ }^{151}$ Szjt. 91. $§(1)$ bek.

${ }_{152}$ Ptk. 3:63-3:87. §.

${ }^{153}$ Cnytv. 63-68/A. §., Ectv. 3-8. §. 
törvény hatálya alá tartozó tevékenységet végző egyesületekre törvény az egyesületre vonatkozó rendelkezésektől eltérő szabályokat állapíthat meg.

Az egyesületi forma a biztosítéka annak, hogy a nagyfokú jogosulti autonómia érvényesülhessen. Ez már az egyesület létrehozásánál is megnyilvánul: a törvényben nem található olyan rendelkezés, amely közös jogkezelő szervezet létrehozására kötelezné a jogosultakat, illetve nem rendelkezik az egyesülethez való kötelező csatlakozásról sem. ${ }^{154}$ Áttételesen viszont elképzelhető egy ilyen helyzet abban az esetben, ha a törvény elöírja a jog közös kezelését, azonban nincsen erre bejegyzett közös jogkezelő szervezet. A müködésben megnyilvánuló tagi autonómia kifejeződése, hogy az egyesület tagja jogosult a döntéshozó szervben részt venni. ${ }^{155} \mathrm{Az}$ alapszabálynak tartalmaznia kell azt, hogy a legföbb szerv kizárólagos, nem átruházható hatáskörében dönt (egyebek mellett) a támogatási politikát is tartalmazó felosztási szabályzat elfogadásáról. ${ }^{156} \mathrm{Ez}$ a forma adja egyben a közös jogkezelő szervezetek legitimációját is a kulturális jelentőséggel is bíró tevékenység ellátása kapcsán. Hagyományosan ugyanis az egyesületek azok, amelyeket ilyen jellegü célok megvalósítására alapítanak. Ez egyben a tevékenység végzésének non-profit jellegét is meghatározza.

Arra nézve, hogy mely jogosultak csatlakozhatnak a közös jogkezelő szervezethez, a törvény nem tartalmaz elöírást, ennek meghatározásáról tehát az alapszabály rendelkezik. Azt azonban a nyilvántartásba vétel feltételéül szabja a törvény, hogy a szervezethez az alapszabályban rögzített kritériumok teljesülése esetén valamennyi jogosult csatlakozhat. ${ }^{157}$ A közös jogkezelő tehát nem zárhatja ki az általa képviselt csoporton belül valamely jogosult taggá válását. ${ }^{158}$ A csatlakozással egyúttal a jogosult korlátlan és kizárólagos megbízást ad a közös jogkezelés keretében kezelt vagyoni jogok gyakorlására. ${ }^{159}$ Természetesen megbízás adására úgy is lehetősége van a

\footnotetext{
${ }^{154}$ Az más kérdés, hogy egyébként a közös jogkezelés hatályát a törvény a nem tag jogosultakra is kiterjeszti.

${ }^{155}$ Ptk. 3:72. § (1)-(2) bek.

${ }^{156}$ Szjt. 92 . $§(1)$ bek. fd) pont.

${ }^{157}$ Szjt. 92 . § (1) bek. a) pont.

${ }^{158}$ A másik irányból történő feltételszabás, tehát az, ha mondjuk a képviselet tagi jogviszony megszünését követő megtartására nézve tartalmaz elöírásokat az alapszabály a szervezetek versenyjogi felügyeletét teszi szükségessé. Az uniós esetjog főleg az ezzel kapcsolatos francia és német gyakorlat kapcsán fejlödött. 159 $\begin{aligned} & \text { Lásd } \\ & \text { http://artisjus.hu/_userfiles/file/szerzoknek/nyomtavanyok/belepesi_nyilatkozat_szerzoi.pdf. }\end{aligned}$
} 
jogosultaknak, hogy nem válnak egyesületi taggá. Ebben az esetben a tagi jogviszonyból fakadó jogok és kötelezettségek sem illetik meg, illetve terhelik a jogosultat.

A közös jogkezelés non-profit tevékenység: ez összecseng az egyesületi formával, ${ }^{160}$ illetve a szervezetek működésére vonatkozó speciális előírásokkal is. Az Szjt. kifejezetten kimondja, hogy közös jogkezelés vállalkozási tevékenységként nem végezhető, és a kiegészítő vállalkozási tevékenységgel (pl. az egyesület tulajdonában álló, közös jogkezelési célra nem hasznosított ingatlan bérbeadása) elért eredmény is csak a közös jogkezelési tevékenység kezelési költségeinek csökkentésére használható fel. $^{161}$

Vagyis Magyarországon a közös jogkezelő szervezethez való csatlakozás vagy megbízás adása önkéntes (maga a közös jogkezelési tevékenység ellátása már nem feltétlenül), tagsággal és önkormányzattal rendelkezik, tevékenységét pedig non-profit jelleggel látja el. Ez egy speciális bizományosi jogállást biztosít a közös jogkezelő szervezetnek, hiszen a tevékenysége végzése körében nem járhat el teljesen szabadon. Bár a felhasználási engedélyeket a saját nevében adja meg, de a jogdíjak mértékének, illetve a felhasználás egyéb feltételeinek kialakításában az egyesületi szervek útján maguk a megbízók (vagyis a jogosultak) döntenek. ${ }^{162}$

\section{B) Társasági forma}

Franciaországban a közös jogkezelők polgári társasági (société civile) ${ }^{163}$ formában müködnek. Ez abból is ered, hogy a francia jogi gondolkodásban a szerződéses szabadság keretén belül, szerződéses konstrukcióként tekintenek a közös

\footnotetext{
${ }^{160}$ Ptk. 3:63. § (2) bek. alapján egyesületet gazdasági-vállalkozási tevékenység ellátására nem lehet alapítani.

${ }^{161}$ Szjt. 89. § (4) bek. A tevékenység jellemzőit az SZTNH által a KJK-irányelv átültetésére vonatkozó részletes koncepció is tartalmazza. A szabály közvetlenül ered egyébként a Ptk. egyesületekkel kapcsolatos szabályaiból is. Ptk. 3:63.§ (3)-(4) bek.

${ }^{162}$ FALUDI (2004) p. 91.

${ }^{163}$ A francia társasági jog különbséget tesz kereskedelmi és polgári társaságok között. A polgári társaságok jogi személyiséggel rendelkező, korlátlan felelősségü, személyegyesesítő társaságok, amelyekre bizonyos esetekben speciális rezsim alkalmazandó. Külön törvényben meghatározott esetekben tökeegyesítő társaságok is lehetnek. VIDAL (2010) p. 18-19. Voltaképpen minden olyan társaság, amely sem formáját, sem pedig a társaság célját tekintve nem kereskedelmi, az polgári társaságnak tekinthető. Ez a társasági forma alkalmas például arra, hogy bizonyos szellemi szabadfoglalkozású szolgáltatási tevékenységet, vagy magánvagyonba tartozó ingatlan kezeleését végezze. COZIAN - VIANDIER - DEBoISSY (2014) p. 624-625.
} 
jogkezelésre. Mivel a szerződéses szabadság alapelvként szövi át a közös jogkezelésről szóló diskurzus egészét, kiemelt jelentőséget kap az is, hogy a törvény által elöírt esetek kivételt jelentsenek az önkéntesség főszabálya alól, jól körülhatároltak, és kivételes, kiegészítő esetekként kell megjelenniük. ${ }^{164}$ Bár az első közös jogkezelő szervezetek ebben az országban alakultak meg, a CPI egészen az 1985. évi törvény ${ }^{165}$ elfogadásáig ${ }^{166}$ nem tartalmazott átfogó rendelkezéseket működésükről, azok elszórtan jelentek meg a francia szerzői jogi törvényben. Az 1957. évi törvény ${ }^{167} 43$. cikke tartalmazott a „szerzöi szakmai szervezetekre” (les organismes professionnel d'auteurs) vonatkozó rendelkezést, a 65. cikk pedig a „szakmai érdekvédelmi szervezetekre” (les organismes de défense professionnelle), ezt megelőzően viszont egyáltalán nem kerültek törvényi szabályozásra. ${ }^{168}$

Az 1985. évi törvény az 1957-es szerzői jogi törvény átfogó felülvizsgálatát jelentette: elismerést nyertek a szomszédos jogok, az audiovizuális mủvekre vonatkozóan speciális rezsim került beiktatásra, illetve a magáncélú másolatra vonatkozó rendelkezések is ekkor kerültek a kódexbe. ${ }^{169}$ Ez utóbbi díjat kötelező közös jogkezelés keretébe utalta a törvény, amely szükségképpen magával vonta azt is, hogy a jogok kezelését végző szervezetek jogi státuszára, müködésére, felügyeletére vonatkozó alapvető szabályok is egy csokorba legyenek gyüjtve. ${ }^{170}$

Korábban a részletes szabályozás híján a társaságokra vonatkozó általános szabályok alapján müködtek a közös jogkezelést végző szervezetek is. Ez többek között a jogi formában megnyilvánuló változatosságot eredményezett, bár többségében már a 20. század második felében is polgári társaságként müködtek (ez a forma igazodott ugyanis a legjobban a közös jogkezelési tevékenység jellegéhez és céljához). Ez alól az SGDL tekinthető kivételnek, amely a közhasznú egyesületi formát ${ }^{171}$ választotta. ${ }^{172} \mathrm{Az}$ érdekvédelmi tevékenység a kezdetektől jellemző volt a társaságoknak, a tevékenységi

\footnotetext{
164 SIIRIAINEN (2007) p. 449-450.

${ }^{165}$ Loi $\mathrm{n}^{\circ}$ 85-660 du 3 juillet 1985 relative aux droits d'auteur et aux droits des artistes-interprètes, des producteurs de phonogrammes et de vidéogrammes et des entreprises de communication audiovisuelle.

166 A törvényhez füzött kommentárt lásd: JOUBERT (1986) p. 181-192. A törvény előkészítésének folyamatáról pedig TOURNIER ad szubjektív beszámolót. TOURNIER (2006) p. 227-240.

${ }_{167}^{160}$ Loi n57-298 du 11 mars 1957 sur la propriété littéraire et artistique.

${ }^{168}$ COLOMBET (1999) p. 339.

${ }^{169}$ EDELMAN (1987).

${ }^{170}$ DE RIDDER (1994) p. 29.

${ }^{171}$ Association déclarée d'utilité publique.

172 SCHMIDT (1971) p. 12.
} 
kör annak ellenére, hogy az 1985 -ös törvényben nem jelent meg, korábban ${ }^{173}$ és ma is fontos szeletét teszi ki a müködésüknek.

A CPI előírásai szerint a szervezet tagjai ${ }^{174}$ szerzők, előadóművészek, hangfelvétel-előállítók vagy videofelvétel-előállítók, kiadók, vagy jogutódaik lehetnek. ${ }^{175}$ A szervezetek viszont jellemzően egy adott jogosulti csoport képviseletére jönnek létre, hiszen az érdekellentétek miatt kedvezőtlen, hogy a szerzők, a kapcsolódó jogi jogosultak, és a felhasználási jogokat szerződéses úton megszerző kiadók egy azon szervezeten belül gyakorolják az engedélyezési jogot. ${ }^{176} \mathrm{~A}$ polgári társasági forma indokául egyrészt a közös jogkezelök által kezelt jogok magánjogi jellege, másrészt pedig a társaság célja szolgálja, amely eltér a kereskedelmi társaságok általános kockázatvállalásban rejlő, profitorientált jellegétől. ${ }^{177}$ Bár nem példa nélküli, hogy a bírói gyakorlat a végzett tevékenység, a szerződéses gyakorlat alapján forma szerint polgári társaságokat de facto kereskedelmi társaságokká minősít, a közös jogkezelő szervezetek esetében a bírói gyakorlat a közös jogkezelési tevékenységet hagyományosan polgári, és nem kereskedelmi tevékenységként értékeli. ${ }^{178} \mathrm{~A}$ felhasználók arra is kísérletet tettek, hogy de facto egyesületté nyilváníttassák a társaságokat, vagy pedig a bíróság kimondja, hogy nem rendelkeznek jogi személyiséggel, amely egyben perképességük megvonását is jelentette volna. ${ }^{179} \mathrm{Ez}$ azzal a következménnyel járhatott volna, hogy az általuk kezelt jogok esetében a jogdíjhoz való igényüket nem érvényesítették volna bírósági úton. Így például az SACD esetében megkérdőjelezték a társaság polgári jellegét, ezzel szemben a SACEM esetében ez nem merült föl. ${ }^{180}$

\footnotetext{
173 SCHMIDT (1971) p. 21-30.

${ }^{174}$ A reprezentativitásról: LE CAM (2014) p.489-503.

175 CPI L.321-1. cikk „Les sociétés de perception et de répartition des droits d'auteur et des droits des artistes-interprètes et des producteurs de phonogrammes et des vidéogrammes sont constituées sous forme de sociétés civiles.

Les associés doivent être des auteurs, des artistes-interprètes, des producteurs de phonogrammes ou de vidéogrammes, des éditeurs, ou leurs ayants droit. Ces sociétés civiles régulièrement constituées ont qualité pour ester en justice pour la défense des droits dont elles ont statutairement la charge."

${ }^{176}$ SIIRIAINEN, Fabrice: Théorie générale de la gestion collective. Logique du droit exclusif de la gestion collective, J.Cl. Propriété littéraire et artistique, Fasc. 1550. 23. pont.

${ }^{177}$ VIVANT - BRUGUIÈRE (2013) p. 710.

${ }^{178}$ Cass. civ., 8 déc. 1913, SACD: Gaz.Pal. 1924, 1, p. 93. és Cass. $1^{\text {re }}$ civ., 10 févr. 1987, SACEM, Bull. civ. I, p. 50.

${ }^{179}$ SCHMIDT (1971) p. 12-14, illetve 19-21.

${ }^{180}$ SCHMIDT (1971) p. 144.
} 
Ez a megszilárdult, polgári jogi jellemzőket megtartó minősítés igaz az általuk megkötött szerződésekre is. Ez egyébként logikusan fakad a szervezet polgári jogi jellegéből, még abban az esetben is, ha az őt alkotó tagok - például a kiadók - adott esetben kereskedőnek minősülnek. ${ }^{181}$ Ezt a választást a CPI L. 321-2. cikke is rögzíti, ugyanis arról rendelkezik, hogy a társasági cél végrehajtása érdekében közös jogkezelő szervezetek által kezelt repertoár egészére vagy részére vonatkozóan a felhasználókkal kötött szerződések polgári jogi szerződések. ${ }^{182}$ Ez egyben utalás arra, hogy a szervezet szabadon tárgyalja meg a jogdíjak mértékét és a felhasználás egyéb feltételeit, ezek alkalmazásához hatósági jóváhagyás nem szükséges. Másrészt pedig az alkalmazandó szerződéses rezsim kijelölése miatt fontos, a kereskedelmi tevékenység körében kötött szerződésekre ugyanis eltérő szabályok vonatkoznak. ${ }^{183}$

A társasági forma ilyen módon való megválasztása természetesen azt is jelenti, hogy a társaságokra vonatkozó általános szabályokat, a polgári társaságokra vonatkozó rendelkezésekkel és a CPI-ben megtalálható közös jogkezelő szervezetekre vonatkozó szabályozással együttesen kell alkalmazni. ${ }^{184}$

A jogosultak és a közös jogkezelő közötti jogviszony meghatározása nem feltétlenül egyértelmü, annak ellenére, hogy a kódex egyértelmű szervezeti formát követel meg. A társasági formából következik az apport szolgáltatásának kötelezettsége, azonban különbséget kell tenni a társasági jogi apport között, amely a társaság alaptőkéjét biztosítja, és a közös jogkezelés keretében meghatározott sajátos apport között, amely a vagyoni jogok gyakorlását biztosítja a szervezetek részére. ${ }^{185}$ Ez utóbbi kapcsolat alapulhat megbízáson (mandat) vagy a jogok átruházásán (cession), előbbi esetben a megbízási szerződés megkötésével a szerző, mint megbízó a társaság tagjává is válik (apport en gérence). ${ }^{186}$ Ez egyben azt is jelenti, hogy a megbízás megszüntetése a tagsági jogviszony megszüntetésével, vagy a társaság megszüntetésével lehetséges. ${ }^{187}$ A megbízási jogviszony előnye egyrészt abban áll, hogy a jogosult mentesül a jövőben

\footnotetext{
${ }^{181}$ SIIRIAINEN, Fabrice: Théorie générale de la gestion collective. Logique du droit exclusif de la gestion collective, J.Cl. Propriété littéraire et artistique, Fasc. 1550. 22. pont.

${ }^{182}$ CPI L. 321-2. Les contrats conclus par les sociétés civiles d'auteurs ou de titulaires de droits voisins, en exécution de leur objet, avec les utilisateurs de tout ou partie de leur répertoire sont des actes civiles.

${ }^{183}$ COLLART-DUTILLEUL - DelebeCQUe (2011) p. 24.

${ }^{184}$ VIVANT - BRUGUIËRE (2013) p. 710.

${ }^{185}$ Cass. 1re civ., 28 juin 1988 : RIDA avr. 1989, p. 220

${ }^{186}$ CA Paris, 6 mars 1933: Gaz. Pal. 1933, p. 958; S. 1935, 1. p, note Gény

${ }^{187}$ CA Paris, 4e ch., 11 juin 1997: RIDA 1997/4, p. 255. - TGI Paris, 3e ch., 19 juin 1998: RIDA 1999/2, p. 410.
} 
megalkotandó müveire vonatkozó jogok gyakorlásának átengedése alól, illetve ebben a jogi konstrukcióban a szerző érdekei is nagyobb védelmet élveznek, ugyanis a vagyoni jog nála marad, tehát adott esetben azt a jogkezelővel párhuzamosan gyakorolhatja. ${ }^{188} \mathrm{~A}$ jogi konstrukció hátránya, hogy a társaság szempontjából ez tekinthető a bizonytalanabb formának: a megbízási szerződés megszüntetésének lehetősége nem garantálja ugyanis a repertoár egységének biztosítását. ${ }^{189}$ Emellett pedig a megbízás a francia jogban is személyhez tapadó szerződés, ${ }^{190}$ amelyet elméleti síkon nehéz összeegyeztetni a jogkezelés közös, kölcsönösségen alapuló jellegével. ${ }^{191}$

A jogkezelő szervezet és a jogosultak közötti másik lehetséges jogviszony a jogok átruházása a jogkezelöre (apport-cession). Ennek előnye, hogy a közös jogkezelő szervezet megszerzi a vagyoni jogok feletti rendelkezési jogot. Vagyis a szerzők egyénileg ezeket már nem gyakorolhatják, az ennek ellenére megkötött szerződések semmisek. ${ }^{192}$ Ez egyben azt is jelenti, hogy a jogsértések elleni fellépésre is a közös jogkezelő szervezet jogosult. ${ }^{193} \mathrm{Az}$ átruházás viszont abból a szempontból érdekes, hogy a közös jogkezelők a jogokat nem a saját javukra, hanem az azokat átruházó jogosultak javára gyakorolja, szintén egyfajta különleges bizományosként. Ez a jogviszony a társaság számára sokkal szélesebb mozgásteret biztosít azon túl, hogy garantálja a repertoár egységességét. A francia jog szerint mindkét szerződéses megoldás visszterhes, vagyis az ellenértéket a társaság jogosultak javára végzett tevékenysége, tehát alapvetően a jogdíjak alapszabály szerinti beszedése és felosztása jelenti. ${ }^{194}$ Ez pedig nem az alaptőkében való részesedés arányában, hanem jellemzően a felhasználási adatok alapszabályban meghatározott módja alapján történik.

\footnotetext{
${ }^{188}$ NÉRISSON (2013) p. 163.

${ }^{189}$ LUCAS - LUCAS - LUCAS-SCHLOETTER (2012) p. 733.

${ }^{190}$ A francia polgári jogi terminológia ezt intuitu personae szerződésnek nevezi. A latin kifejezés értelme: „a személy figyelembe vételével”. Olyan szerződéseket takar, amelyekben valamely szerződő fél személye annak valamely tulajdonsága miatt a szerződés lényeges tartalmi elemét képezi. Például a megbízás az abban fellelhető bizalmi viszony miatt ilyen személhyez tapadó szerződésnek tekinthető. CORNU (2007) p. 513.

${ }^{191}$ LUCAS - LUCAS - LUCAS-SCHLOETTER (2012) p. 734. Az elmélet nem veszi figyelembe a társaság elkülönült jogi személyiségét és a hangsúlyt arra helyezi, hogy a tagok száma, illetve kiléte időben változó, bizonytalan tényező.

${ }^{192}$ NÉRISSON (2013) p. 167.

${ }^{193}$ SIIRIAINEN, Fabrice: Théorie générale de la gestion collective. Logique du droit exclusif de la gestion collective, J.Cl. Propriété littéraire et artistique, Fasc. 1550. 34. pont.

${ }^{194}$ SIIRIAINEN, Fabrice: Théorie générale de la gestion collective. Logique du droit exclusif de la gestion collective, J.Cl. Propriété littéraire et artistique, Fasc. 1550. 37. pont.
} 


\section{§2. A közös jogkezelési tevékenység korlátok közé szorítása}

A szervezetek által ellátott tevékenység különleges volta, illetve a társaságot alkotó tagok nagy száma indokolja azt, hogy müködésükre, felügyeletükre különleges szabályok vonatkoznak. ${ }^{195}$ A francia bírói gyakorlatnak ez a megállapítása igaz a magyar közös jogkezelés esetében is (azon túl persze, hogy a korlátozás indokául a közös jogkezelés kulturális dimenziója is felhozható érvként), ${ }^{196}$ hiszen a jogalkotó ennek a különleges tevékenységi körnek a figyelembe vételével alakította ki a részletes felügyeleti szabályokat. A közös jogkezelési tevékenységet a jogalkotó két módon szorítja korlátok közé. Egyfajta állami kontroll jelenik meg a szervezetek alapítása során, amennyiben ehhez nyilvántartásba vételi kötelezettség, vagy miniszteri jóváhagyás szükséges [A) pont]. Másrészt pedig az ellátott feladatok speciális jellemzői miatt a hasonló jogi formában müködő szervezetekhez képest a működés is szigorúbb felügyeleti szabályoknak van alárendelve, különösen ami az alkalmazott díjszabások hatósági jóváhagyását illeti [B) pont].

\section{A) Állami beavatkozás az alapitás során}

A nyilvántartásba vétel ${ }^{197}$ annak a záloga, hogy a közös jogkezelő a sajátos törvényes képviselői minőségén alapuló müködése zavartalan, hatékony és méltányos legyen. ${ }^{198}$ Az SZTNH közös jogkezelő szervezetekről vezetett nyilvántartása egyébként a közös jogkezeléssel érintett vagyoni jogokra és a jogkezelés típusára, valamint az érintett jogosulti csoportra tekintettel közhiteles hatósági nyilvántartásnak minősül. ${ }^{199}$

A regisztráció feltételeit a törvény részletesen meghatározza, ${ }^{200}$ ezek közül azokat emeljük ki, amelyeknek egyébként a törvény által előírt közös jogkezelés kapcsán jelentőségük lehet, kifejezetten a tag és a nem tag jogosult viszonyának

\footnotetext{
195 Paris, 20 février. 1990: RIDA juill. 1990, p. 365. D. 1991. Somm. 100 obs, Colombet

${ }^{196}$ NÉRISSON (2013) p. 359.

197 A nyilvántartás technikai részletszabályairól, amelyeket e helyütt nem kívánunk részletesen elemezni, lásd: 307/2011. (XII. 23.) Korm. rendelet a közös jogkezelő szervezetek nyilvántartására, felügyeletére, felügyeleti díjára, valamint e szervezetek nyilvántartásával, felügyeletével és díjszabásának jóváhagyásával kapcsolatos eljárásokban az elektronikus úton történő kapcsolattartásra vonatkozó részletes szabályokról

${ }^{198}$ GYERTYÁNFY (2014) p. 504.

${ }^{199}$ Szjt. 90. § (2) bek. b) és c) pont, Szjt. 90. § (3) bek.

${ }^{200}$ Szjt. 92 ..
} 
meghatározása szempontjából. ${ }^{201}$ Az egyesületnek egyfelöl nyitottnak kell lennie, vagyis biztosítania kell azt, hogy bármely jogosult (belföldi és külföldi egyaránt) szabadon csatlakozhasson a szervezethez. A kritérium természetesen nem bármely jogosult bármely szervezethez való csatlakozását jelenti, hanem az alapszabály keretei között, az abban meghatározott feltételek szerint áll fenn a közös jogkezelő szervezetek kötelezettsége. Másfelől pedig az egyesületnek kellően reprezentatívnak is kell lennie, vagyis az általa végzett jogkezelési tevékenységben érdekelt jogosultak jelentős részét képviselnie kell. A reprezentativitás követelményének előírása összefügg azzal, hogy a törvény a közös jogkezelési esetkörök többségét maga határozza meg. Ez garantálja ugyanis a jogosultak szempontjából azt, hogy a felhasználási feltételek meghatározásában nem egy külső érdek, hanem a saját döntésük játszik szerepet. Emellett a felhasználók szempontjából is kedvező ez az elöírás, hiszen ily módon a világrepertoárra szerezhetnek felhasználási jogot. Mivel ennek kifejezetten a kiterjesztett hatályú, kilépést engedő közös jogkezelés körében van jelentősége, ezért a kritérium elemzésére az ezzel foglalkozó fejezetben kerül sor. ${ }^{202}$

A nyilvántartásba vétel feltételeinek Magyarországon jelenleg kilenc közös jogkezelő szervezet felel meg. Ezek lefedik azokon a müveken illetve teljesítményeken fennálló jogokat, amelyeket az Szjt. 91. § (2) bekezdésének példálózó jellegü felsorolása tartalmaz. ${ }^{203}$ Olyan közös jogkezelő szervezet nem szerepel a nyilvántartásban, amely csak önkéntes közös jogkezelés végzésére jött volna létre: a közös jogkezelő szervezetek többsége ellátja a jogalkotói döntés nyomán közösen kezelendő jogok kezelését, illetve bizonyos esetekben jogok önkéntes kezelését. ${ }^{204}$

A legsokrétübb feladatot ellátó közös jogkezelő szervezet az ARTISJUS, amely alapvetően a zenei és irodalmi művek szerzőit képviseli, de több esetben is ez a szervezet biztosítja a különböző díjak beszedését, majd felosztás céljára továbbutalja ezeket a többi közös jogkezelő szervezetnek. Ily módon az ARTISJUS az, amely a mechanikai jogdíjak, ${ }^{205}$ az „on-demand” jogdíjak, ${ }^{206}$ a sugárázási ${ }^{207}$ és nyilvánossághoz

\footnotetext{
${ }^{201}$ Ennek a dilemmának a részletes elemzését lásd az egyes vagyoni jogok kapcsán, de különösen a III. rész I. fejezetében.

202 III. rész I. fejezet.

203 Ezek az irodalmi és zeneművek, egyéb alkotóművészeti alkotások, filmalkotások, előadóművészi teljesítmények, hangfelvételek, filmelöállítói teljesítmények.

${ }^{204}$ A HUNGART esetében például a kiállítási jog kezelése önkéntes közös jogkezelési alapon történik.

${ }^{205}$ Szjt. 19. § (1) bek.
} 
közvetítési jogdíjak, ${ }^{208}$ a nemcsak irodalmi és zenei jogosultak javára eljárva pedig az üres hordozó díjak ${ }^{209}$ és a kábeles jogdíjak ${ }^{210}$ tekintetében megállapítja a díj mértékét és a felhasználás egyéb feltételeit.

A többi közös jogkezelő szervezet az Előadóművészi Jogvédő Iroda, a FILMJUS Filmszerzők és előállítók Szerzői jogvédő egyesülete, a HUNGART Vizuális Művészek Közös Jogkezelő Társasága Egyesület, a Magyar Hangfelvétel-kiadók Szövetsége Közös Jogkezelő Egyesület, Magyar Irodalmi Szerzői Jogvédő és Jogkezelö Egyesület, Magyar Reprográfiai Szövetség, Magyar Szak- és Szépirodalmi Szerzők és Kiadók Reprográfiai Egyesülete, Repropress Magyar Lapkiadók Reprográfiai Egyesülete. $^{211}$

Franciaországban ezzel szemben a nyilvántartást szigorú szabályok nem az összes közös jogkezelő szervezetet, hanem csak azokat érintik, amelyek kötelező közös jogkezelési tevékenységet látnak el - az üres hordozó díjakat kezelő szervezetek kivételével. Ezek külön engedélyezésére vonatkozóan ugyanis a törvény nem tartalmaz elöírást. A jogkezelök közötti megkülönböztetés oka az 1985. évi törvény elfogadásának körülményeiben keresendö. A kormány által benyújtott törvényjavaslat ugyanis eredetileg minden szervezetre nézve kötelezővé tette volna a jóváhagyást, ezt a parlament viszont végül nem fogadta el. ${ }^{212}$

Az állami jóváhagyás célja Franciaországban, hogy a jogosultak önrendelkezési jogának csorbítását megpróbálják egy szorosabb állami felügyelettel pótolni, így igyekeznek megteremteni az egyensúlyt a két ellentétes oldal között. Így a szervezetek alapszabálya nem tesz hátrányos megkülönböztetést az egyes tagok és felhasználók között, illetve visszaszorítja a piacuralmi helyzettel való visszaélés

\footnotetext{
${ }^{206}$ Szjt. 27. § (3) bek.

${ }^{207}$ Szjt. 27. § (1) bek.

${ }^{208}$ Szjt. 27. § (3) bek.

${ }^{209}$ Szjt. 20. § (2) bek.

${ }^{210}$ Szjt. 28. § (3) bek.

${ }^{211}$ Közös jogkezelési tevékenységet ugyan nem végez, de említést érdemel a Pro Art Szövetség a Szerzői Jogokért egyesületet. Alapítói az ARTISJUS, az EJI, a FILMJUS, a MAHASZ, és a HUNGART, a szövetség célja pedig a szerzői érdekvédelmi tevékenység ellátása, ennek körében egyebek mellett szerzöi jogi ismereteket terjesztő tevényeség ellátása. A Szövetség kiadásában jelent meg az on-line elérhető Kézikönyv a szerzői jog érvényesítéséhez címü kiadvány. Kézikönyv a szerzői jog érvényesitéséhez. Útmutató a gyakorlat számára. ProArt Szövetség a Szerzöi Jogokért, 2. kiadás, 2013. (www.szerzoijogikezikonyv.hu).

${ }^{212}$ NÉRISSON (2013) p. 362., különösen 1528. lj.
} 
lehetőségét, valamint a társaságok szervei működésének hatékonyságát biztosítja. ${ }^{213} \mathrm{Az}$ engedély megadásának feltételei között bár nagyon sok hasonlóság található, az egyes társaságok esetében eltérések is felfedezhetők. Míg a kábeles továbbközvetítés jogának gyakorlására engedéllyel rendelkező társaságnak azt kell bizonyítania, hogy a jogosultak számára, és a bevétel nagyságára vagy a forgalomra tekintettel hatékonyan tudja biztosítani a kábeles továbbközvetítési jog gyakorlását, ${ }^{214}$ addig ez a feltétel többletelemekkel kiegészítve jelenik meg a többi külön engedélyhez kötött közös jogkezelő társaság esetében. A reprográfiai többszörözési jogot kezelő közös jogkezelő társaság esetében a két fenti feltétel mellett meg kell jelennie még a sokszínüségnek is az egyes jogosulti csoportokat, illetve a müfajokat illetően. Ennek a sokszínüségnek pedig a társaság szerveiben is fellelhetőnek kell lennie. ${ }^{215}$ Ugyanezek a feltételek találhatóak meg a könyvtári haszonkölcsönzési jogot, illetve a kereskedelmi forgalomban nem kapható könyvek digitalizálásának jogát kezelő közös jogkezelő társaságok esetében is. ${ }^{216}$ A könyvtári haszonkölcsönzési jog és a kereskedelmi forgalomban nem kapható könyvek digitalizálásának jogának kezelését végző közös jogkezelő szervezeteknek ezen kívül azt is bizonyítaniuk kell, hogy a szerzők és a kiadók képviseletét egyenlően látja el a társaság, így biztosítva azt, hogy a felhasználói szerepben lévő kiadók ne képviseltethessék nagyobb súllyal a minden valószínüség szerint szerzőkétől eltérő érdekeiket a társaság legfőbb szervében. Az egyenlőség

${ }^{213}$ Az akkori kultirális miniszter, Jack Lang megfogalmazása, amely a Jolibois-jelentésben olvasható (Rapport au nom de la commission spéciale sur le projet de loi adopté par l'Assemblée nationale relatif aux droits d'auteur et aux droits des artistes-interprètes, des producteurs de phonogrammes et de vidéogrammes et des entreprises de communication audiovisuelle, doc. Sénat $n^{\circ} 212$ ) p. 39.

${ }^{214}$ CPI R.323-1. cikk $1^{\circ}$, „Une société régie par le titre II du livre III peut être agréée au titre du I de l'article L. 132-20-1 et du I de l'article L. 217-2 si elle remplit les conditions suivantes :

$1^{\circ}$ Apporter la preuve de la gestion effective du droit d'autoriser la retransmission par câble, à raison du nombre des ayants droit et de l'importance économique exprimée en revenu ou en chiffre d'affaires"

${ }^{215}$ CPI R.322-1. cikk $1^{\circ}$ „Une société régie par le titre II du livre III peut être agréée au titre de l'article L. 122-10, si elle remplit les conditions suivantes :

$1^{\circ}$ Apporter la preuve de la diversité de ses associés à raison des catégories et du nombre des ayants droit, de l'importance économique exprimée en revenu ou en chiffre d'affaires et de la diversité des genres éditoriaux. Cette diversité doit trouver son expression dans la composition des organes délibérants et dirigeants."

${ }^{216}$ CPI R.326-1. cikk $1^{\circ}$ „Une société régie par les dispositions des articles L. 321-1 à L. 321-13_est agréée au titre del'article L. 133-2 si elle :

$1^{\circ}$ Apporte la preuve, par la composition de ses organes délibérants et dirigeants, de la diversité de ses associés à raison des catégories et du nombre des ayants droit, de l'importance économique exprimée en revenu ou en chiffre d'affaires et de la diversité des genres éditoriaux"

CPI R. 327-1. cikk $1^{\circ}$, ,Une société régie par le titre II du livre III peut être agréée au titre de l'article L. 134-3, si elle :

$1^{\circ}$ Apporte la preuve, par la composition de ses organes délibérants et dirigeants, de la diversité de ses associés à raison des catégories et du nombre des ayants droit, de l'importance économique exprimée en revenu ou en chiffre d'affaires et de la diversité des genres éditoriaux" 
követelményének a legfőbb szerven belül is meg kell jelennie. ${ }^{217}$ Minden esetben igazolni kell, hogy a vezető tisztségviselő alkalmas a feladatok ellátására, akár szerzői minősége, akár képzettsége, vagy ilyen irányú szakmai tapasztalata alapján. ${ }^{218}$ A szerzői minőség egy esetben, a kábeles továbbközvetítési jogok gyakorlását végző szervezet esetében, nem jelenik meg a feltételek között. ${ }^{219}$ További kritérium az is, hogy a közös jogkezelő szervezet infrastruktúráját tekintve alkalmas legyen a jogkezelési tevékenység ellátására, ideértve a jogdíjak beszedésére és felosztására való alkalmasság általános feltételein túl az egyes jogok gyakorlására vonatkozó speciális feltételeket is. A vezetékes továbbközvetítési jog gyakorlása kapcsán ilyen a társszervezetekkel megkötött kölcsönös képviseleti megállapodások megléte, ${ }^{220}$ illetve a kereskedelmi forgalomban nem kapható könyvek esetében annak biztosítása, hogy a szerzők és a kiadók a felosztás során ténylegesen egyenlő arányban részesednek a jogdíjakból. ${ }^{221}$ Hasonló, a tényleges felosztás arányait rögzítő törvényi rendelkezés Magyarországon is megfontolandó lehetne egyébként olyan esetekben, amikor az adott közös jogkezelő szervezet tagjai között a szerzők mellett kapcsolódó jogi jogosultak vagy kiadók is megjelenhetnek, mint például a reprográfiai díjak esetében.

Franciaországban összesen huszonhét közös jogkezelö szervezet müködik. A tevékenységi körük változatos, sokszor csak egy-egy jogosulti csoport egy-egy meghatározott jogának kezelését végzik. Emiatt érthető, bár a rendszert komplikálja, hogy vannak olyan társaságok, melyeket maguk a közös jogkezelő szervezetek hoznak létre. Ezek lényege, hogy tömöríti az adott jogtípus kezelésében érintett valamennyi jogosulti csoportot, jellemzően a törvény által előírt közös jogkezelés körében olyankor, mikor egy adott felhasználási módra tekintettel beszedett (jog)díjakból több jogosulti csoport is részesedik.

\footnotetext{
${ }^{217}$ CPI R. 326-1. cikk 2${ }^{\circ}$, valamint CPI R. 327-1. cikk 2 ${ }^{\circ}$ Emiatt Sylvie NÉRISSON például éles kritikával illeti a francia törvényt. Gondolatmenetének alapja, hogy felhasználókként a kiadóknak nincsen helyük a szerzőket tömörítő közös jogkezelő szervezetekben. Mivel érdekeik a szerzőkétől eltérőek, ezért olyan döntések meghozatalában közremüködhetnek, amelyek a szerzőkre egyébként hátrányosabbak, mintha ezek a kiadók részvétele nélkül kerülnének elfogadásra. NÉRISSON (2013) p. 47-54.

${ }^{218}$ CPI R. 322-1. cikk 2 ${ }^{\circ}$, R. 326-1. cikk 3ㅇ, R. 327-1. cikk $3^{\circ}$.

${ }^{219}$ CPI R. 323-1. cikk 30.

${ }^{220}$ CPI R. 323-1. cikk $4^{\circ}$.

${ }^{221}$ CPI R. 327-1. cikk $5^{\circ}$.
} 
Kilenc olyan társaság van, amelyek a szerzők jogait kezelik, ezek tagjai szerzők, és bizonyos esetekben kiadók. Az irodalmi művek kezelését az $\mathrm{SACD},{ }^{222} \mathrm{a}$ $\mathrm{SCAM}^{223}$ és a SOFIA ${ }^{224}$ végzik. A SCELF ${ }^{225}$ a csak kiadókat tömörítő közös jogkezelő szervezet. A képzőművészeket tömöríti az ADAGP, ${ }^{226}$ a SAJE ${ }^{227}$ és a SAIF. ${ }^{228}$ A zenei jogok közös kezelésének legföbb szereplője a $\mathrm{SACEM}^{229}$ illetve a zenei kiadók képviseletében a SEAM. ${ }^{230}$

A szerzői joggal szomszédos jogok kezelése kapcsán mindenekelőtt az ADAMI- $\mathrm{t}^{231}$ és a SPEDIDAM-ot ${ }^{232}$ kell megemlíteni, amely társaságok az előadómüvészeket tömörítik. A hangfelvétel-előállítók képviseletében az $\mathrm{SCPP}^{233}$ és az $\mathrm{SPPF}^{234}$ jár el. Az audiovizuális müvek tekintetében a szomszédos jogi jogosultak jogainak közös kezelését a PROCIREP ${ }^{235}$ végzi el, az ARP $^{236}$ a filmelőállítókat fogja össze.

A közös jogkezelők által létrehozott szervezetek közül ki kell emelni első helyen az SDRM-et, ${ }^{237}$ amely a mechanikai jogokat kezeli. A CFC $^{238}$ a reprográfiai többszörözés engedélyezését végzi. Az ANGOA ${ }^{239}$ a kábeles jogokat, az $\operatorname{SPRE}^{240}$ pedig a szomszédos jogi jogosultakat megillető díjazást kezeli. A Copie France a hangfelvételek magáncélú másolatára tekintettel fizetett díjakat kezeli, a SORECOP ${ }^{241}$

\footnotetext{
${ }^{222}$ Société des auteurs et compositeurs dramatiques.

${ }^{223}$ Société civile des auteurs multimédias.

${ }^{224}$ Société fraçaise des intérêts des auteurs de l'écrit.

${ }^{225}$ Société civile des éditeurs de langue française.

${ }^{226}$ Société des auteurs dans les arts graphiques et plastiques.

227 Société des auteurs de jeu.

228 Société des auteurs de l'image fixe.

${ }^{229}$ Société des auteurs, compositeurs et éditeurs de musique.

${ }^{230}$ Société des éditeurs et auteurs de musique.

${ }^{231}$ Société pour l'administration des droits des artistes et musiciens, interprètes.

232 Société de perception et de distribution des droits des artistes interprètes et de la musique et de la danse.

${ }^{233}$ Société civile pour l'exercice des droits des producteurs phonographiques.

${ }^{234}$ Société civile des producteurs de phonogrammes en France.

235 Société des producteurs de cinéma et de télévision.

${ }^{236}$ Société civile des auteurs, réalisateurs, producteurs.

237 Société pour l'administration du droit de reproduction mécanique des auteurs, compositeurs et éditeurs.

${ }^{238}$ Centre français d'exploitation du droit de copie.

${ }^{239}$ Association nationale de gestion des $2 u v r e s$ audiovisuelles.

${ }^{240}$ Société civile pour la perception de la rémunération de la communication au public de phonogrammes du commerce.

${ }^{241}$ Société pour la rémunération de la copie privée audiovisuelle.
} 
pedig a videofelvételek tekintetében biztosítja ugyanennek a díjazásnak a beszedését és felosztását.

Ami közös az utolsóként tárgyalt szervezetekben, hogy mindannyian törvény által elöírt közös jogkezelési feladatot látnak el. Alapításukat tehát az indokolta, hogy egy bizonyos jogot minden jogosulti csoportra kiterjedően lehessen gyakorolni, ${ }^{242}$ vagy, hogy a közös jogkezelés által korábban egyáltalán nem, vagy csak kevéssé érintett területek is le legyenek fedve ezzel a joggyakorlási móddal. ${ }^{243}$ Önálló infrastruktúrával sok esetben nem rendelkeznek (az ANGOA pl. a vezetékes továbbközvetítési jogok tekintetében), így a jogkezelést ténylegesen valamely más szervezet (pl. a SACEM) látja el, és osztja szét a többi jogosulti csoport között. Paradox módon éppen ez az egyszerübb jogkezelésre irányuló igény eredményezte azt, hogy a közös jogkezelés szervezeti rendszere a korábbinál összetettebbé, kevésbé átláthatóvá vált. ${ }^{244}$ A müködési és kezelési költségeket is megdrágíthatják a felosztás során az egyes társaságok között beiktatott plusz körök. Ráadásul a közös jogkezelés ilyen mértékü aprózódása a képviselt jogosultak és a kezelt jogok tekintetében összeütközést generálhat a közös jogkezelő szervezetek között, tovább bonyolítva az egyébként is kényes helyzetet. ${ }^{245}$

Néhány esetben viszont a felhasználókkal való könnyebb tárgyalás érdekében kerülnek létrehozásra ezek a szervezetek az önkéntes közös jogkezelésben lévő jogok tekintetében. A SESAM ${ }^{246}$ a multimédiás művek szerzőit összefogó közös jogkezelőket tömöríti annak érdekében, hogy a felhasználók igényeinek minél inkább megfeleljenek. ${ }^{247}$ Hasonlóképpen, a $\mathrm{SCPA}^{248}$ a hangfelvétel-előállítókat tömöríti, az $\mathrm{AVA}^{249}$ a vizuális müvészetek jogosultjainak közös jogkezelőiből áll. A $\mathrm{SAI}^{250}$ az ADAMI-t és a SPEDIDAM-ot fogja össze az előadómüvészek képviseletében. A SORIMAGE a szerzők, kiadók, és a hang- illetve videofelvétel előállítók társaságaiból áll, és célja a magáncélú másolatra tekintettel fizetett díjak kezelése. Végül pedig az

\footnotetext{
${ }^{242}$ Lásd pl. a SORECOP, a COPIFRANCE, a CFC létrehozását.

${ }^{243}$ Lásd pl. a SOFIA létrehozását.

${ }^{244}$ VERCKEN (2002) p. II. 104.

${ }^{245}$ PARIS (2002) p. 139-158.

${ }^{246}$ Société du droit d'auteur dans l'univers multimédia .

${ }^{247}$ NÉRISSON (2013) p. 25.

${ }^{248}$ Société civile des producteurs associés.

249 Société des arts visuels associés.

${ }^{250}$ Société des artistes interprètes.
} 
EXTRA-MEDIA azoknak az audiovizuális mủveknek a jogosultjait képviselö közös jogkezelő szervezeteket, amelyek multimédia müvekbe vannak foglalva.

\section{B) A müködés felügyelete}

A közös jogkezelés alapításán túl a szervezetek által ellátott tevékenység speciális jellege miatt a müködésükre vonatkozóan is külön elöírások érvényesülnek, ezek garantálják ugyanis azt, hogy a szervezetek fennállásuk alatt folyamatosan megfeleljenek a velük szemben támasztott szigorú kritériumoknak, és ez az ellentétele az elismert természetes vagy jogi monopolhelyzetnek. A felügyelet ex ante és ex post eszközökkel megelőzheti, vagy bizonyos esetekben ki is válthatja a külső, versenyjogi felügyeletet. A felügyeletet rendező előírások egy része a müködést általánosan érintő átláthatósági, számviteli szabályok betartásán alapuló rendelkezés [a) pont]. Más része viszont a kötelező közös jogkezelés szempontjából sokkal nagyobb jelentőséggel bír, ez ugyanis a szervezetek által alkalmazott díjszabások jóváhagyásának, illetve elfogadásának rendjét írja elő [b) pont].

\section{a) A müködés felügyeletének általános szabályai}

A 2011. évi törvénymódosítás nyomán „az Szjt. 89. § Európa legszigorúbb müködési és átláthatósági szabályait teremtette meg." 251 Ezek a szabályok, bár csírájukban megjelentek az Szjt. 1999-ben kihirdetett szövegében, mára kiterjednek a könyvvitelen $^{252}$ és az átláthatósági szabályokon ${ }^{253}$ túl arra is, hogy az SZTNH törvényességi felügyeleti jogokat gyakorol a szervezetek felett. Ez megfelel az Ectv. 4. $\S$ (4) bekezdésében foglalt rendelkezésnek, amely elöírja, hogy ha az egyesület olyan tevékenységet végez, amelyet jogszabály engedélyhez (feltételhez) köt vagy egyébként szabályoz, e tevékenység felett a tevékenység szerinti hatáskörrel rendelkező állami szerv a hatósági ellenőrzésre irányadó szabályok alkalmazásával felügyeletet gyakorol.

A közös jogkezelési tevékenység felett gyakorolt felügyelet körében a Hivatal a hatósági ellenőrzés szabályai szerint évente, illetve szükség esetén ellenőrzi, hogy a

\footnotetext{
${ }^{251}$ GYERTYÁNFY (2014) p. 517.

${ }^{252}$ A közös jogkezelő szervezet kettős könyvvitelre és a számviteli törvény szerinti beszámoló készítésére köteles, a beszámolót könyvvizsgálóval felül kell vizsgáltatnia. Szjt. 89. § (13) bek. Az SZTNH egyébként kötelezö számviteli standardot is kibocsátott a közös jogkezelök számára.

253 A törvény részletesen meghatározza, hogy az SZTNH a nyilvántartás részeként mely dokumentumokhoz biztosít hozzáférést. Szjt. 90. § (5) bek.
} 
nyilvántartásba vétel feltételei a közös jogkezelő egyesületnél folyamatosan megvalósulnak-e, továbbá, hogy az alapszabály, a felosztási szabályzat és más belső szabályzat rendelkezései nem ütköznek-e a szerzői jogi jogszabályokba. ${ }^{254}$ Az SZTNH-t a felügyelettel összefüggő napirendi pontok megtárgyalása kapcsán az egyesület legfőbb szervének ülésére is meg kell hívni. ${ }^{255}$

A felügyeleti jogkör gyakorlása körében a Hivatal számára több eszköz is rendelkezésre áll a törvényes müködés helyreállítása érdekében. ${ }^{256}$ A legenyhébb ezek közül az egyesület ügyintéző és képviseleti szervének felhívása a törvényes müködés helyreállítására. Ezen túl megkeresheti az ügyészséget az egyesület törvényességi felügyelete körében meghozható intézkedések megtétele céljából, felügyeleti bírságot szabhat ki, illetve végső esetben (amennyiben a többi felügyeleti intézkedés nem járt eredménnyel) ${ }^{257}$ törölheti a közös jogkezelő szervezetet a nyilvántartásból. ${ }^{258}$

A törvény által elöírt közös jogkezelés (vagyis gyakorlatilag az összes közös jogkezelési eset) körében a közös jogkezelő egyesület törlése a nyilvántartásból az engedélyezési jog gyakorlásának, illetve a jogdíjak beszedésének és felosztásának megszakadását eredményezi, amennyiben az adott tevékenységre a tényleges monopolhelyzetnek megfelelően csak egy szervezetet vettek nyilvántartásba. A törvény új egyesület alapítása felé tolja a jogosultakat, hiszen úgy rendelkezik, hogy ilyen esetben az SZTNH a honlapján és legalább két országos napilapban közzétett hirdetményben felhívja a jogosultakat arra, hogy a legfeljebb egy éves, a Hivatal által kitűzött határidőn belül kezdeményezzék egyesületük közös jogkezelő szervezetként való nyilvántartásba vételét. ${ }^{259}$

Az eltérő társasági formára, illetve a működés egyéb különbözőségeire tekintettel a francia közös jogkezelő társaságok kapcsán kifejezetten azokra a speciális

\footnotetext{
${ }^{254}$ Szjt. 92/K. $§(1)$ bek.

${ }^{255}$ Szjt. 92/K. § (4) bek.

${ }^{256}$ A törvényességi felügyeleti eljárást egyébként a díjszabások jóváhagyása körében az igazságügyért felelős miniszter, illetve a jogdíjak és egyéb bevételek kulturális célú felhasználása körében az NKA elnöke vagy alelnöke is kezdeményezheti. Szjt. 92/K. § (7) bek.

${ }^{257}$ Szjt. 92/K. § (6) bek. d) pont alapján a törlés azokban az esetekben lehetséges, ha:

„, da) a törvényességi felügyeeleti intézkedés nem járt eredménnyel, illetve nem várható töle eredmény, db) az a) pontban emlitett határidő eredménytelenül telt el és a felügyeleti bírság kiszabásától sem várható eredmény, vagy

dc) a felügyeleti bírság - egyszeri vagy ismételt - kiszabása nem járt eredménnyel."

${ }^{258}$ Szjt. $92 /$ K. $§(6)$ bek.

${ }^{259}$ Szjt. 92/G. $\S(1)$ bek.
} 
rendelkezésekre hívjuk fel a figyelmet, amelyek a törvény által elöírt közös jogkezelést végző szervezeteket terhelik. A társaságok alapítására, müködésére vonatkozó általános felügyeleti szabályok a polgári társaságok felügyeletére vonatkozó szabályokkal mutatnak hasonló vonásokat, bár ezek is megerősítésre kerültek, hiszen az 1985. évi törvény nem számolt azzal, hogy a közös jogkezelö szervezeteknek, az általános polgári jogi társaságoktól eltérően, jelentős számú tagja van, amelynek megfelelően kell megalkotni a tagi ellenőrzés, átláthatóság szabályait. ${ }^{260}$ Így a törvény rendelkezik a kultúráért felelős miniszter által kezdeményezett bíróság általi felügyeletről, ${ }^{261}$ a könyvvizsgáló kinevezésére vonatkozó kötelezettségröl, ${ }^{262}$ az irat betekintési jog, ${ }^{263}$ és a kisebbségi jogok szabályozásáról. ${ }^{264}$

A társaságok éves számviteli beszámolójukat, valamint az alapszabály változásait megküldik a kultúráért felelős miniszternek, a miniszter pedig a jogdíjak beszedése és felosztása kapcsán tájékoztatást kérhet. A bírósági kontroll a társaságok müködése során is felmerülhet, ez ugyanis, amennyiben a müködés törvénysértő, megtilthatja bizonyos szektorokra vagy felhasználási módokra nézve a társaság tevékenységét. $^{265}$

A CPI 2000. évi módosításával ${ }^{266}$ egy olyan állandó bizottság (commission permanente de contrôle des sociétés de perception et de répartition des droits) került felállításra, a közös jogkezelő szervezetek müködésének általános felügyeletére. ${ }^{267} \mathrm{~A}$ bizottság tagjai az Államtanács egy tagja, a Semmítőszék egy tagja, egy pénzügyekért felelős felügyelő, egy kulturális ügyekért felelős felügyelő, akiket rendeletben neveznek ki. $^{268}$ A testület minden évben nyilvánosságra hozza a társaságok működéséről szóló jelentését, amelyekben általában ajánlásokat is megfogalmaz a müködés átláthatóbbá tételére. $^{269}$ A bizottság felügyeleti jogköre azonban jelentősen korlátozott, mindössze

\footnotetext{
${ }^{260}$ NÉRISSON (2013) p. 371-373.

${ }^{261}$ CPI L. 321-3. cikk. Az alapítás során a miniszter eddig ritkán kérte a bírósági felügyeletet. Lásd TGI Paris, 3e ch, 1re sect. 16 sept. 2003, État fançais c/ Laing et al. (inédit).

${ }^{262}$ CPI L. 321-4. cikk.

${ }^{263}$ CPI L. 321-5. cikk., R. 321-2. cikk.

${ }^{264}$ CPI L. 321-6. cikk.

${ }^{265}$ CPI L. 321-11. cikk.

${ }^{266}$ Loi $\mathrm{n}^{\circ} 2000-719$ du 1 août 2000 modifiant la loi n $86-1067$ du 30 septembre 1986 relative à la liberté de communication

${ }^{267}$ CPI L. 321-13. cikk.

${ }^{268}$ CPI L. 321-13. cikk.

269 Ezek elérhetőek az állandó bizottság honlapján: https://www.ccomptes.fr/Institutionsassociees/Commission-permanente-de-controle-des-SPRD. A dolgozat kereteit viszont szétfeszítené ezek
} 
ajánlásokat tehet a társaságok müködésére vonatkozóan, ennél erösebb szankciókkal viszont nem rendelkezik.

\section{b) A dijszabások jóváhagyása}

Külön érdemes kitérni a díjszabások, vagyis a jogdíjközlemények jóváhagyásával kapcsolatos eljárásra, mint a magyar közös jogkezelési rendszer egy sarokkövére, illetve sajátosságára Bár a jogintézmény polgári jogi jellegéből, általános szerződési feltételként való alkalmazásából ez eredne, a szervezetek nem teljesen szabadok a jogdíjak és a felhasználás egyéb feltételeinek megszabása során. ${ }^{270}$ Ezeket ugyanis Magyarországon egy véleményező eljárást követően lehet elfogadni, majd az SZTNH javaslatára az igazságügyért felelős miniszter hagyja jóvá és teszi közzé a Hivatalos Értesítőben, ${ }^{271}$ ami az alkalmazás feltétele. Ezt követően bírósági felülvizsgálat és versenyjogi kontroll tárgya is lehet a díjszabás. Franciaországban hasonló általános eljárás nem létezik. Itt a díjigények egy részében (követő jogi díj illetve könyvtári haszonkölcsönzésre tekintettel fizetett díj) a CPI maga állapítja meg a fizetendő összeget, a magáncélú másolatra tekintettel fizetett díjak esetében ezt egy külön bizottság végzi. Erre az engedélyezési jog hiánya miatt van szükség, hiszen így a közös jogkezelő társaságok maguk nem állapíthatják meg a díjmértéket. Ez ráadásul az ágazati szereplők konszenzusos álláspontját tükröző összeg, hiszen a biztottság elnöke az állam egy képviselője, tagjai pedig a jogosulti, forgalmazói és fogyasztói oldal képviselői. Az engedélyezési jogok gyakorlása körében jogdíjak mértékét és a felhasználás egyéb feltételeit pedig a szervezetek állapítják meg, hasonlóan az egyéni engedélyezési jog gyakorlásához. ${ }^{272}$

részletes ismertetése, mivel alapvetően a korlátozások szemszögéből vizsgáljuk a közös jogkezelést. A jelentések elemzését ezért e helyütt mellőzzük.

${ }_{270}$ Bizonyos esetekben (követő jog, könyvtári haszonkölcsönzési jog) maga a törvény határozza meg ezeket a feltételeket. Franciaországban pedig a magáncélú másolatok esetében ezzel a feladattal nem a közös jogkezelö szervezet, hanem egy külön bizottság van megbízva. Ezekre a különleges esetekre az egyes vagyoni jogok tárgyalásánál térünk ki.

${ }^{271}$ Szjt. $92 /$ H. § (3) bek.

${ }^{272}$ A francia közös jogkezelés a szerződéses szabadság talaján áll. Az előadási szerződések esetében a CPI kifejezetten ebbe a körbe tartozónak tekinti a „szerzők szakmai szervezete” által a repertoárjába tartozó művek kapcsán kötött szerződéseket is, vagyis a közös jogkezelő szervezet a megtilthatja a felhasználást, illetve rendelkezhet annak feltételeiről. CPI L. 132-18. cikk: „Est dit contrat général de représentation le contrat par lequel un organisme professionnel d'auteurs confère à un entrepreneur de spectacles la faculté de représenter, pendant la durée du contrat, les oeuvres actuelles ou futures, constituant le répertoire dudit organisme aux conditions prévues par l'auteur ou ses ayants droit." 
A magyar jogalkotó a jóváhagyási eljárás beiktatásával igyekszik a biztosítani, hogy a közös jogkezelő szervezet ne élhessen vissza erőfölényével, és a jogdíjak az egyedi felhasználási szerződésekhez hasonlóan kölcsönösen, mindkét fél által elfogadott alku eredményeként kerülhessenek megállapításra. Mindazonáltal a jóváhagyás a törvény betűje szerint nem árkontrollt, hanem jogi szempontú vizsgálatot jelent. Az előírt eljárási rend alapján elfogadott jogdíjközlemények ráadásul sokkal megalapozottabbá, legitimebbé teszik ezeket, ${ }^{273}$ a felhasználók nem tudják őket olyan könnyen megtámadni. ${ }^{274}$ A jóváhagyás nem jelenti a jogdíjközlemények teljes immunitását, hiszen bíróságon megtámadhatóak, amennyiben nem felelnek meg a jogszabályoknak. ${ }^{275} \mathrm{~A}$ francia gyakorlat az egyedi engedélyekhez hasonló szerződéses gyakorlat fenntartása alapján azt mutatja, hogy ezt önmagában szükségtelen feltételként rögzíteni a jogszabályban, hiszen a szervezetek abban érdekeltek, hogy a felhasználásokat engedélykérés és jogdíjfizetés előzze meg, amelyhez elengedhetetlen az együttmüködés a felhasználókat képviselő szervezetekkel. Ezek a szabadon megtárgyalt, állami jóváhagyáshoz nem kötött jogdíjmértékek és felhasználási feltételek egyébként jobban megfelelnek a szerzői jog természetének és támogatandó példák (természetesen annak figyelembe vételével, hogy ennek megállapítása érdekében adott esetben speciális vitarendezési eljárás szükséges). ${ }^{276} \mathrm{~A}$ díjszabások jóváhagyásánál alkalmazott eljárás Magyarországon csorbítja a közös jogkezelő szervezetek (és így a jogosultak) autonómiáját, hiszen egyébként egyéni joggyakorlás esetében az egyedi szerződéses feltételek meghatározásánál nincsen hatósági kontroll. Míg a kötelező közös jogkezelés esetében ez egyfajta garanciaként szolgál, azonban az önkéntes közös jogkezelés tekintetében vegytisztán szemlélve a szabad megállapodás lenne kívánatos, még akkor is, ha a hatósági jóváhagyás célja eredendően nem az árkontroll. A jogdíjközlemények Hivatalos Értesítőben való közzététele viszont ebben az esetben is a szerzők javát szolgálja. Az engedélyezési jog gyakorlásával nem járó díjak esetében

SIIRIAINEN, Fabrice: Théorie générale de la gestion collective. Logique du droit exclusif de la gestion collective, J.Cl. Propriété littéraire et artistique, Fasc. 1550. p. 39.

${ }^{273}$ Győri İ́télőtábla Gf.I.20.007/2011/14.

${ }^{274}$ DIETZ (2001-2002). p. 906.

275 Szjt. 92/J. § (3) bek. A szerződési feltételek tisztességtelensége miatti megtámadhatóság szempontjából a díjszabás nem minősül jogszabály által megállapítottnak, illetve olyannak, mint amelyet jogszabály elöírásának megfelelően határoztak meg.

276 DIETZ (2001-2002) p. 906-907. Megjegyzendő, hogy ilyen vitarendezési eljárás létezik a magyar szerzői jogban, annak ellenére, hogy a jelentős felhasználók szerephez jutnak a jogdíjközlemények jóváhagyása során is. Az alapvetően a Mühold-irányelv átültesé kapcsán szkségesség vált szabályt a magyar jogalkotó minden felhasználóra nézve kiterjesztette. (Szjt. 102.§). 
viszont a magyar megoldás egyfajta garanciális szereppel bír. A törvényi engedélyek ugyanis, különösen amennyiben a díj mértékét a törvényben rögzítik, hátrányosabbak a jogosultak számára, mintha a piaci igények alapján alakítanák ki annak mértékét. Mind a magyar szabályozás, mind pedig a francia éppen azt teszik lehetővé, hogy ez az alkuhelyzet megmaradjon, és egy viszonylag rugalmas, a felhasználói szokások változását követő szisztéma kerülhessen bevezetésre. A közös jogkezelő szervezetek ugyanis általában előzetesen már tárgyalnak a felhasználókkal vagy azok érdekképviseleti szerveivel, így alakítva az alkalmazott díjakon vagy a felhasználás egyéb feltételein. ${ }^{277}$

A speciális jóváhagyási szabályok a jogdíjközlemények jogi természetére is kihatással vannak. Alapvetően általános szerződési feltételként minősülnek, ${ }^{278}$ viszont kialakításuk (és felülvizsgálatuk) szempontjából speciális szabályok vonatkoznak rájuk. Polgári jogi szempontból vizsgálva tehát (a már korábban is létező eljárás) általános szerződési feltételek előzetes, az egyoldalú megállapításra tekintettel fennálló kontrollja a jóváhagyási eljárás, amely egyben versenyjogi kontroll-szerepet is betölt. ${ }^{279}$ Általános szerződési feltétel jellegük tükröződik abban, hogy a Ptk.-ban foglalt definíciónak megfelelően ${ }^{280}$ minden felhasználó esetében alkalmazni kell őket, az engedély ezek alapján kerül megadásra. Emiatt a törvény rögzíti a felhasználási feltételek meghatározásánál alkalmazandó minimum garanciákat is. Nevezetesen az egyenlő bánásmód követelményével összhangban, ${ }^{281}$ az egyes felhasználók indokolatlan megkülönböztetése nélkül kell ezeket megállapítani és alkalmazni, illetve figyelembe kell venni az érintett felhasználás valamennyi lényeges körülményét is. ${ }^{282}$ A bírói gyakorlat szerint egyébként magáncélú másolatokra tekintettel fizetett díjak esetében főszolgáltatásnak minősül a jogdíjközleménynek az a része, amely azt határozza meg,

\footnotetext{
${ }^{277}$ KOLTAY (2004) p. 244.

${ }^{278}$ BH 2001.380.

${ }^{279}$ FALUDI (2004) p. 96.

${ }^{280}$ Ptk. 6:77. §,Altalános szerződési feltételnek minősül az a szerzödési feltétel, amelyet az alkalmazója több szerzödés megkötése céljából egyoldalúan, a másik fél közremüködése nélkül elöre meghatározott, és amelyet a felek egyedileg nem tárgyaltak meg."

281 Az egyenlő bánásmódnak a felhasználók, nem pedig a díjjal terhelt eszközök tekintetében kell fennállnia. Győri Ítélőtábla Gf.I.20.007/2011/14.

${ }^{282}$ Szjt. 92/H. § (2) bek.
} 
hogy mely üres hordozók után kell díjat fizetni, ez pedig nem képezheti a megtámadás tárgyát. $^{283}$

A jóváhagyási eljárásban a közös jogkezelö szervezetnek igazolnia kell a díjszabás megalapozottságát, ezért ehhez indokolást, és az ezt alátámasztó iratokat kell csatolni. ${ }^{284} \mathrm{Az}$ üres hordozó díjak esetében ezen kívül a magáncélú többszörözés mértékét reprezentatív módon megjelenítő felmérést is csatolni kell. ${ }^{285} \mathrm{~A}$ jogdíjközlemények különleges jogi státusát harmadrészt az a körülmény határozza meg, hogy a Központi Statisztikai Hivatal által az előző naptári évre megállapított fogyasztói árindexet meghaladó mértékü jogdíjemelést, vagy a fizetésre kötelezett felhasználók körét bővítő jogdíjközleményt az igazságügyi miniszter csak a Kormány döntése alapján hagy jóvá. ${ }^{286}$

Az SZTNH a tervezet kézhezvételét követően véleményt kér a jelentős felhasználóktól, felhasználói érdek-képviseleti szervezetektől, illetve a kultúráért felelős minisztertől (a nyilvános előadásra vonatkozó díjszabás tekintetében a kereskedelemért, turizmusért és vendéglátásért felelős minisztertől). ${ }^{287}$ A véleményezési eljárásban jelentős felhasználónak tekintendő az a személy, aki az érintett közös jogkezelő egyesülethez intézett megkeresés alapján kiadott nyilatkozattal igazolja, hogy a bejelentés évét megelőző naptári évben az általa fizetett jogdíj elérte az érintett díjszabás alapján vagy az érintett díjszabásban meghatározott valamely felhasználói csoport által megfizetett összes jogdíj 5\%-át. ${ }^{288}$ A felhasználói érdek-képviseleti szervezetek nyilvántartott tagsággal rendelkező jogi személyek, amelyek tevékenységüket országosan fejtik ki és e tevékenység kiterjed a véleményezési eljárásban a felhasználók érdekeinek képviseletére is. Továbbá az érdek-képviseleti szervezet tagja a felhasználók olyan köre, amely az adott naptári évben az adott díjszabás alapján vagy az adott díjszabásban meghatározott valamely felhasználói

\footnotetext{
${ }^{283}$ Kúria Pfv. IV. 21.272/2012/7. Az általános szerződési feltétel tisztességtelenségének megállapításával szemben a hatályos Ptk. is feltételeket támaszt. Ptk. 6:102. § (3) bek.

${ }^{284}$ Szjt. 92/H. § (4) bek.

285 Szjt. 92/H. § (4) bek. Ez a szabály egyértelműen arra szolgál, hogy a díj mértéke minél körültekintőbben, a valós felhasználási körülményekhez igazodva kerüljön megállapításra. Elkészítése viszont növeli a közös jogkezelő szervezetek müködési költségeit, és így csökkenti a jogosultak között felosztható díj összegét.

${ }^{286}$ Szjt. 92/H. § (10) bek

${ }^{287}$ Szjt. 92/H. § (5) bek.

${ }^{288}$ Szjt. 92/H. $\S(7)$ bek.
} 
csoport által megfizetett összes jogdíj legalább 10\%-át megfizette. ${ }^{289}$ Az üres hordozó és a reprográfiai díjak tekintetében a fizetésre kötelezettek és azok érdek-képviseleti szervei minősülnek felhasználónak, illetve felhasználói érdek-képviseleti szervezeteknek. $^{290}$

A díjszabást a közös jogkezelő egyesület a jóváhagyást követően a saját nevében nyilvánosságra hozza a Hivatalos Értesítőben. ${ }^{291}$ Ezen kívül ezek bárki számára elérhetőek az SZTNH által vezetett nyilvántartásban, valamint a közös jogkezelő szervezetek is közzéteszik őket a honlapjukon.

A jogdíjközlemények polgári peres úton, rendes bíróságok előtti eljárásban megtámadhatóak (illetve kifogásként is lehet hivatkozni a megtámadásra). Az Szjt. viszont leszögezi azt, hogy a szerződési feltételek tisztességtelensége miatti megtámadhatóság szempontjából a díjszabás nem minősül jogszabály által megállapítottnak, illetve olyannak, mint amelyet jogszabály elöírásának megfelelően határoztak meg. ${ }^{292}$ Az Szjt. ezen elöírása implicit módon magába foglalja, hogy az SZTNH jóváhagyása valójában inkább árjellegű, sem pedig jogi kontrollt jelent.

Egyébként amennyiben a jóváhagyási eljárás elhúzódna, arra az esetre az Szjt. a korábbi jogdíjközlemény alkalmazását rendeli el. ${ }^{293}$ Ez megfelel a közös jogkezelési tevékenység folyamatosságának, mint érvényesítendő kritériumnak. Mindez annak figyelembe vételével történik, hogy bizonyos felhasználási módok gyors ütemü változása indokolttá teszi egyébként a jogdíjközlemények évenkénti újra elfogadását. Ráadásul az új közlemény elfogadását követően az esetleges pótlólagos jogdíjbefizetések jelentős terhet róhatnak mind a felhasználókra, mind a közös jogkezelő szervezetekre. ${ }^{294}$

\footnotetext{
${ }^{289}$ Szjt. 92/H. § (8) bek.

${ }^{290}$ Szjt. 92/H. § (5) bek.

${ }^{291}$ Szjt. 92/H. § (11) bek.

${ }^{292}$ Szjt. 92/J. § (3) bek.

${ }^{293}$ Szjt. 92/H. § (11) bek.

${ }^{294}$ FALUDI (2004) p. 96-97.
} 


\section{Az első rész konklúziója}

Az első részben a dolgozat alap problémakörét vázoltuk fel részletesen egy általános ismertetőt nyújtva a közös jogkezelés lényegéről, céljáról, valamint szervezeti felépítéséről, illetve a szerzői jogi korlátozások rendszeréről. Ismertettük a két témakör metszéspontjait: felvázoltuk a közös jogkezelés beilleszthetőségének lehetőségét a korlátozások rendszerébe abból az okból kifolyólag, hogy a joggyakorlás módjának meghatározásaként a kizárólagos jog gyakorlásának korlátozásával azonos hatással bírhat. Ezen kívül pedig bevezetése mögött több esetben hasonló indokok húzódhatnak meg, mint a klasszikus korlátozások körében.

A közös jogkezelés szervezeti oldalának bemutatásakor kiemeltük, hogy közös jogkezelés elismerten mindkét országban az önkéntesség elvén alapszik. Ez az alapelv azonban egészen másként tükröződik a közös jogkezelés szervezeti felépítésében. Míg Franciaországban törekszenek minél teljesebb körü megtartására, addig Magyarországon ez tulajdonképpen kivételnek tekinthető. Ezt mutatja a törvény által elöírt kötelező közös jogkezelési esetek száma, valamint a szervezetek alapításának és müködésének szabályai közötti eltérések. Franciaországban ez az igény egy rendkívül bonyolult, személyi és infrastrukturális átfedésekkel terhelt szervezeti hálót eredményezett. Ugyanis a jogosulti csoportok külön társaságokat alapítottak egy-egy vagyoni jog kezelésére. A törvény által előírt esetekben az érintett szervezetek külön szervezeteket hoztak létre, amelyek általában saját infratruktúra nélkül müködnek, és így a közös jogkezelés hatékonyságát, átlátható és olcsó müködését vonják kétségbe. Ennek megvalósítására a másik lehetséges megoldás egyébként az, amelyet a magyar törvényben találhatunk. Ez pedig azon alapszik, hogy a törvény egy (a hagyományosan legrégebb óta fennálló) szervezetet jelöli ki a (jog)díjak beszedésére és felosztás céljára a többi jogosulti csoportot képviselő szervezetnek történő átutalására. Ez a centralizáció azzal az előnnyel jár, hogy a megfelelő erőforrásokkal rendelkező szervezet az, amely a (jog)díjakat érvényesíti. A tényleges felosztás során viszont megmarad a jogosultak rendelkezési szabadsága, hiszen azt minden illetékes szervezet a saját felosztási szabályzatának megfelelően teszi meg.

A közös jogkezelés törvény általi elöírása speciális garanciákat, felügyeleti szabályokat tesz szükségessé. Az alapfeltevés, hogy az önkéntes közös jogkezelés esetén a jogosultak maguk ellenőrzik a társaság vagy egyesület müködését. 
Amennyiben viszont a közös jogkezelést a törvény írja elö, ezt az ellenőrzést kell szigorúbb állami felügyelettel pótolni. A magyar modellben, különösen a közös jogkezelés átfogó reformja óta, ez az állami kontroll a meghatározó, amely kiterjed az önkéntes jogkezelés ritka eseteire. Ráadásul a müködési szabályok helyenként indokolatlanul szigorúak. Ez azon kívül, hogy jelentősen szükíti a szerzői jogi jogosultak mozgásterét a műveik felhasználása kapcsán, retorikai, illetve szimbolikus jelentőséggel is bír. Azt a téves, és egyébként a szerzői jog logikájával ellentétes képzetet keltheti, hogy a szervezetek valamely állami szervként müködnek, illetve, hogy ügyeikben nem magánszereplőként járnak el, hanem az állam dönt ezekben. A szerződési szabadság is korlátozásra kerül, hiszen a jogdíjközlemények, mint általános szerződési feltételek megtárgyalása és jóváhagyása során is érvényesül az állami felügyelet.

A törvény által elöírt közös jogkezelés tehát Franciaországban kivétel, Magyarországon gyakorlatilag föszabály olyan esetekben, amikor a gyakorlat, a történelmi hagyományok vagy a nemzetközi, illetve uniós jogi elöírások miatt ez szükséges, és ezekben az esetekben is kilépés kapcsolódik a közös jogkezeléshez azokban az esetekben, amikor a nemzetközi és uniós jogi keretek a kötelező közös jogkezelést nem teszik lehetővé. Mindkét esetben elmondható azonban, hogy a szerzői jog általános jogosítási rendszerétől eltérő módot jelent, csak más indokok miatt. Franciaországban önmagában a közös jogkezelés előírásával az állami beavatkozás ténye az, amely atipikussá teszi a jogkezelési módot (míg önmagában a közös jogkezelés nem tekinthető annak). Magyarországon viszont a szerzői jogok jelentős részének közös jogkezelés körébe utalása és az állami felügyelet együttesen eredményezik azt, hogy a szerző müve feletti rendelkezési joga jelentősen csorbul. Ily módon tehát a közös jogkezelés strukturális felépítése önmagában is jelentősen korlátozó jelleggel bír. Az egyes jellemzők alapján egy jól körülhatárolt, a szerzőknek és a javukra eljáró szervezeteknek viszonylag kevés mozgásteret adó (legalábbis a francia modellel összehasonlítva) szabályozással állunk szemben. 


\section{II. rész A törvény által elöírt közös jogkezelés, mint a kizárólagos jog korlátja}

A dolgozatban törvény által elöírt közös jogkezelés (gestion collective imposée par la loi) alatt értünk összefoglalóan minden olyan esetet, amelyben a joggyakorlás ilyen módja nem a jogosultak önkéntes elhatározásán, hanem a jogalkotó akaratán alapul, vagyis a törvény határozza meg, hogy mely vagyoni jogosultságot kell közös jogkezelésbe adni, és adott esetben a joggyakorlás módjának további feltételeire nézve is tartalmaz elöírást.

Ezek közül az esetek közül a szerzői jog korlátja a kötelező közös jogkezelés (gestion collective obligatoire) lehet, amely alatt általánosan azokat az eseteket értjük, amelyekben a jogosultnak egyáltalán nincsen módja arra, hogy jogait egyénileg gyakorolja, tehát ide tartozik a díjigények közös jogkezelő szervezetek által történő kezelése is. Szükebb értelemben viszont csak a kizárólagos engedélyezési jog ilyen módon történő gyakorlására vonatkoztatható a kifejezés. Közös jellemzője a kötelező közös jogkezelés alá tartozó felhasználásoknak, hogy a szervezet képviseleti joga egyfelől kizárólagos, másfelől pedig nem vonható vissza, vagyis a jogosult nem tehet az egyéni joggyakorlásra vonatkozó ex nunc hatályú jognyilaktozatot ${ }^{295}$ abban az esetben, amikor a kötelező közös jogkezelés természetes vagy jogi monopóliumként müködik. Ha az érintett vagyoni jog gyakorlására több közös jogkezelő szervezet is felhatalmazást kapott, a jogosult döntési szabadsága a szervezetek közötti választásra terjed ki. ${ }^{296}$

A fenti meghatározásból is kitünik, hogy a törvény által elöírt közös jogkezelés két esetben jelentheti a jogosultat megillető kizárólagos engedélyezési jog korlátját. A kilépést nem biztosító kötelező közös jogkezelés esetében a joggyakorlás módjának ez a meghatározása jelenti a joggyakorlás korlátját anélkül, hogy a jog fennállása tekintetében (elméletileg) változást jelentene. A szerző viszont azon túl, hogy nem gyakorolhatja egyénileg az engedélyezési jogát, amennyiben nem tagja a közös jogkezelő szervezetnek, azt is kénytelen eltürni, hogy a jogdíj mértékét és a felhasználás egyéb feltételeit az ő véleménye ellenére határozzák meg. Külön figyelmet érdemel

\footnotetext{
295 GYERTYÁNFY (2006b) p. 461.

${ }^{296}$ Ezzel kapcsolatban lásd különösen a KJK-irányelv (19) preambulumbekezdését.
} 
emiatt a nem tag jogosultak érdekeinek figyelembe vétele, a megkülönböztetés-mentes bánásmód biztosítása. ${ }^{297}$

A második eset viszont a szerzői jog valódi (kettős) korlátját képezi abban az értelemben, hogy a közös jogkezelés jellemzően a szerzői jog díjigényre szorításához kapcsolódik, annak mintegy szükséges velejárójaként. A díjigényre szorítás általában egyúttal átalánydíjazást is jelent, ezért a díjak beszedésének és felosztásának a közös jogkezelés gyakorlatilag az egyetlen hatékony módja. Éppen ez az átalánydíjazás teszi lehetővé azt is, hogy a befolyt összeg egy részét a jogosultak számára közvetetten, kulturális és szociális célú támogatások formájában osszák szét.

A két korlátozási forma közötti különbséget GYERTYÁNFY Péter fogalmazza meg találóan: „[v]ilágos, hogy a licence légale esetében a jogszabály címzettje a felhasználó, míg a kötelező közös kezelés esetében a szerző is." ${ }^{298}$ Ez a különbségtétel a felhasználói kategóriák közötti különbségtétel esetében is tetten érhető: míg a törvényi engedély esetében a tömeges felhasználást természetes személyek, mint müélvező felhasználók valósítják meg, addig a kötelező közös jogkezelés esetében a felhasználói kör sokkal inkább a professzionális felhasználókat, vagy legalábbis a felhasználóknak egy jól körülhatárolható körét jelenti.

A jogalkotó jellemzően a többszörözési jog gyakorlása kapcsán élt a korlátozás bevezetésével, több esetben ezeknek a felhasználásoknak a nehéz követhetősége miatt Kötelező közös jogkezelést ír elő a CPI a reprográfiai többszörözés kapcsán, illetve a zenei mechanikai jogok hangfelvétel-kiadáshoz kapcsolódó engedélyezését is jellemzően a közös jogkezelő szervezetek végzik (I. fejezet). A törvényi engedély klasszikus példáját pedig a magáncélú másolatra tekintettel biztosított korlátozás jelenti. Franciaországban ez az üres hordozó díjakat jelenti, Magyarországon azonban ezen kívül a reprográfia útján megvalósított többszörözés is ebbe a körbe tartozik (II. fejezet). Emellett pedig a vezetékes továbbközvetítési jog az, amely a Mühold-irányelv rendelkezései értelmében az EU minden tagállamában (így Magyarországon és Franciaországban is) kizárólag kötelező közös jogkezelés keretében gyakorolható (I. fejezet).

\footnotetext{
${ }^{297}$ Ezzel kapcsolatban lásd különösen a C-169/05. sz. Uradex-ügyben 2006. június 1-jén hozott ítéletet. ${ }^{298}$ GYERTYÁNFY (1997a) p. 131. Kiemelés tőlem: HAJDÚ Dóra.
} 


\section{I. fejezet A jog gyakorlásának korlátozása a közös jogkezelés előírásával}

A szerzőt megillető kizárólagos jog azt jelenti, hogy a szerző maga dönthet arról, hogy mủvének felhasználását kívánja-e engedélyezni vagy sem, és amennyiben igen, akkor azt milyen feltételekkel szeretné megtenni. A jogalkotó a kötelező közös jogkezelés elöírásával éppen ezt a szabad rendelkezési jogot vonja el az alkotótól, és telepíti a jog gyakorlását a közös jogkezelő szervezetekre. Vagyis kiemelten fontos azt megvizsgálni, hogy ez a döntési szabadság mennyiben képeződik le a szervezetek gyakorlatában? Álláspontunk szerint ugyanis a jogosultak rendelkezése minél inkább érvényesül, annál inkább beszélhetünk a jog gyakorlásának „természetes” módjáról. Ezzel szemben, ha a jogalkotó maga szükre szabja a KJK szervezetek mozgásterét, a kötelező közös jogkezelés sokkal inkább hasonlít a törvényi engedélyekre, különösen, ha a jogdíjak felosztása során sem jelenik meg az egyediesítés. ${ }^{299}$ Nem tekinthető viszont külön korlátozásnak az, hogy a szervezetek a meghatározott szabályok, feltételek alapján bármely felhasználóval szerződést kössenek anélkül, hogy a szervezet beleavatkozna abba, hogy a felhasználó ténylegesen mely müveket kívánja felhasználni. ${ }^{300}$ Ez a gyakorlat ugyanis megfelel a közös jogkezelés körében általánosan alkalmazott szerződéses gyakorlatnak, hiszen a felhasználás sokszor a blankettaengedélyek megadásán alapul.

Emellett pedig külön elemzés alá kell vonni magát a kizárólagos jogot is. Álláspontunk szerint ugyanis ezek - hasonlóan a klasszikusak szabad felhasználások vagy kivételekhez sorolt jogokhoz - szüken meghatározott jogok, amely éppen azt húzza alá, hogy a jogalkotó tisztában van a korlátozáshoz hasonló jellegükkel. Bár ehhez azt is érdemes hozzátenni, hogy ezt sokszor eltérő jogpolitikai indokok támasztják alá. Másrészt pedig a kizárólagos jog terjedelme önmagában is behatárolja a joggyakorlás módjának terjedelmét, vagyis vizsgálata két szempontból is nélkülözhetetlen a korlátozás terjedelmének megállapításához. Mind a nyilvánossághoz közvetítési (előadási), mind pedig a többszörözési jogok körében található példa a kötelező közös jogkezelésre. Elöbbi elsősorban (de Magyarországon nem kizárólagosan) a vezetékes továbbközvetítési jog közös kezelését jelenti (1. pont), míg

\footnotetext{
299 A gyakorlatban a (jog)díjak felosztása a mérhető felhasználásokon, illetve azokból kalkulálható becslési módszereken alapul.

${ }^{300}$ GYERTYÁNFY (1997b) p. 257.
} 
II. rész A törvény által előírt közös jogkezelés, mint a kizárólagos jog korlátja

I. fejezet A jog gyakorlásának korlátozása a közös jogkezelés elöírásával

utóbbi a reprográfiai többszörözés jogát és a mechanikai többszörözés jogát foglalja magába (2. pont). 


\section{A nyilvánossághoz közvetítés körébe tartozó egyes jogok közös kezelése}

A fejezet kifejezetten a vezetékes továbbközvetítési jog (droit de retransmission par câble) közös kezelésére koncentrál, mivel ennek közös jogkezelés körébe történő utalására a BUE felhatalmazást ad, ${ }^{301}$ és a Mühold-irányelv kifejezetten a tagállamok kötelezettségévé teszi ${ }^{302}$ a bevezetését. Adott tehát az a nemzetközi és uniós jogi háttér, amely figyelembe vételével a jog gyakorlásának ilyen módja a nemzeti szerzői jogok részét képezi.

Kötelezővé tételének indoka viszont eltér attól, mint ami a közös jogkezelést általában jellemzi. Nem arról van szó ugyanis, hogy a felhasználások tömegessége, és az egyes egyedi engedélykérések lehetetlensége miatt kellene a közös jogkezelés elöírásáról rendelkezni. Eleve a felhasználás maga sem tömeges abban az értelemben, ahogy az amatőr felhasználások esetében használjuk. Ebben az esetben ugyanis azonosítható, mérhető számú szervezet végez vezetékes továbbközvetítést, és ennél fogva az ő felhasználásaik is nyomon követhetőek. A jogosítás módjának meghatározása sokkal inkább arra szolgál, hogy a közönség egyszerübben juthasson a sugárzott müsorokhoz azáltal, hogy a közvetítést végző szervezetek egyszerübben szerezhessenek engedélyt. A Bizottság a BUE-ban meghatározott elvek mentén kívánta a harmonizációt felépíteni annak szem előtt tartásával, hogy a kizárólagos jogot a lehető legkisebb mértékű korlátozás érje - ebből ered a kényszerengedélyek elvetése, és a szerződéses alapokon nyugvó kötelező közös jogkezelés bevezetése. Az egységesítés amiatt is különösen fontos, mert ha a védelem szintjében eltérések mutatkoznak (vagyis egyik tagállam kizárólagos jogként, míg a másik törvényi engedélyként kezeli a továbbközvetítési jogot), fennáll a veszélye annak, hogy a szolgáltatók abban a tagállamban telepednek le, amely a legalacsonyabb szintü védelmet nyújtja. ${ }^{303} \mathrm{Ez}$ indokolja tehát a kötelező közös jogkezelés bevezetését.

A magyar szerzői jogi törvény viszont nem csak a vezetékes továbbközvetítés joga kapcsán rendelkezik a közös jogkezelés elöírásáról. A nyilvánossághoz közvetítés

\footnotetext{
${ }^{301}$ BUE 11 bis cikk (2) bek.

${ }^{302}$ Mühold-irányelv, 9. cikk (1) bek.

${ }^{303}$ Ezzel összefüggésben lásd: BÉRCESI (1996) p. 52.
} 
több alesete kilépést engedő közös jogkezelés alá tartozik, ${ }^{304}$ ezen belül a földfelszíni sugárzás joga kapcsán pedig szintén kötelező közös jogkezelés az irányadó.

A vizsgálat során ezt a kettősséget figyelembe véve először a nyilvánossághoz közvetítésből eredő (az előadási joghoz kapcsolódó) kizárólagos engedélyezési jogok tartalmával (§1. pont), ezt követően pedig ezek gyakorlásával foglalkozunk (§2. pont).

\section{\$1. A jog tartalma}

A nyilvános előadás joga a mü nem anyagi formában történő felhasználásának alapesete: kezdetben az élő előadásokat jelentette, az első ezzel kapcsolatos francia törvény $^{305}$ is a színdarabok nyilvános előadásáról szólt. ${ }^{306}$ A szerzői jog és technológia szimbiózisa kezdetben a nyilvános előadási jogok kiszélesedésén volt tetten érhető. A korábbi, „élő” előadásokkal ellentétben, ahol az előadó a helyszínen jelen lévő közönség számára tette élvezhetővé, befogadhatóvá a szerzői müvet, a rádió és a televízió térhódításával immáron egy sokkal szélesebb nyilvánossághoz vált lehetségessé az e célból készített és rögzített müsor valamint bármilyen élő előadás eljuttatása. A szerzői jogilag releváns felhasználási cselekményt ebben az esetben már nem azok a zenészek, színészek valósítják meg, akik a müvet előadják, hanem az müsorszolgáltató szervezet, amely a technika segítségével a müvet a szélesebb nyilvánosság számára elérhetővé teszi. A sugárzás szerzői jogilag releváns felhasználási cselekményként való értékelését tehát mindenekelőtt az a körülmény befolyásolja, hogy a mű széles (az élő előadásénál mindenképpen szélesebb), távollévő közönséghez jut el. ${ }^{307}$ Hozzá kell tenni persze azt is, hogy a másik fontos elhatároló ismérv ebben az esetben abban áll, hogy a müvek élvezetéhez szükséges valamilyen technikai eszköz igénybevétele is. ${ }^{308}$

Az ilyen jellegű felhasználások elterjedése indokolta a BUE felülvizsgálatát. Így születtek meg a nyilvános előadás jogában gyökerező, abból kicsírázó új, nevesített

\footnotetext{
${ }^{304}$ Erről lásd részletesen a III. rész I. fejezetét.

${ }^{305}$ Loi des 13-19 janvier 1791 relative aux théâtres et au droit de représentation et d'exécution des œuvres dramatiques et musicales

${ }^{306}$ A lényeg egyébként a nyilvánosságon van, vagyis a közvetlen családi körben létrejött előadások a szerzői jogon kívül esnek. GINSBURG - RICKETSON (2006) p. 704.

${ }^{307}$ MASOUYÉ (1978) p. 78.

308 Claude MASOUYÉ ezzel kapcsolatban megjegyzi, hogy bár alapvetően a hanghordozók meghallgatásához is szükséges a technika közremüködése, viszont a rádió és a televízió a müvek sokkal szélesebb skáláját képes egy időben a nézöhöz/hallgatóhoz közvetíteni, amelyek közötti választás a készülékeken lévő gomb megnyomásával végtelenül egyszerü. MASOUYÉ (1978) p. 78.
} 
kizárólagos jogok: a sugárzás és a vezetékes továbbközvetítés joga, amelyeket a BUE módosításokkal az 1928-as római felülvizsgálat óta tartalmaz. ${ }^{309} \mathrm{Az}$, hogy ezek az esetek is kizárólagos jogként lettek definiálva, indokolható egyrészt azzal az igénnyel, hogy a szerzői jog engedélyezésre, vagyis szerződéses jogviszonyra épülő belső koherenciája továbbra is fennmaradjon (adott esetben annak elismerésével, hogy a jog közös jogkezelő szervezet által gyakorolható). ${ }^{310}$ Az előadáshoz képest másodlagos felhasználást pedig nem az egyedileg nehezen beazonosítható, nagyszámú közönség végzi, hanem az a néhány szervezet, amely sugárzással, kábelen keresztül vagy a technológia által biztosított más módon a nyilvánosság számára eljuttatja a művet. Emiatt nem szükséges a szerzői jog díjigénnyé korlátozása, sőt, éppen a kizárólagos jog fenntartása indokolt.

Bár a BUE általában a 11bis cikkben szereplő jogok tekintetében biztosítja annak lehetőségét, hogy a jogok gyakorlásának feltételeit megszabja, az uniós jogalkotó a kötelező közös jogkezelés bevezetését mégis csak a vezetékes továbbközvetítési jog kapcsán tartotta indokoltnak. Azért, hogy ennek indokát megismerjük, érdemes áttekinteni a nyilvános előadási jogokat és annak különböző egyéb megjelenési formáit, elhelyezve bennük a vezetékes továbbközvetítés jogát.

A) Nyilvános előadás, nyilvánossághoz közvetítés és ezekhez köthetö egyéb nevesitett jogok

Az egyes szerzői jogok különböző módon osztályozzák a vagyoni jogokat. A nemzetközi szerzői jog, különösen a BUE azzal a technikával él, hogy egyes jogokat külön nevesítve megállapítja a védelem minimumszintjét, amelyet minden részes félnek biztosítania kell (,jus conventionis”). ${ }^{311}$ A BUE ennek megfelelően rendelkezik a müvek bemutatásának (représentation publique) és előadásának (exécution publique), ${ }^{312}$ a bemutatás és az előadás nyilvános közvetítésének jogáról (transmission publique), ${ }^{313}$ valamint a sugárzásról (radiodiffusion ou communication publique par tout autre moyen), illetve a sugárzott müvek továbbközvetítésének jogáról

\footnotetext{
${ }^{309}$ BUE 11 bis cikk.

${ }^{310}$ ROSÉN (2010) p. 398.

${ }^{311}$ MASOUYÉ (1978) p. 34-35.

${ }^{312}$ A bemutatás kifejezés hagyományosan a színművekkel, zenés színművekkel kapcsolatban használható kifejezés, míg az előadás a zenei müvekre vonatkozik elsősorban. MASOUYÉ (1978) p. 74. A továbbiakban müfajtól függetlenül előadás névvel hivatkozunk a felhasználási cselekményre.

${ }^{313}$ BUE 11. cikk (1) bek., 11 ter cikk (1) bek.
} 
(retransmission). ${ }^{314}$ A sugárzás jogáról a BUE az 1928-as római felülvizsgálat óta rendelkezik, a szöveg viszont ma is hatályos formáját az 1948-as brüsszeli konferencián nyerte el. A 11bis cikk (1) bekezdése alapján a szerzőnek kizárólagos joga van arra, hogy engedélyt adjon 1. müve sugárzására vagy minden más, jel, hang vagy kép vezeték nélküli közvetítésére alkalmas eszközzel történő nyilvános átvitelére; 2. sugárzott mü mindenfajta, akár vezeték útján történő, akár vezeték nélküli nyilvános átvitelére, ha ezt az átvitelt az eredetihez képest más szervezet végzi; 3. a sugárzott mü hangszóró vagy egyéb, annak megfelelő jel-, hang- vagy képközvetítő eszközzel történő nyilvános átvitelére.

Az uniós szerzői jog kapcsán két irányelvet, illetve ezek viszonyát kell figyelembe venni az előadási és nyilvánossághoz közvetítési jogok tekintetében. Az egyik a Műhold-irányelv, amely a sugárzási és vezetékes továbbközvetítési jogokat harmonizálja. A másik pedig az InfoSoc-irányelv, amely általában a nyilvánossághoz közvetítési jogkapcsán tartalmaz elöírásokat, a BUE-nél szélesebb körben, mivel a jog magában foglalja a lehívásra történő nyilvánosság számára hozzáférhetővé tétel jogát is. $^{315}$

Az első francia szerzői jogi törvények a felhasználási módokat hagyományosan dichotóm módon osztályozták: az egyik alapesetet a többszörözés (anyagi formában megvalósuló felhasználás), a másikat pedig a nyilvános előadás (nem anyagi formában megvalósuló felhasználás) képezi. A csoportosítás a szerzői jogi dogmatika gerincét képezi a mai napig, ami azt jelenti, hogy föszabály szerint a további jogokat is ezeknek az eseteknek a körébe próbálják a jogtudósok beilleszteni. ${ }^{316}$ Az előadási jogot (droit de représentation) a francia szerzői jog ennek megfelelően egységként kezeli, és csak az egyes speciális felhasználási módokhoz kapcsolódó vagyoni jogokat nevesíti külön. A CPI általános megfogalmazása értelmében a nyilvános előadás a mü bármilyen módon történő nyilvánossághoz juttatását jelenti, ${ }^{317}$ vagyis a kódex a kizárólagos jog

\footnotetext{
${ }^{314}$ BUE 11 bis cikk (1) bek.

${ }^{315}$ InfoSoc-irányelv, 3. cikk (1) bek. Értelmezését lásd többek között: FALUDI - GRAD-GYENGE (2012)., BERCOVITZ RODRÍGUEZ-CANO (2014) p.35-46.

${ }^{316}$ Az elmélet megdöntéséröl a követő jog (droit de suite) tekintetében lásd a III. rész II. fejezetét. A bírói gyakorlat által kimunkált rendelkezési jogról (droit de disposition) pedig a haszonkölcsönzési jog tárgyalásánál lesz szó, szintén a III. rész II. fejezetében.

317 CPI L. 122-2. cikk. „La représentation consiste dans la communication de l'œuvre au public par un procédé quelconque, et notamment:
} 
biztosítását nem teszi függővé technológiai tényezőktől, vagy a közönség jelen- vagy távollététől, amennyiben a mü eléri a nyilvánosságot, abban az esetben az előadás szerzői jogi értelemben vett felhasználása megvalósul. ${ }^{318}$ Ehhez nem szükséges az sem, hogy az elöadó és a közönség egyszerre legyen jelen az előadás helyszínén. ${ }^{319}$ A jogtudomány a törvény példálózó felsorolását alapul véve elsődleges és másodlagos felhasználási módokat különít el. Elsődleges előadás alatt érti mindazon eseteket, amelyekben a mü közvetlenül jut el a közönséghez, míg másodlagos előadásnak tekinthetőek azok, amelyek valamilyen sugárzott jel továbbközvetítésében állnak. Így elsődleges felhasználásnak tekinthető többek között minden müfajú mü élő előadása, a sugárzás, de a nyilvánosság számára lehívásra hozzáférhetővé tétel, illetve akár a P2P fájlmegosztás is. Másodlagos előadás pedig egy már nyilvánossághoz közvetített mü továbbközvetítése, így például a sugárzott müsor nyilvános helyen való közvetítése, a szállodákban és éttermekben történő közvetítés, a vezetékes és műholdas továbbközvetítés, valamint a közösségi antennák keretében végzett közvetítés. Ezek a másodlagos felhasználási módok jellegükben eltérő problémákat vetnek fel. Ilyenkor ugyanis vizsgálandó szempont, hogy az engedélyezési jog milyen feltételek mellett terjedhet ki rájuk: a technikai megoldás biztosításán túl szükség van-e arra, hogy a továbbközvetítést végző szervezet maga is rendelkezzen a közvetítést tartalma felett, új közönséget kell-e elérnie, a felhasználásnak nyereségorientáltnak kell-e lennie? ${ }^{320}$

Az Szjt. más felfogást követ: a nyilvános előadás és a nyilvánossághoz közvetítés különálló kezelésével a mű nem anyagi formában történő felhasználásának két alapesetét határozza meg. ${ }^{321}$ Ezzel jobban igazodik a BUE felülvizsgálatai során kikristályosodott felosztási módhoz. Mindkét jogforrás vonatkozásában elmondható, hogy a nyilvános előadás és a nyilvánossághoz közvetítés közötti legfontosabb elhatároló ismérve a közönség hollétében rejlik. Míg a nyilvános előadás kapcsán a mü

$1^{\circ}$ Par récitation publique, exécution lyrique, représentation dramatique, présentation publique, projection publique et transmission dans un lieu public de l'ouvre télédiffusée;

$2^{\circ}$ Par télédiffusion."

${ }^{318}$ LUCAS - LUCAS - LUCAS-SCHLOETTER (2012) p. 282. Megjegyzendő, hogy az előadási jog ilyen tágan vett értelmezése adott esetben problémkat szülhet, ha a többszörözési jogtól való elhatárolásról van szó. Lásd: u.o.

${ }_{319}^{319}$ POLLAUd-Dulian (2005) p. 534.

${ }^{320}$ A csoportosításról részletesen lásd: LUCAS - LUCAS - LUCAS-SCHLOETTER (2012) p.284-299. A másodlagos közvetítéssel kapcsolatban felmerült kérdésekre adható válaszok elemzését lásd a dolgozat későbbi fejezeteiben.

${ }^{321}$ GYERTYÁNFY (2014) p. 198. és 207. 
jelenlévő közönség számára történő közvetlen érzékelhetővé tételéről van szó, ${ }^{322}$ addig a nyilvánossághoz közvetítés azon túl, hogy távollévő közönséget céloz meg, a mü maga valamilyen technikai megoldás útján lesz látás és hallás útján érzékelhető a jelenlévők számára. ${ }^{323}$ Claude MASOUYÉ kiemeli, hogy a BUE alkalmazásában a sugárzás, lévén, hogy speciális rezsim alá esik, nem képezi a 11. cikk alá eső általános nyilvánossághoz közvetítési jog részét. ${ }^{324} \mathrm{Az}$ Szjt. viszont, mivel a nyilvánossághoz közvetítést alapesetként kezeli, a sugárzást és ezzel rokon jogokat is ez alá a kategória alá illeszti be, és a BUE szerint nyilvánossághoz közvetítésnek tekinthető egyes eseteket nyilvános előadásként kezel a gyakorlatban.

A magyar törvény rendelkezik mind a földfelszíni, mind pedig a müholdas sugárzásról, illetve a vezeték útján történő nyilvánossághoz közvetítésről. Ezekre a technológiai megoldásokra általában jellemző, hogy azonos müsortartalomnak a nyilvánosság általi egyidejü vételét teszik lehetővé, a különbség tulajdonképpen csak a jelátvitel megvalósításától függ: vezetékes közvetítés esetében ez annyit tesz, hogy nem elektromágneses hullámok a jelhordozók. ${ }^{325}$ Sugárzásnak minősül az Szjt. értelmében a mü érzékelhetővé tétele távollévők számára hangoknak, képeknek és hangoknak, vagy technikai megjelenítésüknek vezeték vagy más hasonló eszköz nélkül megvalósuló átvitele. ${ }^{326} \mathrm{Az}$ Szjt. azt is rögzíti, hogy sugárzásnak minősül a mühold útján történő sugárzás is, ha ez a nyilvánosság körében közvetlenül fogható, ${ }^{327}$ illetve a kódolt sugárzás is, amely csak az után fogható a nyilvánosság körében, hogy a müsort hordozó jeleket erre alkalmassá tették, ${ }^{328}$ vagyis dekódolták őket. Egy műsor a nyilvánosság számára akkor fogható közvetlenül, ha a rádió- vagy televízió-szervezet felelősségével és ellenőrzése alatt műsort hordozó jeleket juttatnak el a műholdhoz, majd onnan a Földre megszakítatlan közvetítés útján azzal a céllal, hogy a jeleket a nyilvánosság vehesse. ${ }^{329}$ Ezeknek az elhatárolásoknak amiatt is jelentőségük van, mivel az Szjt. 27.

\footnotetext{
${ }^{322}$ GYERTYÁNFY (2014) p. 207., MASOUYÉ (1978) p. 75-76.

${ }^{323}$ GYERTYÁNFy (2014) p. 207., MASOUYÉ (1978) p. 76.

${ }^{324}$ MASOUYÉ (1978) p. 76.

${ }^{325}$ GYERTYÁNFY (2014) p. 212

${ }^{326}$ Szjt. 26.§ (1) bek.

${ }^{327}$ Szjt. 26.\$ (2) bek.

${ }^{328}$ Szjt. 26.\$ (3) bek.

329 Szjt. 26. § (2) bek. A müholdas sugárzás kapcsán érdemes megemlíteni azt a polémiát, amely a felhasználás helye, és így a jogosítás helyének meghatározása körül alakult ki. Ez azért fontos kritérium, mert a szerzői jog területiségéből, illetve a BUE alapelveiből adódóan a logikus következtetés az lenne, hogy a sugárzás által érintett minden területre kiterjedően külön-külön kellene engedélyt kérni. Ezzel a vételi elvvel, közkeletű elnevezésével Bogsch-elmélettel ellentétes elv került elfogadásra a Mühold-
} 
§-a földfelszíni sugárzás tekintetében kötelező közös jogkezelést ír elö, míg a müholdas sugárzást kilépést engedő közös jogkezelés keretében kezeli.

A vezetékes továbbközvetítés joga a fenti kritériumok alapján értelmezhető a francia elhatárolás szerinti másodlagos felhasználásként a magyar szerzői jogban is. Lényege ugyanis egy már sugárzott mü továbbközvetítése meghatározott feltételek szerint. A csoportosításnak a közös jogkezelés szempontjából csak elvi jelentősége van. Aláhúzza azt, hogy a törvény által elöírt közös jogkezelés jellemzően a művek másodlagos felhasználásához kötődik, illetve magyarázattal szolgál a joggyakorlás módja szükségességének is. Az általános bevezetőt követően ezért a továbbiakban a vezetékes továbbközvetítési jog tartalmi elemeivel foglalkozunk.

\section{B) A vezetékes továbbközvetítési jog tartalmi elemei}

A Mühold-irányelv részletesen meghatározza azokat a feltételeket, amelyek fennállása esetén a tagállamoknak elő kell írniuk a kötelező közös jogkezelést. Az irányelv alkalmazásában vezetékes továbbközvetítésnek minősül a másik tagállamból származó, a nyilvánosság általi vételre szánt televíziós vagy rádiós müsor vezetékes vagy vezeték nélküli - ideértve a müholdas közvetítést is - eredeti közvetítésének egyidejü, változatlan és teljes terjedelmü, kábeles vagy mikrohullámos rendszeren keresztüli, nyilvánosság általi vételre szánt továbbközvetítése. ${ }^{330}$

A BUE rendelkezései viszont valamivel tágabban határozzák meg a vezetékes továbbközvetítés fogalmát. Az egyezmény vezeték vagy vezeték nélkül történő nyilvános átvitelről szól, ha ezt az átvitelt az eredetihez képest más szervezet végzi. ${ }^{331}$ Mivel külön vagyoni jogként kerül nevesítésre, ezért az mindenképpen megállapítható, hogy a sugárzásra adott engedély nem jelenti egyben a kábeles továbbközvetítésre adott engedélyt is, ${ }^{332}$ vagyis a felhasználónak ezt külön meg kell szereznie.

A Mühold-irányelv tehát, amely az EU tagállamai számára kötelezővé teszi a közös jogkezelés előírását tehát nem ellentétes a nemzetközi elöírásokkal, hiszen a BUE

irányelvben. Az emissziós elv szerint ugyanis a szerzői jogilag releváns felhasználási cselekmény a műsor fellövésének helye szerinti államban valósul meg. Ami azt is jelenti, hogy a felhasználások jogosításának is a kibocsátás helye szerinti államban kell megtörténnie. MUNKÁCSI (2000).

${ }^{330}$ Mühold-irányelv 1 . cikk (3) bek.

${ }^{331}$ BUE 11 bis cikk (1) bek. 2. pont.

${ }^{332}$ EDELMAN (1987) p. 34. 
ezt a megoldást egyébként megengedi a részes államok számára. Ehhez kapcsolódik, hogy Franciaországban az 1985. évi törvény volt az, amely a vezetékes közvetítés jogára vonatkozó rendelkezéseket a BUE alapján beiktatta a CPI-be, anélkül, hogy a kötelező közös jogkezelésről kifejezetten rendelkezett volna. Majd később a Müholdirányelv átültetése a tagállamok közötti vezetékes továbbközvetítésre vonatkozóan elöírta a kötelező közös jogkezelést. A szöveg értelmében „ellenkezö kikötés hiányában a földi sugárzásra adott engedély nem terjed ki a mü vezetékes közvetitésére, kivéve, ha az eredeti engedéllyel rendelkezö szervezet egyidejüleg és teljesen végzi, és nem lépi túl a szerzödésben meghatározott földrajzi kereteket."333 A Mühold-irányelv implementálása $^{334}$ során került a kódexbe az L. 132-20-1. cikk, amely kifejezetten a másik tagállamból származó müsor egyidejü, teljes és változatlan vezetékes továbbközvetítésének módját határozza meg. ${ }^{335}$ Vagyis Franciaországban két rezsim áll fenn egymás mellett, amelyek mind a jog terjedelmében, mind pedig a joggyakorlás módjában eltérnek egymástól. Egyrészt a kódex tartalmaz egy általános rendelkezést a vezetékes továbbközvetítési jog meghatározásáról, amelynek gyakorlását nem utalja kötelező közös jogkezelés körébe. Másrészt pedig tartalmaz egy ettől eltérő rendelkezést, amely tulajdonképpen nem terjed túl az irányelv 9. cikkének szó szerinti megismétlésétől, amelyhez kötelező közös jogkezelést kapcsol a jogalkotó.

A magyar jogalkotó egységes rendelkezést vezetett be a vezetékes továbbközvetítési jog meghatározásánál, ami egyszerre felel meg a BUE és a Müholdirányelv által meghatározott feltételeknek is: kizárólagos jogot biztosít a szerzőknek, viszont annak gyakorlását korlátozza, és a feltételek meghatározásába beépíti az irányelv speciális szabályait. Az Szjt. ugyanis úgy fogalmaz, hogy ,,a szerzőnek az is kizárólagos joga, hogy a rádió- vagy televízió-szervezet, illetve a saját műsort a nyilvánossághoz vezeték útján vagy másként közvetítő műsorában sugárzott, illetve közvetített művének sugárzással, vezeték útján vagy egyéb módon - az eredetihez

${ }^{333}$ CPI L. 132-20. cikk: „Sauf stipulation contraire:

$1^{\circ}$ L'autorisation de télédiffuser une oeuvre par voie hertzienne ne comprend pas la distriution par câble de cette télédiffusion, à moins qu'elle ne soit faite en simultané et intégralement par l'organisme bénéficiaire de cette autorisation et sans extension de la zone géographique contractuellement prévue;"

${ }^{334}$ Loi n ${ }^{\circ}$ 97-283 du 27 mars 1997 portant transposition dans le code de la propriété intellectuelle des directives du Conseil des Communautés européennes n ${ }^{\circ}$ s 93/83 du 27 septembre 1993 et 93/98 du 29 octobre 1993.

${ }^{335}$ CPI. L. 132-20-1.cikk „A compter de la date d'entrée en vigueur de la loi $n^{\circ}$ 97-283 du 27 mars 1997, le droit d'autoriser la retransmission par câble, simultanée, intégrale et sans changement, sur le territoire national, d'une oeuvre télédiffusée à partir d'un Etat membre de la Communauté européenne ne peut être exercé que par une société de perception et de répartition des droits." 
II. rész A törvény által elöírt közös jogkezelés, mint a kizárólagos jog korlátja

I. fejezet A jog gyakorlásának korlátozása a közös jogkezelés elöírásával

képest más szervezet közbeiktatásával - a nyilvánossághoz történő egyidejü, változatlan és csonkítatlan továbbközvetítésére engedélyt adjon." ${ }^{336}$

A vezetékes továbbközvetítési jog tartalmi elemei jelentős hasonlóságokat mutatnak, ezért bemutatásuknál nem a jogforrások szerinti csoportosítást, hanem az egyes ismérvek alapján történő elemzést választottuk. A jog terjedelméhez pedig mind az eredeti közvetítés [a) pont], mind pedig a továbbközvetítés [b) pont] tartalmi jellemzőit meg kell vizsgálni

a) Az eredeti közvetités

Az eredeti közvetítés alapját a müsor fogalma képezi, amelynek ezen túl további jellemzőknek is meg kell felelnie az irányelvben meghatározott kritériumok szerint.

a) A müsor fogalma

Bár a BUE következetesen müvekről beszél, a Mühold-irányelv már a televíziós és rádiós müsort teszi a továbbközvetítés tárgyává. ${ }^{337}$ Ez ugyan következhet a Mủhold-irányelv médiajogi gyökereiből, előzményeiből, ${ }^{338}$ a szerzői jog fogalomkészletétől azonban idegen. Maga az irányelv nem is ad eligazítást azzal kapcsolatban, hogy mit kell müsornak tekinteni. A precíz meghatározás hiánya problémákat vethet fel az irányelv alkalmazása kapcsán. Elmosódhatnak a határok az egyes kérdésekben, így nehézkessé válhat a továbbközvetítés kapcsán alkalmazandó követelmények tiszteletben tartása is. ${ }^{339}$

Az Szjt., összhangban az irányelvvel, de igazodva a szerzői jogi terminológiához, „müsorban sugárzott” művekre terjed ki. A törvény maga nem

\footnotetext{
${ }^{336}$ Szjt. 28. § (2) bek.

${ }^{337}$ Mühold-irányelv, 1. cikk (3) bek.

338 A Televíziózás határok nélkül irányelv (Az Európai Közösségek Tanács 89/552/EK irányelve a tagállamok törvényi, rendeleti vagy közigazgatási intézkedésekben megállapított, televíziós müsorszolgáltató tevékenységre vonatkozó egyes rendelkezéseinek összehangolásáról) „szőrmentén” tartalmazott a kábeles továbbközvetítési jogra vonatkozó (igaz nem szerzői jogi) szabályokat. A 2. cikk (2) bekezdése (bizonyos feltételek fennállásától eltekintve) elöírja a tagállamok számára, hogy biztosítsák a vétel szabadságát és ne korlátozzák a más tagállamokból származó televíziós adások továbbközvetítését saját területükön olyan okoknál fogva, amelyek az irányelv által koordinált területre tartoznak. Az irányelvet elökészítő Zöld könyv viszont még tartalmazott szerzői jogra vonatkozó szabályokat is, ezek viszont kilúgozódtak az elfogadott szövegböl. Ennek egyik oka éppen abban rejlett, hogy a Zöld könyv még a kábeles továbbközvetítési jog kötelező közös jogezelését vízionálta. BÉRCESI (1996) p. 52.

${ }^{339}$ HugENHOLTZ (2009) p.13.
} 
tartalmazza a műsor meghatározását, ${ }^{340}$ a legfrissebb szerzői jogi kommentár viszont nem marad adós ezzel. Elfogadva az ott közzétett definíciót, „[m]üsorokon a músorszolgáltató által alakított, összeválogatott, a közönséghez szóló vegyes programokat, de egy-egy közönség célcsoportnak szánt (például gyermek-, sport-) müsorokat érthetjük." 341

\section{B) Az eredeti közvetités jellemzői}

$\mathrm{Az}$ eredeti televíziós vagy rádiós müsornak az irányelv értelmében három kritériumnak kell megfelelnie. Mindenekelőtt másik tagállamból kell származnia, nyilvánosság általi vételre kell szolgálnia és vezetékes vagy vezeték nélküli (ideértve a müholdat is) közvetítésnek kell lennie.

Mivel az irányelv célja a belső piaccal összefüggő szerzői jogi felhasználások harmonizálása, ezért egyértelmü, hogy már a fogalom meghatározásában is kiemelésre kerül a tagállamokon átívelő felhasználási cselekmények esetében való alkalmazása. Az eredeti müsor másik tagállamból származása azt jelenti, hogy az irányelv hatálya nem terjed ki azokra az esetekre, amelyek egy hazai müsor továbbközvetítésére irányulnak. Hasonlóan, az eredetileg harmadik országból származó műsorok továbbközvetítésére sem alkalmazhatóak a rendelkezései.

Vagyis ebben az utóbbi két esetben a felhasználás engedélyezésére vonatkozó szabályokat a tagállamok szabadon meghatározhatják. A CPI, amely meghagyta a korábban létező rezsimet a belföldi továbbközvetítések esetén, tehát nem ütközik az uniós jogba. A tagállamok persze ettöl függetlenül dönthetnek úgy, hogy az irányelv szerinti kötelező közös jogkezelést írnak elő ezekben az esetekben is. Azonban extrém esetben (legalábbis elméletben) az is előfordulhat, hogy a kábeles továbbközvetítés esetén három különböző rezsim létezik egymás mellett attól függően, hogy a továbbközvetítés alapjául szolgáló eredeti müsor honnan származik. Ez a helyzet viszont a joggyakorlást nagyban megnehezítve kaotikus eredménnyel járna, illetve az egyenlő bánásmód tagállami követelményeinek megsértésével is járhatna. Mivel a

\footnotetext{
${ }^{340}$ Hiszen ez nem a szerzői jog, hanem a médiajog szabályozási körébe tartozó kérdés. Ennek megfelelően a műsor fogalmát a médiaszolgáltatásokról és a tömegkommunikációról szóló 2010. évi CLXXXV. tv. 203. § 44. pontja határozza meg, az alábbiak szerint: rádiós, illetve audiovizuális müsorszámok megszerkesztett és nyilvánosan, folyamatosan közzétett sorozata. A két jogterület által használt fogalmak közös nevezöre hozásáról lásd: SARKADY - GRAD-GYENGE (2012) p. 60-69.

${ }^{341}$ GYERTYÁNFY (2014) p. 222.
} 
közös jogkezelés elöírását a BUE is lehetővé teszi, nem meglepő, ha a tagállamok a vezetékes továbbközvetítést egységes rendszerben kezelik, függetlenül attól, hogy mi a továbbközvetített müsor származási helye - ahogyan azt egyébként az Szjt. is teszi.

Az eredeti közvetítésnek ezen túl a nyilvánosság általi vételre is szolgálnia kell. Ez az előadási jogoknál alapvető kritérium megismétlését jelenti: amennyiben az eredeti közvetítés nem céloz meg egy szük családi, baráti körnél szélesebb közönséget, úgy nem tartozik az irányelv hatálya alá.

A közvetítés technológiai megvalósítása mellékes: történhet vezeték nélkül vagy vezeték útján - ideértve a müholdat is. A semleges megfogalmazás miatt tehát nem szükséges feltétel az, hogy sugárzott műsor kerüljön továbbközvetítésre.

\section{b) A továbbközvetités jellemzöi}

A továbbközvetítés kapcsán több fontos jellemzőt érdemes kiemelni. Az elsődleges szempont annak megvizsgálása, hogy a továbbközvetítésre milyen technológiai megoldás igénybe vételével kerülhet sor, illetve a továbbközvetítésnek milyen egyéb kritériumoknak kell megfelelnie. Ezt követően kell a közvetítést végző szervezet jellemzőit górcső alá venni. Majd pedig ki kell térni arra a kérdésre is, hogy a továbbközvetítésnek egyben azt is kell-e jelentenie, hogy ily módon a mü új közönséghez jut el. Ezek vizsgálata azért elengedhetetlen, mivel valamelyik törvényben rögzített feltétel nem teljesülése esetén a felhasználás elveszíti privilegizált jellegét, és a főszabály szerinti egyedi engedélykérés (vagy esetleg önkéntes közös jogkezelés) szerint jogosítandó. ${ }^{342}$

\section{a) A továbbközvetités technikai megvalósulása}

\section{Egyidejü, változatlan és teljes}

A BUE az eredeti és a továbbközvetített müsor közötti kapcsolatra vonatkozóan nem tartalmaz előírást. A Mühold-irányelv viszont a továbbközvetítést az eredeti műsorral összefüggésben, ahhoz képest határozza meg. Alapvető jellemzője, hogy az eredeti müsornak az egyidejü, változatlan és teljes terjedelmü, kábeles vagy

${ }^{342}$ GAUDEL (1986) p. 74-77. 
II. rész A törvény által előírt közös jogkezelés, mint a kizárólagos jog korlátja

I. fejezet A jog gyakorlásának korlátozása a közös jogkezelés elöírásával

mikrohullámos rendszeren keresztüli nyilvánosság általi vételre szánt továbbközvetítésének kell lennie.

A továbbközvetítés első három együttes feltételét, vagyis azt, hogy egyidejünek, változatlannak és teljes terjedelműnek kell lennie, összekapcsolva érdemes vizsgálni. Egymással szoros kölcsönhatásban és összefüggésben álló fogalmakról van szó, amelyek a továbbközvetítés lényegi ismérveit adják. Ezek jelentik egyébként az elhatároló kritériumot a BUE-hoz képest is, az egyezményben ugyanis ezek nem jelennek meg.

Az egyidejüség azt jelenti, hogy a továbbközvetítésnek időbeli eltolódás nélkül kell megtörténnie, vagyis az előfizetőkhöz ugyanabban az időben kell eljutnia, mint azokhoz, akik közvetlenül az eredeti közvetítést élvezik. A két közvetítésnek tehát egymással párhuzamosan kell folynia. Ez természetesen nem zárja ki azt, hogy a technikai jelátvitelből eredően minimális időbeli eltérés legyen a két közvetítés között. ${ }^{343}$ Arra nézve azonban nincsen semmiféle egzakt meghatározás, hogy ez a minimális technikai eltérés milyen hosszú lehet. Az is kijelenthető, hogy a továbbközvetítés egyidejüségéhez az is szükséges, hogy az automatikusan történjen meg. Amennyiben emberi beavatkozás történik, akár milyen rövid időtartamú is legyen, már sérül az egyidejüség követelménye. A továbbközvetítés változatlan, amennyiben az eredeti müsor egysége nem sérül, és teljes, amennyiben a müsor egészében került továbbközvetítésre. ${ }^{344} \mathrm{~A}$ fentiekből kifolyólag az időben késleltetett továbbközvetítések, vagy azok az esetek, ahol például az eredeti reklámblokkot mással helyettesítik, nem tekinthetők a vezetékes továbbközvetítés irányelvi fogalma alá tartozó eseteknek. Késleltetettség idején sérül az egyidejüség követelménye, míg a reklámblokk kivágásával vagy helyettesítésével a müsor egysége vagy csonkítatlansága kerül veszélybe.

Ezeknek a feltételeknek a meghatározása alapvetően adódik a kötelező közös jogkezelés irányelvben meghatározott indokaiból, vagyis abból, hogy a továbbközvetítést végző szervezet nincsen abban a helyzetben, hogy a müsor összeállítását maga végezze. Mivel ő lényegében csak egy technológiai közbenső szereplő, aki erre saját, a közönséget megcélzó üzletet épít fel, ezért került számára

\footnotetext{
${ }^{343}$ VON LEWINSKI - WALTER (2010) p. 420.

${ }^{344}$ VON LEWINSKI - WALTER (2010) p. 420.
} 
biztosításra ez az egyszerübb engedélyszerzési módszer (amellett persze, hogy nagy valószínüséggel az eredeti müsorra vonatkozóan is közös jogkezelőtől lehet jogot szerezni). Vagyis amennyiben ennek a müsornak valamilyen paraméterét megváltoztatja, kikerül a privilegizált helyzetéből, ami viszont nem jelenti azt, hogy ne kellene engedélyt szereznie a felhasználáshoz.

Az Szjt. a CPI-vel ellentétben, amely teljes egészében átveszi az irányelv kifejezéseit, a teljesség tekintetében eltérő szóhasználatot választott. A törvényben szereplő „csonkítatlan” kifejezés viszont érdemi eltérést nem jelent az irányelvhez képest. Söt, a magyar jogalkotó által használt kifejezés talán még jobban meg is világítja a feltétel valódi értelmét.

Ehhez kapcsolódva érdemes megemlíteni, hogy a kábelszolgáltatók által bevett gyakorlat a „channel sharing”, vagyis az, hogy például bizonyos programokat nappal, míg másokat éjszaka közvetítenek tovább. Az időbeli eltolódás miatt viszont ez a gyakorlat egyértelmüen kiesik a kábeles továbbközvetítési jog irányelv általi fogalma alól, nehézkessé téve így ezeknek a gyakorlati megoldásoknak a jogosítását. ${ }^{345}$

\section{$\underline{\text { Alkalmazott technológia }}$}

A BUE nem tesz különbséget a között, hogy a továbbközvetítés vezetékkel vagy a nélkül valósul meg. Ennek megfelelően minden olyan új technológiai megoldás, amely jelek fizikai vezető általi átvitelét jelenti, a rendelkezés hatálya alá tartozik. Ilyennek tekinthető a sugárzott müsor simulcasting vagy optikai kábel útján történő továbbközvetítése is. ${ }^{346}$

A Mühold-irányelv az eredeti müsor fogalmával ellentétben, a továbbközvetítés technológiai megvalósításánál kifejezetten a kábeles vagy mikrohullámos rendszereket írja elő. Az átültetés szempontjából érdekes kérdéseket vethet fel, hogy az egyes tagállamok megtartották-e ezt a szoros értelmezést vagy pedig általánosabb értelemben foglalkoznak a kábeles továbbközvetítési joggal. ${ }^{347} \mathrm{Az}$ irányelv elfogadásakor, 1993-ban az internet, mint technológia gyerekcipőben járt. A bírói

\footnotetext{
${ }^{345}$ HugENHOLTZ (2009) p. 13.

${ }^{346}$ VON LEWINSKI (2008) p. 150

347 Ausztria például technológia-semleges értelemben használja a fogalmat, míg Németország technológiához kötötten. Erről lásd: DEPREEUW - TRIAILLE (2013) p. 228-232.
} 
gyakorlatban viszont viszonylag hamar felvetödött a kérdés, mely szerint az interneten keresztül megvalósuló közvetítések (kifejezetten a simulcasting eljárás) minősíthető-e vezetékes továbbközvetítésnek. A Bizottság 2002-ben a Mühold-irányelvröl készített hatástanulmányban amellett érvelt, hogy az internetes felhasználások nem tartoznak a vezetékes továbbközvetítés körébe. A Bíróság sem a Mühold-irányelv, hanem az InfoSoc-irányelv rendelkezéseit hívja fel a TVCatchup-ügyben ${ }^{348}$ hozott ítéletében. Ebben a Bíróság arra az álláspontra helyezkedett, hogy az internetes továbbközvetítéstől eltérő, specifikus technikai módon történik, ezért az ilyen továbbközvetítés az InfoSocirányelv 3. cikke szerinti közvetítésnek minősül. ${ }^{349}$

Hasonlóképp, a hotelszobákban történő közvetítés kapcsán is felvetődött a Mühold-irányelv alkalmazása. Az EGEDA-ügy ${ }^{350}$ tényállása szerint egy spanyol szálloda olyan rendszert helyezett üzembe, amely a vendégnek lehetővé tette, hogy a saját szobájában, egyedileg nézhessen földi vagy müholdas szórású televízió müsorokat. Az egyik előzetes döntéshozatalra utalt kérdés éppen arra vonatkozott, hogy az ilyen megoldás a Mühold-irányelv értelmében vett vezetékes továbbközvetítésnek minősülhet-e. A Bíróság viszont kikerülte a válaszadást. Akként foglalt állást, hogy az irányelv nem tartalmaz rendelkezéseket annak a tényállásnak a minősítésére, amelyben egy hotel a müholdas vagy földi sugárzás jeleit kábelen keresztül továbbközvetíti a különböző szobákban, ezt ugyanis a tagállami jognak kell minősítenie. ${ }^{351}$

A magyar törvény a BUE tágabb, technológia-semleges szabályait veszi alapul. Sem az eredeti, sem a továbbközvetített müsor tekintetében nem tartalmaz megkötést, mindkettő megvalósulhat akár vezetékkel, akár más módon. Ennek megfelelően a közös jogkezelési kötelezettség is kiterjed a vezetéktől eltérő közvetítési módokra is. Ez azonban nem áll ellentétben a Mühold-irányelv elöírásaival, hiszen a megoldás jogszerüsége közvetlenül a BUE-ben biztosított felhatalmazásból fakad, és a BUE egyébként csak szélesebb védelem nyújtására ad felhatalmazást, azt szükítő rendelkezéseket a BUE tagállamai nem iktathatnak a törvénybe. Ezen a ponton említésre szorul, hogy az EU ugyan nem tagja a BUE-nak, tagja viszont, mint külön

\footnotetext{
${ }^{348}$ A C-607/11. sz. TVCatchup-ügyben 2013. március 7-én hozott ítélet.

${ }^{349}$ A 26. pontja.

${ }^{350}$ A C-293/98. sz. EGEDA vs. Hoasa-ügyben 2000. február 3-án hozott ítélet. Az ügy elemzését lásd: EDELMAN (2001) p. 1094.

${ }^{351}$ Az EGEDA vs. Hoasa-ügyben hozott ítélet 25. pontja.
} 
II. rész A törvény által elöírt közös jogkezelés, mint a kizárólagos jog korlátja

I. fejezet A jog gyakorlásának korlátozása a közös jogkezelés elöírásával

entitás, a TRIPS-egyezménynek, amely magába foglalja a BUE szerinti kötelezettségvállalást. Vagyis az EU-nak technológia semlegesen felül kellene vizsgálnia a Mühold-irányelv kábeles továbbközvetítési jogának technológiai korlátozását. Amennyiben a kötelező közös jogkezelést korlátozásnak tekintjük, a Mühold-irányelv korlátozása igazolható azzal, hogy voltaképpen egy korlátozás alól vesz ki bizonyos felhasználási módokat, vagyis éppenséggel kiteljesíti, érintetlenül hagyja a szerző vagyoni jogait.

\section{ß) Az új nyilvánosság kérdése}

Az új nyilvánosság kérdése ${ }^{352}$ mindenekelőtt a miatt kap fontos szerepet, mert a továbbközvetítés új, engedélyköteles felhasználásként való minősítését alapozhatja meg. A vezetékes továbbközvetítés esetében vizsgálandó, hogy önmagában a továbbközvetítést végző eltérő szervezet elkülönülése, a saját üzleti tevékenység és/vagy eltérő technológiai megoldás megalapozza-e az önálló szerzői jogi felhasználásként való minősítést.

A BUE mindössze azt tekinti a továbbközvetítés feltételének, hogy azt az eredetihez képest más szervezet végezze el. Ebből a contrario következik, hogy a BUE nem biztosít a szerzőnek kizárólagos jogot abban az esetben, ha az eredeti müsorszolgáltató később továbbközvetíti vagy tovább sugározza a müvet, ${ }^{353}$ az egyezmény ugyanis kifejezetten feltételként írja elő az eredetihez képest más szervezet belépését a közvetítési láncolatba. A közvetítési folyamatba belépô új szereplö, és az elkülönülő üzleti hasznosítás miatt kell ismételten jogosítani a felhasználást. ${ }^{354} \mathrm{Az}$ egyszerü nyelvtani értelmezésből nem vezethető le az új közönség elérésének követelménye, az szükségszerüen egy plusz feltétel támasztását jelentené.

Az új szervezet belépése ennek megfelelően azt sem teszi szükségessé, hogy az eredeti sugárzást végző szervezettől földrajzilag elkülönülten végezze a tevékenységét. Vagyis ,[a]z átvitel ilyen esetben akkor is a szerző engedélyéhez kötött, ha az eredeti sugárzás vételi körzetébe esik vagy a sugárzó kötelező műsorszolgáltatási területén

\footnotetext{
${ }^{352}$ Az új nyilvánosság kérdése főként a nyivánossághoz közvetítési jog kapcsán felmerülő teória, amely vonatkozásában az EuB részletes esetjogot munkált ki. Ennek kritikájáról lásd többek között FicsoR (2014).

${ }^{353}$ VON LEWINSKI (2008) p. 150.

${ }^{354}$ EDELMAN (1987) p.33.
} 
történik."355 A BUE tehát valójában már az új szereplő közbelépésével igazoltnak látja az új közönség elérését. Ez ugyanis azt implikálja, hogy az eredeti sugárzás lefedettségét az adott területre nézve kell kiegészíteni a vezetékes továbbközvetítéssel, vagy pedig ez utóbbi ténylegesen más földrajzi egységet érint. ${ }^{356}$

A Svájci Szövetségi Bíróság is értelmezte a BUE 11bis cikkét. A SUISA v. Rediffusion-ügy ${ }^{357}$ tényállása szerint a kábelszolgáltató vezetéken keresztül közvetítette tovább a sugárzott müveket az előfizetők számára. A cég álláspontja szerint ez nem valósított meg külön felhasználási cselekményt, mivel a továbbközvetítés gyakorlatilag ugyanazt a közönséget érte el, mint amit az eredetileg sugárzott müsor. A svájci bíróságnak tehát abban a kérdésben kellett állást foglalnia, hogy a továbbközvetítés fogalmában foglalt „más szervezet közbeiktatása” egyben annak követelményét is jelenti-e, hogy a müsornak új nyilvánossághoz kell jutnia? A cikket beiktató brüsszeli konferencia előkészítő szövegeiből az olvasható ki, hogy a rendelkezés alkalmazásának nem feltétele az új közönség elérése, sem pedig az eredetileg sugárzott müsor vételi területének kitágítása. ${ }^{358} \mathrm{Az}$ ügy tehát megerősítette a BUE alapvetően egyértelmü megfogalmazását, mely szerint a kábelszolgáltatóknak, amennyiben nem ők az eredeti sugárzást végző szervezetek, minden esetben engedélyt kell kérniük a jogosultaktól. ${ }^{359}$ Az ebben foglalt álláspontot követi több más nemzeti felsőbírósági döntés is. A holland Legfelsőbb Bíróság például megerősítette, hogy a BUE szövegéből nem következik az új közönség elérésének követelménye. ${ }^{360}$

A magyar törvény nem tartalmaz rendelkezést arról, hogy milyen közönséget kell a továbbközvetítésnek elérnie, vagyis az új nyilvánosság követelménye nem létezik. Belföldi eredetü továbbközvetítés esetén ez valószínüleg nem is állná meg a helyét, az azonos földrajzi lefedettség miatt a továbbközvetítéssel elért nyilvánosság vélhetően részben átfedésben lehet az eredeti közvetítéssel elért nyilvánossággal. A meghatározó tehát ebben az esetben is elsősorban az, hogy a másodlagos felhasználást végző

\footnotetext{
355 GYERTYÁNFY (2014), p. 36.

${ }^{356}$ GAUBIAC (2000) p. 26.

357 SUISA (Swiss Society of Authors and Publishers) v. Rediffusion AG, Bundesgericht (Swiss Federal Supreme Court) [1982] ECC 481 (BGE 107 II 57) 20 January 1981. Az ítélet megerősítésre került egy későbbi ügyben, amely már jobban támaszkodott az osztrák bíróság érvelésére. Lásd: Tribunal fédéral suisse, 20 mars 1984 (RIDA 1985 janv).

${ }^{358}$ ABOTT - COTTIER - GURRY(2007) p. 443.

${ }^{359}$ GOLDSTEIN - HUGENHOLTZ (2010) p. 326-327.

${ }^{360}$ C.Cass. des Pays-Bas, 30 oct. 1981 (RIDA avr. 1982.)
} 
II. rész A törvény által előírt közös jogkezelés, mint a kizárólagos jog korlátja

I. fejezet A jog gyakorlásának korlátozása a közös jogkezelés elöírásával

szervezet eltér az elsődleges felhasználást megvalósítótól, amely így magában foglalja az engedélykérés szükségességét.

\section{ү) A továbbközvetitési jog tartalma}

A továbbközvetítési jog tartalmának meghatározásánál a jogtudományban felhozott értelmezéseken túli forrást is felhasználhatunk, mivel az Európai Unió Bíróságának már alkalma nyílt a vezetékes továbbközvetítési jog tárgyának meghatározásával kapcsolatban állást foglalni. Bár a testület közvetlenül nem a müsor fogalmát definiálta, az általa adott értelmezés fontos a továbbközvetítési jog terjedelmének meghatározásában. Az Uradex-döntésben ${ }^{361}$ az alapügyben felvetődött jogi probléma az audiovizuális és nem audiovizuális művek közötti különbségtétellel kapcsolatos. Elöbbiek esetében a belga nemzeti szabályozás értelmében az előadóművész főszabály szerint átruházza a felhasználás kizárólagos jogát az előállítóra. Mivel a közös jogkezelő szervezet csak az előadóművészeket képviseli, ezért nem érvényesíthet több jogot, mint amivel a müvészek rendelkeznek. Következésképp a szervezet audiovizuális művek tekintetében a kábeles továbbközvetítés jogát sem gyakorolhatja a kapcsolódó jogi jogosultak tekintetében. ${ }^{362}$ Bár a Bíróság a kapcsolódó jogi jogosultak vonatkozásában határozott, az értelmezés a szerzői jogosultak viszonylatában is irányadó lehet. Az Szjt. a továbbközvetítési jog tartalmának meghatározása során is a technológia-semlegességet tartja szem előtt. Nem csak a jelátvitel módja, hanem maga a jel is közömbös. Az SZJSZT kifejti, hogy a televízió- és rádiómüsorok egyidejű változatlan és csonkítatlan továbbközvetítése szerzői jogi megítélése szempontjából nincs különbség a müsorjelek analóg vagy digitális továbbközvetítése között. A szakértő testület azt is hozzáteszi, hogy az - a felhasználók számára egyértelműen hátrányosabb - megoldás, mely szerint a szerzői jogi minősítés akkor sem eltérő, ha az eredetileg digitális müholdas, bárki által hozzáférhető (free-toair) müsorjelet valamely kábeltelevíziós rendszer üzemeltetője analóg jelfolyammá alakítja, és analóg formában juttatja el a kábeltelevíziós rendszerhez kapcsolódó előfizetői háztartásokhoz. ${ }^{363}$

${ }^{361}$ A C-169/05. sz. Uradex-ügyben 2006. június 1-jén hozott ítélet. Az ítélet rövid ismertetését lásd: POLLAUD-DULIAN (2006) p. 603.

${ }^{362} \mathrm{Az}$ Uradex-ügyben hozott ítélet 15. pontja.

${ }^{363}$ SZJSZT 43/07/01. A digitális és analóg jelek egyenértékủvé tétele egyébként alkalmazandó a rádió- és televízió-szervezeteket megillető egyedi joggyakorlásra is. 
Az SZJSZT egy másik szakvéleményben leszögezi azt is, hogy a kódolt adásokat, amennyiben a közvetítés folyamatában nem történik megszakítás vagy az adás tartalmát érintő bármely változtatás, és így az egyidejüség és a változatlanság követelményei együttesen megvalósulnak, nem lehet az Szjt. 28. § (2) bekezdés alá szubszumálni és kábeles továbbközvetítésként értékelni. A kábeltelevíziós szervezet technikai közremüködése, vagyis a dekódolás, valamint a kábel rendelkezésre bocsátása és müködtetése ugyanis nem minősül új felhasználási tevékenységnek, hasonlóan a sugárzás megelőző szakaszaiban megvalósuló kódolásnak. Ezek a müveletek (értsd a kódolás és a dekódolás) az egyetlen felhasználási folyamatnak, a sugárzásnak, a sugárzást végző rádió- vagy televízió-szervezet uralma alatt álló, technikailag szükséges, de külön felhasználásnak nem minősülő részei. ${ }^{364} \mathrm{Az}$ Airfield-ügyben született fötanácsnoki vélemény azt hangsúlyozza, hogy ha egy sugárzási engedély nem fedi a második szolgáltatót, és a szolgáltatásnak a gazdasági értékét, akkor a második szereplőnek külön engedélyt kell kérnie. ${ }^{365}$ Az első sugárzási engedély egyébként soha nem fedi a jövőbeli, különböző országokban elérhető előfizetési díjakra eső szerzői jogdíjat.

Míg a BUE a hangsúlyt az eredeti szervezettől eltérő szervezetre helyezte, addig Franciaországban, a területi korlátozásból eredően megjelenik a közönség is, mint elhatároló kritérium. A területi lefedettségböl ugyanis az következik, hogy amennyiben a továbbközvetítés új közönséget ér el, abban az esetben a jogosultak külön engedélyét kell hozzá beszerezni.

A jogirodalomban kiemelésre került azonban az is, hogy valószínűleg az audiovizuális szerződések tartalmaznak ezzel ellentétes kikötést. Ennek a rendelkezésnek, vagyis a földi sugárzás és a kábeles közvetítés egységként kezelésének ugyanis főleg akkor lehetett jelentősége, amíg a kábeles továbbközvetítés arra szolgált, hogy a sugárzással le nem fedett területekre is lehessen közvetíteni. Manapság viszont már ezeken a kábelhálózatokon jellemzően külföldi, illetve mühold útján sugárzott müsorok is elérhetőek. ${ }^{366}$

\footnotetext{
364 SZJSZT 38/2000.

365 A C-431/09. és C-432/09. sz. egyesített Airfield-ügyekben 2011. március 17-én ismertetett fötanácsnoki indítvány 93 . pontja.

${ }^{366}$ RoCHICCIOLI (1991) p.37.
} 


\section{§2. A jog gyakorlása}

A jog gyakorlásának kérdése kapcsán szintén a BUE rendelkezéseit kell alapul venni első helyen. Ez lehetővé teszi, hogy a részes államok a jog gyakorlásának feltételeit meghatározzák. ${ }^{367}$ A feltételeknek mindenekelőtt az azokat megszabó ország területére kell korlátozódnia. Ez a rendelkezés a területiség elvének konkrét helyzetre való alkalmazásának ismételt előírása. ${ }^{368}$ Szintén a szerzői jog alapelveiből fakad az is, hogy a joggyakorlás feltételei nem sérthetik a szerző személyhez füződő jogait. Az utolsó feltétel már eltávolodik az alapelvek hangsúlyozásától és azt írja elö, hogy a feltételek nem sérthetik a szerző méltányos díjazáshoz füződő jogát. Vagyis a részes államoknak nincsen arra lehetőségük, hogy ingyenes felhasználásként határozzák meg a kábeles továbbközvetítést. Ehelyett azt a kötelezettséget rója rájuk, hogy olyan mechanizmust állítsanak fel, amellyel a szerzők megfelelő kompenzációja biztosítható: legyen szó akár központilag meghatározott jogdíjtételekről, akár pedig arról, hogy amennyiben a felek nem tudnak megállapodni a jogdíj mértékéről, akkor ezt bíróság tegye meg helyettük. ${ }^{369}$ A feltételek meghatározásával viszont implicit módon a BUE elismeri annak lehetőségét, hogy a kábeles továbbközvetítés joga korlátozható. A feltételek pedig olyan speciális korlátnak minősülnek, amelyek eleve kijelölik a jogalkotó mozgásterét a bevezetésük során.

Claude MASOUYÉ a korlátozás kapcsán a kényszerengedély (licence obligatoire) kifejezést használja, ugyanis ennek bevezetésével elvileg biztosítható, hogy se a személyhez füződő jogok, se pedig a díjazáshoz való jog ne sérüljön. Tipikusabb viszont a kötelező közös jogkezelés elöírása: ezt a megoldást választotta az uniós jogalkotó is. A feltételekbe ugyanis beillik az is, hogy a nemzeti jogalkotó a kizárólagos jog érintetlenül hagyásával annak gyakorlásának módjáról rendelkezzen ${ }^{370}$ - nem csak a vezetékes továbbközvetítés, hanem a BUE 11bis cikk (1) bekezdésében foglalt többi jog (tehát elsősorban a sugárzás) kapcsán. A BUE kommentárjában Claude MASOUYÉ is

\footnotetext{
${ }^{367}$ BUE 11 bis cikk (2) bek.

${ }^{368}$ Nem tartozik szorosan a témakörhöz, ugyanis versenyjogi szempontú megközelítést tartalmaz, említésre méltónak tarjuk azonban a CISAC-ügyet. A Bizottság a CISAC kölcsönös képviseleti megállapodásainak modellszerződését többek között éppen a vezetékes továbbközvetítési jog és a bárki által fogható müholdas sugárzás engedélyezése kapcsán a területi hatály megjelölését kifogásolta. Holott ez igazolható az anyagi jog területiségével. Az ügy elemzését a magyar szakirodalomban lásd például: FALUDI (2009a) p. 126-135., GYERTYÁNFY (2009) p. 5-34., FALUDI - KABAI (2014) p. 71-104. A francia szakirodalomban pedig: MARÉCHAL (2013) p. 6-9.

${ }^{369}$ MASOUYÉ (1978) p. 82.

${ }^{370}$ FICSOR (2003b).
} 
kiemeli, hogy a közös jogkezelés a sugárzási jogok természetéből adódóan alkalmas arra, hogy akár szerződéses alapon, akár pedig a kötelező engedély alapján széles repertoárok felhasználását engedélyezze úgy, hogy a szerző megfelelö díjazásban részesüljön ezen felhasználások után. ${ }^{371}$

A Mühold-irányelv 9. cikk (1) bekezdése kifejezetten kimondja, hogy a tagállamoknak biztosítani kell, hogy a szerzői vagy szomszédos jogosultak (kivéve a rádió- és televízió-szervezeteket) azon joga, hogy a kábelszervezeteknek engedélyt adjanak a vezetékes továbbközvetítésre, vagy ezt megtagadják (megjegyzendő, hogy az előadóművészek és a hangfelvétel-előállítók esetében díjigényről, nem pedig engedélyezési jogról van szó), csak közös jogkezelő szervezetek által gyakorolható. Ez azt is jelenti, hogy mind az irányelvben, mind pedig a nemzeti szerzői jogokban garanciális rendelkezéseket kellett beépíteni annak érdekében, hogy a kizárólagos jog gyakorlása lehetőség szerint minél kisebb mértékben sérüljön.

\section{A) A vezetékes továbbközvetítéssel rokon jogok gyakorlása}

Élve a BUE-ban biztosított lehetőséggel, a magyar jogalkotó a földfelszíni sugárzás kapcsán szintén kilépést nem engedő kötelező közös jogkezelés előírásáról rendelkezett. $^{372}$

Az Szjt. kifejezetten utal arra, hogy engedélyezési jog gyakorlásáról van szó, hiszen akként fogalmaz, hogy a jogosultak képviseletében a már nyilvánosságra hozott művek sugárzásának engedélyezésére és az ennek fejében fizetendő díjak mértékére vonatkozóan az irodalmi és a zenei művekkel kapcsolatos szerzői jogok közös kezelését végző szervezet köt szerződést a felhasználóval. A jogdíjközlemény ${ }^{373}$ az egyedi szerződések mellett általános szerződési feltételként alkalmazandóak.

\footnotetext{
${ }^{371}$ MASOUYÉ (1978) p. 82.

${ }^{372}$ Szjt. 27. $\S(1)$ bek.

373 Az ARTISJUS Magyar Szerzői Jogvédő Iroda Egyesület közleménye az irodalmi és zeneművek sugárzás útján, vezetékkel vagy egyéb módon a nyilvánossághoz történő közvetítéséért, kódoltan történő eredeztetéséért $\square$ zetendő szerzői jogdíjakról, valamint a felhasználás engedélyezésének egyéb feltételeiröl (R-TV 15). Elérhetö: $\quad$ https://www.artisjus.hu/wpcontent/uploads/2013/04/aktualis_jogdijkozlemeny_r_tv.pdf.
} 


\section{B) A vezetékes továbbközvetitési jog gyakorlása}

A jog gyakorlása kapcsán több rezsim létezhet egymás mellett attól függően, hogy a továbbközvetítés tartalmaz-e nemzetközi vagy belső piaci elemet, vagy ezzel ellentétben tisztán nemzeti tényállásról van szó. Fentebb utaltunk rá, hogy az irányelv csak a belső piaci felhasználások esetén teszi kötelezővé a közös jogkezelés bevezetését. Élve viszont a BUE által biztosított felhatalmazással, nem meglepő, ha egyes tagállamok a vezetékes továbbközvetítést egységes rendszerben kezelik, függetlenül a továbbközvetített műsor származási helyétől.

\section{a) A jogosultak képviselete}

A kötelező közös jogkezelés megvalósítására elméletileg két lehetőség adódik. Az egyik, hogy a jogalkotó minden jogosult számára kötelezővé teszi a közös jogkezelő szervezethez való csatlakozást, vagy legalábbis a képviseleti megbízás adását. ${ }^{374} \mathrm{Az}$ elöírás foganatosítása azonban azon túl, hogy a gyakorlatban nehezen megvalósítható lenne, a jogosultak egyesülési jogból eredő szabadságának is jelentős mértékü csorbításával járna. A francia jogalkotó gyakorlatilag mégis ezt az utat választotta, a jogtudomány ezzel ellentétes álláspontja ellenére. Ez utóbbi szerint a közös jogkezelés kötelezővé tétele, ${ }^{375}$ elismerve azt, hogy a jogkezelést valóban leegyszerüsíti, a francia szerzői jog alapvető elveit kérdőjelezi meg: nevezetesen azt, hogy a szerzői jogok egyénileg kezelendőek, másrészt pedig azt, hogy a közös jogkezelő szervezetek független magánjogi szervezetek. ${ }^{376}$ A kódex azt írja elő, hogy amennyiben a jogosult korábban nem bízta meg egyik közös jogkezelő szervezetet sem jogai kezelésével, akkor kijelöli azt, amelyik a vezetékes továbbközvetítés jogát gyakorolja. Az írásbeli nyilatkozatot a választott közös jogkezelő társaság nem utasíthatja vissza. ${ }^{377}$ A CPI tehát, még ha a szervezethez való csatlakozást nem is tette kötelezővé, azt igen, hogy a vezetékes továbbközvetítés jogának gyakorlására minden jogosult megbízást adjon egy kötelező közös jogkezelő szervezetnek. Ennek ellensúlyozására a CPI a vezetékes továbbközvetítés jogát végző társaságok kapcsán speciális feltételeket iktatott be,

\footnotetext{
${ }^{374}$ Ennek veszélyeiről az emberi jogok tükrében vizsgálva lásd: HELFER (2010) p. 93-98.

${ }^{375}$ REVET (1997) p. 526

${ }^{376}$ FRANÇON (1997) p. 252.

${ }^{377}$ CPI L. 132-20-1. cikk 2. bekezdés „Si le titulaire du droit n'en a pas déjà confié la gestion à l'une de ces sociétés, il désigne celle qu'il charge de l'exercer. Il notifie par écrit cette désignation à la société, qui ne peut refuser."
} 
szélesebb körü állami felügyelettel pótolva a jogosultak önrendelkezésének hiányát. ${ }^{378}$ Felvetődhetne tehát a kérdés, hogy a kötelező megbízás adása nem ellentétes-e a BUE alakszerüséget tiltó ${ }^{379}$ rendelkezésével, azonban, mint láttuk, a közös jogkezelés lehetőségét maga az egyezmény teremti meg és a Műhold-irányelv teszi kötelezővé.

A másik lehetséges jogtechnikai megoldás, amellyel megvalósítható a kötelező közös jogkezelés, az a joggyakorlás módjának kiterjesztése azokra a jogosultakra is, akik egyébként nem tagjai a szervezetnek. ${ }^{380}$ Ezt a problémát egy megdönthetetlen vélelem felállításával hidalja át az uniós jogalkotó. Rendelkezik ugyanis arról, hogy amennyiben a jogosult jogainak érvényesítését nem ruházta át jogkezelő szervezetre, az azonos fajtájú jogok érvényesítését végző szervezetet kell a jogainak érvényesítésére megbízottnak tekinteni. Ha több jogkezelő szervezet foglalkozik ilyen jogok érvényesítésével, a jogosult szabadon választhat, hogy közülük melyiket kell a jogainak érvényesítésére megbízottnak tekinteni. ${ }^{381} \mathrm{Az}$ irányelv nem tartalmaz kiegészítő szabályt arra az esetre, ha a jogosult nem tesz ilyen nyilatkozatot. Garanciális szabályként rögzítésre kerül, hogy a jogosultakat nem lehet megkülönböztetni aszerint, hogy megbízás vagy a vélelem alapján gyakorolja a jogukat a közös jogkezelő szervezet. A kábelszervezettel megkötött szerződésből eredően ugyanazokkal a jogokkal és kötelezettségekkel rendelkeznek, melyeket a „nem tag” jogosult a tagállam által meghatározott, a továbbközvetítéstől számított maximum három éves időtartamon belül érvényesíthet. ${ }^{382} \mathrm{Az}$ Uradex-döntésben megerösítésre került, hogy ha a szerzői vagy szomszédos jogok jogosultja nem ruházta át e jogok érvényesítését jogkezelő szervezetre, az azonos fajtájú jogok érvényesítését végző szervezetet kell a jogainak érvényesítésére megbízottnak tekinteni. ${ }^{383}$ A jogosult választási szabadságát a KJKirányelv is megerősíti, kötelező közös jogkezelés keretében az azonos jogokat kezelő más társaságra korlátozva a döntési szabadságot. ${ }^{384}$

\footnotetext{
${ }^{378}$ Ezt részletesen lásd az I. rész II. fejezetében.

${ }^{379}$ BUE 5. cikk (2) bek.

380 Általánosabb értelemben véve tehát a kötelező közös jogkezelés is kiterjesztett közös jogkezelésnek tekinthető. STROWEL (2010-2011) p. 666. A fogalom két értelemben való használatának elhatárolásáról lásd a III. rész I. fejezetét.

${ }^{381}$ Mühold-irányelv 9. cikk (2) bek.

${ }^{382}$ Mühold-irányelv 9. cikk (2) bek.

${ }^{383}$ Uradex-ügy 21. pont.

${ }^{384}$ KJK-irányelv (19) preambulumbekezdés.
} 
Az Szjt. a kiterjesztett közös jogkezelést nem egyes vagyoni jogok tekintetében, hanem generális jelleggel, minden, a törvényben közös jogkezelésre előirányzott vagyoni jog gyakorlására nézve mondja ki. Így ezt a vélelmet irányadónak kell tekinteni a vezetékes továbbközvetítési jog gyakorlása során is. A törvény bonyolult megfogalmazással él a definíció megalkotása során: ,[h] a valamely jogosulti csoport ugyanolyan vagyoni jogának kezelésére egy közös jogkezelö szervezetet vettek nyilvántartásba, és ez a közös jogkezelö szervezet valamely felhasználónak engedélyt ad a felhasználásra, illetve a felhasználóval szemben dijigényt érvényesit, a felhasználó jogosult a szervezet által végzett jogkezelés szempontjából érintett valamennyi jogosult - e törvény elöírása vagy a jogosultak elhatározása alapján közös jogkezelés alá tartozó - azonos müfajú müveinek vagy kapcsolódó jogi teljesitményeinek felhasználására is, az ezekre a müvekre vagy kapcsolódó jogi teljesitményekre vonatkozó jogdíjak azonos feltételek alapján történő megfizetése mellett." "385 A gyakorlatban ez azt jelenti, hogy minden bel- és külföldi jogosult, vagyis a közös jogkezelő szervezethez tagsági, vagy megbízási alapon nem kapcsolódó jogosultak esetében is a közös jogkezelő szervezet adja meg a felhasználási engedélyeket. Mivel kötelező közös jogkezelésről van szó, törvényi vélelemmel biztosítani kell valamennyi jogosult képviseletét. Éppen ezért az Szjt. előírja azt is, hogy ha ugyanazon jogosulti csoport ugyanolyan vagyoni jogának kezelésére több közös jogkezelő szervezetet vettek nyilvántartásba, akkor a kiterjesztés alapján az a közös jogkezelő szervezet jár el, amelyet az érintett egyesületek erre vonatkozó megállapodásukban kijelöltek. ${ }^{386}$

\section{b) Az engedélyek megadása}

A jogdíjközlemények elfogadásának általános rendje kapcsán nem utaltunk rá, azonban érdemes e helyütt a közös jogkezelő szervezetek által kötött felhasználási szerződések szabályait is elemezni. Egyfelől rögzíteni kell azt, hogy a közös jogkezelő szervezet a saját nevében, de a képviselt jogosultak javára köt szerződést - ez egyébként mindkét vizsgált országban igaz megállapítás. Mindkét országban a szervezet saját nevében fordulhat bírósághoz is, illetve az Szjt. azt is kifejezetten kimondja, hogy a felosztásig rendelkezik (természetesen a jogdíjfelosztás céljára) a beszedett jogdíjakkal.

\footnotetext{
${ }^{385}$ Szjt. 87. § (1) bek.

${ }^{386}$ Szjt. 87. § (1) bek., illetve 92/E. § (3) bek.
} 
A felhasználási szerződések általános szabályai ${ }^{387}$ a közös jogkezelő szervezetek által kötött egyedi szerződésekre is irányadóak.

A felhasználási szerződésben a másik fél pedig az a „kábeltetelvízió” szervezet, amely saját gazdasági, szakmai tevékenységi körében eljárva kíván engedélyt szerezni a szerzői művek felhasználásához. Ebből az következik, hogy nem tekinthető fogyasztónak, így a javára a fogyasztóvédelmi jogi szabályok nem alkalmazhatók.

Az engedély megadása az Artisjus többi érintett jogosulttal egyetértésben megállapított jogdíjközleményében ${ }^{388}$ meghatározott mértékủ jogdíj megfizetésével történik, az engedély megadása a jogdíj megfizetésétől, mint felfüggesztő feltételtől függ. ${ }^{389}$ A felhasználási engedélyek megadása tehát gyakorlatilag automatikus, nem egyedi mérlegelésen és tárgyaláson alapuló szerződésekről van szó ebben az esetben (bár tény, hogy bizonyos felhasználók esetén a jogdíjközlemény kedvezmények adását teszi lehetővé). A valóságban szövetségi keretszerződések állnak fenn, ezek egyedileg megtárgyalt, központosított adtaszolgáltatás, és a nem fizetőkkel szembeni fellépés fejében kedvezményt biztosító szerződések. A felhasználási szerződésekre vonatkozó általános szabályok alapján viszont írásban kötött (egyedi) felhasználási szerződés megkötése is szükséges az engedélyek megadásához. Ezeknek azon túl, hogy meg kell határozniuk a feleket, illetve felhasználási jogot kell adniuk a szervezetnek, rendelkezniük kell a felhasználó által fizetendő jogdíj konkrét mértékéröl, illetve a szerződés hatályáról. Speciális tartalmi elemként jelenik meg a felhasználással érintett művek, mint a szerződés közvetett tárgyának meghatározása, amely nem a művek egyenkénti felsorolásával, hanem a közös jogkezelő szervezet által kezelt repertoárra történő utalással történik meg.

Mivel a közös jogkezelő szervezetek által kötött szerződések átalányjellegüek, a díj minden egyes müre, mürészletre, előadásra azonos, mértéke viszont igazodik a felhasználás jellemzőihez (például a szolgáltatás ingyenességéhez), a terjedelméhez, és

\footnotetext{
387 Szjt. 42-55. §.

${ }^{388} \mathrm{Az}$ ARTISJUS Magyar Szerzői Jogvédő Iroda Egyesület közleménye rádió- vagy televízió-műsorok egyidejü, változatlan, csonkítatlan továbbközvetítői, valamint kódoltan eredeztetett rádió- vagy televíziómüsorok kódoldás után vagy (át)kódoltan történő nyilvánossághoz közvetítésében közreműködők („kábelszervezetek”) által $\square$ fizetendő szerzői jogdíjakról, valamint a felhasználás engedélyezésének $\begin{array}{llllll}\text { egyéb feltételeiről } & \text { (Kábel } & \text { 15) } & \text { (https://www.artisjus.hu/wp- }\end{array}$ content/uploads/2015/06/aktualis_jogdijkozlemeny_kabel.pdf).

${ }^{389}$ Ezek jogi természetével kapcsolatos megállapításainkat lásd az I. rész II. fejezetében.
} 
a gyakoriságához. ${ }^{390}$ A kábeles továbbközvetítési jog esetében a jogdíj mértékének meghatározásánál az ARTISJUS a müsor típusát (rádió vagy televízió müsor), illetve a továbbközvetítéssel érintett háztartások számát veszi alapul. ${ }^{391}$

A Mühold-irányelv egyébként egy speciális jogintézményt, a mediációt is a közös jogkezelés részévé teszi. Annak biztosítására, hogy a szerződés mindenképpen létrejöjjön a közös jogkezelő szervezet és a felhasználók között, az irányelv mediációs eljárás bevezetését írja elő. A mediáció rendszerbe építése viszont azt feltételezi, hogy külső segítség nélkül a szerződés maga már létre sem tud jönni. ${ }^{392}$ Másodsorban pedig a tárgyalási pozíciókkal való visszaélést is meg kell akadályozni, amelynek érdekében a mindenkori gyengébb fél érdekeit szem elött tartó szabályokat épített a rendszerbe az uniós jogalkotó. 393

\section{c) A jogdijak beszedése és felosztása}

A jogdíjközlemény az engedély megadását a jogdíj megfizetésétől teszi függővé. Ez kettős célt szolgál: egyrészt lehetővé teszi, hogy a felhasználás mindenképpen jogosításra kerüljön, másrészt pedig a jogosultak számára is nagyobb garanciát biztosít arra nézve, hogy a megkapják a nekik járó jogdíjat.

Mivel a felhasználó pontos adatszolgáltatásra kötelezett, ezért a jogdíjak tényleges felhasználáson alapuló felosztása nem ütközik nehézségbe. Az Szjt. maga rendelkezik a felosztás arányáról az egyes jogosulti csoportok között az alábbiak szerint: $13 \%$ a filmgyártókat, $19 \%$ a filmalkotások mozgóképi alkotóit, 3\% a képzőmüvészeket, az iparmüvészeket és a fotómüvészeti alkotások szerzőit, $14 \%$ a filmírókat, 15,5\% a zeneszerzőket és zeneszöveg-írókat, 26,5\% az előadóművészeket, valamint $9 \%$ a hangfelvétel-elöállítókat illeti meg. ${ }^{394}$ A törvény - más esetekhez hasonlóan ${ }^{395}$ - lehetőséget biztosít a közös jogkezelő szervezetek számára a rögzített

\footnotetext{
390 GYERTYÁNFY - FALUdI - KABAi Eszter - SZINGER - TÓTH (2004) p. 710.

${ }^{391}$ Fontos megemlíteni azt is, hogy a továbbközvetítésre vonatkozó engedélyt nem csak a szerzőktól kell beszerezni. Ehhez szükséges annak a müsorközvetítő szervezetnek is az engedélye, amelynek a müsorát továbbközvetítik [Szjt. 80. § (1) bek.], hiszen kapcsolódó jogi jogosultként jogi oltalomban részesülnek.

${ }^{392}$ CARON (1999) p. 6.

${ }^{393}$ Magyarországon ilyen mediáció lefolytatásáról nincsen tudomásunk.

394 Szjt. 28. § (4) bek.

${ }^{395}$ Lásd erről részletesen az üres hordozó és reprográfiai díjak felosztását a II. rész II. fejezetében.
} 
arányoktól való eltérésre, ilyen megállapodást azonban az egyesületek nem kötöttek egymással. $^{396}$

Külön szabály vonatkozik a magyar közszolgálati médiaszolgáltató rádió- vagy televízió-szervezet müsorában sugárzott, vezetéken vagy másként közvetített müvek továbbközvetítéséért járó díjakra. Ezek megfizetéséről a Médiaszolgáltatás-támogató és Vagyonkezelő Alapból kell megfizetni, amelyről az Alap kezelője gondoskodik. ${ }^{397}$

Franciaországban a beszedett jogdíjak felosztásában közremüködik egyrészröl az ARP, amely a rendezőket, filmelőállítókat képviselve osztja fel az ANGOA-tól megkapott jogdíjakat. Papíron ugyan az ANGOA az, amely ezeket a díjakat beszedi, ám a valóságban 1994 óta a PROCIREP biztosítja az ehhez szükséges személyi és tárgyi feltételeket. $^{398}$

A Canalsatellite és a TPS nevü kábelszolgáltatóval ambivalens a közös jogkezelő viszonya. A müholdas szolgáltató ugyanis egyidejüleg és teljesen továbbközvetíti a földi sugárzású francia adókat, de nem hajlandó szerződést kötni a felhasználás engedélyezésére. Az ügy pikáns, mert ha a bíróság megállapítja a műholdas szolgáltatók fizetési kötelezettségét, abban az esetben a döntés ellentmond a díjazás kiszámítása módjának. ${ }^{399}$

\section{d) Kivétel a kötelezö közös jogkezelés alól}

A közös jogkezelés általi joggyakorlás alól maga az irányelv határoz meg egy kivételt. Ez alapján a rezsim nem alkalmazandó a műsorsugárzó szervezet által saját müsora tekintetében gyakorolt jogokra, tekintet nélkül arra, hogy az érintett jogok a sajátjai, vagy ezeket más szerzői és/vagy szomszédos jogi jogosultak ruházták rá át. ${ }^{400}$ FICSOR Mihály álláspontja szerint igazolja a közös jogkezelés bevezetésének kivételes jellegét, vagyis azt, hogy csak olyan esetekben lehet róla szó, amikor a jog érvényesítése más módon nem lehetséges. ${ }^{401}$

\footnotetext{
${ }^{396}$ Szjt. 28. § (4) bek.

397 Szjt. 28. § (6) bek.

398 BERNAULT (2013) p. 469.

${ }^{399}$ BERNAULT (2013) p. 472.

${ }^{400}$ Mühold-irányelv 10. cikk.

${ }^{401}$ FICSOR (2003b) p. 6-7.
} 


\section{A többszörözés jogával kapcsolatos közös jogkezelés}

A nyilvános előadási, illetve nyilvánossághoz közvetítési jogok mellett a többszörözés kizárólagos joga is képezheti kötelező közös jogkezelés tárgyát. Nem állítható fel tehát egy olyan hipotézis, mely szerint a többszörözés joga a gyakorlatban csak a szerzői jogi korlátozásokon keresztül illeszthető bele a kötelező közös jogkezelés rendszerébe. Az ebbe a körbe tartozó két kizárólagos jog a hangfelvétel-kiadáshoz nélkülözhetetlen mechanikai többszörözés joga, valamint Franciaországban a reprográfiai úton megvalósuló többszörözés joga.

A mechanikai többszörözésre tekintettel megállapított korlátozás a BUE 13. cikk (1) bekezdésén alapul. Ez világosan kimondja, hogy ,zenemü szerzőjének és szövegírójának a zenemü - adott esetben szöveggel történö - hangfelvételének engedélyezésére vonatkozó kizárólagos jogával kapcsolatban az Unióhoz tartozó országok mindegyike az adott országot illetöen fenntartásokkal élhet és feltételeket szabhat, ha a szövegíró már engedélyezte a szövegnek a zenemüvel történö felvételét; de minden ilyen természetü fenntartás és feltétel szigorúan azokra az országokra korlátozódik, amelyek azokat megszabták, és semmiképpen sem sérthetik a szerzőnek azt a jogát, hogy - békés megegyezés hiányában - az illetékes hatóság által megállapított méltányos dijazásban részesüljön.” Az Szjt. beépítette a magyar szerzői jogi rezsimbe ezt a korlátozási lehetőséget azáltal, hogy a jog közös jogkezelés keretében való gyakorlásáról rendelkezett. Érdekesség, hogy a korábban hatályos szöveg gyakorlatilag úgy került megfogalmazásra, hogy azt kényszerengedélyként is lehetett értelmezni. A BUE-nak való megfelelés elérését célzó módosítást követően viszont a többi kötelező közös jogkezelési esethez hasonló engedélyezési formát állított fel a jogalkotó.

Franciaországban nem vezettek be hasonló korlátozást, önkéntes közös jogkezelésként müködik a felhasználások engedélyezése. Ezzel szemben viszont a francia törvény ismer egy olyan korlátozást, amelyet a magyar törvény szabályoz máshogyan. Nevezetesen a reprográfiai többszörözés jogát utalták kötelező közös jogkezelés alá. 
A francia jogalkotó viszonylag későn, az 1995. január 3-ai törvénnyel ${ }^{402}$ iktatta be a CPI-be a reprográfiával történő többszörözésre vonatkozó kizárólagos engedélyezést biztosító vagyoni jogot (droit de reproduction par reprographie), egyúttal elrendelve ennek kötelező közös jogkezelés alá vonását is. ${ }^{403}$ A húsz éves törvény egy igen komplex, a bírói gyakorlat által több ponton megszorítóan értelmezett rendszert hozott létre, amely a klasszikus joggyakorlási módtól eltérő alapokon nyugszik. ${ }^{404}$ Egyes nézetek szerint végeredményét tekintve ez a megoldás sem különbözik sokban a törvényi engedélyektől: a szerzők nem gyakorolhatják közvetlenül az őket megillető kizárólagos jogot, és csak a meghatározott díjazásra jogosultak. ${ }^{405}$

A jogalkotó által választott irány két szempontból is újszerünek tünik. Egyfelöl ez egy olyan kivételes módosítása a CPI-nek, amelyet nem Franciaország európai uniós tagságából eredő jogharmonizációs kötelezettség hívott elő. A francia jogalkotó a saját útját járta, és mivel az 1990-es évek elején a szerzői jogi harmonizáció foka a jelenleginél lényegesen alacsonyabb volt, és a többszörözés jogáról általánosságban, különösen pedig a reprográfia útján megvalósuló többszörözésről irányelvi szinten nem rendelkezett az uniós jog (annak ellenére, hogy az 1988-ban kiadott Zöld Könyv említi a problémát), a kérdés újszerü és rugalmas rendezése elé ez nem gördített akadályt.

A másik érdekesség, hogy a jogalkotó eltért az üres hordozóra történő magáncélú másolatra (copie privée) vonatkozó szabályozási módszertől, amely szerzői jogi kivételként definiálta a felhasználási cselekményt. A reprográfiai többszörözést ezzel szemben a szerzőt megillető kizárólagos többszörözési jog egyik eseteként külön nevesítésre került, gyakorlását pedig a törvényhozó testület meghatározott módhoz kötötte. Az engedélyezési jog gyakorlásának nehézségei miatt a jogalkotó a kötelező közös jogkezelést választotta a jogosítás módszeréül. ${ }^{406}$

\footnotetext{
${ }^{402}$ Loi n ${ }^{\circ}$ 95-4 du 3 janvier 1995 sur la reprographie.

403 A WIPO és az IFFRO közös kiadványa alapján 2005-ben Franciaország volt az egyetlen olyan ország, amely a reprográfiai többszörözés engedélyezési jogát kötelező közös jogkezelés körébe rendelte. A kizárólagos jog fenntartása nem egyedülálló, azonban az ezt az elvet valló országok egy része más elvet (pl. a skandináv államok a kiterjesztett közös jogkezelést) követ. La gestion collective en matière de $\begin{array}{llll}\text { reprograhpie, OMPI } & - & \text { IFFRO, } & 2005\end{array}$ (http://www.wipo.int/edocs/pubdocs/fr/copyright/924/wipo_pub_924.pdf) p. 20-24.

${ }^{404}$ FRANÇON (1995) p. 121.

${ }^{405}$ LUCAS - LUCAS - LUCAS-SCHLOETTER (2012) p. 386.

${ }^{406}$ DERIEUX (1995) p. 28
} 
Ezen a megközelítésen az sem változtatott, hogy az InfoSoc-irányelv 5. cikk (2) bekezdés $a$ ) pontja a tagállamoknak lehetővé tette, hogy a reprográfiával történő többszörözést szerzői jogi kivételként vagy korlátozásként ültessék át nemzeti jogrendszerükbe. A meglévő rezsimet fenntartották az irányelv átültetése után is. Emiatt, bár a francia jog irányelvnek való megfelelését közvetlenül nem kell vizsgálni, álláspontunk szerint ezt az irányelvi rendelkezést értelmező VG Wort-döntés ${ }^{407}$ egyes elemeit a reprográfia fogalmának pontosításánál mégis érdemes figyelembe venni. Ez ugyanis párhuzamba állítható azzal a nagyon is gyakorlati jellegü, francia jogirodalomban is felvetődött kérdéssel, hogy az előbb digitalizált majd papíron többszörözött másolatok hogyan értékelhetőek a reprográfia útján történő többszörözés szempontjából.

Mivel a magyar jogalkotó a reprográfiával történő többszörözés kivételként való meghatározása mellett döntött, ezért a magyar szabályozást e helyütt utalás szintjén sem említjük, ennek részletes kifejtése egy későbbi fejezetben ${ }^{408}$ történik majd meg. Hasonlóan, a kizárólagos jog fenntartásának és a törvényi engedély bevezetésének előnyeit és hátrányait is ebben a fejezetben mutatjuk majd be.

\section{§1. A jogok tartalma}

A jogok elemzésének két követelménynek kell megfelelnie. Először is meg kell határozni az egyes fogalmakat. Ez különösen a reprográfia esetén jelentős, mivel a digitális technológiák elterjedése hatással lehet a fogalom használatának fejlődésére. Ezt követően pedig arra kell kitérni, hogy a kizárólagos jog konkrétan mely felhasználási cselekmények engedélyezésére terjed ki - másképp szólva azt keressük, hogy hol húzódnak az engedélyezési jog határai.

Figyelembe véve, hogy a mechanikai többszörözés [A) pont] és a reprográfiai többszörözés [B) pont] egymástól jelentősen eltérő jogokat takar, az elemzést a jogok szerinti csoportosításban végezzük el.

\footnotetext{
${ }^{407}$ A C-457/11-C-460/11. sz. VG Wort egyesített ügyekben 2013. június 27-én hozott ítélet.

${ }^{408}$ II. rész II. fejezet.
} 


\section{A) A mechanikai többszörözés}

A CPI a többszörözési jog meghatározása során tartalmaz egy nem taxatív listát arról, hogy mely cselekmények tartoznak különösen a szerző engedélyezési joga körébe. Ebben a listában szerepet kap a mechanikai felvétel (enregsitrement mécanique) is anélkül, hogy a törvény maga bővebb rendelkezéseket tartalmazna róla. Franciaországban a jog kezelése önkéntes közös jogkezelés keretében történik, a SACEM és az AEEDRM által létrehozott SDRM felel az engedélyezési jog gyakorlásáért.

A jogot az Szjt. is rögzíti, egyes formáinak gyakorlását pedig kifejezetten kötelező közös jogkezelés körébe utalja. Ennek érdekessége, hogy korábban kényszerengedélyként került a törvényben megfogalmazásra, a nemzetközi szerzői jognak való megfelelés indokolta a törvénymódosítást. A mechanikai többszörözési jog korlátozására ugyanis a zenemüvek körében maga a BUE teremti meg a lehetőséget. ${ }^{409}$ A kommentár alapján ez azzal jár, hogy a részes felek kényszerengedélyeket vezethetnek be, amelyre vonatkozó feltételek a személyhez füződő jogok védelmére vonatkozó kifejezett utalástól eltekintve megegyeznek azokkal, amelyeket a sugárzás és a vezetékes továbbközvetítés kapcsán elemeztünk. ${ }^{410}$

\section{a) A mechanikai többszörözés fogalma}

Általános értelemben véve a mechanikai többszörözés alá tartozik az anyagi hordozón való rögzítés, mint engedélyköteles felhasználás. Az elnevezés arra utal, hogy a művek „természetes” előadási módjától, az élő előadástól eltérően itt egy gép (a korábbi magyar szerzői jogi terminológia szerint mechanikai előadás céljára szolgáló készülékek) segítségével valósulhat meg a műélvezet. ${ }^{411}$ A kifejezés utal azonban arra is, hogy a müvek nem hangfelvételekre való többszörözése is szükségképpen valamilyen müszaki megoldás segítségével valósul meg.

\footnotetext{
${ }^{409}$ BUE 13. cikk (1) bek. „Zenemü szerzöjének és szövegírójának a zenemü - adott esetben szöveggel történö - hangfelvételének engedélyezésére vonatkozó kizárólagos jogával kapcsolatban az Unióhoz tartozó országok mindegyike az adott országot illetöen fenntartásokkal élhet és feltételeket szabhat, ha a szövegíró már engedélyezte a szövegnek a zenemüvel történö felvételét; de minden ilyen természetü fenntartás és feltétel szigorúan azokra az országokra korlátozódik, amelyek azokat megszabták, és semmiképpen sem sérthetik a szerzönek azt a jogát, hogy - békés megegyezés hiányában - az illetékes hatóság által megállapitott méltányos dijazásban részesüljön."

${ }^{410}$ MASOUYÉ (1978) p. 91-92.

411 GYERTYÁNFY (2014) p. 166
} 
Az Szjt. terminológiájában a 19. §-ban foglalt felhasználási cselekményeket értjük mechanikai többszörözés alatt. A szakasz akként rendelkezik, hogy a zeneszerzők és a szövegírók a már nyilvánosságra hozott nem színpadi zeneműveknek és zeneszövegeknek, valamint az ilyen színpadi zenemüvekből vett részleteknek hangfelvételen való újabb többszörözésére és példányonkénti terjesztésére vonatkozó jogukat csak közös jogkezelő szervezetük útján érvényesíthetik, díjukról csak a felosztás időpontját követő hatállyal, a rájuk jutó összeg erejéig mondhatnak le. ${ }^{412}$

A mechanikai jog tehát, az egyes vagyoni jogok kölcsönhatása, egymásra épülése miatt a többszörözést és a terjesztést is összefoglalóan jelenti. Közvetlen tárgyát pedig a „kisjogos” zenemüvek képezik - amelyekre vonatkozó joggyakorlás hagyományosan egyébként is a közös jogkezelés körébe tartozik.

\section{b) A mechanikai jog tartalma}

A mechanikai jog tartalmának meghatározásakor figyelemmel kell lenni a konkrét felhasználási cselekményre. Ez különösen azért fontos, mert a magyar szerzői jogi törvény eredeti, 1999-ben elfogadott szövege koncepciójában a hatályos változathoz képest eltérő felfogást tükrözött. Másrészt pedig a jog gyakorlása kapcsán az átdolgozás és a többszörözés elhatárolása kiemelten jelentős.

a) Az érintett jogok köre

A hatályos szabályok szerint, amelyek a 2008. évi CXII. törvénnyel kerültek megállapításra, a kötelező közös jogkezelés az alábbi művekre és jogokra terjed ki: a nem színpadi zeneművek és zeneszövegek, illetve a színpadi zeneművekből vett részleteknek a hangfelvételen való újabb többszörözése és példányonkénti terjesztése. $A$ contrario értelmezéssel belátható, hogy színpadi zenemüvek teljes egészükben csak a jogosulttal kötött egyedi felhasználási szerződés alapján többszörözhetőek, azok nem tartoznak a kötelező közös jogkezelés körébe. A nemzetközi gyakorlat szerint a színpadi zenemü egy-egy felvonása vagy ún. keresztmetszete már nem tekinthető részletnek a mechanikai többszörözési jog gyakorlása tekintetében. ${ }^{413}$

\footnotetext{
${ }^{412}$ Szjt. 19. § (1) bek.

${ }^{413}$ GYERTYÁNFY (2014) p. 167.
} 
A korábbi szöveg szerint viszont idetartozott a kisjogos müvek digitális hordozón terjesztett multimédia müben, videofelvételen és elektronikus adatbázisban való újabb többszörözése és példányonkénti terjesztése is. ${ }^{414} \mathrm{~A}$ filmalkotások tekintetében pedig vitatott volt az Szjt. 19. § alkalmazásának lehetősége. Vagyis olyan felhasználási módokra is kiterjedt a korlátozás, amelyekre vonatkozóan nem található a BUE-ben felhatalmazás. ${ }^{415}$ A magyar törvény tehát nem felelt meg a nemzetközi szerzői jogból eredő kötelezettségeknek. A törvény miniszteri indokolása hangsúlyozza, hogy a módosítás ennek a csorbának a kiköszörülését szolgálja, mivel a szerzői jogok korlátozása csak abban a körben lehetséges, amelyben a nemzetközi normák arra lehetőséget biztosítanak. A hivatkozott SZJSZT szakvélemény is megerösíti, hogy arra sincsen mód többek között, hogy a zenemüveket és zeneszövegeket audiovizuális müben (tehát nem hangfelvételként) rögzítve, a többszörözés jogára vonatkozóan a nemzeti jogalkotó feltételeket határozzon meg. Az ilyen feltételek ugyanis nem felelnek meg a BUE elöírásainak. ${ }^{416}$

A hangfelvétel fogalma tágan értelmezendő, abba a klasszikus vinyl lemezen, kazettán kívül a CD és a DVD is beletartozik, de a flash-memória típusú hordozókra (pendrive, memóriakártya), illetve a zenegépekben való rögzítésre is kiterjed. Soha nem tartozhat viszont ide a zenemü kottában történő megjelenési formája. ${ }^{417}$

A módosítást követően tehát az új szöveg már összhangban áll a nemzetközi egyezménnyel tekintettel arra, hogy csak a fent meghatározott müvek többszörözésére (és példányonkénti terjesztésére) ír elő közös jogkezelési kötelezettséget.

\footnotetext{
${ }^{414}$ A korábbi szöveg az alábbi volt: 19. § (1) A hangfelvétel-elöállitó, valamint a multimédia mü létrehozója és az elektronikus adatbázis összeállitója követelheti, hogy a már nyilvánosságra hozott nem szinpadi zenemüveknek és zeneszövegeknek, valamint az ilyen színpadi zenemüvekböl vett részleteknek hangfelvételen, videofelvételen, digitális hordozón terjesztett multimédia müben vagy elektronikus adatbázisban való újabb többszörözését és példányonkénti terjesztését megfelelö dijazás ellenében számára is engedélyezzék. A felhasználási szerzödést az irodalmi es a zenei müvekkel kapcsolatos szerzöi jogok közös kezelését végzö szervezettel kell megkötni.

(2) Az átdolgozási jogra és e jog gyakorlására az (1) bekezdésben foglalt rendelkezés nem alkalmazható. ${ }^{415}$ Az értelmezést alátámasztja az SZJSZT 01/2009/1. számú szakvéleménye.

${ }^{416}$ A „régi” 19. § értelmezése kapcsán egyébként a szakértő tesütlet arra az álláspontra helyezkedett, hogy a nem színpadi zenemü digitális hordozón rögzített multimédia müben való újabb többszörözése, függetlenül attól, hogy az a filmmel együtt, vagy attól elkülönítve történik, az Szjt. 19. § (1) bekezdése szerint az Artisjus közös jogkezelésébe tartozik. Ez az értelmezés ugyan megfelelt a szakasz korábbi szövegének, azonban, mint láttuk, ütközött a BUE elöírásaival. Lásd: SZJSZT 15/08. sz. szakvéleménye.

${ }^{417}$ GYERTYÁNFY (2014) p. 167.
} 
Fontos körülmény, hogy a mechanikai többszörözés nyilvánosságra hozott müvekre terjed ki. Ebből a szempontból megtévesztő lehet a szövegben szereplő „újabb” kitétel, hiszen a nyilvánosságra hozatal nem csak a hanglemez első kiadásával valósulhat meg, hanem például nyilvános élő előadás, vagy online felületen megvalósuló nyilvánossághoz közvetítéssel is. Ilyen esetekben pedig már a nyilvánosságra hozatalt követő első rögzítés, illetve hangfelvétel-kiadás is a közös jogkezelő szervezetek engedélyezési joga körébe tartozik. ${ }^{418}$

\section{ß) Többszörözés vagy átdolgozás?}

A törvény leszögezi, hogy az átdolgozási jogra és annak gyakorlására a kötelező közös jogkezelés keretében történő joggyakorlás nem alkalmazható. ${ }^{419} \mathrm{Ez}$ azt jelenti, hogy az újabb felvétel engedélyezése akkor történik ilyen „könnyített módon” a közös jogkezelő szervezetek közremüködésével, ha az újabb hangfelvétel megegyezik az eredetivel. Amennyiben ez nem így történik, az eredeti szerző engedélyét kell a felvétel elkészítéséhez kérni.

A többszörözés vagy átdolgozás volt a témája annak a jogesetnek is, amely a Fővárosi Bíróság elé került. A bírói fórum (az SZJSZT szakvéleményének teljes elfogadásával) megállapította, hogy nem minősül átdolgozásnak, vagyis ily módon engedélyköteles felhasználásnak, a dalszöveg és a dallam kisebb megváltozatása (a szöveg egy sorának értelmet nem befolyásoló megváltoztatása, a zenemű tempójának kismértékü változtatása, az instrumentális szóló rész lerövidítése a struktúra megváltoztatása nélkül, illetve a bevezető és lezáró részben bevezetett változtatás). Ezek a változtatások nem érték el azt az egyéni-eredeti jelleget, amely miatt azok a mü egészéhez való alkotó hozzájáruláshoz lennének tekinthetőek. ${ }^{420}$ A többszörözési jog gyakorlása tekintetében tehát a konkrét esetben az Szjt. 19. § (1) bekezdése volt alkalmazandó. $^{421}$

\footnotetext{
${ }^{418}$ GYERTYÁNFY (2014) p. 166-167.

${ }^{419}$ Szjt. 19. $§(2)$ bek.

${ }^{420}$ Fővárosi Bíróság P.22419/2006/25., SZJSZT 18/2010.

${ }^{421}$ Az eljárás még a korábban hatályos verzió alkalmazásával folyt le, ez azonban az átdolgozást érintő kérdés tekintetében nem releváns.
} 


\section{B) A reprográfia útján megvalósuló többszörözés}

A többszörözési jog keretében a reprográfiai többszörözéssel kapcsolatban vezethető be még egyébként kötelező közös jogkezelés. Ez a felhasználás jellemzőire vezethető vissza, hiszen sok esetben egyrészt tömeges (vagyis a közös jogkezelés körébe könnyedén beilleszthető), másrészt viszont aránylag egyszerűen ellenőrizhető és követhető, professzionális felhasználók által megvalósított felhasználásokról van szó. A jog jellemzőinek további feltárásához [b) pont] mindenekelött nélkülözhetetlen a reprográfia fogalmának tisztázása [a) pont].

a) A reprográfia fogalma

Reprográfia alatt a köznyelvben alapvetően a fénymásolást értjük. A fogalom pontos meghatározása azonban a digitális technológiák elterjedésének köszönhetően közel sem ennyire egyértelmű. A CPI L. 122-10 cikkének (2) bekezdése az alábbiak szerint fogalmaz: „Reprográfia alatt értjük a papírra vagy ehhez sorolható hordozóra fotómechanikai vagy ezzel azonos hatással bíró eljárással készitett másolatokat, amelyek közvetlen olvasást tesznek lehetővé." ${ }^{222}$ A fogalomnak tehát két meghatározó eleme van. Az első a többszörözés anyagi hordozón való manifesztálódásának a követelménye, és a hordozó fizikai jellemzőinek meghatározása [ $\alpha$ ) pont]. A másik lényeges elem pedig a többszörözéshez használt eljárás technikai megvalósulása $[\beta$ ) pont]. A reprográfia alapvetően analóg hordozóra, papírra való többszörözést jelent. A digitális forradalom azonban ebben a kérdésben is változást hozott, felvetve például a szkennelés pontos szerzői jogi minősítésének kérdését. Emiatt mindkét jellemzőt két szempontból, analóg és digitális értelmezés kapcsán is elemzünk.

a) A papír vagy ehhez hasonló hordozó követelménye

\section{Analóg értelmezés}

Úgy tünik, hogy a francia törvény a többszörözés eredményeképpen létrejött másolatra helyezi a hangsúlyt annak megfogalmazásával, hogy annak a tartalom közvetlen olvasását kell lehetővé tennie. Az ehhez vezető fotómechanikai vagy más, azonos hatással bíró eljárási mód gyakorlatilag közömbös. Fontos viszont, hogy a

\footnotetext{
${ }^{422}$ CPI L. 122-10. cikk: La reprographie s'entend de la reproduction sous forme du copie sur papier ou
} support assimilé par une technique photographique ou d'effet équivalant permettant une lecture directe. 
másolásnak papírra vagy más hasonló hordozóra kell történnie. Épp emiatt kerül ki a digitális hordozóra történő másolás a reprográfiával történő többszörözés hatálya alól és nyer szabályozást a klasszikus magáncélú másolás keretében. ${ }^{423}$

Ez a két körülmény együttesen eredményezi azt, hogy elsősorban szöveges müvek (pl. szép- és szakirodalmi müvek, a nyomtatott sajtóban megjelenő újságcikkek), illetve a kottában megjelenő zenemủvek képezhetik a reprográfia tárgyát. A közös jogkezelés szempontjából ezeknek az alapvető besorolásoknak jelentőségük van, Franciaországban eltérő közös jogkezelő szervezet foglalkozik az egyes jogok kezelésével.

A bírói gyakorlat nem ad útmutatást azzal kapcsolatban, hogy papír vagy ehhez sorolható hordozó alatt mit kell érteni. ${ }^{424}$ A papírhoz hasonló hordozók körébe általában a vásznat és a különböző fóliákat szokták sorolni, amelyek alkalmasak arra, hogy képeket vagy ábrákat megjelenítsenek rajtuk.

\section{Digitális hordozók}

Nem tartoznak azonban ide a digitális hordozók, valamint az olyan többszörözések, amelyeknél az olvashatóság közvetett, mivel számítógépen keresztül történik a megjelenítés. Továbbá a bírói gyakorlat alapján az sem, ha egy dal szövege karaoke előadás keretében egy képernyőn kivetítésre kerül. ${ }^{425}$ Bár ebben az esetben is többszörözésről van szó, igen érdekes érv alapján zárta ki a francia bíróság a reprográfiával történő többszörözés alkalmazását: úgy ítélte meg, hogy jelen esetben az érzékelhetővé tétel csak közvetett, ugyanis nem az olvasás a dalszöveg megjelenítésének célja, hanem annak emberi hang segítségével való többszörözése.

\footnotetext{
${ }^{423}$ Nem véletlen, hogy a 3D-nyomtatást is az üres hordozóra történő magáncélú másolással hozzák összefüggésbe. Erröl lásd részletesen: COURTOIS (2013) p. 71-80.

${ }^{424}$ Érdemes felhívni a figyelmet egy nem érdemi eltérésre az InfoSoc-irányelv és a CPI szóhasználata között. Az elöbbi ugyanis a „papier ou support similaire” (az irányelv hivatalos magyar fordítása: papír vagy hasonló hordozó), míg utóbbi a „papier ou support assimilé” (papír vagy ehhez sorolható hordozó) kifejezést használja. André LUCAS hívja fel a figyelmet arra, hogy az irányelv szóhasználata szerencsésebb, mivel lényegében nem a papírhoz való besorolhatóságról, hanem a papírhoz való hasonlatosságról van szó. Lásd: LUCAS, André: Droit de la reproduction par reprographie (CPI, art. L.122-10 à L.122-12), J.Cl. fasc. 1265. 10. pont.

${ }^{425}$ CA Paris, 13e ch. 28 avril 2000, RIDA janv. 2001, p. 303. Comm. com. électr. 2001. comm. 36 note C. Caron.
} 
A VG Wort-ügyben is hasonló konklúziót vont le az EuB, amikor kimondta, hogy az InfoSoc-irányelv 5. cikk (2) bekezdésének a) pont tárgyi hatálya alól ki kell venni valamennyi nem analóg másolásra alkalmas hordozót, azaz föleg a digitálisakat. $^{426}$ SHARPSTON főtanácsnok megfogalmazásában ahhoz, hogy a többszörözésre szolgáló hordozó a papírhoz hasonló legyen, a hordozófelületnek meg kell tudnia jelenítenie az emberi érzékszervek általi észlelésre és értelmezésre alkalmas fizikai ábrázolást, és azon az ábrázolásnak ténylegesen meg is kell jelennie. ${ }^{427}$ A CPI szövegében szereplő közvetlen olvashatóság is voltaképpen nem más, mint ennek a követelménynek a megtestesülése.

\section{B) A fotómechanikai vagy azzal azonos hatással bíró eljárás}

\section{$\underline{\text { Analóg eljárás }}$}

A hordozó meghatározásánál élénkebb vitákat generált az, hogy mi tekinthető fotómechanikai vagy azzal azonos hatású eljárásnak. Ez utóbbi éppen a technológiai fejlődés következtében bekövetkező változásokra rugalmasan alkalmazható törvény elfogadásának szempontját érvényesítve került a szövegbe. ${ }^{428}$ A törvény parlamenti előkészítése során például a faxot reprográfiának minősítették, mivel ennek lényege éppen abban áll, hogy másolatot hozzanak létre egy távoli eszközön.

A jogalkotó láthatóan igyekezett technológia-semleges meghatározást alkalmazni, amely a felhasznált eljárástól, illetve annak egyes részfolyamataitól független. Erre utal az is, hogy bár a törvényjavaslat eredeti szövegében az ,azonnali olvashatóság” szerepelt kritériumként, az elfogadott szövegbe végül „közvetlen olvashatóság" került bele.

\section{Digitális eljárás}

Az új technológiák elterjedése ebben az esetben is jelentős hatást gyakorolt a jogi kategóriák értelmezésére. Arról kell ugyanis dönteni, hogy vajon a reprográfiához hasonló eljárásnak csak a papírról papírra történő többszörözések tekinthetők, vagy esetleg ide tartozhat a digitális utat is a folyamatban felhasználó többszörözés is?

\footnotetext{
${ }^{426}$ A VG Wort-ügyben hozott ítélet, 67. pont.

${ }^{427}$ A VG Wort-ügyben ismertetett fötanácsnoki indítvány 63. pontja.

${ }^{428}$ BÉCOURT (1995a) p. 59. 36. bekezdés.
} 
A digitális többszörözések kapcsán két eset között lehet különbséget tenni, attól függően, hogy a többszörözött példány milyen módon került rögzítésre. Ennek megfelelően az egyik eset az eleve digitális formában létrejött anyagok analóg többszörözése. A másik pedig az analóg forrás digitalizálása, majd a digitalizált fáj1 analóg többszörözése.

Az eleve digitális forrásból történő többszörözés már a honatyákat is foglalkoztatta a törvény elfogadásakor, a Nemzetgyülés és a Szenátus ugyanis ellentétes álláspontot képviselt abban a kérdésben, hogy egy adatbázisból nyomtatás útján való többszörözést reprográfiának lehet-e tekinteni.

Amennyiben azt a nézetet követjük, hogy a másolatnak ugyanúgy kell kinéznie, mint az eredeti münek, vagyis csak a fakszimile elfogadható, akkor az eleve digitális formában lévő müről történő többszörözés nem tekinthető reprográfiának. A papírra többszörözött (tipikusan kinyomtatott) dokumentum kinézete ugyanis valószínűleg el fog térni attól, ahogyan az a monitoron megjelenik - már pusztán a papír véges fizikai kiterjedése miatt is, ami a dokumentum tördelését teszi szükségessé. A képernyőn ugyanis (természetesen programtól függően) ezek általában folyószövegként jeleníthetőek meg, oldaljelölés nélkül, ahol az előrehaladás a szövegben lapozás helyett a görgetősáv segítségével történik. ${ }^{429}$ A CFC is ezt az értelmezést tekinti irányadónak a honlapján közzétett tájékoztató szerint. ${ }^{430}$

A kérdést a VG Wort-ügyben eljáró SHARPSTON fötanácsnok is vizsgálta. Egészen pontosan azzal is foglalkozott indítványában, hogy vajon az eleve digitális forrásokból készült másolat a reprográfiai többszörözés fogalma alá tartozhat-e (pl. honlapról letöltött tartalom vagy egy e-mailhez csatolt fájl). Hasonló a probléma abban az esetben is, ha az analóg forrás úgy kerül digitalizálásra, például valamely OCR szoftver $^{431}$ segítségével, hogy a kimenet nem az eredeti forrás fakszimiléje. ${ }^{432}$ A főtanácsnok az InfoSoc-irányelv 5. cikk (5) bekezdésében meghatározott háromlépcsős

\footnotetext{
${ }^{429}$ Gondoljunk péládul egy híroldal megjelenésére. Az egyes jogi adatbázisokban elérhető tudományos cikkek is ehhez hasonló módon olvashatóak, amennyiben a szöveget nem konvertáljuk át valamely más program által kezelendő fájllá.

${ }^{430} \mathrm{http} / / / \mathrm{www} . c f c o p i e s . c o m / l e x i q u e / \mathrm{r}$

$431 \mathrm{Az}$ OCR az angol „optical character recognition” kifejezés (magyarra fordítva optikai karakterfelismerés) rövidítése. Lényege, hogy az analóg eredeti forrást oly módon digitalizálja, hogy ezt követően a szöveg számítógéppel könnyen feldolgozható legyen.

${ }^{432}$ A VG Wort-ügyben ismertetett fötanácsnoki indítvány 65. pontja.
} 
teszt értelmezésével járta körül a kérdést. Abból eredően, hogy az irányelvben kivételként lett meghatározva a reprográfiával való többszörözés, annak szoros értelmet kell tulajdonítani. Mivel a CPI-ben hangsúlyozottan nem kivételről van szó, ezért a főtanácsnok érvelését csak ezzel a szükségszerü megkülönböztetéssel együtt érdemes elemezni. Mindenesetre SHARPSTON fötanácsnok szerint a fotómechanikai szó az analóg eredeti optikai vagy ahhoz hasonló bevitelét igényli. „Azzal érvelni, hogy a »hasonló hatású« fordulat mindössze azt jelenti, hogy »amelynek eredménye hasonló ahhoz, mint amelyet a fotómechanikai eljárás hozott volna létre«, a »fotómechanikai« szó jelentéstartalmának teljes figyelmen kivül hagyásával lenne egyenértékü, ugyanis bármely papirra vagy hasonló hordozófelületre végzett többszörözés »hasonlóként» irható le a fotómechanikai eljárással végzetthez." ${ }^{433}$ Vagyis a főtanácsnok is elsősorban a technológiai sajátosságokon alapuló érvelést tekintette irányadónak.

Az EuB szerencsére nem kötötte magát szorosan a fötanácsnok által leírtakhoz, ugyanis azzal kezdte álláspontjának kifejtését, hogy ,,az ügy irataiban semmi nem utal arra, hogy az a kérdés, hogy adott esetben milyen jellegünek kell lennie annak az eredeti példánynak, amelyről a másolatot készítik, releváns az alapeljárásbeli jogvita elbírálása szempontjából. E tekintetben tehát nem szükséges határozni." ${ }^{434}$ Az ítélet tehát korántsem egyértelmű e tekintetben, ${ }^{435}$ és nem feltétlenül segíti az általunk feltett kérdés megválaszolását.

André LUCAS álláspontja szerint inkább egy tágabb definíciót kellene elfogadni a fotómechanikai eljáráshoz hasonló eljárások értelmezése kapcsán. Szerinte a szerzői jognak a technológiai semlegesség alapelvét kellene figyelembe venni, és a rendelkezés egészét vizsgálni a végtelenségig folytatható viták helyett arról, hogy mi tekinthető „fotómechanikai eljáráshoz hasonló eljárásnak. ${ }^{436} \mathrm{Ez}$ annál is lényegesebb, mivel a digitális másolatok egyre inkább felváltják a hagyományos papír alapúakat - különösen az oktatásban. ${ }^{437}$ LUCAS annak ellenére ezen az állásponton van, hogy a CPI szövege ebben a tekintetben mintha szükebb lenne, mint az InfoSoc-irányelvé. A francia törvény

\footnotetext{
${ }^{433}$ A VG Wort-ügyben ismertetett fötanácsnoki indítvány 69. pontja.

${ }^{434}$ A VG Wort-ügyben hozott ítélet 63. pontja.

${ }^{435}$ LUCAS, André: Droit de la reproduction par reprographie (CPI, art. L.122-10 à L.122-12) J.Cl. Propriété littéraire et artistique, Fasc. 1265 11. pont.

${ }^{436}$ LUCAS, André: Droit de la reproduction par reprographie (CPI, art. L.122-10 à L.122-12) J.Cl. Propriété littéraire et artistique, Fasc. 1265. 11. pont.

${ }^{437}$ DIRINGER (2011) p. 309.
} 
ugyanis kifejezetten a fotómechanikai eljárással azonos hatású eljárásról rendelkezik. Bár tény, hogy mivel nem kivételről van szó, a bíróságok némileg szabadabban értelmezhetnék a fordulatot. A CFC viszont, mint ahogyan már fent említésre került, önkorlátozást alkalmaz, és nem tekinti ilyennek az eleve digitális forrásból származó többszörözéseket.

Némileg eltérő a helyzet a digitalizálást követően megvalósuló többszörözések tekintetében. Úgy tünik, hogy mind a fötanácsnok, mind a Bíróság hasonló álláspontot képvisel a VG Wort-ügyben, amely egyébként nem tér el a CFC és a jogirodalom értelmezésétől sem. A legfőbb szempont ebben az esetben annak vizsgálata, hogy többszörözés során megvalósuló egyes részfolyamatok mennyire tekinthetők egységesnek.

Az EuB a többszörözés eredményére helyezte a hangsúlyt kifejezetten kiemelve, hogy „[a]mennyiben ez az eredmény biztositott, a müveletek száma vagy a szóban forgó többszörözés folyamata során alkalmazott módszer vagy módszerek jellege kevésbé számit, már amennyiben ezen egységes folyamat nem elkülönithető különbözö elemei és szakaszai ugyanazon személy felügyelete mellett valósulnak meg, és közülük mindegyik a münek vagy más, jogi védelem alatt álló teljesitménynek papírra vagy ahhoz hasonló hordozóra történő másolására irányul." ${ }^{438}$

SHARPSTON fötanácsnok azt is kiemelte, hogy a szkenner és a nyomtató együttesen alkalmazva nagyjából ugyanazt a funkciót tölti be, mint a fénymásoló. ${ }^{439}$ Vagyis analóg eredetiből digitális úton megvalósuló többszörözés esetében az eljárás három szakaszra tagolódik: egy beviteli szakaszra, amely állhat az eredeti analóg kép optikai beviteléből vagy az eredeti digitális kép nem optikai eljárással történő létrehozásából. A közbenső szakasz magában foglalhat egy vagy több tárolási, átviteli vagy módosító műveletet, akár analóg, akár digitális formában. Végül pedig a kimeneti szakasz a látható, analóg formában történő képmegjelenítést foglalja magában. ${ }^{440}$

A többszörözésnek az eljárás egésze tekintetében kell a fotómechanikai eljáráshoz hasonlónak lennie. ${ }^{441}$ Vagyis analóg másolatot kell eredményeznie

\footnotetext{
${ }^{438}$ A VG Wort-ügyben hozott ítélet 70. pontja.

${ }^{439}$ A VG Wort-ügyben ismertetett fötanácsnoki indítvány 55. pontja.

${ }^{440}$ A VG Wort-ügyben ismertetett fötanácsnoki indítvány 57. pontja.

${ }^{441}$ A VG Wort-ügyben ismertetett fötanácsnoki indítvány 69. pontja.
} 
végeredményben oly módon, hogy a folyamat egészét ugyanaz a személy végezze el vagy egyetlen műveletből álljon. ${ }^{442}$ Tehát például elfogadható az, ha a beszkennelt dokumentumot a számítógép memóriájában eltárolják, és így nyomtatják ki. De már nem tartozik ide, ha a beszkennelt dokumentumot feltöltik egy honlapra, majd azt egy másik személy letölti, és ezt követően kerül sor a nyomtatásra. ${ }^{443}$

A nyomtatást megelőző szkennelés önmagában is többszörözésnek minősül, viszont nem tekinthető reprográfiának. Amennyiben viszont az előzetes digitalizálás elengedhetetlen ahhoz, hogy papír alapú másolatot kapjunk, ennek a folyamatnak egy közbenső lépcsője, a digitalizálás is a reprográfia részeként értékelhető. ${ }^{444}$

A digitális többszörözés kérdése a francia bírói gyakorlatban a sajtófigyelés, lapszemle (panorama de presse) kapcsán vetödött fel különös éllel. Ilyen tevékenység alatt azt értjük, amikor egy adott témát feldolgozó különböző sajtóorgánumban megjelent cikkeket teljes terjedelmükben, vagy azok részleteit teszik elérhetővé. Célja, hogy a külső források segítségével a gazdasági szektorról, az egyes termékekről vagy a versenyről nyújtson ismereteket. ${ }^{445}$ Ezt általában különböző szervezetek készítik dolgozóik számára belső felhasználás céljából. Eredetileg fénymásolással készültek, és mint ilyenek így a reprográfiával történő többszörözés hatálya alá tartoztak. A technológiai fejlődés következtében viszont újabban már ezek is intraneten/interneten keresztül érhetők el. A bírói gyakorlatban felvetődött kérdés tehát az volt, hogy az ilyen felhasználások vajon továbbra is a reprográfiával megvalósuló többszörözés körében értékelendőek?

A Vecteur Plus elnevezésü gazdasági társaság ilyen sajtófigyelő szolgáltatást nyújtott ügyfeleinek: az előzetesen digitalizált cikkeket a felhasználóik részére úgy tették elérhetővé, hogy azokat kinyomtathatták vagy a számítógép képernyőjén olvashatták. A társaság két szerződést kötött a CFC-vel, egyet a kötelező közös jogkezelés alá tartozó reprográfiai többszörözések jogosítása érdekében, egyet pedig a digitális lapszemle szolgáltatás nyújtására vonatkozóan (ez utóbbi a jogosultak önkéntes elhatározásán alapuló jogkezelés alá tartozott). A felperes társaság, az $S P Q R$ kereseti

\footnotetext{
${ }^{442}$ A VG Wort-ügyben ismertetett fötanácsnoki indítvány 74. pontja.

${ }^{443}$ A VG Wort-ügyben ismertetett fötanácsnoki indítvány 71-72. pontjai.

${ }^{444}$ DIRINGER (2011) p. 309.

${ }^{445}$ A meghatározást lásd a CFC honlapján: http://www.cfcopies.com/lexique/p.
} 
kérelme arra irányult, hogy a bíróság állapítsa meg, hogy a Vecteur Plus által végzett felhasználási cselekmény nem tartozik a reprográfiával történő többszörözés körébe. A bíróság nem a ténylegesen megvalósuló részfolyamatokat, hanem a $\mathrm{CFC}$ felhasználási szerződését elemezte, mivel az csak az eredetivel megegyező másolatok készítését tette lehetővé. Mivel a sajtófigyelés keretében létrejött többszörözött példányok nem ilyenek voltak, a Vecteur Plus megsértette a vonatkozó szerződéses kikötést. ${ }^{446}$ Vagyis a bíróság akként foglalt állást, hogy a cikkek digitalizálása önmagában is engedélyköteles felhasználási cselekmény lett volna.

\section{b) A reprográfiai többszörözés joga}

A jogalkotó nem kivételként, hanem a szerzőt megillető kizárólagos jogként rendelkezett a reprográfiával való többszörözésröl. Nem új jogot hozott azonban létre a jogalkotó, inkább a többszörözési jog egyik nevesített eseteként emelte ki külön a reprográfiai többszörözés jogát. Mivel az oktatási intézmények tekinthetők az egyik legjellemzőbb felhasználóknak, vizsgálni érdemes a kizárólagos jog természete mellett az összefüggéseit a szerzői jogi kivételekkel is - különös tekintettel az oktatási célú kivételekre.

a) A kizárólagos jog

A reprográfia útján való többszörözés jogként való meghatározásának több fontos következménye van. Az egyik természetesen az, hogy a felhasználások fejében a jogosultat nem az InfoSoc-irányelvben is említett „méltányos díjazás” (compensation équitable) illeti meg - aminek célja, hogy a jogosultat az engedélyezési jog gyakorlásának hiányából fakadó hátrányt ellentételezze ${ }^{447}$-, hanem a felhasználás engedélyezése fejében járó jogdíj.

Negatív oldalról megközelítve a kérdést, a jog természete egyben azt is magában hordozza, hogy a jogosult bizonyos felhasználásokat megtilthat. ${ }^{448} \mathrm{~A}$ gyakorlatban ez ott mutatható ki leginkább, hogy bár elvben az engedélyezés teljes müvek többszörözésére is vonatkozhatna, a közös jogkezelő szervezetek mégis

\footnotetext{
446 TGI Paris 3ème chambre du 30 juin 2004.

${ }^{447}$ Lásd: VG Wort-ügy. A hátrány fogalmáról részletesen: HAJDÚ (2014a) p. 53-60

${ }^{448}$ LUCAS, André: Droit de la reproduction par reprographie (CPI, art. L.122-10 à L.122-12) J.Cl. Propriété littéraire et artistique, Fasc. 1265 13. pont.
} 
meghatározott oldalszámra korlátozott engedélyeket adnak. Az egyetemek számára adott engedélyekben például kifejezetten szerepel az a kitétel, hogy teljes müvek másolása tilos. $^{449}$

André LUCAS kritikával illeti ezt a gyakorlatot. Álláspontja szerint ez az InfoSoc-irányelvben vázolt szerzői jogi kivételben vagy korlátozásban megtestesülő felfogásban lehetne vállalható, a kizárólagos engedélyezési jog gyakorlása esetén semmi nem igazolja ezt a megkülönböztetést. ${ }^{450}$ LUCAS viszont nem veszi figyelembe azt, hogy a reprográfiai többszörözés a müveknek mindenképpen csak másodlagos felhasználása lehet. Olyan tömeges jellegü felhasználások esetén, mint amilyen az egyetemeken valósul meg, a mennyiségi korlátozás célja éppen a müvek elsődleges piacának védelmében keresendö. A törvényben semmi nem zárja ki azt, hogy adott esetben a CFC teljes müvek többszörözésére is engedélyt adjon. Söt, az olyan könyvek esetében, amelyeket a kiadó már nem árusít, ${ }^{451}$ az ilyen egyedi és a mü teljes terjedelmére vonatkozó engedélyezés lehetősége expressis verbis szerepel a szerződésben. ${ }^{452}$

Másik fontos eleme a kizárólagos jognak, hogy egészen addig, amíg a többszörözés ilyen módon történő engedélyezésére vonatkozó jog át nem száll a közös jogkezelő szervezetre, addig azt a szerző gyakorolhatja. Ez elvben azt is jelenti, hogy másnak - jellemzően a kiadónak - átengedheti.

\section{B) A kizárólagos jog viszonya a kivételekhez}

A többszörözés jogával kapcsolatban több kivétel alkalmazása is felvetődhet, amelyek így értelemszerűen összeütközésbe kerülhetnek a reprográfia kapcsán megállapított kizárólagos joggal. A kivételként meghatározott esetekben ugyanis engedélykérés nem szükséges. Éppen ezért érdemes megvizsgálni azt, hogy a CPI-ben található listában fellelhető-e olyan rendelkezés, amely a reprográfiai többszörözésre vonatkozó engedélykérés alóli kivételt határoz meg. Ez különösen amiatt fontos, mert a

\footnotetext{
449 CFC szerződés 3.4. pont. (http://www.cfcopies.com/images/stories/pdf/Utilisateurs/Copiespedagogiques-papier-et-numeriques/Etablissements-d-enseignement/Enseignementsuperieur/Universite/Photocopie/Contrat-sup-univ.pdf).

${ }^{450}$ LUCAS, André: Droit de la reproduction par reprographie (CPI, art. L.122-10 à L.122-12) J.Cl. Propriété littéraire et artistique, Fasc. 126513. pont.

${ }^{451}$ Livres épuisés.

${ }^{452}$ CFC szerződés 3.4. pont.
} 
reprográfia útján történő felhasználások jelentős része oktatási intézményekben történik. Ezen kívül az egyéb magáncélú, illetve a sajtó számára biztosított kivételek is fontosak lehetnek ebből a szempontból.

Az oktatáshoz nem köthető kivételek köréből egyértelműen a magáncélú másolatot kell(ene) kiemelni, a felhasználási cselekmény hasonlóságai miatt. Erre a dolgozat magáncélú másolattal kapcsolatos fejezetében térünk ki külön, ${ }^{453}$ e helyütt azt ismételjük csak meg, hogy a hang- vagy videofelvétel rögzítésére alkalmas hordozóra történő másolás az egyik legfontosabb elhatárolási ismérv a két fogalom között. Tárgyát tekintve tehát ez képezi a tágabb kategóriát, a szabályozás viszont egyéb pontokon jelentősen szükebb, és sokkal inkább eltérő jellemzőket mutat.

A fentebb már részletesen tárgyalt sajtófigyelés miatt is ide kívánkozik a sajtó részére biztosított kivételhez (revue de presse) kötődő elemzés. ${ }^{454} \mathrm{Az}$ idézéshez hasonlóan ebben az esetben is meg kell jelölni a szerző nevét és a forrás pontos helyét. A kivétel fogalma a törvényben nem meghatározott, a Semmítőszék megfogalmazásában viszont a célja, hogy egy adott téma vagy esemény különböző újságírók által készített, egymással összekapcsolt, összehasonlított bemutatása. ${ }^{455}$ Vagyis a kivétel lényege röviden abban ragadható meg, hogy a különböző vélemények párhuzamba állításával az olvasókban gondolatokat ébresszenek. Éppen emiatt az értelmező, véleményformáló jelleg miatt több ez a kivétel a szövegek puszta egymás mellé másolásánál, és igazolja a sajtó számára biztosított lehetőség létjogosultságát. ${ }^{456}$

Az oktatási intézmények a reprográfiával történő többszörözés egyik legnagyobb felhasználói. Mivel az oktatási célú kivétel alkalmazási feltételei meglehetősen szigorúak, ezért az oktatás keretében a felhasználásokat a többi kivétel szürőjén keresztül is érdemes megvizsgálni. Így például az idézés és elemzés (analyses et courtes citations $)^{457}$ reprográfiához füződő kapcsolata első pillantásra távolinak

\footnotetext{
${ }^{453}$ Lásd a II. rész II. fejezetét.

${ }^{454}$ CPI L. 122-5. cikk $3^{\circ}$ b) pont: „,[Lorsque l'oeuvre a été divulguée, l'auteur ne peut interdire] Sous réserve que soient indiqués clairement le nom de l'auteur et la source: Les revues de presse."

${ }^{455}$ Cass. crim., 30 janv. 1978 : D. 1979, p. 583, note J. Le Calvez ; Gaz. Pal. 1978, 2, p. 466 ; RTD com. 1979 , p. 456, obs. A. Françon.

${ }^{456}$ LUCAS, André: Droits des auteurs - Droits patrimoniaux - Exceptions au droit exclusif (CPI, art. L. 122-5 et L. 331-4), J.Cl. Propriété littéraire et artistique, Fasc. 1248. 64. pont.

${ }^{457}$ CPI L. 122-5. cikk $3^{\circ}$ a) pont ,[Lorsque l'oeuvre a été divulguée, l'auteur ne peut interdire] Sous réserve que soient indiqués clairement le nom de l'auteur et la source: Les analyses et courtes citations
} 
tünhet, ám az oktatásban betöltött szerepe miatt fontos ennek is a vizsgálata. A kivételek alkalmazására kevés lehetősége nyílik a pedagógusnak, mivel az idézés megköveteli az idézett szöveg inkorporálását a másodlagos müben. ${ }^{458}$ Az iskolai oktatás keretén belül pedig kérdéses a másodlagos mü létrejötte, vagyis, hogy a tanórán elhangzottak, illetve az oktató által ehhez készített segédanyagok egyéni, eredeti jellegüknél fogva megfelelnek-e a szerzői jogi oltalom kritériumainak. Vagyis az oktatás keretében a reprográfiai többszörözés jogával összefüggésben a kivétel alkalmazhatósága kérdéses, amely megerősíti a kizárólagos engedélyezési jog kötelező közös jogkezelő szervezetek általi gyakorlásának indokoltságát.

Az oktatási célú kivétel (exception pédagogique) a többszörözés (és emellett az előadás) engedélyezése alól vesz ki bizonyos felhasználásokat, ${ }^{459}$ így érdemes megvizsgálni a reprográfiai többszörözéssel való összefüggéseit. A kivétel mindenekelőtt csak a művek egy speciális csoportjára, az oktatás céljára készült müvekre, valamint a kották részleteire, illetve célja is meghatározott: kizárólag az oktatási és kutatási tevékenység keretében (amely alól a játékok vagy szabadidős tevékenységek ki vannak zárva), a tanagyag illusztrálása céljából engedélyezett a felhasználás. Ennek logikus folyománya az a további megszorítás, amely a közönséget érinti, ennek ugyanis jórészt diákokból, egyetemi hallgatókból, oktatókból és kutatókból kell állnia. A reprográfiai többszörözéssel való kapcsolatát maga a kivételt beiktató rendelkezés határozza meg. A CPI vonatkozó cikke ugyanis amellett, hogy az alkalmazási köréből kizár minden kereskedelmi célú felhasználást, díjfizetéshez köti a kivételt, ez a díjazás azonban nem lehet sérelmes a reprográfiai többszörözés jogának

justifiées par le caractère critique, polémique, pédagogique, scientifique ou d'information de l'oeuvre à laquelle elles sont incorporées."

${ }^{458}$ LUCAS, André: Droits des auteurs - Droits patrimoniaux - Exceptions au droit exclusif (CPI, art. L. 122-5 et L. 331-4), J.Cl. Propriété littéraire et artistique, Fasc. 1248. 62. pont.

${ }^{459}$ CPI L. 122-5. cikk $3^{\circ}$ e) pont: ,, [Lorsque l'oeuvre a été divulguée, l'auteur ne peut interdire] Sous réserve que soient indiqués clairement le nom de l'auteur et la source: La représentation ou la reproduction d'extraits d'oeuvres, sous réserve des oeuvres conçues à des fins pédagogiques et des partitions de musique, à des fins exclusives d'illustration dans le cadre de l'enseignement et de la recherche, y compris pour l'élaboration et la diffusion de sujets d'examens ou de concours organisés dans la prolongation des enseignements à l'exclusion de toute activité ludique ou récréative, dès lors que cette représentation ou cette reproduction est destinée, notamment au moyen d'un espace numérique de travail, à un public composé majoritairement d'élèves, d'étudiants, d'enseignants ou de chercheurs directement concernés par l'acte d'enseignement, de formation ou l'activité de recherche nécessitant cette représentation ou cette reproduction, qu'elle ne fait l'objet d'aucune publication ou diffusion à un tiers au public ainsi constitué, que l'utilisation de cette représentation ou cette reproduction ne donne lieu à aucune exploitation commerciale et qu'elle est compensée par une rémunération négociée sur une base forfaitaire sans préjudice de la cession du droit de reproduction par reprographie mentionnée à l'article L. 122-10." 
átengedésére. Vagyis összegét mindenképpen annak fényében lenne érdemes meghatározni, hogy az oktatási intézmények már a nem kedvezményezett felhasználás esetében jogdíj fizetésére kötelezettek. A feltételes mód használata ebben az esetben indokolt, hiszen a két rendelkezés közötti átfedés indokolhatja azt, hogy míg az audiovizuális és zenei művek esetében a díjazás összege megállapításra került, addig a szöveges (irodalmi) müvek tekintetében ez elmaradt. ${ }^{460}$

Egy másik jelenségre is fel kell hívni a figyelmet a reprográfiai többszörözés engedélyezési jogként történő meghatározása és a kivételek között. Az InfoSoc-irányelv 5. cikk (2) bek. a) pontja ugyanis, lehetővé teszi a tagállamok számára a reprográfiai többszörözés kizárólagos joga alóli kivételek és korlátozások bevezetését - a kották kivételével. Vagyis, ez azt jelenti, hogy azokban a tagállamokban, ahol a reprográfiai többszörözés jogára vonatkozó díjigényt vezetett be a jogalkotó, ${ }^{461}$ a kották esetében az engedélyezési jogot fenn kell tartani, és a kották többszörözése egyébként az InfoSocirányelv 5. cikk (2) bek. b) pont hatálya alá tartozó magáncélú másolás keretei között sem lehetséges. ${ }^{462}$ Franciaországban viszont, mivel a jogalkotó a különbségtétel nélkül, minden mütípus vonatkozásában a vagyoni jogot engedélyezési jogként kezeli, a kották reprográfiai többszörözésére is alkalmazandóak mind a kizárólagos jog fennállásával, mind pedig annak gyakorlásával kapcsolatban elmondottak.

\section{\$2. A jogok gyakorlása}

\section{A) A jog gyakorlásának átengedése}

A jog gyakorlásának átengedése a közös jogkezelő szervezetre két eltérő megoldással történhet. Az Szjt. hatályos verziója szakított a törvény szövegének korábbi megfogalmazásával, így egy koherens, konzekvens rendszerrel állunk szemben. Ettől eltérően a CPI a vezetékes továbbközvetítés jogához képest is másképpen fogalmazza meg a jog átszállását. Nem a kötelező tagságról beszél ugyanis, hanem a jog kötelező átszállásáról.

\footnotetext{
${ }^{460}$ LUCAS, André: Droits des auteurs - Droits patrimoniaux - Exceptions au droit exclusif (CPI, art. L. 122-5 et L. 331-4), J.Cl. Propriété littéraire et artistique, Fasc. 1248. 73. pont.

${ }^{461}$ Így például Magyarországon is az uniós jognak való megfelelés indokolta, hogy a kotta reprográfiai többszörözése visszakerüljön az engedélyezési jog körébe. GYENGE (2010) p. 217-222.

${ }^{462}$ A C-572/13. sz. Reprobel-ügyben 2015. november 12-én hozott ítélet 51-53. pontja.
} 
a) A „klasszikus” törvényi fordulat alkalmazása

Az Szjt. 2009. február 1. napját megelőző szövege jellegében a kényszerengedélyhez hasonló megoldással élt a mechanikai többszörözési jog gyakorlása tekintetében. A törvénymódosítás viszont ezt megváltoztatva egyébként a kötelező közös jogkezeléssel tette egy tekintet alá a jog gyakorlását.

a) A korábban hatályos szöveg

Az Szjt. 19. § (1) bekezdés szövege a törvénymódosítás előtt az alábbi volt: „A hangfelvétel-elóállitó, valamint a multimédia mü létrehozója és az elektronikus adatbázis összeállitója követelheti, hogy a már nyilvánosságra hozott nem színpadi zenemüveknek és zeneszövegeknek, valamint az ilyen színpadi zenemüvekböl vett részleteknek hangfelvételen, videofelvételen, digitális hordozón terjesztett multimédia müben vagy elektronikus adatbázisban való újabb többszörözését és példányonkénti terjesztését megfelelö díjazás ellenében számára is engedélyezzék. A felhasználási szerződést az irodalmi es a zenei müvekkel kapcsolatos szerzöi jogok közös kezelését végzö szervezettel kell megkötni."

A módosítást megelőző szöveg azért tekinthető kényszerengedélynek, mivel arról rendelkezett, hogy a hangfelvétel-előállítók követelhették, hogy a többszörözést és a példányonkénti terjesztést számukra is engedélyezzék. Ahogyan az SZJSZT vonatkozó szakvéleménye is kiemeli, a BUE-nek való megfelelés szempontjából az lényegében mindegy, hogy kényszerengedélyként vagy kötelező közös jogkezelésként kerül-e bevezetésre. A nemzetközi egyezmény ugyanis általában a feltételek bevezetéséről rendelkezik.

A módosításnak tehát inkább abból a szempontból van jelentősége, hogy ennek köszönhetően a szerzői jog eszközrendszerétől idegen megoldás helyett egy abba jobban illeszkedő eszközt vezetett be a jogalkotó.

\section{ß) A jelenleg hatályos szöveg}

A jelenleg hatályos szöveg a többi jog esetében is bevett fordulatot használja, vagyis arról rendelkezik, hogy a jogosultak jogukat csak közös jogkezelő szervezet útján érvényesíthetik és a díjukról csak a felosztást követő hatállyal, a rájuk jutó összeg 
II. rész A törvény által előírt közös jogkezelés, mint a kizárólagos jog korlátja

I. fejezet A jog gyakorlásának korlátozása a közös jogkezelés elöírásával

erejéig mondhatnak le. Ily módon nem tapasztalható eltérés a többi, közös jogkezelést elöíró rendelkezéshez képest. A jog gyakorlását a szerzőket tömörítő szervezet, az Artisjus végzi.

b) A jog átszállása a közös jogkezelö szervezetre

A reprográfiai engedélyezés jogának gyakorlását két közös jogkezelő szervezet végzi Franciaországban. A zenemüvek többszörözése tekintetében a SEAM kapott erre felhatalmazást, míg az összes többi műfajú mủ esetében a CFC végzi a jogosítást.

Érdekes módon - talán abból eredően, hogy nem az uniós jog implementációjának következménye a törvényi rendelkezés - nem a müholdas sugárzásról szóló irányelv szóhasználata kerül átvételre. Vagyis nem azt mondja a CPI, hogy a jogosult jogát csak közös jogkezelő szervezeten keresztül gyakorolhatja, hanem a jog gyakorlásának törvényi átszállásáról rendelkezik. ${ }^{463}$

a) Az átszállás természete

A jog gyakorlásának közös jogkezelés alá vonása a különböző intézményi (elsősorban oktatási) felhasználások tömeges jellege miatt is szükségszerü volt. Mint a fentiekben bemutatásra került, a szerzői jogi kivételek per definitionem kevéssé alkalmasak ezeknek a felhasználásoknak a rendezésére. A jogosultak pedig a felhasználások tömeges jellege miatt nem képesek hatékonyan engedélyezni a reprográfia útján történő többszörözést.

Az engedélyezési jog a törvény erejénél fogva, a jogosult szándékától függetlenül kerül át a közös jogkezelő szervezethez - vagyis automatikus, kizárólagos és nem önkéntes (automatique, exclusive et forcé) ${ }^{464}-$, a jogirodalom ezt az aktust a „törvényi átszállásnak” (cession légale) nevezi, amely bizonyos nézőpont szerint nem más, mint egy kötelező szerződés (contrat forcé). ${ }^{465}$ A lényeg azonban abban áll, hogy az átszállás következtében a közös jogkezelő szervezet lesz az, amelyik a kizárólagos

\footnotetext{
${ }^{463}$ CPI L. 122-10. cikk (1) bek.: La publication d'une oeuvre emporte cession du droit de reproduction par reprographie à une société régie par le titre II du livre III et agréée à cet effet par le ministre chargé de la culture. Les sociétés agréées peuvent seules conclure toute convention avec les utilisateurs aux fins de gestion du droit ainsi cédé, sous réserve, pour les stipulations autorisant les copies aux fins de vente, de location, de publicité ou de promotion, de l'accord de l'auteur ou de ses ayants droit."

464 DERIEUX (1995) p. 28.

${ }^{465}$ CARON (2013a) p. 284.
} 
II. rész A törvény által előírt közös jogkezelés, mint a kizárólagos jog korlátja

I. fejezet A jog gyakorlásának korlátozása a közös jogkezelés elöírásával

jogot gyakorolhatja, ennek megfelelően a szerzői jogok megsértése (contrefaçon) ellen is felléphet. ${ }^{466}$

A megjelenés aktusa (publication) az, amely az átszállást keletkezteti. ${ }^{467}$ Kógens szabályról van szó, ugyanis az átruházás kiterjed minden kiadott müre, függetlenül a kiadás időpontjától és az ezzel ellentétes szerződéses kikötésektőll. ${ }^{468} \mathrm{~A}$ „publication” viszont egyike a jogtudomány legbizonytalanabb, legnehezebben meghatározható fogalmainak, mert jelentése több faktor vizsgálatától függ. ${ }^{469}$ Etimológiailag a kifejezés az ötletek, hírek, művek stb. nyilvánosság számára elérhetővé tételét jelenti, később alakult át a hordozó (könyv, újság stb.) megjelentetésére. ${ }^{470}$ Törvényi és bírói gyakorlatban meghatározott értelmezés hiányában a jogtudomány egymástól jelentősen eltérő értelmet tulajdonít neki.

A fogalom tisztázása érdekében mindenekelőtt vissza kell kanyarodni a BUE 3. cikk (3) bekezdésére, amely az alábbiakról rendelkezik: „«[m]egjelent müvek» alatt a szerző hozzájárulásával kiadott müvek értendök, bármi legyen is a müpéldányok elöállitási módja, feltéve, hogy ezeket - a mü jellegének figyelembevételével - oly módon bocsátották a közönség rendelkezésére, hogy kielégitsék annak ésszerü szükségleteit." ${ }^{471}$ Vagyis a BUE a kiadás aktusához kapcsolja a mủ megjelenését.

Ezzel szemben André LUCAS szerint tágan kell értelmezni a fogalmat, és már a mü nyilvánosságra hozatala is publikálásnak számít. Ezt azzal támasztja alá, hogy a törvény elfogadásakor a kultúráért felelős miniszter ténykérdésként (fait matériel) hivatkozott a megjelenés aktusára. ${ }^{472}$

A CFC viszont ennél lényegesen szűkebb fogalmat használ, jobban közelítve a BUE definíciójához, megerősítve, hogy a nem megjelent müvekre az engedély nem

\footnotetext{
${ }^{466}$ TGI Paris, 11 mai 2000, (RIDA avril 2001 n $^{\circ} 188$, p. 379)

${ }^{467}$ CPI L. 122-10. cikk (1) bek. „La publication d'une oeuvre emporte cession du droit de reproduction par reprographie (...)."

${ }^{468}$ CPI L. 122-10. cikk (4) bek. „Nonobstant toute stipulation contraire, les dispositions du présent article s'appliquent à toutes les oeuvres protégées quelle que soit la date de leur publication."

${ }^{469}$ DERIEUX (2010a), e-verzió.

${ }^{470}$ BARRAUD (2012), e-verzió 11. bekezdés.

${ }^{471}$ BUE 3. cikk (3) bek. „Par «œuvres publiées», il faut entendre les ouvres éditées avec le consentement de leurs auteurs, quel que soit le mode de fabrication des exemplaires, pourvu que la mise à disposition de ces derniers ait été telle qu'elle satisfasse les besoins raisonnables du public, compte tenu de la nature de l'œuvre."

${ }^{472}$ LUCAS, André: Droit de la reproduction par reprographie (CPI, art. L.122-10 à L.122-12) J.Cl. Propriété littéraire et artistique, Fasc. 1265, 22. pont.
} 
vonatkozik. A nem megjelent müvekről példálózó felsorolást is tartalmaz, kifejezetten a felsőoktatási szférában előforduló müvekre fókuszálva: így ide tartoznak a doktori disszertációk, a szakdolgozatok és a „szürke irodalomba” tartozó egyéb dokumentumok. ${ }^{473}$ Vagyis gyakorlatilag a CFC is a kiadó általi kiadást tekinti az átszállást keletkeztető ténynek.

A jogirodalomban fellelhető más álláspont is ehhez a szükebb meghatározáshoz csatlakozik. Ez ugyanis úgy foglal állást, hogy a megjelenést a köznapi értelmében kell használni, ami a könyvek és sajtótermékek nyilvánossághoz juttatásának közvetett módját jelöli a nyomtatott kiadás útján. ${ }^{474}$

A megjelenés időpontjának pontos meghatározása amiatt is fontos, mivel ezt megelőzően a reprográfiával történő többszörözés joga is a szerzőhöz tartozik, vagyis ő szabadon rendelkezhet vele. A contrario értelmezéssel ez azt is jelenti, hogy szabadon átengedheti - tipikusan a kiadóra. Ez a tény két tekintetben juthat fontos szerephez. Az egyik, hogy a korlátozások esetén ki engedélyezi a kereskedelmi célú felhasználásokat, a törvény ugyanis a szerzőt vagy jogutódját említi. Emellett pedig a jogdíjak felosztásánál juthat fontos szerephez a jog előzetes átengedése: nem mindegy ugyanis, hogy a CFC-ben a szerzőket vagy a kiadókat tömörítő szervezetek képviselik a jogosultak érdekeit. ${ }^{475}$

A kiadás helye viszont közömbös: mind a Franciaországban, mind a külföldön kiadott müvek tekintetében a CFC és a SEAM végzi a jogosítást. Az utóbbi kategória kapcsán ennek lehetőségét a közös jogkezelő szervezetek közötti együttmüködés teremti meg.

\section{B) Az átszállás korlátai}

A többszörözési jog azonban csak bizonyos korlátokkal száll át a közös jogkezelő szervezetre, vagyis egyes esetekben a szervezet engedélyezési joga nem teljes.

\footnotetext{
${ }^{473}$ CFC szerződés 3.1. pont.

474 BÉCOURT (1995a) p. 59. 40. bekezdés.

${ }^{475}$ VERCKEN (2005) p. 52.
} 
A CPI két ilyen esetet nevesít, mindkettőt az ún. kereskedelmi célú felhasználások körében. A törvényi rendelkezés értelmében ugyanis egyrészt a szerzők és jogutódaik számára fenn van tartva az a jog, hogy jóváhagyják a közös jogkezelő által kötött olyan szerződéseket, amelyek a többszörözést adásvétel, bérlet, hirdetés vagy reklámozás céljából engedélyezik. ${ }^{476}$ Ezen kívül a szerzőt és jogutódját megilleti az a jog is, hogy többszörözzék a müvet szintén adásvétel, bérlet, hirdetés vagy reklámozás céljából. ${ }^{477}$

A rendelkezés indokoltságát érthető módon alapvetően az adja, hogy a többszörözött példányok kereskedelmi hasznosítása ne jelentsen konkurenciát a művek elsődleges felhasználásával szemben. Ugyanis míg az oktatási intézmények keretében történő felhasználások az intézménynek plusz bevételt nem jelentenek, az így keletkezett másolatok az oktatási tevékenységet egészítik ki, addig a kereskedelmi célú felhasználások már közvetlenül hátrányosak lehetnek a jogosultak számára. A jogalkotó éppen ezért építette be egyfajta fékként a rendszerbe a jogosult külön engedélyezési jogát az ilyen felhasználások esetén.

Mint látható, a két rendelkezés eltérően lett megfogalmazva a CPI-ben. A joggyakorlatban és a jogirodalomban is felvetődött a cikk értelmezése kapcsán az a kérdés, hogy ezek a rendelkezések (azaz leginkább az első helyen említett külön jóváhagyáshoz kötött engedélyekről szóló fordulat) csak a jog gyakorlása elé állítanak-e korlátot, vagy maga a jog sem száll át a közös jogkezelő szervezetre. ${ }^{478}$

A jogirodalomban olvasható egyik tábor ${ }^{479}$ szerint a törvényt úgy kell értelmezni, hogy az a szerző és a közös jogkezelő szervezet közös engedélyezését írja elő. Ugyan a közös jogkezelő szervezet az, amelyik a szerződést megköti a felhasználóval, de ehhez a szerző külön jóváhagyása is szükséges. Ez azonban nem jelentheti a közös jogkezelő szervezet megkerülését. Más szóval nem lehet közvetlenül

\footnotetext{
${ }^{476}$ CPI L. 122-10. cikk (1) bek. „Les sociétés agréées peuvent seules conclure toute convention avec les utilisateurs aux fins de gestion du droit ainsi cédé, sous réserve, pour les stipulations autorisant les copies aux fins de vente, de location, de publicité ou dre promotion, de l'accord de l'auteur ou de ses ayants droits."

${ }^{477}$ CPI L. 122-10. cikk (3) bek. „Les dispositions du premier alinéa ne font pas obstacle au droit de l'auteur ou de ses ayants droit de réaliser des copies aux fins de vente, de location, de publicité ou de promotion."

${ }^{478}$ Ez utóbbi állásponthoz lásd például: BOIRON (2004) p. 18-22.

479 LUCAS, André: Droit de la reproduction par reprographie (CPI, art. L.122-10 à L.122-12) J.Cl. Propriété littéraire et artistique, Fasc. 1265. 35. pont, BOIRON (2004) p. 21.
} 
a szerzőtől engedélyt kérni a felhasználásra. Éppen emiatt a jóváhagyást nem a felhasználónak kell külön beszereznie, hanem a közös jogkezelő szervezetnek. A kötelező közös jogkezelés bevezetése ugyanis éppen azt eredményezi, hogy az egyéni engedélyezés lehetősége ki van zárva. ${ }^{480}$

Az elmélet pártolói szerint voltaképpen a reprográfiával történő többszörözés joga három különböző engedélyezési rezsimnek lehet alávetve a felhasználás típusától függően. Egyrészt szó lehet egyéni felhasználásokról, amelyek a jogosult egyedi engedélyezését feltételezik (ezek adott esetben minősülhetnek szerzői jogi kivételnek is); a nem kereskedelmi jellegű, de közös célú ${ }^{481}$ felhasználások, amelyek tisztán közös jogkezelés alá tartoznak (az oktatási intézményekben megvalósult felhasználások); illetve a kereskedelmi és közös célú felhasználások, amelyeket bár szintén közös jogkezelés alá vont a jogalkotó, de a szerző külön jóváhagyásához kötöttek. ${ }^{482}$

$\mathrm{Az}$ ezzel ellentétes vélemények ${ }^{483}$ szerint viszont a kereskedelmi célú reprográfiával történő engedélyezés nem is képezi részét a közös jogkezelő szervezetre átszálló jogoknak. Ez azt eredményezi, hogy a felhasználóknak ezekben az esetekben a szerzőktől egyedi engedélyt kell kérniük, közvetlenül a szerzőtől, vagy annak jogutódjától. Mivel a reprográfiával való többszörözés jogának gyakorlását a kiadói szerződésben a szerző általában átruházta a kiadóra, éppen ezért ez azt jelenti, hogy a kiadótól kell a felhasználási engedélyt megszerezni. Ez számukra sokkal előnyösebb megoldás, mivel egyrészt a felhasználási feltételeket maguk határozhatják meg, nem pedig a közös jogkezelő szervezeten keresztül. Másrészt pedig az engedély fejében járó jogdíjat sem a felosztási szabályzat alapján kell a szerzővel megosztaniuk, hanem a kiadói szerződésben megkötött feltételek szerint. Nem ok nélküli tehát a kiadóknak az törekvése, hogy a rendelkezés értelmét ebbe a második irányba tolják el.

A felhasználók szempontjából viszont ez mindenképpen kedvezőtlenebb helyzet a közös jogkezelő általi joggyakorláshoz képest, mivel a tervezett felhasználás függvényében kell az engedélyért vagy a közös jogkezelő szervezethez, vagy pedig a

\footnotetext{
${ }^{480}$ DIRINGER (2011) p. 304.

481 A cél kiemelése a magáncélú másolattól való elhatárolás miatt szükséges. A több személy közös müélvezetét szolgáló, közös célra megvalósított többszörözések ugyanis nem tartoznak a magáncélú másolat kivételének hatálya alá. Erről lásd részletesen a II. rész II. fejezetét.

${ }^{482}$ LUCAS, André: Droit de la reproduction par reprographie (CPI, art. L.122-10 à L.122-12) J.Cl. Propriété littéraire et artistique, Fasc. 1265 36. pont.

${ }^{483}$ CARON (2013a) p. 245. VERCKEN (2005) p. 50-51.
} 
jogosulthoz fordulniuk. Illetve nincs meg az az elönyük sem, hogy a közös jogkezelö szervezet repertoárjába tartozó valamennyi müvet használhassák - ami a törvényi átszállás értelmében valamennyi kiadott mü, legyen az francia vagy külföldi. Vagyis elveszni látszik az az előny, amit a közös jogkezelés biztosítani tud, nevezetesen az egyszerübb jogosítás.

Ez a második felfogás tehát nem tesz különbséget a közös jogkezelésen belül olyan esetek között, amelyhez a jogosult külön hozzájárulása kellene. Az általános többszörözési jogból kihasított reprográfiai többszörözéshez való jogot tovább aprózva a kereskedelmi célú felhasználásokat kiveszi a közös jogkezelés hatálya alól. Ez azt is előrevetíti ugyanakkor, hogy mivel a jogosult egyéni engedélyezése a főszabály, ezért azokat az eseteket, amire a közös jogkezelés kiterjedhet, szüken kell értelmezni.

A jogirodalomban felvetődött kérdésre a bírói gyakorlat részletes választ adott. A CFC ugyanis eleinte az elsőként bemutatott álláspontot képviselte és rendszeresen kötött kereskedelmi célú felhasználási szerződéseket is. A kiadók viszont igyekeztek érvényt szerezni az ő érdekeikhez közelebb álló értelmezésnek, ezért rendre bíróság elé vitték az ilyen felhasználási szerződések alapján megvalósult felhasználásokat.

Már egy 2004-es ítéletben ${ }^{484}$ megállapításra került, hogy a kereskedelmi hasznosítás engedélyezésének joga a kiadóktól nem szállt át a CFC-re. A Prisma Presse nevü kiadó gondozásában jelent meg két olyan magazin is, amely egyébként megtalálható a CCIP honlapján található adatbázisban. A felhasználók a kiválasztott cikkekről teljes terjedelmü másolatot kérhettek egy meghatározott összeg fizetése ellenében. Mikor azonban a Prisma Presse belépett a CFC-be, kikötötte, hogy a közös jogkezeléssel csak a nem kereskedelmi célú reprográfiai többszörözések érintettek. Emiatt az első- és másodfokú bíróság is elmarasztalta a CCIP-t. Mivel a CCIP és a CFC úgy érvelt, hogy a másolatok elkészítése a dokumentációs szolgáltatáshoz képest csak kiegészítő, járulékos szolgáltatás volt, ezért azt nem is lehet a CPI szerinti kereskedelmi cél fogalma alá vonni. ${ }^{485}$

${ }^{484}$ CA Paris 24 mars 2004.

485 Azt mellékesen érdemes megjegyezni, hogy a bíróság nem foglalkozott annak kérdésével, hogy egyáltalán lehet-e Prisma Presse-t a szerzői jogok jogosultjának tekinteni. Egy nem kellően meggyőző érveléssel „œevre collective”-nek minősítette a magazinokat annak érdekében, hogy közvetlenül a kiadót lehessen jogosultnak tekinteni. Erről lásd részletesen: BOIRON, Patrick: i.m.,. p. 20-22. 
II. rész A törvény által előírt közös jogkezelés, mint a kizárólagos jog korlátja

I. fejezet A jog gyakorlásának korlátozása a közös jogkezelés elöírásával

Egy újabb ügy ${ }^{486}$ tényállása szerint David Forest ügyvéd eljárást indított az Inist Diffusion nevü cég ellen, mivel az az interneten az ő engedélye nélkül tette közzé több cikkét is. Az Inist Diffusion beavatkozóként perbe hívta a CFC-t is, mivel a közös jogkezelőtől engedélyt kapott a cikkek reprográfia útján történő többszörözésre. Az Inist Diffusion szerződést kötött a Chapitre.com nevü céggel, amely így az interneten darabonként 19,50 euró áron árulta a kérdéses cikkeket, az Inist pedig 13,87 eurós egységáron.

Az ügyben az nem merült fel kérdésként, hogy a kérdéses tevékenység kereskedelmi célú felhasználásnak minősül-e, mivel ezt egyik fél sem kérdőjelezte meg. A TGI a kérdéses cikk célját úgy foglalta össze, hogy ebben a jogalkotó meg akarta különböztetni az ingyenes fénymásolást a visszterhestöl. Az ügyben tehát a cikkek adásvételéről volt szó, mivel a többszörözés nem valamilyen másik tevékenység kiegészítő felhasználásaként szolgált, és a társaság egységáron tette ezeket elérhetővé a felhasználó számára. ${ }^{487}$

Más álláspont szerint viszont a jog eleve nem kerül át a közös jogkezelő szervezethez, mivel a szerző egyedül dönthet a kereskedelmi célú felhasználások engedélyezéséről. Mind a TGI, mind pedig a másodfokon eljáró Cour d'appel de Paris ezt az álláspontot erősítette meg. A Cour d'appel egyenesen úgy fogalmazott, hogy a CPI L.122-10. cikke, „,amely a reprográfia útján történő többszörözés jogának törvényi átszállásáról rendelkezik egy közös jogkezelö társaság javára és lerontja a szerzö engedélyezésének föszabályát szoros értelmezést követel."488 Majd tovább folytatta annak kiemelésével, hogy a fent említett jog nem tartozik a törvényi átszállás körébe. ${ }^{489}$

A másodfokú ítélet megsemmisítése érdekében a CFC és az Inist Diffusion a Semmítőszékhez fordult. Beadványukban továbbra is amellett érveltek, hogy a reprográfiai többszörözéshez való jog a maga teljességében szállt át, és emiatt a jogosult

\footnotetext{
${ }^{486}$ Az elsőfokú bíróság ítéletét lásd: TGI Paris 3e ch, 2e sect., 9 juillet 2010. A másodfokú ítélet: CA Paris 2e ch 27 mai 2011. A Semmítőszék döntése: C.cass. civ. 1re, 11 décembre 2013.

487 A fenti logika nyomán az ítélet egyik kommentátora azt is felvetette, hogy az egyetemek és könyvtárak, amelyek dokumentációs szolgáltatást nyújtanak és a fénymásolatok előállításának költségének fedezésére szednek be díjat a felhasználóktól, nem minősül kereskedelmi tevékenységnek, és ily módon nem kell hozzá a jogosult külön engedélye. Lásd: SPITZ (2010) p. 20.

${ }^{488}$ „Qu'en effet, cet article L 122-10 qui organise une cession légale du droit de reproduction par reprographie au bénéfice d'une société collective et déroge au principe de l'autorisation de l'auteur requiert une stricte interprétation".

${ }^{489}$, ,...) le droit de reproduction commerciale par reprographie est exclu du périmètre de la cession légale".
} 
engedélyét nem is kellett volna kérni a kérdéses cselekményhez. Ez egyben ahhoz is vezetett volna, hogy a jogosult jóváhagyása nem kötött alakszerüséghez, ezért a felhasználás jogszerü volt. Mivel a joggal nem a szerző rendelkezik, ezért nem is indíthat szerzői jogok megsértése miatt eljárást az Inist Diffusion ellen. A jóváhagyás kérésének elmulasztása miatt egyedül a CFC-vel szemben léphetne fel.

A Semmítőszék azonban megerősítette, hogy a másodfokú bíróság a törvényi rendelkezés pontos alkalmazásával döntött az ügyben, vagyis az Inist Diffusion a kérdéses cikkek többszörözésével és eladásra kínálásával megsértette David Forest vagyoni jogát.

Több kommentátor véleménye szerint a Semmítőszék által megerősített álláspont a helyes, ${ }^{490}$ vagyis a jog egyáltalán nem szállt át a közös jogkezelő szervezetre. Ez egyben azt is jelenti, hogy a CFC nem köthet erre irányuló szerződéseket - kivéve persze, ha a jogosult a jogot önkéntes közös jogkezelésbe adta, ami a fenti indokok miatt nem tünik életszerünek.

A korábban megkötött szerződések kapcsán viszont ez a megoldás problémás: azok a felhasználók ugyanis, akiknek a CFC korábbi gyakorlata alapján adott engedélyt, tarthatnak attól, hogy a jogosult (tipikusan a kiadó) szerzői jogok megsértése miatt fellép ellenük. (A jogirodalom azt is felveti, hogy ezek a felhasználók a CFC-től követelhetnék a megfizetett jogdíj visszatérítését azon az alapon, hogy a szervezet nem volt jogosult az engedélyek kiadására. ${ }^{491}$ )

A második kivétel kapcsán bírói gyakorlat egyelőre nem ismert. Nem is valószínü, hogy ezzel kapcsolatos eset felmerül a bíróságok elött, mivel itt nincs olyan harmadik fél (mint az előző fordulat esetében a kiadó), akinek jogi érdeke füződne az esetleg jogosulatlan felhasználások miatti fellépésre.

A rendelkezés indokoltsága vitathatatlanul abban áll, hogy a jogosult maga is készíthessen másolatokat, és azokat felhasználhassa. Mivel ezek a felhasználások, még ha kereskedelmi célból kerül is rájuk sor, nem állítanak konkurenciát az elsődleges

\footnotetext{
${ }^{490}$ POLlAUd-Dulian (2014) p. 115. CASTETS-RENARD (2014) e-verzió.

${ }^{491}$ VERCKEN (2005) p. 51.
} 
müvel szemben. Vagy ha mégis, ez a jogosult elhatározásán alapul, az ő mérlegelésének következménye, illetve az általa meghatározott feltételek szerint valósul meg.

Érdekes azonban a bekezdés megfogalmazásában, hogy a másolatok tényleges elkészítésére vonatkozik. Az engedélykérésre nem utal a törvényszöveg, amiböl arra is lehet következtetni, pláne elfogadva az átszállás egységességének elvét, hogy ezeket a felhasználásokat is engedélyeztetni kellene a közös jogkezelővel.

Ez az értelmezés azonban nem férne össze a szabály rendeltetésével, illetve életszerütlen is lenne, hogy a szerző a saját müvének reprográfiai úton való többszörözéséhez engedélyt kérjen a CFC-töl. Ráadásul a bírói gyakorlat alapján a más általi kereskedelmi felhasználás sem kötött a CFC engedélyéhez.

\section{B) A joggyakorlás módja}

A joggyakorlás módjával kapcsolatos kérdések tárgyalásánál az engedélyezési jog gyakorlásának kérdésére kell külön kitérni, hiszen eltérések mutatkozhatnak a vezetékes továbbközvetítési joghoz képest [a) pont]. Ezt követően pedig a jogdíjak beszedése és felosztása is figyelmet érdemel, mivel a francia közös jogkezelő szervezetek különös figyelmet fordítanak ezek felhasználással arányos kezelésére [b) pont]. Mindkét esetben a mechanikai jogot és a reprográfiai többszörözés jogát elkülönülten elemezzük. Erre az eltérő nemzeti jog alkalmazásán túl a jog és a felhasználás eltérő jellemzői miatt is szükség van.

a) Az engedélyezési jog gyakorlása

Az engedélyezési jog gyakorlását szintén a két jog külön-külön történő elemzésével mutatjuk be.

a) A mechanikai jog

A mechanikai jogok körébe, mint láttuk, a többszörözés és a terjesztés tartozik. Mivel azonban két külön vagyoni jog gyakorlásáról van szó, az engedélyezés általában egy közös szerződéssel, de mindkét jog említésével valósul meg. Kiegészítő szabályként hivatkozni kell az Szjt. 47. § (4) bekezdésére is, amely arról rendelkezik, hogy kétség esetén a többszörözésre vonatkozó engedély kiterjed a többszörözött müpéldányok terjesztésére is. Az ARTISJUS jogdíjközleménye egyébként a fentiekkel 
összhangban azt tartalmazza, hogy a felhasználó a terjesztésre akkor szerez engedélyt, ha az egyes felhasználási módokkal kapcsolatban a jogdíjközlemény a terjesztésre vagy kiadásra való utalást tartalmaz. ${ }^{492}$ Az engedélyt a jogdíj megfizetésével szerzi meg a felhasználó. ${ }^{493}$

Azzal kapcsolatban, hogy mely hordozóra történik a többszörözés, szintén külön szerződéses kikötést kell beiktatatni, ugyanis a többszörözésre adott engedély csak kifejezett kikötés esetén ad a felhasználónak jogot arra, hogy a müvet kép- vagy hangfelvételen rögzítse, illetve hogy azt számítógéppel vagy elektronikus adathordozóra másolja. ${ }^{494}$ A jogdíj mértékének meghatározását a jogdíjközlemény hordozónkénti bontásban, részletesen tartalmazza.

Az engedélyezés gyakorlására egyébként két mód terjedt el. Az egyik, az ARTISJUS által is főszabályként alkalmazott megoldás szerint a jogokat elöre, hangfelvételenként és meghatározott példányszámban történő többszörözésre kell megszerezni. ${ }^{495}$ A jogdíjközlemény azt is kifejezetten rögzíti, hogy a jogdíjminimumot abban az esetben is meg kell fizetni, ha a többszörözött példányok terjesztése ingyenesen történik. ${ }^{496}$

A másik lehetséges mód az ún. BIEM-IFPI típusú megállapodás, amely az utólagos elszámolást teszi lehetővé negyedévenként, speciális, szigorú feltételek mellett. Az ARTISJUS ezt olyan felhasználóval szemben adja meg, amelynek jogdíjtartozása nincs; a felhasználó huzamosabb ideje jogszerü hangfelvétel- illetve filmkiadói gyakorlatot folytat; folyamatosan nagy számú hangfelvételt, illetve filmet tartalmazó kiadványt hoz forgalomba; a felhasználási szerződésben meghatározott mértékü, a jogdíj megfizetését biztosító óvadékot nyújt; és az ilyen típusú felhasználási szerződés megkötését a felhasználás sajátos körülményei vagy a felhasználás és ennek folytán a felhasználó által fizetendő jogdíj jelentős mértéke lehetővé és indokolttá teszi. ${ }^{497}$

\footnotetext{
${ }^{492}$ Az ARTISJUS Magyar Szerzői Jogvédő Iroda Egyesület közleménye a hangfelvételen többszörözött, illetve $\square$ lmalkotásokba foglalt, videón vagy DVD-n többszörözött zenemúvekre megállapított mechanikai jogdíjakról (M15) (A továbbiakban: M15 jogdíjközlemény), II.4.2. pont.

${ }^{493}$ M15 jogdíjközlemény, II.4.1. pont.

${ }^{494}$ Szjt. 47. § (2) bek.

${ }^{495}$ M15 jogdíjközlemény

${ }^{496}$ M15 jogdíjközlemény, II.1. pont.

${ }^{497}$ M15 jogdíjközlemény, II.8.1. pont.
} 
Az engedélyezési jog gyakorlásánál külön ki kell térni a szerzői kiadás jogintézményére is, amely lényegében lehetővé teszi a „kilépést” a jogosult számára a mechanikai többszörözés keretében annak ellenére, hogy alapvetően kilépést nem engedő, kötelező közös jogkezelésről van szó. Az idézőjel használata azért indokolt, mert ebben az esetben nem olyan kilépési jogról esik szó, mint amilyet a III. rész I. fejezetében tárgyalunk majd, a törvény ugyanis nem úgy fogalmaz, hogy a jogosult kiléphet a közös jogkezelés alól. A lehetőséget a szerzői kiadás intézménye teremti meg a számára, amely saját felhasználás, azaz a szerző és a felhasználó szerzői jogi értelemben vett összeolvadása, konfúziója. Amennyiben ugyanis úgy dönt, hogy saját maga, hangfelvétel-elöállító közremüködése nélkül kívánja a müveit többszörözni, és a többszörözött példányokat terjeszteni, nem kell a felhasználáshoz előzetesen engedélyt kérnie, sem jogdíjat fizetnie. ${ }^{498}$ Erre lehetőséget az Szjt. vagyoni jogokra vonatkozó általános rendelkezése biztosít, amely elsősorban a szerző számára garantálja a felhasználást. ${ }^{499}$ Vagyis előrebocsátva az összehasonlítással leszűrhető konklúziót, a szerzői kiadás esetében a szerző maga használja fel a müvét, ezzel egyúttal harmadik személyeket gyakorlatilag kizár a felhasználásból (az adott mű adott hordozóra adott példányszámban történő többszörözése egyszeri cselekmény, így erre párhuzamos, nem kizárólagos felhasználási engedély nem szerezhető). Ezzel szemben a kilépést biztosító többi közös jogkezelési eset kapcsán a kilépéssel a szerző a felhasználás engedélyezésének a jogát gyakorolja egyedileg. A közös jogkezelés kötelező jellegét támasztja alá a Fővárosi Ítélőtábla egy döntése is, amely kimondja, hogy a már nyilvánosságra hozott zenemü ismételt többszörözése esetén nincs lehetőség egyedi szerződéskötésre a hangfelvételt-elöállító és a szerző között, mert a többszörözés jogával kapcsolatos, ún. zenei mechanikai jogok esetében a felhasználáshoz az engedélyt a közös jogkezelő szervezet, az ARTISJUS adja meg és a közös jogkezelő szervezet gondoskodik a szerzőket megillető díjak kifizetéséről is. Az Szjt. 19. §-a a szerzői jogosultak, így az adott ügy felperese is csakis a közös jogkezelő szervezeten keresztül teljesíthető szerződéskötési kötelezettségét írja elő, ha a mü egyszer már nyilvánosságra került és azt bármely felhasználó többszörözni kívánná. Ilyen

\footnotetext{
${ }^{498}$ Ez nyilvánvalóan egyben azt is jelenti, hogy a befolyt jogdíjakból sem részesedik a szerző.

${ }^{499}$ Szjt. 16. § (1) bek. 1. fordulat: „A szerzői jogi védelem alapján a szerzőnek kizárólagos joga van a mü egészének vagy valamely azonositható részének anyagi formában és nem anyagi formában történö bármilyen felhasználására és minden egyes felhasználás engedélyezésére."
} 
kényszerengedély esetén tehát jogdíjat a kiadó közvetlenül nem fizet, azt a szerző az ARTISJUS-on keresztül kapja meg. ${ }^{500}$

A szerzői kiadásról egyébként a szerző bejelentési kötelezettséggel tartozik. ${ }^{501}$ Erre alapvetően a szerző érdekében kerül sor, ugyanis a szerző által bejelentett példányszámban ezeket a hangfelvételeket is ellátják a jogosítás meglétét igazoló hologramos címkével. Másodsorban pedig ez a bejelentett példányszám szolgál az üreshordozó díj felosztásához. ${ }^{502}$

B) A reprográfiai többszörözés

A francia törvény szövege egyértelművé teszi, hogy engedélyezési jog gyakorlásáról van szó, ugyanis úgy fogalmaz, hogy a szerződéseket a közös jogkezelő szervezet köti meg a felhasználókkal. Ez egyrészt jelenti a jogdíj mértékének és a felhasználás egyéb feltételeinek a meghatározását, másrészt pedig azt is, hogy felléphet a jog érvényesítése érdekében.

A reprográfiai (jog)díjak mértékének meghatározására általában négy lehetséges metódust szoktak megkülönböztetni. Alapját képezheti a többszörözésre használt eszköz (ez az ún. készülék díj); az egy évben készített másolatok számával arányosan megállapított ún. üzemeltetői díj; az iskolák tanulóinak vagy a cégek alkalmazottainak száma; illetve a fenti három módszer valamely kombinációja. ${ }^{503}$ Franciaország alapvetően a harmadik opciót követi, míg Magyarország a készülékek utáni díjkivetést alkalmazza. ${ }^{504}$

A CFC által a honlapon elérhetővé tett formaszerződések elemzéséből több dolog is kitűnik. Egyfelől az engedélyek nem teszik lehetővé a felhasználó számára teljes könyv vagy folyóirat lemásolását: könyv esetén a másolás általában annak 10\%ára, folyóirat esetében pedig 20\%-ára korlátozódik. A szerződés mellékletében található listán szereplő művekre pedig az engedély egyáltalán nem terjed ki.

\footnotetext{
${ }^{500}$ Fővárosi Ítélőtábla 8.Pf.21.470/2011/4.

501 Az Szjt. 16. § (7) bekezdése is elöírja, hogy a törvény eltérő rendelkezése hiányában a felhasználó köteles a szerzőt vagy jogutódját, illetve a közös jogkezelő szervezetet a felhasználás módjáról és mértékéröl tájékoztatni.

${ }^{502}$ GYERTYÁNFY (2014) p. 168. Az üres hordozó díjak felosztásáról lásd részletesen a II. rész II. fejezetét. 503 GUIBAULT (2003).

${ }^{504}$ A magyar díjrendszert lásd részletesen a II. rész II. fejezetében.
} 
A szerző személyhez füződő jogainak védelme érdekében a szerződések kifejezetten rendelkeznek arról, hogy a másolt münek az eredeti mü bibliográfiai adatait fel kell tüntetnie. A személyhez füződő jogok sérelme miatt a jogosult kérésére egyébként a CFC meg is tilthatja bizonyos mủvek többszörözését. ${ }^{505}$

A felhasználónak ezen kívül fel kell tüntetnie a másolaton vagy az ahhoz csatolt dokumentumon, hogy az a CFC engedélyével készült, és az eredeti mü nem többszörözhető a CFC engedélye nélkül.

A jogdíj meghatározása bizonyos esetekben történhet átalánydíjként is. Ebből $a$ contrario értelmezéssel következik az, hogy egyéb esetekben a jogdíj mértékének meghatározásakor érvényes törvényi rendelkezést kell figyelembe venni: vagyis a felhasználás mértékéhez kell elsősorban igazodnia. ${ }^{506} \mathrm{Az}$ átalánydíjat azokban az esetekben lehet megszabni a reprográfiával történő többszörözés esetében, amennyiben (1) az arányos díjazás számításának alapjának meghatározása gyakorlati nehézségekbe ütközik; (2) a díjazás arányosságának ellenőrzése nem kivitelezhető; (3) a kiszámítás módja és ellenőrzése meghaladná az arányos díjazás alkalmazásával elérhető összeget.

Minden egyes felhasználást azok azonosíthatósága végett be kell jelenteni a közös jogkezelő szervezetnek. Ez a gyakorlatban egy táblázat kitöltését jelenti, az egyetemekkel kötött szerződések esetén az oktatótól, amelyben a fénymásolt mü pontos bibliográfiai adatai szerepelnek annak megjelölésével, hogy hány oldal került fénymásolásra műből és azt hány egyetemi hallgató számára készítették.

\section{b) A jogdijak beszedése és felosztása}

2013-ban több, mint 31 millió euróról kellett a CFC-nek rendelkeznie. Ebből a kezelési költségek (az összeg 8,08\%-a) levonása után a könyvszektorban érdekeltek között felosztott összeg majdnem 22 millió eurót tett ki. ${ }^{507}$ A fennmaradó, nagyjából 6 millió euróra rúgó összeg a sajtótermékek jogosultjait illeti meg. ${ }^{508}$

\footnotetext{
${ }^{505}$ CFC Szerződés, 3.2. pont.

506 A felhasználás mértékéhez igazodó arányos, illetve az átalánydíj jellegű árképzérsől lásd részletesen: ALLAYAEYS (2007) p. 269-278.

507 Répartition des redevances auteurs $\quad-\quad$ éditeurs: Livres. $2013 . \quad$ p. 1. http://www.cfcopies.com/images/stories/pdf/Auteurs-Editeurd/Photocopie/Notice-repartition-Livre.pdf 508 Répartition des redevances auteurs - éditeurs: Presse. 2013. p. 1. http://www.cfcopies.com/images/stories/pdf/Auteurs-Editeurd/Photocopie/Notice-repartition-Presse.pdf
} 
A törvény a jogdíjak felosztására vonatkozóan nem tartalmaz semmilyen elvet, azt a közös jogkezelő szervezetek maguk alakítják ki. ${ }^{509}$ A jogdíj meghatározásakor a közös jogkezelő szervezet igyekszik minél széleskörübben érvényesíteni a reprográfia sajátos jellemzőiből adódó különbségeket. Ennek megfelelően egyenlő arányban képviseltetik magukat a szerzők és szerzők érdekeit képviselő szervezetet, valamint a könyvkiadók és sajtóterméket kiadók a CFC igazgatóságába. Ezután kerülnek felállításra azok a bizottságok, amelyek a felosztási szabályzatra is javaslatot tesznek.

A kiadvány (könyv vagy sajtótermék) fajtája, többek között illusztráltságának mértéke és ára a jogdíjak meghatározásában jelentős szerepet játszik. A felosztási szabályzatban meghatározott kategóriák szerint a jogdíjakat a szöveges és az illusztrált részek szerint külön osztják meg a szerzők és a kiadók között, eltérő kulcsok alapján. A felosztási szabályzat a széles olvasóközönséggel bíró, nagy példányszámú művek esetében (pl. az általános irodalomként meghatározott kategória) egyenlő arányú felosztásról rendelkezik. A kockázatosabb, a kiadó részéről nagyobb anyagi ráfordítási igénylö, szükebb körü olvasóközönséghez eljutó mủvek esetében pedig ez az egyensúly a kiadó javára billen el (pl. iskolai könyvekben a befolyt jogdíjak 70\%-át kapja a kiadó, 500 darabnál kevesebb példányszámú természettudományos vagy orvosi könyvek esetében pedig már 90\%-ot). ${ }^{510}$ Ezek az arányok egyben tükrözik a másolás gyakoriságát az egyes kategóriákon belül: míg a szépirodalomnál ez relatíve ritka, addig a szakirodalom esetében jóval elterjedtebb. Azoknak a könyveknek az esetében, amelyeket a kiadó már nem forgalmaz, a felosztás aránya szintén egyenlő a szerző és a kiadó között.

Mivel egyedileg azonosítható módon történik a felhasználások monitorozása és feldolgozása, ezért a másolt oldalak összesített számának meghatározását követően a kezelési költségekkel csökkentett összegek kerülnek felosztásra. A mérhető felhasználásokhoz igazodó jogdíjmérték a kizárólagos jogok esetében alapvető fontosságú, de az $\mathrm{EuB}$ joggyakorlata alapján az átalánydíjaknak is a tényleges felhasználásokhoz kell igazodniuk. Az EuB ezért az InfoSoc-irányelv 5. cikk (2) bek. a) pontjával ellentétben állónak találta olyan tagállami rendszerek létezését, amelyben a díj

\footnotetext{
${ }^{509}$ CPI L. 122-12.

510 Tájékoztató, p. 20.
} 
összegét kizárólag azon sebesség függvényében határozzák meg, amellyel a készülék müszaki értelemben a többszörözés elvégzésére képes. ${ }^{511}$

A könyvekben szereplő képek arányának megállapításához reprezentatív mintának elemzésével határoztak meg értékeket. Egyes kategóriák esetében viszont ezt az arányt könyvenként felül kell vizsgálni, amennyiben a jogdíj mértéke a 300 eurót meghaladja.

Könyvek esetében a jogdíjat a kiadónak utalja a CFC, ${ }^{512}$ amely azt folyósítja a szerzőnek. A szöveges mü tekintetében azt tekintik szerzőnek, akivel a kiadó szerződéses kapcsolatban áll. A képek szerzője tekintetében többféle változat áll fenn, attól függően, hogy az illusztrációt kifejezetten a kiadó rendelte-e meg, vagy már eleve létező művet használtak erre a célra, vagy pedig egyik kategóriába sem illik bele az eset. Ez utóbbi két kategória fennállása esetén a szerzőket képviselő közös jogkezelő társaságok kapják meg a jogdíjat és fizetik ki a jogosultak részére. Amennyiben a kiadó jogutód nélkül megszünt, a jogdíj teljes összegét közvetlenül a szerzőnek utalja a CFC. A CFC-nek egyébként joga van ellenőrizni, hogy a kiadók kifizették-e a szerzőknek a nekik járó összeget, szükség esetén ezt bírósági úton is érvényesítheti.

A sajtótermékek esetében is ezek az elvek alkalmazandók - azzal a fontos különbséggel, hogy a képek gyakoribb használata miatt a befolyt jogdíjakat nem egyenlő arányban osztják meg a képek és a szöveg szerzői (illetve a kiadó) között.

Egyes esetekben a másolt mű nem azonosítható be pontosan: ezt a fénymásolóüzletekben és az egyes könyvtárakban végzett másolatok jelentik. Ezen kívül azok az összegek is idetartoznak, amelyeket a CFC-vel együttmüködésben álló külföldi közös jogkezelő szervezetek azonosítás nélkül küldenek.

Ezek az összegek egyenlő arányban, de eltérő módszer alapján kerülnek felosztásra a szerzők és a kiadók között. Előbbiek közvetlenül a CFC-től nem kapnak ezen a jogcímen semmit, ugyanis a nem azonosítható jogdíjakat a szerzőket képviselő közös jogkezelő szervezetnek kerülnek átutalásra. Ezek aztán saját szervezeti és

${ }^{511}$ A C-572/13. sz. Reprobel-ügyben 2015. november 12-én hozott ítélet 77. pontja.

${ }^{512}$ A közös jogkezelő szervezet a kiadónak fizet, mert a kiadói szerződésben többszörözés jogát a szerző a kiadóra ruházza. Viszont a kiadó és a szerző közötti szerződést felülírja a felosztási szabályzat. akármi is van a szerződésekben. ehhez lásd: VERCKEN (2005) p. 52-53. 
II. rész A törvény által előírt közös jogkezelés, mint a kizárólagos jog korlátja

I. fejezet A jog gyakorlásának korlátozása a közös jogkezelés elöírásával

müködési szabályzatuk és felosztási szabályzatuk szerint intézkedik a jogdíjak kifizetéséről. $^{513}$

A könyvkiadók kollégiumának döntése értelmében pedig a ténylegesen azonosítható jogdíjak arányában kerülnek felosztásra a nem beazonosítható jogdíjak, amennyiben azok összege meghaladja a 150 eurót.

${ }^{513}$ LUCAS, André: Droit de la reproduction par reprographie (CPI, art. L.122-10 à L.122-12) J.Cl. Propriété littéraire et artistique, Fasc. 1265 32. pont. 


\section{II. fejezet A kizárólagos jog díjigényre korlátozása révén bevezetett közös jogkezelés}

Több okra is visszavezethető (legalábbis jórészt angolszász copyright nézőpontból) ${ }^{514}$ a kizárólagos jogok díjigénnyé való leszorításának elvetése. Ebből a szempontból hasonló a kontinentális szerzői jogi rezsimhez, vagyis a díjigények a kizárólagos joghoz képest másodlagosak, és ezek alátámasztására hasonló érveket szokás felhozni. A szakirodalom egyrészt érvként hozza fel ezeknek a merevségét: a jogalkotó által meghatározott díjak és feltételek nehézkesen, lassan változtathatók, nem követik megfelelően a technológiai változásokat, ${ }^{515}$ ráadásul gazdasági szempontból nem elenyésző mértékü tranzakciós költségeket is generálnak. ${ }^{516}$ Ezen kívül a méltányos díjazás fogalma kapcsolódik a szellemi tulajdonvédelem körében rosszul csengő kényszerengedély fogalmához. ${ }^{517}$ Vagyis a jogosultat így nemcsak attól a jogától fosztják meg, hogy a felhasználás feltételeit megszabja, hanem attól is, hogy meghatározza, kinek akar felhasználási jogot engedni. ${ }^{518}$

A törvényi engedélyek mindezek ellenére a kontinentális szerzői jog nem elhanyagolható részét képezik, hiszen úgy biztosítanak díjazást a jogosultaknak, hogy közben a felhasználók számára is széles mozgásteret nyújtanak. Az engedélyezési jog megvonása miatt viszont értelemszerüen mind a francia, mind a magyar szerzői jogban kivételes eszközként kerülnek meghatározásra, amelynek az alkalmazását külön garanciákkal kell biztosítani. A törvényi engedélyek és a törvény által elöírt közös jogkezelés között egyébként több összefüggés is felfedezhető. Ez arra vezethető vissza, hogy mindkettő hasonló problémára kíván válasszal szolgálni, ez pedig elsősorban a felhasználások tömegessége. Nem véletlen tehát, hogy a törvényi engedélyhez egyébként közös jogkezelés is kapcsolódik.

\footnotetext{
514 A hivatkozott két tanulmány közül Anette KUR kifejezetten az Egyesült Államokbeli copyright ellenvetéseit sorolja fel. Amerikai szerzői jogászként Jane GINSBURG álláspontja is ezt a felfogást tükrözi. Ez természetesen nem azt jeleni, hogy a kontinentális szerzői jogászok minden kritika nélkül elfogadnák a díjigényekre korlátozott kizárólagos jogot, talán csak álláspontjuk nem annyira sarkos ebben a kérdésben. Ez ugyanis alkalmas arra, hogy megfelelő átmenetet képezzen a teljesen ingyenes felhasználások és a szerző kizárólagos rendelkezési joga alá tartozó felhasználások között.

515 GinsBURG (2009).

${ }^{516}$ KUR, Anette: Of Oceans, Islands and Inland Water - How Much Room for Exceptions and Limitations under the Three Step-Test? Max Planck Institute for Intellectual Property, Competition and Tax Law Research Paper Series No. 08-04, http://papers.ssrn.com/sol3/papers.cfm?abstract_id=1317707, p. 12.

${ }^{517}$ U.o. p. $11-12$.

${ }^{518}$ GINSBURG (2009).
} 
A legeklatánsabb példája ennek a magáncélú többszörözés, amely több országban (így Magyarországon is) magában foglalja mind a reprográfiai többszörözést, mind pedig üres hordozóra történő egyéb többszörözési cselekményeket. Ahogyan láttuk, Franciaországban a jogalkotó a két másolás eltérő kezeléséről döntött, így mielőtt rátérnénk az üres hordozóra történő magáncélú többszörözés kérdéseire (2. pont), az eltérő megközelítési mód indokait vesszük górcső alá (1. pont).

\section{Hasonló probléma, eltérő megoldás}

A két elképzelés, a kizárólagos jog díjigénnyé szorítása, illetve ennek érintetlenül hagyásával a közös jogkezelés elrendelése közötti különbséget kiválóan példázza a reprográfiai többszörözés és a magáncélú másolat közötti különbség. Ez amiatt is különösen érdekes, mivel azon túl, hogy jellegében hasonló a felhasználási cselekmény (mindkét esetben többszörözésről van szó, bár eltérő hordozóra), a felhasználás körülményei is hasonlóak. (Magyarországon például mindkét eset szerzői jogi korlátként került meghatározásra, a díjfizetés sémája is hasonlóságot mutat.) Mindkét esetben a felhasználások tömegessége, az egyedi engedélyezési jog gyakorlásának szinte lehetetlen volta indokolja a kollektív jogkezelést. Ehhez kapcsolódik az is, hogy az 1957. évi francia szerzői jogi törvény nem kínált adekvát megoldást a fénymásolás és magnetofon elterjedésére, vagyis szükségszerü volt az ehhez kötődő reformok bevezetése. ${ }^{519}$ Csak amíg ez az egyik esetben az engedélyezési jog fenntartásával, a másik esetben ennek megszüntetésével jár. Az összefüggések feltárása érdekében először röviden vázoljuk a többszörözési jog korlátozásának szerzői jogi lehetőségeit (§1. pont), majd pedig összefoglaljuk a két megközelítési mód közötti különbségeket (§2. pont).

\section{§1. Eltérö megközelítési módok}

Az eltérő megközelítési mód eltérő jogi szabályozáshoz vezet [B) pont], amely mindenekelőtt a két másolás jellemzőinek különbségéből ered [A) pont].

${ }^{519}$ KEREVER (1974) p. 56-57. 
II. rész A törvény által előírt közös jogkezelés, mint a kizárólagos jog korlátja

II. fejezet A kizárólagos jog díjigényre korlátozása révén bevezetett közös jogkezelés

\section{A) A felhasználás jellemzői}

A magáncélú másolatra (értve ez alatt kifejezetten az audiovizuális másolatokat) tekintettel fizetett díj az 1960-as évek Németországának újítása, és egyben egyik legszemléletesebb példája a szerzői jog és a technológia összefonódásának. ${ }^{520} \mathrm{~A}$ hangfelvételek többszörözésére alkalmas magnetofonok háztartásokban való elterjedése gyökeresen átalakította a korábbi felhasználási szokásokat. Ezek segítségével már nem csak stúdió körülmények között vált lehetővé a hangfelvételek előállítása, illetve ezek másolása, hanem az otthonában bárki felvételeket készíthetett. Az ekkoriban már hosszú ideje létező német közös jogkezelő szervezet, a GEMA ${ }^{521}$ igazgatója, Erich SCHULzE látta meg ebben a gyakorlatban a hangfelvételek forgalma visszaesésének csökkenését, az ő ötlete volt a másolatkészítést lehetővé tevő készülékekre jogdíjat kivetni és ily módon kompenzálni a szerzői jogi jogosultakat a kieső bevételek miatt. ${ }^{522}$

Vagyis a díj bevezetése voltaképpen nem más, mint reakció egy nem elhanyagolható méretet öltött társadalmi jelenségre. A magáncélú másolat kivételként való definiálása viszont már korábban megvalósult: a francia bírói gyakorlatban a 19 . század során kimunkált elvek $^{523}$ például már az 1957. évi francia szerzői jogi törvényben megerősítést nyertek. Ez jórészt a másolatok csekély számának volt köszönhető, ugyanis a másolatok megvalósítására gyakorlatilag csak kézzel, jelentős befektetett emberi munka által volt lehetőség (főként a nyomtatásban megjelent müvek esetén). ${ }^{524}$ A magánszféra védelme is indokolja a magánfelhasználások külön kezelését, valamint azt, hogy ezek ne képezzék az engedélyezési jog tárgyát.

A többszörözést lehetővé tevő eszközöknek a háztartásokban való elterjedése a jogosultak oldalán viszont nyilvánvaló bevételkiesést generált, a másolatok számának növekedése ugyanis hatással volt a müvek elsődleges felhasználására is. Másfelől viszont a jogalkotó továbbra is figyelemmel kívánt lenni ezeknek a felhasználásoknak a

\footnotetext{
${ }^{520}$ Erről a jelenségről részletesen: MEZEI (2012a) p. 197-208.

${ }^{521}$ Gesellschaft für musikalische Aufführungs- und mechanische Vervielfältigungsrechte.

${ }^{522}$ HuGENHOLTZ (2012) p. 182. 1965-ben végül a német szerzői jogi törvény volt a világon az első, amely bevezette a magáncélú másolásra tekintettel fizetett díjat.

${ }^{523}$ RENOUARD (1839) p. 42.

${ }^{524}$ Megjegyzendő, hogy az ilyen „klasszikus” módon megvalósuló többszörözési cselekmények (tehát például egy vers kézírással történő lemásolása) ma is ingyenes, függetlenül attól, hogy a jogalkotó időközben a magáncélú másolás díjfizetéssel történő kompenzációjáról döntött.
} 
privát jellegére. A kialakított konstrukció ${ }^{525}$ (amelyet egyébként Magyarországon az elsők között vezettek be 1982-ben, szakmai berkekben jelentős nemzetközi elismerést aratva ezzel) $^{526}$ alkalmas arra, hogy a két érdek közötti egyensúlyt helyreállítsa. A felhasználók mentesülnek az egyedi engedélykéréstől (és jogdíjfizetéstől), a jogosultak pedig türik a müveik bizonyos felhasználását, aminek fejében a felhasználók/esetleg mások a használt eszközök (legyen az a többszörözés elkészítéséhez szükséges eszköz, vagy az a hordozó, amire a többszörözés történik) után meghatározott díjat fizetnek.

Kezdetben nem volt egyértelmủ a díjazás szerzői jogi jellege. Franciaországban 1976-ban egy járulék jellegü díj ${ }^{527}$ bevezetése vetődött fel, amellyel a hangfelvevő eszközöket terhelték volna. Az ebből befolyt összegből pedig egy Nemzeti Zenei Pénztár felállítását tervezték. Ez azzal járt volna együtt, hogy közérdekü célként fogták volna fel a magáncélú másolatra tekintettel fizetett díjakat, és a közös jogkezelö szervezetek megkerülésével az állam felelt volna a szétosztásukért. ${ }^{528}$ Amennyiben viszont adó jellegü díjazásként definiáljuk a beszedett összegeket, az egyben a kifejezetten a magáncélú másolásra való tekintettel beszedett szerzői jogi jellegü díjazást, és így a közös jogkezelőknek ezzel kapcsolatban kifejtett tevékenységét zárná ki. $^{529}$

A reprográfia és az audiovizuális másolatok közötti különbség, bár első ránézésre hasonló cselekményekről van szó, gyakorlatilag ezen a ponton kezdett nyilvánvalóvá válni. A magánszférába be nem avatkozó szerzői jogi szabályozásnak ugyanis két módja képzelhető el: vagy a másolást lehetővé tevő eszközre kivetett díj, vagy pedig a másolatokat rögzítő hordozóra kivetett díj formájában. ${ }^{530}$ A reprográfia

525 Az Európai Uninó tagállamainak többségében létezik ilyen rendszer, Dél-Amerika és Afrika egyes államaiban, valamint Japánban is megtalálható, az európainál sokkal korlátozottabb keretek között Kanadában és az Amerikai Egyesült Államokban is működik. Lásd: WIPO International Survey on Private Copying, $2013 . \quad$ p. 3. (http://www.wipo.int/export/sites/www/freepublications/en/copyright/1037/wipo_pub_1037_2013.pdf) ${ }_{526}^{526}$ MOINET (1987) p. 13-18.

${ }^{527} \mathrm{Az}$ eredeti javaslat az ún. taxe parafiscale adójogi kategóriába sorolta volna ezt a díjat. Ennek jellegzetessége, hogy egy meghatározott jogi személy gazdasági vagy szociális érdekében lehet beszedni. 2001-ben viszont a jogalkotó hatályon kívül helyezte a taxe prafiscale beszedéséről rendelkező jogszabályhelyet. (Loi organique $\mathrm{n}^{\circ}$ 2001-692 du 1er aout relative aux lois de finance). LAMARQUE NÉGRIN - AYRAULT (2014) p. 80-86.

${ }^{528}$ LAPOUSTERLE (2009) p. 122.

${ }^{529}$ U.o. p. 122

${ }^{530}$ Időbe telt, mire letisztult az, hogy ezt a jelenséget a szerzői jog berkein belül érdemes kezelni. Kezdetben ugyanis leginkább valamilyen adó jellegü, állam által beszedett és felhasznált díjként tekintettek a készülékekre és hordozókra kivetett díjakra. 
kapcsán, mivel a papír felhasználása nyilvánvalóan sokrétü, ez előbbi megoldás nyert elfogadást, míg az egyéb másolatok tekintetében némi bizonytalanságot követően a hordozóra kivetett díjazás vált általánosan elfogadottá és alkalmazottá. A reprográfiai többszörözés ráadásul sokáig többnyire nem a háztartásokban valósult meg (a mai napig léteznek fénymásolószalonok), az ilyen tevékenységgel foglalkozó vállalkozások nyomon követése pedig nem vetette fel a magánszféra sérelmének kérdését. Másrészt pedig a fénymásolással megvalósuló többszörözést sok esetben intézmények végzik, a többszörözés nem védett müveket is érint, ${ }^{531}$ illetve sok esetben szakmai célokra szolgál. Emiatt nem meglepő, hogy a francia jogalkotó (több más nemzeti jogalkotóhoz hasonlóan) a reprográfia útján megvalósuló többszörözés kizárólagos engedélyezési jogként történő definiálása mellett foglalt állást. ${ }^{532} \mathrm{Az}$ engedélyezési jog fenntartása ráadásul valószínűleg hatékonyabb közös jogkezelést eredményez, mint a magáncélú másolat kivételének kompenzálása a reprográfiai többszörözések esetében, hiszen a jogdíj mértéke is a felek közötti tárgyalás eredményét tükrözi, illetve kevesebb társadalmi ellenérzéssel párosul.

A két felhasználási mód összefüggéseit a Reprobel-ügyben nyilvánosságra hozott fötanácsnoki indítvány ${ }^{533}$ mutatja be. Az alapügy a multifunkcionális készülékeket (nyomtató, fénymásoló, szkenner) Belgiumba importáló Hewlett-Pakard és a reprográfiai díjak beszedéséért felelős belga közös jogkezelő szervezet, a Reprobel között áll fenn. Előbbi cég ugyanis sérelmezi a reprográfiai díjak megfizetését a szóban forgó készülékek után. Ilyen körülmények között az alapügyben eljáró belga bíróság (Cour d'appel de Bruxelles) előzetes döntéshozatali eljárást kezdeményezett az InfoSocirányelv értelmezésére. Az ügyben eljáró Villalón főtanácsnok vizsgálta az InfoSocirányelv 5. cikk (2) bek. a) és b) pontjának, vagyis a magáncélú másolat és a reprográfiai többszörözés egymáshoz való viszonyát, tekintettel arra, hogy ezen multifunkciós készülékek segítségével végzett többszörözési cselekmények (kifejezetten a szkennelési funkció miatt) adott esetben mindkét tényállás keretei közé beilleszthetőek. Az irányelv eltérő szempontokat határoz meg a két kivétel vagy

\footnotetext{
${ }^{531}$ DAVIES - HuNG (1993) p. 8.

${ }^{532} \mathrm{Az}$ ennek kapcsán bevezetett speciális közös jogkezelési rendszerről a II. rész I. fejezetében írtunk bővebben.

${ }^{533}$ A C-572/13. sz. Reprobel-ügyben 2015. június 11-én nyilvánosságra hozott fơtanácsnoki indítvány.
} 
korlátozás bevezethetőségével kapcsolatban, ${ }^{534}$ a magáncélú használat a reprográfiai többszörözésről szóló 5. cikk (2) bek. a) pontjában nem szerepel. A felvetődő kérdés tehát, hogy a tágabb személyi körrel bíró reprográfiai többszörözés esetében a tagállamoknak figyelembe kell-e venniük a magáncélú használatot vagy sem a díjazás megállapítása során. ${ }^{535}$ A fötanácsnok arra a következtetésre jut, hogy bár a tagállamokat ilyen irányú kötelezettség nem terheli, de lehetőségük van a reprográfiai díj megállapításánál a természetes személyek által magáncélra végrehajtott többszörözés korrekciójára. ${ }^{536}$ A főtanácsnoki indítvány tehát az irányelvből levezeti a felhasználási módok eltérő jellegét, és jóváhagyja azokat a megoldásokat, amelyek a díjazás megállapítása során eltérő szempontokat alkalmaznak, nem véve figyelembe a reprográfiai többszörözés esetén a magáncélú felhasználásokat. A tagállamoknak tehát ebben a körben a mozgástere két szinten jelentkezik. Egyrészt dönthetnek úgy, hogy nem ültetik át a reprográfiai és/vagy a magáncélú másolat InfoSoc-irányelvben megfogalmazott kivételét vagy korlátozását. Másrészt pedig a reprográfiai többszörözés esetében nincsenek kötve az irányelv 5. cikk (2) bek. b) pontjában meghatározott magáncélú felhasználás követelményéhez.

\section{B) Az eltérö szabályozásból adódó különbségek}

Mint láttuk, Magyarországon mindkét felhasználási mód azonos elbírálás alá esik, díjfizetéssel ellentételezett törvényi engedélyként került meghatározásra. Így a szabályozás különbségeire kifejezetten a díj és az ehhez kapcsolt közös jogkezelés elemzésénél térünk ki.

A CPI viszont teljesen más megoldást követ: a reprográfiai többszörözéstől eltérő helyen taglalja a magáncélú többszörözést, amely a kivételeket felsoroló L. 1225. cikkben található. Ez alapján a nyilvánosságra hozott mü esetében a szerző nem tilthatja meg „, másolatokat vagy többszörözéseket, amelyek kizárólag a másolást végzö

\footnotetext{
${ }^{534}$ A C-572/13. sz. Reprobel-ügyben 2015. június 11-én nyilvánosságra hozott főtanácsnoki indítvány 41. pont.

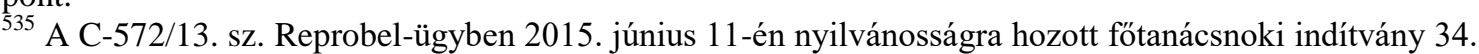
pont.

536 A C-572/13. sz. Reprobel 2015. június 11-én nyilvánosságra hozott fötanácsnoki indítvány, 52-53. pont.
} 
II. rész A törvény által előírt közös jogkezelés, mint a kizárólagos jog korlátja

II. fejezet A kizárólagos jog díjigényre korlátozása révén bevezetett közös jogkezelés

személy magáncélú használatára, és nem pedig közösségi használatra szolgálnak."537 Az ehhez köthető díjazásról szóló rendelkezés viszont nem ebben a cikkben, hanem ettől eltérő helyen található meg a törvényben. ${ }^{538}$ A CPI hatályos, a 2011. december 20ai törvénnyel módosított szövege úgy fogalmaz, hogy a hangfelvételben és videofelvételben foglalt művek szerzői és előadóművészei, valamint a hangfelvételek és videofelvételek előállítói díjazásban részesülnek ezeknek a müveknek a CPI-ben meghatározott feltételek szerint jogszerü forrásból származó többszörözése tekintetében. A törvényi rendelkezés (2) bekezdése értelmében a díj az egyéb hordozón rögzített müvek szerzőit és kiadóit is megilleti, amennyiben a többszörözés szintén a fenti feltételek szerint jogszerü forrásból, digitális hordozóra történik. ${ }^{539}$

Ez alól a szabály alól a képzőmüvészeti alkotásokról készült másolatok, illetve a szoftverekről és adatbázisokról készült másolatok bizonyos esetei képeznek kivételt. A képzőművészeti alkotások esetében a többszörözés nem tartozik a magáncélú másolat kivételének hatálya alá, amennyiben a másolat az eredetivel megegyező célra készült (vagyis tulajdonképpen a sorozatban készült művek). Az elektronikus adatbázisokról készült másolatok minden esetben ki vannak véve a magáncélú másolat hatálya alól, a szoftverek esetében pedig csak az irányelv ${ }^{540}$ által is engedett biztonsági másolat tartozik ide. ${ }^{541}$

\footnotetext{
${ }^{537}$ CPI L. 122-5. cikk: „Lorsque l'oeuvre a été divulguée l'auteur ne peut interdire (...) les copies ou reproductions réalisées à partir d'une source licite et strictement réservées à l'usage privé du copiste et non destinées à une utilisation collective (...)".

${ }^{538}$ A DADVSI-törvény elfogadásáig egyébként ez volt az egyetlen olyan kivétel, amelyet a jogalkotó díjfizetési kötelezettséggel párosított.

${ }^{539}$ CPI L. 311-1. cikk: „Les auteurs et les artistes-interprètes des oeuvres fixées sur phonogrammes ou vidéogrammes, ainsi que les producteurs de ces phonogrammes ou vidéogrammes, ont droit à une rémunération au titre de la reproduction desdites oeuvres, réalisée à partir d'une source licite dans les conditions mentionnées au $2^{\circ}$ de l'article L. 122-5 et au $2^{\circ}$ de l'article L. 211-3.

Cette rémunération est également due aux auteurs et aux éditeurs des oeuvres fixées sur tout autre support, au titre de leur reproduction réalisée à partir d'une source licite, dans les conditions prévues au $2^{\circ}$ de l'article L. 122-5, sur un support d'enregistrement numérique."

${ }^{540}$ Szoftver-irányelv 5. cikk (2) bek.

${ }^{541}$ CPI L. 122-5. cikk $2^{\circ}$,Les copies ou reproductions réalisées à partir d'une source licite et strictement réservées à l'usage privé du copiste et non destinées à une utilisation collective, à l'exception des copies des oeuvres d'art destinées à être utilisées pour des fins identiques à celles pour lesquelles l'oeuvre originale a été créée et des copies d'un logiciel autres que la copie de sauvegarde établie dans les conditions prévues au II de l'article L. 122-6-1 ainsi que des copies ou des reproductions d'une base de données électronique." A szoftverekről készült biztonsági másolat miatt felvetődik az a kérdés, hogy a szoftverek esetében a jogosultak részesedhetnének-e a magáncélú másolatra tekintettel fizetett díjból. Nicolas BINCTIN elfogadja ennek az alkalmazásnak a lehetöségét. BINCTIN, Nicolas: Rémunération pour copie privée, J. Cl. Propriété littéraire et artistique, Fasc. 1510. 20. pont.
} 
Érdemes kitérni arra is, hogy a felhasználás szerzői jogi természete nem csak az engedélyezési jog - kivétel koordinátarendszerben helyezhető el. Létezik olyan vélemény is, amely a francia jogirodalomban a magáncélú többszörözést egyáltalán nem tekinti a szerzői jog hatálya alá tartozó cselekménynek. A CPI a többszörözés kapcsán is megköveteli, hogy az a mű nyilvánossághoz juttatását szolgálja. ${ }^{542}$ A magáncélú többszörözés esetében viszont, nevéből adódóan, a felhasználás egy kiaknázatlan másolatot eredményez, amely nem jut el a közönséghez, emiatt teljesen szabad, a szerzői jog által fogalmilag le sem fedett felhasználást (nem a magyar törvény értelmében vett kifejezéssel élve) eredményez. Ez kizárja azt is, hogy a felhasználónak alanyi joga legyen a másolat elkészítésére. ${ }^{543}$ Ilyen értelemben inkább a közkinccsé vált szerzői művek felhasználásával mutat rokon vonásokat a magáncélú többszörözés.

E helyütt kell felhívni arra is a figyelmet, hogy az InfoSoc-irányelv, bár lehetővé teszi a többszörözés jogának korlátozását mind az üres hordozóra történő másolatok esetében, mind pedig a reprográfiai többszörözés tekintetében, a magáncélt csak ez előbbi esetben teszi a korlátozás bevezetésének feltételévé. Ez egyben azt is jelenti, hogy a természetes személyektől eltérő felhasználók, illetve a természetes személyek által nem magáncélra vagy kereskedelmi célra végzett többszörözések kizárólag a reprográfiai kivétel hatálya alá tartozhatnak ${ }^{544}$ - már amennyiben a tagállam ezt bevezette.

Az általánosan elfogadott vélemény, és egyébként az InfoSoc-irányelv által követett megoldás is az, amely szerzői jogi korlátozásként tekint a magáncélú többszörözésre. ${ }^{545}$ Ebből a különbségtételből fakad az, hogy a reprográfiai többszörözés esetén a francia megoldás alapján elvileg az InfoSoc-irányelvben foglalt háromlépcsős teszt alkalmazása nem merül fel, hiszen nem kivétel formájában került meghatározásra a felhasználás. A magáncélú másolat kapcsán viszont ennek vizsgálata nélkülözhetetlen, hiszen ez az egyik klasszikus példája a jogok leszorításának. Ebből az eltérésből erednek egyébként a magáncélú másolatra tekintettel fizetett díjaknak azok a jellegzetességei is, amelyek a dolgozatban ismertetésre kerülnek.

\footnotetext{
${ }^{542}$ CPI L. 122-3. cikk „La reproduction consiste dans la fixation matérielle de l'oeuvre par tous procédés qui permettent de la communiquer au public d'une manière indirecte."

543 GAUDRAT - SARDAIN (2005) p. 10.

${ }_{545}^{544}$ A C-572/13. sz. Reprobel-ügyben 2015. november 12-én hozott ítélet 34. pontja.

${ }^{545}$ InfoSoc-irányelv 5. cikk (2) bek. b) pont.
} 
A korlátozással összefüggésben, illetve a francia szerzői jogban a reprográfiától eltérő megközelítési mód miatt merülhet fel az a kérdés is, hogy a magáncélú másolat keletkeztet-e a felhasználók oldalán alanyi jogot a másolat készítésére? A szakirodalomban az az álláspont kristályosodott ki, hogy ilyen alanyi jogról nem beszélhetünk, ${ }^{546}$ a magáncélú másolat megmarad a szerzői jog díjfizetési kötelezettséggel ellentételezett korlátozásának.

\section{§2. A többszörözési jog korlátozása és a háromlépcsös teszt}

A szerzői jog dogmatikai szempontú elemzésének egyik leghangsúlyosabb terepe a háromlépcsős teszt analízise. A jogirodalomban az első felbukkanása óta kiemelt szerepet játszik, nem véletlenül. A teszt alkalmas ugyanis arra, hogy a szerzői jogi korlátozások kereteit kijelölve a különböző érdekek közötti egyensúlyszerepet megtartsa. A magáncélú másolattal (illetve tágabban ideértve a reprográfiai többszörözés kapcsán bevezetett kötelező közös jogkezelést) összefüggésben történő értelmezése [B) pont] napjainkban különösen a fájlcsere miatt vált hangsúlyossá, de ettől függetlenül is, szerepe a különböző jogforrásokban való megjelenése miatt lényeges kérdéseket vet fel [A) pont].

\section{A) A háromlépcsős teszt a különböző szintü jogforrásokban}

A háromlépcsős tesztet a többszörözés jogára vonatkozóan a BUE vezette be elöször az 1967-es stockholmi felülvizsgálat során. A szövegét több-kevesebb módosítással a BUE-t követő nemzetközi szerzői jogi egyezmények is átvették. A nemzeti szerzői jogokba az InfoSoc-irányelv közvetítésével került [a) pont], amelynek köszönhetően az általa betöltött szerep is módosult [b) pont].

a) A teszt egyes szövegváltozatai

A teszt, mint látni fogjuk, eltérő szövegváltozatokkal jelenik meg a különböző jogforrásokban, a vizsgált nemzeti jogokban nem is három lépcsőből áll. Emiatt külön fontosnak tarjuk egymás mellé rendezni az egyes szövegváltozatokat. E helyütt nem térünk ki az eltérésekből fakadó értelmezési kérdések tárgyalására [ez a b) alpontban

${ }^{546}$ GAUDRAT - SARDAIN (2005) p. 10 
történik majd meg], pusztán felhívjuk a figyelmet az egyes feltételek elhagyására, illetve betoldására, illetve a szóhasználatbeli különbségekre.

A BUE-ban található eredeti szöveg szerint „,[a]z Unióhoz tartozó országok törvényhozó szervei jogosultak arra, hogy különleges esetekben lehetővé tegyék az említett mủvek többszörösítését, feltéve, hogy az ilyen többszörösítés nem sérelmes a mü rendes felhasználására, és indokolatlanul nem károsítja a szerző jogos érdekeit." ${ }^{547} \mathrm{Az}$ InfoSoc-irányelv visszautal az 5. cikkben foglalt kivételek és korlátozások listájára, amikor kimondja, hogy ezek, az (1), (2), (3) és (4) bekezdésekben foglalt kivételek és korlátozások kizárólag olyan különös esetekben alkalmazhatók, amelyek nem sérelmesek a mü vagy más, védelem alatt álló teljesítmény rendes felhasználására, és indokolatlanul nem károsítják a jogosult jogos érdekeit. ${ }^{548}$

A CPI megfogalmazásában az L. 122-5. cikkben szereplő kivételek nem lehetnek sérelmesek a mü rendes felhasználására és indokolatlanul nem károsíthatják a szerző jogos érdekeit. ${ }^{549}$ A teszt tehát ebben az esetben csak két lépcsőre csökkent, a különleges esetekre való hivatkozás helyett a jogalkotó az alkalmazási körét az L. 1225. cikkben meghatározott kivételek listájára szükítette.

Az Szjt. a tesztnek egy, a korábbiaktól eltérő szövegváltozatát tartalmazza. A törvény szövege szerint „[a] felhasználás a szabad felhasználásra vonatkozó rendelkezések alapján is csak annyiban megengedett, illetve díjtalan, amennyiben nem sérelmes a mủ rendes felhasználására és indokolatlanul nem károsítja a szerző jogos érdekeit, továbbá amennyiben megfelel a tisztesség követelményeinek és nem irányul a szabad felhasználás rendeltetésével össze nem férő célra." ${ }^{, 550}$ A magyar törvény tehát az első lépcső klasszikus megfogalmazását elhagyva és két új feltételt támasztva négy lépcsőssé bővítette a feltételt. Bár önmagában a teszt szövegezésétől, más szövegváltozataitól ez a követelmény idegen, kifejeződik benne a szerzői jognak és a polgári jognak a szoros összekapcsolódása, annak megerősítése, hogy a polgári jog a szerzői jog anyajoga. Ez ugyanis a Ptk.-ban szereplő elvnek a megismétlése a szerzői

\footnotetext{
${ }^{547}$ BUE 9. cikk (2) bek.

${ }^{548}$ InfoSoc-irányelv 5. cikk (5) bek.

549 CPI L. 122-5. cikk „Les exceptions énumérées par le présent article ne peuvent porter atteinte à l'exploitation normale de l'oeuvre ni causer un préjudice injustifié aux intérêts légitimes de l'auteur."

550 Szjt. 33. § (2) bek.
} 
II. rész A törvény által előírt közös jogkezelés, mint a kizárólagos jog korlátja

II. fejezet A kizárólagos jog díjigényre korlátozása révén bevezetett közös jogkezelés

jogi törvényben. ${ }^{551}$ Másrészt pedig a szabad felhasználás rendeltetésével össze nem férő cél értelmezhető akként is, hogy ez a feltétel lefedi a különleges esetek fogalmát.

Általánosítva ezeket a feltételeket az a következtetés vonható le, hogy a szerzői jogi korlátozásoknak (1) különleges esetekre kell vonatkozniuk, (2) nem lehetnek sérelmesek a mű rendes felhasználására, és (3) indokolatlanul nem károsíthatják a szerző jogos érdekeit. A teszt értelmezését ezek mentén a kritériumok mentén végezzük el.

b) A teszt szerepének változása

A teszt szerepe a különböző jogforrásokba történő inkorporációja során többrétegü változáson esett át. Ez érinti egyfelől azt, hogy mely jogosultságok kapcsán lehet a tesztet alkalmazni, másfelől pedig azt is, hogy csak a jogalkotót vagy ad absurdum a jogalkalmazót is kötik-e a rendelkezései.

A BUE eredetileg csak a többszörözés jogára vonatkozóan írta elö a háromlépcsős teszt alkalmazását. A teszt tehát ebben az értelemben speciális korlátozás, hiszen nem terjed ki a BUE-ben biztosított többi jogra, vagyis az ezekre vonatkozó korlátozásokat a BUE értelmében nem kell alávetni a tesztnek. A többszörözés jogára vonatkozó különös korlátozások esetében viszont érvényesül a lex specialis derogat legi generali elv, vagyis ezek a háromlépcsős teszttől függetlenül, attól elkülönülten alkalmazandóak. ${ }^{552}$

A TRIPS-megállapodás volt az, amely felismerte, hogy a teszt alkalmas a szellemi tulajdonjogok korlátozásának általános mércéjévé válni, így annak alkalmazását kiterjesztette valamennyi szerzői vagyoni jogra. ${ }^{553}$ Az átfogó jelleg abban mutatkozik meg, hogy ehhez hasonló rendelkezést kell alkalmazni a szerzői joghoz kapcsolódó jogok, valamint a szabadalmi és a védjegyoltalom korlátozására is. A nemzetközi szerződések értelmezésének általános elvei segítségül hívásával a BUE és a TRIPS-egyezmény viszonyából viszont az a következtetés vonható le, hogy szándéka

${ }^{551}$ Az új Ptk. 1:3. §-a rendelkezik a jóhiszemüség és a tisztesség követelményéről. Ennek értelmében a jogok gyakorlása és a kötelezettségek teljesitése során a felek a jóhiszeműség és tisztesség követelményének megfelelően kötelesek eljárni.

${ }_{552}^{552}$ GYENGE (2006) p. 173.

553 TRIPS-egyezmény 13. cikk. Magyarországon kihirdette az Általános Vám- és Kereskedelmi Egyezmény (GATT) keretében kialakított, a Kereskedelmi Világszervezetet létrehozó Marrakesh-i Egyezmény és mellékleteinek kihirdetéséröl szóló 1998. évi IX. törvény. 
II. rész A törvény által előírt közös jogkezelés, mint a kizárólagos jog korlátja

II. fejezet A kizárólagos jog díjigényre korlátozása révén bevezetett közös jogkezelés

ellenére, a TRIPS-megállapodásban található teszt ,érdemi funkciót csak a bérleti jogra vonatkozó korlátozások tekintetében tud betölteni," 554 hiszen a BUE-hoz képest ez jelenti a szerzőknek biztosított kizárólagos jogok bővülését.

A WCT a TRIPS-megállapodáshoz hasonlóan inkorporálja a BUE rendelkezéseit, és maga is bevezeti a háromlépcsős tesztet. ${ }^{555}$ Mércéül az újonnan garantált kizárólagos jog, a nyilvánosság számára lehívásra történő hozzáférhetővé tétel tekintetében szolgál. Leszögezi viszont azt, hogy a BUE-ban található speciális korlátozások is csak annyiban megengedettek, amennyiben megfelelnek a 10. cikk (2) bekezdésének, vagyis különleges esetekre vonatkoznak, nem sérelmesek a mü rendes felhasználására és indokolatlanul nem károsítják a szerző jogos érdekeit. Rögzítették viszont azt is a cikkhez füzött közös nyilatkozatban, hogy a BUE korlátozásai alkalmazásának terjedelmét a WCT nem korlátozza és nem terjeszti ki.

Vagyis ebből GYENGE Anikó megfogalmazásában az a következtetés vonható le, hogy ,a háromlépcsős teszt a közvetlen alapja a BUE szerint a többszörözés, a TRIPS-megállapodás szerint a bérlet és a WCT szerint a lehívásra történö hozzáférhetővé tétel jogának a közösségi és a belső jogban megjelenő korlátozásainak. Ugyanakkor a többi, (kizárólag) a BUE-ban nevesített korlátozás tekintetében csak olyan közvetett, értelmező funkciót tud betölteni, hogy a BUE-ban meghatározott feltételek teljesülése egyben a három lépcsős tesztnek való megfelelést is jelent. Ebből az is adódik, hogy a többi jog tekintetében csak a BUE-ban meghatározott keretekben van csak lehetőség a korlátozásra, annak meghaladására nincs nemzetközi jogi alap."

Az InfoSoc-irányelv élezte ki azt a dilemmát, amely arra vonatkozik, hogy a tesztet a bíróságoknak alkalmazniuk kell-e az egyes ügyek eldöntésénél. Azzal, hogy az irányelv szövegében is megjelenik, egyrészt lehetőséget ad az EuB-nak az értelmezésére, másrészt viszont a tagállami bíróságok számára is alkalmazandóvá válik az implementáció miatt. ${ }^{557}$ Amennyiben azt az értelmezést fogadjuk el, hogy a teszt csak a jogalkotót köti, ezzel elzárjuk a bíróságok elől annak lehetőségét, hogy az adott

\footnotetext{
${ }^{554}$ GYENGE (2006) p. 174.

${ }^{555}$ WCT 10. cikk. Magyarországon kihirdette a Szellemi Tulajdon Világszervezete 1996. december 20 án, Genfben aláírt Szerzői Jogi Szerződésének, valamint Előadásokról és Hangfelvételekről szóló Szerződésének kihirdetéséről szóló 2004. évi XLIX. tv.

${ }_{556}^{556}$ GYENGE (2006) p. 175.

${ }^{557}$ A téma szempontjából nem bír jelentőséggel, emiatt nem térünk ki külön az irányelvek közvetlen hatályának és alkalmazhatóságának kérdésére.
} 
egyedi esetben ezt alkalmazzák. Vagyis a feladatuk csak annak vizsgálatára korlátozódik, hogy a történeti tényállásban megvalósult felhasználási cselekmény megfelel-e a jogszabályban foglalt korlátozás szövegének. Azzal viszont már nem kell foglalkozniuk, hogy ez egyébként megfelel-e a háromlépcsős tesztnek. A Semmítőszék ezen az elméleti megfontoláson lépett túl, amikor a háromlépcsős tesztet úgy értelmezte, hogy az még nem került a CPI-be belefoglalásra. ${ }^{558}$ A második lehetőség ezzel ellentétben viszont azt is jelenti, hogy a teszt tulajdonképpen a jogalkotó által biztosítotton túli többletelemet tartalmaz, vagyis a konkrét felhasználási cselekménynek még a háromlépcsős teszt előírásainak is meg kell felelnie. Vagyis a vita azt is jelenti, hogy absztrakt, vagy konkrét mérceként kell-e a tesztet figyelembe venni. ${ }^{559}$

Az InfoSoc-irányelv általi inkorporáció egyrészt azzal a következménnyel jár, hogy az EuB értelmezheti a tesztet. A Bíróság értelmezése az adott ügyben eljáró tagállami bíróságot köti. Emellett viszont az uniós jognak való megfelelés miatt ezt mind a többi tagállami bíróság, mind pedig a nemzeti jogalkotók figyelembe szokták venni az ítélkezési gyakorlatukban, illetve a jogalkotás során. Amint azonban a teszt a belső jogba is átültetésre kerül, ez azt is jelenti, hogy a bíró által kikényszeríthető szűrő válik belöle.

\section{B) A teszt értelmezése}

A teszt értelmezése során autentikus forrásként figyelembe kell venni az egyes bírói (szakértői) fórumok által hozott döntéseket (szakvéleményeket). Mivel ezek száma nem jelentős, a jogtudományban elfogadott értelmezési keretek szintézise is fontos szerephez jut. Hasonlóan, a teszt eltérő szerepe miatt érdemes különválasztani az eltérő szintű jogforrások értelmezése kapcsán született koncepciókkal - elismerve ugyanakkor azt, hogy ezek egymással szoros kölcsönhatásban állnak.

\section{a) A teszt értelmezése nemzetközi és uniós szinten}

Mivel mind nemzetközi, mind pedig uniós szinten alapvetően a jogalkotó számára ír elő kötelezettséget a szerzői jogi korlátozások bevezetésének módjával kapcsolatban, ezért érdemes ezeket összevontan, egy csokorban tárgyalni.

\footnotetext{
${ }^{558}$ Lásd a Mulholland Drive-ügyet, Civ. 1re, 28 février 2006, Studio Canal et Sté Universal Pictures et al. c/ UFC Que Choisir et Perquin, dit „Mulholland Drive”, n 05-15.824.

${ }^{559}$ DUSOLLIER (2007) p. 438.
} 
a) A WTO vitarendezési panel és a nemzetközi szakirodalom

Az egyetlen olyan eset, amelyben a teszt nemzetközi szinten került értelmezésre, a TRIPS-megállapodásban foglalt szövegváltozattal kapcsolatos, a Világkereskedelmi Szervezet Amerikai Egyesült Államok, illetve az Európai Közösségek és tagállamai közötti vitarendezési eljárás volt. ${ }^{560}$ Nem elhanyagolható tehát annak összefoglalása sem, hogy a jogtudományban milyen elméletek jelennek meg.

A teszt értelmezése kapcsán a nemzetközi szakirodalomban két álláspont található. Az egyik a tesztet a nevéből adódóan lépcsőfokonként kívánja elemezni. Vagyis amellett foglal állást, hogy sorrendben haladva amennyiben valamely feltétel nem teljesül, úgy a felhasználás már biztosan nem tekinthető kedvezményezettnek. Emiatt a további tényezők vizsgálata már nem is indokolt.

Ennek megfelelően a „különleges esetek” jelentése két aspektusból vizsgálva ragadható meg. Egyrészt a kérdéses felhasználásnak célhoz kötöttnek kell lennie. Másrészt pedig ennek a célnak a közérdek, vagy más méltányolható körülmény által igazolhatónak kell lennie. ${ }^{561}$ Bármely értelmezést is fogadjuk el, az világos, hogy a kifejezés célja a korlátozások keretek közé szorítása. Ha ugyanis ez a feltétel nem teljesül, és a korlátozás egy egész felhasználási módot venne ki a szerző rendelkezési joga alól, az ütközne a háromlépcsős teszt követelményeibe. ${ }^{562}$ Ez a korlátok közé szorítás kiválóan megmutatkozik a reprográfiai többszörözés engedélyezési jogának kötelező közös jogkezelés keretében történő gyakorlása kapcsán elemzett francia megoldásban. Mint láttuk, a vagyoni jog a jogalkotó, és a bírói gyakorlat által kellően szűkre szabott, hiszen csak bizonyos paramétereknek megfelelő többszörözési cselekmények tartozhatnak ebbe a körbe, és a digitális másolatok például (a hordozó eltérő jellege miatt) nem tartoznak ide. A különleges eset fogalmának fennállása tehát első lépcsőként mindenképpen alátámasztható, mivel jól körülhatárolt felhasználási módról van szó, amely a müvek másodlagos felhasználását érinti azzal a céllal, hogy a szerzők vagyoni jogainak kizárólagosságát a lehető legteljesebb mértékig megtartsa.

\footnotetext{
${ }^{560}$ WTO Panel DS160 - United States Section 110(5) Copyright Act

${ }^{561}$ FICSOR (2002) p. 284.

${ }^{562}$ FICSOR (2002) p. 284.
} 
A második lépcső, a mü rendes felhasználása tiszteletben tartásának követelménye egyrészt magában foglal egy empirikus elemet. Vagyis a szóban forgó korlátozás sérelmes a mủ rendes felhasználására, ha olyan helyzetet eredményez, amely aláássa a jogosult lehetőségét a mü kiaknázására, ezzel versenyezni képes. ${ }^{563}$ Vagyis hátrányosan befolyásolja a mütípus összfelhasználásán belül jelentősnek tekinthető tényleges vagy potenciális bevételi forrásokat. ${ }^{564}$ Másrészt viszont ez normatív szinten is értelmezhetö, amely abban nyilvánul meg, hogy minden olyan felhasználás engedélyezését fenn kell tartani, amely a szerző számára gazdasági vagy gyakorlati jelentőséggel bírhat. ${ }^{565}$ Ez különösen az új technológiák szempontjából bír jelentőséggel. A normatív megközelítés figyelembevételével ugyanis ezek rövid idő alatt versenytársaivá válhatnak a korábbi felhasználási módoknak, vagyis azon túl, hogy ezeknek is engedélyköteles felhasználásoknak kell maradniuk, kifejezetten erre vonatkozó korlátozás bevezetése úgy tűnik, nem megengedett. A rendes felhasználás kapcsán rá kell világítani arra is, hogy mára több esetben az online felhasználások is a müvek rendes felhasználásának számítanak elterjedtségük miatt. Az olyan felhasználások esetében viszont, amelyek még jelenleg ritkák, elszórtan fordulnak elő, megkérdőjelezhető a rendes felhasználásba ütközés. A reprográfiai többszörözés szintén iskolapéldája a rendes felhasználás követelményének betartására. Egyrészt azért, mert az engedélyezési jog fenntartásával a szerző továbbra is ura marad a mü felhasználásának. Másrészt pedig, mivel másodlagos felhasználási módról van szó, a reprográfiai többszörözés közös jogkezelés alá utalása nem érinti a szerzőnek azt a jogát, hogy a mű elsődleges felhasználására kiadói szerződést kössön.

A harmadik lépcső pedig a szerző jogos érdekeinek indokolatlan károsításának tilalmát tartalmazza. A korlátozások bevezetése önmagában károsítja a szerző érdekeit, a harmadik lépcső célja tehát egy olyan mérce felállítása, amely alatt ez elfogadható. A szerző jogos érdeke ahhoz füződik, hogy az öt megillető jogokat annak teljességében tudja gyakorolni. Az ehhez kapcsolódó indokolatlanság pedig közvetlenül kapcsolódik a korlátozás bevezetésének céljához, vagyis az ahhoz szükséges mértékig lehet megengedett. Fontos, hogy a kizárólagos jog díjigénnyé szorítása nem jelenti automatikusan azt, hogy a felhasználás megfelelne a háromlépcsős tesztnek. A

\footnotetext{
${ }^{563}$ FICSOR (2002) p. 285.

${ }^{564}$ GYENGE (2006) p. 177.

${ }^{565}$ GYENGE (2006) p. 177.
} 
díjfizetési kötelezettség elöírása mindössze a harmadik lépcső kapcsán vizsgálandó, vagyis amennyiben az első két feltétel teljesül, ez igazolhatja, hogy a szerző jogos érdekei indokolatlanul nem sérülnek. ${ }^{566}$ A közös jogkezelésről pedig a fenti két lépcső elemzését követően megállapítható, hogy nem a szerző jogos érdekeinek indokolatlan károsítását jelenti, hanem éppen ellenkezőleg, azt biztosítja, hogy a szerző ezeket a minél hatékonyabb módon tudja gyakorolni. A felhasználások tömegessége, és a felhasználók professzionális mivolta miatt ugyanis ezeknek az engedélyezésére a közös jogkezelő szervezet általi joggyakorlás sokkal inkább megfelel, mint egyébként az egyéni jogkezelés, hiszen így kedvezőbb feltételek mentén tudnak megállapodni a felhasználásokról.

A másik álláspont ezzel szemben annak ad hangot, hogy a teszt rugalmasabb értelmezése alkalmasabbá tenné azt a digitális forradalom által nyújtott kihívások kezelésére. Egy jogtudósi csoport szakítva a klasszikus értelmezéssel amellett érvel, hogy a tesztet nyitott kapuként egységesen és összességében, nem pedig elemeire bontva kell alkalmazni. Müncheni nyilatkozat ${ }^{567}$ címmel fejtették ki erre vonatkozó részletes álláspontjukat. A kezdeményezés egyik leghangosabb támogatója, Martin SENFTLEBEN még a teszt átfogalmazására is adott javaslatot. A professzor az alábbi szövegváltozatot javasolja az InfoSoc-irányelvbe beépíteni: „Azokban a különleges esetekben, amelyek az (1), (2), (3) és (4) bekezdésben felsorolt kivételekhez és korlátozásokhoz hasonlóak, további olyan kivételek és korlátozások lehetnek azonosíthatóak, amelyek nem sérelmesek a mü vagy más, védelem alatt álló teljesítmény rendes felhasználására, és indokolatlanul nem károsítják a jogosult jogos érdekeit." ${ }^{\text {568 }}$ A módosítás célja az lenne, hogy a kívánatosnak tartott szélesebb mozgásteret biztosítsa

A nyilatkozatot számos kritika érte, FICSOR Mihály például azt kifogásolja, hogy követendőnek tartott flexibilis értelmezés nem hogy megoldaná, hanem csak súlyosbítaná a digitalizáció szerzői jogra gyakorolt hatásából eredő problémákat. ${ }^{569}$ GYENGE Anikó az általános kritikai észrevételek megfogalmazásán túl részletesen levezeti, hogy a nyilatkozat jegyzői által meghatározott szempontok a jelenlegi

\footnotetext{
${ }^{566}$ FICSOR (2002) p. 288.

${ }^{567}$ GEIGER - HILTY - GRIFFITHS - SUTHERSANEN (2008).

568 SENFTLEBEN (2012) p. 71.

${ }^{569}$ FICSOR (2012a) p. 55-62.
} 
II. rész A törvény által előírt közös jogkezelés, mint a kizárólagos jog korlátja

II. fejezet A kizárólagos jog díjigényre korlátozása révén bevezetett közös jogkezelés

értelmezési keretek között is helytállóak, kivéve a lépcsők sorrendiségének megváltoztatásával kapcsolatosat. Erre viszont a fennálló nemzetközi szerződések értelmezésére irányadó szabályok szerint jelenleg nincs lehetőség. ${ }^{570}$

\section{B) Az ACI Adam-ügy és az uniós értelmezési keretek}

A Bíróság eddig tizenöt ügyben ${ }^{571}$ hivatkozott az indokolásában az InfoSocirányelv 5. cikk (5) bekezdésére. ${ }^{572}$ Ezek közül elsősorban az ACI Adam-ügyet tárgyaljuk, mert a magáncélú többszörözés kapcsán ebben az ügyben került elő hangsúlyozottan a háromlépcsős teszt értelmezése. Mindenekelőtt azonban érdemes áttekinteni az irányelv szabályozási mechanizmusát.

Az InfoSoc-irányelv horizontális harmonizációt biztosít a szerzői jog területén - legalábbis ami az érintett vagyoni jogokat illeti. ${ }^{573}$ Ennek keretében a vagyoni jogok határait megvonó szerzői jogi kivételek és korlátozások listáját is átfogóan kívánja szabályozni, elismerve egyúttal a tagállamok számára annak lehetőségét, hogy ezeket a szabályokat saját nemzeti jogrendszerüknek megfelelően ültessék át. Ennek eredménye egy lényegében tagállami szinten divergáló kivétel- és korlátozáslista lett. A nem kellően pontosan meghatározott feltételek ugyanis nem csak bináris skálán biztosítanak a tagállamok számára választási lehetőséget. Azaz az egyes kivételek implementálásán túl a kivételek tartalmának meghatározásánál is viszonylag nagy szabadságot kaptak a nemzeti parlamentek. Emiatt a tagállamok az általuk jelentősnek ítélt, vagy jogi

\footnotetext{
${ }^{570}$ GYENGE (2010) p. 88-89.

${ }^{571}$ Az ügyek az alábbiak: a C-360/13. sz. Public Relations Consultants Association ügyben 2014. június 5-én hozott ítélet; a C-117/13. sz. Ulmer ügyben 2014. szeptember 11-én hozott ítélet, a C-463/12. sz. Copydan Båndkopi-ügyben 2015. március 5-én hozott ítélet; a C-435/12. sz. ACI Adam-ügyben 2014. április 10-én hozott ítélet; a C-351/12. sz. OSA-ügyben 2014. február 27-én hozott ítélet; a C-457/11. sz. VG Wort-ügyben 2013. június 27-én hozott ítélet; a C-510/10. sz. DR és TV2 Danmark-ügyben 2012. április 26-án hozott ítélet; a C-302/10. sz. Infopaq International-ügyben 2012. január 17-én hozott végzés; a C-277/10. sz. Luksan-ügyben 2012. február 9-én hozott ítélet; a C-145/10. sz. Painer-ügyben 2011. december 11-én hozott ítélet; a C-462/09. sz. Opus-ügyben 2011. június 16-án hozott ítélet; a C-467/08. sz, Padawan-ügyben 2010. október 21-én hozott ítélet; a C-403/08. sz. Football Association Premier League és társai ügyben 2011. október 4-én hozott ítélet; a C-5/08. sz. Infopaq International ügyben 2009. július 16-án hozott ítélet; a C-479/04. sz. Laserdisken-ügyben 2006. szeptember 12-én hozott ítélet.

${ }^{572}$ Ezek közül azonban szelektálni kell. Egyfelöl nem mindegyik ítélet az 5. cikk (2) bek. a) vagy b) pontjával kapcsolatos, másrészt pedig nem mindegyikben a konkrét cikk értelmezéséről volt szó. Néhány esetben csak támogató érvként jelenik meg az 5. cikk (5) bekezdése. A Painer-ügyben például hiába merült fel a cikk alkalmazása, a Bíróság azt nem lépcsőnként levezetve tette, hanem általánosságban utalt az alapügy körülményeinek egyes elemeire, amelyek azok összefüggéseiben nem feleltek meg az InfoSoc-irányelv 5. cikk (3) bek. c) pontjának. Lásd a C-145/10. sz. Painer-ügyben 2011. december 1-jén hozott ítélet 110-116. pontjait.

${ }^{573}$ Pollaud-Dulian (2002) p. 7.
} 
hagyományaikba beilleszthető kivételeket ültették át nemzeti jogukba, ${ }^{574}$ egyes esetekben nem szimplán az irányelv szövegének szó szerinti átvételével, hanem annak értelmezésével. ${ }^{575}$ A lista - egy nagyon szük kiskapu kivételével - gyakorlatilag zárt, ami azzal jár együtt, hogy a felsoroltakon túl más kivételt nemzeti jogukba nem vezethetnek be, a már meglévőeket pedig ennek megfelelően kellett a tagállamoknak felülvizsgálni. ${ }^{576}$ A kivételek viszont egyfelől csak az InfoSoc-irányelvben foglalt vagyoni jogok tekintetében alkalmazandóak, a többi vagyoni jogra vonatkozóan itt nem kerültek szabályozásra. Másrészt pedig csak egy kivétel ${ }^{577}$ kötelezően átültetendő, a többiből a tagállamok szabadon válogathatnak.

A kivételek és korlátozások ilyen módon történő meghatározása miatt az irányelvvel kapcsolatban több helyen fogalmaztak meg kritikát. A harmonizáció jellegéből adódóan a szerzői jog nélkülözhetetlen eleme lenne a határainak pontos megvonása. ${ }^{578}$ Ráadásul ez a katalógus a harmonizáció helyett ráirányította a figyelmet a kivételek és korlátozások tagállami szabályainak nagyfokú eltéréseire, ${ }^{579}$ ami miatt az irányelvvel kapcsolatban elmondható, hogy a preambulumában megfogalmazott jogbiztonság helyett bizonytalanságot eredményezett. ${ }^{580}$ Ezen feltételek mellett a Bíróság a háromlépcsős teszt szerepéről megállapította, hogy az InfoSoc-irányelv 5. cikk (5) bekezdése nem új kivételt vagy korlátozást állapít meg, hanem az irányelvben foglalt ilyen rendelkezések terjedelmének pontosítására korlátozódik. ${ }^{581}$ Majd az ACI Adam-ügyben amellett érvelt, hogy a háromlépcsős teszt nem határozza meg az 5. cikk (2) bekezdésben foglalt kivételek és korlátozások tartalmát, csupán azok tagállamok általi alkalmazására irányul. ${ }^{582}$ Vagyis olybá tünik, hogy a Bíróság akként foglalt állást, hogy az 5. cikk (5) bekezdés a tagállami jogalkotók számára ír elő kötelezettséget. Talán erre is visszavezethető, hogy a testület általában igyekszik kerülni a részletes értelmezést, de helyenként fogódzót ad az egyes szempontok mérlegeléséhez. Másfelől viszont a Bíróság azt is megállapította, hogy amennyiben az 5. cikk (1) bekezdésében

\footnotetext{
${ }^{574}$ Az irányelv átültetésével kapcsolatban lásd különösen: GUIBAULT - WESTKAMP -RIEBER-MOHN Hugenholtz (2007). WestKAMP (2007). A legújabb elemzést pedig lásd: TriaILlE - DusOlliER DEPREEUW - HUBIN - COPPENS - DE FRANCQUEN (2013).

${ }^{575}$ GUIBAULT (2010) p. 56.

${ }^{576}$ LEHMANN (2003) p. 525.

${ }^{577}$ InfoSoc-irányelv 5. cikk (1) bek.

${ }^{578}$ DREIER (2010) p. 52.

${ }^{579}$ BÉNABOU (2010) e-verzió, 19. bekezdés.

${ }^{580}$ HugENHOLTZ (2000) p. 501.

${ }^{581}$ A C-351/12. sz. OSA-ügyben 2014. február 27-én hozott ítélet 40. pontja.

${ }^{582}$ A C-435/12. sz. ACI Adam-ügyben 2014. április 10-én hozott ítélet 25. pontja.
} 
II. rész A törvény által előírt közös jogkezelés, mint a kizárólagos jog korlátja

II. fejezet A kizárólagos jog díjigényre korlátozása révén bevezetett közös jogkezelés

foglalt feltételek teljesülnek, úgy a felhasználás megfelel a mü rendes felhasználásának, és indokolatlanul nem sérti a szerző jogos érdekeit sem. ${ }^{583}$ Vagyis, legalábbis az idöleges többszörözés tekintetében úgy tünik, hogy a Bíróság eleve azt feltételezte, hogy a korlátozás megszövegezése kapcsán az uniós jogalkotó tiszteletben tartotta a háromlépcsős teszt minden elemét. ${ }^{584}$

Ennek megismétlése azért bír relevanciával, mert az EuB az InfoSoc-irányelv 5. cikk (5) bekezdésének és az 5. cikk (2) bekezdés b) pontjának együttes értelmezésekor nem foglalkozott az első lépcsővel, vagyis azzal, hogy a kivételeknek és korlátozásoknak különleges esetekre kell vonatkozniuk. Erre pedig egy lehetséges magyarázattal szolgálhat az az értelmezés, mely szerint ez a taxatív lista önmagában tartalmazza ezeket a különleges eseteket, vagyis az első lépcső eleve más értelmet kap az InfoSoc-irányelvben, mint a többi nemzetközi dokumentumban. ${ }^{585}$ A Bíróság viszont ennek elfogadásával arra a következtetésre jutna, hogy az irányelvben szereplő háromlépcsős teszt bizonyos eleme (vagyis az első lépcső) jogalkotói (és itt kifejezetten az uniós jogalkotót kell érteni) kötelezettséget ír elö, nevezetesen azt, hogy taxatív jelleggel határozza meg azokat az eseteket, amelyeket kivételnek vagy korlátozásnak tekint. Ezzel szemben viszont a másik két lépcső már a jogértelmezés kereteit jelöli ki. Nem szerencsés ez az értelmezés, ugyanis még bizonytalanabbá teszi a teszt alkalmazásának módszereit, összemosva azt, hogy a jogalkalmazóval vagy a jogalkotóval szembeni kötelezettséget állít. ${ }^{586}$

Helyesebb lett volna annak elemzése, hogy vajon konkrétan a magáncélú másolattal kapcsolatban az irányelvben megfogalmazott kritériumok olyanok-e, amelyek különleges helyzetre tekintik alkalmazandónak a kérdéses rendelkezést. Más szóval azt kellett volna megvizsgálni az EuB-nak, hogy , ,...] vajon kellöen korlátozott, szük, világos kereteket szab-e a felhasználók engedély nélküli magatartásai

${ }^{583}$ A C-302/10. sz. Infopaq International-ügyben 2012. január 17-én hozott végzés 56. pontja.

${ }^{584}$ Megjegyzést érdemel, hogy egyébként a tagállamok is szükíthetik a kivételek szabályait. Lásd ezzel kapcsolatban a C-117/13. sz. Eugen Ulmer-ügyben 2014. szeptember 11 -én hozott ítéletet.

${ }^{585}$ SIRINELLI (2007) p. 48-49. Vagyis ez azt is jelentheti, hogy amíg a nemzetközi szerzöi jog a nemzeti jogalkotó számára támasztott jól körülhatárolt szempontokat a kivételek bevezetésénél, addig lehet, hogy az irányelv nyomán ez a szabadság a nemzeti jogalkotóról a bíró kezébe háramlik. Pierre SIRINELLI elveti ennek a lehetősését, mivel ez az értelmezés a flexibilis bírói jogalkalmazás eredményeképpen gyengítené a jogbiztonságot.

${ }_{586} \mathrm{Az}$ Eugen Ulmer-ítéletben ugyan csak érintőlegesen vetődött fel az 5. cikk (5) bekezdésének alkalmazása. Mindössze annyiban vizsgálta a kérdést a Bíróság, hogy a német jogalkotó a háromlépcsős teszt elöírásainak megfelelő figyelembe vételével ültette-e át az irányelvet. Lásd a C-117/13. sz. Eugen Ulmer-ügyben 2014. szeptember 11-én hozott ítélet 48. pontja. 
II. rész A törvény által előírt közös jogkezelés, mint a kizárólagos jog korlátja II. fejezet A kizárólagos jog díjigényre korlátozása révén bevezetett közös jogkezelés

számára. ${ }^{, 587}$ Maga a Bíróság is alátámasztja egyébként azt, hogy mindhárom lépcsőt alkalmazni kell a kivételek és korlátozások esetében, ugyanis kifejti, hogy az irányelv 5. cikk (5) bekezdése csupán arra szorítkozik, hogy meghatározza az irányelv 5. cikkének (2) bekezdésében meghatározott, a többszörözés joga alóli kivételek és e jog korlátozásai alkalmazásának feltételeit, így többek között azt is, hogy különleges esetre kell vonatkozniuk. ${ }^{588}$ Ráadásul ezt az értelmezést alkalmazza további olyan döntéseiben is, amelyekben felmerült az 5. cikk (5) bekezdésének alkalmazása, vagyis a különleges esetet az alapügy történeti tényállásának fényében, a meghatározott kivételek és korlátozásokkal összefüggésben értelmezi. ${ }^{589}$

A második lépcső értelmezése, amely a rendes felhasználás sérelmének kizárását írja elő. Az ítélet 39. pontja az alábbiak szerint érvel a rendes felhasználás sérelmének kapcsán: „,...] annak elismerése, hogy e többszörözésre sor kerülhet jogellenes forrásból, elösegíti a hamis, illetve hamisitott müvek terjesztését, szükségszerüen csökkentve ezáltal a védelem alatt álló müvek értékesitési mennyiségét, illetve a védelem alatt álló müvekkel kapcsolatos jogi ügyleteket, és ekképpen sérelmesek azok rendes felhasználására." A bírói fórum tehát jól láthatóan egyfajta szűkítő aspektusból elemezte a második lépcsőt, azt a rendes felhasználás belső piaci összefüggéseire konkretizálva. Bár tény, hogy ez összecseng az irányelv harmonizációs céljával, szükséges lett volna az állítás részletesebb megvilágítása.

$\mathrm{Az}$ EuB nem tér ki arra, hogy hogyan kell értelmezni a hamis vagy hamisított müvek terjesztése fordulatot. ${ }^{590}$ Erre két lehetséges alternatíva képzelhető el, amelyek közötti választás a Bíróság részéről további kifejtést tett volna indokolttá: a „többszörözö személy általi továbbadás, illetve a jogellenes tartalmat felkínáló személy további jövőbeli jogsértéseinek az iránya." ${ }^{591}$ Az első verzió nyilvánvalóan túllép a magáncélú másolat keretein, ugyanis nem a többszörözési cselekményre, hanem a másolat ezt követően megvalósuló terjesztésére helyezi a hangsúlyt azt implikálva, hogy

\footnotetext{
${ }^{587}$ MEZEI - HAJDÚ (2014) p. 41.

${ }^{588}$ ACI Adam-ítélet, 25. pont.

${ }^{589}$ A Public Relations Association Agency-ügyben például a következő érvelés olvasható: „e tekintetben emlékeztetni kell elöször is arra, hogy mivel a képernyőn készült és a gyorsitótárban tárolt másolatok csak a weboldalak megtekintése céljából készültek, emiatt különös esetnek tekinthetők." A C-360/13. sz. Public Relations Association Agency-ügyben 2014. június 5-én hozott ítélet 55. pontja.

${ }^{590} \mathrm{Az}$ indokolás másik hibája, hogy a jogellenes forrás tekintetében sem nyújt eligazítást. Ennek részletes kifejtésére viszont nem e helyütt, hanem jelen fejezet 2. pontjában térünk ki, a magáncélú többszörözés fogalmi elemeinek konkrét vizsgálatakor.

${ }^{591}$ MEZEI - HAJDÚ (2014) p. 41.
} 
ez utóbbi cselekmény az, amely elsősorban ellentétes a háromlépcsős teszttel. ${ }^{592} \mathrm{~A}$ második verzióban pedig a terjesztés a ,jogellenes források” mint kínálati oldal megerősödésére utal. Ebben az esetben sem csupán a magáncélú többszörözés, hanem az annak alapjául szolgáló engedély nélküli felhasználás (terjesztés vagy nyilvánossághoz közvetítés) az, amely nem felel meg a második lépcsőnek. ${ }^{593}$

A Bíróság azáltal, hogy ily módon kitágította a magáncélú másolat értelmezési kereteit, szembe ment a háromlépcsős teszt kívánalmaival. Ez az értelmezés (bármelyiket is fogadjuk el a kettő közül helyesnek), ugyanis már nem biztos, hogy megfelel az első lépcsőnek. A két felhasználási cselekmény egybekapcsolása nem felel meg a különleges eset fogalmának sem abban az esetben, ha ez alatt az irányelv konkrét listáját értjük, sem pedig akkor, ha egyébként külön értelmezés tárgyává tesszük. Másrészt pedig a rendes felhasználás fogalmába is beleért olyan járulékos cselekményeket, amelyek nem az engedélymentes felhasználói magatartás körében értékelendőek. Ezzel a Bíróság gyakorlatilag a mellett foglal állást, hogy az engedélyhez nem kötött felhasználás a cselekményeket azok összefüggéseiben és dinamikájában vizsgálva $a b$ ovo sérelmes a müvek rendes felhasználására. Ez az értelmezés pedig kérdésessé teszi a korlátozásrendszer legitimitását, illetve azt, hogy a háromlépcsős teszt adekvát eszköz-e ennek keretek közé szorítására.

A Bíróság a harmadik lépcső értelmezését sem fejtette ki bőven. Mindössze arra utalt, hogy az alapügyben szereplő holland szabályozás ,,a szerzői jog jogosultjának indokolatlan károsulását eredményezheti. ${ }^{, 594}$ Ez abból adódik, hogy a jogosultnak nem kell türnie a jogainak a magáncélú másolatra vonatkozó kifejezett korlátozáson túlmenő megsértését. ${ }^{595}$ Vagyis a Bíróság arra hivatkozik, hogy „a korlátozások és kivételek szigorú értelmezésének követelménye nem teszi lehetővé kiterjesztő módon, széleskörüen a másolatkészítést, így ugyanis a szerzői jogosultak nem gyakorolhatnák kizárólagos engedélyezési jogukat." ${ }^{256}$ Ennek vizsgálatára viszont álláspontunk szerint sokkal inkább az első lépcső keretében lett volna alkalma a bíróságnak. E helyütt inkább

\footnotetext{
${ }^{592}$ Az Szjt. egyébként (két kivételtől eltekintve, ahol a szabad felhasználás magát a terjesztési jogot érinti) kifejezetten a szerzö engedélyéhez köti a szabad felhasználások keretében többszörözött példányok terjesztését. (Szjt. 40. §)

${ }^{593}$ MEZEI - HAJDÚ (2014) p. 41.

${ }^{594}$ ACI Adam-ítélet 40. pont.

595 ACI Adam ítélet 31. pont.

${ }^{596}$ MEZEI - HAJDÚ (2014) p. 42.
} 
arra kellett volna hangsúlyt helyezni - összhangban a szakirodalomnak a harmadik lépcsőre vonatkozó értelmezésével - hogy a magáncélú többszörözésre tekintettel díjazás jár a jogosultaknak. ${ }^{597}$ Az pedig külön hiányossá teszi az érvelést, hogy az EuB nem támasztja alá kellően a jogosultak jogos érdekeinek sérelmét, mindössze rögzíti ennek lehetséges bekövetkeztét.

\section{b) A teszt értelmezése nemzeti szinten}

A CPI, mint láttuk, nem is tartalmazza az első lépcsőfokot abból a megfontolásból, hogy a kódexben eleve felsorolásra kerülnek azok a különleges esetek, amelyek maguk a korlátozások. Ez egyben a teszt értelmezésének többféle lehetőségét is felveti. Az egyik álláspont szerint a háromlépcsős teszt az egyes kivételeknél támasztott feltételeken túli többletelemet tartalmaz, és a díjazás megfizetése nem jelenti azt, hogy a felhasználó egyébként jogszerüen jár el, ha ezek nem teljesülnek. Ez az értelmezés tehát konkrét felhasználási cselekmények mércéjéül teszi meg a háromlépcsős tesztet, jogbizonytalanságot teremtve ezzel a felhasználók számára: mivel az esetek megítélése a bíróság mérlegelésétől függ, az eltérő értelmezési lehetőségek miatt nem lehetnek biztosak abban, hogy jogszerüen járnak el. Ráadásul ez a felhasználások gazdasági, közgazdaságtani szempontú elemeit tekinti elsődlegesnek annak megítélésénél, hogy a felhasználási cselekmény sértette-e a szerző jogos érdekeit. A másik értelmezés szerint viszont a jogalkotó által kivételként felsorolt esetek eleve beleillenek a háromlépcsős teszt keretei közé, vagyis a bírónak nem kell esetről esetre vizsgálnia a feltételek meglétét. A teszt ebben az esetben általános mércéül szolgál. ${ }^{598}$

Az Szjt. 33. § (2) bekezdését következetesen alkalmazó egyedi bírósági döntés egyelőre még nem született. A Debreceni Ítélőtábla egy eseti döntésében hivatkozott ugyan a kérdéses rendelkezésre, azonban nem elemezte azt részletesen. Mindössze azt szögezte le, hogy a müszaki fejlődés révén a magáncélú másolás olyan mértékben elterjedt, ami bizonyíthatóan csökkenti a papíralapon többszörözhető művek, könyvek,

\footnotetext{
597 A Stichting de Thuiskopie-ügyben ezzel ellentétesen a díjazás bevezetését az EuB egyértelműen a harmadik feltétellel összefüggésben értelmezi. A C-462/09. sz. Stichting de Thuiskopie-ügyben 2011. június 16-án hozott ítélet 21-22. pontjai.

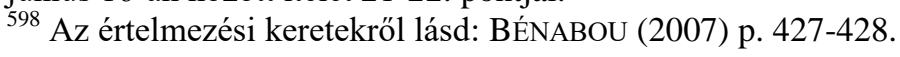


folyóiratok eladhatóságát, ami jövedelem kiesést, azaz károsodást jelent a szerzői jogosultaknak. Erre tekintettel került bevezetésre a reprográfiai díj jogintézménye is. ${ }^{599}$

Az SZJSZT-nek is volt alkalma értelmezni a tesztet, kifejezetten a magáncélú másolatok esetében a többszörözés forrásával kapcsolatban. Ennek megfelelően az első lépcső kapcsán az eljáró tanács is leszögezi, hogy a magáncélú másolat kivétele nem önmagában tekinthető különleges esetnek, hanem elsősorban a másolás jellege és célja transzformálhatja ezeket ilyen esetekké. ${ }^{600}$ Másrészt viszont az eljáró tanács megismételte, hogy a különleges esetnek általános társadalmi, jogpolitikai indokon kell alapulnia. $^{601}$ Mivel a lépcsőfokokat a maguk sorrendjében kell értelmezni, ezért elméletileg nem lenne szükség arra, hogy az eljáró tanács a többi lépcsőt is megvizsgálja, az elemzés teljességének érdekében azonban ezt mégis megteszi, bár az elemzés e téren kétség kívül lényegretörőbb, mint az első lépcső esetében. A magyar törvény kiegészítő jellegü feltételei kapcsán a szakirodalom rámutat arra, hogy azok következnek egyrészt az első lépcső tartalmi oldalából, másrészt a harmadik lépcső értékorientált jellegéböl. ${ }^{602}$

A teszt értelmezése kapcsán tehát, bármilyen szinten is tesszük ezt meg, levonható az a következtetés, hogy az abszolút érvényü, generálisan alkalmazható szempontokat a szakirodalom igyekszik megadni. A bírói gyakorlat viszont a tesztet a konkrét történeti tényállásra vonatkoztatva értelmezi. A két módszer között párbeszéd zajlik, a szakirodalomban megállapított szempontok hatnak a jogalkalmazói értelmezésre, a jogtudósok pedig az egyedi esetekből következtetve próbálnak általános megállapításokat tenni. Ahogyan maga a teszt szövege, úgy az értelmezése eltéréseket mutathat egyébként a szabályozás szintjétől is függően.

\section{A magáncélú többszörözésre tekintettel fennálló díjigény közös jogkezelése}

A háromlépcsős teszt gyakorlati alkalmazásának legszemléletesebb példája a magáncélú többszörözéssel kapcsolatos korlátozás. A magyar szerzői jog ezt törvényi engedélyként ismeri, tekintettel arra, hogy bár a 35. § (1) bekezdése a magáncélú többszörözésről, mint szabad felhasználási esetről rendelkezik, a 20. § (üres hordozó

\footnotetext{
${ }^{599}$ Debreceni Ítélőtábla Pf.I.20.220/2010/4.

${ }^{600}$ SZJSZT 17/2006. 35. pont.

${ }^{601}$ SZJSZT 17/2006. 31. pont.

${ }^{602}$ SZJSZT 17/2006. 39. pont.
} 
II. rész A törvény által előírt közös jogkezelés, mint a kizárólagos jog korlátja II. fejezet A kizárólagos jog díjigényre korlátozása révén bevezetett közös jogkezelés

dijj) és 21. § (reprográfiai díj) díjfizetést rendel a felhasználáshoz. A díjfizetési kötelezettséget viszont a jogalkotó nem közvetlenül a felhasználóra, hanem bizonyos meghatározott hordozók forgalmazóira, illetve készülékek üzemeltetőire telepíti. Az egyedi felhasználások azonosíthatatlansága miatt átalányrendszert dolgozott $\mathrm{ki}$ a jogalkotó, amely az Alkotmánybíróság megfogalmazásában érdekkiegyensúlyozó, érdekösszeegyeztető funkcióval bír a felhasználók és a szerzők között. Az átalányjellegből következik az is, hogy esetenként ugyan sérelmes lehet, ezen funkció miatt azonban összességében ésszerü és elfogadható megoldás. ${ }^{603}$

Franciaországban is - legalábbis az üreshordozó díjak, vagyis a „klasszikus” magáncélú másolat tekintetében - a magyarhoz hasonló megoldást léptettek életbe. Sőt, a magáncélú többszörözés különleges helyzetét kiválóan példázza, hogy 1985-ös bevezetésétől a DADVSI-törvény elfogadásáig ez volt az egyetlen díjfizetéssel egybekötött korlátozás. A fennálló szisztéma tesztjét - egyebek mellett a háromlépcsős tesztnek való megfelelést is - viszont az EUB végezte el, amelynek eredményeként több törésvonal is keletkezett az eddigi rendszerben.

A magáncélú másolat fogalmi elemeinek bemutatását (1. § pont) követően a díjigény gyakorlására vonatkozó közös jogkezelés ismertetése következik, ebbe a körbe bevonva a magyar reprográfiai többszörözésre vonatkozó közös jogkezelést is $(2$. $§$ pont).

\section{§1. A magáncélú többszörözzés fogalmi elemei}

A francia jogirodalom három kumulatív feltételben foglalja össze a magáncélú másolat CPI-ben található követelményeit. ${ }^{604}$ A másolatnak jogszerü forrásból kell származnia (la copie doit être réalisée à partir d'une source licite); magán, és nem közösségi használatra kell szolgálnia (la copie doit être destinée à l'usage privé et non à une utlisation collective); valamint a használónak a másolást végző személynek kell

\footnotetext{
603 124/B/2004. AB határozat III.2.1. pont.

${ }^{604}$ A szerzői jog körében a kódex az alábbi megfogalmazással él az L. 122-5. cikk $2^{\circ}$ pontjában: „les copies ou reproductions réalisées à partir d'une source licite et strictement réservées à l'usage privé du copiste et non destinées à une utilisation collective (...).” A szomszédos jogi jogosultak esetében a magáncélú másolatról a törvény külön rendelkezik, a feltételek azonban nem térnek el a szerzőt érintő magáncélú másolat körében meghatározottaktól. CPI L. 211-3. cikk: $2^{\circ}$ Les reproductions réalisées à partir d'une source licite, strictement réservées à l'usage privé de la personne qui les réalise et non destinées à une utilisation collective.
} 
II. rész A törvény által előírt közös jogkezelés, mint a kizárólagos jog korlátja II. fejezet A kizárólagos jog díjigényre korlátozása révén bevezetett közös jogkezelés

lennie (l'usage privé doit être celui du copiste). ${ }^{605}$ A magyar törvény is, ehhez hasonló módon körülírja a szabad felhasználásként meghatározott többszörözéssel szemben támasztott követelményeket. Az Szjt. 35. § (1) bekezdésének első mondata jelöli ki a legfontosabb kritériumokat, amelyekre vonatkozó pontosítást tartalmaz a szakasz többi része. Ennek megfelelően tehát „,természetes személy magáncélra a müröl másolatot készithet, ha az jövedelemszerzés vagy jövedelemfokozás célját közvetve sem szolgálja."

Az InfoSoc-irányelv 5. cikk (2) bekezdés b) pontja csak a kifejezés legelemibb fogalmi elemeire nézve tartalmaz követelményeket. Ennek ellenére logikusan adódik az a kérdés, hogy ha az ehhez kapcsolt méltányos díjazás az uniós jog önálló fogalmát képezi az EuB szerint (annak ellenére, hogy négy tagállam egyébként nem ültette át a vonatkozó irányelvi rendelkezést), akkor a magáncélú többszörözés is az-e? ${ }^{606}$ Ebbe az irányba mutató lépést jelent az ACI Adam döntés a többszörözés forrásának jogszerüsége követelményének kimondásával. Az irányelv ugyanis mindössze azt tartalmazza, hogy a magáncélú másolatra tekintettel bevezethető kivétel vagy korlátozás a természetes személy által, bármely hordozóra történő másolást jelentheti. A felhasználás célja pedig kereskedelmi célt közvetve sem szolgáló magáncél lehet.

Ahhoz, hogy szintetizálni tudjuk mind az uniós jog, mind pedig a nemzeti szerzői jogok megoldásait, három értelmezési keret vizsgálata tünik indokoltnak: a többszörözést végző személy [A) pont], a többszörözés célja [B) pont], és a többszörözés forrása [C) pont]. Hangsúlyozottan utalunk arra is, hogy a magyar megoldás sajátosságai miatt a reprográfia útján megvalósuló többszörözést is ezek között a keretek között tárgyaljuk.

\section{A) A többszörözést végzö személy}

Az InfoSoc-irányelv világosan kimondja, hogy a többszörözést végző személy csak természetes személy lehet. Emiatt kellett a magyar szerzői jogi törvényt is módosítani, ${ }^{607}$ korábban ugyanis, a német és osztrák megoldáshoz hasonlóan jogi

\footnotetext{
${ }^{605}$ CARRE (2015) p. 305.

${ }^{606}$ LUCAS (2011) p. 93.

${ }^{607}$ A 2003. évi CII. törvény hatálybalépése előtt az Szjt. 35. § (4) bekezdése az alábbi rendelkezést tartalmazta: „A célnak megfelelö módon és mértékig saját célra, valamint - vállalkozási tevékenységen kívüli - belső intézményi célra is készithető másolat, ha az jövedelemszerzés vagy jövedelemfokozás célját közvetve sem szolgálja, és

a) tudományos kutatáshoz szükséges,
} 
személyek is végezhettek saját célra többszörözést. ${ }^{608} \mathrm{Ez}$ pedig egyben azt is jelenti, hogy a haszonszerzési célból gazdasági tevékenységet nem végző jogi személyek, mint az alapítványok vagy egyesületek eleve ki vannak zárva a magáncélú másolat kedvezménye alól.

Az Szjt. hatályos szövege tehát az irányelvnek megfelelően egyfelől rögzíti a természetes személy követelményét, másfelől pedig a számítógépen, illetve elektronikus adathordozóra való másolás tekintetében egy speciális megszorítást is tartalmaz. Nem minősül ugyanis szabad felhasználásnak, ha a müről más személlyel készíttetnek másolatot számítógépen vagy elektronikus adathordozóra. ${ }^{609}$ A megszorítás független attól, hogy ez a megbízott természetes vagy jogi személy-e, akár egy barát, könyvtár, de adott esetben erre specializálódott vállalkozás lehet. ${ }^{610}$ A szabad felhasználás alóli kizárásuk voltaképpen arra vezethető vissza, hogy ezek a másolatok az eredeti példányokkal képesek versenyezni a piacon. ${ }^{611}$ A törvény viszont azt nem zárja ki, hogy magáncélú másolat keretében más személlyel analóg másolatot készíttessen a felhasználó. Nem szabad azonban megfeledkezni arról sem, hogy az Szjt. egyébként bizonyos, meghatározott körben jogi személyek számára is biztosítja a szabad másolás kedvezményét, ${ }^{612}$ amelyet az üres hordozó díj egyébként lefed. ${ }^{613}$

A CPI nem tartalmazza kifejezetten a természetes személyre való utalás kritériumát, sőt, a másolást végző személy (copiste) meghatározására nézve sem tartalmaz rendelkezést. A jogtudományra és a bírói gyakorlatra hárul tehát a fogalom tartalommal való megtöltése. A legpragmatikusabb meghatározás értelmében a „copiste” az, aki a másolatot előállítja. Ez egyfelől azt jelenti, hogy a másolást a

b) saját példányról archiválásként tudományos célra vagy a nyilvános könyvtári ellátás céljára készül, vagy

c) megjelent mü kisebb részéröl, illetve újság-vagy folyóiratcikkröl készül."

608 A terminológiai szabatosság, illetve a két esetkör elhatárolására való tekintettel ezt saját célú többszörözésként ismeri a szakirodalom. MEZEI (2006). MEZEI (2007).

${ }^{609}$ Szjt. 35. § (3) bek.

610 A Magyar folyóiratok tartalomjegyzékének kereshető adatbázisa (MATARKA) biztosít olyan szolgáltatást, amelyben a kiválasztott cikket digitalizálva (szkennelve) fizikai hordozón elküldik a felhasználónak.

${ }^{611}$ GYERTYÁNFY (2014) p. 254

${ }^{612}$ Szjt. 35. § (4), (5) és (7) bek. bizonyos szervezetek (nyilvános szolgáltatásokat nyújtó könyvtárak, iskolai oktatás célját szolgáló intézmények, muzeális intézmények, levéltár, közgyüjteménynek minősülő kép-, illetve hangarchívum) saját célú másolatai, az oktatási célú másolás, és a müsorszolgáltatók ún. „efemer” rögzítései kapcsán. Valamint az Szjt. 35.§ (8) bek., amely a 20-21. § elöírásait (azaz a díjfizetést) ebben az esetben is alkalmazandónak rendeli el.

${ }^{613} \mathrm{Ez}$ a gyakorlat nem ütközik semmilyen uniós irányelvi rendelkezésbe, viszont külön tanulmányt érdemelne annak megválaszolása, hogy az EuB joggyakorlata mennyiben alkalmazandó e tekintetben. 
másolatot használó természetes személynek magának kell elvégeznie. ${ }^{614}$ Vagyis nem tartozik a kivétel alá az a helyzet, amikor más személy (barát, családtag, vagy esetleg egy másoló cég) készíti a másolatot a természetes személy részére. Ahogyan az sem tekinthető másolónak, aki egy más által üzemeltetett digitális felvevőrendszert használ a többszörözés elvégzéséhez. ${ }^{615}$ Ez tehát gyakorlatilag azt eredményezi, hogy a másolást végző személynek mind a másolás tárgyát képező szerzői mü, mind pedig a másolást végző technikai eszköz felett rendelkeznie kell. ${ }^{616}$

Másfelől a megfogalmazás utalhat arra, hogy kézzel készített másolatról van szó. Ebben a tekintetben viszont álláspontunk szerint szükségtelen különbséget tenni kézzel vagy géppel készült, illetve analóg vagy digitális másolatról. ${ }^{617}$ Érdekes módon Henri DESBOIS az 1970-es évek végén született átfogó szerzői jogi kézikönyvében még akként érvel, hogy a magnetofonok által készített másolatok (vagyis a hagyományosan a magáncélú másolat körében értékelt felhasználási cselekmények) nem felelnek meg ezeknek a kritériumoknak. A törvény ugyanis a másoló személyes közreműködését igényli a másolat elkészítésénél, amely szerinte a készülék által készített másolat esetében hiányzik. A jogtudós ezen kívül hivatkozik a képzőművészeti alkotások esetében meglévő kivételre is, ugyanis a DEBOIS szerint a másolat célja ilyen esetekben is megegyezik az eredetivel, vagyis nem lehet szó magáncélú másolatról. Harmadrészt pedig a hangfelvételekről készített másolatok esetén a többszörözés nem a szerzői mủvekre, hanem az előadómüvészi teljesítményekre vonatkozik, a kivétel pedig szöveg, vagy kotta többszörözésére vonatkozik elsősorban. Ezek pedig nem férnek össze a kivétel szoros értelmezésére vonatkozó általános alapelvvel, amelyből az a következtetés vonható le, hogy a magnetofonok által készített magáncélú másolás nem tartozik a törvényi kivétel hatálya alá. ${ }^{618}$ DESBOIS is elismeri azonban, hogy nem lehet a háztartásokban megvalósuló összes többszörözést nyomon követni, és egyesével

\footnotetext{
${ }^{614}$ BERTRAND (2002) p. 62.

${ }^{615}$ TGI Paris, ord.réf. 6 août 2008, RIDA 2008, n ${ }^{\text {o } 217, ~ p . ~ 343 . ~ e t ~ p . ~ 247 . ~ o b s . ~ S i r i n e l l i, ~ P r o p r . ~ i n t e l l . ~ 2008, ~}$ n29, 427 obs. JM Bruguière.

${ }^{616}$ LATREILLE (2004) p.403.

${ }^{617}$ LUCAS - LUCAS - LUCAS-SCHLOETTER (2012) p. 357. CA Paris, 4ch 22 avr. 2005, RIDA 1/2006, p. 374, JCP G 2005, II, 10126, note Geiger, Comm. com. électr. 2005, comm 98, note Caron, Propr. intell. 2005 , p. 340, obs. A. Lucas et Sirinelli

${ }^{618}$ DESBOIS (1978) p. 311.
} 
engedélyeztetni, ő azonban, jobb híján, a felvevő készülékekre vagy a magnószalagokra kivetett, majd a szerzők között szétosztott adó bevezetését javasolta. ${ }^{619}$

\section{B) A többszörözés célja}

A felhasználást átfogóan magáncélú másolat (copie privée) névvel illetjük, amely a többszörözési cselekmény célhoz kötöttségét feltételezi. Az InfoSoc-irányelv ezzel összefüggésben azt a követelményt tartalmazza, hogy a felhasználást közvetve sem szolgálhat kereskedelmi célra. A tagállami szerzői jogok viszont pontosították ennek a fogalmát.

A magyar törvény kettős követelményt támaszt a másolás céljával kapcsolatban. Egyrészt az InfoSoc-irányelvben foglalthoz hasonlóan a követelményt oly módon fogalmazza meg, hogy a másolat jövedelemszerzés vagy jövedelemfokozás célját közvetve sem szolgálja. Ezt már korábban, a régi Szjt. is tartalmazta, ${ }^{620}$ és általánosan vonatkozik a 35. §-ban foglalt szabad felhasználási esetkörökként meghatározott többszörözésekre (tehát nem csak a magáncélú többszörözésre). A kritérium azt jelenti, hogy a másolásnak közvetlen gazdasági célja nem lehet. ${ }^{621} \mathrm{Az}$ Szjt. ezen kívül tartalmazza a „magáncél” követelményét is, ami konkretizálja a nem gazdasági célú felhasználások fogalmát. Ennek megfelelően a magáncél ,,[...] átfogja a magán és személyes felhasználási másolást, mindazt, ami a saját vagy a széles ismeretségi kör müélvezetét szolgálja. A további közvetett cél - tanulás, oktatás, szórakozás stb. - közömbös. "622 Nem értünk egyet a Nagykommentár szerzőinek álláspontjával azzal kapcsolatban, hogy a magáncélú többszörözésnek a széles ismeretségi kör javára kellene szolgálnia. Ez ugyanis egy olyan tág felhasználói kört jelent, amely azon túl, hogy sérelmes lehet a mű rendes felhasználására, nem felel meg a kivételek szüken értelmezésére vonatkozó általános alapelvnek. Egyetértünk viszont azzal, hogy a további közvetett cél (pl. tanulás, oktatás) közömbös, de csak abban az esetben, ha ez jövedelmszerzés vagy jövedelemfokozás célját közvetve sem szolgálja.

\footnotetext{
${ }^{619}$ U.o. p. 312.

${ }^{620}$ A szerzői jogról szóló 1969. évi III. tv. 18. § (1) bek.

${ }^{621}$ GYERTYÁNFY (2014) p. 253.

${ }^{622}$ U.o. p. 253.
} 
Tehát nem tartozik ide az az eset, ha pl. ellenszolgáltatás fejében, iskolarendszeren kívüli korrepetálás körében történik a másolás. ${ }^{623}$

A CPI plusz követelményként rögzíti, hogy a másolás közösségi célt nem szolgálhat, csak a másoló magán célját. Ez már a kivétel első, 1957. évi törvénybe iktatásánál fontos szerepet játszott. A közösségi célok kizárása, amely egy újabb szükítés a szükítésen belül, arra az indokra vezethető vissza, hogy a szerzői jogi törvény elfogadása előtt a magánjellegü összejövetelek a nyilvános előadás szempontjából problémákat szültek. A jogalkotó tehát ebből a példából kiindulva attól félt, hogy kifejezett kikötés nélkül elharapóznának egy egyesület, vagy kör által, a tagok javára végzett többszörözések, amelyek ily módon szerzői jogi kivételnek minősülnének. ${ }^{624} \mathrm{~A}$ magáncél viszont többféle indokot is magában foglalhat, közöttük akár vitatható módon a másoló szakmai céljainak elősegítését szolgáló célokat is. Antoine LATREILLE szerint a másolás pontos célja indifferens, szolgálhat a másoló szórakozására, de tanulás céljára, szakma gyakorlására is. ${ }^{625} \mathrm{~A}$ francia bírói gyakorlatban található viszont olyan ítélet, amely kifejezetten azt mondja ki, hogy a szakmai célú használat keretében végzett többszörözés a jogosultak engedélyéhez kötött. ${ }^{626}$

A magán és a közösségi cél elhatárolása tekintetében irányadó lehet a többszörözött példányszám, így például a kérdéses mü egy fejezetének nagyjából tíz példányban való többszörözése ez utóbbi célt valószínüsíti. ${ }^{627}$ A közösségi használatra a példányszám alapján való következtetést viszont fenntartással kell kezelni. Elképzelhető ugyanis, hogy egyetlen példány többszörözése sem felel meg a magáncélú másolat követelményének, amennyiben az nem a másoló saját használatára, hanem harmadik személy használatára történik; illetve 2-3 példány is illeszkedhet a törvényi tényállásba, ha a másoló azt különböző hordozókon tárolja. ${ }^{628}$

A bírói gyakorlatban az alakult ki, hogy a nyilvános előadás jogánál ismert kivételhez hasonlóan, a szűk családi körben, ${ }^{629}$ esetleg barátok körében ${ }^{630}$ történő

\footnotetext{
${ }^{623}$ Az oktatási célú szabad felhasználásról az Szjt. 35. § (5). bek. rendelkezik, az iskolai oktatás céljának fogalmát pedig az Szjt. 33. § (4) bek. határozza meg.

${ }^{624}$ DESBOIS (1978) p. 306-307.

${ }^{625}$ LATREILLE (2004) p. 403.

${ }^{626}$ Civ. 1re 20 janv. 1969: Gaz. Pal. 1969. 1. 217.

${ }^{627}$ Paris, 8. oct. 1982, RIDA janv. 1983, p. 138. RTD Com. 1983. 434 obs. Françon.

${ }^{628}$ BENSAMOUN (2008) p. 249-250.

${ }^{629}$ Paris, 4e ch., 22 avr. 2005, et Paris 4e ch. 4 avr. 2007.
} 
II. rész A törvény által előírt közös jogkezelés, mint a kizárólagos jog korlátja

II. fejezet A kizárólagos jog díjigényre korlátozása révén bevezetett közös jogkezelés

müélvezet még beleillhet a magáncélú többszörözés keretei közé, annak ellenére, hogy a jogirodalom egy része ennek lehetőségét elutasította. ${ }^{631}$ Ebbe a körbe viszont már nem férnek bele egy társaság részvényesei, ${ }^{632}$ ahogyan az sem, ha a másolást végző személy harmadik személyeknek adja kölcsön a másolatokat, mivel így felhagy a másolat feletti rendelkezési jogával, vagyis az a továbbiakban már nem saját használatra szolgál. ${ }^{633}$ Olyan ítélet is ismert, amely a magáncélú felhasználás kereteinek túllépése miatt állapított meg jogsértést abban az esetben, amikor a felhasználó az internetre feltöltötte a másolatot. ${ }^{634}$

\section{C) A többszörözés forrása}

A többszörözés forrása az egyik legvitatottabb kérdése a magáncélú másolásnak. Az analóg világban is problémaként vetődhetett fel, meghatványozódását viszont egyértelműen a fájlcserélés térhódításának köszönhetjük. A 2000-es évek elején indult egy olyan diskurzus, amelynek központi kérdése annak megvilágítása volt, hogy vajon a nem jogszerü forrásból származó többszörözés beleillik-e a korlátozás kedvezményes rezsimjébe. Az irányelv tág mozgásteret biztosító szabálya egyébként azzal az eredménnyel járt, hogy eltéröen ültették át a tagállami jogokba, ${ }^{635}$ ideértve azt is, hogy egyes nemzeti jogokban már az átültetés során feltételül szabták a többszörözés forrásának jogszerüségét. ${ }^{636} \mathrm{Az}$ alapvetően elfogadott válasz a többszörözés forrása jogszerüségének a kérdésre egy jogi maxima segítségül hívásával könnyen levezethető. A ,nemo plus iuris” elv szerint ugyanis a jogtalanra jogosat alapítani nem lehet. ${ }^{637} \mathrm{~A}$ bírói jogértelmezésben fellelhető ezzel kapcsolatos bizonytalanságokat az okozza, hogy

\footnotetext{
${ }^{630}$ Montpellier, 3e ch corr. 10 mars 2005 SACEM c/ Aurélien D: JCP G 2005, II, 10078, note Caron; JCP E 2005, no 1216, § 4, obs. Pignatari; JCP E 2006, no 1195, § 8, obs. Vivant; D. 2005, jurispr. p. 1294, note Kessler; D. 2005, pan. p. 1488, obs. Sirinelli; Propr. intell. 2005, no 15, p. 165, obs. Sirinelli; RLDI 2005 mars, no 86 p. 21, obs. Costes; Rev. Lamy dr. aff. avr. 2005, no 5086, obs. Costes; Légipresse 2005, no 222, III, p. 120 note Wekstein; Comm. com. électr. 2005, comm. 77, note Caron.

${ }^{631}$ Pollaud-Dulian (2012) p. 89.

${ }^{632}$ Paris, 4e ch., 1er oct. 1990, D. 1990. IR. 235; RIDA 1991, n 149, 206, obs. Kéréver. Ezzel ellentétes következtetésre jutott viszont a bíróság abban az esetben, amikor kutatók egymás közötti belső hálózatán közzétett másolatokat a magáncélú másolat körébe utalt. TGI Paris, réf. 10 juin 1997: D. Affaires 1997. 1156: D. 1998, 621 note Edelman; JCP 1997 II. 22974, obs. Olivier; Expertises, août 1997, p. 283.

${ }^{633}$ Cass. crim., 4 janv. 1991 : JurisData ${ }^{\circ} 1991-003606$.

${ }^{634}$ A bíróság tehát érdekes módon nem azzal érvelt, hogy a lehívásre történő nyilvánossághoz közvetítés jogát sértette meg a felhasználó (sőt, leszögezte, hogy sugárzást a felhasználó nem valósított meg), hanem azt mondta, hogy a felhasználás túllépte a magáncél kereteit. TGI Paris, réf., 5 mai 1997, Queneau: RIDA oct. 1997. p. 265; JCP 1997. II. 22906, note Olivier; Expertises, juin-juill. 1997, p. 219.

${ }^{635}$ WESTKAMP (2007) p. 17.

${ }^{636}$ Ilyen tagállam Németország, Finnország, Svédország, Olaszország, Portugália, Spanyolország.

${ }^{637}$ MEZEI (2012b) p. $168-169$.
} 
a jogszabályszövegek több esetben ezt nem támasztják kifejezett feltételként a magáncélú másolás elé. Erre alapozva mondta ki a Semmítőszék a Mulholland Driveügyben, hogy a kivétel a forrás jogszerüségétől függetlenül ítélendő meg. ${ }^{638}$ Ezzel szemben a Semmítőszék büntető kollégiuma már kifejezetten a forrás jogszerüségének szükségessége mellett foglalt állást. ${ }^{639}$ A vita végére a CPI 2011. évi módosítása ${ }^{640}$ tett pontot, a törvényszöveg részévé téve a forrás jogszerüségének követelményét. Korábban ugyanis az irányelvet átültető DADVSI-törvény megfogalmazása nem volt eléggé pontos, ami miatt a kivételek körébe lehetett vonni olyan felhasználási cselekményeket is (tipikusan a fájlcserélés körében megvalósuló cselekményeket), amelyek egyébként a kizárólagos engedélyezési jog alá esnének. ${ }^{641}$ Az új rendelkezés alapján viszont nem teljesen egyértelmü, hogy ez a követelmény az összes szerzői jogi kivételre vonatkozik-e, vagy csak a magáncélú többszörözésre. A cikk rendszertani értelezése ugyan ezt a második értelmezést támogatja, más álláspont szerint viszont nem teljesen elvetendő ennek alkalmazása a többi kivételre sem. ${ }^{642}$

Az SZJSZT fentebb már idézett szakvéleményében a jogellenes forrás kapcsán leszögezte, hogy a többszörözés ilyen eredetének megengedése ellentmondana a különleges eset feltételeinek. ${ }^{643}$ Más jogirodalmi források viszont ezeket a másolatokat is a magáncélú másolat körében kívánják elhelyezni. ${ }^{644} \mathrm{E}$ mögött a felfogás mögött két indok húzódik meg. Az egyik a kialakított díjfizetési rendszer egységessége megtartásának az igénye. Praktikus okokból egyszerübb (még ha dogmatikailag nem is feltétlenül helyes) az összes természetes személy általi magáncélból megvalósuló felhasználást egy kalap alá venni. Másrészt pedig indoka az egyéni felhasználók védelmének jogpolitikai indoka: hiszen ilyen módon csak müvet a nyilvánosság számára elérhetővé tévő személy sértené meg a szerzői jogokat (és kapcsolódhat a cselekményhez szankció), a müről másolatot készítő személy viszont nem.

Az Európai Unió szintjén is úgy tünik, nyugvópontra kerül a kérdés az ACI Adam-ítélet után. Az EuB kifejtette ugyanis, hogy „, ha a tagállamoknak joga volna

\footnotetext{
${ }^{638}$ Civ. 1re, 28 février 2006, Studio Canal et Sté Universal Pictures et al. c/ UFC Que Choisir et Perquin, dit „Mulholland Drive”, $\mathrm{n}^{\circ}$ 05-15.824

${ }^{639}$ Arrêt du 30 mai 2006.

${ }^{640}$ Loi n ${ }^{\circ} 2011-1898$ du 20 décembre 2011 relative à la rémunération pour copie privée.

${ }^{641}$ DESURMONT (2006) p. 177.

${ }^{642}$ LUCAS (2012) p.238-239.

${ }^{643}$ SZJSZT 17/2006. 36. pont.

${ }^{644}$ GYERTYÁNFY - FALUDI - KABAI - SZINGER - TÓTH (2005) p. 130.
} 
II. rész A törvény által előírt közös jogkezelés, mint a kizárólagos jog korlátja II. fejezet A kizárólagos jog díjigényre korlátozása révén bevezetett közös jogkezelés

eldönteni, hogy elfogadnak-e olyan jogszabályt, amely lehetövé teszi, hogy a magáncélú többszörözésre jogellenes forrásból is sor kerülhessen, ez egyértelmüen a belsö piac megfelelö müködésének veszélyeztetését eredményezné."645 Ezzel pedig egyértelmüen a szorosabb szerzői jogi harmonizáció felé igyekszik a tagállamokat terelni a Bíróság, hiszen ez implicit módon azt is jelenti, hogy a magáncélú többszörözés is az „uniós jog önálló fogalma". ${ }^{646} \mathrm{Az} \mathrm{EuB}$ viszont mintha tartózkodna végigjárni a megkezdett ösvényt, és a magáncélú másolat fogalmával kapcsolatos harmonizációs törekvéseket szorosabbá tenni. A Copydan Båndkopi-ügyben, bár a nemzeti bíróság kifejezetten rákérdezett a jogellenes forrásból megvalósuló többszörözés értékelésére, az EuB az ACI Adam-ítéletben foglaltakon túli magyarázattal nem szolgált, mindössze azt pontosította, hogy jogellenes forrásként azt tekinti, amely müveket a jogosultak engedélye nélkül bocsátottak a nyilvánosság rendelkezésére. ${ }^{647}$ A főtanácsnoki véleményből az tünt ki, hogy mivel a kérdést előterjesztő bíróság nem pontosította mit ért ,,jogellenes forrás" alatt, a kérdésre nem adható válasz. ${ }^{648}$

Viszont a Bíróság adós maradt annak meghatározásával, hogy mit ért jogellenes forrás alatt, az alapügy tényállásában ugyanis semmi ilyen konkrét forrás nem szerepelt. Az alapügy felperese is azt kifogásolta, hogy a holland szerzői jogi törvény nem tett különbséget az üreshordozó-díj megfizetése kapcsán a többszörözés forrása szerint. A jogellenesség viszont a magáncélú többszörözéssel összefüggésben nem általános, hanem konkrét kategória, amely nagyban függ a nemzeti jogszabályok által biztosított keretektől is. Jogellenes forrásból származhat a többszörözés akkor, ha az a jogosult engedélye nélkül került terjesztésre vagy nyilvánossághoz közvetítésre. De előfordulhat olyan eset is, amikor a többszörözés csak a másoló tulajdonában lévő müpéldány esetén lehetséges, olyankor viszont nem, amikor az csak a birtokában van. A jogellenesség tehát a törvény ilyen irányú rendelkezése esetén megállapítható lenne például egy baráttól kölcsönkapott CD-lemez lemásolása esetén is. Ez a kérdés felvetődött a Copydan-ügyben is. A Bíróság úgy ítélte meg, hogy a kérdés nem képezi uniós harmonizáció tárgyát, mivel a díjazás meghatározásának módjára terjed ki. A

\footnotetext{
${ }^{645}$ ACI Adam-ítélet, 35. pont.

${ }^{646} \mathrm{Az}$ EuB ezt eredetileg a Padawan-döntésben a magáncélú többszörözésre tekintettel fizetett méltányos díjazás tekintetében mondta ki. Részletes elemzését lásd a következő (§2.) pontban.

${ }^{647}$ Copydan Båndkopi-ítélet, 75-79. pontok.

648 A Copydan Båndkopi-ügyben ismertetett fötanácsnoki indítvány 81-85. pontjai. Hasonló kritika az ACI Adam-üggyel kapcsolatban a Bíróság szemére is vethető. Erről lásd részletesen: MEZEI - HAJDÚ (2014) p. 32-47.
} 
II. rész A törvény által előírt közös jogkezelés, mint a kizárólagos jog korlátja

II. fejezet A kizárólagos jog díjigényre korlátozása révén bevezetett közös jogkezelés

tagállamok mozgástere tehát megmarad erre vonatkozó szabályozás kialakítása tekintetében. ${ }^{649} \mathrm{~A}$ francia jogirodalom is jogszerű forrásként tekint erre az esetre, mivel a magáncélú másolat megvalósulhat a mű feletti időleges rendelkezési jog (pl. bérlet vagy haszonkölcsön) gyakorlásával; a lényeg, hogy a forrásmü a jogosultak engedélyével váljon hozzáférhetővé. ${ }^{650}$ A felhasználás jogszerüségét a szerződéses kapcsolat, illetve az ennek fejében történő díjfizetés alapozza meg. ${ }^{651}$

\section{§2. A közös jogkezelés müködése}

Az InfoSoc-irányelv átültetése mindkét vizsgált tagállamban hasonló módon valósult meg, hiszen az egyedi másolatok beazonosításának nehézsége, illetve egy fenntartható díjfizetési rendszer miatt átalánydíjrendszert vezettek be. Az EuB folyamatosan csiszolódó joggyakorlata ${ }^{652}$ miatt viszont a tagállamok egyre több, a harmonizációból fakadó szempontot kötelesek figyelembe venni a díjrendszer fenntartása során. Mindezek miatt szükségesnek tartjuk a korábbi elemzési keretek megtartását, és az átalányrendszereknek az uniós jog fényében való elemzését. Erre annál is inkább igény mutatkozik, mivel Franciaország a Padawan-döntést követően jelentősen módosította a díjfizetés korábbi rendszerét.

A díjfizetési rendszer nagyfokú hasonlósága (vagyis a díj fizetésére mindkét tagállamban a gyártó vagy a forgalmazó köteles) ${ }^{653}$ mellett természetesen eltérések is adódnak, amelyek nem kizárólag a díjjal terhelt hordozók körét, vagy a díj pontos mértékét érintik. A közös jogkezelés szempontjából ugyanis sokkal inkább jelentősége van annak, hogy Magyarországon maguk a közös jogkezelők azok, amelyek a díjat a jogdíjközleményben megállapítják. Ezzel szemben Franciaországban ezt egy külön bizottság végzi, amelynek elnöke az állam egy képviselője, tagjai pedig felerészben a jogosultak képviseletében, negyed részben a gyártók vagy forgalmazók képviseletében,

\footnotetext{
${ }^{649}$ A C-463/12. sz. Copydan Båndkopi-ügyben 2015. március 5-én hozott ítélet 79. pontja, valamint 8091. pontjai.

${ }^{650}$ LATREILLE (2010) p. 8.

${ }^{651}$ LATREILLE (2004) p.403.

${ }^{652}$ Erröl lásd például: CARON (2013b) p. 23-24.

${ }^{653}$ Szjt. 20. § (2) bek., CPI L. 311-4. cikk (1) bekezdés „La rémunération prévue à l'article L.311-3 est versée par le fabricant, l'importateur, ou la personne qui réalise des acquisitions intracommunautaires, au sens du $3 o$ du I de l'article 256 bis du code général des impôts, de supports d'enregistrements utilisables pour la reproduction à usage privé d'oeuvres, lors de la mise en circulation en France de ces supports."
} 
negyed részben pedig a fogyasztók képviseletében járnak el. ${ }^{654}$ A magyarnál jelentősebb állami részvétel, illetve a külön bizottság felállítása a díjat eltávolítja a közös jogkezelés általános elveitől, és egyfajta hatósági árhoz hasonló megoldáshoz teszi hasonlatossá. Ez egyrészt aláhúzza a kizárólagos jogok gyakorlása körében, illetve a szerzői jogi korlátozások ellentételezése kapcsán fennálló különbséget, egyúttal viszont némileg megfosztja szerzői jogi jellegétől a díjat. A díj beszedésével és felosztásával pedig (a jogosultak nevében) a közös jogkezelő szervezeteket bízza meg a törvény. ${ }^{655} \mathrm{E}$ helyütt kell utalni arra is, hogy Magyarországon az üreshordozó díjak is jogdíjközlemények, tehát az elfogadásukkal kapcsolatban korábban ismertetett szabályozás ezekre is vonatkozik, illetve általános szerződési feltételként funkcionálnak (hiszen a díj fizetésére kötelezettek tekintetében alkalmazza őket a szervezet) annak ellenére, hogy nem felhasználási szerződések (és így az ezekre vonatkozó általános szabályok alkalmazására nem is kerülhet sor).

A közös jogkezelés müködése körében szólni kell egyfelől a felhasználás ellentételezéseként fizetett díjról [A) pont], tekintettel arra, hogy az InfoSoc-irányelv a korlátozás bevezetését mind az audiovizuális, mind pedig a reprográfiai úton megvalósuló többszörözés tekintetében „méltányos díjazás” megfizetéséhez köti. ${ }^{656}$ Másrészt pedig a díj beszedése és felosztása során alkalmazott elveket célszerü megvizsgálni, különös tekintettel arra, hogy a díjazás egy része általában közvetett módon, kulturális és szociális támogatások révén jut el a jogosultakhoz [B) pont].

\section{A) A felhasználásért fizetendö dij}

A felhasználásért fizetendő díj célja, hogy a felhasználás tömeges jellegére tekintettel visszaállítsa a szerzők és felhasználók között megbomlott egyensúlyt. A szerzői jogi szabad felhasználással vagy kivétellel összekapcsolva a díjazás bevezetése tehát tulajdonképpen szükíti a teljesen szabad, díjtalan magáncélú másolási eseteket,

\footnotetext{
${ }^{654}$ CPI L. 311-6. cikk (1) bekezdés „Les types de support, les taux de rémunération et les modalités de versement de celle-ci sont déterminés par une commission présidée par un représentant de l'État et composée, en outre, pour moité, de personnes désignées par les organisations représentant les bénéficiaires du droit à rémunération, pour un quart, de personnes désignées par les organisations représentant les fabricants ou importateurs des supports mentionnés au premier alinéa du précédent article et, pour un quart, de personnes désignées par les organisations représentant des consommateurs." ${ }^{655}$ CPI L. 311-6. cikk (1) bekezdés „La rémunération prévue à l'article L. 311-1 est percue pour le compte des ayants droit par un ou plusierus organismes mentionnés au titre II du présent livre.

${ }^{656}$ InfoSoc-irányelv, 5. cikk (2) bek. a) és b) pontok.
} 
amelyeket az Szjt. 35. § (1) bekezdése szabályoz, ${ }^{657}$ illetve amelyek vonatkozásában a CPI L. 122-5. cikke alkalmazható. A magyar Alkotmánybíróság „Üreskazettahatározatában" megállapította, hogy a díjazás annak átalányjellege miatt esetenként sérelmes lehet ugyan, érdekkiegyenlítő funkciója folytán azonban összességében ésszerü és elfogadható megoldás. ${ }^{658}$

Ebből a megfontolásból rendelkezett az uniós jogalkotó is a korlátozás mellé bevezetendő „méltányos díjazásról”. Ez azzal is járt az EuB értelmezésében, hogy ha a felhasználási cselekmény maga nem is, de a díjazás az „uniós jog önálló fogalma”, vagyis a tagállamokban egységesen értelmezendő fogalom. Ez amellett, hogy nem elhanyagolható kérdéseket vet fel a tagállami és az uniós terminológia összeegyeztethetősége kérdésében [a) pont], a díj megfizetése [b) pont] és meghatározásának egyéb szempontjai [c) pont] kapcsán is újabb szempontokkal gazdagította a fennálló tagállami rendszerekkel kapcsolatos elvárásokat.

\section{a) Terminológiai problémák}

Az EuB a Padawan-döntésben leszögezte, hogy a méltányos díjazás fogalma az uniós jog önálló fogalma, amelyet azokban a tagállamokban, amelyek átültették az irányelv ezen rendelkezését, egységesen kell értelmezni. Az átültetés fakultatív jellege és a szándékos minimumharmonizáció miatt viszont a fogalom tartalmi elemei nem meghatározottak (vagyis tagállami hatáskörben van a másolatok elkészítésére alkalmas eszközök és hordozók megállapítása, illetve a hátrány mértéke, az esetleges minimális hátrány fogalmának bevezetése vagy elvetése, a díj mértéke és meghatározásának módja), ${ }^{659}$ ami nehezíti az egységes értelmezés kialakítását. ${ }^{660} \mathrm{Az}$ EuB emellett kiemelte, hogy a tagállamok maguk határozhatják meg a méltányos díjazás formáját, finanszírozásának módozatait, beszedését, valamint mértékét, ${ }^{661}$ ami a harmonizáció ellen hat.

\footnotetext{
${ }^{657}$ GYERTYÁNFY (2014) p. 170.

658 124/B/2004. AB végzés, 2.1. pont.

659 KRETSCHMER (2011) p. 10. Frissebb összehasonlító elemzés az egyes jogdíjrendszerekről: WIPO International Survey on Private Copying, 2013, http://www.wipo.int/export/sites/www/freepublications/en/copyright/1037/wipo_pub_1037_2013.pdf ${ }^{660}$ POllaud-Dulian (2010) e-verzió, 2. bekezdés.

${ }^{661}$ Padawan-ítélet, 37. pont.
} 
Az egységes terminológia kialakítását az a tényező is veszélyezteti, hogy a tagállamokban más-más elnevezést használtak az irányelv átültetése előtt már létező díjazás megnevezésére $[\alpha$ ) pont]. Az elnevezés sokszor tükrözi azt a koncepciót is, amely a méltányos díjazás tagállami felfogásának egyes jellemzőit, vagyis leginkább azt, hogy mely elemek alapozzák meg a díjazás indokoltságát [ $\beta$ ) pont].

\section{a) Az elnevezés nehézségei}

Az elnevezés kapcsán kialakult nehézségek arra vezethetőek vissza, hogy a tagállamokkal eltérő névvel, és e mögött részben eltérő koncepcióval illetik az uniós jog önálló fogalmaként meghatározott méltányos díjazást. Így a kifejezések tartalma bizonyos fokig elmosódik, ezek egymásnak való megfeleltethetősége kérdésessé válhat.

\section{A méltányos díjazás az uniós jog önálló fogalma}

Az InfoSoc-irányelv által tágan megvont nemzeti mozgástér, illetve az EUB hezitálása az egységes kritériumrendszer felállításával kapcsolatban szembekerül a Bíróságnak az InfoSoc-irányelv értelmezése kapcsán eddig zsinórmértékül szolgáló két alapkövetelményével, nevezetesen azzal, hogy a szerzői jogi szabályok konzisztenciáját és a belső piac müködését megtartsa. Sőt, szembekerül magával a Padawan-ügyben alkalmazott érvelési módszerrel is. Annak alátámasztására ugyanis, hogy a méltányos díjazás fogalma az uniós jog önálló fogalma, a Bíróság felhozza, hogy ellentétes lenne az irányelvvel annak olyan értelmezése, amely lehetővé teszi a tagállamok számára, hogy a méltányos díjazás fogalmát, mint alapvető elemet, magában foglaló kivétel bevezetése esetén ennek paramétereit szabadon, inkoherens és harmonizációt nélkülöző módon, tagállamonként eltérően határozzák meg. ${ }^{662}$ Vagyis a tagállamok számára biztosított széles lehetőség mellőzésével tulajdonképpen a Bíróság a minél kiterjedtebb egységesítés irányába törekedne, igyekszik befoltozni az InfoSoc-irányelv hiányosságait, ám egyúttal fél ingoványos talajra tévedni a tagállami jogok különbségei miatt. ${ }^{663}$ Ez a megfogalmazás kicsit olyan, mint a népmesei fordulat: a testület hozott is ajándékot, meg nem is. A népmesével ellentétben viszont, ahol az okos lány remekül megoldotta a feladványt, az EuB ezzel saját maga számára állított csapdát, amennyiben az ezt követő döntéseiben tartózkodik a pontosabb fogalmi elemek meghatározásától.

\footnotetext{
${ }^{662}$ Padawan-ítélet, 36. pont, ACI Adam-ítélet, 49. pont.

${ }^{663}$ LUCAS-SCHLOETTER (2015) p. 15
} 
Az eltérő mértékü díjazás bevezetése belső piacon aránytalanságokat eredményezhet. Például Szlovákia és Magyarország viszonylatában az előbbi ország által alkalmazott feltűnően alacsony díjai ${ }^{664}$ miatt felvetődik az a kérdés, hogy a szlovák díjak ilyen meghatározása vajon megfelel-e a méltányos díjazás követelményének, amellett persze, hogy a felhasználók árérzékenységét kihasználva az olcsóbb szlovák hordozók vásárlását ösztönzi. Ez a bizonytalansági tényező vezetett el egyébként az Opus-ügyben hozott előzetes döntéshez is. A Németországban bejegyzett cég ugyanis sem a székhelye szerinti tagállamban, sem pedig Hollandiában nem fizetett díjat, kihasználva a tagállami jogszabályok hézagait, illetve a közös jogkezelő szervezetek koordinációja közötti hiányt. Miután viszont a Bíróság kijelentette, hogy a díjat a felhasználó lakóhelye szerinti tagállamban mindenképpen meg kell fizetni, az Opus a további bonyodalmak elkerülése végett röviddel az ítélet meghozatalát követően bejelentette, hogy holland felhasználók számára ezentúl nem értékesít üres hordozókat. ${ }^{665}$

A Padawan-ügyben a bíróság objektív kritériumot állapított meg a díjfizetés alapjául, mivel az üres hordozók magáncélú másolat elkészítésére való puszta alkalmassága jogdíjfizetést keletkeztet. ${ }^{666}$ Ebből következően tehát nem kell vizsgálni azt, hogy a hordozókat ténylegesen magáncélú másolásra használták-e: mindegy, hogy saját müvek, közkinccsé vált müvek, jogellenes vagy jogszerü forrásból származó művek többszörözése történik meg a hordozón. ${ }^{667}$

A Bíróság tulajdonképpen igazolta az átalánydíjak alkalmazhatóságát. Ez „[m]üködését tekintve egyfajta kötelező felelősségbiztosításhoz hasonlítható, ahol bizonyos eszköz vásárlói, használói azért (a ténylegesen nem biztos, hogy bekövetkező) lehetőségért fizetnek, hogy a megvásárolt eszköz révén szerzői jogi védelem alatt álló művet fognak felhasználni." 668 Ez a gondolkodásmód nem idegen a szerzői jog logikájától, ugyanis maga a felhasználási engedély is a felhasználás lehetőségét hordozza magában. Ennek megfelelően a tagállamok a számukra biztosított rendkívül

\footnotetext{
${ }^{664}$ A Visegrad Investments tanulmányában közölt táblázat alapján 2012-ben egy DVD-R lemez 0,75 euróban megállapított egységára mellett adíj mértéke Szlovákiában 0,03 euró, míg Magyarországon 0,51 euró volt. Lásd: VISEGRAD INVESTMENTS (2013) p. 78.

665 VAN LOON (2011) p. 854.

${ }^{666}$ BONADIO - CANTORE (2011) p. 262.

${ }^{667}$ CARON (2011b) e-verzió, 6. bekezdés.

${ }^{668}$ FODOR (2009) p. 81.
} 
széles mérlegelési jogkörön belül szabadon határozhatják meg azt, hogy a hordozóknak mely körét terhelik jogdíjfizetéssel. A felhasználási módok miatti különbségtétel azonban nem feltétlenül áll összhangban az átalánydíj-rendszerrel. Söt, ily módon elörevetíthető, hogy a felhasználók egyéb esetekben is hivatkozni fognak a díj megfizetésének megkülönböztetés-mentes mivoltára, szétszabdalva így a tagállamok többségében fennálló rendszert. ${ }^{669} \mathrm{Az}$ első ilyen esetre nem is kellett sokáig várni. Az ACI Adam-ügy jelentősége azért is nagy, mert a Bíróság az átalánydíjak alkalmazásának megtörése mellett érvelt a többszörözés forrása szerinti distinkció bevezetésével.

\section{A díjazás eltérő használata}

A tagállamokban kialakult szóhasználat (és a mögötte meghúzódó tartalom) gátját képezi annak, hogy a méltányos díjazás uniós jogi fogalma egy az egyben megfeleltethetö legyen valamely nemzeti rezsimnek. A Padawan-döntésben a főtanácsnok is utalt arra, hogy a spanyol szerzői jog részét képezte „remuneración” elnevezéssel a magáncélú másolat fejében fizetendő ellentételezés, amelyet az irányelv átültetését követően, annak szóhasználatát átvéve a „compensación” kifejezéssel illettek. A két kifejezés egymás mellett létezését mi sem bizonyítja jobban annál, hogy a francia szerzői jogi terminológia is a „rémunération"670 kifejezést használja (rémunération pour copie privée), illetve ez a nemzetközi szerzői jog bevett szóhasználata is. ${ }^{671}$

Az irányelv ettől eltérő fogalomalkotása tehát értelmezhető akként, hogy ez az önálló uniós szerzői jogi terminológia kialakítása érdekében tett megkülönböztetés, amely hủen tükrözi, hogy egy speciális uniós jogi jogintézményről van szó. A „compensation” kifejezés ugyanis kompromisszumos megoldásként - a kontinentális szerzői jogi hagyományokkal rendelkező tagállamok és az Egyesült Királyság és

\footnotetext{
${ }^{669}$ MineRO (2011) p. 469.

${ }^{670}$ A kifejezés első jelentése általános értelemben minden, pénzben vagy hasonló módon meghatározott szolgáltatás, amelyet egy munka vagy egy szolgáltatás ellenértékeként adnak. CoRNU (2007) p. 799, „Rémunération”. Mivel a szerzői jog esetében nincsen szó munkáról, hanem pusztán a mü felhasználásának ellenértékéről, Nicolas BINCTIN szerint helyesebb lenne a díjat „redevance pour copie privée" kifejezéssel illetni. BINCTIN, Nicolas: Rémunération pour copie privé, J. Cl. Propriété littéraire et artistique, Fasc. 1510. A magyarra leginkább ,járadék” szóval fordítható „redevance” kifejezés viszont egyik értelmében adójogi kategóriaként használatos, bár az általánosabb fogalom minden, bizonyos időszakonként rendszeresen fizetendő díjat magában foglal. CORNU (2007) p. 777-778, „Redevance”.

${ }^{671}$ BUE 11 bis cikk (2) bekezdés és 13. cikk (1) bekezdés.
} 
Írország között a méltányos díjazás kérdésében meglévő ellentét feloldása érdekében került elfogadásra. ${ }^{672}$

Ezt támasztja alá az az EuB által helyesen értelmezett körülmény is, hogy az irányelv szóban forgó rendelkezése a tagállami jogokra kifejezett utalást nem tartalmaz. $\mathrm{Az}$ EuB érvelését csak látszólag erősíti a SENA-üggyel ${ }^{673}$ vont párhuzam, mivel ebben az ügyben az irányelvben szereplő, magyar nyelvre szintén „méltányos díjazásként” fordított „rémunération équitable” kifejezésről került megállapításra, hogy az uniós jog önálló fogalmát képezi. ${ }^{674}$ Így viszont az igényel további tisztázást, hogy hasonló értelemben használt két fogalom között, amelyek mindketten az uniós jog önálló fogalmai, milyen különbségek fedezhetőek fel.

Ezt az ellentétet látszólag feloldja a Bíróság Luksan-ügyben hozott döntése. Kimondta ugyanis, hogy a szóhasználatbeli eltérés ellenére a „rémunération” kifejezéssel illetett díjazás fogalom célja is abban áll, hogy ellentételezést biztosítson a szerzők számára, mivel ez is a nekik okozott hátrány esetén kerül alkalmazásra. ${ }^{675}$ Álláspontja szerint ráadásul az InfoSoc-irányelv elfogadásakor az uniós jogalkotó megtartotta a szellemi tulajdon védelmének korábbi irányelvek keretében kidolgozott különböző fogalmait, amennyiben nem rendelkezett kifejezetten eltérően. ${ }^{676}$

Ugyan ilyen kifejezett eltérést nem találunk a szövegben, az a körülmény, hogy a kontinentális és angolszász típusú szerzői jogi rendszerrel bíró országok nem tekintették kölcsönösen elfogadható kifejezésnek a korábban bevett „rémunérationt”, 677 a két fogalom közötti egyenlőségjel megkérdőjelezéséhez vezet. Másrészt pedig az irányelv elfogadásakor az olasz „,compenso” szóval jelölték a „méltányos díjazást”. Ezt fordították angolra és franciára is a „compensation” szóval, ami viszont nem feleltethető meg az olasz kártérítési terminológiában bevett „,compensazione” fogalmának. ${ }^{678} \mathrm{Ez}$ is arra utal, hogy az uniós jogalkotó egy teljesen új fogalmat kívánt bevezetni.

\footnotetext{
${ }^{672}$ VON LEWINSKI - WALTER (2010) p. 1028.

${ }^{673}$ A C-245/00. sz. SENA-ügyben 2003. február 6-án hozott ítélet.

674 Ez egyébként mérhető felhasználáshoz kötött, szomszédos jog nyilvánossághoz közvetítési szomszédos jogi díjigényről van szó.

${ }^{675}$ Luksan-ítélet, 103. pont.

${ }^{676}$ Luksan-ítélet, 104. pont.

677 VON LEWINSKI - WALTER (2010) p. 1028.

${ }^{678}$ LUCAS-SCHLOETTER (2013a) p. 598.
} 
A terminológia szempontjából fontos elhatárolás, hogy szabatosan a magyar nyelvben is díjnak, nem pedig jogdíjnak kell hívni a díjazást. Ennek oka abban áll, hogy a jogdíj alapvetően a kizárólagos jog gyakorlásából ered, míg a díj arra utal, hogy a kizárólagos jog díjigénnyé lett leszorítva.

\section{B) A jogosultaknak okozott hátrány}

A díj egyik központi kérdésköre, hogy mire tekintettel kell megfizetni, mi alapozza meg a beszedését. Az EuB és a tagállami gyakorlat ebben a kérdésben is (nem meglepő módon) jelentős eltéréseket mutat. ${ }^{679}$ A magyar bírói gyakorlatban a díj 1982ben történő bevezetése ${ }^{680}$ óta gyakorlatilag állandósult az a joggyakorlat, amely a díjazást a tényleges felhasználástól függetlenül, a felhasználás lehetőségének megteremtéséhez köti, ${ }^{681}$ a hordozó fizetésére kötelezett forgalomba hozó ugyanis nem minősül szerzői jogilag releváns felhasználónak. ${ }^{62}$ Vagyis a magyar joggyakorlatban elismerésre került a díj átalányjellege. Mint már említésre került, az Alkotmánybíróság a díj érdekkiegyensúlyozó szerepét hangsúlyozta, nem került viszont elemzésre az, hogy a jogosultaknak milyen módon okozott hátrányt kompenzál a díj. Az érdekkiegyensúlyozó szerep egyébként a törvényi engedély lényegét takarja. A jogosultak nem gyakorolhatják a kizárólagos engedélyezési jogukat, cserébe viszont anyagi ellentételezésben részesülnek.

Hasonlóképpen, a francia bírósági gyakorlatban is kimondásra került, hogy a díjazás megfizetéséhez elegendő, ha az üres hordozók hang- vagy videofelvételek magáncélú többszörözésére alkalmas. ${ }^{683}$ Vagyis a francia bírói gyakorlat sem követel meg valamilyen ténylegesen bekövetkező, a jogosultak által elszenvedett sérelmet. A díjfizetés egy ennél absztraktabb konstrukció eredménye. Éppen ez az absztrakt törvényi felhatalmazás az, amely miatt kizárt a beszedett díjak jogalap nélküli gazdagodásként való minősítése. ${ }^{684}$

\footnotetext{
${ }^{679}$ A hátrány fogalmáról az EUB szóhasználatában lásd BÉNABOU (2011) p. 95-100.

680 15/1982 (IX. 20.) MM rendelet.

${ }^{681}$ BH 1992.756.

${ }^{682}$ BH 1993.158.

${ }^{683}$ Crim. 18 décembre 2001. D. 2002. AJ 646, Légipresse $2002 \mathrm{n}^{\mathrm{o}}$ 190, III, p. 62, CCE 2002, n 37, note Caron, RIDA avr. 2002, p. 377, obs. Kérever

${ }^{684}$ TGI Paris, 17 janvier 1990. RIDA, avr. 1990,p. 231.
} 
A francia Államtanács viszont egy kevésbé elvont elméleti álláspontot képvisel. Meglátása szerint a díjnak az a célja, hogy a jogosultak által elszenvedett bevételkiesést pótolja. ${ }^{685}$ Első ízben ez az Államtanács egy 2008-as határozatában jelent meg, amelyben kimondta, hogy a magáncélú másolatra tekintettel fizetett díjazás a „szerzőt megillető jogok kiaknázásának különleges módja” (,une modalité pariculière d'exploitation des droits des auteurs"). ${ }^{686}$ Ezzel némileg ellentétben áll annak egyidejü kimondása, hogy a díjazás célja a bevételkiesés pótlása. Vagyis mintha az Államtanács is azt sugallná, hogy valamely hátrány kompenzálásáról van szó, ${ }^{687}$ ezzel megelőlegezve az EuB sokat vitatott megállapításait.

A Bíróság a Padawan-döntésben a jogosultnak okozott hátrányhoz, mint egyetlen körülményhez kapcsolta a díj megállapítását. Az EuB az irányelv (35) preambulumbekezdésétől eltért, ez ugyanis az „esetleges kárt” a díjazás mértékének egyik, de nem kizárólagos szempontjaként határozta meg, míg az EuB az „okozott hátrányt” az egyetlen vizsgálandó szempontként tüntette fel. Bár a későbbi döntésekben a kár fogalmának meghatározása kicsit pontosabbá vált, azonban továbbra is kellően nem meghatározott fogalomról van szó, mivel többféle értelem tulajdonítható neki.

Ennek elemzéséhez az irányelv és az ítéletek szövegének különböző nyelvi változatait érdemes megvizsgálni. Összevetve ugyanis az általunk értett magyar, francia és angol nyelvü fordításokat, a magyarra „kárként”, „hátrányként”, sőt, „sérelemként” fordított fogalmak mindkét idegen nyelven azonos kifejezéssel szerepelnek: az „esetleges kár” fogalma franciául „préjudice potentiel”, angolul „possible harm”, a szerzőknek okozott hátrány pedig ,préjudice causé”, illetve „harm caused”. Az eltérő szóhasználatból pedig eltérő értelmezések fakadnak, ami szükségképpen megnehezíti a fogalom EuB által megkívánt egységes értelmezését.

A francia jogirodalomban a „méltányos díjazásnak” a kár fogalmához kötése található meg, ebben az értelmezésben a célja a kár megtérítése. ${ }^{688} \mathrm{~A}$ helyes értelmezéshez azonban a kártérítési terminológiától eltérő kontextusba kell helyezni a

\footnotetext{
${ }^{685}$ Ezzel párhuzamba állítható egy rendes bírósági ítélet, amely megállapította, hogy a díj megfizetése nem eredményez jogalap nélküli gazdagodást, hiszen ez a törvény elöírásaiból ered. TGI Paris, 1re ch., 1re sect, 17 janv. 1990: JurisData no 1990-046766; RIDA 1990 no 144, p. 231; JCP G 1990, I, 4378, obs. B. Edelman.

${ }^{686}$ Conseil d'État Arrêt du 11 juillet 2008.

${ }^{687}$ CARRE (2015) p. 310.

${ }^{688}$ MARINO (2010) e-verzió 23. bekezdés. BINCTIN (2011) e-verzió 4. pont.
} 
„méltányos díjazás” fogalmának elemzését, különösen, ha elfogadjuk, hogy a jogsértő forrás kizárja a díjigényt. A Padawan-ügyben a főtanácsnok kiemelte, hogy a „méltányos díjazásnak” nem célja a jogosultak kártalanítása a művek és szomszédos jogi teljesítmények tiltott többszörözésével összefüggő illegális cselekmények miatt. ${ }^{689}$ Hasonló álláspontra helyezkedett a magyar Alkotmánybíróság is. Az „üreskazettajogdíjat” vizsgáló határozatában az $\mathrm{AB}$ akként fogalmazott, hogy „[...] nem egy jogellenesen okozott kár kompenzálását célzó kártérítésről, hanem jogszerüen okozott vagyoni hátrány kiegyenlítéséről van szó [...]”. 690

Az angolszász jogirodalomban viszont fellelhető olyan álláspont, amely a „harm” fogalmának bizonytalanságára, nehéz meghatározhatóságára utal. ${ }^{691}$ A magyar nyelvü változatban szereplő „hátrány” mibenléte sem határozható meg egyértelműen. Ha a kártérítési terminológiát vesszük alapul, akkor elmaradt haszonként/vagy a ténylegesen bekövetkezett kárként lehetne definiálni. Amennyiben a szerzői jog oldaláról közelítjük meg a problémát, akkor a „hátrány” abban áll, hogy a jogosult nem gyakorolhatja kizárólagos engedélyezési jogát olyan mértékben, mint amilyen mértékben a magáncélú másolat helyettesíti az egyéb kultúra fogyasztásából megszerezhető jövedelmet. Gazdasági szempontú megközelítésben pedig a jogosultak oldalán az eredeti példányok megvásárlásának hiányában keletkező jövedelem kiesését is a „hátrány” fogalma alá kell vonni.

Az EuB tehát szúkítő jogértelmezéssel egy bizonytalan fogalomhoz, mint egyetlen kritériumhoz rendelte a „méltányos díjazás” megfizetésének szükségességét annak ellenére, hogy az irányelv (35) preambulumbekezdése ezt alkalmazható, nem pedig alkalmazandó szempontként említi. A szakirodalomban ismert olyan álláspont, mely szerint az EuB ezzel contra legem jogértelmezést alkalmazott, mivel az irányelv nem írja elő a „méltányos díjazás” ilyen szüken vett értelmezését. ${ }^{692}$ A legfrissebb, Copydån-ügyben már láthatóak annak a jelei, hogy a Bíróság finomítani kíván álláspontján, hiszen a korábbi formula helyett a méltányos díjazásnak a hátrányhoz

\footnotetext{
${ }^{689}$ A C-467/08. sz. Padawan-ügyben Verica Trstenjak 2010. május 11. napján ismertetett indítványa, 78. pont.

690 124/B/2004. (IX. 11.) AB határozat, ABH 2007, 1601, p. 1605

${ }^{691}$ KARAPAPA (2013) p. 131.

${ }^{692}$ LUCAS-SCHLOETTER (2013a) p. 598.
} 
kötődéséről beszél. ${ }^{693} \mathrm{Ez}$ a tendencia örvendetes, hiszen a kompenzációs, hátrány megtérítésén alapuló jelleg felveti a díj kulturális és szociális célokra történő felhasználásának indokolatlanságát - amit egyébként az EuB összeegyeztethetőnek talált az irányelvvel. Amennyiben ugyanis a díj célja valamely hátrány kiegyenlítése, ${ }^{694}$ azzal nehezen egyeztethető össze a kölcsönös szolidaritásvállaláson, kultúratámogatáson alapuló pályáztatási rendszer, amely a díj egy részének felhasználását jellemzi. ${ }^{695}$

Ehelyütt ismét utalni kell a VG Wort-ügyben a kivételek és korlátozások kapcsán elmondottakra. Ebböl ugyanis világosan az a következtetés vonható le, hogy a jogosultat azért éri sérelem, mert nem gyakorolhatja a kizárólagos engedélyezési jogból fakadó jogait. A Bíróság tehát a magáncélú többszörözés kapcsán ebben a későbbi döntésben egyértelműen a szerzői jogi értelmezés mellett tette le a voksát.

A hátrány fogalmának további pontosítása az ACI Adam-ügyben történt meg annak megvizsgálásával, hogy a jogellenes forrásból származó művek után a méltányos díjazás beszedhető-e. Már a Padawan-ügyben is utalt arra fötanácsnok, hogy a méltányos díjazás nem szolgálhat a jogellenes forrásból származó másolatok utáni kompenzációra, ${ }^{696}$ a Bíróság ekkor azonban még érdemben nem tárgyalta ezt a szenzitív kérdést. A tagállamok ebben a kérdésben sem képviseltek egységes álláspontot az irányelv átültetésénél. Mindössze hét tagállam nevesítette külön a forrás jogszerüségének követelményét. ${ }^{697}$ Hollandia ezzel szemben például a magáncélú másolat szélesebb körü, nem jogszerü forrásból történő alkalmazását követelte meg, jórészt praktikussági, illetve gazdasági szempontok miatt. Más tagállamokban, ahogyan Magyarországon is, kifejezett törvényi rendelkezés hiányában egyéb jogelvek segítségül hívásával vezethető le magáncélú másolás esetén a jogszerű forrás követelménye. A magyar szerzői jog vonatkozásában irányadónak tekinthető SzJSzT 17/2006 számú szakvélemény a háromlépcsős teszt részletes elemzése után kategorikusan elutasítja,

\footnotetext{
693 Copydan Båndkopi-ügy, 21. pont: „A fentiekre tekintettel a méltányos dijazásnak, valamint ebböl eredően az alapjául szolgáló rendszernek és a méltányos dijazás mértékének a magáncélú másolatok készitése folytán a jogosultakat ért hátrányhoz kell kötödnie."

${ }^{694}$ Ezzel összhangban áll, hogy a közös jogkezelő szervezetek a díjak felosztása során igyekeznek minél inkább a tényleges felhasználási szoksásokat tükröző becslési módszereket alkalmazni.

${ }^{695}$ Lucas (2012) p. 232-233.

${ }^{696}$ A Padawan-ügyben ismertetett fötanácsnoki indítvány, 78. pont.

${ }^{697}$ WESTKAMP (2007) p. 20.
} 
hogy a többszörözésre jogszerütlen forrásból is sor kerülhessen. ${ }^{698} \mathrm{~A}$ díjmérték újrakalkulásához az Szjt. előírása alapján ${ }^{699}$ felmérés készült, amely tartalmazott a hátrány mértékére vonatkozó becslést is, amely a díjszint csökkentését eredményezte.

Mind a fötanácsnok, mind a Bíróság utalt arra az ACI Adam-ügyben, hogy a hátrány megítélésénél a jogszerü forrás dilemmájának feloldása csak a háromlépcsős teszttel összefüggésben lehetséges. Ez azért is különösen érdekes, mert felveti annak az értelmezésnek a lehetőségét, mely szerint a hátrány voltaképpen megfeleltethető a háromlépcsős teszt harmadik lépcsőjében található ,jogosult jogos érdeke” fordulatnak. $^{700}$ Villalón fötanácsnok az ACI Adam-ügyben kijelentette, hogy az irányelvet akként kell értelmezni, hogy a magáncélú másolat kivétele csak a szerzői vagy szomszédos jogi védelem alatt álló művek vagy teljesítmények jogszerü forrásból történő többszörözésére vonatkozik. ${ }^{701}$ Kifejtette azt is, hogy a magáncélú másolat után járó díjazás jelenlegi koncepciója nem alkalmas a ,jogosultnak abból következő elmaradt hasznának megfelelő kompenzálására, hogy műveiket és védelem alatt álló teljesítményeiket erőteljesen terjesztik az interneten, ezzel megsértve kizárólagos többszörözési, nyilvánossághoz közvetítési, illetve terjesztési jogukat."702 A Bíróság az ACI Adam-ügyben hozott döntésben leszögezte, hogy a jogosultak engedélyezési jogának megszűnése nem jár azzal, hogy el kellene viselniük jogaik magáncélú másolatok készítését követő megsértését, ${ }^{703}$ vagyis a nem jogszerű forrásból származó másolás megengedése a szerzői jog jogosultjának indokolatlan károsulását eredményezheti. $^{704}$ A Bíróság végkövetkeztetése, hogy a magáncélú másolat jogintézménye nem vonatkozik azokra az esetekre, amikor a többszörözésre nem jogszerü forrásból kerül sor. ${ }^{705}$ Ezek tehát nem érthetők bele a jogosultnak okozott hátrány fogalmába, vagyis a méltányos díjazás meghatározásánál sem lehet őket figyelembe venni.

${ }^{698}$ SZJSZT 17/2006.

699 Szjt. 92/H. § (4) bek.

${ }^{700}$ LUCAS-SCHLOETTER (2015) p. 25.

701 A C-435/12. sz. ACI Adam-ügyben Pedro Cruz Villalón fötanácsnok 2014. január 9-én ismertetett indítványa, 79. pont.

${ }^{702} \mathrm{Az}$ ACI Adam-ügyben ismertetett fötanácsnoki indítvány, 76. pont

${ }^{703}$ ACI Adam-ítélet, 31. pont.

${ }^{704}$ ACI Adam-ítélet, 40. pont.

705 ACI Adam-ítélet, 41. pont. 
II. rész A törvény által előírt közös jogkezelés, mint a kizárólagos jog korlátja

II. fejezet A kizárólagos jog díjigényre korlátozása révén bevezetett közös jogkezelés

b) A dij megfizetöje

$\mathrm{Az}$ EuB által is jóváhagyott tagállami díjrendszer egyik legfontosabb jellemzője, hogy szétválik a díj fizetésére ténylegesen kötelezett, ám a jogosultaknak hátrányt nem okozó, valamint a díj gazdasági terhét viselő, a magáncélú többszörözést megvalósító személy. Mivel azonban a Bíróság ezen túlmenően is különbséget tett az egyes felhasználási módok között, több szinten is törést alakított ki ezen az egyébként hatékonyan müködő szisztémán.

a) A hátrányt okozó személy

Nem vitás, hogy a jogosultaknak hátrányt okozó személy a magáncélú másolást elvégző természetes személy. Ö ugyanis az, aki a magáncélú többszörözés felhasználási cselekményét elvégzi. A Bíróság rámutatott azonban arra is, hogy ezeknek a személyeknek az egyedi beazonosítása nehézséget jelenthet, illetve az általuk okozott hátrány mértéke egyedileg minimális. ${ }^{706}$ Vagyis praktikus okokból az EuB jóváhagyta olyan tagállami rendszerek létezését, ahol a díj beszedésére kötelezett személy az üres hordozók gyártója vagy forgalmazója abban az esetben, amennyiben a díj mértékét továbbháríthatja a végső felhasználó természetes személyre. ${ }^{707}$

A gyakorlatban a tagállamok kizárólag ezt a megoldást választva ültették át az irányelvet, ${ }^{708}$ hiszen ez biztosítja a költséghatékony kompenzációt, amely lehetővé teszi azt is, hogy végső soron a felhasználók viseljék a terhet. ${ }^{709}$ Nem meglepő módon a magyar és a francia törvény is hasonló megfogalmazással él a díj fizetésére kötelezett meghatározásánál: a CPI a gyártóra, az importőrre, vagy arra a személyre telepíti a fizetési kötelezettséget, aki az általános adótörvénykönyv alapján közösségen belüli vásárlást valósít meg, a hordozók Franciaországban történő forgalomba hozatala után fizetik meg a díjat. ${ }^{710} \mathrm{Az}$ Szjt. megoldása alapján, a díjat az üres kép- és hanghordozó

\footnotetext{
${ }^{706}$ Padawan-ítélet, 46. pont.

${ }^{707}$ Padawan-ítélet, 50. pont.

${ }^{708}$ WESTKAMP 2007. i.m.

${ }^{709}$ Az átalánydíj jellegen kívül egy másik érv is felhozható amellett, hogy az egyéni felhasználók miért nem igényelhetik(nék) vissza az üres hordozó árába beépített összeget. A díj fizetésére ugyanis nem ök a kötelezettek, hanem a gyártó vagy forgalmazó: éppen emiatt a törvény alapján ők lehetnének jogosultak a visszatérítésre. Annak megengedése viszont, hogy tekintettel a nem szerzői jogi célú felhasználásra, ők is visszaigényelhetnék a megfizetett összeget, aláásná a teljes, korábban felépített díjfizetési mechanizmust. 710 CPI L. 311-4. cikk „La rémunération prévue à l'article L. 311-3 est versée par le fabricant, l'importateur ou la personne qui réalise des acquisitions intracommunautaires, au sens du $3^{\circ}$ du I de
} 
gyártója, külföldi gyártás esetén pedig a jogszabály szerint vám fizetésére kötelezett személy, vagy - vámfizetési kötelezettség hiányában - egyetemlegesen a hordozót az országba behozó személy és az azt belföldön elöször forgalomba hozó személy köteles megfizetni. ${ }^{711}$ A CPI 2011. évi módosítása egyértelművé tette, hogy bár a díj fizetését a fent meghatározott személyi körre terheli, annak tényleges viselője a felhasználást megvalósító természetes személy, a fogyasztó, akinek a javára tájékoztatási kötelezettséget ír elő a kódex. Ennek értelmében az adott hordozót terhelő díj mértékét, illetve a díjról és annak céljáról szóló tájékoztatót a vásárló tudomására kell hozni az értékesítéskor. $^{712}$ A rendelkezés kettős célt szolgál: a felhasználók általános felvilágosításán és a szerzői jogi tudatosság fejlesztésén túl a szakmai szervezetek számára jelzéssel bír arról, hogy a díj alól megfizetése alóli mentesítést kérjenek, vagy visszaigényeljék a már megfizetett díjat. ${ }^{713}$

Nem ez az egyetlen módja azonban a jogosultaknak járó díjazás megfizetésének. Spanyolország a Padawan-döntést követően teljes mértékben átalakította díjrendszerét, így ezt 2012-től a központi költségvetésből finanszírozzák ${ }^{714}$ (hasonló a helyzet egyébként Finnországban és Norvégiában is). Olyan rendszer viszont, amelyben a végfelhasználók közvetlenül fizetik meg a díjat, a Bíróság által említett okok miatt gyakorlatilag kivitelezhetetlennek tünik.

A minimális hátrány szerepének körüljárása azért is lényeges, mert mint láttuk, a fogalom nem csak a hátrányt okozó személy, hanem a használt hordozó szempontjából is vizsgálható. Ebben a kontextusban merül fel az a kérdés, hogy a méltányos díjazásnak az egyes eszközök által konkrétan okozott hátrányt kell-e kompenzálnia, vagy a rendszer egészének kell a kompenzációt megvalósítania. ${ }^{715} \mathrm{Az}$ Európa-szerte változatos hordozókra kivetett különböző mértékü díjak a szakirodalomban ismert álláspont szerint ez utóbbi értelmezés elfogadása felé

l'article 256bis du code général des impôts, de supports d'enregistrement utilisables pour la reproduction à usage privé d'oeuvres, lors de la mise en circulation en France de ces supports."

${ }^{711}$ Szjt. 20. $\S(2)$ bek.

${ }^{712}$ CPI L. 311-4-1. cikk

${ }^{713}$ BinCTIn, Nicolas: Rémunération pour copie privé, J. Cl. Propriété littéraire et artistique, Fasc. 1510. 50. pont.

714 PARDO - LUCAS-SCHLOETTER (2013) p. 468. Az újabb EGEDA-ügyben előzetes döntéshozatalra feltett kérdés éppen arra irányul, hogy ez az állami költségvetésböl fedezett rendszer, amelyekben a végfelhasználók nem viselik a díj terheit, összeegyeztethető-e az InfoSoc-irányelvvel. Lásd: A C-470/14. sz. EGEDA és társai kontra Administración del Estado és társai ügyben elözetes döntéshozatalra feltett kérdések.

${ }^{715}$ VISEGRAD INVESTMENTS (2013) p. 63. 
mutatnak. ${ }^{716}$ Véleményünk szerint a minimális hátrány fogalmának általánosságban az üres hordozókra való vonatkoztatása is ezt az értelmezést támasztja alá. Ez nem zárja ki azt, hogy egyes esetekben bizonyos jogosultakra levetítve meghatározott hordozóra történő másolás ne haladhatná meg a minimális hátrány mértékét. A jelenlegi átalánydíj rendszer lényege viszont nem az egyedi érdeksérelmek ellentételezésén, hanem egy össztársadalmilag jelentős jelenség rendszerszintű kompenzálásán alapszik, vagyis figyelmen kívül marad az, hogy az adott felhasználó által adott hordozóra végzett többszörözés ténylegesen mekkora hátrányt okoz a jogosultaknak.

Bár azt is elismerte a Bíróság, hogy az egyedi felhasználók nehezen beazonosíthatók, a díjfizetés alapjául szolgáló egyik kritériumot mégis valamilyen módon a természetes személyek azonosításához köti. Pontosításra került ugyanis, hogy a hátrány ott keletkezik, ahol az azt okozó természetes személy lakóhellyel rendelkezik. ${ }^{717}$ Vagyis a belső piacot érintő kérdések esetében annak a tagállamnak keletkezik eredménykötelme arra, hogy a díjat a jogosultak számára biztosítsa, amelyikben a természetes személy lakóhelye található. Ennek a tételnek a határokon átívelő kereskedelmi ügyletek vonatkozásában van relevanciája. Fontos kérdés ugyanis, hogy hogyan hoztató közös platformra a belső piac müködése a szerzői jog territorialitásából adódó díjfizetési mechanizmusokkal. Ezt nehezíti az a körülmény, hogy a tagállamok nem koherensen ültették át az irányelvet, illetve néhány tagállam egyáltalán nem is vezette be a magáncélú másolatra vonatkozó rendelkezéseket.

A díjakra vonatkozó eddigi joggyakorlatban ez talán az egyetlen olyan pont, ahol a fötanácsnok álláspontja és a Bíróság véleménye markánsan eltér egymástól. Az Opus-ügyben eljáró Jääskinen főtanácsnok a Bíróságénál pragmatikusabb megközelítésben érvelt, hangsúlyozva a tagállamokon átívelő kereskedelmi ügyletek követéséből és az irányelv implementálásának különbözőségeiből fakadó nehézségeket. A fötanácsnok ugyanis kategorikusan kijelentette azt, hogy „véleményem szerint a 2001/29 irányelv nem követeli meg, hogy a különböző tagállamokat érintő valamennyi távollévők között kötött szerződés esetén méltányos díjazást kelljen fizetni, különösen, mivel ezek olyan tagállamok vevőit is célozhatják, amelyek nem engedélyezik a

\footnotetext{
${ }^{716}$ U.o.

${ }^{717}$ Opus-ítélet 35. pont.
} 
II. rész A törvény által előírt közös jogkezelés, mint a kizárólagos jog korlátja

II. fejezet A kizárólagos jog díjigényre korlátozása révén bevezetett közös jogkezelés

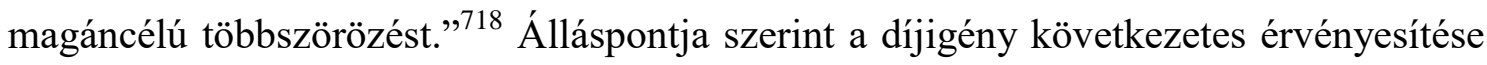
a belső piac torzulásával járna, ugyanis gyakorlati nehézségeket okoz minden olyan vállalkozás azonosítása, amelyek külföldi vevőknek értékesít üres adathordozókat, a vállalkozások között éppen ezért csak önkényes megkülönböztetést lehetne tenni a jogdíjfizetés szempontjából. ${ }^{719}$ Ráadásul hangsúlyozza azt is, hogy több tényezőnek köszönhetően (nyelvi akadályok, magasabb szállítási költségek, stb.) a fogyasztók csak korlátozott számú esetben fognak más tagállamban székhellyel rendelkező vállalkozásoktól vásárolni. ${ }^{720}$ Ezeknek a minimális összegeknek a beszedése pedig szintén gyakorlati nehézségekbe ütközik. ${ }^{721}$ Vagyis a fötanácsnok amellett érvelt, hogy valamely másik tagállamban székhellyel rendelkező vállalkozás csak akkor köteles a méltányos díjazás megfizetésére, ha kifejezetten a kérdést előterjesztő bíróság tagállamában élő fogyasztókat céloz meg. ${ }^{722}$

A Bíróság ezzel ellentétes álláspontot képviselve azon az elven áll, hogy a felhasználók és a jogosultak érdekei közötti egyensúly azt feltételezi, hogy a díjat minden felhasználási cselekmény után meg kell fizetni. ${ }^{723}$ Vagyis a Bíróság elutasítja az on-line webáruházak tevékenységi területük szerinti megkülönböztetését. A kérdés tisztázásához tartozik annak meghatározása, hogy a hátrány bekövetkezésének helye a felhasználó lakóhelye, vagyis a méltányos díjazás megfizetését ennek a tagállamnak kell biztosítania.

\footnotetext{
${ }^{718}$ A C-462/09. sz. Opus-ügyben N. Jääskinen fötanácsnok 2011. március 10-én ismertetett indítványa, 46. pont.

${ }^{719}$ Az Opus-ügyben ismertetett fötanácsnoki indítvány, 47. pont.

${ }^{720} \mathrm{Az}$ Opus-ügyben ismertetett fötanácsnoki indítvány, 48. pont.

${ }^{721} \mathrm{Az}$ Opus-ügyben ismertetett fötanácsnoki indítvány, 48. pont.

${ }^{722} \mathrm{Az}$ Opus-ügyben ismertetett fötanácsnoki indítvány, 51. pont.

${ }^{723}$ Franciaországban érdekesen épült fel a hasonló tényállás alapján a különböző szintű bíróságok érvelése. Az elsőfokú bíróság ugyanis akként foglalt állást, hogy a külföldön letelepedett, webshopot üzemeltető kereskedő köteles tájékoztatni a francia végfelhasználót arról, hogy a termék végső árát a fogyasztó által megfizetendő díjjal növelten kell érteni. (T. com. Bobigny, 15 septembre 2005, CCE 2005, $\mathrm{n}^{\mathrm{O}} 168$, note Caron). Fellebbezés folytán a másodfokú bíróság ehhez képest azt mondta ki, hogy a kereskedő nem köteles sem a díj megfizetésére, sem pedig a felhasználó tájékoztatására. (CA Paris, 22 mars 2007, CCE 2007, n ${ }^{0}$ 70, note Caron). Ezt a döntést viszont a Semmítőszék megsemmisítette, érvelését a tájékoztatási kötelezettség meglétére vagy hiányára élezve ki. A Semmítőszék álláspontja szerint a másodfokú bíróság nem megfelelő következtetésre jutott amikor kimondta, hogy a francia fogyasztók tájékoztatásának hiánya nem hibás annak megállapításával együtt, hogy a díj hatással van a termék végső árára, amiröl a fogyasztót egyébként tájékoztatni kell (Civ 1re 27 novembre 2008, Propr. intell, 2009, $\mathrm{n}^{\mathrm{O}} 31$, p. 170, obs. Bruguière).
} 
Ez az érvelés a joghatósági kérdéseket rendező 1215/2012 rendelet $^{724}$ elveire $^{2}$ épül, azonban a szerzői jogi logikát nem feltétlenül türközi. Ez utóbbi ugyanis a felhasználás-díjfizetés értékpárján alapszik, ami alapesetben független a felhasználó lakóhelyétől. Való igaz, hogy az esetek többségében a felhasználó lakóhelye a felhasználás helyével azonos, illetve ennek köszönhetően azonosíthatóak be azok az esetek, amelyekben a kereskedő tevékenysége nem kizárólag a székhelye szerinti tagállam területén értékesít üres hordozókat. Mindez azonban csak az on-line kereskedelem esetén érvényesül maradéktalanul. A belső piaci négy szabadság egyike, a személyek szabad áramlása azonban (igaz feltehetőleg nem számottevő mértékben) csorbítja ennek az alapelvnek a teljes érvényesülését. Ugyanis a fogyasztó lakóhelye és egyben a felhasználás helye a hagyományos, személyesen történő kereskedelmi ügyletek esetében eltérhet a vásárlás helye szerinti tagállamtól. Ezekben az esetekben a szállítási cím alapján sem következtethetünk erre az eltérésre, így pedig a díj nem a fogyasztó lakóhelye szerinti tagállamban kerül megfizetésre. A Bíróság által az on-line környezetre értelmezett, távollévők között kötött kereskedelmi ügyletek esetében alkalmazott alapelv tehát az offline térben sérül. Ezeknek az eseteknek egy részében a felhasználás helye szerinti logika sem érvényesül, amennyiben a vásárlás és a szerzői jogilag releváns felhasználás más tagállamban történik.

A lényeg viszont e pontatlanságok mellett is abban áll, hogy a díjat valamelyik tagállamban mindenképpen meg kell fizetni. A Bíróság kategorikusan kijelentette, hogy abban az esetben, ha a díj nem került megfizetésre egyik tagállamban sem, a hatóságoknak, különösen a nemzeti bíróságoknak a feladata a nemzeti jogszabály olyan értelmezése, hogy a díjat meg lehessen fizetni. ${ }^{725}$

Emellett viszont megoldást kell találni arra az esetre is, ha a kereskedő a díjat megfizette a székhelye szerinti tagállamban, azonban a Bíróság logikája szerint a végfelhasználó lakóhelye szerinti tagállam is ennek megfizetésére kötelezi. A kettős díjfizetés ugyanazért a felhasználási cselekményért nem fér össze sem a szerzői jog, sem pedig a belső piac müködésének logikájával. Az Amazon-ügy jelentősége ennek a kérdésnek a tisztázásában áll, azonban már Jääskinen fötanácsnok is kiemelte ezt a problémát az Opus-ügyben, rögzítve, hogy „,egy vállalkozás nem kötelezhető a

${ }^{724}$ Az Európai Parlament és a Tanács 1215/2012/EU rendelete (2012. december 12.) a polgári és kereskedelmi ügyekben a joghatóságról, valamint a határozatok elismeréséről és végrehajtásáról.

725 Opus-ítélet, 39. pont. 
méltányos díjazás megfizetésére, ha azt valamely másik tagállamban már megfizette. ${ }^{, 726} \mathrm{Ez}$ a javaslat szintén beleilleszkedik a fötanácsnok pragmatikusabb megközelítésébe, amely a díjak beszedésének és felosztásának minél egyszerübb mechanizmusát tartja szem előtt. Ez az érvelés ugyanis figyelmen kívül hagyja, hogy az üres hordozók megvásárlásának a helye nem feltétlenül esik egybe a fogyasztó lakóhelyével vagy a felhasználás helyével.

A Bíróság Amazon-ügyben adott válasza - bizonyos követelmények kielégítése mellett - jóváhagyja a díjak visszatérítésének rendszerét, ami a gyakorlatban a közös jogkezelő szervezetek közötti szorosabb koordináció igényét teremti meg. ${ }^{727} \mathrm{~A}$ döntés elfogadhatónak tartja a díjfizetés természetes személyek és vállalkozások közötti különbségtétel nélküli elöírását, ha az adott tagállam rendelkezik a díj visszatérítéséröl. Ennek azonban több feltételnek is meg kell felelnie: gyakorlati nehézségeknek kell indokolniuk a méltányos díjazás finanszírozásának ilyen rendszerét, a visszatérítéshez való jognak ténylegesnek kell lennie és a tagállam nem teheti túl nehézzé a díj megtérítését. ${ }^{728}$

\section{ß) A felhasználások szétválasztása}

A Bíróság Padawan-ügyben adott értelmezése alapján a díj megfizetése csak abban az esetben írható elő, amennyiben az ténylegesen magáncélú másolatokhoz kötődik. Az irányelv értelmezéséből az következik, hogy a méltányos díjazás csak a magáncélú másolat kivételének ellentételezése. Ennek két következménye lett: az egyik, hogy el kell választani a természetes személyek által, magáncélú másolat készítésére szolgáló felhasználásokat, a vállalkozások és egyéb szakmai szervezetek által végzett egyéb felhasználási módoktól. Ezt a szempontot egyébként a Reprobel-ítélet alapján a méltányos díjazás tekintetében a reprográfiai többszörözés kapcsán is érvényesíteni kell. $^{729}$

\footnotetext{
${ }^{726}$ Az Opus-ügyben ismertetett fötanácsnoki indítvány, 55. pont.

${ }^{727}$ Ismert olyan lengyel bírósági döntés, amely azt állapította meg, hogy a magáncélú többszörözésre tekintettel elöírt lengyel jogdíjat (üres hordozó és reprográfiai jogdij) nem kell megfizetni abban az esetben, ha egy hasonló jogdíj azonos javak tekintetében már megfizetésre került egy másik EUtagállamban. Lásd: KoliCZY - ANTAS (2012) p. 732-737.

${ }^{728}$ Amazon-ítélet, 31-33. pont.

${ }^{729}$ Reprobel-ítélet, 42. pont.
} 
A másik felvetődő probléma pedig ennek fordítottja, vagyis az a kérdés, hogy amennyiben magánszemélyek magáncélú többszörözéstől eltérő célra használják az üres hordozókat, abban az esetben kell-e díjat fizetni. Árnyalva a kérdést, ide tartozik annak meghatározása, hogy a természetes személy által jogellenes forrásból végzett többszörözési cselekmény után a díj beszedhetö-e. Ez a két megkülönböztetés, különösen pedig a természetes személyek által végzett felhasználási cselekmények közötti különbségtétel átrendezheti a tagállamok többségében alkalmazott átalánydíjra épülő rendszert.

\section{Vállalkozások és természetes személyek általi felhasználás közötti különbségtétel}

A Bíróság dogmatikailag helytálló különbségtétele pragmatikus szempontból problémákat okoz. A különbségtétel ugyanis az irányelv szövegének egyszerü nyelvtani-logikai értelmezéséből adódik, mivel a magáncélú másolás kedvezményezettjeként az irányelv egyértelmüen a természetes személyeket jelöli meg. ${ }^{730}$ Kérdéses, hogy milyen módon lehet elkülöníteni egymástól az egyes felhasználói köröket és az egyes felhasználási módokat.

Erre nézve többféle megoldási lehetőség is kínálkozik, attól is függően, hogy a kereskedelmi láncolat mely pontján álló személyt kívánjuk mentesíteni. Erre példaként szolgálhat a Copydan Båndkopi-ügy. Az ügy tanulsága szerint Dánia két pilléren álló rendszert állított fel, amely rendelkezik az előzetes mentesítésről, valamint az utólagos visszatérítéshez való jogról is. A dán jogalkotó által felállított rendszer érdekessége az előzetes döntéshozatalra terjesztett kérdésekből kiindulva, hogy az előzetes mentesítés akkor lehetséges, amennyiben a szakmai szervezet a Copydan által vezetett nyilvántartásban szerepel. ${ }^{731}$ Sajnos a fötanácsnok arra hivatkozva, hogy az előzetes döntéshozatalra utaló határozat nem tartalmaz konkrét és pontos utasítást a mentesítés körülményeire, vagy a részletszabályokra vonatkozóan, így ezeknek a körülményeknek a mérlegelését a tagállami bíróságra hagyta. ${ }^{732}$

A díjak utólagos visszatérítése kapcsán már fentebb említést tettünk az Amazon-ügyről, ismertettük ennek feltételeit. Megjegyzendő az is, hogy bár a magyar

\footnotetext{
${ }^{730}$ A német gyakorlat megengedte a nem természetes személyek általi többszörözést bizonyos esetekben. Erről lásd: MEZEI (2007).

${ }^{731}$ A Copydan Båndkopi-ügyben előterjesztett hatodik kérdés.

${ }^{732}$ Copydan Båndkopi-ügyben ismertetett fötanácsnoki indítvány 109-112. pontjai.
} 
szerzői jogi törvényben erre vonatkozó kifejezett rendelkezést nem találunk, az Artisjus díjszabását mégis módosította a Padawan-döntésben foglalt elvnek megfelelően. Ebben ugyanis az áll, hogy az üres hordozó díj megfizetése alól mentesülhet az annak fizetésére kötelezett személy, ha hitelt érdemlően igazolja, hogy a mentesíteni kívánt üres hordozó nem kerül a szabad felhasználás keretében az Szjt. által másolat készítésére feljogosított személy birtokába és azt nyilvánvalóan és kizárólag az Szjt.ben szabad felhasználássá nyilvánított másolatkészítéstől eltérő célra használják. ${ }^{733}$ Amennyiben pedig a jogosult jogsértés miatti igényt érvényesít, és a jogsértéssel elért gazdagodás visszatérítését követeli, vagy pedig egyébként a polgári jog szabályai szerint kártérítési igénnyel lép fel, a gazdagodás vagy kártérítés mértéke megállapításánál figyelembe kell venni a megfizetett üreshordozó díj mértékét. ${ }^{734}$

Nem szabad megfeledkezni arról sem, hogy a törvényi rendelkezések értelmében bizonyos, jellemzően vállalkozások által megvalósított felhasználások eleve nem tartoztak a díjfizetés hatálya alá. A mentesítés alapja az az indok, hogy a hordozók bizonyos használata teljesen bizonyosan magáncélú másolattól eltérő használatot jelent. Az Szjt.-ben ez két esetet jelent: egyrészt az export céljából történő forgalomba hozatalt, ${ }^{735}$ másrészt pedig a kizárólag olyan készülékekhez (pl. stúdióberendezéshez, diktafonhoz) használható kép- és hanghordozókra, amelyeket rendeltetésszerü felhasználás esetén nem használnak müvek, előadóművészi teljesítmények, illetve hangfelvételek másolatainak magáncélú készítésére. ${ }^{736}$ Az Artisjus díjszabása ezeket a rendelkezéseket egészíti ki. A CPI a megfizetett díj visszatérítéséről rendelkezett már a Padawan-döntés elött is, ezt a szakaszt azonban a kódex 2011. évi módosítása jelentősen érintette. Az új elemet az általános visszatérítési jog bevezetése jelentette azokban az esetekben, ahol a magáncélú felhasználás nem vélelmezhető. Ezt a kódex akként írja körül, hogy díjazás nem jár azokban az esetekben, amelyekben a hordozókat szakmai célokból szerzik be, és a felhasználás körülményei alapján a magáncélú felhasználás nem vélelmezhető. ${ }^{737}$ Megmaradt az eredeti szövegezés, amely arról

\footnotetext{
733 Az ARTISJUS Magyar Szerzői Jogvédő Iroda Egyesület közleménye a magáncélú másolásokra tekintettel megállapított üres hang- és képhordozó jogdíjakról (Ü15), 3.3.1. pont.

${ }_{734}^{734}$ Szjt. 94. § (11) bek.

735 Jellemzően ebben az esetben az export helye szerinti állam, amennyiben ismeri az üres hordozó díjat, az országba behozó személyt díj fizetésére fogja kötelezni.

${ }^{736}$ Szjt. 20. § (3) bek.

${ }^{737}$ CPI L. 311-8. cikk II. pont: „La rémunération pour copie privée n'est pas due non plus pour les supports d'enregistrement acquis notamment à des fins professionnelles dont les conditions d'utilisation ne permettent pas de présumer un usage à des fins de copie privée."
} 
rendelkezett, hogy a törvényben felsorolt személyi kör visszaigényelheti a díjat, ${ }^{738}$ amennyiben az saját felhasználásra vagy előállításra szolgál. ${ }^{739}$ Az érintett szervezetek pedig egyrészről a hang- vagy videofelvétel-előállítók és azok, akik ezek számára a hang- és videofelvételek többszörözését végzik. A rendelkezés indoka nyilvánvaló: az eredeti felvételek előállításához is szükség van üres hordozókra. Hasonló okok miatt került a törvénybe 2001-ben a digitális hordozókon kiadott művek kiadói javára fenntartott kivétel is. ${ }^{740}$ Elkerülendő, hogy egyszerre legyenek a díj jogosultjai és megfizetésére kötelezettek is, a törvény a megfizetett díj részükre történő visszatérítéséről rendelkezik. ${ }^{741} \mathrm{~A}$ rádió- és televíziószervezetek (entreprises de communication audiovisuelle) szintén visszaigényelhetik a díjat. ${ }^{742}$ Bár ők is kapcsolódó jogi jogosultak, mint látni fogjuk, a díj felosztásában nem részesednek, a jogalkotó ezt a hiányosságot a részükre nyújtott mentességgel kívánta pótolni. ${ }^{743}$ Harmadrészt pedig a korábbi rendelkezések is mentességet biztosítottak azoknak a jogi személyeknek vagy szervezeteknek, amelyek szerepelnek a kultúráért felelős miniszter által összeállított listán, és amelyek a hordozókat a látásban vagy hallásban sérült személyek segítésére használják. ${ }^{744}$

\section{Megkülönböztetés a természetes személyek általi felhasználások esetén}

A fogyasztó szempontjából történő különbségtétel tulajdonképpen két további alesetet ölel fel. Az egyik az, amikor a természetes személy bizonyíthatóan magáncélú másolástól eltérő célra használja a hordozókat. A másik pedig, amikor bár többszörözési cselekmény történik, az nem jogszerü forrásból származik. Az első eset azt a választási lehetőséget járja körül, hogy a díj átalánydíj-jellegü-e, avagy konkrét felhasználásokhoz

\footnotetext{
${ }^{738}$ Megjegyzendő, hogy a gyakorlati szempontok figyelembevételének igénye miatt a bizottság az esetek többségében nem az utólagos visszatérítését, hanem a díj meg nem fizetésének részletszabályait rendezte. (Décision $\mathrm{n}^{\mathrm{o}} 1$ ).

739 CPI. L. 311-8. cikk „La rémunération pour copie privée donne lieu à remboursement lorsque le support d'enregistrement est acquis pour leur propre usage ou production par (...)".

${ }^{740}$ CPI L. 311-8. cikk $2^{\circ}$ és $2^{\circ}$ bis cikkek: „Les producteurs de phonogrammes ou de vidéogrammes et les personnes qui assurent pour le compte des producteurs de phonogrammes ou de vidéogrammes, la reproduciton de ceux-ci; les éditeurs d'oeuvres publiées sur des supports numériques."

${ }^{741}$ Binctin, Nicolas: Rémunération pour copie privé, J. Cl. Propriété littéraire et artistique, Fasc. 1510. 52. pont.

${ }^{742}$ CPI L. 311-8. cikk $1^{\circ}$ „les entreprises de communication audiovisuelle”.

${ }^{743}$ BinCTIN, Nicolas: Rémunération pour copie privé, J. Cl. Propriété littéraire et artistique, Fasc. 1510. 52. pont.

${ }^{744}$ CPI L. 311-8. cikk $3^{\circ}$,les personnes morales ou organismes, dont la liste est arrêtée par le ministre chargé de la culture, qui utilisent les supports d'enregistrement à des fins d'aide aux handicapés visuels ou auditifs."
} 
kötött. A másik probléma is ezzel függ össze, szlogenszerủen megfogalmazva annak a kérdésnek a tisztázása tartozik ide, hogy vajon a díjfizetés legalizálja-e a jogellenes forrásból történő többszörözést, tipikusan a fájlcserét.

Az első esetben kérdés, hogy a természetes személy felhasználó visszakaphatja-e a befizetett díjat a felhasznált pendrive után, ${ }^{745}$ amennyiben azt például a nyaraláson saját maga által készített fotók tárolására használja. Éppen ezzel példálózva szokták hevesen támadni a díjrendszert, ${ }^{746}$ a köztudatban ez valamiféle büntetésként, sarcként terjedt el. Akik kicsit képletesebben érvelnek, azok azt mondják, hogy az átalánydíj olyan, mintha vennének egy mozijegyet és utána mégsem mennének el megnézni a filmet. Azt azonban ezek az érvek figyelmen kívül hagyják, hogy a magánjogi gondolkodásmódtól sem idegen a hasonló logikára épülő konstrukciók megalkotása: gondoljunk itt például a gépjármü felelősség-biztosításra, vagy a különböző hálózatos szolgáltatók díjaira. Ráadásul az egyes felhasználások követése is szinte lehetetlen lenne, tekintettel arra, hogy azoknak a hordozóknak, amelyekre a díjfizetési kötelezettség kiterjed, jelentős része újraírható. Emiatt nem zárható ki annak a lehetősége, hogy a saját tartalmak törlését követően magáncélú másolatok elkészítésére használják az adott hordozót.

Álláspontunk szerint a Padawan-döntés érvelése ezt a különbségtételt kizárja, mivel az EuB nem a másolatok tényleges elkészítéséhez, hanem az adathordozók másolat készítésére való puszta alkalmasságához, mint megdönthetetlen vélelemhez kötötte a díjfizetést.

Ezt az értelmezést támasztja alá az SGAE-üggyel vont párhuzam is. Ennek az ügynek ugyanis az volt a lényege, hogy nyilvános felhasználás valósul-e meg azzal, ha a hotel fenntartója a szállodaszobában televíziókészüléket helyez el, és azon keresztül különböző televízió- és rádióműsorokat érzékelhet a kereskedelmi szálláshely igénybe vevője. $^{747} \mathrm{Az}$ EuB igenlő választ adott a kérdésre kifejtve, hogy ,[...] a nyilvánossághoz közvetítés fennállásához elegendő, ha a művet úgy bocsátják a

\footnotetext{
${ }^{745}$ Spanyolországban találunk erre példát: Sentencia del Juzgado de Primera Instancia $\mathrm{n}^{\circ} 7$ de Alcalá de Henrares, juicio verbal número 726/2004, valamint Sentencia de la Audiencia Provincial de Málaga, Rollo 267/2006.

${ }^{746}$ A francia jogirodalomban már jóval a Padawan-döntés elöttröl olvashatunk olyan véleményt, amely szerint az átalánydíj alkalmazása esetén hiányzik jogalap, amennyiben a dij a hordozóknak magáncélú másolattól eltérö célokra történő felhasználása után is jár. GiTTON (2001) p. 64

${ }^{747}$ FALUDI - GRAD-GYENGE (2012) p. 80.
} 
közönség rendelkezésére, hogy annak tagjai ahhoz hozzá tudjanak férni. Ebből adódóan, a Rafael és az Írország által állítottakkal ellentétben e tekintetben nem meghatározó, hogy azok a vendégek, akik nem kapcsolták be a televíziókészüléket, nem férhettek hozzá a müvekhez.",748

Vagyis az EuB joggyakorlatában nem példa nélküli, hogy a szerzői műhöz vagy szomszédos jogi teljesítményhez való hozzáférés lehetősége keletkezteti a díjfizetési kötelezettséget. Ezt a logikát fordította át az EuB a Padawan-ügyben releváns felhasználási cselekményre, és vonta le azt a következtetést, hogy az adathordozók magáncélú másolat elkészítésére való puszta alkalmassága megalapozza a díjfizetést. A szerzői jog alapelve ráadásul éppen az, hogy a jogosultat megillető díjat/jogdíjat a felhasználási engedély megadásáért cserében kell megfizetni, függetlenül a felhasználás tényleges megvalósulásától. Ez utóbbi a díj mértékének meghatározásánál bírhat jelentőséggel.

Az üres hordozó díj tehát a tagállami rendszerekben abból a feltevésből táplálkozik, hogy a hordozót elsősorban magáncélú többszörözésre használják. Az egyedi felhasználások követése egyrészt nehézkes lenne a hordozók fizikai tulajdonságai miatt, másrészt pedig indokolatlan beavatkozást jelentene a felhasználó magánszférájába. Továbbá a Bíróság azon tétele, miszerint minimális hátrány nem keletkeztet díjfizetési kötelezettséget, visszafelé is igaz lehet. Az egyes hordozók árában ugyanis a díj nem feltétlenül jelent akkora összeget, amely miatt érdemes lenne egy adminisztratív procedúrának alávetnie magát a pénzt visszaigényelni kívánó felhasználónak. Az átalánydíjak alkalmazása természetesen nem zárja ki annak lehetőségét, hogy egy reprezentatív felmérést követően a díjak mértékének meghatározásánál figyelembe vegyék a magáncélú másolattól eltérő felhasználások mértékét. $^{749}$

Az ACI Adam-ügyben ez a problémakör szofisztikáltabban jelenik meg annak érzékeltetésével, hogy a méltányos díjazás megfizetésénél a forrás jogszerüségét figyelembe kell-e venni. A francia jogirodalomban már a 2011-es törvénymódosítás előtt is úgy érveltek, hogy a forrás jogszerüségének kérdése a díjazás mértékének meghatározására nem jelent befolyásoló tényezőt, azt ugyanis eleve csak a jogszerü

\footnotetext{
${ }^{748}$ SGAE-ítélet, 43. pont.

${ }^{749}$ A tabletek esetében ez az egyedi azonosítás már megvalósult.
} 
másolatok után kalkulálva kell kiszámítani. Ilyen módon tehát nem lehet azt mondani, hogy a díjazás megfizetése önmagában jogszerüvé tenné az illegális forrásból származó többszörözéseket. $^{750}$

Ebben a tekintetben is fel kell hívni a Szerzői Jogi Szakértő Testület már idézett szakvéleményét. A Testület részletesen levezeti, hogy annak ellenére, hogy a jogellenes forrásból származó többszörözés a háromlépcsős teszt követelményeivel ütközik, a díjak átalánydíjként való meghatározása, és így kiterjesztése ezekre a felhasználási módokra is, megengedhető. Részletesen megvizsgálva a díjigények arányos csökkentésének lehetőségeit, az eljáró tanács azt a következtetést vonta le, hogy ezek alkalmazása szükségtelen. Ugyanis ily módon a jogszerütlenül eljáró felhasználók nem kerülnének kedvezőbb helyzetbe, mint azok, akik jogszerü forrásból végzik a többszörözést. A díj megfizetése azonban nem legalizálná a kalózkodást, mivel a szerzői jogi jogosultak kárigényüket továbbra is érvényesíthetnék azzal a megkötéssel, hogy a befizetett díj összegét ebbe bele kellene számítani. ${ }^{751}$

Az ACI Adam-ügyben a Bíróság ezzel ellentétes álláspontra helyezkedett. Azzal érvelt, hogy amennyiben a díjigény nem kerül csökkentésre a jogellenes forrásból származó többszörözések arányában, valamennyi felhasználó szükségképpen hátrányosan van érintve. Ily módon ugyanis a jogszerüen eljáró felhasználó is hozzájárul a jogellenes másolatok által okozott kár megtérítéséhez. ${ }^{752}$ Ez pedig nem felel meg a méltányos díjazásban részesülő szerzők, valamint a felhasználók jogai és érdekei között megteremtendő megfelelő egyensúly feltételének. ${ }^{753}$

A teljesség kedvéért megemlítendő, hogy a fötanácsnok is ugyanerre a konklúzióra jutott, bár eltérő érvek alapján. Ö ugyanis arra helyezte a hangsúlyt, hogy annak megengedése a tagállamok számára, hogy szabadon dönthessenek arról, hogy a nem jogszerü forrásból származó többszörözések után is beszedjék a jogdíjat, ellentétes lenne az InfoSoc-irányelv általános harmonizációs törekvéseivel. Ráadásul ez egy sui generis díj létrehozását jelentené a jogellenes forrásból történő többszörözések tekintetében. ${ }^{754}$ Villalón főtanácsnok is azt az álláspontot képvislelte, hogy a díj

\footnotetext{
${ }^{750}$ GaUBIAC (2008) 23. pont.

${ }^{751}$ SzJSzT 17/2006. szakvélemény, 60. pont.

752 ACI Adam-ítélet, 56. pont.

753 ACI Adam-ítélet, 57. pont.

${ }^{754} \mathrm{Az}$ ACI Adam-ügyben ismertetett fötanácsnoki indítvány 82. pontja.
} 
megfizetése közvetetten jogszerüvé teszi a művek és védelem alatt álló teljesítmények rendes felhasználásának súlyos megsértését. ${ }^{755}$

Ezzel a tétellel ellentmondani látszik a Bíróság Amazon-ügyben kifejtett álláspontja, mivel ebben igazolásra került a tagállamok azon elismert joga, hogy a díjrendszer felállítása során megdönthető vélelmeket állapítsanak meg. ${ }^{756}$ Vagyis a Bíróság továbbra is elismerte ugyan az átalánydíjak alkalmazhatóságát, azonban azt csak megdönthető vélelmek mentén hagyta jóvá. Ebből következik az is, hogy a forrás jogszerüségének kérdéskörén kívül a magáncélú másolattól eltérő célok esetén is megkérdőjelezhető a díj megfizetése, ami a jelenlegi átalánydíj-rendszer elaprózódásához vezethet. ${ }^{757}$

\section{c) A díjazás meghatározásánál alkalmazandó egyéb szempontok}

Az InfoSoc-irányelv 5. cikk (2) bekezdésének b) pontja alapján a méltányos díjazás meghatározásánál a műszaki intézkedések alkalmazását figyelembe kell venni, ezen túlmenően viszont az irányelv nem tartalmaz konkrét rendelkezést a díjazás meghatározásának szempontjairól. Ezt bővíti ki a (35) preambulumbekezdés annyival, hogy a jogosultat ért esetleges kár is figyelembe vehető, vagyis az InfoSoc-irányelvből két kritérium vezethető le. Az EuB ez utóbbi fogalommal a jogosultaknak okozott hátrány elnevezéssel rendkívül részletesen foglalkozott, ez válik a tagállami jogokban a díjazás alapjának egyik kritériumává (ebbe természetesen beletartozik a forrás jogszerüségének a dilemmája is, amelyről fentebb már részletesen szóltunk).

A tagállami jogokban ez eltérően körvonalazódik, ugyanis a nemzeti jogalkotó sokszor egyéb szempontokat is figyelembe vett a díjazás meghatározásánál. A francia szerzői jogban (és egyébként a magyarban is) például alapelv a felhasználással elért bevétellel arányos díjazás, ${ }^{758}$ ezért külön ki kell emelni, amikor ettől eltérően,

\footnotetext{
${ }^{755}$ Az ACI Adam-ügyben ismertetett fótanácsnoki indítvány 83. pontja.

${ }^{756}$ Amazon-ítélet, 43. pont.

${ }^{757}$ Itt ismét utalni kell arra, hogy az Szjt. a reprográfiai és üres hordozó díjakat nem csak a magáncélú másolatok esetében írja elö, hanem a több más, a törvényben szabad felhasználásként biztosított többszzörözési cselekmény kapcsán is. Lásd a már hovatkozott Szjt. 35. § (8) bekezdést.

${ }^{758}$ CPI L. 131-4. cikk (1) bek. „La cession par l'auteur de ses droits sur son oeuvre peut être totale ou partielle. Elle doit comporter au profit de l'auteur la participation proportionnelle aux recettes provenant de la vente ou de l'exploitation.” Az Szjt. 16. § (4) alapján: „Ha e törvény másképp nem rendelkezik, a szerzöt a mü felhasználására adott engedély fejében díjazás illeti meg, amelynek - eltérő megállapodás hiányában - a felhasználáshoz kapcsolódó bevétellel kell arányban állnia. A dijazásról a jogosult csak kifejezett nyilatkozattal mondhat le."
} 
átalányjelleggel állapítható meg a szerzőt megillető anyagi kompenzáció mértéke. A magáncélú másolatra tekintettel fizetett díj ilyennek tekinthető, hiszen maga a CPI rendelkezik expressis verbis ezeknek a szabályoknak az alkalmazásáról. ${ }^{759}$ Ennek egyértelművé tétele a díjazás mértékének meghatározását végző bizottság eljárása során alkalmazott elvek miatt szükséges.

\section{a) A hatásos müszaki intézkedések szerepe a dij megállapitásában}

A műszaki intézkedések definíciója az irányelv 6. cikk (3) bekezdésében olvasható, amely minden olyan technológiát, eszközt vagy alkatrészt jelent, amely rendes működés során alapvetően arra szolgál, hogy a művek és más, jogi védelem alatt álló teljesítmények tekintetében megelőzze, illetve megakadályozza a jogszabályban meghatározott jogosultak által nem engedélyezett cselekményeket. A müszaki intézkedés akkor minősül „hatásosnak”, ha a jogi védelem alatt álló mü vagy más teljesítmény felhasználását a jogosult valamely hozzáférés-ellenőrzési vagy védelmet nyújtó eljárással - így például kódolással, titkosítással vagy a mű vagy más teljesítmény egyéb átalakításával - vagy olyan másolatkészítést ellenőrző mechanizmus útján ellenőrzi, amely a védelem célját megvalósítja.

Az EuB-nak elsősorban a VG Wort-ügy kapcsán nyílt alkalma megvizsgálni a hatásos műszaki intézkedéseknek a díj meghatározásában betöltött szerepét. Ezt alapvetően két szintre elkülönítve tette meg: egyfelöl a méltányos díjazáshoz való jog fennállásával kapcsolatban, majd pedig a díjazás mértékével kapcsolatban tett megállapításokat. Figyelemmel ezen eszközök alkalmazásának önkéntes jellegére a Bíróság úgy érvelt, hogy alkalmazásuk hiánya nem vonhatja maguk után a méltányos díjazásra való igény megszünését. ${ }^{760}$ A tagállam azonban a méltányos díjazás konkrét szintjét függővé teheti ezeknek az eszközöknek az alkalmazásától annak érdekében, hogy ezek használatát elősegítse a jogosultak körében. ${ }^{761}$

Az ACI Adam-ügy ezt az elvet gyakorlatilag nem fejlesztette tovább, hiszen mindössze azt állapította meg, hogy a többszörözés forrásával kapcsolatos nemzeti jogszabály irányelvvel való összeegyeztethetőségének vizsgálata független attól, hogy

\footnotetext{
${ }^{759}$ CPI L. 311-3. cikk „La rémunération pour copie privée est, dans les conditions ci-après définies, évaluée selon le mode forfaitaire prévu au deuxiéme alinéa de l'article L.131-4."

${ }^{760}$ VG Wort-ítélet, 57. pont.

${ }^{761}$ VG Wort-ítélet, 58. pont.
} 
nem létezik olyan hatásos müszaki intézkedés, amellyel az ilyen többszörözések ellen küzdeni lehetne. ${ }^{762}$ A Copydan Båndkopi-ügyben a kérdés ismét felvetődött, ám a főtanácsnok a VG Wort-ügyben tett megkülönböztetés megismétlésén kívül egyéb érdemi választ nem adott. ${ }^{763}$

\section{B) A díjazással terhelhetö hordozók}

A díjjal terhelt hordozókat a tagállamok viszonylag széles skálán határozzák meg. Ebben változást az EuB joggyakorlata sem hozott, hiszen a Bíróság tartózkodott attól, hogy ezzel kapcsolatban állást foglaljon. Sőt, a méltányos díjazás meghatározásának módját kifejezetten tagállami hatáskörbe utalta. Így általában kiterjednek az elavult, mára már alig használt hordozókra (audiokazetta), az egyszer írható optikai lemezekre (CD-R, DVD-R), az újraírható üres hordozókra (CD-RW, háttértárolók), set-top boxokra, üreshordozó-kapacitással rendelkező eszközökre (pl. tablet) és telefonokra, ${ }^{764}$ egyes esetekben a számítógépekbe beépített merevlemezekre is. $^{765}$ Európában a legszélesebb tarifarendszert Franciaország vezette be, ${ }^{766}$ amely kiterjed a CD és DVD lemezeken túl többek között a televíziókészülékekbe épített memórián át a pendrive-okra és az okostelefonokba integrált memóriára is. ${ }^{767}$

Az olyan digitális adathordozók viszont aggályosak voltak az átalánydíj szempontjából, amelyek fő funkciója nem a magáncélú másolatok elkészítése, de erre a célra is alkalmasak, mint az okostelefonokban megtalálható memóriakártyák. ${ }^{768}$ Körültekintő mérlegelést igényelt annak eldöntése, hogy az ilyen eszközök után is fennálljon-e a díjfizetési kötelezettség. Bizonyos tagállamok ezekre is kiterjesztették a díjat a felhasználási szokásokra való tekintettel. Ugyanis a felhasználók egy része ezeket az eszközöket magáncélú többszörözésre is használja. Ráadásul a Padawanügyben kimunkált formula alapján ezekre a hordozókra is kiterjeszthető a díjfizetés, mivel másolatkészítésre alkalmasak. A Copydan Båndkopi-ügyben felvetődött a

\footnotetext{
${ }^{762}$ ACI Adam-ítélet, 45-46. pont.

${ }_{763}^{76}$ A Copydan Båndkopi-ügyben ismertetett fötanácsnoki indítvány 79. pontja.

764 Az Artisjus a közelmúltban terjesztette ki a díjfizetést a tabletekre is, amelyet a felhasználók erőteljesen kritizáltak. A francia bizottság 13. és 14. számú döntéseivel terjesztette ki a díjfizetési kötelezettséget a tabletekre is. (Décision n 13 du 12 janvier 2011, Décision $n^{\circ} 14$ du 9 février 2012).

${ }^{765}$ VISEGRAD INVESTMENTS (2013) p. 19-27.

766 VISEGRAD INVESTMENTS (2013) p. 27.

${ }^{767}$ Ezek részletes felsorolását lásd BINCTIN, Nicolas: Rémunération pour copie privé, J. Cl. Propriété littéraire et artistique, Fasc. 1510. 74. pont.

${ }^{768}$ KARAPAPA (2011) p. 256.
} 
II. rész A törvény által előírt közös jogkezelés, mint a kizárólagos jog korlátja

II. fejezet A kizárólagos jog díjigényre korlátozása révén bevezetett közös jogkezelés

különbségtétel kérdése arra való hivatkozással, hogy ezen eszközök elsődleges vagy legfontosabb célja mégsem többszörözésben rejlik. Az EuB viszont következetesen elutasítja a hordozó funkciója szerinti megkülönböztetést, megerősítve azt, hogy önmagában a hordozó magáncélú másolatra való alkalmassága keletkezteti a díjfizetési kötelezettséget. A hordozó többfunkciós jellege ezek alapján a díj mértékének meghatározásánál jöhet számításba. ${ }^{769}$

A vonatkozó előzetes döntéshozatali eljárásokban született ítéletek figyelembe vételével a Kúria is hasonló következtetésre jutott. Az eljárás tárgyát itt is a mobiltelefonokba épített memóriakártyák képezték, amellyel kapcsolatban a bírói fórum azt a megállapítást tette, hogy „köztudomás szerint is megállapítható, hogy a mobiltelefonokba integrált tárolóegység - egyéb funkciók mellett - alkalmas zenei és képfájlok rögzítésére, azaz az Szjt. 20. §-a alá eső olyan hordozó eszköz, amelyre a törvényi díjfizetési kötelezettség kiterjed."

Az ilyen eszközök után kivetendö díj meghatározása viszont körültekintést igényel. Az Államtanács a magáncélú másolatra tekintettel fizetendő díj megállapítására felállított francia bizottság ${ }^{771}$ több olyan határozatát is megsemmisítette, amelyben többfunkciós hordozókra vagy multimédia eszközökre kívánta kiterjeszteni a díjfizetési kötelezettséget. ${ }^{772}$ A második megsemmisített döntés kifejezetten a memóriakártyákra, pendrive-okra és a külső merevlemezekre kívánta a díjat kiterjeszteni. Az Államtanács álláspontja szerint a bizottság csak az eszközök tárolókapacitását vette figyelembe a díj mértékének megállapításakor, de azt nem, hogy ezeket milyen arányban használják jogszerü és jogellenes forrásból történő többszörözésekre. Ez utóbbiak ugyanis nem képezhetnék a díj alapját, ennek következtében pedig a bizottság nem a jogszabályoknak megfelelően járt el. ${ }^{773}$ A bizottság 2008-ban hozott határozatában

\footnotetext{
${ }^{769}$ A C-463/12. sz. Copydan Båndkopi-ügyben 2015. március 5-én hozott ítélet 68-73. pontjai.

${ }^{770}$ Kúria Pf.IV.21.272/2012/7. Hasonlóan: Fővárosi Bíróság P.20.497/2008/18.

${ }^{771}$ A továbbiakban röviden csak bizottság névvel illetjük a testületet.

${ }^{772}$ Az első ilyen határozatot 2006-ban hozta a bizottság. Décision $n^{\circ} 7$ du 20 juillet 2006. Ennek megsemmisítéséről rendelkezik az Államtanács alábbi határozata:CE 10e et 9e ss-sect. réunies, 11 juillet 2008, Synd. de l'industrie des matériels audiovisuels électroniques c/ Sorecop et Copie France: Propr. intell. 2008, no 29, p. 428, obs. A. Lucas. A döntés kommentárját lásd: BINCTIN (2008) étude 21.

${ }^{773}$ Décision $\mathrm{n}^{\circ} 8$ du 9 juillet 2007. Az Államtanács megsemmisítést kimondó határozata pedig: CE, 10e et 9e ss-sect. 17 déc. 2010, no 310195: JurisData no 2010-024376, Comm. com. électr. 2011, chron. 9. obs. P. Tafferau; Comm. com. électr. 2012, chron. 4, obs. X. Daverat. Kommentárját lásd: STROWEL (2009) p. 56. Hasonló indokolás alapján került megsemmisítésre a bizottság 9. és 10. számú döntése is (Décision no 9 du 11 décembre 2007, Décision no 10 du 27 février 2008), amely a multimédia hordozókra ésa mobiltelefonokba integrált memóriakártyákra kívánta a díjat kiterjeszteni. CE 10e et 9e ss-sect, 17 déc.
} 
II. rész A törvény által előírt közös jogkezelés, mint a kizárólagos jog korlátja

II. fejezet A kizárólagos jog díjigényre korlátozása révén bevezetett közös jogkezelés

figyelembe vette az Államtanács korábbi érveit, és a jogellenes forrásból származó másolatok kizárásával állapította meg a díjak mértékét a multifunkcionális hordozók tekintetében. Ez a döntés viszont a Padawan-ügy miatt került megsemmisítésre: az Államtanács álláspontja szerint figyelembe kellett volna venni a szakmai és magáncélú felhasználások elkülönítését a díj megállapításakor. ${ }^{774}$ Azért, hogy feloldásra kerüljön a bizottság gyakorlata, valamint az Államtanács és az EuB ítélkezési gyakorlata között feszülő ellentét, a jogalkotó törvényt fogadott el a magáncélú másolatra tekintettel fizetett díjak meghatározásáról, ${ }^{775}$ amelyben (mint fentebb már utaltunk rá) több korábban vitatott probléma végére is pontot tett.

A hordozókkal kapcsolatos legújabb megválaszolandó kérdés a felhőalapú szolgáltatások (cloud computing) azon részszolgáltatásának díjjal terhelése, amely az ügyfél (a szolgáltatás igénybevevője) által a számára dedikált tároló felületre másolt, csak az ügyfél számára hozzáférhető, más szerzői jogával védett, egyébként a díj hatálya alá tartozó mü/teljesítményfajta esetében vetődik fel. Ez a problémafelvetés alkalmas a magáncélú másolatra tekintettel fizetett díjak kérdésének újragondolására. Ugyanis a technológia, vagyis önmagában a szolgáltatás nem jelent hordozót, amelyre tekintettel jelenleg a díjfizetés történik, hanem általában a mögötte fellelhető szerverparkokat kívánják a díjfizetéssel terhelni. Másrészt viszont ugyanahhoz a szolgáltatáshoz, a felhőben lévő tartalmakhoz több olyan eszköz, csatlakoztatható akár egy időben, amelyre tekintettel jelenleg is fennállhat a díjfizetési kötelezettség (számítógép, mobiltelefon, tablet stb.). Nem marginális vizsgálódási szempontról van azonban szó, ugyanis a technológiai fejlődés a mobilinternet-hálózatok

2010, n 314308, Comm. com. électr. 2011, chron. 9, obs. P. Tafforau; Comm. com. électr. 2012, chron 4, obs. X Daverat. A 10. számú döntés megsemmisítéséröl pedig lásd: CE et 9e ss-sect, 17 déc. 2010, n ${ }^{\circ}$ 315832, Comm. com. électr. 2011, chron. 9, obs. P. Tafforeau; Comm. com. électr. 2012, chron. 4, obs. X. Daverat. A 8. és 10. számú döntés megsemmisítését követően perek sorozataa indult a rendes bíróságok előtt annak megállapítására, hogy a Copie France jogelennesen járt el a megsemmisített döntések alapján kivetett jogdíjak beszedésekor. A bíróság ítéletében kötelezte a közös jogkezelö szervezetet a már megfizetett díjak visszafizetésére. (TGI Paris, 3e ch., 1er sect. 15 mai 2012, Propr. intell. 2012, n $^{\mathrm{o}}$ 44, p. 338, obs. A Lucas; RLDI, août/sept 2012, p. 28. obs. L Costes).

${ }^{774}$ Décision no 11 du 17 décembre 2008. Az Államtanács rendkívül széles körben kommentált határozata pedig: CE 9e et 10e ss-sect., 17 juin 2011 n $^{\circ}$ 324816, Propr. intell. 2011, nº 41, p. 401. obs. A. Lucas; $D$. 2012, p. 2836, P. Sirinelli ; RTDE 2011, p. 888, obs. D. Ritleng ; LPA 16 nov. 2011, n 228, p. 5, note A. Troianiello ; Gaz. Pal. 27 oct. 2011, jurispr. p. 3072, note L. Marino ; Comm. com. électr. 2012, chron. 9, obs. P. Tafforeau ; Comm. com. électr. 2012, chron. 4, obs. X. Daverat).

${ }^{775}$ Loi n $^{\circ}$ 2011-1898 du 20 décembre 2011 relative à la rémunération pour copie privée. A törvény átmeneti rendelkezéseit az Alkotmánytanács nem találta jogellenesnek, ezzel szemben viszont másik cikkét igen. 
sávszélességének rohamos fejlődésével és az ennek vételére alkalmas készülékek egyre népszerübbé válásával bizonyos típusú adathordozók teljes eltünését vázolja fel.

A másik nehézséget pedig a felhasználási célok elkülönítése adja. Az érvelés értelmezéséből az következik, hogy azok az eszközök, amelyeket kizárólag nem természetes személyek, magáncélú másolattól eltérő célra használnak fel, nem tartoznak a „méltányos díjazás” hatálya alá. Egy ilyen alapvető különbségtételt a magyar szerzői jogi törvény is ismer, ugyanis a díjfizetés nem terjed ki a kizárólag olyan készülékhez (pl. stúdióberendezéshez, diktafonhoz) használható kép- és hanghordozókra, amelyeket rendeltetésszerü felhasználás esetén nem használnak művek, előadóművészi teljesítmények, illetve hangfelvételek másolatainak magáncélú készítésére. ${ }^{776}$

Az adathordozók többsége (például a CD és DVD lemezek) azonban tipikusan olyan, amelyet természetes személyek, magáncélú többszörözésre, illetve vállalkozások és egyéb szakmai szervezetek ettől eltérő célra egyaránt használhatnak. A cloud computinggal kapcsolatban is felvetődhet ugyanez az érv, hiszen számos cég tért át a vállalati adatok ilyen módon való tárolására, még bizonytalanabbá téve a szolgáltatás magáncélú másolásra tekintettel fizetendő díjak körébe vonásával kapcsolatos lehetőségeket. Gyakorlati problémákat vet fel a díj beszedése az ilyen adathordozók esetében. A Padawan-döntés ugyanis ezzel kapcsolatban kétfajta értelmezési lehetőséget veti fel: az egyik a vállalkozások és szakmai szervezetek teljes mentesítése függetlenül az adathordozó típusától. A másik lehetséges értelmezés pedig a díj mértékének meghatározásánál figyelembe venni azt, hogy egyes hordozók egyaránt szolgálhatnak természetes személyek magáncélú másolataira, valamint vállalkozások és szakmai szervezetek ettől eltérő célra való használatára. ${ }^{777}$ A francia közös jogkezelő szervezetek ez utóbbi értelmezést tették magukévá, kiadott közleményükben hangsúlyozva a CPI összhangját a Padawan-döntéssel. ${ }^{778}$ Kérdés, hogy a jogosultak és a felhasználók érdekei közötti egyensúlyba belefér-e egy ilyen, a gyakorlatban könnyen kivitelezhető megoldás. A Bíróság úgy tünik, hogy a szilárd dogmatikai alapokon nyugvó megoldások felé hajlik. A díjak mértékének egyszerü csökkentése pedig úgy tünik, nem felel meg teljesen ennek a követelménynek, ugyanis továbbra sem teszi

\footnotetext{
776 Szjt. 20. $§(3)$ bek.

${ }_{777}^{778}$ DALEAU (2010) e-verzió 3-4. bekezdés.

$778 \mathrm{http}: / /$ www.sacem.fr/cms/home/la-sacem/derniers-communques_2/usages-pro-supports-assujettisoct 2010
} 
lehetővé az egzakt elhatárolást a természetes személyek és vállalkozások általi felhasználások között.

Ennek a különbségtételnek egyébként a jogosultak számára a legsúlyosabb lehetséges következménye nyilvánvalóan a kibúvó keresése a díj megfizetése alól. Amennyiben a vállalkozás megveszi az adathordozót magáncélú másolattól eltérő használat céljából, a magáncélú másolatra tekintettel fizetett díjat nem kell megfizetnie. Ha viszont az adathordozót mégis természetes személy használja magáncélú másolat elkészítésére, a jogosultak elesnek az öket e címen megillető díjtól. Ez pedig ellentétes az irányelvben elöírt „méltányos díjazás” követelményével, valamint a jogosultak és a felhasználók közötti érdekegyensúly megtartásának követelményével. Az EuB érvelésének következetes végiggondolásával tehát azt találjuk, hogy a Padawan-döntés rendelkezései egymással ellentétben állhatnak.

A reprográfiai díjak szempontjából ezen a ponton érdemes kitérni a multifunkciós (fénymásoló, nyomtató, szkenner) helyzetére. A Reprobel-ügyben VILLALÓN fötanácsnok három feltételhez kötötte az átalánydíjak alkalmazhatóságát. Ezeknek a szempontoknak, és az ügynek az ismerete azért is különösen fontos, mivel a magyar reprográfiai díjrendszer is hasonló elven működik, tehát a díjat a készülékek forgalomba hozója vagy üzemeltetője fizeti. Egyrészt feltétlen kapcsolatnak kell fennállnia a reprográfiai berendezésekre kivetett átalánydíj és ezek védelem alatt álló mủvek többszörözésére való használata között. ${ }^{779} \mathrm{Ez}$ a kapcsolat vélelmezhető (mind a belga, mind egyébként a magyar díjrendszer tekintetében), hiszen a személyes vagy szakmai célokhoz kötött felhasználásokon kívül a készüléket védett művek többszörözésére is használják. Másodsorban az átalánydíjnak az arányosság kritériumának kell megfelelnie. Vagyis a jogosultaknak a többszörözéssel okozott potenciális hátrányhoz kell igazodnia a készülékek használatának, ennek megállapításához pedig objektív körülményeket kell figyelembe venni. ${ }^{780}$ Önmagában a fénymásolási sebesség nem biztos, hogy elegendő ennek megállapításához, több kritérium együttes vizsgálata szükséges. Harmadrészt pedig a díjazás visszatérítéséhez való jogot elemezte a főtanácsnok. Ezzel kapcsolatban megállapította, hogy az a korábbi

\footnotetext{
${ }^{779}$ A C-572/13. sz. Reprobel-ügyben 2015. június 11-én nyilvánosságra hozott főtanácsnoki indítvány, 83. pont.

780 A C-572/13. sz. Reprobel-ügyben 2015. június 11-én nyilvánosságra hozott főtanácsnoki indítvány, 87-90. pont.
} 
ítélkezési gyakorlatban csak speciális esetekben szerepelt feltételként, amely nem terjeszthető ki automatikusan a reprográfiai többszörözés jogára. Vagyis ennek hiánya nem tekinthető a jogosultak és a felhasználók érdekei között fennálló méltányos egyensúlyt sértő körülménynek. ${ }^{781} \mathrm{Az}$ EuB megállapította, hogy a fénymásolási sebesség, mint műszaki kategória, önmagában nem kielégítő jellemzője a „méltányos díjazás" megállapításának, ugyanis nem biztos, hogy a felhasználók teljes mértékben kihasználják a másolókapacitást. ${ }^{782}$

A magyar jogalkotó egyébként a reprográfiai díjak megállapítására és beszedésére nyilvántartásba vett Magyar Reprográfiai Szövetség autonómiáját szokatlan módon szükítette. Egyrészt a reprográfiai díjjal terhelendő készülékek körét kormányrendelet határozza meg, vagyis a közös jogkezelő szervezet nem dönthet szabadon, saját maga ezek megállapításáról. ${ }^{783}$ Másrészt pedig, a „,magyar szerzői jog történetében példa nélkül álló módon" ${ }^{784}$ a jogalkotó a szerzői jogi törvényben $2 \%$-ban maximalizálta a megállapítható díj mértékét. ${ }^{785}$

\section{B) A dijak felosztása}

A díjak felosztása egyrészről hasonlóságot mutat a korábban ismertetett felosztási metódussal. Bármely testület is az, amely a díjak mértékét meghatározza, a beszedés és a felosztás mindkét esetben a közös jogkezelő szervezeteket terheli. Ezek pedig igyekeznek a felhasználás tényleges arányaihoz igazodó, azt tükröző becslési módszerek alkalmazásával készpénzben átutalni a beszedett díjat a jogosultak részére [a) pont]. Ezen kívül viszont a kulturális és szociális célok jogosultak javára történő megvalósításának lehetővé tételével a jogalkotó egy speciális rezsimet is létrehozott [b) pont].

a) A hagyományos felosztás

Mind a CPI, mind pedig az Szjt. meghatározza azt a jogosulti kört, amely részesedhet a beszedett díjakból, a részesedés arányának megállapításával. Ezek

\footnotetext{
781 A C-572/13. sz. Reprobel-ügyben 2015. június 11-én nyilvánosságra hozott főtanácsnoki indítvány, 96-97. pont, 120-122. pont.

${ }^{782}$ A C-572/13. sz. Reprobel-ügyben 2015. november 12-én hozott ítélet 75-77. pontjai.

783 158/2000. (IX. 13.) Korm. rendelet a reprográfiára szolgáló készüékek körének meghatározásáról.

${ }^{784}$ GYERTYÁNFY (2014) p. 181.

${ }^{785}$ Szjt. 21. § (4) bek.
} 
alapvetően a szerzőket jelentik, de az InfoSoc-irányelv újszerü megközelítésmódjával összhangban, ${ }^{786}$ illetve tekintettel az érdekkiegyensúlyozó szerepre, nem meglepő, hogy a kapcsolódó jogi jogosultaknak is jár a díjból. A kiadók (akik egyébként alapvetően a művek felhasználói) támogatása viszont már túlmutat a szerzői jog hagyományos keretein, ${ }^{787}$ az ő felvételük ebbe a körbe tehát a kultúrpolitikai célkitűzések és a szerzői jog eszközrendszerének összefonódását példázza.

a) A dij jogosultjai

Magyarországon törvényben rögzített arányok „,egyrészt a 25 éves kialakult gyakorlatot, másrészt az egyes mükategóriák, teljesítmények másolásban előforduló statisztikai és müsorelemzéssel megállapított gyakoriságát, részét tükrözik." "788 A törvény egyébként lehetőséget biztosít az eltérésre, az érintett közös jogkezelő szervezetek ugyanis a rögzített arányoktól minden év március 31. napjáig megkötött megállapodásukban eltérhetnek. ${ }^{789}$

Hanghordozók esetében a zeneszerzőket és írókat a befolyt díjak kezelési költségek levonását követően megmaradt összegének $45 \%$-a, ${ }^{790}$ képhordozók esetén $22 \%$ a filmalkotások mozgóképi alkotóit, $4 \%$ a képzőmüvészeket, az iparművészeket és a fotóművészeti alkotások szerzőit, $16 \%$ a filmírókat, $20 \%$ a zeneszerzőket és a zeneszöveg-írókat illeti meg. ${ }^{791}$ A CPI is hasonló elven jár el, a törvényi részben rögzítve a beszedett díjaknak egyes jogosulti csoportok közötti felosztását. Hangfelvételekben foglalt müvek magáncélú többszörözése után a szerzőknek $50 \%$, az előadóművészeknek $25 \%$, illetve a hangfelvétel-előállítóknak is $25 \%$ részesedést ír elő a befolyt díjakból. Videofelvételekben foglalt müvek esetében a díj egyenlő arányban illeti meg a szerzőket, előadóművészeket, illetve a filmelőállítókat. Illetve egyéb

\footnotetext{
${ }^{786}$ A nemzetközi szerzői jogban az InfoSoc-irányelv 2. cikkében biztosított többszörözési jog az első, amely egy kalap alá veszi a szerzőket és a kapcsolódó jogi jogosultakat. SIRINELLI (2001) p. 82.

${ }_{787}$ Ebben a körben a jogosultak között természetszerüleg nem szerepelnek a szoftverekre vonatkozó vagyoni jogok jogosultjai. Az Alkotmánybíróság megfogalmazásában mivel a szoftver másolata (a biztonsági másolat Szjt.-ben biztosított kivételétől eltekintve) minden esetben jogellenes, ezért amennyiben részesednének a díjakból, az a jogellenes többszörözés legalizálását eredményezné. 124/B/2004. AB határozat III.2.2. pont.

${ }^{788}$ GYERTYÁNFY (2014) p. 173.

789 Szjt. 20. § (4)-(5) bek. Hasonló szabály vonatkozik a reprográfiai díjak törvényben rögzített küszöbértékeinek közös jogkezelő szervezetek általi módosítására is. Szjt. 21. § (7) bek.

${ }^{790}$ Szjt. 20. § (4) bek.

${ }^{791}$ Szjt. 20. § (5) bek.
} 
hordozókon rögzített müvek esetében a díj fele-fele arányban illeti meg a szerzőket és kiadókat. $^{792}$

Mivel a magáncélú másolat alapvetően a szerzők számára biztosított kizárólagos jog gyakorlását lehetetleníti el, természetes, hogy általában nagyobb arányban őket illeti az ebből befolyt díj. Az InfoSoc-irányelv azonban elöírja a díj méltányosságát is, amelynek értelmezésére két szinten lehet kísérletet tenni. A magunk részéről a méltányosságot a díj összegszerüségében látjuk indokoltnak. Azaz álláspontunk szerint a díj mértéke nem lehet jelképes méretü ahhoz, hogy megfeleljen ennek a kritériumnak. A másik értelmezése a fogalomnak viszont az egyes jogosulti csoportok közötti méltányosságot jelentheti. Ennek szoros értelmezése jelenik meg a francia törvény szövegében a videofelvételek (és az egyéb hordozókban foglalt müvek) felosztásánál alkalmazandó kulcsok meghatározásánál: a kódex ugyanis ezt a három jogosulti csoport (valamint a szerzök és a kiadók) között egyenlö arányban rendeli felosztani. ${ }^{793}$ Ebből a szempontból nézve tehát a jogalkotó egyenlőséget tesz az alkotói tevékenység, valamint az előadói, és ennek háttereként szolgáló befektetési tevékenység között. ${ }^{794}$

A magyar felosztási szabályok differenciálnak az egyes mütípusok szerzői között az egyes hordozótípusokon való előfordulásuk feltételezett aránya szerint. A francia kódex viszont ennél is továbbment, hiszen egészen a CPI 2001. évi módosításáig ${ }^{795}$ csak a hang- és videofelvételben foglalt művek szerzőit illette meg a díjazás. Bár a többi hordozón foglalt mủvek szerzői javára a jogalkotó korrigálta ezt a mulasztást, de a felosztási arányok így is a hang- és videofelvételek forgalmát tükrözik. Ehhez hozzá kell tenni azt is, hogy a CPI csak az első alkalommal Franciaországban, vagy az Európai Unió tagállamában rögzített müvek jogosultjainak biztosítja a díjazást,

\footnotetext{
${ }^{792}$ CPI L. 311-7. cikk „La rémunération pour copie privée des phonogrammes bénéficie, pour moitié, aux auteurs au sens $d u$ présent code, pour un quart, aux artistes-interprètes et, pour un quart, aux producteurs. La rémunération pour copie privée des vidéogrammes bénéficie à parts égales aux auteurs au sens du présent code, aux artistes-interprèteset aux producteurs. La rémunértion pour copie privée des oeuvres visées au second alinéa de l'article L. 311-1 bénéficie à parts égales aux auteurs et aux éditeurs."

${ }^{793}$ Lásd a CPI fent idézett L. 311-7. cikkét.

${ }^{794}$ BINCTIN, Nicolas: Rémunération pour copie privé, J. Cl. Propriété littéraire et artistique, Fasc. 1510, 34. pont.

${ }^{795}$ Loi n $2001-624$ du 17 juillet 2001 portant diverses dispositions d'ordre social, éducatif et culturel
} 
II. rész A törvény által előírt közös jogkezelés, mint a kizárólagos jog korlátja

II. fejezet A kizárólagos jog díjigényre korlátozása révén bevezetett közös jogkezelés

amennyiben a viszonosságot nemzetközi egyezmény nem írja elő. ${ }^{796}$ Ennek hiányában tehát a külföldi (Európai Unión kívüli) jogosultak kirekesztődnek a francia felhasználások tekintetében járó díjból.

A jogosultak pontos meghatározásához tehát mindenekelőtt definiálni kell a hang- és videofelvétel (illetve a francia törvény alkalmazásában az egyéb hordozó) fogalmát. Ez nem csak a CPI szempontjából fontos, hiszen a magyar jogszabály is eltérő kulcsokat határoz meg a két külön hordozótípus esetében. Explicit definíciót egyik jogforrás sem tartalmaz, azonban a CPI-ből levezethető ennek tartalma. Hangfelvétel alatt „hangok sorozatát” (séquence de son), ${ }^{797}$ videofelvétel alatt pedig „hangokkal ellátott vagy néma képek sorozatát" (séquence des images sonorisées ou non) ${ }^{798}$ érti a törvény. Vagyis alapvetően a francia terminológia szerint, ahogyan egyébként azt a magyar felosztási arányok is tükrözik, elsősorban a zeneművek, illetve az audiovizuális müvek (ideértve a filmalkotásokat is) szerzői (és szomszédos jogi jogosultjai) részesülhetnek a beszedett díjakból. A digitalizáció elterjedésének köszönhető az, hogy a CPI-be az egyéb hordozón foglalt müvek szerzői (de a szomszédos jogi jogosultak nem) is helyt kaptak a jogosultak között, ami biztosítja, hogy gyakorlatilag minden szerzőt a díjra jogosultnak lehessen tekinteni. A törvény viszont egy megszorítást tartalmaz ezzel kapcsolatban: nevezetesen azt, hogy a díjazás csak akkor jár, amennyiben a másolat elkészítése digitális hordozóra történik. A jogalkotó tehát az analóg másolatokat kizárta a törvény hatálya alól a hang- és videofelvételtől eltérő hordozóban rögzített müvek esetén. ${ }^{799}$

A szomszédos jogi jogosultak tekintetében a magyar törvény alapján hanghordozók esetében az előadómüvészeket 30\%, a hangfelvétel-előállítókat pedig $25 \%$ illeti meg. ${ }^{800}$ Képhordozók esetén pedig $13 \%$ a filmelőállítókat, valamint $25 \%$ az

\footnotetext{
${ }^{796}$ CPI L. 311-2. cikk ,Sous réserve des convventions internationales, le droit à rémunération mentionné à l'article L. 214-1 et au premier alinéa de l'article L. 311-1 est réparti entre les auteurs, les artistesinterprètes, producteurs de phonogrammes ou de vidéogrammes pour les phonogrammes ou vidéogrammes fixés pour la première fois dans un État membre de la Communauté européenne." Mivel a DADVSI-törvény elfogadásáig csak a Franciaországban rögzített müvek szerzői részesülhettek a díjból, a CPI nem felelt meg az EK-szerződés diszkrimináció-tilalmat rögzítő cikkének. CHABERT (2004) 5. pont.

${ }^{797}$ CPI L. 213-1. cikk: „Le producteur de phonogrammes est la personne, physique ou morale, qui a l'initiative et la responsabilité de la première fixation d'une séquence de son."

798 CPI L. 215-1. cikk: „Le producteur de vidéogrammes est la personne, physique ou morale, qui a l'initiative et la responsabilité de la première fixation d'une séquence d'images sonorisée ou non."

${ }^{799}$ BInCTIN, Nicolas: Rémunération pour copie privé, J. Cl. Propriété littéraire et artistique, Fasc. 1510, 18. pont.

${ }^{800}$ Szjt. 20. § (4) bek.
} 
II. rész A törvény által előírt közös jogkezelés, mint a kizárólagos jog korlátja II. fejezet A kizárólagos jog díjigényre korlátozása révén bevezetett közös jogkezelés

előadóművészeknek jár. ${ }^{801}$ A rádió és a televízió a sugárzás céljára készített hangfelvétel miatt nem tekinthető a bekezdés hatálya alá tartozó hangfelvételelőállítónak, hiszen „a díj a magáncélú másolatokra tekintettel jár és a rádiót és televíziót a magáncélú másolások miatt nem éri érdeksérelem.” ${ }^{802}$ A filmelőállítók, az alkotófolyamatban kapcsolódó jogi jogosultkénti elismerésük ${ }^{803}$ mellett a filmszerzőktől, mint eredeti jogosultaktól tipikusan átruházott jogok miatt szerepelnek listában. ${ }^{804}$

A reprográfiai díjak esetében nagyon hasonló felosztási sémáról beszélhetünk. A magyar jogszabály ugyanis vélelmezve azoknak a müveknek a körét, amelyek érintettek lehetnek a többszörözéssel, meghatározza a felosztás küszöbértékeit. Ennek megfelelően a díjak 40\%-a a kiadókat illeti. A fennmaradó $60 \%$-ot pedig a szerint kell felosztani, hogy abból a szakirodalmi, tudományos müvek szerzőit 25 , a többi irodalmi mű szerzőit 25 , a képzőművészeket és a fotóművészeket 10 százalék illeti meg. ${ }^{805} \mathrm{~A}$ közös jogkezelő szervezetek viszont a fénymásolási szokásokról készített felmérés eredményére tekintettel megállapodást kötöttek, amelyben eltértek a törvényben rögzített értékektől. Ez a megállapodás vezette be, hogy bár az Európai Unióhoz történő csatlakozásunkat követően a kották magáncélú többszörözésének lehetősége megszűnt és így az ARTISJUS is lemondott az ezek után járó díjakról, a zeneszövegírók képviseletében a felmérés eredményeire tekintettel az említett szervezet fellépett a reprográfiai díj iránti igénnyel. 2012-től kezdődően tehát a megállapodás szerinti felosztási kulcsokat kell alkalmazni az alábbiak szerint: a szak- és szépirodalmi szerzők és a könyvkiadók képviseletére tekintettel a MASZRE kapja a díjak 77,7\%-át. A vizuális művek képviseletében a HUNGART-nak jár 13,5\%, az időszaki lapok kiadói képviseletére tekintettel a REPROPRESS-t a díjak 5,8\%-a illeti meg. A zeneszövegek,

\footnotetext{
${ }^{801}$ Szjt. 20. $\S(5)$ bek.

${ }^{802}$ LB Pf.IV.721/1984/9.

${ }^{803}$ Szjt. 1. § (8) bek. „Az elöadómüvészek, a hangfelvétel-elöállitók, a rádió- és a televizió-szervezetek, a filmelöállitók, valamint az adatbázis-elöállitók teljesitményei az e törvényben meghatározott védelemben részesülnek."

${ }^{804}$ Az Szjt. 106. § (1) bek. „Ahol e törvény szerzöt emlit, azon megfelelöen érteni kell a szerzö jogutódját, illetve a szerzői jog más jogosultját is.” Illetve Szjt. 66. § (1)-(2) bek. „A filmalkotás létrehozására kötött szerzödés (a továbbiakban: megfilmesitési szerzödés) alapján a szerzö - kivéve a szöveges vagy a szöveg nélküli zenemü szerzőjét - ellenkezö kikötés hiányában átruházza az elöállitóra a filmalkotás felhasználására és a felhasználás engedélyezésére való jogot. A felhasználás engedélyezésére vonatkozó jog átruházása nem terjedhet ki a 20. §-ban, a 23. § (3) és (6) bekezdésében, valamint a 28. §-ban szabályozott vagyoni jogokra."

${ }^{805}$ Szjt. 21. § (6) bek.
} 
dalszövegek szerzőinek képviseletében pedig az ARTISJUS-nak jár a kezelési költségekkel csökkentett díjak 3\%-a. ${ }^{806}$

Az Szjt. eredeti szövege alapján csak a könyvként vagy folyóiratban megjelent müvek kiadói szerepeltek a reprográfiai díj jogosultjai között. Ez azt a visszás helyzetet eredményezte, hogy a napilapban megjelent mü szerzője igen, kiadója viszont nem részesült reprográfiai díjban. ${ }^{807} \mathrm{Az}$ Szjt. 2008-as módosítása ezt az ellentmondást feloldotta, törölve a kiadókra vonatkozó szükítő feltételt.

Franciaországban az egyéb hordozóban foglalt müvek esetén a magáncélú másolatra tekintettel fizetett díjak körében, Magyarországon pedig a reprográfiai díjak körében illeti meg a kiadókat részesedés a beszedett díjakból annak ellenére, hogy kapcsolódó jogi védelemben az ő teljesítményeik nem részesülnek. Ez a törekvés egyrészt azt mutatja, hogy talán nincsen messze az az idő, amikor a kiadók is a felhasználói pozícióból jogosulti pozícióba kerülnek, ${ }^{808}$ másrészt viszont álláspontunk szerint utal arra, hogy a díj nem pusztán szerzői jogi természetü, hanem a kultúratámogatás egy eszköze is. Az üreshordozó és reprográfiai díjban való részesedésüket egyébként az indokolja, hogy a kiadói szerződés alapján általában ők rendelkeznek a többszörözési jog gyakorlásával. Vitatható viszont a díjból történő részesedésük, amelyet a Reprobel-ügyben előterjesztett előzetes döntéshozatali kérdés is megerősít. A főtanácsnok kifejtette, hogy a tagállamoknak lehetőségük van egy ilyen sui generis díjazás fenntartására, hiszen az irányelv csak a szerzői jogi jogosultaknak juttatandó méltányos díjazást teszi kötelezővé. Viszont ez a sui generis díjazás, amely a kiadóknak okozott hátrányt veszi figyelembe, nem hathat negatívan a szerzők számára előírt méltányos díjazásra. ${ }^{809} \mathrm{~A}$ főtanácsnok fontos további megállapítást tett annak kimondásával, hogy a kiadók nem hasonlítanak a szerzők javára létrehozott olyan szociális és kulturális intézményeknek, és nem bizonyított, hogy az kiadók számára

806 Az RSZ és tagjai közötti megállapodás a reprgráfiai díjak átadása tárgyában, 9. pont (http://www.reprografia.hu/doc/RSZ_tagok_megallapodas_110331.pdf).

${ }^{807}$ SZJSZT 21/07/1.

${ }^{808}$ BinCTIN, Nicolas: Rémunération pour copie privé, J. Cl. Propriété littéraire et artistique, Fasc. 1510, 23. pont. Erre utaló másik jel, hogy a közös jogkezelő szervezetekben is tagként részt vesznek, szavazati joggal rendelkeznek.

${ }^{809}$ A C-572/13. sz. Reprobel-ügyben 2015. június 11-én nyilvánosságra hozott főtanácsnoki indítvány, 140-141. pontok. 
II. rész A törvény által előírt közös jogkezelés, mint a kizárólagos jog korlátja

II. fejezet A kizárólagos jog díjigényre korlátozása révén bevezetett közös jogkezelés

folyósított díjazás ténylegesen a szerzők javát szolgálná. ${ }^{810}$ A fötanácsnok által meghatározott feltételek szerint megkérdőjelezhető mind a magyar, mind a francia gyakorlat. Nem biztos, hogy sui generis díjazásról van szó ugyanis, tekintettel arra, hogy egységként kezeli mindkét jogszabály a díjazást. A felosztási kulcsok alkalmazása pedig emiatt hátrányos lehet a szerzők számára. A főtanácsnok által javasolt sui generis díjazás bevezetése pedig olyan, mintha hallgatólagosan lehetőséget adna a tagállamok számára az InfoSoc-irányelvben nem foglalt, elsősorban kulturális célú szerzői jogi díjazás bevezetésére, vagyis kvázi mintha szomszédos jogi jogosultságokkal ruházná fel a kiadókat. ${ }^{811}$ A Bíróság ítéletében nem is fogadta el ennek a sui generis díjazásnak a létezését, hanem egyenesen leszögezte, hogy a kiadók nem szerepelnek az irényelvben foglalt díjazás jogosultjai között, amely miatt nem is részesülhetnek a díjból. ${ }^{812}$

Az üres hordozó díjak felosztását a szerzők részére az ARTISJUS végzi, a felosztási szabályzatban meghatározott becslési módszer alapján (a szakzsargon ezt ráosztásnak nevezi), amely az egyedileg beazonosítható felhasználások adatait veszi alapul. ${ }^{813}$ A reprográfiai díjakat az RSZ utalja át a tagjainak, amelyek a saját felosztási szabályzataik alapján intézkednek azok jogosultak javára történő felosztásáról, ${ }^{814}$ szintén valamely más (jog)díjcsoport adatait alapul véve. ${ }^{815}$

${ }^{810}$ A C-572/13. sz. Reprobel-ügyben 2015. június 11-én nyilvánosságra hozott fötanácsnoki indítvány, 130-131. pontok.

${ }^{811}$ EUROPEAN COPYRIGHT SOCEITY: Opinion on the The Reference to the CJEU in Case C-572/13 Hewlett-Packard Belgium SPRL v. Reprobel SCRL (5 September 2015) (http://www.create.ac.uk/wpcontent/uploads/2014/03/Opinion-in-Case-C572_13-HP-Belgium-Reprobel-2015.pdf), p. 5.

${ }^{812}$ A C-572/13. sz. Reprobel-ügyben 2015. november 12-én hozott ítelet 47-49. pontjai.

${ }^{813}$ A felosztási szabályzatot, mint ahogyan korábban már volt szó róla, az egyesület legfőbb szerve (azaz maguk a szerzők) fogadja el. Álláspontunk szerint a dolgozat keretei között a felosztás technikai jellegü kérdéseinek ennél részletesebb ismertetésére nincsen szükség. Lásd ezzel kapcsolatban az Artisjus Felosztási $\quad$ szabályzat $\quad 8-9 . \quad$ részét $\quad$ (http://www.artisjus.hu/wpcontent/uploads/2015/06/felosztasi_szabalyzat_hatalyos.pdf), illetve közérthető magyarázattal az Artisjus Füzetek Zenei jogdíjfelosztás - Érthetően címü kötetét (http://dalszerzo.hu/2015/05/06/zeneijogdijfelosztas-erthetoen-megjelent/). Érdekes összehasonlítási alaput nyújthat a francia közös jogkezelő szervezetek becslési módzsere is. A felosztási szabályzatok alapján ugyanis eltérő felmérések és játszási adatok figyelembe vételével határozza meg a SACEM, a SCAM, az ADAMI és a SPEDIDAM. Ez utóbbi sajátosan a díjat a hangfelvételben rögzített előadómüvészi-teljesítmények száma alapján, illetve az első hangfelvétel megjelenési ideje alapján kalkulált „rangidősségi” szorzó figyelembe vételével határozza meg. Binctin, Nicolas: Rémunération pour copie privé, J. Cl. Propriété littéraire et artistique, Fasc. 1510. 35. pont.

814 Magyar Reprográfiai Szövetség Szervezeti és Működési Szabályzat (http://www.reprografia.hu/doc/SZMSZ.pdf).

815 Lásd: ARTISJUS Felosztási Szabályzat 12. rész., MASZRE Felosztási Szabályzat (http://vu2113.admin.databoss.hu/public/upload/files/Felosztasi\%20Szabalyzat\%202015(2).pdf),

HUNGART Felosztási Szabályzat (http://www.hungart.org/oldal.php?azon=46), Repropress Folyóirat és 
2011-ig Franciaországban a közös jogkezelő szervezetek által erre a célra létrehozott SORECOP volt az, amely beszedte az üreshordozó díjakat a hangfelvételek alapján, majd továbbutalta azokat a tagjai felé, ${ }^{816}$ amelyek elvégzik a végső jogosultak közötti felosztást. A Copie France pedig az a társaság volt, amely az audiovizuális müvek tekintetében végzett hasonló tevékenységet: azaz beszedte a díjakat, valamint felosztás céljára továbbutalja a tagszervezeteknek. ${ }^{817}$ A közös jogkezelő szervezeteket felügyelő állandó bizottság ajánlása nyomán, mivel a bevételek nem igazolták a hang és az audiovizuális másolatok megkülönböztetésének fenntartása jogosságát, illetve a szervezeti és személyzeti összefonódás miatt is, 2011-ben a két társaság egyesült. Ettől az időponttól kezdve tehát egyedül a Copie France az, amely a díjak kezelését végzi. ${ }^{818}$

Az üres hordozó díjak felosztása Franciaországban külön eljárás szerint müködik. Mivel gyakorlatilag lehetetlen meghatározni a felhasználás pontos arányait, ${ }^{819}$ a főszabály szerinti díjazás megállapítása komoly nehézségekbe ütközne, így indokolt az átalánydíj (rémunération forfaitare) alkalmazása. Az üres hordozó díj azonban ezekhez képest is eltérő jellemzőket mutat, mivel az átalánydíjak általában egy összegben kerülnek teljesítésre, ezek a díjak viszont rendszeresen visszatérő jelleggel. ${ }^{820}$

A felosztás során az illetékes közös jogkezelő szervezetek ennek ellenére a lehető legteljesebb mértékben törekszenek az arányosságra, ami igazodik a magáncélú másolatok megvalósításának tényleges mutatóihoz. ${ }^{821}$ Éppen ezért a közös jogkezelő szervezetek felmérések adatait alapul véve becslési módszerekkel határozzák meg az egyes jogosultakra jutó díj mértékét.

Napilap Felosztási Szabályzat (http://pressjus.hu/Repropress_Folyoirat_Felosztasi_Szabalyzat.pdf, http://pressjus.hu/Repropress_Napilap_Felosztasi_Szabalyzat.pdf).

${ }_{816}$ SDRM (amely a SACEM-et, az SACD-t és a SCA-t tömöríti), az SCPA (az SCPP-t és az SPPF-et fogja össze), az ADAMI és a SPEDIDAM.

${ }^{817}$ Tagjai az SDRM, ADAMI, SPEDIDAM, PROCIREP és SCPA.

${ }^{818}$ A Copie France saját infrastruktúrájának hiányában a technikai megvalósítást a SACEM végzi.

${ }^{819}$ CPI L. 131-4. cikk ${ }^{\circ}$ pont.

${ }^{820}$ BINCTIN, Nicolas: Rémunération pour copie privé, J. Cl. Propriété littéraire et artistique, Fasc. 1510, 31. pont.

${ }^{821}$ CPI L. 311-6. cikk ,,[La rémunération pour copie privée] est répartie entre les ayants droit par les organismes mentionnés á l'alinéa précédent, à raison des reproductions privées dont chaque oeuvre fait l'objet." 
II. rész A törvény által előírt közös jogkezelés, mint a kizárólagos jog korlátja

II. fejezet A kizárólagos jog díjigényre korlátozása révén bevezetett közös jogkezelés

\section{B) A dijról való lemondás lehetösége}

Az EuB nemcsak a díjak megállapításával és beszedésével kapcsolatban tett fontos megállapításokat a bemutatott releváns előzetes döntéshozatali eljárások keretében, hanem a díjak felosztásával kapcsolatban is. A Luksan-ügyben az InfoSocirányelv 5. cikk (2) bekezdés b) pontjának szószerinti és teleologikus értelmezése alapján $^{822}$ kiemelte azt, hogy a díjakról nem lehet lemondani, sem pedig azt másik jogosultnak átengedni, a tagállamok pedig nem állíthatnak fel olyan vélelmet, amely alapján a filmalkotás főrendezője az őt megillető méltányos díjazáshoz való jogot a film előállítójára ruházta át, függetlenül attól, hogy ez a vélelem megdönthetetlen vagy el lehet térni tőle. ${ }^{823} \mathrm{Ez}$ az értelmezés tehát nem teszi lehetővé azt a jogosult számára, hogy egy vagyoni jogosultságról szabadon rendelkezzen. ${ }^{824}$

Bár az Szjt. 16. § (5) bekezdése lehetővé teszi a díjazásról való lemondást kifejezett nyilatkozattal, azt is hozzáteszi, hogy a törvény kizárhatja az ilyen díjazásról való lemondás jogát. Mind a 20. $\S$, mind pedig a 21. § esetében található rendelkezés a lemondás jogának korlátozásáról, de ez nem jelenti ennek kizárását. Ugyanis a jogosultak csak a felosztást követő hatállyal, a rájuk jutó összeg erejéig mondhatnak le. ${ }^{825}$ Ennek rögzítése azon túl, hogy a jogosultak nekik járó díj mértékének pontos ismeretében hozhassanak megalapozott döntést, a miatt is kiemelkedően fontos, mivel a felosztás elött a díjigényt a közös jogkezelő szervezet saját igényként érvényesíti, és azzal a felosztásig rendelkezik is. ${ }^{826}$

A francia kódex a lemondással kapcsolatban nem tartalmaz rendelkezést legalábbis a magáncélú másolatra tekintettel fizetett díjak esetében. A szerzői jogok átruházhatatlansága egyébként is kivételnek tekinthető, ${ }^{827}$ és mivel a törvény hallgat a kérdésről, megalapozottnak tünik annak a következtetésnek a levonása, hogy a díj

\footnotetext{
${ }^{822}$ POllaud-Dulian (2012) e-verzió, 5. bekezdés.

${ }^{823}$ Luksan-ítélet, 109. pont.

${ }^{824}$ LE ROY (2012) e-verzió, 14. bekezdés.

${ }^{825}$ Szjt. 20. $\S(7)$ bek. és $21 . \S(8)$ bek.

${ }^{826}$ Szjt. 88. § (2) bek. Hasonló szabály érvényesül egyébként a francia közös jogkezelő szervezetek esetében is, ugyanis ők is jogosultak bíróság előtt érvényesíteni azokat a jogokat, amelyeket az alapszabály szerint kezelnek. CPI L. 321-1. cikk (2) bekezdés. „Ces sociétés civiles régulièrement constituées ont qualité pour ester en justice pour la défense des droits dont elles ont statutairement la charge." A közös jogkezelő szervezetek igényérvényesítési lehetőségeiről lásd különösen: TóTH (2004) p. 309-329. BINCTIN (2009) II, p. 52. BRUGUIÈRE (2009) p. 1471.

827 A CPI a személyhez füződő jogok (L. 121-1. cikk) és a droit de suite (L. 122-8. cikk) kapcsán rendelkezik a jogok jogok elidegeníthetetlenségéről.
} 
II. rész A törvény által előírt közös jogkezelés, mint a kizárólagos jog korlátja

II. fejezet A kizárólagos jog díjigényre korlátozása révén bevezetett közös jogkezelés

ingyenesen másnak átengedhető. ${ }^{828}$ Ez mindkét esetben, a magyar és a francia törvény esetében is összecseng azzal, hogy a díjazás jogosultjai nem kizárólag a szerzők, hanem a kapcsolódó jogi jogosultak is. Ez az a szempont, amit egyébként a Bíróság nem vett figyelembe a Luksan-ügyben: nevezetesen azt, hogy a jogosultak nem csak a szerzők, hanem a kapcsolódó jogi jogosultak is lehetnek.

Az EuB megállapításának szigorú betartása felvetné egyébként annak a kérdését is, hogy vajon jogszerü-e a közös jogkezelő szervezetek megállapodása a törvényben rögzített küszöböktől való eltérés esetén (amennyiben az a szerzők részére hátrányosabb) annak ellenére, hogy erre maga az Szjt. biztosít felhatalmazást. Mivel az EuB a vélelmek alkalmazásáról rendelkezik, az eseti szerződéssel megvalósuló lemondás továbbra is lehetséges marad. A magyar törvény rendelkezése tehát megfelel ennek a gyakorlatnak, hiszen az az utólagos, esetenkénti lemondást teszi lehetővé. A szerződéses viszonyokban általában gyengébb pozícióban lévő szerző és az előadóművész védelme érdekében viszont indokolt a Bíróság megállapításának megfelelően az, hogy a díjat ne lehessen előre, másik jogosulti csoport vagy felhasználó részére átengedni.

\section{b) A szociális és kulturális célok}

A tagállamok egy részében bevett gyakorlat, hogy a magáncélú másolatra tekintettel fizetett díjak egy részét nem közvetlenül a jogosultak számára utalják, hanem kihasználva a közös jogkezelés kollektív jellegét, illetve azt, hogy nehezen egyediesíthető díjakról van szó, a jogosultak számára szociális és kulturális célok megvalósítására fordítják. A magyar törvényben is létezik erre vonatkozó gyakorlat (és egyébként létezett már korábban is), illetve a CPI is lehetővé teszi a közös jogkezelő társaságok számára, hogy az üres hordozó díjak negyedét ilyen módon használják fel. ${ }^{829}$

${ }^{828}$ BinCTIN, Nicolas: Rémunération pour copie privé, J. Cl. Propriété littéraire et artistique, Fasc. 1510, 13. pont.

${ }^{829}$ CPI L. 321-9. cikk. A kulturális és szociális célra fordítható összegek alapját képezi még egyébként a reprogáriai jogdíjak, a kábeles továbbközvetítési jogdíjak, az előadómüvészeknek és hangfelvételelőállítóknak a hangfelvételek nyilvános előadása, illetve sugárzása, kábeles továbbközvetítése, valamint az ezekhez szükséger többszörözésére tekintettel fizetett jogdíjak, illetve üres hordozó díjak (vagyis gyakorlatilag a kötelező közös jogkezelésben lévő díjak) fel nem osztható része. A fel nem oszthatóság kér okból eredhet: vagy nemzetközi egyezmények alkalmazása miatt (első ízben külföldön rögzített müvek, amelyek esetében nincsen viszonosság), vagy pedig azért, mert a jogosult az elévülési időn belül nem azonosítható vagy nem lelhető fel. A francia szakirodalom ezeket a díjakat külön összefoglaló elnevezéssel ,irrépartissables"-ként hivatkozza, annak ellenére, hogy az üres hordozzó díjak egy része nem a feloszthatatlanságuk miatt, hanem a törvényi rendelkezés értelmében tartozik ebbe a kategóriába. 
$\mathrm{Az}$ EuB is jóváhagyta ezt a gyakorlatot, kiemelve, hogy megfelel az InfoSocirányelvnek, ha a méltányos díjazást szociális és kulturális célokra fordítják, azonban ennek ténylegesen a jogosultak javára kell szólnia, és nem lehet diszkriminatív a díj ilyen célú felhasználása. ${ }^{830}$ A nem diszkriminatív kivétel ebben az esetben az uniós jogi terminológia szerinti értelmet hordozza, vagyis a tagállami szabályozás a nem állampolgárokat nem hozhatja kedvezőtlenebb helyzetbe, mint a tagállam saját állampolgárait.

Az Szjt. egyik legutóbbi módosítása során került be a törvénybe a 89. § (11a) bekezdése, amelynek értelmében a magáncélú többszörözésre tekintettel fizetett díjakból származó bevétel 25\%-át a jogosultak érdekében kulturális célra kell felhasználni. Ezt a bevételt a díjakat megállapító közös jogkezelő szervezet, vagyis az Artisjus a törvény értelmében köteles átadni az NKA-nak, amely azt a külön törvényben ${ }^{831}$ foglalt támogatási célokra használja fel. Ebből az összegből indították útjára a Cseh Tamás Programot, ${ }^{832}$ amely meghívásos vagy nyílt pályázatok útján támogatja a könnyüzenei életet. ${ }^{833}$

Vitatható a hatályos törvényi rendelkezés, amely egy magánjogi alapokon nyugvó díjazást állami intézmény kezelésébe helyez, az állami kultúrpolitika eszközévé téve ezeket az összegeket. A közös jogkezelés rendeltetésével, müködési elveivel ugyanis leginkább az férne össze, ha a jogosultak a felosztási szabályzatban maguk rendelkezhetnek az ilyen célra fordítandó összeg felhasználásának konkrét módjáról. Ez a kollektivizáció az, amely a közös jogkezelés megkülönböztető jegyét adja az üzleti alapú jogkezeléshez képest, és jelenti egyben a jogintézmény lényegét. ${ }^{834}$

Vitathatatlan, hogy az összegek jogosultak általi döntésével a befizetett díjak egy része a kultúra támogatásának eszközévé válik. Hiszen önmagában a közös jogkezelő szervezetek által fenntartott programok alkalmasak a további alkotómunkák ösztönzésére. Emiatt a misszió miatt érdemes párhuzamot vonni a könyvtári haszonkölcsönzési díjakkal, hiszen az is tradicionálisan hasonló célokat szolgálhat. Ott

${ }^{830}$ Amazon-ítélet, 49-54. pontok.

831 1993. évi XXIII. tv. a Nemzeti Kulturális Alapról.

${ }_{833}^{832}$ A Nemzeti Kulturális Alap Bizottságának 25/2014. (III.19.) számú határozata.

${ }^{833}$ Az új törvényi szabályozás egyébként nemcsak a magáncélú másolatra tekintettel fizetett díjakat érinti. A jogdíjak (az ARTISJUS esetében a nyilvános előadási jogdíjak) 10\%-a kerülhet ilyen céllal elkülönítésre, amely összeg 70\%-a felett szintén az NKA rendelkezik. Szjt. 89. § (10)-(11) bek.

${ }^{834}$ Lásd az I. rész II. fejezetét a közös jogkezelés általános jellemzöiről. 
viszont a folyamat iránya ellentétes, mivel az állami költségvetésből fedezik a díj teljesítését. Ezzel ellentétben az üreshordozó díjak kapcsán a közös jogkezelő egyesületek által beszedett és a kezelési költségekkel csökkentett magánjogi díj az, amelyet az állam használ fel. Ez szimbolikusan és retorikáját tekintve is veszélyeket rejt magában. A közös jogkezelő szervezetek ugyanis nem kevés energiát fektetnek abba, hogy hangsúlyozzák: nem adó megfizetéséről van szó a díjfizetési igény érvényesítése kapcsán. Az állami szerv bevonása a folyamatba viszont jelentősen visszavetheti a közös jogkezelők szerzői jogi tudatosság kiépítése terén elért eddigi teljesítményeit. Nem mellesleg pedig az átláthatóságot is veszélyezteti, míg ugyanis az összegek felhasználására az egyesületek támogatási politikát kötelesek elfogadni, és azt honlapjukon nyilvánosságra hozni, ${ }^{835}$ addig az NKA-t ilyen kötelezettség nem terheli.

A fenti kritikai észrevételeken túl a hatályos megoldás az EuB által felállított kritériumainak nem felel meg. A Bíróság szerint a díj felhasználásának megkülönböztetés-mentesnek kell lennie. Jelenleg viszont az NKA pályáztatási rendszerében csak magyar állampolgárok részesülhetnek kulturális vagy szociális támogatásban. A kizárólag a jogosultak javára történő felhasználás kitétele sem feltétlenül valósul meg, a program keretében már meghirdetett meghívásos pályázatok közül egyértelműen ettől eltérő célra szolgál a Design Terminál Nemzeti Kreatívipari Központban létrejövő Cseh Tamás Programiroda és honlap fenntartása. ${ }^{836}$ A jogosultak érdekében történő felhasználás azt követelné meg, hogy a program müködtetéséhez szükséges infrastruktúra kiépítése egyéb forrásokból valósuljon meg.

Ennek a kritériumnak a megvalósulása egyébként akkor sem biztosított, ha a jogosultak döntése nyomán a közös jogkezelö szervezet az összegek szociális és kulturális célú felhasználására együttmüködési megállapodást köt egy szakmai érdekképviseleti szervezettel. A FILMJUS korábban megállapodást kötött az IRKA Irodalmi Filmszerzők Egyesületével a jogdíjak egy részének kulturális és szociális felhasználása céljára. A megállapodás értelmében a FILMJUS a magáncélú másolatokra tekintettel beszedett díjak egy részét továbbutalta az IRKA Egyesületnek, aki ezért

\footnotetext{
${ }^{835}$ Szjt. 89. § (3) és (11) bek.

${ }^{836}$ A programiroda létrehozása különösen annak fényében érdekes, hogy az első éves beszámoló alapján a 2015-2016. évre a program céljára 100-100 millió forint biztosított, és ugyanekkora összeg került feltüntetésre a programiroda létrehozása céljára is. Lásd: A Cseh Tamás Program első évének eredményei - Sajtótájékoztató (http://online.nka.hu:81/NKA_belso/_temp/ckfinder/files/sajtoszoba/sajtanyag_150603.pdf) 
cserébe évente beszámoló készítésére volt köteles a pénzösszeg célnak megfelelő felhasználásáról. Mivel az IRKA Egyesület a kapott összeg 80\%-ot meghaladó részét saját müködési költségeire fordította, a FILMJUS rendkívüli felmondással megszüntette a szerződést. ${ }^{837}$ A FILMJUS eljárása összecseng az EUB későbbi ítélkezési gyakorlatával, hiszen a befolyt díjaknak valamely szervezet müködési költségeire való fordítása álláspontunk szerint nem tekinthető a jogosultak javára történő felhasználásnak

A kulturális és szociális cél egyébként egyik jogszabályban sincsen konkrétan definiálva, emiatt többféle tevékenységet is takarhat. Tipikusan azonban a további alkotótevékenységet segítő, vagy a szociális helyzetük alapján rászoruló jogosultak pályázhatnak támogatásra. ${ }^{838}$ A CPI ráadásul konkrétabb felhasználási módokat ír elő, ugyanis az alkotás, az élő előadások terjesztése, illetve a müvészek képzése céljára teszi lehetővé a díjak felhasználását. ${ }^{839} \mathrm{Az}$ Államtanács egy döntése ${ }^{840}$ segít pontosabban körülhatárolni ezeknek a fogalmaknak a tartalmát. A döntés értelmében a közös jogkezelő szervezetek ilyen irányú tevékenységének az alkotás támogatásával kell közvetlen kapcsolatban lenniük.

\footnotetext{
${ }^{837}$ Fővárosi Bíróság 29.P.24.337/2009/22.

838 A francia törvény alapvetően a kulturális célokról rendelkezik, a szociális célok némileg háttérbe tolásával. Az R. 321-9. cikk az, amely a kiírható pályázatokról rendelkezik.

${ }^{839}$ CPI L. 321-9. cikk „Ces sociétés utilisent à des actions d'aide à la création, à la diffusion du spectacle vivant et à des actions de formation des artistes...”.

${ }^{840}$ CE 8 déc. $2000, n^{\circ} 202076$ et 203626 , Assoc. „Protection des ayants droit”, JurisData n ${ }^{\circ} 2000-061506$; Comm. com. électr. 2001, comm. 15, obs. Caron.
} 


\section{A második rész konklúziója}

A kötelező közös jogkezelés az esetek többségében a nemzetközi vagy uniós szerzői jog előírásainak megfelelően történik, sőt a vezetékes továbbközvetítés jog esetében maga a Mühold-irányelv írja elő ennek bevezetését. Bár a Mühold-irányelv nem teszi kötelezővé, Magyarországon a nem dramatikus zenei és irodalmi művek földfelszíni és azzal együttes müholdas sugárzása vagy vezetékes nyilvánossághoz közvetítésének szerzői engedélyezési jogai is kötelező közös jogkezelésben állnak. Ennek bevezetésének lehetősége viszont közvetlenül a BUE-ból ered. A reprogáfiai többszörözési jog kizárólagos engedélyezési jogának kötelezö közös jogkezelésbe vonására viszont nincsen kifejezett nemzetközi jogi felhatalmazás, ez a háromlépcsős tesztböl vezethető le általánosan. Ez aláhúzza annak igazolását, hogy a kötelező közös jogkezelés előírása a szerzői jog korlátozásának tekinthető, amelyre adott esetben a háromlépcsős teszt alkalmazandó.

Különösen a reprográfiai többszörözés joga kapcsán mondható el, hogy a francia jogalkotó, illetve a bírói gyakorlat igyekszik ezeket a jogokat a lehető legszükebben megvonni, ezáltal csak bizonyos meghatározott jogosulti kör bizonyos meghatározott joga tekintetében gyakorlandónak elrendelni. Ez tekinthető egyben úgy is, hogy a kizárólagos jogok közös jogkezelés alá utalása különleges esetre vonatkozik. De közös jogkezelés alá rendelt vagyoni jogoknak ez a fajta szüken meghatározottsága a többi vizsgált engedélyezési jog tekintetében is megfigyelhető. A közös jogkezelés alá nem tartozó tényállások esetében pedig a szerző engedélyezési joga feléled: a francia jogesetek remekül példázzák, hogy a közös jogkezelő szervezetek engedélyezési joga valójában mennyire korlátozott. Ezek az esetek voltaképpen a mü rendes felhasználásának megvalósítását teszik lehetővé. A tételt megfordítva a reprográfiai többszörözés esetében a tömeges felhasználások, a vezetékes továbbközvetítési jog körében pedig a felhasználások egyéb vizsgált jellemzői azt vetítik előre, hogy az egyéni joggyakorlás gyakorlatilag lehetetlen lenne. A kizárólagos jog biztosításával, illetve a felhasználás mértékéhez igazodó jogdíj előírásával és a tényleges felhasználási adatokon alapuló felosztás segítségével pedig a szerzők jellemzően olyan mértékü bevételt érhetnek el, mint amilyet egyébként az egyéni joggyakorlás keretében érhettek volna el. Ez a jogdíjközlemények sajátos elfogadási rendjének ellenére Magyarországon is helytálló, tekintettel a közös jogkezelő szervezetek erősebb tárgyalási pozíciójára. 
A közös jogkezelés ezekben az esetekben tehát, bár a szerzői jog korlátjának tekinthető, ez a korlátozás a szerzők érdekében áll és az ő javukat szolgálja. Bevezetésük pedig alapvetően illeszkedik a szerzői jog logikájába, megfelel az egyébként bevett jogosítási gyakorlatnak.

A szerzői jogok díjigénnyé szorításával kombinált közös jogkezelés hasonló jellemzőket mutat (bár tény, hogy ezekben az esetekben nem maga a közös jogkezelés jelenti a korlátot). A magáncélú másolatokra tekintettel beszedett üres hordozó és reprográfiai díjak esetében viszont a közös jogkezelés kötelező elöírásán kívül más lehetőség a díj hatékony érvényesítésére nincsen. A korlátozás itt két szinten jelenik meg (legalábbis a magyar törvényben). Egyfelől korlátnak tekinthető a díjigénnyé változtatás ténye. Másfelől pedig álláspontunk szerint a díjak egy részének állami szerv általi felhasználása (még ha az a jogosultak érdekében kulturális és szociális célra történik is) szintén korlátnak tekintendő. Ezen összegek felhasználása tekintetében ugyanis teljesen megszünik a jogosultak rendelkezési joga.

A szerzői jog arra épül, hogy a jogosultaknak a kizárólagos jog minél szélesebb értelmezésével biztosítson minél több mozgásteret a múvek felhasználásának engedélyezésére, ily módon pedig a bevétel elérésére. A kivételek szoros értelmezése tehát nem csak az „exceptio est strictissimae interpretationis” általános jogi maximából következik, hanem ez a másodlagos indok is meghúzódik mögöttük. Vagyis minél kevesebb teret engedünk a kivételek érvényesülésének, a kizárólagos jog annál inkább tud a maga teljességében megjelenni. ${ }^{841}$ A jogosultak kizárólagos jogának egyéni engedélyezés körében hagyására vonatkozó törekvést illusztrálta a vezetékes továbbközvetítési és reprográfiai többszörözési jog. Paradox módon viszont a magáncélú másolat tekintetében fizetett díjak azt példázzák, hogy a jogosultaknak nem feltétlenül kedvező az elv maradéktalan érvényesítése. A rendszer átalakításával, a kivétel lehető legszükebb megvonásával ugyanis bevételtől estek el, ennek fejében viszont az engedélyezési jog gyakorlása a kivétellel nem érintett területeken továbbra is nehézségekbe ütközik. A felhasználások hasonló, általában tömeges jellege miatt megfontolandó lehet egy, a francia reprográfiai többszörözéshez hasonló kötelező közös jogkezelési rendszer bevezetése. Ennek előnye a jogosult engedélyezési jogának

${ }^{841}$ GAUTIER (2012) p. 40. 
megtartásában, illetve a pontosabb nyomonkövehetőség miatt a tényleges felhasználáshoz jobban igazodó jogdíj megállapításában állna. 


\section{III. rész A törvény által előírt közös jogkezelés, mint a joggyakorlás módja}

A törvény által elöírt közös jogkezelés bizonyos esetekben úgy tünik, hogy sokkal inkább a joggyakorlást segítő módként, sem pedig korlátként értékelhető. A kizárólagos engedélyezési jogok esetében ilyenkor a nemzetközi és uniós dokumentumokban nem található utalás a joggyakorlás módjának állami meghatározhatóságára, vagy egyébként a közös jogkezelés előírására. A díjigényként meghatározható vagy meghatározott vagyoni jogok esetében pedig a klasszikus modelltől eltérő indokok vezetnek a közös jogkezelés előírására. A jogalkotó tehát elsősorban a jogkezelés hatékony müködésének szempontját tartotta szem előtt ezeknek az eseteknek törvénybe iktatásakor. Éppen emiatt kell ezeket különös figyelemmel vizsgálni: előfordulhat ugyanis, hogy a hatékonyság mindenek felett álló figyelembe vétele eredményezi a szerzői jog korlátozását.

A közös jogkezelés hatékonyságát két oldalról lehet vizsgálni. A szerzők szempontjából ez akkor valósul meg, ha a felhasználási feltételek meghatározásában a lehető legteljesebb módon veszik ki a részüket, illetve a beszedett jogdíjakból a lehető legteljesebb mértékben részesednek. Ez természetesen összefügg a közös jogkezelő szervezetek átlátható müködésével, illetve azzal is, hogy a kötegben történő jogkezelés miatt a szerzőknek el kell fogadniuk a díjazás kezelési költségekkel való csökkentését, valamint a felosztás során bizonyos fokú torzulást. A felhasználó szempontjából pedig a közös jogkezelés akkor hatékony, ha biztosítja, hogy a jogszerzés minél egyszerübben, a lehető legszélesebb repertoárra terjedjen ki; illetve ha lehetővé teszi, hogy a díjazást a felhasználók a lehető legkevesebb adminisztrációs teher elviselése mellett tudják megfizetni.

Ez utóbbi szempontnak a figyelembe vételével születtek meg a jogosultak kilépését lehetővé tevő, törvény által elöírt közös jogkezelési esetek. Sokan éppen emiatt az opt-out miatt támadják ezeket a törvényi elöírásokat, a szerzői jog alapelvének kifordítását látva bennük. A jogosult ugyanis, az önkéntes közös jogkezeléssel ellentétben, nem arról dönthet, hogy csatlakozni kíván-e a szervezethez, hanem éppen 
ellenkezőleg, nyilatkozhat arról, ha mégis inkább egyénileg szeretné az engedélyezési jogát gyakorolni (I. fejezet).

Más esetekben a közös jogkezelés díjigények gyakorlásához kapcsolódik. Ezek a díjigények viszont általában eleve ilyen módon lettek meghatározva, tehát egyfelől nem tekinthetők a szerzői jog korlátjának (hiszen nem egy engedélyezési jog speciális eseteként díjigényre való szorításaként meghatározott felhasználást jelentenek), másfelől pedig közös jogkezelésbe utalásuk önmagában sem jelent korlátot. Ezt a megállapítást azzal a megszorítással tesszük, hogy a nemzetközi egyezményes, vagy uniós jogi alapon létező díjigény eleve nem minősül korlátozásnak. Természetesen a kérdéskör megközelíthető absztraktabban is: ebben az esetben minden, felhasználásnak minősülő magatartással szemben a kizárólagos jognál korlátosabb igény a szerzői jog korlátja. Az üres hordozó díjakhoz képest eltérést mutatnak abban a tekintetben is, hogy a közös jogkezelésre nemcsak a felhasználás tömeges jellege (vagy legalábbis ennek eltérő jellemzői) miatt van szükség. A szervezetek sokkal inkább közvetítő adminisztrátori szerepre vannak kárhoztatva, lévén, hogy a szerzői jogi törvények részletesen meghatározzák a díjazás mértékét és a felhasználási feltételeket, a közös jogkezelés célja pedig leginkább abban áll, hogy a felhasználók számára megkönnyítsék a díj megfizetését. (II. fejezet). 


\section{I. fejezet Az engedélyezési jog gyakorlása kilépést engedő közös jogkezelés körében}

A kilépést engedő közös jogkezelés a müködési elve miatt egyfajta hibrid, átmeneti megoldást képez az egyéni és a kötelező kollektív jogkezelés között. Elsősorban a felhasználók számára segíti elő az engedély megszerzését, nekik ugyanis egyszerübb egyetlen szervezettől ezt igényelni (egyablakos ügyintézés, one stop-shop), semmint valamennyi jogosultat felkutatni. A jogosult számára viszont megmarad annak a lehetősége, hogy dönthessen az egyéni joggyakorlás mellett. Emiatt tekinthető elönyös rendszernek: mindkét oldal számára igyekszik vállalható kompromisszumok mellett optimális jogosítási rendszert felállítani. Ez okozza viszont azt, hogy müködésének kereteit aprólékosan kell meghatározni, fenntartva a hatékonyság és a szerzői jogok korlátozásának nem megengedhetősége közötti kényes egyensúlyt.

A kilépést engedő közös jogkezelésnek egy speciális megjelenési formája a kiterjesztett hatályú közös jogkezelés. A skandináv szerzői jogban bevezetett modell lényege, hogy a törvényi rendelkezés felhatalmazása alapján a KJK szervezetek olyan felhasználási szerződéseket kötnek, amelyek a felhasználó számára engedélyt biztosítanak a szervezet által nem képviselt, de azonos műfajú mü felhasználására is. ${ }^{842}$ Általánosabb értelemben véve viszont kiterjesztett hatályú közös jogkezelésnek tekinthető az a jogtechnikai megoldás, amelynek alapján a felhasználó azonos felhasználási feltételek mellett jogosult olyan müvek használatára is engedélyt szerezni, amelyek jogosultja nem tagja, vagy egyébként nem adott képviseleti megbízást a közös jogkezelő szervezetnek. Ez a megoldás teszi lehetővé, hogy a felhasználók az egész világrepertoárra szerezhessenek felhasználási jogosultságot. Kötelező közös jogkezelés esetében, mint láttuk, a jogkezelés természetszerüleg csak kiterjesztett hatályú lehet. Más esetekben viszont ez a kilépést engedő közös jogkezelés valamely nemzeti változatához kapcsolódik. A magyar jogalkotó is több jog gyakorlása kapcsán írja elö a joggyakorlásnak ezt a módját, éppen emiatt lényeges külön fejezetet szentelni a vizsgálatának (2. pont).

A kilépést engedő közös jogkezelés másik lehetséges megjelenési formája, amikor a joggyakorlás nem rendelkezik kiterjesztett hatállyal. A felhasználók szempontjából ez a megoldás valamivel kedvezőtlenebb, mivel csak azzal az előnnyel

${ }^{842}$ RIIS - SCHOVSBO (2009-2010/) p. 471-495. 
jár, hogy nem kell felkutatniuk a jogosultat, hanem jó eséllyel közvetlenül a szervezettől szerezhetnek engedélyt. Ilyen módon tehát hasonló megoldás alkalmas lehet a digitalizációval összefüggő egyes kérdések megoldására, egyebek mellett az árva müvek engedélyezése is elképzelhető ilyen keretek között. Létező példa viszont Franciaországban a kereskedelmi forgalomban nem kapható könyvek digitalizálásának engedélyezése (1. pont).

\section{Kilépést engedő közös jogkezelés: kötelező közös jogkezelés és az egyéni joggyakorlás között}

A kilépést engedő közös jogkezelés francia változata egy speciális szerzői jogi problémára adott válasz: a kereskedelmi forgalomban nem kapható könyvek digitalizálást elősegítő megoldás. A vezetékes továbbközvetítési jog gyakorlásához hasonlóan nem az a célja, hogy a tömeges felhasználások miatt nehézkessé váló engedélyszerzést megkönnyítse. Sokkal inkább olyan megoldást jelent, amelyben a közös jogkezelö szervezetnek egyfajta közvetítő szerepe van a felhasználók és a jogosultak között, ennek tudható be az is, hogy a kiterjesztett hatály nem képezi a konstrukció részét. Ennek elnevezésére egységes terminológia még nem alakult ki a francia szakirodalomban: egyesek egyszerüen kötelező közös jogkezelésként, mások kiterjesztett közös jogkezelésként ${ }^{843}$ hivatkoznak rá, de olvasható a vélelmezett közös jogkezelés ${ }^{844}$ fogalma is. A jogintézmény lényegét talán a vélelmezett közös jogkezelés adja vissza leginkább. Nem lehet szó ugyanis kötelező közös jogkezelésről a kilépés lehetősége miatt. A kiterjesztett közös jogkezelés elnevezés sem helytálló, mivel azonos müfajon belül csak a müveknek egy meghatározott részére terjed ki a joggyakorlási mód.

Az egységes terminológia kialakítása iránti igényt árnyalja az is, hogy a kereskedelmi forgalomban nem kapható könyvek francia modellje mellett ${ }^{845}$ Németország is kialakított egy ettől eltérő alapokon nyugvó megoldást. Ennek legfőbb eltérése a francia modellhez képest, hogy a felhasználást nem kereskedelmi alapon kívánja engedélyezni, hanem lényegében az Árva mü irányelvben meghatározott kedvezményezetti kör számára biztosítja a felhasználást a közös jogkezelésen

\footnotetext{
${ }^{843}$ PIRIOU (2012b) e-verzió 4. bekezdés.

844 ÉMILE-ZOLA-PLACE (2012) p. 360.

${ }^{845}$ Ezt követi egyébként Szlovákia is (2014. szeptember 12-i 283/2014. tv.).
} 
keresztül. ${ }^{846}$ A KJK-irányelv átültetésének részletes koncepciójában az SZTNH szerepeltet egy a német modellt alapulvéve kialakított önálló közös jogkezelési eset bevezetésére tett javaslatot is. ${ }^{847}$ Elismerve, hogy egy előkészítő anyagról van szó, amely a normaszöveg konkrét megfogalmazására nézve sem tartalmaz javaslatot, nem tartjuk indokoltnak a koncepció egyes elemeit bemutatni, erre álláspontunk majd csak a végleges normaszöveg ismeretében kerülhet sor. ${ }^{848}$

Ennek megfelelően mindenekelőtt a francia törvény tárgyi hatályának elemzésére kell kitérni, amely a kereskedelmi forgalomban nem kapható könyvek digitalizálásának engedélyezésére terjed ki (§1. pont). A közös jogkezelés gyakorlati megvalósítása kapcsán pedig ki kell emelni, hogy az eltérést mutat a többi francia megoldástól. Azon túl, hogy biztosítja a kilépés lehetőségét, a közös jogkezelési feladatokat megosztja a BNF és a közös jogkezelést végző társaság között (§2. pont).

\section{§1. A közös jogkezelés tárgya: a kereskedelmi forgalomban nem kapható könyvek digitalizálása}

A dolgozatot átszövik a szerzői jog és az új technológiák összefonódásával kapcsolatos kérdések. Nincsen ez másként a könyvdigitalizálás kérdésével sem, ugyanis ez is a meglévő szerzői jogi kategóriák új környezetben való alkalmazását teszi szükségessé. Ez tulajdonképpen nem jelent mást, mint a szerzői jog egyik legklasszikusabb fogalmának, az irodalmi münek az adaptálását a modern környezetünkbe. ${ }^{849} \mathrm{~A}$ digitalizálás elsődleges értelmében tág fogalom, hiszen ide tartoznak az eredendően digitális formában létrejött tartalmak, úgymint az e-könyvek és a hangoskönyvek. A fogalom azonban szükíthető, amennyiben könyvdigitalizálás alatt csak a nyomtatott formában megjelent könyveknek a számítógép nyelvére való

\footnotetext{
${ }^{846}$ Szellemi Tulajdon Nemzeti Hivatala Részletes koncepció a szerzői és szomszédos jogokra vonatkozó közös jogkezelésröl és a zeneművek belső piacon történő online felhasználásának több területre kiterjedő hatályú engedélyezéséröl szóló 2014/26/EU irányelv átültetéséhez megalkotandó magyar jogi szabályozás föbb tartalmi kérdéseivel kapcsolatban (a továbbiakban: Átültetési koncepció), p. 32-33. (http://www.sztnh.gov.hu/sites/default/files/20150710_kjk_ire_reszletes_atultetesi_koncepcio_konzultaci ora_0.pdf)

${ }_{847}$ Átültetési koncepció, p. 31-36.

${ }^{848}$ A francia megoldás elemzéséről magyar nyelven lásd: HAJDÚ (2013) p. 53-59. TARR (2013) p. 108134.

${ }^{849}$ A szakirodalom az utóbbi időben széleskörüen foglalkozik a kérdéssel, lásd például: CASTEX, (2010) p. 84-92. DERIEUX (2010b) p. 80-101., CARRE (2005) p. 22-25., BRUGUiÈRE - FAUCHOUX (2011) everzió, SYNODINOU (2013) p. 220-227.
} 
III. rész A törvény által elöírt közös jogkezelés, mint a joggyakorlás módja

I. fejezet Az engedélyezési jog gyakorlása kilépést engedő közös jogkezelés körében

átültetését értjük. ${ }^{850} \mathrm{~A}$ továbbiakban könyvdigitalizálás alatt ezt a szűkebb fogalmat használjuk.

Franciaországban már 2005 óta napirenden van a könyvdigitalizálás kérdése, több jelentés is született a témában, körüljárva többek között a könyvtári könyvdigitalizálás és az e-könyvek jogi és piaci helyzetének kérdéseit. ${ }^{851}$ A közkinccsé vált müvek digitalizálásában már példaértékű gyakorlattal is rendelkeznek: az országos könyvtár, a BNF végzi ezt a feladatot. ${ }^{852}$ Nem csak az ilyen művek digitalizálása merült azonban fel. A Google könyvdigitalizálási gyakorlata ugyanis kiterjedt a még védelem alatt álló mủvek szkennelésére is. ${ }^{853} \mathrm{Az}$ Európai Unió tavaly elfogadott irányelve az árva művekről szintén tartalmaz rendelkezéseket ${ }^{854}$ a digitalizálásra nézve.

Ezek a projektek irányították rá a figyelmet az irodalmi müveknek egy olyan „szürke zónájára”, amelynek digitalizálása eddig nehézségekbe ütközött. Olyan könyvekről van szó, amelyek még nem váltak közkinccsé, ám kereskedelmi forgalomban nem kaphatóak, és emiatt lassan a feledés homályába vesznek. Franciaországban ennek a nagyjából 500.000 művet $^{855}$ számláló kategóriának a

\footnotetext{
${ }^{850}$ TÓSZEGI (2006).

${ }^{851}$ Ezeket lásd: STASSE, François: Rapport au ministre de la culture et de la communication sur l'accès aux cuvres numériques conservées par les bibliothèques publiques, avril 2005 (http://www.ladocumentationfrancaise.fr/rapports-publics/054000450/index.shtml); PATION, Bruno: Rapport sur le livre numérique, 30 juin 2008 , (http://www.culture.gouv.fr/culture/actualites/conferen/albanel/rapportpatino.pdf); TESSIER, Marc: Rapport sur la numérisation $d u$ patrimoine écrit, 12 janvier 2010 (http://www.ladocumentationfrancaise.fr/rapports-publics/104000016/index.shtml); GAILLARD, Yann: La politique du livre face au défi du numérique, 25 février 2010 (http://www.senat.fr/rap/r09-338/r09338.html); AlBANEl, Christine: Pour un livre numérique créateur des valeurs, avril 2010 (http://www.ladocumentationfrancaise.fr/rapports-publics/104000189/index.shtml).

${ }^{852}$ Ez az ún. Gallica-projekt, amelyet 1997-ben indítottak, és ma már több mint 2 millió dokumentumhoz nyújt hozzáférést (http://gallica.bnf.fr/). A világban számos ilyen kezdeményezés létezik, amelyek közül a legismertebb minden bizonnyal az amerikai kezdeményezésü, 1970-es években indított Gutenbergprojekt (http://www.gutenberg.org/). Az Európai Unió átfogó digitalizálási kezdeményezése, az Europeana (http://www.europeana.eu/portal/) is beleillik ebbe az irányvonalba. A könyvtári digitalizálásról lásd pl. MEZEI Péter: The painter, the one horn cow and ole Hank Wilson's back lot - The future of library digitization in the European Union and Hungary, kézirat.

${ }^{853}$ Erről lásd: MEZEI (2011) p. 8-10., illetve EFRONI - GEBERT (2011) p. 532.

854 Az Európai Parlament és a Tanács 2012/28/EU irányelve az árva müvek egyes megengedett felhasználási módjairól, 6. cikk.

${ }^{855}$ KHIARI, Bariza: Rapport fait au nom au nom de la commission de la culture, de l'éducation et de la communication sur la proposition de loi de M. Jacques Legendre relative à l'exploitation numériquedes livres indisponiblesdu XXème siècle, rapport nº 151 du Sénat, p. 16. (A továbbiakban: Rapport du Sénat).
} 
digitalizálását érintő kérdésekről fogadtak el 2012-ben törvényt, amely a kereskedelmi forgalomban nem kapható XX. századi könyvek digitális felhasználása címet viseli. ${ }^{856}$

A jogalkotó által kínált megoldás, vagyis a kilépést engedő, nem kiterjesztett hatályú közös jogkezelés bevezetése lehetővé teszi a könyvek kereskedelmi alapon történő digitalizálását (hiszen a kiadókat erre törvényben kötelezni lehetetlen volna), amelyek így újra elérhetővé válnak a felhasználók számára, és újabb bevételi forrást jelentenek a szerzőknek. ${ }^{857}$ A rezsim vizsgálata előtt viszont a kereskedelmi forgalomban nem kapható könyv fogalmát indokolt elemezni.

Az új definíciót a CPI L. 134-1. cikkében találjuk: e fejezet értelmében kereskedelmi forgalomban nem kapható könyv minden olyan könyv, amelyet 2001. január 1-jét megelőzően Franciaországban adtak ki, amelyet a kiadó már kereskedelmi forgalomban nem forgalmaz, és jelenleg nem képezi sem nyomtatott, sem pedig elektronikus kiadás tárgyát. ${ }^{858}$

Vagyis a kereskedelmi forgalomban nem kapható könyvként való minősítéshez a három fogalmi kritériumnak egyidejüleg teljesülnie kell. Mindenekelőtt a münek könyvnek kell lennie, amelyet Franciaországban egy meghatározott időpont előtt adtak ki, és már nem kapható.

\section{A) A könyv fogalma}

Egyes szerzők véleménye szerint a jogalkotó nem szabatos kifejezést használt a törvény tárgyi hatályának meghatározásakor. A könyv ugyanis önmagában nem szerzői jogilag védett kategória, az pusztán a szerzői jog által védett mű hordozója. Ráadásul a könyv szerepel ugyan a szerzői mủvek felsorolása között, ${ }^{859}$ de sem a jogalkotó, sem pedig a bírói gyakorlat nem adta a fogalom meghatározását. ${ }^{860}$ Így a jogalkotó

\footnotetext{
${ }^{856}$ Loi n $^{\circ}$ 2012-287 du 1er mars 2012 relative à l'exploitation numérique des livres indisponibles du XXe siècle.

${ }^{857}$ BRUGUIÈRE (2014) p. 11.

${ }^{858}$ CPI L. 134-1. cikk: „On entend par livre indisponible au sens du présent chapitre un livre publié en France avant le ler janvier 2001 qui ne fait plus l'objet d'une diffusion commerciale par un éditeur et qui ne fait pas actuellement l'objet d'une publication sous une forme imprimée ou numérique."

${ }^{859}$ CPI L. $112-2$. cikk $1^{\circ}$ pont.

${ }^{860}$ MACREZ (2012) e-verzió, 4. bekezdés.
} 
megsértette a CPI-nek a münek a hordozójától való függetlenségét kimondó rendelkezését. $^{861}$

Mások védelmezik a megfogalmazást, mivel megítélésük szerint a jogalkotó szándékának megfelelő szóhasználatról van szó. Tudniillik a jogalkotó így egyértelmüen leszükítette a törvény tárgyi hatályát, nem kívánva azt kiterjeszteni bármilyen szerzői müre. ${ }^{862}$ A CPI rendelkezései között sem idegen a hordozóra történő utalás: a hangfelvétel és a videofelvétel is magát a hordozót jelenti.

Mindezek mellett a könyv és az e-könyv fogalma is más jogszabályokban meghatározott. Ezért egyik fogalom használata sem eredményez bizonytalanságot, nem ad lehetőséget eltérő értelmezésre. A könyv fogalma egyrészt megtalálható az általános forgalmi adóra vonatkozó szabályok között, ${ }^{863}$ a legáltalánosabban használt fogalom azonban egy adóügyi leiratban található. E szerint a könyv olyan nyomtatott egység, amely akár el van látva illusztrációkkal, akár nem, egy vagy több szerzö szellemi alkotását testesiti meg oktatás, a gondolatok és a kultúra terjesztése céljából. ${ }^{864} \mathrm{~A}$ szenátusi jelentés is az adójogban meghatározott fogalmat tekinti a legtágabb és a leginkább alkalmazható fogalomnak. ${ }^{865}$

E helyütt kell említést tenni a nyomtatott könyvhöz képest az e-könyv fogalmáról, amelyet az e-könyvek árának meghatározásáról szóló törvény első cikke tartalmaz. Visszautalva a nyomtatott könyv fogalmára a meghatározás szerint $a z e$ könyv olyan egy vagy több szerzö által alkotott szellemi alkotás, amelyet akár digitális formában hoztak kereskedelmi forgalomba és nyomtatva is kiadtak, akár a tartalma és felépitése miatt a kizárólag a digitális kiadásra jellemző elemek kivételével nyomtatásra alkalmas. ${ }^{866} \mathrm{Az}$ e-könyv fogalma tehát nincs elválasztva a nyomtatás tényétől, illetve a nyomtatott könyv fogalmától.

Más jellegü kérdéseket vet fel a kereskedelmi forgalomban nem kapható könyv fogalma és a törvény egyik deklarált célja között feszülő ellentét. A kulturális sokszínüség védelme ugyanis megkívánná, hogy a nyilvánosságra hozott, de ki nem

\footnotetext{
${ }^{861}$ CPI L. 111-3. cikk.

${ }^{862}$ PIRIOU (2012a) e-verzió, 6. bekezdés.

${ }^{863}$ Code général des impôts L. 278 bis cikk.

${ }^{864}$ Circulaire $\mathrm{n}^{\circ} 82$ du 12 mai 2005.

${ }^{865}$ Rapport du Sénat, p. 26.

${ }^{866}$ Loi n ${ }^{\circ} 2011-590$ du 26 mai 2011 relative au prix du livre numérique, 1. cikk.
} 
adott művek (doktori disszertációk, szakdolgozatok, különböző jelentések) is digitalizálásra kerüljenek. A törvény rendelkezései azonban csak a kiadott, korábban kereskedelmi forgalomban kapható könyvekre alkalmazhatóak. ${ }^{867}$

\section{B) A kiadás helye és ideje}

A francia törvény hatálya alá azok a könyvek tartoznak, amelyeket Franciaországban adtak ki 2001. január 1. napját megelőzően.

A magyar koncepcióban csak a kiadás ideje kerül pontosításra. A tervek szerint az 1999. augusztus 31. előtt kiadott müvek kapcsán kerülne felállításra a kereskedelmi forgalomban nem kaphatóság megdönthető vélelme.

a) A kiadás helye

A kiadás helyével kapcsolatban a törvényt elökészítő francia szenátusi jelentés kiemelte, hogy a nem Franciaországban kiadott kötelespéldányok nem tartoznak a kereskedelmi forgalomban nem kapható könyvek fogalma alá. A francia nyelvre fordított, Franciaországban kiadott külföldi könyvek problémásak ebből a szempontból. Ugyanis, bár formálisan a rendelkezések hatálya alá tartoznának, csak a közös jogkezelő szervezetek nemzetközi együttmüködésének megteremtése után lehetne a törvény hatályát ezekre is kiterjeszteni. ${ }^{868}$

\section{b) A kiadás ideje}

A kiadás idejének meghatározása a francia törvényben nem elég egyértelmü. A törvény címével való összevetés alapján csak XX. századi könyvekröl lehet szó, vagyis a kiadás idejeként az 1901. január 1. és 2000. december 31. közötti időintervallum jöhet szóba. Mindazonáltal a CPI-be beiktatott új fejezet már nem tartalmazza a XX. századi jelzőt, a fejezet mindösszesen „A kereskedelmi forgalomban nem kapható könyvekre vonatkozó rendelkezések" címet viseli.

Ezek alapján akár a közkinccsé vált könyvek is minősülhetnének egyben kereskedelmi forgalomban nem kapható könyvnek. A jogalkotó szándéka szerint azonban egyértelműen csak a még védelem alatt álló müvek képezik az új kategóriát. ${ }^{869}$

\footnotetext{
${ }^{867}$ Ehhez lásd: ÉMILE-ZOLA-PLACE (2012) p. 357.

${ }^{868}$ Rapport du Sénat, p. 24-25.

${ }^{869}$ Rapport du Sénat, p. 18.
} 
Csupán a törvény végrehajtási rendelete utal arra, hogy a nyilvántartásból törölni kell azokat a könyveket, amelyek védelmi ideje már lejárt. ${ }^{870}$

A kiadás időpontjaként egyébként 2001. január 1. napja azért lett meghatározva, mert a jogalkotó vélelmezte, hogy ettől az időponttól kezdve a kiadói szerződések részét képezik a digitális felhasználások engedélyezésére vonatkozó kikötések.

Problémásak ebből a szempontból az 1957-es szerzői jogi törvény hatályba lépése előtt megkötött kiadói szerződések. A bírói gyakorlat ugyanis a digitális felhasználásokat ezekre a szerződésekre is kiterjesztette. 2005-ben merült fel a Semmítőszék előtt egy ügy, ${ }^{871}$ melyben a bíróság az 1793-as szerzői jogi törvény ${ }^{872}$ alapján 1907-ben és 1909-ben megkötött szerződéseket értelmezte. Ezekben a szerződésekben a szerző minden jogát átruházta a kiadóra. A bíróság előtt felmerülő egyik kérdés az volt, hogy az 1793-as rendeletben nem érintett felhasználási módokra (nevezetesen audiovizuális és hangfelvételre történő felhasználások) vonatkozó jogok is átruházásra kerültek-e a kiadóra. A fellebbviteli bíróság álláspontja szerint a jogátruházás csak a szerződés megkötésének időpontjában előre látott vagy előre látható felhasználásokra vonatkozik. A Semmítőszék viszont nem fogadta el ezt az érvelést és a döntést megsemmisítette. ${ }^{873}$ Egy idén tavasszal meghozott döntés pedig megerősítette a korábbi álláspontot annak kimondásával, hogy egy 1946-ban kötött szerződés alapján is lehetőség van a digitalizálásra, mivel a jogok átruházása kiterjed a szerződés megkötésének időpontjában nem ismert felhasználási módokra is. ${ }^{874}$

Vagyis ezeknek a müveknek a digitalizálása az eredeti kiadó által eddig is lehetséges volt annak ellenére, hogy 1992 óta a CPI részét képezi egy olyan rendelkezés, amely szerint a felhasználási szerződés megkötésének időpontjában előre nem látható, vagy már létező, de előre nem látott felhasználási módokra kötött szerződésnek kifejezettnek kell lennie, és a felhasználásból arányos díjazást kell

\footnotetext{
${ }^{870}$ CPI R. 134-2 cikk.

${ }^{871}$ Civ. 1re, du 25 mai 2005, 02-17305., ún. Colette-ügy.

${ }^{872}$ Loi des 19 et 24 juillet 1793 relatif aux droit sde propriété des auteurs, compositeurs de musiques, peintres et dessinateurs.

${ }^{873}$ Az ügy kommentárját lásd például: CARON (2005).

${ }^{874}$ Cass. crim., 12 mars 2013, $\mathrm{n}^{\circ}$ 12-85.163, F-D, Alexis M. et les Éditions du Cerf: JurisData ${ }^{\circ} 2013-$ 006702 .
} 
kikötnie. ${ }^{875}$ A megszilárdult bírói joggyakorlat alapján ugyanis a felhasználási szerződéseket a megkötésük időpontjában hatályban lévő törvény alapján kell elbírálni. ${ }^{876}$

\section{C) Kereskedelmi forgalomban nem kapható}

Ez a feltétel két további, jellegében hasonló kritériumot foglal magában. Egyrészt szükséges, hogy a könyv kereskedelmi forgalomban már ne legyen kapható, másrészt pedig sem hagyományos, sem pedig elektronikus formában nem került újra kiadásra.

a) A könyv kereskedelmi forgalomban nem kapható

A francia törvény nem tartalmaz eligazítást arra nézve, hogy mikor tekinthető egy könyv kereskedelmi forgalomban nem kaphatónak. Mekkora példányszám alapján lehet ezt kijelenteni? A fogalom csak a kiadó általi forgalmazásra vonatkozik? Bár a kérdések megválaszolását a Szenátus jelentése ${ }^{877}$ igyekszik megkönnyíteni, a kiadói szerződésekkel kapcsolatos rendelkezések jelentősen árnyalják ezt a képet.

A kiadói szerződés fogalma alapján a kiadónak úgynevezett hasznosítási kötelezettsége áll fenn, ami a mű kiadásában és terjesztésében áll. ${ }^{878}$ Részletezve: ez a kötelezettség nem pusztán azt jelenti, hogy a müvet az olvasóközönség számára elérhetővé kell tennie, hanem azt is, hogy a müvet ,gyümölcsöztetnie” kell. ${ }^{879} \mathrm{~A}$ törvényi megfogalmazás értelmében a kiadónak a mü állandó és folyamatos hasznosítását és kereskedelmi forgalomban való terjesztését kell biztosítania a szakmai szabályok alapján. ${ }^{880}$ A kiadó ezt a hasznosítási kötelezettségét megszegi, ha a készlet kimerül. Ezt abban az esetben lehet megállapítani, ha a kiadóhoz érkezett két szállítási igény három hónapon belül nem kerül kielégítésre. ${ }^{881}$ Legsúlyosabb esetben ez a szerződés megszüntetéséhez vezet, de a bírói gyakorlat ettől enyhébb szankciókat is

\footnotetext{
${ }^{875}$ CPI L. 131-6. cikk. Ennek elemzését lásd: BRUGUIÈRE - FAUCHOUX (2011) e-verzió, 22-24. bekezdés.

${ }^{876}$ CARON (2013c) 1. bekezdés.

${ }^{877}$ Rapport du Sénat p. 5.

${ }^{878}$ CPI L. 132-1. cikk.

${ }^{879}$ CPI L.132-12. cikk. VIVANT - BRUGUIÈRE (2012) p. 618

${ }^{880}$ CPI L. 132-12. cikk.

${ }^{881}$ CPI L. 132-17. cikk.
} 
megállapított. ${ }^{882}$ A kiadók azért, hogy elkerüljék a szerződés megszűnését, általában tartanak raktáron az általuk kiadott könyvekből. Ismert azonban olyan álláspont is, amely szerint 25 darab az a példányszám, amely alatt a készlet kimerültnek tekinthetö. $^{883}$

A kereskedelmi forgalomban nem kapható könyv definíciójából logikusan következne az, hogy a kiadó a hasznosítási kötelezettségének nem tett eleget, és a készlet kimerült. A CPI viszont elválasztja a készlet kimerülését a kereskedelmi forgalomban nem kaphatóság kritériumától. Egyértelműen kimondja ugyanis, hogy nem lehet a készlet kimerülésére hivatkozva szankciót érvényesíteni a kiadóval szemben abban az esetben, ha a könyvet a kereskedelmi forgalomban nem kapható könyvek nyilvántartásába veszik. ${ }^{884}$ Hasonlóképpen, a kiadó nem mentheti ki magát a készlet kimerülése esetén alkalmazandó szankció alól, ha egyébként a kereskedelmi forgalomban nem kapható könyvek esetén alkalmazandó rezsim rendelkezéseinek megfelelően bizonyítja azt, hogy a könyvet megfelelően hasznosítja. ${ }^{885}$ Sajnos a törvényalkotó eléggé szükszavú volt, és sem a pontos elhatárolási ismérveket nem állapította meg, sem pedig a kereskedelmi forgalomban nem kaphatóság feltételeit nem tisztázta.

Az megállapítható, hogy a könyv hozzáférhetősége az antikvár kereskedelem csatornáin nem jelenti azt, hogy a könyv kereskedelmi forgalomban kapható. A jogirodalomban fellelhető olyan álláspont, amely szerint viszont a nem kiadó által kiadott müvekre sem vonatkozik az újonnan kialakított rezsim. Így például az egyetemi kiadások, magánkiadások is kívül esnek a kereskedelmi forgalomban nem kapható könyv meghatározásán. ${ }^{886}$

\section{b) A mü nem képezi újabb kiadás tárgyát}

A második kritérium pedig szóhasználata miatt nem egyértelmű, ugyanis a „publication” kifejezést használja. A fogalom meghatározásának nehézségeiről már

\footnotetext{
${ }^{882}$ VIVANT - BRUGUIÈRE (2012) p. 623.

${ }^{883}$ PIRIOU (2012b) e-verzió, 8. bekezdés. A kiadói szerződéseknek a készletek kezelésére vonatkozó rendelkezéseiről lásd részletesen: KERJEAN (2011) prat. 13., e-verzió.

${ }^{884}$ CPI L. 134-2. cikk.

885 CPI L. 134-4 II. cikk (2) bekezdés.

${ }^{886}$ MACREZ (2012) 9. bekezdés.
} 
szóltunk a reprográfia kapcsán, így e helyütt csak kiegészítjük az ott elmondottakat. ${ }^{887}$ A kiadásra két terminus technicus is használatos: „édition” és „publication”. Egy álláspont szerint a két fogalom szinonimaként használható, jelentésükben nincsen eltérés. ${ }^{888}$ Ezt a nézetet támasztja alá magának a CPI-nek a szóhasználata is, mivel a kiadói szerződés meghatározásában is mindkét szó (vagy annak képzett változata) felmerül. ${ }^{889}$ Más vélemények szerint viszont az „édition” lenne a szabatos kifejezés, föleg azért, mert jelentésbeli különbség fedezhető fel a kifejezések között. ${ }^{890}$

\section{\$2. A közös jogkezelés a gyakorlatban}

A francia jogalkotó egy rendhagyó, kétszintü közös jogkezelési rendszer felállításáról rendelkezett. A rezsim kiindulópontja egy nyilvántartás, ${ }^{891}$ amelyet a BNF vezet a kereskedelmi forgalomban nem kapható könyvekről. A nyilvántartásba vételt bárki kezdeményezheti, ${ }^{892}$ de csak a törvényi definíciónak megfelelő könyvek kerülhetnek bele. A BNF minden év márciusában gondoskodik a nyilvántartás frissítéséről.

Az engedélyezést viszont már nem a könyvtár, hanem a SOFIA, az írókat tömörítő közös jogkezelő szervezet végzi, ${ }^{893}$ igazodva a szerzői jog engedélyezési rendszerével szemben támasztott általános elvárásokhoz.

A rezsim lényegét a kilépés lehetősége adja. Erre alapvetően a szerzőnek (a végrehajtási rendelet pontosításában a jogutódoknak is $)^{894}$ van lehetősége, szűkebb körben ez a jog a könyv eredeti kiadóját is megilleti. Két mód nyílik arra, hogy az erre jogosultak kivonják a könyvet a közös jogkezelés hatálya alól: vagy tiltakoznak a könyv nyilvántartásba vétele ellen, vagy a nyilvántartásba vételt követően kilépnek a közös jogkezelésből.

\footnotetext{
${ }^{887}$ II. rész II. fejezet.

${ }^{888}$ VIVANT - BRUGUIÈRE (2012) p. 616.

${ }^{889}$ CPI L. 132-1. cikk.

${ }^{890}$ DERIEUX (2012) e-verzió 11 . bekezdés.

891 A nyilvántartás az alábbi címen érhető el: http://relire.bnf.fr/accueil. Az elnevezése (ReLIRE) egy kifejező nyelvi lelemény eredménye, ugyanis egyfelöl a Registre des livres indisponibles en reédition électronique (Elektronikusan újra kiadásra kerülő nem kapható könyvek nyilvántartása) rövidítését takarja. Másfelől pedig a „relire” ige jelentése: újraolvasni.

${ }^{892}$ CPI L. 134-2 cikk.

${ }^{893}$ Arrêté du 21 mars 2013 portant agrément de la Société française des intérêts des auteurs de l'écrit.

${ }^{894}$ CPI R. 134-5. cikk (3) bekezdés.
} 


\section{A) A közös jogkezelés müködése}

Ahogyan fentebb már utaltunk rá, mindkét esetben a közös jogkezelési struktúra lényegét a kilépés lehetősége adja ( $\alpha$ pont). A másik kardinális kérdés pedig, ahogyan a többi esetben is, az engedélyek megadása, illetve ezt követően a jogdíjak beszedése és felosztása ( $\beta$ pont).

\section{a) A kilépési lehetöségek gyakorlása}

A francia törvény két módot határoz meg a szerzők (és a kiadók) részére a kilépési joguk gyakorlása érdekében. Egyfelől tiltakozhatnak a nyilvántartásba vétel ellen, másrészt pedig, amennyiben egyénileg kívánják a müvet hasznosítani, kiléptethetik azt a közös jogkezelés alól.

\section{a) Tiltakozás a nyilvántartásba vétel ellen}

A tiltakozás lehetősége a nyilvántartásba vételtől számított hat hónapon belül áll nyitva a szerző részére, aki ezt a BNF-hez intézett írásbeli nyilatkozattal indokolás nélkül megteheti. A tiltakozás feljegyzésre kerül a nyilvántartásban, és az érintett mü nem kerül közös jogkezelés alá. ${ }^{895}$

A könyv eredeti kiadóját ez a jog már csak abban az esetben illeti meg, ha kötelezettséget vállal a könyv két éves határidőn belüli digitális felhasználására. Ebben az esetben a mű szintén kikerül a közös jogkezelés alól, ennek fejében viszont a felhasználásról az eredeti kiadónak bizonyítékot kell szolgáltatnia a Sofia felé. Amennyiben az eredeti kiadó ezt a kötelezettségét megszegi, a könyv visszakerül a közös jogkezelés hatálya alá. ${ }^{896}$

A hat hónapos határidő elmulasztása esetén még egy további lehetőség áll a szerző rendelkezésére. A Sofiához intézett írásbeli nyilatkozatával kérheti a könyv nyilvántartásból való törlését abban az esetben, ha a felhasználás a becsületére, jó hírnevére sérelmes. ${ }^{897}$ Két kritikai megjegyzés füzhető ehhez a rendelkezéshez. A hat hónapos határidő elteltével a könyv már közös jogkezelés alá kerül, a törvény azonban a nyilvántartásból való törlésről rendelkezik, nem pedig a közös jogkezelés hatálya alóli kikerülésről. Emiatt arra nézve sem találunk eligazítást, hogy a már kiadott felhasználási

\footnotetext{
${ }^{895}$ CPI L. 134-4 I. cikk.

${ }^{896}$ CPI L. 134-4 II. cikk.

${ }^{897}$ CPI L. 134-4 I. cikk.
} 
engedélyek sorsa mi lesz: a könyv nyilvántartásból való törlésével érvényüket vesztik, vagy a már kiadott engedélyeket a törlés nem érinti, és csak újabb engedélyek nem adhatók ki?

A normaszöveg ezen kívül egyértelmü utalást tartalmaz a szerző BUE-ban meghatározott személyhez füződő jogaira és annak védelmére. ${ }^{898}$ A francia szerzői jogi felfogás a BUE szellemiségének megfelelően a személyhez füződő jogok sérelmét általánosabban határozza meg, ${ }^{899}$ az nem pusztán a szerző becsületének és jó hírnevének sérelmére van leszükítve. ${ }^{900}$ Nincs tisztázva a két jogszabályhely közötti viszony, sem arra vonatkozóan, hogy a jogalkotó a személyhez füződő jogok egy speciális esetét iktatta-e törvénybe, sem pedig arra vonatkozóan, hogy ebben az esetben a személyhez füződő jogok megsértésének jogkövetkezményei alkalmazhatóak-e. Annyit mond ki mindössze a törvény, hogy kártérítésre a tiltakozással élő szerző nem jogosult. ${ }^{901} \mathrm{~A}$ törvény a bizonyítás módjára nézve sem tartalmaz rendelkezéseket.

Az alábbi táblázat szemlélteti összefoglalva a tiltakozási lehetőségeket.

\begin{tabular}{|c|c|c|c|}
\hline & Tiltakozás & & \\
\hline Ki? & szerző & kiadó & Szerző \\
\hline Kihez? & $\mathrm{BNF}$ & $\mathrm{BNF}$ & Sofia \\
\hline Mód? & írásban & írásban & írásban \\
\hline Határidő? & $\begin{array}{l}\text { nyilvántartásba } \\
\text { vételtől számított } \\
6 \text { hónap }\end{array}$ & $\begin{array}{l}\text { nyilvántartásba } \\
\text { vételtől számított } 6 \\
\text { hónap }\end{array}$ & $\begin{array}{l}\text { nyilvántartásba } \\
\text { vételtől számított } 6 \\
\text { hónapon túl }\end{array}$ \\
\hline Feltétel? & nincs & $\begin{array}{l}\text { két éven belül a mü } \\
\text { felhasználása }\end{array}$ & $\begin{array}{l}\text { a felhasználás } \\
\text { becsületére vagy jó } \\
\text { hírnevére sérelmes }\end{array}$ \\
\hline
\end{tabular}

${ }^{898}$ BUE, 6bis cikk.

${ }^{899}$ CPI L. 121-1. cikk (1) bek. „L'auteur jouit du droit au respect de son nom, de sa qualité et de son oeuvre."

900 POLLAUD-DULian (2012c) e-verzió 8. bekezdés.

${ }^{901}$ CPI L. 134-4 I. cikk. 
III. rész A törvény által elöírt közös jogkezelés, mint a joggyakorlás módja I. fejezet Az engedélyezési jog gyakorlása kilépést engedő közös jogkezelés körében

\begin{tabular}{|c|c|c|c|}
\hline Jogkövetkezmény? & $\begin{array}{l}\text { - tiltakozás } \\
\text { feljegyzése az } \\
\text { adatbázisban } \\
\text { - a mű nem kerül } \\
\text { közös jogkezelés } \\
\text { alá }\end{array}$ & $\begin{array}{l}\text { - tiltakozás } \\
\text { feljegyzése az } \\
\text { adatbázisban } \\
\text { - mű nem kerül } \\
\text { közös jogkezelés } \\
\text { alá } \\
\text { - a kiadó kötelezett } \\
\text { a mü } \\
\text { felhasználására }\end{array}$ & $\begin{array}{l}\text { - a mü kikerül a } \\
\text { nyilvántartásból } \\
\text { - személyhez füződő } \\
\text { jogok megsértésének } \\
\text { jogkövetkezményei? }\end{array}$ \\
\hline
\end{tabular}

1. sz. táblázat: Tiltakozási lehetőségek a nyilvántartásba vétel ellen

\section{ß) Kilépés a közös jogkezelés alól}

A fentebb kifejtettnek megfelelően a közös jogkezelés alóli kikerülés másik módja a kilépés a közös jogkezelés alól. ${ }^{902}$ Erre szintén a szerzőnek, illetve jogutódjának van lehetősége. Emellett a szerző és a kiadó közösen is kérheti az érintett könyv közös jogkezelés alóli kiléptetését, ${ }^{903}$ amelyre mindkét esetben a Sofiához intézett írásbeli nyilatkozattal nyílik lehetőség.

A szerző számára biztosított jog szigorú feltételekhez kötött: mindössze abban az esetben lehetséges, ha a szerző bizonyítani tudja, hogy ő rendelkezik a kizárólagos jogokkal. ${ }^{904}$ Ennek bizonyíthatósága azonban kétséges. Fentebb kifejtésre került, hogy a közös jogkezelés bevezetésére azért van szükség, mert a kiadói szerződések nem rendelkeztek a szerzői művek digitális felhasználásairól. A szerződés értelmezése alapján ezek a jogok így a szerzőnél maradtak, ${ }^{905}$ vagyis ebben az esetben a múvek közös jogkezelés alá kerülnek. Ennél fogva a szerző csak abban az esetben tudja bizonyítani, hogy ezekkel a jogokkal valóban ő rendelkezik, ha a kiadói szerződésbe expressis verbis belefoglaltak egy olyan kikötést, amely a digitális felhasználásokra vonatkozó jogok engedélyezését kizárta. Ez a bizonyítási kényszer viszont egy ördögi

\footnotetext{
902 CPI L. 134-6. cikk.

903 CPI L. 134-6. cikk (1) bekezdés.

${ }^{904}$ CPI L. 134-6. cikk. (2) bekezdés

905 CPI L. 122-7. cikk. A szerződések értelmezéséről lásd többek között VIVANT - BRUGUIÈRE (2012) p. 591-595.
} 
körhöz vezet: a rezsim létrehozásának indoka és kiindulópontja ugyanis az volt, hogy a kiadói szerződésekben egyáltalán nem rendelkeztek a digitális felhasználásokról.

Abban az esetben, ha a szerző és a kiadó közösen kéri a mü kiléptetését, a kiadónak kötelezettséget kell vállalnia a mű felhasználására. Ekkor viszont már csak 18 hónap áll a kiadó rendelkezésére, szemben a tiltakozás lehetőségénél rögzített két évvel. Ez a kilépés a már harmadik félnek kiadott felhasználási engedélyeket nem érinti. A harmadik fél az engedélyből hátra lévő idő alatt a mü felhasználását zavartalanul folytathatja. ${ }^{906}$ Így tulajdonképpen nem kizárólagos, egymással versengő párhuzamos felhasználási jogosultságokkal állunk szemben.

A kilépési lehetőségeket az alábbi táblázat segítségével mutatjuk be.

\begin{tabular}{|c|c|c|}
\hline & Kilépés & \\
\hline Ki? & szerző & szerző + kiadó \\
\hline Kihez? & Sofia & Sofia \\
\hline Mód? & írásban & írásban \\
\hline Határidő? & bármikor & bármikor \\
\hline Feltétel? & $\begin{array}{l}\text { ő rendelkezik a kizárólagos } \\
\text { jogokkal }\end{array}$ & $\begin{array}{l}18 \text { hónapon belül a mü } \\
\text { felhasználása }\end{array}$ \\
\hline Jogkövetkezmény? & $\begin{array}{l}\text { - kilépés feljegyzése az } \\
\text { adatbázisban } \\
\text { - a mü kikerül a közös } \\
\text { jogkezelés hatálya alól }\end{array}$ & $\begin{array}{l}\text { - kilépés feljegyzése az } \\
\text { adatbázisban } \\
\text { - kikerül a közös jogkezelés } \\
\text { hatálya alól } \\
\text { - } 18 \text { hónapon belül: } \\
\text { felhasználási kötelezettség } \\
\text { - felhasználók értesítése, de: }\end{array}$ \\
\hline
\end{tabular}

${ }^{906}$ CPI L. 134-6 cikk. 
III. rész A törvény által elöírt közös jogkezelés, mint a joggyakorlás módja I. fejezet Az engedélyezési jog gyakorlása kilépést engedő közös jogkezelés körében

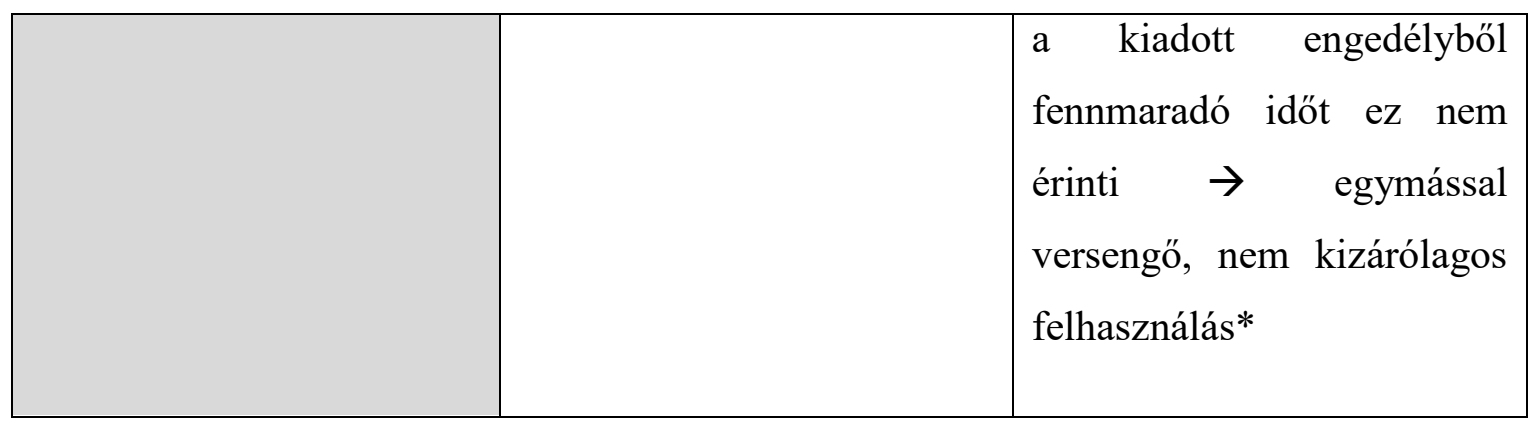

2. számú táblázat: Kilépési lehetőségek a közös jogkezelés alól

b) Az engedélyek megadása és a jogdíjak felosztása

a) Az engedélyek megadása

A nyilvántartásba vett művek a fentiek alapján csak abban az esetben kerülnek közös jogkezelés alá, amennyiben sem a szerző, sem pedig az eredeti kiadó nem élt tiltakozási vagy kilépési jogával. Az eredeti kiadó azonban kedvezményezett helyzetben van harmadik felekkel szemben, ugyanis ő több módon is megszerezheti a felhasználási jogokat. Egyfelől - amennyiben él a tiltakozási vagy kilépési jogával, és kötelezettséget vállal a mü felhasználására - automatikusan megszerzi ezeket a jogokat; másfelől a Sofia először az eredeti kiadónak ajánl felhasználási engedélyt. Amennyiben utóbbi ezt elfogadja, úgy tíz éves időtartamra kizárólagos felhasználási jogot szerez, amely felhasználásnak három éven belül kell megtörténnie. Ellentétes nyilatkozat hiányában a felhasználási engedély a tíz éves időtartam lejártával automatikusan ismét megadásra kerül. $^{907}$

Harmadik fél (úgymint a Google, az Amazon vagy a Fnac) ${ }^{908}$ csak abban az esetben szerezhet felhasználási engedélyt, amennyiben az eredeti kiadó nem él sem a tiltakozási, sem a kilépési jogával, ha az eredeti kiadó nem lelhető fel, vagy ha nem fogadja el a számára felkínált felhasználási engedélyt. Harmadik felek ebben az esetben nem kizárólagos, öt éves időtartamra szóló, megújítható felhasználási engedélyt szerezhetnek. $^{909}$

\section{B) A jogdijak beszedése és felosztása}

Az engedélyek kiadása főszabály szerint nem ingyenesen történik, mivel kereskedelmi célú felhasználásokról van szó. A jogdíjak kezelése (beszedése és

${ }^{907}$ CPI L. 134-5 cikk.

908 DERIEUX (2012) p. 3.

${ }^{909}$ CPI L. 134-3 cikk. 
felosztása) az egyik legfontosabb indoka annak, hogy miért szükséges közös jogkezelés alá vonni az engedélyezési mechanizmust. ${ }^{910}$ A törvény a jogdíjaknak a szerzők és eredeti kiadók közötti egyenlő arányú felosztásáról rendelkezik. ${ }^{911}$ Ez a látszólag a jogdíjak kiegyensúlyozott elosztását biztosító rendelkezés torzul, ha figyelembe vesszük azt, hogy az eredeti kiadó minden esetben részesül a jogdíjakból, abban az esetben is, ha nem biztosítja a könyvek digitális felhasználását. ${ }^{912}$ A törvény ugyancsak hallgat az eredeti kiadó jogdíjfizetési helyzetéről. Emiatt az a furcsa szituáció áll elő a jogszabály értelmezése alapján, hogy amennyiben az eredeti kiadó elfogadja a neki felkínált engedélyt, abban az esetben kifizeti a jogdíjat a Sofiának, majd a felosztás után részesül a saját maga által befizetett jogdíjból.

Amennyiben a kereskedelmi forgalomban nem kapható mü egyben árva münek is minősül, speciális rendelkezések vonatkoznak a jogdíjak felosztására. Azokat a jogdíjakat ugyanis, amelyeket nem tudnak kifizetni, mert azok jogosultja nem azonosítható vagy nem lelhető fel, a beszedésüket követő 10 év elteltével a Sofia az alkotómunka, az írói képzések és a könyvtári olvasás terjesztésének elősegítésére használja fel. ${ }^{913}$ A törvény viszont további rendelkezéseket nem tartalmaz az árva művekre nézve, így például hallgat arról, hogy kinek kellene felkutatnia a jogosultat. ${ }^{914}$ Ennek ellenére a jogirodalomban létezett egy olyan (kiterjesztő) értelmezés, amely szerint a Sofia feladata a jogosultak felkutatása. ${ }^{915}$

Ezen kívül a kultúra terjesztését szolgálja a törvény utolsó olyan cikke, amely a (majdnem) árva müvekről rendelkezik. Ez alapján ugyanis a Sofia a nyilvános könyvtárak számára ingyenesen engedélyezi azoknak a könyveknek a többszörözését és a felhasználóik számára történő digitálisformában történő hozzáférhetővé tételét, amelyek a könyvtári állományában megtalálhatóak és a nyomtatott formában való többszörözés jogosultja az első felhasználási engedély kiadásának időpontjától számított

\footnotetext{
${ }^{910}$ CARON (2012a) e-verzió, 7. bekezdés.

${ }^{911}$ CPI L. 134-3 III $5^{\circ}$ cikk.

912 POLLAUD-DULIAN (2012c) e-verzió 3. bekezdés.

${ }^{913}$ CPI L. 134-9. cikk.

914 A kérdés az Árva mü-irányelv átültetését elvégző törvény rendezi, amely egy új fejezetet iktatott be a CPI-be az „Árva müvek egyes felhasználásaire vonatkozó különleges rendelkezések” címmel. Lásd: Loi $\mathrm{n}^{\circ}$ 2015-195 du 20 février 2015 portant diverses dispositions d'adaptation au droit de l'Union européenne dans les domaines de la propriété littéraire et artistique et du patrimoine culturel.

${ }^{915}$ CARON (2012a) e-verzió 7. pont.
} 
10 éven belül nem fellelhető. ${ }^{916}$ Ehhez az általános rendelkezéshez két megszorítást füz a jogalkotó. Egyfelől a nyilvános könyvtárnak a felhasználásból nem származhat gazdasági, kereskedelmi előnye. Ezen kívül pedig amennyiben a nyomtatott többszörözés jogosultja felbukkan, bármikor kérheti ez alól az ingyenes engedélyezés alóli azonnali hatályú kiléptetést. ${ }^{917}$

\section{B) A nemzetközi és uniós jogi keretek, alkotmányossági kérdések}

A nemzetközi szerzői jog nem tartalmaz kifejezett korlátozást a digitális többszörözés tekintetében, és nem rendelkezik ennek közös jogkezelés alá utalásáról sem. Az uniós szerzői jogban sem találhatunk erre nézve rendelkezéseket, annak ellenére, hogy a kérdés nem ismeretlen a döntéshozók elött. A kilépést engedő, de nem kiterjesztett hatályú közös jogkezelés tehát abban az értelemben nem képez korlátot, hogy a jogalkotó nem eleve ezzel a céllal iktatta be a közös jogkezelést a szerzői jogi törvénybe. ${ }^{918}$ Hatása azonban lehet a szerzői jogok korlátozása, ${ }^{919}$ emiatt tehát érdemes a három lépcsős teszt szerinti elemzést elvégezni annak érdekében, hogy a rendszer szerzői jogi koherenciájáról állást foglalhassunk.

A már létező francia (és egyébként a Magyarországon tervezett) közös jogkezelési modellben közös, hogy a kizárólagos jog fenntartásával kívánják a digitalizálást ösztönözni, a felhasználást nem teszik teljesen ingyenessé és nem is szorítják le díjigénnyé. A kilépés, illetve a tiltakozás lehetősége pedig biztosítja azt, hogy a rendelkezések ne a szerzői jog korlátozásának, hanem annak gyakorlását elősegítő eszköznek legyenek tekinthetők. A fentiek alapján ez úgy tűnik, megfelel mind a nemzetközi szerzői jogi gyakorlatnak, mind pedig az InfoSoc-irányelv rendelkezéseinek. Vagyis ebből azt a hipotézist állíthatjuk fel, hogy kötelező közös jogkezelés megfelel a szerzői jogi korlátozásrendszernek. Az egyetlen eltérés ebben az esetben abban áll (amely egyébként igaz minden törvény által elöírt, kilépést engedő közös jogkezelési esetre), hogy a joggyakorlás klasszikus módja megfordul: vagyis a törvény a közös jogkezelők útján történő felhasználást vélelmezi, a szerzőnek (és a

\footnotetext{
${ }^{916}$ CPI L. 134-8. cikk (1) bekezdés.

${ }^{917}$ CPI L. 134-8. cikk (2) és (3) bekezdés.

918 Lásd különösen a vezetékes továbbközvetítési jog gyakorlásának kötelező közös jogkezelésére vonatkozó rendelkezéseket (II. rész I. fejezet).

${ }^{919}$ Erre utal egyébként mind az Alkotmánytanács eljárása, mind pedig az EUB-hoz felteerjesztett előzetes döntéshozatali eljárás mutatja.
} 
kiadónak) pedig ettől eltérő szándékuk szerint léptethetik ki a müvet a közös jogkezelés alól.

Említést érdemel, hogy az Alkotmánytanács szürőjén egyszer már átment a törvény. Alkotmányossági eljárás ${ }^{920}$ keretében ugyanis az Államtanács előtti eljárásban a felperesek az Alkotmányban garantált alapjogaik sérelmére hivatkoztak a törvény végrehajtási rendelete kapcsán, amely így előzetes alkotmányossági kérdés eljárásban vizsgálta a törvény rendelkezéseit. ${ }^{921}$ Az Alkotmánytanács az első két kifogást (a törvényhozási eljárás során felvetődő problémák, illetve a törvény világossága hiánya miatt) elutasította, hiszen ezek vagy nem alapjogot sértenek, ${ }^{922}$ vagy pedig az állandósult joggyakorlat alapján önmagában nem valósítanak meg alapjogi sérelmet. ${ }^{923}$ Az Alkotmánytanács a harmadik kifogást viszont már érdemben vizsgálta: ez arra vonatkozott, hogy a szerzők tulajdonhoz való joga sérül-e. A testület mindenekelőtt megismételte, hogy az irodalmi és művészi tulajdon a tulajdonhoz való jog keretében védelmet élvez, illetve részletezte, hogy az alapjog korlátozása közérdekből, a cél által indokolt mértékben lehetséges. ${ }^{924}$ A szóban forgó rendelkezések viszont megfelelnek az arányosság követelményének, hiszen a jól körülhatárolható vagyoni jogokra vonatkoznak, amelyek nem érintik a személyhez füződő jogok (különösen a névhez való jog és az első nyilvánosságra hozatal joga említhető ebben a körben), sem pedig a nem digitális jogok gyakorlását. A felhasználás feltételei kellően pontosan meghatározottak, illetve biztosított a kilépés lehetősége, ${ }^{925}$ Különösen ez utóbbi feltétel volt az, amely a testületet meggyőzte arról, hogy a közös jogkezelés megfelel a tulajdon korlátozására vonatkozó alkotmányossági követelményeknek. Ez pedig az elérendő közérdekű célhoz mérten, vagyis ahhoz, hogy a 20. századi kereskedelmi forgalomban nem kapható mủveket megőrizzék, a digitális formában újra a közönséghez juttassák, amiért a szerzőket díjazás illeti meg, ${ }^{926}$ arányos korlátozásnak minősül és semmiképpen

\footnotetext{
${ }^{920}$ Question prioritaire de la constitutionnalité.

${ }^{921}$ Décision $n^{\circ}$ 2013-370 QPC du 28 février 2014.

922 U.o. 11. pont.

${ }_{923}$ U.o. 19. pont.

${ }^{924}$ U.o. 12-13. pontok.

${ }_{925}$ U.o. 15-17. pontok.

${ }^{926}$ U.o. 14. pont.
} 
sem eredményezi a tulajdonhoz való jog elvonását, ${ }^{927}$ vagyis a törvény nem ellentétes az Alkotmánnyal. ${ }^{928}$

Az alkotmányossági tulajdonkorlátozás francia tesztjén tehát minden jel szerint átment a bevezetett rendszer. Nem mindenben értünk azonban egyet az Alkotmánytanács érvelésével. Álláspontunk szerint ugyanis a törvény a közös jogkezelés alá utalt jogokat meglehetősen szélesen határozza meg, pláne, ha ezt összevetjük a többi kötelező közös jogkezelés esetében elvégzett elemzéssel, amelyekben a jogalkotó s a bírói gyakorlat igyekezett minél szükebben ezt megvonni. Itt a jogalkotó gyakorlatilag minden a vagyoni jogok digitális környezetben értelmezhető formáját közös jogkezelés alá utalta, a törvény ugyanis a digitális többszörözés és előadás jogáról beszél. Vagyis a közös jogkezelés érinti a digitális formában létrejövő többszörözött példányok elkészítésére vonatkozó engedélyt éppúgy, mint ezeknek nyilvánosság számára hozzáférhetővé tételét. Lehetne hivatkozni arra, hogy a jogalkotó ezt a hiányosságot voltaképpen orvosolja a törvény tárgyi hatályának szükre szabásával. Ez az elemzés sem biztos egyébként, hogy megfelelö eredményre vezet, a kettőnek együttesen kellene ugyanis fennállnia ahhoz, hogy egy megfelelöen korlátok közé szabott rendszerröl beszélhessünk.

Ezt követően az a kérdés marad megválaszolatlanul, hogy vajon a háromlépcsős teszt egyes eleminek is megfelel-e a francia rezsim? Ennek elökérdése annak megválaszolása, hogy a háromlépcsős teszt mely változata szerint futtatjuk le az elemzést.

A CPI-ben foglalt teszt értelemszerüen nem alkalmazható a kérdésben, hiszen arról már a magáncélú többszörözés kapcsán kimutattuk, hogy csak a CPI L. 122-5. cikkben felsorolt kivételek esetében alkalmazható. Ez egyrészt azzal az általános következménnyel jár, hogy a francia jogalkotó értelemszerüen ezt az esetet (a többi törvény által előírt közös jogkezelési esethez hasonlóan) nem tekinti szerzői jogi kivételnek, csak a joggyakorlás módja meghatározásának.

Az uniós jog szintjén azzal a problémával szembesülünk, hogy amennyiben kivételnek vagy korlátozásnak tekintjük a közös jogkezelés rendszerét, akkor a francia

\footnotetext{
${ }^{927}$ U.o. 18. pont.

${ }^{928}$ Elemzését lásd: GALOPIN (2015) p. 207-221.
} 
jogalkotó az InfoSoc-irányelvben foglalt kivételek és korlátozások ellenében vezetett be egy újabb kivételt, vagyis megsértette az uniós harmonizációból eredő követelményeket. Ez az érvelés egyébként különösen annak fényében érdekes, hogy az Államtanács előzetes döntéshozatali eljárást kezdeményezett a rendszer uniós joggal való összhangjának megvilágítása érdekében, az EuB-nak így első ízben nyílik lehetősége a kilépést engedő közös jogkezelés és az InfoSoc-irányelv összhangjának vizsgálatára. A kérdés az alábbiak szerint hangzik: a 2001/29/EK irányelv ,fent emlitett rendelkezéseivel ellentétes-e, ha a jelen határozat 1. pontjában elemzetthez hasonló szabályozás az engedélyezett közös jogkezelö szervezetekre bízza a »nem elérhetö könyvek« digitális formában történö többszörözése vagy megjelenitése engedélyezéséhez való jog gyakorlását azzal, hogy az ott meghatározott feltételek mellett lehetővé teszi e könyvek szerzői vagy azok jogutódai számára, hogy tiltakozzanak e joggyakorlás ellen vagy véget vessenek annak?"929

Elméleti szinten felvetődik még ezen túl a háromlépcsős tesztnek a nemzetközi szerzői jogi dokumentumok szerinti szövegének alkalmazása a kérdésre. A BUE eredetileg, mint már ismert, csak a többszörözés jogára tekintettel vezette be a korlátozást. Ahogyan fent megállapítottuk, a nyilvánosság számára lehívásra való hozzáférhetővé tétel joga tartozik még a közös jogkezelés keretébe. Erre vonatkozóan pedig a WCT terjesztette ki a háromlépcsős tesztet, így ennek a szövegváltozata veendő figyelembe a korlátozás tekintetében.

\section{Kilépést engedő, kiterjesztett hatályú közös jogkezelés: a rendelkezési jog korlátozása?}

A megoldás kidolgozóinak számító skandináv országok az 1960-as években elsősorban a televíziószervezetek számára optimalizált mechanizmust dolgoztak ki, amelyet később elkezdtek kiterjeszteni többek között az oktatási célú, illetve a könyvtári

\footnotetext{
${ }^{929}$ A C-301/15. sz. Soulier és Doke ügyben feltett kérdés. A kérdést eredetileg az alábbi szöveggel került megfogalmazásra az Államtanács előzetes döntéshozatali eljárást megindító határozatában: (...) la directive 2001/29/CE du 22 mai 2001s'opposent à ce qu'une réglementation, telle que celle qui a été analysée au point 1 de la présente décision, confie à des sociétés de perception et de répartition des droits agréées l'exercice du droit d'autoriser la reproduction et la représentation sous une forme numérique de "livres indisponibles", tout en permettant aux auteurs ou ayants-droit de ces livres de s'opposer ou de mettre fin à cet exercice, dans les conditions qu'elle définit. 20. pont, Conseil d'Etat, (10e et 9e sous-sect. réunies), 6 mai 2015, M. G. AQ. et a.
} 
felhasználásokra is. Mindezt megtehették, hiszen a kiterjesztett közös jogkezelés tekintetében nemzetközi vagy uniós jogi elöírásokat nem találhatunk. ${ }^{930}$

Az InfoSoc-irányelv (18) preambulumbekezdése is leszögezi, hogy az irányelv nem érinti a jogkezelésre, például a kiterjesztett közös jogkezelés körébe tartozó felhasználási engedélyekre vonatkozó tagállami rendelkezéseket. Néhány tagállam ezt úgy értelmezte, hogy az irányelv lehetőséget nyújt számukra kiterjesztett közös jogkezelés bevezetésére nem csak a kivételekhez kapcsolódó különleges esetekben, hanem az engedélyezés általános mechanizmusaként. Mivel ez rugalmasabb szabályokat biztosít a jogalkotónak, nemzetközi szinten a kiterjesztett közös jogkezelés válik a kötelező közös jogkezelés (ideértve a díjigényekre leszorított kizárólagos jogokat is) legfőbb konkurensévé. ${ }^{931}$ Magyarországon is megfigyelhető, hogy a törvény által előírt közös jogkezelési esetek jelentős része ilyen módon került meghatározásra.

Bár a mechanizmus hatékonysága elismerésre került, a szakirodalom azt is kiemeli, hogy a művek elsődleges piacára mért hatására figyelemmel minden ilyen megoldást alá kell vetni a háromlépcsős teszt mércéjének. ${ }^{932}$ Vagyis ez azt is jelenti, hogy hagyományosan a kiterjesztett közös jogkezelést meg kellene hagyni a másodlagos felhasználások (pl. oktatási célú felhasználások) jogosításának. Ez azonban nem minden esetben alakul így, hiszen például Dániában is törvénybe iktattak egy kiterjesztett közös jogkezelésre vonatkozó generálklauzulát. ${ }^{933}$ FICSOR Mihály hasonló elveket állapít meg a kiterjesztett közös jogkezelés bevezetésének feltételéül. Álláspontja szerint ezt azokban az esetekben lehet bevezetni, amelyekben a közös jogkezelés az érintett jog gyakorlásának természetes és szükséges módja. Ezen kívül a közös jogkezelő szervezet mind a hazai, mind pedig a külföldi jogosultak vonatkozásában kellő reprezentativitással rendelkezik (és így a kiterjesztett hatály csak különleges esetekre vonatkozik). Harmadrészt pedig a jogosultaknak indokolatlan nehézségek nélkül lehetőségük van kilépni a közös jogkezelés alól. ${ }^{934}$

A kiterjesztett hatályú, kilépést engedő közös jogkezelés esetében tehát hangsúlyosan jelenik meg a korlátozás vagy joggyakorlási mód szemléletmódja. Ez

\footnotetext{
${ }^{930}$ FICSOR (2002) p. 72-73.

${ }^{931}$ KARNELL (1991) p. 17.

932 SHAPIRO (2011) p. 45.

${ }_{933}$ RIIS - SCHOVSBO (2009-2010). 2.2. pont.

${ }^{934}$ FICSOR (2011) p. 267.
} 
III. rész A törvény által elöírt közös jogkezelés, mint a joggyakorlás módja I. fejezet Az engedélyezési jog gyakorlása kilépést engedő közös jogkezelés körében

különösen azért lehet így, mert a modellt a jogalkotó többnyire olyan kizárólagos engedélyezési jogok esetében vezette be, amelyek korlátozása vagy közös jogkezelés alá utalása kapcsán a nemzetközi és uniós szerzői jog nem tartalmaz kifejezett elöírást. Emiatt tekinthető ambivalensnek a jogtudomány álláspontja: legtöbben elismerik gyakorlati előnyeit, ${ }^{935}$ a dogmatikai helyességéről viszont, mint láttuk, megoszlanak a vélemények.

Klasszikus formájában ráadásul ez a skandináv szerzői jogok újítása, és mint ilyen, rendszeridegenként aposztrofálható a nemzeti (különösen a francia) szerzői jogban. A francia szerzői jogban éppen ezért egy esetben találkozhatunk a kiterjesztett hatály jogtechnikai megoldásával a szerzőket megillető jogosultságok tekintetében. ${ }^{936}$ Audiovizuális felhasználási szerződések esetében a szerzők díjazását megállapító szerződések, amennyiben azokat a közös jogkezelő szervezetek vagy szerzői szakmai szervezetek kötik az iparági képviselőket tömörítő szervezetekkel, miniszteri rendeletben kötelezővé tehetőek. ${ }^{937}$ Még ebben a jól körülhatárolt esetben is éles kritikával illették ezt a megoldást. Annak ellenére, hogy ez elvben a nem tagoknak biztosít kedvezőbb feltételeket, mint amelyeket az egyéni tárgyalással értek volna el, alapjaiban sérti a közös jogkezelés önkéntességét és szerződéses jellegét. Azokat a szerzőket is belekényszeríti ugyanis egy készként kapott helyzetbe, akik eredendően nem kívántak a közös jogkezelő szervezet tagjává válni, gyakorlatilag kötelező közös jogkezelést írva elő. ${ }^{938}$ Ez a törvényi rendelkezés nem is tekinthető a kiterjesztett közös jogkezelés esetének, sokkal inkább a munkajogból ismert kollektív szerződésnek a szerzői jog világába történő becsempészését jelenti. ${ }^{939}$

\footnotetext{
935 FICSOR Mihály például a teljesen kiépült közös jogkezelési rendszer egyik legfontosabb elemeként hivatkozik a kiterjesztett közös jogkezelésre. FICSOR (2003) p. 6.

936 Nem hagyható figyelmen kívül, hogy a kötelező közös jogkezelés megfelelő működéséhez per definitionem elengedhetetlen annak kiterjesztett hatálya. Végeredményben a kötelező közös jogkezelés Műhold-irányelvben meghatározott formája, illetve a francia reprográfiai jogdíjak kezelése is kiterjesztett közös jogkezelésnek minősül, mivel a hatékony jogkezeléshez elengedhetetlen az, hogy a felhasználási engedély ne csak azoknak a jogosultaknak a müveire vonatkozzon, akik tagjai a közös jogkezelö szervezetnek

937 CPI L. 132-25. cikk (3) bek. „Les accords relatifs à la rémunération des auteurs conclus entre les organismes professionnels d'auteurs ou les sociétés de perception et de répartition des droits mentionnées au titre II du livre III et les organisations représentatives d'un secteur d'activité peuvent être rendus obligatoires à l'ensemble des intéressés du secteur d'activité concerné par arrêté du ministre chargé de la culture."

${ }_{938}$ BÉNABOU (2007) p. 430.

939 A kiterjesztett közös jogkezelés egyébként az eredeti skandináv megoldás szerint éppen a kollektív szerződések működési mechanizmusából építkezett.
} 
A magyar szerzői jogba a 2011. évi CLXXIII. törvény iktatta be a kiterjesztett közös jogkezelés hatályos, általános megfogalmazását, bár a konstrukció elődje már az Szjt. eredeti, 1999-ben elfogadott szövegének is részét képezte, ${ }^{940}$ sőt, a közös jogkezelést még a régi Szjt. talaján állva új alapokra helyező kormányrendelet is tartalmazta. ${ }^{941}$ A törvény 2003. évi módosítása néhány, korábban kilépést nem engedő vagyoni jog tekintetében bevezette a kilépést. A generális szabály legutóbbi átfogalmazása elsősorban a közös jogkezelési tevékenység liberalizációjához kötődik, azt kellett ugyanis rendezni, hogy ha a törvényben elöírt közös jogkezelés elvégzésére több szervezetet vesznek nyilvántartásba, akkor közülük melyik végezheti az engedélyezést kiterjesztett hatállyal. A felhasználók szempontjából ugyanis kiemelkedően fontos, hogy annak ellenére a világrepertoárra szerezhessenek felhasználási jogosultságot, ha Magyarország területén ugyanazon jogosulti csoport azonos jogosultsága tekintetében több közös jogkezelő szervezet is müködik. A jogbiztonság fenntartásához viszont szükséges az, hogy a nem képviselt jogosultak tekintetében csak egyetlen szervezet végezzen kiterjesztett hatályú közös jogkezelést, vagyis rendezni kell azt, hogy amennyiben azonos jogosulti csoport azonos jogának gyakorlására több közös jogkezelö szervezetet vettek nyilvántartásba, melyik az, amelyik a világrepertoárra kiterjedő engedélyt ad.

Érdekes módon a törvényi rendelkezés nem tartalmaz kifejezett megszorítást arra nézve, hogy a kiterjesztett hatály csak a törvény által elöírt közös jogkezelési esetkörökre vonatkozna. Ebböl azt a következtetést lehet levonni, hogy a kiterjesztett hatály az önkéntes közös jogkezelés esetében is alkalmazandó. ${ }^{942} \mathrm{Ez}$ az elv, bár kétségtelenül összecseng a közös jogkezelés Szjt.-ben található definíciójával, alapvetően ellentétes az önkéntes közös jogkezelés logikájával. Ennek ugyanis a jogosult rendelkezési szabadságán kellene alapulna, amelybe durva beavatkozást jelent a közös jogkezelés hatályának kiterjesztése. Ezt támasztja alá egyébként az Szjt. egy másik rendelkezése is, amely viszont így ellentmondásba keveredik a törvény korábbi szakaszaival. A magyar törvény 92/E.§ (3) bekezdése ugyanis a kiterjesztett hatállyal kapcsolatban csak a „kötelező vagy egyébként kiterjesztett hatályú” közös jogkezelést említi.

\footnotetext{
940 Szjt. közlönyállapota, $91 . \S$.

941 146/1996. (IX.19.) Korm. rend. a szerzői és szomszédos jogok közös kezeléséről, 7. §.

942 GYERTYÁNFY (2014), p. 510-511.
} 
A kérdés tárgyalásakor tehát figyelmet kell szentelni mind a közös jogkezelés szervezeti oldalára (§1. pont), mind pedig az engedélyezési jogok gyakorlására ( 2 . pont), hiszen ezek azok a faktorok, amelyek mentén vizsgálható a jogintézménynek a szerzői jog nemzetközi jogi dokumentumokban rögzített alapelveivel való koherenciája.

\section{\$1. A kiterjesztett közös jogkezelés szervezeti oldala}

A kiterjesztett közös jogkezelés szervezeti oldalához tartozónak tekintjük a reprezentativitás megvalósulását [A) pont], mint a szisztéma egyik sarokkövét. Az ehhez tartozó, illetve ezzel összefüggő másik legfontosabb elem pedig a kilépés lehetőségének a biztosítása azon jogosultak számára, akik ezzel élni kívánnak [B) pont].

\section{A) A reprezentativitás követelménye}

A magyar szerzői jogi törvényben a reprezentativitás összefügg a közös jogkezelés nyilvántartásba vételének szigorú feltételeivel, a kötelező közös jogkezelési esetkörök magas arányával és azzal, hogy a kiterjesztett hatály a közös jogkezelés minden típusára vonatkozik. A reprezentativitás elöírása ugyanis az egyesület SZTNH által vezetett nyilvántartásába vételének egyik kritériuma. ${ }^{943}$

A közös jogkezelési tevékenységet végezni kívánó egyesületnek a szabályok szerint egyfelől nyitottnak kell lennie, vagyis biztosítania kell azt, hogy bármely jogosult (belföldi és külföldi egyaránt) szabadon csatlakozhasson a szervezethez. ${ }^{944}$ Másfelől pedig kellően reprezentatívnak is, vagyis az általa végzett jogkezelési tevékenységben érdekelt jogosultak jelentős részét képviseli. A reprezentativitás követelménye tehát két szinten fogalmazódik meg a törvényben. Mindenekelőtt a belföldi jogosultak kapcsán, az egyesületi tagok vagy az egyébként egyedi megbízással képviseleti jogot adó jogosultak kapcsán kell fennállnia. ${ }^{945}$ Ezzel konjunktív feltétel pedig, hogy a közös jogkezelőnek külföldi társszervezetekkel kötött kölcsönös vagy egyoldalú képviseleti megállapodásai ${ }^{946}$ (contrat de représentation réciproque) alapján a külföldi jogosultak jelentős részét is képviselnie kell. ${ }^{947}$

\footnotetext{
${ }^{943}$ Szjt. $92 . \S(1)$ bek. a)-c) pontok.

${ }^{944}$ Szjt. $92 . \S(1)$ bek. a) pont.

${ }^{945}$ Szjt. $92 . \S$ (1) bek. ba)-bb) és c) pontok.

946 A kölcsönös képviseleti szerződések hálózata az, amely lehetővé teszi a külföldi művek belföldi jogosítását is, ez az egyik mozgatórugója a közös jogkezelés működésének. A piacuralmi helyzettel való
} 
A ,jelentős rész” meghatározásához a jogalkotó igyekezett támpontot adni, és figyelembe veendő szempontként meghatározni a jogosultak létszámán túl a műveik, illetve teljesítményeik felhasználási arányát és a jogdíjakból való részesedésük arányát. ${ }^{948}$ A felhasználási adatok számszerüsíthetősége, pontos mérhetősége miatt ezek jó fogódzót nyújtanak a rendelkezés alkalmazásához.

A jelentős résszel kapcsolatban viszont további kérdések is felmerülhetnek: vajon a jogosultak jelentős részét képviseli az a közös jogkezelő szervezet, amelynek számszerüen a jogosultak 51\%-as tagja vagy egyébként képviseleti megbízást adott a jogok kezelésére, ám a műveik felhasználása és ebből kifolyólag a jogdíjakból részesedésük aránya ennél jóval alacsonyabb? Illetve általánosságban, a jogosultak 30\%-át képviselő szervezet, amelynek kezelésében lévő müvek vagy teljesítmények aránya szintén nagyjából ekkora részt tesz ki, vajon megfelel a jogosultak jelentős része képviseletére vonatkozó kritériumnak? A hatóság mérlegelési jogköre segíti az esetlegesen felmerülő ilyen esetek megoldását. A kilépést engedő közös jogkezelés elöírásával a jogalkotó egyébként sokkal inkább versenyhelyzetet teremtett az egyéni és a közös jogkezelés között, mint amely az önkéntes közös jogkezelés és az egyéni jogkezelés között fennáll. A kiindulási helyzet változik meg ugyanis ilyenkor: továbbá már nem a főszabályként létező egyedi joggyakorlás és az ahhoz képest kisegítő közös jogkezelésröl beszélünk. Ellenkezőleg, a közös jogkezelés az a kiindulási alap, amelyből a szerzőknek lehetőségük van visszatérni a joggyakorlás természetes módjához. Ráadásul a kilépés nem kötődik ahhoz a feltételhez, hogy a jogosult másik szervezetet bízzon meg a jogai kezelésével, vagyis a versenyhelyzet valójában nem a szervezetek, hanem a joggyakorlási módok között áll fenn. ${ }^{949}$ A gyakorlatban viszont a kilépést követően az egyéni joggyakorlás valószínűsége minimális. A gyakorlatban közös jogkezelő szervezeti jogállással nem rendelkező vállalkozások „független jogkezelök" gyüjtik be ezeket a repertoárokat és kezelik piaci alapon a szerzők jogait. A közös jogkezelő szervezeteknek tehát ilyen esetekben ezekkel a piaci jogkezelőkkel kell versenyezniük.

visszaélés mellett ezeknek a szerződéseknek (különösen a szerzöi jog területiségéből fakadó területi jellegnek) a versenyjogi vizsgálata több ízben is problémaként vetődött fel az Európai Unióban. Erről lásd különösen a CISAC-ügyet. A zeneművek online határokon átnyúló engedélyezése kapcsán a KJKirányelv ezt az elvet töri át.

947 Szjt. 92. $§(1)$ bek. bc) pont.

948 Szjt. 92. $\$(2)$ bek. pont.

${ }^{949}$ Ez megfigyelhető a KJK-irányelv 5. cikk (6) bekezdésének előírásában is. NÉRISSON (2014) p. 140. 
A reprezentativitás követelményének biztosítása kapcsolatban áll egyébként a diszkrimináció mentességgel is, különösen, ami a külföldi jogosultak képviseletét illeti. Ezt ugyanis a közös jogkezelő szervezet nem csak közvetetten, a képviseleti szerződések útján láthatja el, hanem a jogosultak közvetlen képviseletével. Ilyen esetben pedig, az uniós szerzői jog kezdetektől fogva érvényesülő pillérének megfelelően, a diszkrimináció alóli mentességnek érvényesülnie kell. A Bizottság eljárást indított a GVL-lel szemben, mivel a szervezet nem kötött szerződést olyan külföldi előadóművészekkel, akik külföldiek voltak és nem volt németországi tartózkodási helyük. Ráadásul ezek a müvészek más jogkezelőhöz sem tudtak fordulni a GVL monopóliuma miatt. ${ }^{950}$ A Bizottság határozatát a Bíróság is elfogadta, és a GVL gyakorlatát egyébként a diszkrimináció tilalmába ütközőnek minősítette. ${ }^{951}$

\section{B) A kilépés biztositása}

A kiterjesztett közös jogkezelés alapvető eleme annak határainak kijelölése, vagyis a rendelkezés arról, hogy a jogosult hogyan léphet ki a közös jogkezelés alól. Ez jelenti a kötelező közös jogkezeléssel összevetve az egyik legfőbb elhatárolási szempontot, illetve a BUE-nek való megfelelés érdekének garanciáját. ${ }^{952}$ Azaz nem önmagában a kilépés ténye, hanem az, hogy ezáltal az egyéni joggyakorlás is lehetséges marad ezeknek a jogoknak a körében. ${ }^{953}$ A kilépés tartalmilag az egész jogkezelésből való kilépést eredményezi. Nem lehet csak bizonyos felhasználásokat, felhasználási módokat kiléptetni ugyanazon jogok körében más felhasználások, felhasználási módok közös jogkezelés alatt tartása mellett.

A kilépés lehetőségét maga az Szjt. biztosítja a jogosultaknak azoknak a jogoknak a meghatározásánál, amelyeket egyébként közös jogkezelés körébe utal. Ez egyrészt a nem dramatikus zenemüvek és nem dramatikus szépirodalmi művek nyilvános előadásának szerzői engedélyezési jogait, ${ }^{954}$ a nem dramatikus zenemüvek és nem dramatikus szépirodalmi müvek földfelszínivel együttes müholdas sugárzásának és saját müsorral vezetékes nyilvánossághoz közvetítésének szerzői engedélyezési

\footnotetext{
${ }^{950}$ 81/1030/EEC: Commission Decision of 29 October 1981 relating to a proceeding under Article 86 of the EEC Treaty (IV/29.839 - GVL), Official Journal L 370 , 28/12/1981 P. 0049 - 0059. 55. pont.

951 A 7/82. sz. Gesellschaft zur Verwertung von Leistungsschutzrechten mbH (GVL) kontra az Európai Közösségek Bizottsága ügyben 1983. március 2-án hozott ítélet.

952 KARNELL (1985-86) p. 76.

${ }^{953}$ TRUMPKE (2012) p. 277.

954 Szjt. 25. § (3) bek.
} 
jogait; ${ }^{955}$ a másként, mint sugárzással vagy saját müsor vezetékes nyilvánossághoz közvetítésével, így különösen nyilvánosság számára lehívással hozzáférhetővé tételre vonatkozó előadóművészi és nem dramatikus zenemüvek esetén szerzői engedélyezési jogokat; ${ }^{956}$ valamint az előadás, illetve nem dramatikus zenemủ ismételt sugárzás vagy a nyilvánossághoz átvitel céljára készült rögzítésének szomszédos jogi díjazási igényeit, illetve szerzői engedélyezési jogait ${ }^{957}$ jelentik. Egyértelmüen látszik a felsorolásból, hogy az általában hagyományosan önkéntes közös jogkezelés körébe tartozó jogok azok, amelyek Magyarországon kilépést engedő, kiterjesztett hatályú törvény által előírt közös jogkezelési kategóriába tartoznak. Törvény általi elöírásuk viszont véleményünk szerint nem jelenti azt, hogy az uniós szerzői jogban kimunkált, a jogosultak jogait minél szélesebb körben biztosító elveknek, így például a kilépés elvének ne kellene érvényesülniük. Ebben a tekintetben a magyar szabályozás egyébként elvileg jobban megfelel az uniós jog elvárásainak, hiszen a kilépés lehetősége törvény által biztosított, nem pedig a közös jogkezelök alapszabályától függ, és a kilépési jog biztositása kedvezőbb a jogosultak számára, mint a KJK-irányelv által előírt rendelkezések. ${ }^{958}$ Utalni kell arra is, hogy természetesen az önkéntes közös jogkezelés keretében is élhet a jogosult a kilépés jogával. Ez következik egyrészt az önkéntesség alapelvéből, másrészt pedig abból, hogy az Szjt. erre vonatkozó kifejezett tiltást nem tartalmaz.

Amennyiben viszont a közös jogkezelő szervezet megakadályozza, hogy a jogosult éljen a kilépés jogával, azzal egyértelmüen sérti ezeket az elveket. A Daft Punk-ügyben például az Európai Bizottság (ugyan versenyjogi alapokon állva) kimondta, hogy mivel a szerzők számára nem kizárt a felhasználókkal közvetlen kapcsolatba kerülni az Internet segítségével, a közös jogkezelők visszaélnek gazdasági erőfölényükkel a 82. cikk (ma EUMSZ 102. cikk) értelmében, amennyiben arra kényszerítik őket, hogy a jogaikat közös jogkezelők kezelésére bízzák. ${ }^{959}$ A törvényben rögzített reprezentativitási követelmény, és egyébként a közös jogkezelés hatékony müködésének a biztosítása is szükségessé teszi, hogy lehetőleg minél kevesebb jogosult éljen a kilépés jogával. Erre vezethetőek vissza azok a szerződéses kikötések,

\footnotetext{
${ }^{955}$ Szjt. 26. § (7) bek. és 27. § (2)-(3) bek.

${ }^{956}$ Szjt. 27. § (3) bek., 74. § (2) bek. Az Artisjus már korán, két évvel a WCT elfogadását és a kizárólagos jog elismerését követően, 1998-ban készen állt ezeknek a jogoknak a jogosítására. SZINGER (2009) p. 329.

957 Szjt. 26. § (6) bek. 74. § (2) bek.

958 GYERTYÁNFY (2005-2006) p. 92.

959 Affaire COMP/C2/37.219 Banghalter \& Homem Christo v SACEM („Daft Punk”).
} 
amelyekben a nyugat-európai közös jogkezelö szervezetek a tagság megszünése után is kizárólagos képviseleti jogot kötöttek ki maguknak - és amelyek miatt az uniós versenyjogi szabályokba ütközés okán sorra elmarasztalták őket. ${ }^{960}$ A GEMA-ügyben például a Bizottság azzal kapcsolatban foglalt állást, hogy a közösségi versenyjogba ütközik, ha a jogosultaknak olyan meghatalmazást kell aláírniuk, amely szerint minden jelenlegi és jövőben keletkező jogukat átruházzák a GEMA-ra, és a szerződés minimum hat éves időtartama alatt nem lehetett felmondani. Még abban az esetben sem, ha ezen időszakon belül a szerző egyébként nem volt már tagja a GEMA-nak. Ily módon ugyanis a közös jogkezelő olyan módon köti magához a tagjait, amely egyébként nem lenne szükséges, és ezzel megnehezíti, hogy a tagok más közös jogkezelö szervezethez csatlakozzanak. $^{961}$

A szervezetek tehát puhább eszközökkel igyekeznek a jogosultakat maradásra bírni. Az Artisjus például Támogatási politikájában rögzíti, hogy a kulturális és szociális támogatásra az a szerző jogosult, aki nem lépett ki a rendszerből. ${ }^{962}$ Azt is hozzá kell tenni, hogy más részről viszont nem lenne tisztességes szociális és kulturális támogatásban részesíteni olyan jogosultat, akinek a jogdíja egyébként nem képezi a támogatás alapját.

A kilépési jog gyakorlására írásbeli nyilatkozat megtételével van lehetősége a jogosultnak. Szerzőtársak esetében nincsen szükség az együttes joggyakorlásra, ami azt jelenti, hogy a kilépési jog önállóan gyakorolható. A szerző kizárólagos jogát komolyan korlátozná az az értelmezés, mely szerint a kilépési jog csak együttesen gyakorolható. ${ }^{963}$ Ha az egyik jogosult kilép, ily módon az engedélyezési jog gyakorlása a továbbiakban a közös jogkezelővel közösen történik. A szerző jogutódai (pl. örökösei esetében) viszont a kilépés csak együttes jognyilatkozattal lehetséges, hiszen ők csak a szerző jogán gyakorolhatják a vagyoni jogokat. Mivel a kilépési jog csak a szerzőt illeti meg, a felhasználó (pl. zenemükiadó), annak ellenére, hogy egyébként szomszédos jogi

960 Az uniós szerzői jog közös jogkezelőkre vonatkozó elvei ezeknek a döntéseknek a nyomán kristályosodtak ki. Lásd: 71/224/CEE Décision de la Commission du 2 juin 1971 relative à une procédure d'application de l'article 86 du traité CEE (IV/26760 - GEMA); a 127-73. sz BRT c/ SABAM et Fonior ügyben 1974. március 24-én hozott itélet;

961 71/224/CEE Décision de la Commission du 2 juin 1971 relative à une procédure d'application de l'article 86 du traité CEE (IV/26760 - GEMA), 2. pont.

962 Artisjus Támogatási politika (http://www.artisjus.hu/wpcontent/uploads/2013/04/tamogatasi_politika_hatalyos.pdf), 4.1.2. pont.

${ }^{963}$ FALUDI (2004) p. 93. 
jogosultsággal rendelkezik, a szoros értelmezés alapján nem élhetne ezzel a lehetőséggel.

A kilépési jog gyakorlása szorosan összefügg a reprezentativitás követelményével is. Előfordulhat ugyanis olyan helyzet, amikor a kilépések aránya olyan magas lesz, hogy az megszünteti a közös jogkezelő szervezet belföldi reprezentativitását. A jogi monopólium keretei között ez egyfajta ,szukcesszív versenyhelyzet” kialakulását eredményezhette (volna), hiszen a kilépett jogosultak új szervezet hozhattak volna létre, amely nyilvánvalóan a kilépések megakadályozására törekszik. $^{964}$

\section{§2. Az engedélyezési jogok gyakorlása}

A kizárólagos jogok gyakorlása során egyrészt az engedélyek megadásáról kell szólni, amelynek körében külön ki kell térni arra is, hogy a jogdíjközlemények ilyen esetekben mennyire tekinthetők sajátosnak [A) pont]. Másrészt pedig ezzel összefüggésben azt kell elemezni, hogy a kívülálló (eleve nem képviselt és a kilépés jogával élő) jogosultak milyen helyzetbe kerülnek a kilépést követően [B) pont].

\section{A) A felhasználási engedélyek megadása}

A felhasználási engedély a reprezentativitás és a kiterjesztett hatály értelmében a kívülálló nem tag, vagy egyébként más módon nem képviselt jogosultakra is kiterjed. A magyar megoldás ezen a ponton tér el jelentősen a skandináv gyökerektől. Ott ugyanis maga a felhasználási szerződés az, amely kiterjesztett hatályú, míg a magyar törvény a közös jogkezelés egészére nézve írja elő ezt az elvet. A felhasználási engedélyek megadása természetszerüen ebben az esetben is a jogdíjközleményekben meghatározott feltételek szerint történik.

A kilépési jog gyakorlásával függ össze, hogy a felhasználási szerződéseknek alapvetően tartalmazniuk kell azoknak a műveknek a konkrét meghatározását, amelyek nem tartoznak a közös jogkezelő szervezet által kezelt portfólióba. A kiterjesztett hatály tehát ebből a szempontból nem teljes. A felhasználási szerződésekben ennek megfelelően utalni kell arra is, hogy a repertoárba nem tartozó művek felhasználása

${ }^{964}$ FALUDI (2004) p. 94. 
esetén egyedi jogosítás útján kell engedélyt szerezni, másként ugyanis jogszavatosság nem nyújtható.

Összefüggésben viszont azzal, hogy a felhasználó gyakorlatilag a teljes világrepertoárra szerez felhasználási jogosultságot, adatot kell szolgáltatnia az általa ténylegesen felhasznált, a kilépés hatálya alá nem tartozó művekről. Ez teszi ugyanis lehetővé a jogdíjak felosztását a közös jogkezelő szervezet számára.

\section{B) A nem tag jogosultak és a közös jogkezelö viszonya}

A kötelező közös jogkezeléstől eltérően, amely tulajdonképpen csak megfordítja a jogosult jogdíj igényléséhez való jogát (ti. egyedi jogkezelés esetén ez a felhasználókkal szemben áll fenn, míg a kötelező közös jogkezelés esetén a szervezettel szemben), ${ }^{965}$ a kiterjesztett hatályú, kilépést engedő közös jogkezelés esetében - éppen az opt-outra tekintettel a nem tag jogosultaknak a szervezethez való viszonyát is vizsgálni kell. Ez különösen a miatt fontos, mivel az ilyen módon képviselt jogosultak nincsenek abban a helyzetben, hogy egyébként befolyást gyakoroljanak a szervezet működésére, nem tudnak a díjszabás elfogadásában sem közremüködni.

Az egyenlő elbánás és a díjazáshoz (felosztáshoz) való jog együttesen biztosítja a kívülálló jogosult számára, hogy ne kerüljön hátrányosabb helyzetbe, mint amibe törvényi engedély vagy kényszerengedély alapján kerülne. Azt is be kell látni viszont, hogy ez az elméleti feltételezés nem biztos, hogy minden esetben beigazolódik, mivel kívülállóként a jogosult nem vesz részt a jogdíj mértékének, illetve a felosztás egyéb szabályainak kialakításában - azt a közös jogkezelö szervezet tagjai teszik meg. Vagyis a rendszer csak akkor müködhet megfelelően, ha a közös jogkezelő szervezetek kellően átlátható módon müködnek annak érdekében, hogy a kívülálló jogosultak is biztosan részesüljenek az őket megillető jogdíjakból. ${ }^{966}$

Kiterjesztett közös jogkezelés esetében ez a szabály a felhasználó irányában teljes, vagyis a szóban forgó vagyoni jog közös kezelése körében érintett bel- és

\footnotetext{
965 AXHAMN (2013) p. 180. Álláspontunk szerint ez a szerzői jog természetében is változást hoz, hiszen a közös jogkezelők és a szerzők azonos pólust képviselnek. Így a jogdíj érvényesítétshez való igény egy felhasználókkal szemben fennálló, és ebben az értelemben vett „külső” jogviszonyból egy azonos érdekoldalon álló szereplök közötti „,belső” jogviszonnyá változik.

${ }^{966}$ AXHAMN - GUIBAULT (2011) p. 512-513.
} 
külföldi jogosultra kiterjedő jogszavatosságot eredményez. ${ }^{967}$ Ha ugyanis egy adott jogosult jogainak gyakorlására a közös jogkezelő szervezet semmilyen egyedi jogviszony alapján nem jogosult, a kiterjesztett hatály alapján (tehát ipso iure) a felhasználó ezeknek a mủveknek a felhasználására is szerezhet engedélyt.

A kiterjesztett hatály magában foglalja annak a veszélyét, hogy a közös jogkezelő szervezet visszaél a piacuralmi helyzetével a nem tag jogosult viszonyában. ${ }^{968}$ Ennek megakadályozása érdekében törvényi garanciákat kell beépíteni a kiterjesztett közös jogkezelés szervezeti és múködési feltételei közé - különös tekintettel arra, hogy a magyar törvény nem csak a kötelező, kilépést nem engedő közös jogkezelés esetében teszi lehetővé a kiterjesztett hatályt. Így a reprezentativitás követelményének folyamatosan fent kell állnia, mint ahogy a diszkrimináció tilalmának is érvényesülnie kell. A közös jogkezelő szervezetnek tehát a jogdíjak beszedése és felosztása során úgy kell eljárnia a nem képviselt jogosultak esetében, mint ahogy azt a tag vagy a szerződés alapján képviselt jogosultak tekintetében teszi.

A kiterjesztett közös jogkezelés kölcsönös képviseleti szerződések hálózata mellett sajátosan érvényesül a külföldi jogosultak tekintetében, legalábbis a közös jogkezelésről szóló korábban hatályban lévő kormányrendelet alapján. ${ }^{969}$ A magyar közös jogkezelő a külföldi jogosultak jogdíjait kölcsönös képviseleti szerződés híján is jogosult beszedni és köteles a belföldiekkel azonosan kezelni a felosztás során. Ezzel kapcsolatban a közös jogkezelésre vonatkozó kormányrendelet elfogadását követően kritikaként felvetödött, hogy „egyenlötlen helyzethez vezethet olyan ország viszonylatában, ahol az ottani közös jogkezelö nem hajlandó (vagy csak egyoldalú feltételekkel lenne hajlandó) kölcsönös képviseleti szerzödést kötni a magyar partnerével, nem hajlandó beszedni, átutalni a magyar jogosultaknak járó jogdijakat." 970 Ma már azonban ez nem létező helyzet, az az alapelv viszont továbbra is megmaradt, hogy minden „kívülálló” jogosultat ki kell fizetni.

A nem tag jogosultakra vonatkozó garanciák betartásával a kiterjesztett közös jogkezelés magyar megvalósítása gyakorlatilag ötvözi a blanketta-engedélyek

\footnotetext{
${ }^{967}$ GYERTYÁNFY (2012) p. 504.

${ }^{968}$ GYERTYÁNFY (2004) p. 148

969 146/1996. (IX. 19.) Korm. rendelet a szerzői és szomszédos jogok közös kezeléséről 7. §.

${ }^{970}$ GYERTYÁNFY (1997) p. 262.
} 
megadásának másik lehetséges módjaként számon tartott rendszer előnyeit. Ennek a garancia-alapú megoldásnak a lényege ugyanis abban áll, hogy a törvény vélelmet állít fel az engedélyezések jogosságára nézve. A közös jogkezelö szervezet szavatosságot vállal arra, hogy a jogosultak egyénileg nem érvényesítenek igényt olyan felhasználóval szemben, akinek a szervezet felhasználási engedélyt adott. Ha ez mégis bekövetkezne, a szervezet helytáll az egyéni jogosultakkal szemben. A közös jogkezelő társaság pedig azt is vállalja, hogy a kívülálló jogosultak jogai képviseletében is kellő gondossággal jár el. ${ }^{971} \mathrm{~A}$ fentiek alapján viszont belátható, hogy a magyar törvény mindezen garanciákat egyébként biztosítja a nem tag jogosultak számára is.

${ }^{971}$ FICSOR (2003) p. 6. 


\section{II. fejezet Közös jogkezelés a hatékonyság szolgálatában}

Az eleve díjigényként meghatározott jogok közös jogkezelés alá utalása körében a praktikus szempontok a legszembetünőbbek. Ezek viszont nem ugyanazok, mint amelyek a többi jog gyakorlásánál megjelentek: vagyis nem a jogosultak számára történő egyszerübb joggyakorlás, helyette a felhasználók érdekeinek védelme az, amely szembetűnő. A közös jogkezelő szervezetek szerepe tulajdonképpen adminisztrátori tevékenységgé csökken. Ezek az esetek valójában a közös jogkezelés elvének megcsonkított variációját jelentik. A szervezet eleve csak díjigényeket érvényesít, kizárólagos jogokat nem kezel. Ezek meghatározásában viszont nem játszik szerepet, hiszen a jogalkotó rögzítette a mértéküket. Közös jellemzőjük viszont, hogy konkrét, mérhető felhasználásokon alapulnak, ami miatt különböznek az átalánydíjak közös kezelésétől. ${ }^{972}$. Ráadásul a díjigények érvényesítése nem is igényelné szükségszerüen a közös jogkezelö szervezetek közbeiktatását, elméletileg ugyanis mindkét díjazás kapcsán másfajta mód is elképzelhető (a követő jogi díj esetében az egyéni joggyakorlás, míg a haszonkölcsönzés esetében az állami kompenzáció).

A közös jogkezelés tehát mindenekelött a hatékonyságot szolgálja ezekben az esetekben. A jogalkotói döntés pedig érthető, hiszen ezáltal egy már jól müködő szervezeti struktúrára tudott új feladatot ruházni. A szervezeteknél ugyanis rendelkezésre állnak azok az információk, amelyek a jogosultak azonosítását teszik lehetővé. A felhasználóknak így nem szükséges a felkutatásukkal foglalkozni, a díjfizetési kötelezettségnek a közös jogkezelő szervezet részére való teljesítéssel eleget tudnak tenni.

A két vizsgált jog a haszonbérleti jog gyakorlása kapcsán elöírt közös jogkezelés, valamint ehhez kapcsolódóan a bérleti jog gyakorlása során a szerzőnél maradó díjigény (droit résiduel) tekintetében bevezetett joggyakorlási mód (1. pont). A másik pedig a droit de suite, vagyis a követő jog kapcsán létrehozott közös jogkezelési rendszer (2. pont).

A közös ezekben, hogy mindkettő (a magyar jog értelmében véve) a terjesztés jogához (droit de distribution) kapcsolódik, amely egyébként ilyen módon nevesítve a

\footnotetext{
972 A kapcsolódó jogi díjigények vonatkozásában is, a fenti jellemzőkkel ellentétesen, a jogosultak autonómiája érvényesül.
} 
francia szerzői jogban nem létező kategória. ${ }^{973}$ A kizárólagos jogot ugyanis egy bírói gyakorlat által jelentősen fejlesztett konstrukcióba értik bele. A CPI több cikkéből ${ }^{974}$ is levezethető, hogy az alapján a szerzőnek joga van a müpéldányok felhasználását engedélyezni. Ebből ered az is, hogy a követő jogot, vagy közismert francia elnevezésével élve a droit de suite-et külön vagyoni jogosultságként ismerik el, a CPI is külön rendelkezéseket tartalmaz ezzel kapcsolatban.

\section{A bérlet és haszonkölcsönzési jog tekintetében fennálló díjigények közös kezelése}

A bérleti és haszonkölcsönzési jog, bár polgári jogi természetüket tekintve jelentősen hasonlítanak egymásra (az elhatároló tényezőt lényegében a visszterhesség vagy az ingyenesség jelenti), szerzői jogi szempontból viszont a sok hasonlóság ellenére eltérő jellemzőket is tartalmaznak.

A nyilvános haszonkölcsönzési jog (droit de prêt public) nemzetközi szerzői jogi dokumentumokban nem meghatározott, ilyen módon nem garantált jog. Bár könyvtárak mindig is léteztek, sokáig nem vetődött fel annak a gondolata, hogy az itt megvalósuló felhasználásoknak a szerzői jogi engedélyeket kellene magával vonzaniuk. Ez arra vezethető vissza, hogy a haszonkölcsön rendkívül szenzitív, nemzeti kultúrpolitikát érintő kérdésekkel is összefüggésben áll a könyvtárak sokszor állami fenntartása, támogatása miatt. Az 1988-as Zöld könyv éppen erre a közérdekü jellegre tekintettel még nem tartotta szükségesnek a haszonkölcsönzési jog elismerését és az uniós harmonizáció szükségességét, illetve díjigényként, nem pedig engedélyezési jogként tekintett erre a felhasználási módra. ${ }^{975}$ Csak a későbbiekben vált szemponttá a bérlet és a haszonkölcsön egymáshoz való közelítése, annak felismerésével, hogy a haszonkölcsönzés is a mü felhasználásának egy formája. ${ }^{976} \mathrm{Az}$ irányelv elfogadása ${ }^{977}$ előtt az akkori tagállamok nagy többségében a nyilvános haszonkölcsönzés nem számított szerzői jogi értelemben vett felhasználásnak. Pár tagállamban létezett ugyan valamiféle díjfizetés a jogosultak részére, azonban egyedül Dánia volt az, amely

\footnotetext{
973 Mivel mind a magyar szerzői jog, mind pedig az InfoSoc-irányelv 4. cikke ismeri ezt a kategóriát, indokoltnak tarjuk átfogó elnevezéssel az irányelvben foglalt terminológia használatát.

${ }^{974}$ CPI L. 131-3. cikk (3) bek, L. 332-2. cikk (2) bek, L. 335-3. cikk.

975 Green paper on copyright and the challenge of technology - Copyright issues requiring immediate action, $\operatorname{COM}(88) \quad 172$ final, 1988 (http://ec.europa.eu/greenpapers/pdf/green_paper_copyright_and_chanllenge_of_thecnology_com_(88)_172_final.pdf), p. 153154.

${ }_{976}$ REINBOTHE - VON LEWINSKI (1993) p. 34.

977 Az irányelv elemzését lásd: BÉRCESI (1997) p. 337-342.
} 
kizárólagos jogot tartott fenn a filmalkotások és a szoftverek haszonkölcsönzése tekintetében. ${ }^{978}$ Ebből a szempontból tehát az irányelv valójában nem harmonizációt valósított meg, hanem egy teljesen új jogot teremtett.

A bérleti jog (droit de location) eltérő vonásokat mutat, hiszen a felhasználás gazdasági jellege egyértelmű. Ennek elismerése is a technológiai fejlődés következtében kialakuló újabb felhasználói szokásokra vezethető vissza: a jogosultak ugyanis részesedni kívántak a videokölcsönzés virágzásából. Ennek köszönhető, hogy bár a BUE nem ismeri a bérleti jogot, a későbbi nemzetközi szerzői jogi egyezmények lépésről lépésre haladtak a jog minél szélesebb körü biztosítása érdekében. Az Európai Unióban különösen a belső piacra gyakorolt hatások felismerésének köszönhetően került a jog harmonizálásra. ${ }^{979}$

A dolgozat eddigi felépítéséhez hasonlóan a végül megvalósított jogkezelési rendszer elemzése (§2. pont) előtt a haszonkölcsönzési és bérleti jog tartalmát világítjuk meg (1. § pont).

\section{\$1. A bérlet és haszonkölcsönzési jog tartalma}

Mindkét jog esetében célszerünek tünik előbb a vagyoni jog egyes elemeit áttekinteni [(A) pont] annak érdekében, hogy ezek korlátozásának mikéntje érthetőbb legyen [(B) pont]. Erre a felosztásra azért van szükség, mivel a nyilvános haszonkölcsönzés a klasszikusan haszonkölcsönzésbe adott mütípusok tekintetében tulajdonképpen mindkét tagállamban díjigényként került meghatározásra az engedélyezési jog gyakorlásának nehézségei miatt. ${ }^{980}$

\section{A) A vagyoni jogok meghatározása}

Mind a haszonkölcsönzés, mind a bérlet a terjesztés jogából vezethető le. Mivel a francia szerzői jogi dogmatika a vagyoni jognak ezt a kifejezett formáját nem

\footnotetext{
${ }^{978}$ COMTE (1993) p.27.

979 A dolog érdekessége, hogy a bérleti jog időközben, szintén a technológiai fejlődésnek köszönhetően, sokat veszített gazdasági jelentőségéből, bevételkiesést okozva ezáltal a jogosultak oldalán is. Elméleti síkon viszont ez a fejlődés rendkívül érdekes problémákat vet fel: a terjesztési jog (beleértve a bérleti jogot is) alkalmazását, alkalmazhatóságát az online környezetben, különös tekintettel a nyilvánosság számára lehívásra történő hozzáférhetővé tétellel való ütköztetése, illetve a jogkimerülés tételének alkamazhatóságára.

${ }^{980}$ Franciaországban ehhez a fent említett, és a jog tartalmának megállapításánál részletesen kifejtett dogmatikai nehézségek is indokolják egyébként a díj meghatározását.
} 
ismeri, külön dogmatikai konstrukciót kellett alkotni annak érdekében, hogy ezek megfelelően beilleszthetőek legyenek a francia szerzői jogi rezsimbe. A közös gyökerek ellenére az egyéb jellemzők különbségei miatt a két jogot elkülönítve tárgyaljuk, a hangsúlyt a speciális közös jogkezelési rezsimre helyezve [a) pont], amelyet a bérleti jog elemzése követ [b) pont].

\section{a) A nyilvános haszonkölcsönzési jog jellemzöi}

A nyilvános haszonkölcsönzési jog voltaképpen a könyvtári, de legalábbis a nyilvánosság számára történő haszonkölcsönzést jelenti, ilyen módon elsősorban a nyomtatott formában megjelenő, illetve másodlagosan a hangfelvételbe foglalt szerzői müveket érinti $\left[\alpha\right.$ ) pont]. A kizárólagos jog az Szjt. rendelkezéseinek megfelelően ${ }^{981} \mathrm{a}$ terjesztés jogának részeként értékelendő. Ez nem ilyen egyértelmü a francia szerzői jogi dogmatikában, ahol a terjesztés jogának speciális felfogása miatt a haszonkölcsönzés rendszertani elhelyezése külön indokolást igényel [ $\beta$ ) pont].

\section{a) A haszonkölcsönzési jog tartalma}

A francia jogalkotó a 2003. június 18-i törvénnyel ${ }^{982}$ valósította meg a Bérletirányelv implementációját. Magyarországon pedig a 2008. évi CXII. törvény ${ }^{983}$ iktatta be a nyilvános könyvtárak által végzett haszonkölcsönzésre vonatkozó külön szabályokat. A haszonkölcsönzési jog tartalmát tehát ezen törvények figyelembe vételével kell megállapítani.

\section{A haszonkölcsönzési jog fogalma}

A haszonkölcsönzés jogára vonatkozóan a magyar szerzői jog (a franciához hasonlóan) nem tartalmaz meghatározást - a törvény annyit szögez le mindössze, hogy a nyilvános haszonkölcsönzés a terjesztés jogának körében a szerző engedélyezési joga alá tartozik. ${ }^{984}$ Ez egyébként logikusan következik a szerzői jog általános rendeltetéséből, vagyis abból, hogy a nyilvánossághoz jutó felhasználások képezik az engedélyezés tárgyát. Ennek eredménye pedig az, hogy a magánfelek között létrejövő

\footnotetext{
${ }^{981}$ Szjt. 23. § (3) bek.

${ }^{982}$ Loi $\mathrm{n}^{\circ}$ 2003-517 du 18 juin 2003 relative à la rémunération au titre du prêt en bibliothèque et renforçant la protection sociale des auteurs.

${ }^{983}$ A szerzői jogról szóló 1999. évi LXXVI. törvény módosításáról szóló 2008. évi CXII. tv.

${ }^{984}$ Szjt. 23. § (3) bek. „A terjesztés joga kiterjed a mü egyes példányainak a nyilvánosság részére történő haszonkölcsönbe adására is."
} 
ügyletek kívül esnek a szerzői jog (és így a haszonkölcsönzési jog) hatókörén. A jog tartalmának meghatározásához emiatt érdemes a polgári jogi definícióra is kitérni, különösen, mivel az Szjt. 3. §-a Ptk-t háttérjogszabályává teszi ${ }^{985}$ Az új Ptk. érdemben nem módosította a haszonkölcsön tartalmi elemeit, vagyis a szerződés alapján a kölcsönadó meghatározott dolog időleges használatának ingyenes átengedésére, a kölcsönvevő pedig a dolog átvételére köteles. ${ }^{986}$ A haszonkölcsön egyik elhatároló ismérve tehát az ingyenesség, a másik pedig a használat időleges átengedése.

A CPI kifejezetten a nyilvánosság számára nyitva álló könyvtárak keretében történő haszonkölcsönzést kifejezetten csak a kiadói szerződésnek megfelelően kiadott könyvek esetén ismeri el, és biztosítja a díjazás lehetőségét. ${ }^{987}$ Ez tehát azt jelenti, hogy a sajtótermékek, folyóiratok, adott esetben hangfelvételek esetében nem áll fenn a speciális rezsim. Ezek haszonkölcsönzése az általános szabályok szerint viszont álláspontunk szerint nincsen kizárva, hiszen a francia dogmatika és bírói gyakorlat kifejezett törvényi rendelkezés hiányában is elismeri a haszonkölcsönzési jogot.

A jog tartalmának további megállapításánál emiatt a Bérlet-irányelvben szereplő fogalomból érdemes kiindulni. Ez pedig haszonkölcsönzés alatt a nyilvánosság számára nyitva álló intézmény útján határozott időre történő olyan használatba adást érti, amely sem közvetlenül, sem közvetetten nem irányul gazdasági vagy kereskedelmi előny szerzésére. ${ }^{988}$

Az irányelv maga nem fogalmazza meg, hogy mit ért nyilvánosság számára nyitva álló könyvtár fogalma alatt, vagyis a tagállamoknak lehetőségük van ennek rendezésére. A magyar jogalkotó a meghatározást nem a szerzői jogról szóló törvényben, hanem a muzeális intézményekről, a nyilvános könyvtári ellátásról és a közművelődésről szóló 1997. évi CXL. törvényben helyezte el. E szerint a nyilvánosság számára nyitva álló könyvtárnak több kritériumnak is meg kell felelnie. Az

\footnotetext{
985 Szjt. 3. § A szerzői jogok és a szerzői joghoz kapcsolódó jogok átszállására, átruházására, megterhelésére, valamint az e törvény hatálya alá tartozó művekkel és egyéb teljesítményekkel összefüggő egyéb személyi és vagyoni jogviszonyokban az e törvényben nem szabályozott kérdésekben a Polgári Törvénykönyv rendelkezései az irányadók.

${ }_{986}^{9}$ Ptk. 6:357. § (1) bek.

${ }^{987}$ CPI L. 133-1. cikk: „Lorsqu'une oeuvre a fait l'objet d'un contrat d'édition en vue de sa publication et de sa diffusion sous forme de livre, l'auteur ne peut s'opposer au prêt d'exemplaires de cette édition par une bibliothèque accueillant du public.

Ce prêt ouvre droit à rémunération au profit de l'auteur selon les modalités prévues à l'article L. 133-4." ${ }^{988}$ Bérlet irányelv, 2. cikk (1) bek. b) pont.
} 
intézménynek mindenki által használhatónak és megközelíthetőnek kell lennie, amelynek vezetője felsőfokú szakirányú végzettséggel rendelkezik és könyvtári szakembert alkalmaz. Ezen kívül rendelkeznie kell kizárólagosan a könyvtári szolgáltatások céljaira alkalmas helyiséggel; rendszeresen, a felhasználók többsége számára megfelelő időpontban kell nyitva tartania és helyben nyújtott alapszolgáltatásai ingyenesek. Működéséről statisztikai adatokat kell szolgáltatnia, el kell látnia a törvény által ráruházott alapfeladatokat, valamint nevében is meg kell jelennie a könyvtár kifejezésnek. $^{989}$ Ebbe a fogalomba egyébként az országos, megyei és városi könyvtárakon kívül az egyetemi könyvtárak is beleértendőek, bár értelemszerüen az ő tevékenységük alapvetően a nyilvánosságnak egy szükebb körét célozza.

A nyilvánosság számára nyitva álló könyvtár fogalmát a francia törvény kijelölt helyi könyvtárak, a felsőoktatásért felelős miniszter irányítása alatt álló felsőoktatási, tudományos, kulturális vagy szakmai közintézmények könyvtárai, az üzemi tanácsok könyvtárai, valamint minden olyan könyvtár vagy szervezet, amely gyüjteményét a nyilvánosság számára eléretővé teszi, és az éves szinten beszerzett könyvek több mint felét a beiratkozott tagok részére haszonkölcsönbe adja. ${ }^{990} \mathrm{~A}$ francia meghatározás utolsó eleme tehát nyitottá teszi ezt a listát, amelybe bizonyos kritériumok teljesülése esetén magán- és közkönyvtárak is bekerülhetnek. Ez megfelel a Bérlet-irányelv tág megfogalmazásának is, amely alapján nemzetközi szervezetek, bíróságok, különböző vállalatok nyilvánosság számára álló dokumentációs központjai is beleértendőek. $^{991}$

\footnotetext{
989 A muzeális intézményekröl, a nyilvános könyvtári ellátásról és a közművelődésről szóló 1997. évi CXL. törvény 54. § (1) bekezdése. Fontos kiemelni, hogy a törvény 54 . § (2) bek. értelmében a nyilvános könyvtárakról az illetékes miniszter jegyzéket vezet.

${ }_{990}$ CPI R. 133-1. cikk: „Les bibliothèques accueillant du public pour le prêt mentionnées aux articles L. 133-3_et L. 133-4_sont :

$1^{\circ}$ Les bibliothèques des collectivités territoriales désignées aux articles L. 310-1 à L. 310-6_et L. 320-1 à L. 320-4 du code du patrimoine ;

$2^{\circ}$ Les bibliothèques des établissements publics à caractère scientifique, culturel et professionnel et des autres établissements publics d'enseignement supérieur relevant du ministre chargé de l'enseignement supérieur ;

$3^{\circ}$ Les bibliothèques des comités d'entreprise ;

$4^{\circ}$ Toute autre bibliothèque ou organisme mettant un fonds documentaire à la disposition d'un public, dont plus de la moitié des exemplaires de livres acquis dans l'année est destinée à une activité organisée de prêt au bénéfice d'usagers inscrits individuels ou collectifs."

${ }_{991}$ LeBoIs, Audrey: Droits patrimoniaux - Droit de location et de prêt, J. Cl. Propriété littéraire et artistique, Fasc. 1254. 21. pont.
} 
A Bérlet-irányelv egyértelmüen fogalmaz, amennyiben haszonkölcsönzésként a határozott idejü használatba adást érti. A könyvtári feladatok ellátása kapcsán felvetődő egyik leggyakoribb probléma azzal függ össze, hogy a haszonkölcsönzési jog indokolatlanul tesz különbséget a könyvtár egyes szolgáltatásai között. A határozott időre történő használatba adásba ugyanis általában nem értendő bele a helyben olvasás (az 1997. évi CXL. tv. értelmében a könyvtár helyben nyújtott alapszolgáltatásai ráadásul ingyenesek), csak az, amikor az olvasó ténylegesen kikölcsönzi az adott művet azzal a céllal, hogy annak tartalmát egy általa szabadon választott helyen ismerje meg. Ezt az értelmezést a Bérlet irányelv (10) preambulumbekezdése is megerősíti. A kiállításra és a hangfelvételek vagy filmek nyilvános előadás vagy sugárzás céljából történő hozzáférhetővé tételére sem terjed ki a haszonkölcsönzés joga, de ezeket, a helyben olvasástól eltérően a vagyoni jogok keretében külön ki is szokták emelni, mint engedélyköteles felhasználásokat. A preambulumbekezdés azt is rögzíti, hogy a könyvtárközi kölcsönzésre sem terjed ki a haszonkölcsönzési jog. A magyar szerzői jog egyébként ez utóbbi felhasználási módot is a terjesztés egyik formájának tekinti, vagyis alapvetően engedélyköteles felhasználásról lenne szó. Ezzel szemben viszont a könyvtárközi kölcsönzés vonatkozásában a törvény szabad felhasználást állapít meg. ${ }^{992}$

A nyilvános haszonkölcsönzési jog harmadik konjunktív fogalmi eleme pedig az, hogy a tevékenység sem közvetlenül, sem közvetve nem irányulhat gazdasági vagy kereskedelmi előny szerzésére. Mind az irányelv (11) preambulumbekezdése, mind pedig az irányadó magyar kommentárok álláspontja szerint egy csekély mértékü könyvtári beiratkozási díj, amelynek összege nem haladja meg az intézmény müködési költségeinek fedezéséhez szükséges mértéket, még nem teszi a haszonkölcsönzést gazdasági előnnyel járó tevékenységgé. ${ }^{993} \mathrm{Az}$ önköltség elérése viszont már azt eredményezheti, hogy a szerző engedélyéhez kötött felhasználásról van szó, a bérleti jog körében értékelve a felhasználási cselekményt. ${ }^{994}$

\footnotetext{
992 Szjt. 40. § „A szabad felhasználás keretében többszörözött példányok - a könyvtárközi kölcsönzés és a 36. $\S(5)$ bekezdésében foglalt eset kivételével - nem terjeszthetők a szerzö engedélye nélkül." A könyvátrközi kölcsönzésre vonatkozó szabad felhasználásról részletesen a haszonkölcsönzési jog korlátozásánál szólunk.

993 A Bérlet irányelv (11) preambulumbekezdése így szól: „Amennyiben a nyilvánosság számára nyitva álló intézmény általi haszonkölcsönzése esetén olyan dijat kell fizetni, amelynek összege nem haladja meg az intézmény müködési költségeinek fedezéséhez szükséges mértéket, akkor ezen irányelv értelmében ez nem minösül közvetlen vagy közvetett gazdasági vagy kereskedelmi elönynek."

${ }^{994}$ GYERTYÁNFY (2014) p. 270-271.
} 


\section{$\underline{\text { A haszonkölcsönzési jog közvetett tárgya és jogosultja }}$}

A haszonkölcsönzési jog tárgya alapvetően bármely szerzői mü lehet, bár az irányelv értelmében ez alól az építészeti és iparművészeti alkotások ki vannak zárva. ${ }^{995}$ A harmonizáció hiánya természetesen nem jelenti azt, hogy a tagállamok ne terjeszthetnék ki a jogot ezekre a müvekre is. ${ }^{996}$

A CPI alapján csak a kiadói szerződés keretében kiadott könyvek tartozhatnak a díjazás alá. Felvetődhet az a kérdés is, hogy ebből kifolyólag Franciaország nem megfelelően ültette át az irányelvet, az ugyanis csak a díjazás mértékének meghatározását bízza a tagállamok szabad rendelkezésére. ${ }^{997}$ A részleges átültetés következtében a francia jogalkotó nem tett eleget az irányelvek átültetésével kapcsolatban megfogalmazott alapvető követelménynek, vagyis a konformitásnak. ${ }^{998} \mathrm{Ez}$ a mulasztás tovább mélyíti az egyes szerzők közötti megkülönböztetést azáltal, hogy a szerzői kiadásban megjelentetett müveket kizárja a haszonkölcsönzési jog gyakorlásából, ráadásul ezáltal burkoltan kiadói szerződések megkötésére is sarkallja a szerzőket. További szükítést jelent, hogy csak a könyv formában kiadott müvekre vonatkozik a rendelkezés, vagyis az eredendően e-könyvként kiadott müvek szerzői szintén nem tartoznak a rezsim hatálya alá. ${ }^{999}$ Az egyéb szerzői mủvek, így a könyvtárakban tipikusan megtalálható folyóiratok, illetve hang- és videofelvételek szintén kizárásra kerültek.

\section{ß) A haszonkölcsönzési jog rendszertani elhelyezése, egyéb jellemzöi}

\section{$\underline{\text { A haszonkölcsönzés a vagyoni jogok között }}$}

A haszonkölcsönzési jogot, mint már utaltunk rá, tipikusan a terjesztési jog részeként szokás felfogni, annak ellenére, hogy az uniós irányelvek ezt a két jogot egymástól eltérően kezelik. Ez egyrészt annak köszönhető, hogy a Bérlet-irányelv hamarabb került elfogadásra, az InfoSoc-irányelv tárgyalása során pedig a már harmonizált kérdéseket nem érintették. Az InfoSoc-irányelv terjesztési jogra vonatkozó

\footnotetext{
995 Bérlet irányelv, 3. cikk (2) bek.

${ }^{996}$ GYERTYÁNFY (2014) p. 193.

997 ALLEAUME (2004) p.723.

${ }^{998}$ ZOLYNSKI (2007) p. 159.

$999 \mathrm{Az}$ e-könyvek haszonkölcsönzése egyébként napjaink szerzői jogi diskurzusának egy fontos elemét képezi a licencia és az adásvétel elhatárolásának kérdése miatt.
} 
4. cikke pedig nem foglalja magában a haszonkölcsönzés jogát. ${ }^{1000}$ Ebböl logikusan az következnék, hogy a terjesztés jogába automatikusan nem értendő bele a haszonkölcsönzési jog. ${ }^{1001}$

A magyar törvény viszont a két jog viszonyát kifejezetten nevesíti az Szjt. 23. § (3) bekezdésében, és a terjesztés jogának körébe tartozónak tekinti a haszonkölcsönzési jogot. ${ }^{1002}$ A könyvtári haszonkölcsönzés díjigényként való meghatározása tehát tulajdonképpen a terjesztési jog egy korlátjának is tekinthető. ${ }^{1003}$

A francia szerzői jog nem ismeri a terjesztés jogát, amely miatt a haszonkölcsönzési jog meghatározása, dogmatikailag pontos elhelyezése is nehézségekbe ütközik. Christophe ALLEAUME meghatározása szerint a haszonkölcsönzési jog egy oltvány a francia szerzői jogban, a skandináv jog ráerőltetése közösségi közvetítéssel egy latin jogi hagyományokkal bíró országra. ${ }^{1004}$ Annak ellenére mondja mindezt, hogy Henri DESBOIS 1966-ben megjelent szerzői jogi kommentárja $^{1005}$ óta gyakorlatilag általánosan elfogadott ${ }^{1006}$ az a vélemény, mely szerint a francia jog igenis ismeri a haszonkölcsönzés jogát, amely a rendelkezésre bocsátási jogból (droit de destination) eredeztethető. Ez utóbbi azt jelenti, hogy a szerző a felhasználási jogainak átengedésekor meghatározhatja, hogy a forgalomba hozott példányoknak mely konkrét felhasználási módjait engedélyezi. ${ }^{1007}$

\footnotetext{
${ }^{1000} \mathrm{Az}$ EuB például egyik ítletében úgy fogalmazott, hogy az InfoSoc-irányelv 4. cikk (1) bekezdése értelmében vett ,adásvételtől eltérő más módon történő nyilvános terjesztés” fogalma kizárólag a tárgy tulajdonjogának átruházását foglalja magában. Tehát sem az a tény, hogy a mủ példányainak használatát lehetővé teszik a nyilvnosság számára, sem az, hogy az említett példányokat nyilvánosan bemuttaják azok használata lehetőségének engedélyezés nélkül, nem tekinthető a terjesztés ilyen formájának. A C-456/06. sz. Peek and Cloppenburg-ügyben 2008. április 17-én hozott ítélet. De pl. az értékesítáési célú reklámozástól eltiltást lehet kérni. A C-516/13 sz. Dimensione Direct Sales and Michele Labianca ügyben 2015. május 13-án hozott ítélet.

${ }^{1001}$ A bérleti jogot viszont az irányelvek is a terjesztési jog részének tekintik. Nagykommentár, p. 192.

${ }^{1002}$ Szjt. 23. § (3) bek. „A terjesztés joga kiterjed a mü egyes példányainak a nyilvánosság részére történő haszonkölcsönbe adására is. A hangfelvételben foglalt müvek szerzöi e jogukat a 78. § (2) bekezdésének megfelelöen gyakorolhatják. A filmalkotások szerzöi e jogukat szintén csak közös jogkezelés útján gyakorolhatják, díjukról csak a felosztás idöpontját követö hatállyal, a rájuk jutó összeg erejéig mondhatnak le."

${ }^{1003}$ A korlátozásról részletesen lásd a következő, B) pontot.

${ }^{1004}$ ALLEAUME (2004) p.721.

${ }^{1005}$ DESBOIS (1978) $\mathrm{n}^{\mathrm{O}} 288$.

${ }^{1006}$ Lásd ezzel kapcsolatban pl. GaUtier (2012), LuCAS (1998), Pollaud-Dulian (1989), ALLEaume, (1997).

${ }^{1007}$ Alleaume (2001) p. 44.
} 


\section{$\underline{\text { A haszonkölcsönzési jog szerepe }}$}

A Bérlet-irányelv rendelkezései a korábban szabadon végzett haszonkölcsönzési tevékenységet is engedélyköteles felhasználássá tették. Az könnyen belátható, hogy a gyakorlatban az előzetes engedélyek beszerzése jelentősen megnehezítené, sőt mi több, ellehetetlenítené a könyvtári haszonkölcsönzés korábban müködő rendszerét. A könyvtárak ugyanis képtelenek lennének ellátni azt a feladatukat, hogy a közönség egésze számára a lehető legteljesebb gyüjteményt kínálják annak érdekében, hogy az olvasók információhoz juthassanak, és az intézmény hozzájáruljon a felhasználók tudományos és kulturális művelődéséhez. A kizárólagos jog bevezetése természeténél fogva azt is jelenti, hogy a jogosultak megtilthatják műveik nyilvános haszonkölcsönzését. Ennek a jognak a gyakorlása viszont veszélybe sodorná a könyvtári feladatok ellátását. ${ }^{1008}$ Ráadásul egy ilyen rendszer azzal a negatív következménnyel is járna, hogy a nagyközönség nehezebben, illetve adott esetben sokkal szükebb körben férhetne hozzá a könyvtárakban őrzött kulturális kincsekhez. A kizárólagos jog biztosítása tehát gyakorlati szempontokból nézve nem több puszta deklarációnál, egy gesztusnál, megvalósítása ugyanis sokkal több hátrányt okozna, mint amennyi előnyt a jogosultak élveznek az engedélyezési jog gyakorlásából.

Mindezen hátrányok ellenére a haszonkölcsönzési jog kizárólagos jogként való definiálását két érv indokolja. Az egyik a haszonkölcsönzési jog és a bérleti jog összekapcsolása jelentette az irányelv elfogadásának folyamatában. Mivel a két felhasználási mód nagyon hasonló cselekményeket rejt magában, a jogosultak számára hátrányt jelentett volna, ha csak az egyik kapcsán biztosítják számukra a kizárólagos jogot. A másik érv, amelyet fel szoktak hozni ennek alátámasztására, abban áll, hogy a haszonkölcsönzés alternatívát nyújt a felhasználóknak az adásvételhez képest, és mint ilyen, befolyással bír a szerzői müvek elsődleges forgalmára. Más szóval élve alkalmas arra, hogy gyakorlásával a jogosultaknak (anyagi) hátrányt okozzon.

\section{b) A bérleti jog}

A bérleti jogot a BUE ugyan nem nevesíti, de a haszonkölcsönzési joggal ellentétben, egyéb nemzetközi szerzői jogi egyezmények rendelkeznek róla. A Bérletirányelv révén uniós harmonizáció tárgyát is képezi. A Bérlet-irányelv az alábbi

${ }^{1008}$ COMTE (1993) p. 35. 
megfogalmazást használja a vagyoni jog meghatározásához: határozott időre történő használatba adás közvetlen vagy közvetett gazdasági vagy kereskedelmi előny érdekében. ${ }^{1009} \mathrm{~A}$ fogalomnak megfelelően, és a haszonkölcsönzési jog elemzése során alkalmazott metódust követve elöször a bérleti jog tartalmát elemezzük [ $\alpha$ ) pont], mielőtt rátérnénk az ennek átruházása kapcsán a szerzőt megillető díjigényre [ $\beta$ ) pont].

\section{a) A bérleti jog tartalma}

A magyar szerzői jogi törvény szerint a terjesztés magában foglalja a műpéldány bérbeadását is. ${ }^{1010} \mathrm{~A}$ jogügylet tartalmának meghatározása viszont a nem a szerzői jog, hanem a polgári jog körébe tartozik. A Bérlet-irányelv nem a visszterhesség, ${ }^{1011}$ hanem a tágabban értelmezhető közvetlen vagy közvetett gazdasági előny kategóriáját alkalmazza a fogalom meghatározásánál, amelynek egy határozott időre történő használatba adáshoz kell kötődnie. ${ }^{1012}$ A szerzői jogi felhasználási cselekmény megvalósulása szempontjából viszont az üzletszerüség nem feltétel, ${ }^{1013} \mathrm{de}$ a visszterhesség viszont igen. A bérleti jog minden mütípusra kiterjed, ${ }^{1014}$ bár a jog tárgyának meghatározása kapcsán a törvény (a Bérlet-irányelv megoldásának megfelelően) kiemeli, hogy ez a jog az építészet, az iparművészet és az ipari tervezőművészet körében csak a tervekre vonatkozik. ${ }^{1015}$

\section{ß) A bérbeadásra tekintettel a szerzőt megillető dijigény}

A Bérlet-irányelv a szerzők védelmében egy külön rendelkezést iktatott a be, amely a bérleti jog átengedése esetén is méltányos díjazáshoz való jogot biztosít a szerzőknek és előadóművészeknek. Az irányelv ezzel a szabállyal láthatóan a kizárólagos jog és a díjigény optimális kombinációját kívánta megvalósítani, azzal a céllal, hogy a jogosulti érdekek hatékonyabb érvényesülését biztosítsa. ${ }^{1016}$ Álláspontunk szerint ez nem tekinthető korlátozásnak, így a bérleti jog díjigénnyé való leszorításának,

\footnotetext{
${ }^{1009}$ Bérlet-irányelv, 2. cikk (1) bek. a) pont.

${ }^{1010}$ Szjt. 23. § (2) bek.

1011 Ptk. 6:331. § (1) bek. „Bérleti szerződés alapján a bérbeadó meghatározott dolog időleges használatának átengedésére, a bérlő a dolog átvételére és bérleti dij fizetésére köteles."

${ }^{1012}$ Bérlet-irányelv 2. cikk (1) bek. a) pont.

1013 GYERTYÁNFY (2014) p. 188.

1014 A szoftverek bérbeadására is, hiszen azt már a Szoftver-irányelv 4. cikke is biztosította a jogosultak részére. Tehát annak ellenére, hogy a Bérlet-irányelv kifejezetten kizárja a hatálya alól a számítógépi programok bérbeadását (4. cikk), egyben vissza is utal annak Szoftver-irányelv szerinti alkalmazására. 1015 Szjt. 23. § (4) bek.

1016 BÉRCESI (1997) p. 341.
} 
hiszen célja éppen a jog gyakorlásának átengedése esetén az anyagi kompenzáció biztosítása. Az Szjt. ugyanis akként rendelkezik (összhangban a Bérlet-irányelv 5. cikkével), ${ }^{1017}$ hogy ha a szerző a filmalkotásra vagy a hangfelvételben foglalt müre vonatkozó bérbeadási jogát a film vagy a hangfelvétel előállítójára ruházta, vagy egyébként engedélyezte számára e jog gyakorlását, a mű bérbeadással történő terjesztése ellenében továbbra is megfelelő díjazást követelhet a film vagy a hangfelvétel előállítójától. ${ }^{1018}$

A felhasználási szerződések megkötésekor általában jellemző a szerző gyengébb szerződéses pozíciója (annak ellenére, hogy elvileg ők azok, akik a művek felhasználására kizárólagos joggal rendelkeznek), ${ }^{1019}$ amelynek eredményeként többnyire a bérleti jog gyakorlását is átengedi a film- vagy hangfelvétel előállítónak. ${ }^{1020}$ A francia bírói gyakorlatban merült fel egyébként az a kérdés, hogy a jog ingyenesen átengedhető-e, különös tekintettel arra a dogmatikai megoldásra, amelynek értelmében a bérleti jog a többszörözési jogból levezethető rendelkezési jog részét képezi (azonban kifejezetten nem került a CPI-ben elismerésre). A bírói gyakorlat igenlő választ adott a kérdésre azzal a megkötéssel, hogy a szerződésben a bérleti jog ingyenes átengedésének kifejezetten szerepelnie kell. ${ }^{1021}$ A díjazáshoz való jog szempontjából fontos utalni arra is, hogy a francia szerzői jog az audiovizuális felhasználási szerződésekben (contrat de production audiovisuelle) a bérleti jog átengedése automatikusan vélelmezésre kerül. ${ }^{1022}$ A szerzőt azonban ebben az esetben is megilleti a díjazáshoz való jog. ${ }^{1023} \mathrm{Az}$ irányelvnek való megfelelés tehát egyben tulajdonképpen ki is üresíti az ingyenes átengedéshez való jogot, mivel erről a díjigényről nem lehet lemondani.

1017 Bérlet-irányelv 5. cikk (1) bek. „Ha egy szerző vagy elöadómüvész hangfelvételre vagy egy film eredeti vagy többszörözött példányára vonatkozó bérleti jogát a hangfelvétel vagy film elöállitójára ruházta vagy nekik átengedte, a szerzö vagy elöadómüvész a bérlet ellenében továbbra is méltányos dijazást követelhet."

${ }^{1018}$ Szjt. 23. § (6) bek.

${ }^{1019}$ GYENGE (2004) és GYENGE (2005a).

${ }^{1020}$ Tekintettel azonban arra, hogy a tulajdon átruházását és a bérletet az Szjt. külön nevesíti, külön jogként ismerve el öket, előfordulhat olyan szerződés is, amelyben az egyik részjogosultság átengedésre kerül, míg a másik nem. Bár az ilyen típusú szerződések leginkább a (jogokkal a szerzőktől származtatott módon rendelkező) film- és hanfelvétel-elöállítók, valamint a felvételek terjesztését végző ügynökségek között állnak fenn.

${ }^{1021}$ CA Paris, 4e ch., 1er juill. 1998: RIDA janv. 1999. p. 390.

${ }^{1022}$ CPI L. 132-24. cikk

${ }^{1023}$ CPI L. 132-25. cikk. Megjegyzendő, hogy a francia jogalkotó nem megfelelően ültette át az irányelvet, mivel az előadóművészek számára nem biztosította a díjazásra tekintettel fennálló jogot. LEBOIS, Audrey: Droits patrimoniaux - Droit de location et de prêt, J. Cl. Propriété littéraire et artistique, Fasc. 1254. 51. pont. 
A Bérlet-irányelv egyébként méltányos díjazást ír elő ebben az esetben is ${ }^{1024}$ hasonlóan az InfoSoc-irányelvben található magáncélú másolatra tekintettel fizetett díjazáshoz. Azzal kapcsolatban, hogy hogyan kell a méltányos díjazást ebben a vonatkozásban értelmezni, az irányelvben még a magáncélú másolatra tekintettel fizetett díjak kapcsán meghatározott szempontokhoz képest is kevesebb útmutatást találunk. A Bérlet-irányelv (13) preambulumbekezdése annyit mond, hogy mértékének meghatározásánál figyelembe kell vennie a film, illetve hangfelvétel előállításában a szerzők, illetve előadómüvészek hozzájárulásának mértékét. A tagállamok tehát szabadon megállapíthatnak átalánydíjat, de a bérleti jog gyakorlásából eredő bevételhez igazodó arányos díjazást is. ${ }^{1025}$

\section{B) A jog korlátozása}

A nyilvános haszonkölcsönzési jog esetében a tagállamokban végül bevezetett rendszerek kapcsán sokkal hangsúlyosabb szerepet kap a jog korlátozhatósága és korlátozása, hiszen mind Magyarország, mind Franciaország díjigényként, nem pedig engedélyezési jogként ültette át a vagyoni jogot a klasszikusan haszonkölcsönzés útján terjesztett müvek esetében ${ }^{1026}$ [a) pont]. A bérleti jog tekintetében viszont a díjigény sokkal inkább a jog tényleges érvényesítésének eszközeként, semmint korlátként fogható fel [b) pont].

\section{a) A nyilvános haszonkölcsönzési jog korlátozása}

A haszonkölcsönzési jog esetében az irányelv alapvetően a kizárólagos jog biztosítását írja elő a tagállamoknak, viszont korlátozás bevezetését is lehetővé teszi számukra. Ezt annak a felismerése miatt teszi, hogy a haszonkölcsönzési jognak, azaz hangsúlyozottan az ennek fejében járó díjazásnak a könyvtárak tevékenysége révén sokkal inkább kultúratámogató szerepe is lehet, mint a többi díjnak. Az uniós harmonizáció ezért ezen a területen változatosabb eredményhez, többfajta megoldási kísérlethez vezetett, mint például a magáncélú másolatokra tekintettel fizetett díjak esetében. Ezt egyébként maga az irányelv is elismeri annak kimondásával, hogy a

\footnotetext{
${ }^{1024}$ Bérlet-irányelv 5. cikk.

${ }^{1025}$ LEBOIS, Audrey: Droits patrimoniaux - Droit de location et de prêt, J. Cl. Propriété littéraire et artistique, Fasc. 1254. 52. pont.

1026 Más mütípusok esetében ennek megfelelően továbbra is a haszonkölcsönzési jogra vonatkozó kizárólagos jog főszabálya az irányadó.
} 
díjazás mértékéről a tagállamok szabadon, kultúrpolitikai céljaiknak megfelelően dönthetnek. ${ }^{1027}$

A Bérlet-irányelv - figyelembe véve a fent kifejtett kulturális szempontokat is - lehetővé teszi, hogy a tagállamok ne kizárólagos jogként állapítsák meg a haszonkölcsönzés jogát. Az irányelv 6. cikk (1) bekezdése akként fogalmaz, hogy a tagállamoknak lehetőségük van kivételeket megállapítani a haszonkölcsönzési jog alól, amennyiben a szerzők díjazásban részesülnek. Álláspontunk szerint, amennyiben a tagállamok a kizárólagos jog megtartása mellett döntetnének, az magában foglalná a közös jogkezelés bevezetését is, legalábbis azon müfajták esetében, amelyeket hagyományosan így is haszonkölcsönzés körében kezelnek. Az egyéni engedélyezési jog gyakorlása ugyanis aránytalan teherrel járna, ráadásul nehezen megvalósítható lenne a könyvtári állományban őrzött müvek változatos jogi helyzete miatt - hasonlóan ahhoz a problémakörhöz, amelyet egyébként a könyvtári könyvdigitalizálás körében figyelhetünk meg. A könyvtárak zavartalan müködéséhez viszont elengedhetetlen, hogy felhasználási jogokat szerezzenek, ennek a tömeges engedélyadási módnak egy másik lehetséges megoldása a kényszerengedélyek bevezetése lenne. Ez viszont szerzői jogtól idegen természete miatt kerülendő megoldás. Támogatandónak ítéljük meg tehát azon tagállami álláspontokat, amelyek élve az irányelvben biztosított lehetőséggel, díjigényként határozzák meg a haszonkölcsönzési jogot. ${ }^{1028}$

A magyar szerzői jog a nyilvános haszonkölcsönzés jogát két irányból korlátozza. Az egyik irány a könyvtárközi kölcsönzés esetében megvalósuló szabad felhasználás, amellyel azt éri el a jogalkotó, hogy a Bérlet irányelv (10) preambulumbekezdésében meghatározott módon erre a felhasználási formára semmi esetre se terjedjen ki a kizárólagos jog. ${ }^{1029}$ A könyvtárközi kölcsönzés az 1997. évi CXL. törvény 1 . sz. mellékletének $\mathrm{n}$ ) pontja értelmében valamely dokumentum szolgáltatása egyik könyvtárból a másikba, beleértve az eredeti dokumentum kölcsönzését, a másolatok szolgáltatását, valamint a könyvtárközi dokumentumszolgáltatásra vonatkozó kérések közvetitését is. A szakasz a könyvtárak (a

\footnotetext{
${ }^{1027}$ Bérlet iránelv 6. cikk (1) bek.

1028 A tagállamok többsége kötelező közös jogkezeléshez kötött díjigényként határozta meg a haszonkölcsönzés jogát, amelyet többnyire az adófizetők pénzéből, állami támogatás formájában finanszíroz. KIKKIS (2014) p. 463.

${ }^{1029}$ GYERTYÁNFY (2014) p. 193.
} 
III. rész A törvény által elöírt közös jogkezelés, mint a joggyakorlás módja II. fejezet Közös jogkezelés a hatékonyság szolgálatában

törvény nem él szükítéssel, tehát nem csak a nyilvános szolgáltatást nyújtó könyvtárak vagy az országos szakkönyvtárak tartozhatnak ide) számára biztosít szabad felhasználási lehetőséget. Ennek értelmében a szabad felhasználás ${ }^{1030}$ keretében létrejött dologi példányok terjeszthetőek könyvtárközi kölcsönzés keretén belül. ${ }^{1031}$

A másik, ennél sokkal fontosabb korlátozása a kizárólagos jognak az országos szakkönyvtárak javára beiktatott szabad felhasználási eset. ${ }^{1032}$ A törvény 2003-as módosításakor a szabad felhasználást a nyilvános szolgáltatásokat nyújtó könyvtárak javára változtatták (amely nem egyezik meg a nyilvános könyvtár fentebb meghatározott fogalmával). Figyelemmel az irányelv harmonizációs céljára, illetve az Európai Unió Bíróságának esetjogára, 2009-ben ismét módosításra kerül a rendelkezés, ekkor nyerte el a jelenleg hatályos formáját. Az Szjt. tehát jelenleg az országos szakkönyvtárak részére biztosítja a szabad felhasználást. ${ }^{1033} \mathrm{Ez}$ viszont nem ingyenes felhasználás, ami egyébként következik az irányelv rendelkezéseiből is. Az Szjt. 23/A. §-a díjazás megfizetését rendeli el, a Bérlet-irányelv rendelkezésének megfelelően.

A CPI a kivételek általános megfogalmazásához ${ }^{1034}$ hasonló fordulattal élve vezeti be a haszonkölcsönzési jog korlátozását. Arról rendelkezik ugyanis, hogy a szerző nem tiltakozhat művének ilyen felhasználása ellen. A törvény érdekessége, hogy explicit módon a haszonkölcsönzési jogot, mint kizárólagos jogot nem tartalmazza, ennek fennállására a negatívból való következtetés elvének alkalmazásával juthatunk

${ }^{1030}$ Szjt. 35. § (4) bek. „Nyilvános szolgáltatásokat nyújtó könyvtár, iskolai oktatás célját szolgáló [33. § (4) bek.] intézmény, muzeális intézmény, levéltár, valamint a közgyüjteménynek minősülö kép-, illetve hangarchívum a müröl másolatot készithet, ha az jövedelemszerzés vagy jövedelemfokozás célját közvetve sem szolgálja, és

a) tudományos kutatáshoz vagy archiváláshoz szükséges,

b) nyilvános könyvtári ellátás vagy a 38. § (5) bekezdésében meghatározott felhasználás céljára készül,

c) megjelent mü kisebb részéröl, illetve újság-vagy folyóiratcikkröl belső intézményi célra készül, vagy

d) külön törvény azt kivételes esetben, meghatározott feltételekkel megengedi."

${ }^{1031}$, GYERTYÁNFY (2014) p. 272.

${ }^{1032}$ Szjt. 39. §,Az országos szakkönyvtárak a mü egyes példányait szabadon haszonkölcsönbe adhatják. Ez a rendelkezés nem vonatkozik a szoftverre és a számitástechnikai eszközökkel müködtetett adatbázisra."

${ }^{1033}$ Az országos szakkönyvtárak felsorolását a az 1997. éci CXL. törvény 3. sz. melléklete tartalmazza. Ilyen intézménynek minősül az alábbi tizenegy intézmény: Budapesti Müszaki Egyetem Országos Müszaki Információs Központ és Könyvtár, az Országos Egészségtudományi Szakkönyvtár, a Magyar Tudományos Akadémia Könyvtára, a Magyar Mezőgazdasági Múzeum és Könyvtár, az Országgyűlési Könyvtár, az Országos Idegen nyelvű Könyvtár, az Oktatáskutató és Fejlesztő Intézet Pedagógiai Könyvtár és Múzeum, a Fővárosi Szabó Ervin Könyvtár, a Központi Statisztikai Hivatal Könyvtár, a Magyar Nemzeti Digitális Archívum és Filmintézet Könyvtára, a HM Hadtörténeti Intézet és Múzeum Hadtörténeti Könyvtár.

${ }^{1034}$ CPI L.122-5. cikk. 
III. rész A törvény által elöírt közös jogkezelés, mint a joggyakorlás módja II. fejezet Közös jogkezelés a hatékonyság szolgálatában

el. ${ }^{1035}$ Ráadásul a szöveg megfogalmazása arra is utalhat, hogy a törvény kényszerengedélyként vezette be a haszonkölcsönzési jogot. Ez viszont nem áll fenn, hiszen a könyvtáraknak nem kell a felhasználáshoz előzetesen engedélyt kérni sem a közös jogkezelő szervezettől, sem pedig a jogosultaktól.

Más jellegü korlátot jelent a hangfelvételben foglalt müvek és a filmalkotások szerzői tekintetében felállított közös jogkezelés. ${ }^{1036}$ Az Szjt. ezekre az esetekre nem írja elő a szabad felhasználás bevezetését, tehát a kizárólagos jog érintetlen marad. Ezzel szemben viszont a szerzők e jogukat csak közös jogkezelés útján gyakorolhatják. ${ }^{1037}$

\section{b) A bérleti jog korlátozása}

A közös jogkezelés szempontjából a bérleti jog korlátozásának, illetve korlátozhatóságának nincsen jelentősége. Mint utaltunk rá, a szerzőket a bérleti jog gyakorlásának átengedése vagy átruházása esetén megillető díjigény nem a kizárólagos jog díjigénnyé való csökkentésének tekinthető (mint a magáncélú másolatra tekintettel fizetett díj). Sokkal inkább egy kiegészítő garancia biztosítása a szerző gyengébb tárgyalási pozíciójára tekintettel.

\section{§2. A jog gyakorlásának módjai}

A közös jogkezelő szervezetek szerepe korlátozottan érvényesül a díj megállapítása során [A) pont], így voltaképpen közvetítő, adminisztrátori szerepet töltenek be a díjak beszedésénél és felosztásánál [B) pont].

\section{A) A dij megállapítása}

A díj megállapítása a könyvtári haszonkölcsönzési díjigény körében Magyarországon költségvetési törvényben, Franciaországban pedig a CPI-ben történik,

\footnotetext{
${ }^{1035}$ Vagyis ebben az esetben is felvetődhet az irányelv nem megfelelő átültetésének problémája. Úgy tünik ugyanis, hogy a francia jogalkotó nem implementálta a Bérlet-irányelv kizárólagos jogot biztosító 1 . cikk (1) bekezdését. RENEAUD (2004) p. 71.

${ }^{1036}$ Szjt. 23. § (3) bek. „A terjesztés joga kiterjed a mü egyes példányainak a nyilvánosság részére történő haszonkölcsönbe adására is. A hangfelvételben foglalt müvek szerzöi e jogukat a 78. § (2) bekezdésének megfelelöen gyakorolhatják. A filmalkotások szerzöi e jogukat szintén csak közös jogkezelés útján gyakorolhatják, dijukról csak a felosztás idöpontját követö hatállyal, a rájuk jutó összeg erejéig mondhatnak le."

${ }^{1037}$ A vezetékes továbbközvetítési jog körében elmondottak, mivel lényeges különbség nem található a jog gyakorlásának módjában, itt is érvényesek. Azzal a megszorítással, hogy a közös jogkezelés tárgya természetszerüleg a hangfelvételbe foglalt müvek, valamint a filmalkotások szerzőit megillető haszonkölcsönzési jog gyakorlása.
} 
ami a közös jogkezelő szervezetek díj megállapításában játszott szerepének jelentős csökkenésével jár [a) pont]. Ez pedig, a haszonkölcsönzési jog szerepével összevetve megkérdőjelezéséhez vezet, hogy a felhasználásra tekintettel fizetett díj lényegét tekintve szerzői jogi díjnak tekinthető-e [b) pont].

\section{a) A dij megállapitásának általános szempontjai}

A magáncélú másolat kapcsán ismertetett dilemmánál is kényesebb kérdést vet fel, hogy a haszonkölcsönzés tekintetében fizetendő díj kit terheljen. A szerzői jogilag releváns cselekményt ugyanis a könyvtár végzi, a Bérlet-irányelv meghatározásának megfelelően az intézmény az, amely időlegesen használatba adja az állományában megtalálható szerzői műveket. Ezek viszont gyakran állami fenntartású szervezetek, amelyek a költségvetésükböl nehezen tudják kigazdálkodni a díj megfizetését. A problémára adott válaszként felmerülhet a díj továbbhárítása az olvasóközönségre, mint ahogyan ez a magáncélú másolat esetében is történik. Ez azonban egyrészt nem felelne meg a könyvtári müködés alapelveinek, másrészt vélhetően a haszonkölcsönzés ingyenességét is sértené, emiatt az irányelvbe ütköző megoldás lenne. Christophe ALLEAUME ezzel ellentétes véleményt képvisel. Ö ugyanis megjegyzi, hogy egyrészt a haszonkölcsönzési szerződés ingyenessége nem jelent abszolút ingyenességet (erre utal az éves beiratkozási díj is), továbbá ez nem a haszonkölcsönzési szerződés részét képező díj lenne, hiszen nem a könyvtár, hanem a szerződésen kívüli harmadik fél, vagyis a szerző a jogosultja. Mindebből pedig a jogtudós szerint az következik, hogy a felhasználás nem válna visszterhessé. ${ }^{1038}$

A Bérlet-irányelv 2003-ban történt implementációját megelőzően Franciaországban felvetődött olyan javaslat is, amely eredetileg az olvasókra kívánta telepíteni a díjfizetési kötelezettséget. A szerény mértékü átalánydíj felosztását a javaslat a szerzők és a kiadók között 70-30\% arányban kívánta rendezni. Ez a javaslat (értelemszerűen) politikai okok miatt került elutasításra. Szerzői jogi szempontból sem feltétlenül lenne védhető, mivel a felhasználási cselekményt a könyvtárak valósítják meg a müvek haszonkölcsönbe adásával, nem pedig az olvasók a haszonkölcsönbe vétellel.

${ }^{1038}$ ALLEAUME (2001) p. 48 
A harmadik megoldási kísérlet, ha az állam eleve költségvetési támogatásként átvállalja a díj megfizetését. Így végső soron a nyilvános haszonkölcsönzésre tekintettel fizetett díj egy szerzői jogi köntösbe bújtatott állami támogatási rendszerré válik. Ez annak fényében különösen jelentős, hogy a díjak egy része szociális vagy kulturális alapon osztható fel - legalábbis a francia törvény ilyen szempontokat is figyelembe vesz a felosztási kulcsok meghatározásánál. Előnye abban rejlik, hogy a támogatás mértéke általában objektív alapokon nyugszik. ${ }^{1039}$ Hátránya viszont, hogy a költségvetési források szűkössége miatt a kompenzáció mértéke jelképes is lehet. ${ }^{1040}$

A díj kapcsán az irányelv nem rendelkezik arról, hogy annak megfelelőnek, vagy arányosnak kell-e lennie, pusztán a díjfizetési kötelezettség bevezetését írja elő. Ebböl az is következhet, hogy a tagállamok kiüresíthetik a haszonkölcsönzési jogot oly módon, hogy mindössze jelképes összegü díjat állapítanak meg. Másrészt pedig a szerzőkön kívüli többi jogosult az irányelv szoros értelmezése alapján nem részesülhet a díjazásban. Egyes vélemények szerint ez diszkriminatív a többi jogosulttal szemben, ${ }^{1041}$ azonban az nem következik egyenesen az irányelv szövegéböl, hogy a tagállamok ne biztosíthatnának díjazást a többi jogosult részére is. Ebből a megfogalmazásból egyébként egy ellentétes előjelü következtetés is levonható lenne: nevezetesen az, hogy az uniós jogalkotó azt szerette volna kifejezni, ha ez a díjazás a szerzőket megillető elidegeníthetetlen jogosultság lenne. Ezt az érvelést gyengíti, hogy ahol ez volt a jogalkotó szándéka, ott kifejezetten rendelkezett a díjazáshoz való jog elidegeníthetetlenségéről, ahogyan azt tette például a bérbeadásra tekintettel a szerzőnél maradó jog esetében. ${ }^{1042}$

Az irányelv pontosabb rendelkezéseinek hiányában a Bíróság jogértelmező tevékenységét kell figyelembe venni. Ez pedig a magáncélú többszörözésre tekintettel fizetett díjakhoz hasonlította a könyvtári haszonkölcsönzési díjakat. ${ }^{1043}$ Ez a párhuzam

\footnotetext{
${ }^{1039}$ Az objektív kritérium alapulvétele nem feltétlenül jelenti a támogatási rendszer ,igazságosságát”. Bár az Európai Unióban a diszkrimináció tilalmának alapelvként kell érvényesülnie, föként a skandináv országokban (volt) jellemző a díjnak a csak hazai szerzők kölcsönzési adatainak megállapítása utáni kifizetése.

${ }^{1040}$ Fabrice RENEAUD álláspontja szerint egyébként a közös jogkezelést éppen a beszedendő díjak szerény mértéke igazolja. RENEAUD (2004) p. 85.

${ }_{1041}^{1041}$ COMTE (1993) p. 37-39.

${ }^{1042}$ Nem szabad azonban azt sem elfelejteni, hogy az üres hordozó díjak esetében a jogalkotó nem rendelkezett a dijak átruházhatatlanságáról, azt a Bíróság mondta ki az InfoSoc-irányelvet értelmezve. ${ }^{1043}$ A C-271/10. sz. Vereniging van Educatieve en Wetenschappelijke Auteurs (VEWA) c/ Belgische Staat ügyben 2011. június 30-án hozott ítélet 29. pontja.
} 
egyben azt is jelenti, hogy a Padawan-ügyben (és ezt követö ügyekben) elmondottak mutatis mutandis alkalmazandóak a könyvtári haszonkölcsönzés esetében bevezetett díjakra is. ${ }^{1044}$ Vagyis egyrészt megállapítható, hogy a díj bevezetésének indoka ebben az esetben is a jogosultak számára okozott hátrány. Másrészt ebből álláspontunk szerint az is következik, hogy megállapításánál indokolt a hátrányhoz igazodó valamilyen méltányossági, arányossági kritérium bevezetése. Arra egyébként maga az EuB is utalt, hogy mivel a díj nem a kereskedelmi felhasználások körében kerül bevezetésre, nem lehet egyenlőségjelet tenni közé és a SENA-ügyben ${ }^{1045}$ vizsgált méltányos díjazás (rémunération équitable) közé. Ez egyben arra is utal, hogy a díjazás mértéke alacsonyabb lehet ennél a díjnál, nem lehet viszont szimbolikus összegü. A pontos mérték meghatározásának nehézségei miatt a Bíróság jóváhagyta az átalánydíjak alkalmazását a könyvtári haszonkölcsönzés esetében. ${ }^{1046}$

\section{b) A dijj megállapításának konkrét módozatai}

A díjat az Szjt. szerint a közös jogkezelő szervezet az évenként megállapított jogdíjközleményében, a kultúráért felelős miniszter által felügyelt költségvetési fejezetben külön törvényi soron meghatározott összeg keretén belül állapítja meg. ${ }^{1047}$ A jogdíjközlemények jóváhagyásának rendje miatt (azt az igazságügyért felelős miniszter végzi) az a faramuci helyzet áll elő, hogy a közlemény jóváhagyását végző, illetve a jogdíjak megfizetésére kötelezett személy végső soron azonos lesz (az állam). ${ }^{1048}$

Franciaországban különbséget kell tenni a szerint, hogy a felhasználás a haszonkölcsönzési jog megállapításáról szóló 2003. évi törvény szerint történik-e, ${ }^{1049}$ hiszen ezek azok a felhasználások, amelyek a díjfizetés alapját képezik. A bevezetett rendszer egyébként egy komplex, két pilléren nyugvó kompenzációt ír elő. Az első pillér az állam által fizetett rész, amely egy átalánydíj. ${ }^{1050}$ Mértékét nem a haszonkölcsönzések száma, hanem a könyvtárba beiratkozott olvasók száma alapján határozzák meg. A díjazás kalkulálásának tekintetében az egyetemi könyvtárakat és az

\footnotetext{
${ }^{1044}$ CARON (2011a) 4. pont.

1045 A C-245/00. SENA-ügyben 2003. február 6-án hozott itélet.

1046 A C-271/10. sz. Vereniging van Educatieve en Wetenschappelijke Auteurs (VEWA) c/ Belgische Staat ügyben 2011. június 30-án hozott ítélet 33. pontja.

1047 Szjt. 23/A. $§(2)$ bek.

1048 GONDOL (2009) p. 74

1049 A törvény rövid kommentárját lásd: BELLIVIER (2003) p. 558.

${ }^{1050}$ CPI L. 133-3. cikk.
} 
egyéb területi könyvtárakat kell figyelembe venni. Az iskolai könyvtárak viszont ebbe a körbe nem számítanak bele. Illetve az összes többi, a törvény által a haszonkölcsönzésre tekintettel fizetett díj mértékének meghatározásába beszámító könyvtár olvasóinak számát a területi könyvtárakba beiratkozott olvasók 4\%-ában kell megállapítani. Az állam a szolgáltatott adatok alapján beiratkozott olvasónként 1,50 euró összeget térít meg a jogosultaknak (egyetemi könyvtár esetén ez az összeg 1 euró). Ez a rész tekinthető a törvényi engedély ,árának”, ${ }^{1051}$ vagyis annak a kompenzálásának, hogy a jogosultak elveszítették engedélyezési jogukat.

A második pillér célja a művek konkrét felhasználásonkénti kompenzációja, ${ }^{1052}$ azonban ez sem a kölcsönzési adatokon alapszik. A jogalkotó egyszerüsíteni kívánta a jogdíj beszedésének módját, azzal hogy nem tett különbséget a kölcsönzés céljára vásárolt és a helyben használt könyvek között, hanem általánosan a beszerzésekhez kötötte a díjfizetést. Ezzel viszont elmosta a díjazás eredeti célját, nevezetesen azt, hogy a haszonkölcsönzést hivatott kompenzálni a díjfizetés. ${ }^{1053}$ Vagyis a felállított vélelem alapján minden könyvvásárlás egyben a kölcsönbeadás lehetőségét is magában hordozza. A díjnak ezt a részét a könyvtárak által vásárolt könyvek nettó árának 6\%-a adja, amelyet viszont nem a könyvtáraknak, hanem az azokat ellátó könyvkereskedéseknek kell megfizetniük. A rendelkezés némileg ellentmondásos módon éppen a könyvtárakat hozza nehezebb helyzetbe. Míg a törvény hatályba lépése előtt jelentős kedvezményeket kaptak a könyvek árából, addig a törvénymódosítás ezt 9\%-ban maximalizálta. ${ }^{1054}$ Más szóval a könyvtáraknak a haszonkölcsönzési díj bevezetése miatt többet kell a beszerzésekre költeniük (és valószínűleg kevesebb könyvet tudnak vásárolni), amely viszont így veszélyezteti a közfeladataik ellátását is.

Ebben a helyzetben is felvetődik a díj áthárításának kérdése. Vagyis hogy a könyvkereskedések a díjfizetés közvetlen kötelezettjei, vagy mint az üreshordozó díjak tekintetében, csak közvetett kötelezettnek tekinthetőek? Christophe ALLEAUME álláspontja szerint az első értelmezést elfogadva közvetlen kötelezettnek kell tekinteni a

1051 AllaUme (2014) p. 724.

1052 ALLAUME (2014) p. 724.

1053 RENEAUD (2004) p. 95.

${ }^{1054} \mathrm{Ez}$ egyben azt is jelenti, hogy a könyv árának meghatározásáról szóló törvényt módosítani kellett annak érdekében, hogy a nagyobb, tőkeerős könyvesboltok ne tudjanak nagyobb kedvezményeket biztosítani a könyvtáraknak, kiszorítva ezzel a kisebb kereskedéseket a biztos piacot jelentő könyvtári beszerzésekből. 
könyvkereskedéseket. ${ }^{1055} \mathrm{Ez}$ az értelmezés felel meg jobban annak az elképzelésnek, hogy a könyvtárak költségvetését a lehető legkisebb mértékben terhelje az újonnan bevezetett szabályozás. Hiszen, mint láttuk, a díjfizetés puszta léte hátrányos a könyvtárakra nézve.

\section{B) A dijj beszedése és felosztása}

Sem a haszonkölcsönzési, sem a bérleti jog átengedésére tekintettel fennmaradó díj beszedésével és felosztásával kapcsolatban sem tartalmaz a Bérletirányelv konkrét rendelkezéseket. A bérleti jog átengedésére tekintettel fennmaradó díjigényről a (13) preambulumbekezdés annyit határoz meg, hogy a méltányos díj egy összegben vagy részletekben, a szerződés megkötésekor vagy azt követően bármikor kifizethető. A díjazás felosztása kapcsán ezért érvényesül ugyanaz a két elv, amely a magáncélú másolatra tekintettel fizetett díjak esetében is megfigyelhetünk. Egyrészröl a közös jogkezelő szervezetek a felhasználásokkal valamilyen mértékben arányosítva igyekszenek a jogosultaknak juttatni a díjazásból [a) pont]. Ezen kívül a díjak felosztása kapcsán megjelenhetnek szociális és kulturális szempontok is [b) pont].

\section{a) A klasszikus felosztási séma}

A felállított rendszer alapján 2011-től kezdődően a közös jogkezelő szervezetminden évben adatszolgáltatásra kér fel legfeljebb 20, nyilvános haszonkölcsönzést végző könyvtárat. E könyvtárak között kell lennie egy fővárosi önkormányzat által fenntartott közkönyvtárnak, legalább két megyei, három városi, két községi és két egyetemi könyvtárnak. ${ }^{1056}$ A kölcsönzött könyvek és kották alapvető azonosító adatain ${ }^{1057}$ túl ennek az adatszolgáltatásnak tartalmaznia kell a kölcsönzések számát is, ${ }^{1058}$ mivel a díj felosztásának alapja a kölcsönbeadások száma. ${ }^{1059} \mathrm{Az}$ irodalmi müvek nyilvános haszonkölcsönzésére a MISZJE, a kottában rögzített mủvek nyilvános haszonkölcsönzésére pedig az ARTISJUS és a MISZJE van nyilvántartásba véve.

\footnotetext{
1055 Allaume (2014) p. 724.

${ }^{1056} 14 / 2011$. (IV.7.) NEFMI rendelet a nyilvános haszonkölcsönzésért a szerzőt megillető díj megállapításához és felosztásához szükséges adatokról, valamint az adatszolgáltatásra kötelezett nyilvános könyvtárakról, 3 . § (2) bek.

1057 Ezek az adatok a mü címe, szerzőségi adatai, megjelenésének helye, kiadójának neve, megjelenésének éve, ha van, akkor a nemzetközi azonosító száma.

1058 14/2011. (IV.7.) NEFMI rendelet 2. §.

1059 Szjt. 23/A. $§(5)$ bek.
} 
Első ízben tehát 2012-ben kerültek a nyilvános haszonkölcsönzésre tekintettel fizetett díjak felosztásra. A 2015. évre a költségvetési törvényben a haszonkölcsönzési díj címén 79.200.000,- Ft lett elkülönítve a jogosultak javára, ez képezi tehát a felosztható díj alapját. ${ }^{1060}$

A Sofia nyilvántartása alapján 2007-ben több, mint 350.000 könyv tartozott a közös jogkezelés alá. Annak érdekében, hogy az egyes könyvek esetében a kezelési költségek ne haladják meg a kifizetendő díj mértékét, a közös jogkezelő társaság közgyülése úgy határozott, hogy a 15 eurót el nem érő összegeket elkülönített számlán tartja egészen addig, amíg a könyvvásárlások alapján befizetett díj mértéke el nem éri ezt az összeget. Ekkor kerül átutalásra a jogosultaknak. ${ }^{1061}$

Bár a francia törvény nem tartalmaz erre vonatkozó rendelkezéseket, viszont egyértelműnek tünik az, hogy a szerző nem mondhat le az őt megillető díjról. Ez egyben azt is jelenti, hogy azok a szerződések, amelyek a haszonkölcsönzési jog átruházásáról szóltak, semmisek. Ez összefügg azzal, hogy a haszonkölcsönzési jogra tekintettel bevezetett díjat szintén a szerzők érdekében és az ő javukra állapították meg. Ezzel a céllal pedig ellentétes lenne az átruházhatóság megengedése. A kérdés különösen annak fényében érdekes, hogy a kiadói szerződésekben általában a szerzők a bármilyen módon történő hasznosítás jogát (ideértve a haszonkölcsönt is) átruházzák a kiadókra. ${ }^{1062}$

\section{b) A felosztás során érvényesülö szociális és kulturális szempontok}

A díjazás szociális, illetve kulturális jellegét erősíti a Franciaországban alkalmazott felosztási kulcs is. Másik oldalról megközelítve éppen ez az egyik olyan indok, amely miatt megkérdőjelezhető a díj szerzői jogi jellege. ${ }^{1063}$

A CPI szerint a díjazás egyik fele egyenlő részben kerül felosztásra a szerzők és a kiadók között a könyvtárak számára értékesített éves eladott példányszám alapján. A második rész pedig, amely nem haladhatja meg a teljes díjazás mértékének a felét,

\footnotetext{
${ }^{1060}$ Magyarország 2015. évi központi költségvetéséről szóló 2014. évi C. tv. 1. sz. melléklete XX. Emberi Erőforrások Minisztériuma fejezet 20/13/9. jogcímcsoporton „Könyvtárközi kölcsönzési jogdíjak” elnevezés.

${ }^{1061}$ PIRIOU (2008) p. 239.

1062 PIERRAT (2000) p. 79.

${ }^{1063}$ CARON (2013a) p. 278.
} 
pedig azok között a szerzők között kerül felosztásra, akik egyébként nem részesülnek kiegészítő öregségi nyugdíjban. ${ }^{1064}$

A kiadók díjból való részesedése hasonló a magáncélú másolatra tekintettel fizetett díjakéhoz. Kritikával illethető e gyakorlat, hiszen ők alapvetően nem kapcsolódó jogi jogosultak, és a kódex sem pontosítja, hogy milyen jogcímen kell a díjból részesülniük. ${ }^{1065}$ Másrészről viszont a jogalkotó egy eddig elhanyagolt jogosulti csoportot kívánt támogatni a nyugdíj bevezetésével, a törekvés tehát jelentős elörelépésként értékelendő. ${ }^{1066}$ Különösen azzal összefüggésben, hogy a magáncélú másolatra tekintettel fizetett díjak esetében a jogalkotó csak azok kulturális célú felhasználásáról rendelkezik, a szociális szempontok mellőzésre kerültek.

\section{A droit de suite}

A követő jogra vonatkozó szabályok Franciaországban 1920-ban kerültek bevezetésre. ${ }^{1067}$ A követőjog bevezetésének közvetlen oka egy nagy visszhangot kapott eset: egy MiLlET-kép ${ }^{1068}$ arcátlanul magas áron kelt el, miközben a festő örököse nyomorgott. $^{1069}$ A jogintézmény lényege tehát annak felismerésében áll, hogy a képzőművészeti alkotások általában a müvész halálát követően értékelődnek fel. Könnyen elképzelhető, hogy az a mü, amelyet a festő életében aprópénzért adott el, később vagyonokat ér, viszont a követő jog hiányában a szerző jogutódai nem profitálhatnának ebböl az értéknövekedésböl. Bevezetése azt jelenti, hogy a képzőművészeti alkotások továbbértékesítése esetén díjazás illeti meg a jogosultat

\footnotetext{
${ }^{1064}$ CPI L. 133-4. cikk: „La rémunération au titre du prêt en bibliothèque est répartie dans les conditions suivantes:

$1^{\circ}$ Une première part est répartie à parts égales entre les auteurs et leurs éditeurs à raison du nombre d'exemplaires des livres achetés chaque année, pour leurs bibliothèques accueillant du public pour le prêt, par les personnes morales mentionnées au troisième alinéa $\left(2^{\circ}\right)$ de l'article 3 de la loi $n^{\circ} 81-766$ du 10 août 1981 précitée, déterminé sur la base des informations que ces personnes et leurs fournisseurs communiquent à la ou aux sociétés mentionnées à l'article L. 133-2_;

$2^{\circ}$ Une seconde part, qui ne peut excéder la moitié du total, est affectée à la prise en charge d'une fraction des cotisations dues au titre de la retraite complémentaire par les personnes visées aux troisième et quatrième alinéas de l'article L. 382-12 du code de la sécurité sociale."

${ }^{1065}$ LUCAS - LUCAS - LUCAS-SCHLOETTER (2012) p. 277.

1066 PIRIOU (2003) p. 92.

${ }^{1067}$ Loi du 20 mai 1920 frappant d'un droit au profit des artistes les ventes publiques d'objet d'art. A törvény részletes (összehasonlító) jogi elemzéséről lásd: DUCHEMIN (1948).

1068 Jean-François MILLET (1814-1875) a francia realista festőiskola egyik kiemelkedő alakja volt.

${ }^{1069}$ CARON (2013a) p. 270.
} 
(tipikusan a szerző jogutódját). ${ }^{1070} \mathrm{Ez}$ a körülmény azért is fontos, mivel a képzőmüvészeti alkotások jogosultjait is megilleti a többszörözés joga, ezeknek az alkotásoknak ez mégsem a tipikus felhasználási módja. ${ }^{1071}$ Természetükből adódóan az ilyen művek esetén a szerző jövedelme gyakorlatilag teljes egészében a mü tulajdonjogának átruházásáért kapott ellenérték. ${ }^{1072}$

A követő jog tehát a szerzői jognak is egy viszonylag kései konstrukciója, amely a nemzetközi egyezményekben, illetve nemzeti szerzői jogokban is a 20. század derekán kerültek elismerésre. A BuE-be az 1948-as brüsszeli felülvizsgálat során iktatták be az erről szóló 14ter cikket, amely a részes felek számára fakultatív jelleggel tette lehetővé a követő jog bevezetését. Magyarországon az 1978. évi 27. törvényerejü rendelet vezette be a jogintézményt. A követö jogból eredő problémák gyökere is összefüggésben áll ezzel a kései bevezetéssel. Mivel a BUE csak fakultatív jelleggel írja elő, így teljes körü harmonizáció nehezen valósulhat meg ezen a téren. ${ }^{1073} \mathrm{Ez}$ csak abban a nem túl valószínű esetben lenne elérhető, ha minden részes fél bevezetné a követő jogot. Az eltérő szabályozás belső piacra gyakorolt torzító hatásának következtében viszont az uniós jogalkotó a Követő jogi irányelv 2001-es elfogadásával a tagállamok számára kötelezővé tette a követő jog bevezetését.

A közös jogkezeléshez kapcsolódó problémák ehhez a kiindulási helyzethez képest marginálisnak tünhetnek. Ez a miatt is igaz lehet, mivel a képzőmüvészet terén, tekintettel arra, hogy a müvek tömeges felhasználása azok tulajdonságainál fogva nem jellemző, a közös jogkezelés sem rendelkezik olyan mély hagyományokkal, mint a többi műfajú mü esetében. A Követő jogi irányelv sem teszi kötelezővé a közös jogkezelés előírását, csak lehetőséget biztosít a tagállamok számára ennek bevezetésére, annak ellenére, hogy a közös jogkezelők bevonása egyébként a szerzők érdekeinek figyelembe vétele miatt kívánatos. ${ }^{1074}$ A területen a közös jogkezelés megerősítésének igényét szintén a digitális technológia elterjedésének köszönhetjük, az online felhasználások a képzőművészet területén is egyre jelentősebbé válik. A felhasználások

\footnotetext{
${ }^{1070}$ Maga az elnevezés is arra utal, hogy a szerző „nyomonköveti” művének sorsát, így részesül annak értéknövekedéséből. A magyar terminológia egyébként a francia kifejezés tükörfordítása.

${ }^{1071}$ DESBOIS (1978) p. 375.

1072 GYERTYÁNFY (2014) p. 422.

1073 GINSBURG - RICKETSON (2006) p. 676

${ }^{1074}$ VON LEWINSKI - WALTER (2010) p. 871.
} 
nyomonkövethetőségének általános problémájával összefüggésben pedig az önkéntes közös jogkezelés is egyre nagyobb szerepet kap ezen a területen is. ${ }^{1075}$

Magyarországon a díjigény kötelező közös jogkezelés alá tartozik. Franciaország pedig, bár nem élt ezzel az eszközzel, a gyakorlatban mégis jelentős szerephez jut ez a típusú joggyakorlási mód. Elemzését önkéntes jellege ellenére az uniós harmonizáció miatt tartjuk indokoltnak, hiszen így lehetőségünk van rámutatni az ebből eredő hiányosságokra. A közös jogkezelés ismertetését [§2. pont] a követő jog, mint vagyoni jog jellemzőinek elemzését követően végezzük el [§1.pont].

\section{§1. A követö jog tartalma}

A követő jog tartalmának meghatározásakor mindenekelőtt ismertetni kell annak természetét, hiszen más felfogást tükröz ezzel kapcsolatban a terjesztés jogát ismerő magyar, és a rendelkezési jog koncepciójával operáló francia szerzői jog. Ráadásul a nemzetközi szintű harmonizáció hiányából is fontos nemzetközi magánjogi problémák következnek [A) pont]. Ezt követően lehet rátérni a követő jog egyes fogalmi elemeinek meghatározására [B) pont].

\section{A) A követö jog természete}

A követő jog természete kapcsán mindenekelőtt érdemes felvillantani a BUEban részlegesen megvalósított harmonizációból eredő nemzetközi magánjogi kérdéseket [a) pont]. Ezek után pedig a követő jog rendszertani elhelyezését kell megvilágítani [b) pont].

a) A részleges harmonizációból eredö kérdések

A francia törvény elfogadása után közel harminc évvel a követő jog indokoltságát a BUE is elismerte a brüsszeli felülvizsgálat során, 1948-ban. Speciális rezsim vonatkozik viszont rá, mivel az egyezmény általánosan érvényesülő nemzeti elbánás elvétől eltérően ez esetben az anyagi viszonosság követelményét írja elő. ${ }^{1076}$ Ebből az következik, hogy „a BUE-ban részes ország állampolgára az egyezmény alapján csak abban az esetben tudja érvényesiteni a követö jogi igényét, ha ez mind a

\footnotetext{
1075 VON LEWINSKI (2012) p. 105.

${ }^{1076}$ BUE 14ter cikk (2) bek.
} 
saját, mind az igényérvényesités országában létezik."1077 Ráadásul mivel az egyezmény csak ajánlja a bevezetését, de nem teszi kötelezővé, ebből az is következik, hogy a részes államok opcionális jelleggel vezethetik be a jogrendjükbe a követőjogra vonatkozó szabályokat.

Mivel több EU tagállam is élve a BUE által biztosított opcionális lehetőséggel nem vezette be a követő jogra vonatkozó szabályokat, a BUE-ban biztosított viszonosságra vonatkozó rendelkezés összeütközésbe került az EKSZ állampolgársági alapú diszkriminációt tiltó 12. cikkével (ma: EUMSZ 18. cikk). Az ezt a cikket értelmező Bírósági joggyakorlat ugyanis alapvetően kizárta a viszonosságra hivatkozást a tagállami jogviszonyokban. ${ }^{1078} \mathrm{Ez}$ azt jelentette, hogy azoknak a tagállamoknak, amelyek ismerik a követő jog jogintézményét, más tagállam állampolgárságával rendelkező szerző esetén akkor is biztosítania kellett volna a követő jog általi védelmet, ha az állampolgárság szerinti tagállam egyébként nem vezette be a jogintézményt. Alapvetően ez a körülmény vezetett ahhoz, hogy az Európai Parlament és a Tanács elfogadta a Követő jogi irányelvet, ${ }^{1079}$ amely valamennyi tagállam számára előírta a követő jog bevezetését.

\section{b) A követö jog dogmatikai elhelyezése}

A követő jog természetéről a magyar szerzői jogban BATTA János azt vallotta, hogy az a mü nyilvánossághoz való juttatásának egyik esete, amelyben noha a nyilvánosság korlátozottan érvényesül, de ezt kompenzálja, hogy a nyilvánosság köre kibővül a többszöri eladások során. ${ }^{1080}$ Az Szjt. rendszerében a követő jog a vagyoni jogok része, de nem kizárólagos engedélyezési jogként, hanem díjigényként érvényesíthető. ${ }^{1081}$ Kiegészíti a terjesztési jogot, amelyet a szerző az alkotás első átruházásával gyakorol, majd pedig ezt követően - a terjesztési jog kimerülésére tekintettel - a követő jogot. ${ }^{1082}$

\footnotetext{
1077 GYENGE (2005b) p. 87.

1078 A C-92/92. és C-326/92. sz. egyesített Phil Collins-ügyben 1993. október 20-án hozott ítélet, valamint a C-360/00. sz. Puccini II. ügyben 2002. június 6-án hozott ítélet

${ }^{1079}$ Az Európai Parlament és a Tanács 2001/84/EK irányelve (2001. szeptember 27.) az eredeti műalkotás szerzőjét megillető követő jogról.

${ }^{1080}$ BATTA (1978) p. 997.

1081 GYENGE (2005) p. 88.

1082 GYERTYÁNFY (2014), p. 423.
} 
A francia szakirodalom megosztott a követő jog jogi természetével kapcsolatban, abban azonban egyetértenek, hogy a többi vagyoni jogtól eltérően a követő jog nem biztosít a mü hasznosítására, felhasználására vonatkozó jogot. ${ }^{1083}$ Sőt, azt is hozzáteszik az érveléshez, hogy a követő jog atipikus módon a müvet megtestesítő fizikai dolog, a hordozón fennálló tulajdonjog megváltozásához kapcsolódik.

Az egyik álláspont a droit de suite-nek a többi vagyoni (engedélyezési) joghoz képest eltérő voltát emeli ki. Henri DESBOIS például így fogalmaz a követő jog kapcsán: ez a jogalkotó mesterséges megoldása azért, mert bizonyos mütípusok esetén a többszörözési jog egyáltalán nem, vagy csak jelentősen korlátozott mértékben gyakorolható. A követőjog tehát nem tekinthető a többszörözési és nyilvános előadási jog mellett a szerzői jog harmadik pillérének. ${ }^{1084}$ Ezzel szemben a másik álláspont igyekszik ezt a rendszeren belül elhelyezni. Frédéric POLLAUD-DULIAN például nem ért egyet az éles különbségtétellel, álláspontját leginkább azzal támasztja alá, hogy a követő jog a szerzőt a mű alkotásától kezdődően megilleti (a többi vagyoni joghoz hasonlóan), és csak a díj kifizetését keletkeztető tény az eladás aktusa. ${ }^{1085}$

A követő jog viszont álláspontunk szerint nem értelmezhető kizárólagos engedélyezési jogként, még abban az esetben sem, ha a jogosultak egyénileg gyakorolják. Egyfelől azért, mert az adásvételek megakadályozására az engedélyezési jog gyakorlása által a jogosultaknak a jogkimerülés elve miatt eleve nincsen joga. Másrészt pedig figyelembe kell venni azt is, hogy a követő jogi díjazás mértéke maga is jogszabályban meghatározott. Ennél fogva tehát a vagyoni jogok részét képező díjigényként érdemes a droit de suite-re tekinteni. A követő jog ráadásul, sajátos módon kivétel a kivétel alól. A jogkimerülés a terjesztési jog egyik legfontosabb korlátját képezi, amely alapján ,a szerzői jogosult köteles türni az általa, illetve az ő engedélyével más által jogszerüen, adásvétel útján vagy a tulajdonjog bármely más átruházása révén forgalomba hozott szerzői művek adott műpéldányainak utólagos akár haszonszerzési célú - terjesztését, amennyiben a müpéldány értékesítéséért megfelelő díjazásban részesült."1086 A követő jog pedig, a müpéldányok egyes

\footnotetext{
1083 CARON (2013a) p. 270.

${ }^{1084}$ DESBOIS (1978) p. 377.

1085 POLLAUD-DULIAN (2005) p. 553-554.

${ }^{1086}$ MEZEI (2014c). p. 6-7.
} 
III. rész A törvény által elöírt közös jogkezelés, mint a joggyakorlás módja II. fejezet Közös jogkezelés a hatékonyság szolgálatában

értékesítési aktusaihoz kötődve a díjfizetés bevezetésével ennek a kivételnek a kizárólagosságát töri meg.

\section{B) A követö jog tartalmi elemei}

A követő jog természetének tisztázását követően szót kell ejteni arról, hogy mely elemek teszik azzá a jogintézményt, ami. Ennek kapcsán külön ki kell térni a tárgyi hatályát adó müvek meghatározására [a) pont], illetve a díjfizetés alapját képező átruházások azonosítására [b) pont].

a) A követö jog tárgya

A követő jog tárgya kapcsán két dologra kell kitérni. Egyfelől azoknak az alkotásoknak a meghatározása igényel körültekintést, amelyek után érvényesíthető a követő jogi igény [ $\alpha$ ) pont]. Másrészt pedig szólni kell az ezekkel szemben támasztott plusz feltételről, az eredetiség kritériumáról [ $\beta$ ) pont].

\section{a) A képzömüvészeti alkotások}

A BUE a képzőmüvészeti alkotásokat, illetve a kéziratokra vonatkozóan teszi lehetővé a követő jog bevezetését. ${ }^{1087}$ Azt a BUE kommentárja is elismeri, hogy kéziratok ritkábban képezik ilyen eladások tárgyát, így a követő jognak is lényegesen nagyobb szerepe van a képzőmüvészeti alkotások eladása körében. ${ }^{1088}$ Ennek megfelelően több olyan államban, ahol a követő jog elismerésre került, a kéziratok adásvétele nem képezi a díjfizetés tárgyát. Ezen a téren a Követő jogi irányelv is tudatosan eltért a BUE megfogalmazásától, a (19) preambulumbekezdésben rögzítve azt, hogy a harmonizáció nem vonatkozik az írók és zeneszerzők eredeti kézirataira.

\footnotetext{
${ }^{1087}$ Megjegyzést érdemel, hogy a BUE-t kihirdető 1975. évi 4. törvényerejủ rendelet fordítása a követő jog kapcsán nem pontos. A magyar szöveg „írók és zeneszerzők eredeti müalkotását és eredeti kéziratai” fordulatot tartalmazza a hivatalos francia nyelvü „les æuvvres d'art originales et les manuscrits originaux des écrivains et compositeurs" kifejezés helyett. A tisztán nyelvi értelmezés alapján valóban nem egyértelmü, hogy a birtokos jelző a szerkezet egészére, vagy csak a kéziratokra vonatkozik-e. A cikk célja, az előkészítő szövegek és a kommentár viszont egyértelmüvé teszi, hogy képzőmüvészeti alkotásokról és az írók és zeneszerzők kéziratairól van szó. Nem adja vissza a követő jog lényegét az a fordulat sem, mely szerint a szerzők elidegeníthetetlen joga, hogy „részt vegyenek a mü eladására vonatkozó müveletekben.” Ehhez persze hozzá kell tenni, hogy a magyar fordítás nem minősül a BUE hivatalos szövegének (eredendően az Egyezmény és a felülvizsgálati Szerződések nyelve a francia) a 37. cikk alapján. A különböző szövegek értelmezésére vonatkozó vita esetére pedig a 37. cikk (1) bekezdés c) pontja a francia szöveget jelöli ki irányadóként. Így a szöveg értelmezésénél a magyar szöveget ezekkel a megszorításokkal vettük figyelembe.

${ }^{1088}$ MASOUYÉ (1978) p. 105-106.
} 
Ennek másik indoka a csekély gyakorlati jelentőségen kívül a mü és a hordozója közötti, az irodalmi és zenei művektől eltérő természetü kapcsolat. Míg ez utóbbiaknál szinte mindegy, hogy a mü milyen hordozón testesül meg, az ár ebben az esetben nem a bennük rögzített mủ értékét tükrözi, ${ }^{1089}$ ezzel szemben ez a kapcsolat sokkal erősebb a képzőművészeti alkotások esetében, a hordozó megválasztása ugyanis önmagában is az alkotói szabadság egy elemének tekinthető. A két elem közötti kapcsolat tehát sokkal szorosabb, elválaszthatatlan egységet képez. A kéziratoknak ez a kizárása a követő jog köréből arra a következtetésre is elvezethet, hogy a droit de suite tárgya valójában nem is a mü, hanem az a tárgyiasult forma, az a hordozó, amelyben az alkotás megtestesül. ${ }^{1090}$ Ily módon tehát a követő jogi díj jellegét tekintve párhuzamba állítható az üreshordozó díjakkal, hiszen lényegében ott sem magához a mühöz, hanem az annak többszörözésére használt hordozóhoz kötődik a díjfizetési kötelezettség.

Bár az egyezmény nem tartalmazza a képzőmüvészeti alkotás definícióját, általánosan elfogadott, hogy a rajzok, festmények, szobrok, litográfiák, metszetek tartoznak ebbe a körbe, az építészeti és iparművészeti alkotások viszont nem sorolhatók ide. $^{1091}$

A Követő jogi irányelv ezzel szemben részletes felsorolást tartalmaz, és a BUE-vel ellentétben a képző- és iparmüvészet határmezsgyéjén mozgó alkotásokat is a követő jog hatálya alá tartozónak tekint. Így külön nevesítésre kerül a falikárpit, kerámia és üvegtárgy, mint a követő jog tárgya. Ezek iparmüvészeti alkotásként való minősítése az irányelv hatályának kiterjesztését jelentené: a felsorolás példálózó jellege miatt ugyanis akkor a többi ilyen jellegü alkotás is a követő jog hatálya alá tartozna. Mivel ezt a kérdést nem érinti a harmonizáció, így a tagállamok szabadon dönthetnek arról, hogy az iparművészeti alkotások tekintetében bevezetik-e a követő jogot. A magyar szerzői jogban ez hagyományosan így történik, ennek megfelelően a törvény kifejezetten rögzíti, hogy a követő jogi díj az iparmüvészeti alkotások esetében is megfizetendő. ${ }^{1092}$ Fontos megjegyezni azt is, hogy a fotómüvészeti alkotások újraeladása esetén is alkalmazandó a követő jog. A fotómüvészeti alkotások viszont annyiban elkülönülnek a többi mütípustól, hogy körükben a többszörözés jogának

\footnotetext{
${ }^{1089}$ GYENGE (2005) p. 93.

${ }^{1090}$ COLOMBET (1999) p. 176-177.

${ }^{1091}$ MASOUYÉ (1978) p. 106.

1092 Szjt. 70. § (1) bek.
} 
gyakorlása is sokkal nagyobb szerepet játszik, az alkotóknak nem szükséges csak a követő jogi díjakra hagyatkozniuk, a többszörözés és terjesztés is tágabb körben valósul meg, mint például a festmények, szobrok esetében. A felsorolás példálózó jellege egyébként mind a francia, mind a magyar szerzői jogban összhangban áll a védelem alapvető jellemzőivel, természetével; vagyis azzal, hogy a szerzői müvekről (így a képzőművészeti alkotásokról) nem adható zárt felsorolás, azt az oltalom kritériumainak fennállása szerint esetileg kell értékelni.

A CPI az előzőektől eltérő fogalmakat használ: térbeli és grafikus müként (ceuvres graphiques et plastiques) hivatkozik a követő jog tárgyára. A törvény végrehajtási rendelete pontosította a megfogalmazást átvéve az irányelvben szereplő példálózó felsorolást. ${ }^{1093}$ A jogtudomány is megerősíti, hogy elsősorban a képzőművészet keretébe tartozó alkotások tartoznak ebbe a körbe, de bizonyos esetekben a követő jogi védelem megilleti az iparmüvészeti alkotásokat is. ${ }^{1094}$ Ezek meghatározása a bírói gyakorlat körébe tartozik.

\section{ß) Az eredetiség követelménye}

Minden forrásban megjelenik, hogy a képzőmüvészeti alkotásnak eredetinek kell lennie, ez az eredetiség viszont nem azonos a védelem előfeltételét jelentő eredetiség kritériumával.

1093 CPI R. 122-3. cikk: „Les oeuvres mentionnées à l'article R. 122-1 sont les oeuvres originales graphiques ou plastiques créées par l'auteur lui-même, telles que les tableaux, les collages, les peintures, les dessins, les gravures, les estampes, les lithographies, les sculptures, les tapisseries, les céramiques, les verreries, les photographies et les créations plastiques sur support audiovisuel ou numérique.

Les oeuvres exécutées en nombre limité d'exemplaires et sous la responsabilité de l'auteur sont considérées comme oeuvres d'art originales au sens de l'alinéa précédent si elles sont numérotées ou signées ou dûment autorisées d'une autre manière par l'auteur. Ce sont notamment :

a) Les gravures, estampes et lithographies originales tirées en nombre limité d'une ou plusieurs planches; b) Les éditions de sculpture, dans la limite de douze exemplaires, exemplaires numérotés et épreuves d'artiste confondus;

c) Les tapisseries et oeuvres d'art textile faites à la main, sur la base de modèles originaux fournis par l'artiste, dans la limite de huit exemplaires ;

d) Les émaux entièrement exécutés à la main et comportant la signature de l'artiste, dans la limite de huit exemplaires numérotés et de quatre épreuves d'artiste ;

e) Les oeuvres photographiques signées, dans la limite de trente exemplaires, quels qu'en soient le format et le support;

f) Les créations plastiques sur support audiovisuel ou numérique dans la limite de douze exemplaires."

${ }^{1094}$ CARON (2013a) p. 270 
A BUE-ben ez a sajátos eredetiség a müvész saját keze által alkotott müpéldány(oka)t jelenti. ${ }^{1095}$ A Követő jogi irányelv megengedőbb ebben a kérdésben, és az irányelv átültetése miatt mindkét vizsgált tagállami jog is ezt a szóhasználatot alkalmazza. Eredeti a müalkotás akkor, ha azt maga a szerző készítette, vagy eredeti müalkotásnak minősül, vagyis, ha azt korlátozott példányban a müvész, vagy az ő irányításával mások készítették. ${ }^{1096}$ Az Szjt. ehhez magyarázatként hozzáfüzi, hogy ilyennek tekinthető a sorszámmal, a szerző kézjegyével ellátott, vagy más alkalmas módon a szerző által megjelölt müpéldány. ${ }^{1097}$

A két eredetiségnek kumulatívan kell fennállnia. Vagyis abban az esetben, ha valami oknál fogva a képzőművészeti alkotás nem felel meg a szerzői müvekkel szemben támasztott kritériumoknak, alkotója követő jogi díjra sem tarthat igényt. A szerző által, egy példányban létrehozott alkotások esetén ennek megítélése egyszerü, ugyanis amennyiben a mü megfelel a szerzői jogi oltalom feltételeinek, a követő jogi díj is megilleti. A szerző által készített több müpéldány igényérvényesítési szempontból nem okoz kihívást, dogmatikai szempontból viszont annak elismerését jelenti, hogy több müpéldány is lehet eredeti. Vagyis az alkotófolyamat maga relatív, nem egyszeri, megismételhetetlen cselekményt jelent. ${ }^{1098}$

Problémásabb emiatt annak megítélése, ha a szerző irányításával más készítette a szerzői müvet. A francia bírói gyakorlat ebben a tekintetben RoDIN ${ }^{1099}$ szobrai kapcsán részletes, jelentős esetjog alakult ki. A másodfokú bíróság úgy ítélte meg, hogy nem felelnek meg az eredetiség feltételének azok a bronz szobrok, amelyeket a RoDIN által készített modell alapján öntöttek, de méretei eltérnek mind a művész saját keze által készített szobortól, mind pedig azoktól a „másolatoktól”, amelyeket életében öntöttek ki. ${ }^{1100}$ Ezzel szemben a követő jogi díj érvényesítése tekintetében eredetinek minősülnek azok a müvek, amely a müvész kezei alól kerül ki abban az értelemben,

\footnotetext{
1095 MASOUYÉ (1978) p. 106.

1096 Követő jogi irányelv 1. cikk (1)-(2) bek. Szjt. 70. § (2) bek. CPI L. 122-8. cikk (2) bek.

1097 Szjt. 70. § (2) bek.

${ }^{1098}$ GYENGE (2005) p. 90.

1099 Auguste RoDIN (1840-1917) francia szobrászművész.

${ }^{1100}$ CA Orléans, 8 févr. 1990, RIDA janv. 1991, p. 333, note Gaudel. Cass. 1re civ., 15 novembre 1991: Bull. civ. I, no 303, D. 1992, p. 361, note Edelman et 1993, somm. comm. 89, obs. Colombet
} 
hogy ha azt nem is ő készítette, de az irányítása és felügyelete alatt készült és ilyen formán magán viseli a megalkotója személyiségének lenyomatát. ${ }^{1101}$

\section{b) A követö jog tartalma}

A követő jog tartalmi elemeinek meghatározása kapcsán egyfelől a jogosult meghatározása okozhat problémákat. Ez különösen nemzetközi elemet is magában foglaló átruházások esetén ütközhet nehézségbe a viszonosság elvének alkalmazása miatt $[\alpha)$ pont]. Másrészt pedig pontosításra szorul az is, hogy melyek a követő jogi díjigényt megalapozó átruházások $[\beta)$ pont].

\section{a) A jogosult meghatározása}

A BUE az általános alapelvével ellentétben a követő jog tekintetében a viszonosságot rendeli alkalmazni. Ez azt jelenti, hogy a részes államok szabadon dönthetnek a követő jog bevezetése mellett, vagy elutasíthatják azt. De amennyiben bevezetik, úgy a jogosult csak a védelem igénylésének helye szerinti ország szabályai alapján érvényesítheti erre vonatkozó jogait. ${ }^{1102}$ Nem illeti meg őt tehát a nemzeti elbánás elve. Emiatt a nemzetközi magánjogi kérdések kifejezetten erősen felbukkannak a követő jog tárgyalása során. ${ }^{1103}$

A CPI kifejezetten rögzíti, hogy a követő jog az EU és az EGK honosságú szerzőket illeti meg, harmadik országbelieket Franciaországban pedig csak akkor, ha az a saját szerzőiknek is biztosítja a jogot. ${ }^{1104}$ Az Szjt. az irányelv előírásainak megfelelően harmadik ország állampolgárainak csak akkor biztosítja a követő jogi védelmet, ha a viszonosság az összes EGT-tagállam tekintetében fennáll. Kiegészítő szabályként abban az esetben is biztosítja a védelmet, ha a szerző ugyan nem EGT-tagállam állampolgára, de szokásos tartózkodási helye Magyarországon van. ${ }^{1105}$

A követő jog körében annak jellegénél fogva sokszor előfordul, hogy nem maga a szerző, hanem jogutódként az örökösei részesülnek az adásvételek után járó

\footnotetext{
${ }^{1101}$ Cass. 1re civ., 13 oct. 1993: JCP G 1993, IV, 2628; D. 1994, 138 note Edelman; D. 1994, somm. comm. (sommaire commenté) 93, obs. Colombet, arrêt cassé: Paris, 4e ch 28 janv. 1991, 28 janv. 1991, D. 1992, somm. 17, obs. Colombet.

1102 MASOUYÉ (1978) p. 106.

${ }^{1103}$ A követő jog nemzetközi magánjogi kapcsolóelemeiről lásd például: AZZI (2012) p. 288-294

${ }^{1104}$ CPI L. 122-8. cikk (1) és (5) cikk.

${ }^{1105}$ Szjt. 70. § (12) bek.
} 
díjazásból. Az Európai Unió Bírósága elé került DALÍ-ügy a nemzetközi magánjogi kérdéseken túl emiatt is jelentős. Az EuB ugyanis akként foglalt állás, hogy nem ellentétes a Követő jogi irányelvvel az olyan tagállami rendelkezés, amely a követő jog élvezetét a művész törvényes örökösei javára tartja fenn, a végrendeleti örökösöket kizárva. $^{1106}$

\section{ß) A követő jog hatálya alá tartozó adásvételek}

A BUE nem tartalmaz semmilyen további megszorítást, mindössze arról rendelkezik, hogy a szerzőknek joguk van részt venni az első átruházást követő további adásvételekben. A Követő jogi irányelv viszont ehhez képest pontosan meghatározza azokat az adásvételeket, amelyek a díj megfizetését keletkeztetik.

Az irányelv kifejezetten kimondja a követő jogi díj alkalmazását a művészeti piac képviselői (így például aukciós házak, mủvészeti galériák és általában mükereskedők) részvételével, akár eladóként vagy vevőként, akár pedig közvetítőként létrejövő újraeladások esetén. Ezzel egyidejüleg ez azt is jelenti, hogy a többi ügylet (pl. magánszemélyek közötti adásvétel, vagy ingyenes ügyletek) után nem kell a díjazást megfizetni.

Az Szjt. a mükereskedő közremüködésével történő visszterhes átruházásokról beszél. Ebből két következtetés vonható le. Az egyik az, hogy nem csak az adásvétel keletkezteti a követő jogi díjigény megfizetését, hanem egyéb, a dolog tulajdonjogának átruházásával járó visszterhes aktus (pl. csere) is. A mükereskedői tevékenység független a társasági iratokban szereplő tevékenységmegjelöléstől, ugyanis minden olyan személy ide tartozik, akinek az üzleti tevékenysége kiterjed a müalkotások tulajdonjogának rendszeres átengedésére. ${ }^{1107}$

\section{§2. A követö jogi dij érvényesítése}

A szerzőknek járó díj meghatározásán [A) pont] túl szót kell ejteni ennek beszedése és felosztása kapcsán felvetődő kérdésekről is [B) pont].

\footnotetext{
1106 A C-518/08. sz. Fundación Gala-Salvador Dalí ügyben 2010. április 15-én hozott ítélet 36. pontja. ${ }^{1107}$ GYERTYÁNFY (2014), p. 423.
} 


\section{A) A dij meghatározása}

A díj mértékének meghatározásában a szerzők nem játszanak szerepet. Már a BUE is azt tartalmazza, hogy a díj mértékét és beszedésének módozatait az egyes országok törvényei határozzák meg. ${ }^{1108}$ Ennek megfelelően a díj az irányelv elfogadását megelőzően is törvényben rögzített mértékek alapján került beszedésre. Az irányelv pedig egy rugalmas, a tagállami mükincspiac sajátosságaihoz igazítható, sávosan meghatározott rendszert vezetett be. Ennek megfelelően a díj megfizetéséről [a) pont], illetve beszedéséről és felosztásáról is elemzést kell készíteni [b) pont].

\section{a) A dij megfizetése}

A díj megfizetésére kötelezett, bár úgy tünik, egyértelmüen rögzítésre került a Követő jogi irányelvben, a gyakorlatban mégis érdekes problémákat vetett fel. [ $\alpha$ ) pont]. A díj alapjának és mértékének meghatározása során viszont csak az irányelv keretein belül maradó eltérések fedezhetőek fel [ $\beta$ ) pont].

\section{a) A dij fizetésére kötelezett}

Az irányelv értelmében a díj megfizetése az eladót terheli. ${ }^{1109}$ A CPI is megismétli ezt a szabályt hozzátéve, hogy a megfizetéséért az eladásban résztvevő professzionális kereskedőt terheli felelősség, ha a vevő is az, akkor pedig az eladót. ${ }^{110}$ A magyar törvény pontosításában ez a mükereskedőt terheli. ${ }^{1111}$ A mükereskedő további meghatározását viszont a törvény nem tartalmazza, bár a szöveg világosabbnak tünik, mint a korábban használt „,kereskedelmi tevékenységet folytató gazdálkodó szervezet” fordulat. A törvénymódosítás tükrözi a gyakorlatban elterjedt szűkebb értelmezési kereteket, amely általában nem bármely, kereskedelmi tevékenységet folytató gazdálkodó szervezetet tekintett a díjfizetésre kötelezettnek, hanem csak azokat, amelyek mükereskedelemmel üzletszerüen foglalkoznak.

A francia szabályozás, az irányelvnek megfelelően, szintén azt írja elő, hogy a díj fizetésére az eladó a kötelezett. Yves SAINT-LAURENT és Pierre BERGÉ hagyatékának elárverezése kapcsán viszont a Christie's aukciósház szerződésben kikötötte, hogy a

\footnotetext{
${ }^{1108}$ BUE 14ter cikk (3) bek.

${ }^{1109}$ Követő jogi irányelv 1 . cikk (4) bek.

${ }^{1110}$ CPI L. 122-8. cikk.

1111 Szjt. 70. § (9) bek.
} 
vevőnek kell megfizetnie a követő jogi díjat (amit aztán az aukciósház utalt tovább a közös jogkezelő szervezetnek). Ez a szerződéses gyakorlat, azon túl, hogy versenytorzító hatással bír azok között a piaci szereplök között, akik a törvény elöírásainak megfelelően járnak el, és azok között, akik áthárítják a díj megfizetését, ráadásul azzal az eredménnyel is járhat, hogy ugyanaz a személy kétszer fizeti meg a díjat. Egyszer vevőként, ha a szerződés így rendelkezik, majd pedig a mü továbbértékesítésekor eladóként, amennyiben a CPI L.122-8. cikkét alkalmazza. ${ }^{1112} \mathrm{~A}$ bírói gyakorlat egyébként megosztott ennek megítélésében, ugyanis létezik olyan döntés, amely közrendbe ütközés okán megsemmisítette a szerződést, ${ }^{113}$ egy későbbi döntés viszont ezt érvényes szerződéses kikötésnek ismerte el. ${ }^{114}$ Ilyen tényállás mellett a Semmítőszék kezdeményezett előzetes döntéshozatali eljárást, amely a Christie’s szerződéses gyakorlatának kedvezett, vagyis nem ellentétes az irányelvvel az a kikötés, amely alapján a vevő köteles megfizetni a követő jogi díjat, ${ }^{1115}$ hiszen az egy másik ügylet az előbbi adásvételhez képest.

\section{ß) A dij alapja és mértéke}

A díjazás alapjának és mértékének meghatározásakor, mivel az teljes egészében jogszabályban rögzített, a közös jogkezelő szervezetek (és a jogosultak) még az egyéb esetekben meglévő rendelkezési szabadságukat is elveszítették. Emiatt lényegében tehát szerepük nem terjed túl egy puszta adminisztratív szerepen, amely azon az indokon alapul, hogy gyakorlati szempontokat figyelembe véve a díj megfizetése lényegesen egyszerübb, ha a szervezet közremüködésével történik.

A díj alapja az irányelv és a nemzeti jogok meghatározásában is az alkotás adót és más köztartozást nem tartalmazó ellenértéke, vételára. ${ }^{1116}$

A díj mértékét a követő jogi irányelv egy sávosan degresszív megoldást választott, amelynek átültetésénél azért a tagállamok számára biztosított valamennyi mozgásteret. Különösen azáltal, hogy mivel a kis értékü ügyletek feltételezhetően nem érintik a belső piac működését, a szubszidiaritás elvének figyelembe vételével a

\footnotetext{
1112 AZZI (2011) p. 69.

${ }^{1113}$ CA Paris, pôle 5, 4e ch., 12 déc. 2012, D. 2013, act. 174.obs. Emile-Zola-Place

${ }^{1114}$ CA Paris, pôle 5, 4e ch. 3 juill. 2013, Comité prof. des galeries d'art: Propr. intell. 2014, nº 50, p. 84, note Lucas.

${ }_{1115}$ A C-41/14. sz. Christie's France-ügyben 2015. február 26-án hozott ítélet 32. pontja.

${ }^{1116}$ Követő jogi irányelv 5. cikk, Szjt. 70. § (4) bek., CPI R. 122-5. cikk.
} 
tagállamokra tartozik annak a küszöbértéknek a meghatározása, amely alatt egyáltalán nem kell díjat fizetni. Ennek megfelelően a magyar jogalkotó tekintettel tudott lenni a hazai mükincspiac két sajátosságára. Nevezetesen arra, hogy a képzőművészeti alkotások átlagára 75.000 forint körül alakult, illetve arra, hogy a galériákból rövid időn belül magánkézbe kerülnek, ahonnan hosszú ideig nem is térnek vissza a kereskedelmi forgalomba. ${ }^{1117}$

A magyar törvény tekintettel a pályakezdő művészek támogatásának igényére, a magyar mütárgypiac átlagáraira, illetve arra, hogy a magyar követőjogi szabályozás hagyományosan nem állapít meg a fizetési kötelezettség tekintetében alsó határt, 5.000,Ft-ban határozza meg azt a minimális vételárat, amely után már díjazást kell fizetni a szerzőnek. A francia törvényben ez a küszöbérték 750 euróban lett meghatározva. ${ }^{1118}$

Az Szjt.-t is módosító 2011. évi CLXXIII. törvény a fennálló követő jogi rezsim alapját nem érintő, a díjazás mértékének meghatározását viszont a jogosultak kárára csökkentő változtatásokat eszközölt. Az indokolás szerint a korábban, az irányelvben foglalt minimumértéknél magasabb százalék ${ }^{119}$ fenntartása a piaci igényekre való tekintettel nem szükséges. Ez alapvetően a felhasználói érdekek érvényesítését jelenti a díj mértékének meghatározása során. ${ }^{1120}$

A díjazás kapcsán egyébként emellett a sávosan degresszív konstrukció mellett más megoldás is elképzelhető lett volna.

\section{b) A dij megfizetése alóli mentesités}

A haszonkölcsönzési jognál bemutatottakhoz hasonlóan a kultúra megőrzése, mint érték a követő jogi díj megfizetéséhez képest elsőbbséget élvez. Éppen ezért a Követő jogi irányelv (18) preambulumbekezdése kifejezetten elöírja, hogy a jog nem terjeszthető ki magánszemélyek által a nyereségszerzés célja nélkül a nyilvánosság számára hozzáférhető múzeumok részére végzett újraeladásra. A rendelkezést ennek megfelelően mindkét nemzeti szerzői jog átültette.

\footnotetext{
1117 GYENGE (2005) p. 92.

${ }^{1118}$ CPI R. 122-5. cikk.

1119 A Követő jogi irányelv 4. cikk (2) bekezdésében foglalt $5 \%$.

${ }^{1120}$ Miniszteri indokolás a szellemi tulajdonra vonatkozó egyes törvények módosításáról szóló T/4859. számú javaslathoz, p. 47.
} 


\section{B) A dij beszedése és felosztása}

A díjak beszedésére Magyarországon kizárólag a közös jogkezelő szervezet jogosult, hiszen a követő jog az Szjt. értelmében kötelező közös jogkezelés alatt áll. Franciaországban ezzel szemben ez csak választható megoldás [a) pont]. A felosztás ennek megfelelően tehát csak azokban az esetekben releváns, amikor közös jogkezelő szervezet jár el a díj kezelése során [b) pont].

a) A dij beszedése

A magyar törvény szabályai alapján a mükereskedő a díjat negyedévenként, a negyedévet követő hónap 20. napjáig köteles megfizetni. Az elszámoláshoz részletesen közölni kell a szerző nevét (hacsak annak megállapítása nem bizonyul lehetetlennek), a mü címét, illetve mủvenként a vételár összegét és a jogdíj mértékét. ${ }^{1121}$

A közös jogkezelő szervezet ráadásul a szerződés megkötésétől számított 3 évig követelheti azoknak az adatoknak a megadását, amelyek a díj beszedéséhez szükségesek. ${ }^{1122}$ Ezzel kapcsolatban arra kell felhívni a figyelmet, hogy mivel a díj nem a szerződés megkötésének időpontjában, hanem naptári negyedévenként esedékes, és a mükereskedők nem kötelesek a szerződés megkötésének időpontjáról adatot szolgáltatni, a határidő pontos számítása nehézségekbe ütközhet. Másrészt viszont, ahogyan azt a Szerzői jogi nagykommentár is kiemeli, ennek a határidőnek a lejárta nem érinti a többi igény, így például a díj megfizetésére irányuló igény érvényesítését. $^{1123}$

A törvény részletes szabályokat tartalmaz arra az esetre nézve is, ha az ügyletben egyébként több mükereskedő vesz részt. Azon túl, hogy a díj megfizetéséért egyetemlegesen felelnek, a kötelezettség alapvetően az eladót terheli - de ettől eltérően is megállapodhatnak. Ha egyik sem eladóként vesz részt az ügyletben, akkor pedig a vevőt terheli a kötelezettség. ${ }^{1124}$

\footnotetext{
${ }^{1121}$ Szjt. 70. $\S(10)$ bek.

${ }^{1122}$ Szjt. 70. § (11) bek.

1123 GYERTYÁNFY (2014), p. 424.

${ }^{1124}$ Szjt. 70. § (9) bek.
} 


\section{b) A közös jogkezelö szervezet eljárása a díj felosztása során}

Mind az irányelv, ${ }^{1125}$ mind a nemzeti törvények rögzítik, hogy követő jog a szerző elidegeníthetetlen joga, amelyről lemondani sem lehet. Ez a szerzőt védő rendelkezés, hiszen a díjazásról való lemondás meghiúsítaná a jogintézmény eredeti rendeltetését. Ez összhangban áll az Szjt. 16. § (5) bekezdésével, amely a díjazáshoz való jogok esetében általában lehetővé teszi az arról való lemondást, annak részletezésével, hogy törvény kizárhatja az ilyen díjazásról való lemondás jogát.

Mivel a díj beszedése is egyediesítve történik, a közös jogkezelő szervezet a díjakat is az indokolt kezelési költségek levonását követően egyediesítve fizeti ki. A HUNGART Felosztási szabályzata értelmében egyébként a díjfizetés a beszedést követően 30 napos határidőn belül valósul meg. ${ }^{1126}$

A díj kifizetése kapcsán a jogosultaknak teljesítendő adatszolgáltatási kötelezettséggel kapcsolatban a Fővárosi Ítélőtábla hozott döntést. A HUNGART ugyanis a kialakult gyakorlatának megfelelően mindazokat az adatokat közölte a jogosultakkal, amelyeket ő megkapott a mükereskedőktől a díjak beszedése során. Az ügy felperese viszont ezeken túli kiegészítő adatokra (különösen az adásvétel és a díj közös jogkezelő részére való átutalásának időpontja) vonatkozó kereseti kérelmét erre vonatkozó kifejezett jogszabályi elöírás hiányában a bíróság megalapozatlannak találta. $^{1127}$

Franciaországban, mint utaltunk rá, a közös jogkezelés csak önkéntes alapon müködik a követő jog körében, nem tartozik viszont a törvény által elöírt esetek közé. Ennek ellenére a CPI tartalmaz a szervezetek külön nyilvántartásba vételéről szabályt, amely pedig a törvény által elöírt esetek jellemzője. A rendelkezés értelmében a kultúráért felelős miniszter vezet egy nyilvántartást azokról a közös jogkezelő szervezetekről, amelyek a követő jogi díj jogosultjait tájékoztatni tudják, és ennek érdekében tudomással bírnak a követő jogi díj megfizetése alá tartozó adásvételekről. A szervezeteknek hasonló feltételeknek kell megfelelniük, mint amelyeket egyébként a

\footnotetext{
${ }^{1125}$ Követő jogi irányelv 1. cikk (1) bek. A szerzőt jog elidegeníthehetlenségét elöször a követő jog esetében mondta ki az uniós jogalkotó. DUCHEMIN (2002) p. 39. Természetesen arra van példa, hogy valamely díjazáshoz való jogról (például a bérbeadásra tekintettel a szerzőt megillető díjazáshoz való jogról) így rendelkezzen az uniós jogalkotó.

${ }_{1126}$ HUNGART Felosztási szabályzat 15.2. pont.

${ }^{1127}$ Fővárosi Ítélótábla 8.Pf.20.304/2007/7. sz. itélet.
} 
törvény által előírt közös jogkezelés ellátásával megbízott társaságoktól követel meg a jogalkotó. Vagyis a képviselt jogosultak számának és összetételének változatosságát igazolnia kell, ahogyan a vezető tisztségviselőnek a feladat ellátására való alkalmasságát is. Ezen kívül a szervezetnek azt is bizonyítania kell, hogy a szervezeti felépítése, a müködés technikai feltételei, illetve a jogosultak (ideértve a külföldi jogosultakat is) tájékoztatására való képessége megfelelő. ${ }^{1128}$

A díj a közös jogkezelés önkéntessége miatt közvetlenül a szerzők részére teljesítendő, amennyiben a szerzők erre irányuló nyilatkozatot tettek. Ennek hiányában az adásvétel létrejötte szerinti negyedév végét követő három hónapon belül a díj fizetésére kötelezettnek a közös jogkezelő szervezethez kell fordulnia, az adásvételre vonatkozó adatok megküldésével. A szervezet ezt követően értesíti a jogosultat, amennyiben pedig a jogosult nem azonosítható, fel kell kutatnia a díjazásra valószínüsíthetően jogosult személyeket akár a követő jog kezelését végző többi szervezet megkeresésével, akár pedig nyilvános hirdetmények útján. ${ }^{1129}$

${ }^{1128}$ CPI R. 122-7. cikk : „I.-Le ministre chargé de la culture fixe par arrêté une liste de sociétés de perception et de répartition de droits aptes à informer les bénéficiaires du droit de suite et susceptibles à ce titre d'être avisées des ventes d'oeuvres originales graphiques ou plastiques dans les conditions fixées au II de l'article R. 122-9.

II.-Pour être inscrite sur la liste mentionnée au I du présent article, une société de perception et de répartition de droits doit à l'appui de sa demande :

$1^{\circ}$ Apporter la preuve de la diversité de ses associés et du nombre des ayants droit;

$2^{\circ}$ Justifier la qualification de ses gérants et mandataires sociaux, appréciée en fonction de leur expérience professionnelle dans le secteur des arts graphiques ou plastiques ou de la gestion d'organismes professionnels ;

$3^{\circ}$ Donner toutes informations relatives à son organisation administrative, à ses conditions d'installation et d'équipement et à sa capacité à informer les bénéficiaires du droit de suite, y compris à l'étranger.

Est radiée de la liste, par arrêté du ministre chargé de la culture, toute société qui en fait la demande ou, sous réserve d'avoir été mise à même de faire valoir ses observations dans un délai de deux mois, toute société qui ne remplit plus les conditions auxquelles est subordonnée l'inscription sur la liste.

III.-Les arrêtés du ministre chargé de la culture mentionnés au I et au II sont publiés au Journal officiel de la République française."

${ }_{1129}$ CPI R. 122-10. cikk: „I.-Lorsqu'il est saisi d'une demande du bénéficiaire, le professionnel responsable du paiement du droit de suite lui verse le montant de celui-ci dans un délai qui ne peut excéder quatre mois à compter de la date de réception de la demande ou, si cette demande est reçue antérieurement à la vente, à compter de la date de cette vente.

Si l'oeuvre est due à la collaboration de plusieurs auteurs, le bénéficiaire en fait la déclaration et précise la répartition du droit de suite décidée entre les auteurs.

II.-S'il n'est saisi d'aucune demande, le professionnel responsable du paiement du droit de suite avise par lettre recommandée avec demande d'avis de réception, au plus tard trois mois après la fin du trimestre civil au cours duquel la vente a eu lieu, l'une des sociétés de perception et de répartition des droits mentionnées à l'article R. 122-6de la réalisation de la vente en lui indiquant la date de la vente, le nom de l'auteur de l'oeuvre et, le cas échéant, les informations relatives au bénéficiaire du droit de suite dont il dispose.

Lorsque une société de perception et de répartition des droits est avisée d'une vente ouvrant droit à la perception du droit de suite au profit d'un bénéficiaire mentionné àl'article R. 122-7, elle est tenue de l'en 
III. rész A törvény által elöírt közös jogkezelés, mint a joggyakorlás módja II. fejezet Közös jogkezelés a hatékonyság szolgálatában

informer. Lorsque le bénéficiaire n'est pas identifié, la société de perception et de répartition des droits procède aux diligences utiles pour informer les personnes susceptibles de bénéficier du droit de suite, au besoin en faisant appel aux autres sociétés de perception et de répartition de droits mentionnées à l'article R. 122-6. A défaut d'avoir pu informer le bénéficiaire, elle procède aux mesures de publicité appropriées sous forme électronique ou par tout autre moyen adapté." 


\section{A harmadik rész konklúziója}

A törvény által elöírt közös jogkezelési esetek második csoportja mindenekelőtt a joggyakorlás megkönnyítésének érdekében került bevezetésre. A jogalkotó a kizárólagos jogok közös kezelése kapcsán igyekezett elkerülni annak látszatát, hogy a szerző kizárólagos engedélyezési jogát korlátozza, emiatt akár kiterjesztett hatályú, akár ezt nélkülöző rezsimről van szó, minden esetben biztosította a kilépés lehetőségét a jogosultak számára. Ezáltal olyan megoldást tett főszabállyá az egyéni jogkezelés másodlagos szerepüvé kényszerítésével, amely a szerzői jog természetétől idegennek hat. Azt sem szabad elfelejteni azonban, hogy éppen a francia közös jogkezelő szervezetek voltak azok, amelyek alapszabályukat módosítani kényszerültek, mivel az önkéntes közös jogkezelés körében gyakorlatilag kizárták a jogosultak egyedi joggyakorlását. Ez pedig azon túl, hogy a versenyjog szabályai szerint erőfölénnyel való visszaélésként értékelhető, felveti annak a lehetőségét is, hogy a közös jogkezelő szervezetek túlzott mértékben korlátozzák a szerzők rendelkezési jogát. A kilépés jogának törvényi biztosítása tehát ebben a tekintetben kedvezőbb a szerzők számára. A megfelelő reprezentativitás, a kilépés lehetőségének biztosítása, illetve az, hogy a magyar jogalkotó olyan esetekben vezette be a kiterjesztett jogkezelést, amelyekben a jog gyakorlásának természetes módja egyébként is ez lenne, együttesen eredményezik, hogy a magyar sajátosságokra is tekintettel a felállított rendszer megfelel a nemzetközi és uniós szerzői jogi követelményeknek.

A díjigények közös jogkezelésének elöírása szintén praktikussági okokat szolgál. A könyvtári haszonkölcsönzések kezelésének gyakorlatilag nincsen más elképzelhető módja a közös jogkezelésen kívül. Ráadásul a díj amiatt is különleges, mert részben vagy egészben állami forrásból táplálkozik. Meghatározása, és egyébként a díj felhasználása is tehát egyéb szociális, kulturális szempontokkal is összefügg. A közös jogkezelés tehát ezekben az esetekben tisztán adminisztratív, elosztó szerepet játszik, érdemi befolyással azonban nem rendelkezik a díjak alakulására. Mivel a díjak beszedésének és elosztásának módja törvényben meghatározott, a szervezetek jobbára az állami kultúrpolitika végrehajtóivá válnak.

A fejezetben kivételesen foglalkoztunk egy alapvetően önkéntes közös jogkezelési formával is, mivel a CPI a Követő jogi irányelv átültetésénél nem tette kötelezővé a közös jogkezelést. Valójában azonban mégis törvény által elöírt 
jogkezelési esetnek tekinthető, amely álláspontunk szerint átmenetet képez a két közös jogkezelési forma között (hasonlóan a kereskedelmi forgalomban nem kapható könyvek digitalizálására elöírt közös jogkezeléshez). Ennek indoka a díj irányelv általi meghatározásán, valamint a díj tárgyát képező képzőművészeti alkotások, illetve a díjfizetés alapját képező adásvételek meghatározásán túl legföképpen a közös jogkezelő szervezetek működésének részletes szabályozásában rejlik. A kódex hasonló feltételeket támaszt a követő jog érvényesítését végző közös jogkezelő társaságokkal szemben, mint amilyeneket egyébként a kötelező közös jogkezelést végző társaságokkal szemben elöír. Bár eltérések is megfigyelhetőek, a lényeg, hogy az illetékes miniszter nyilvántartást vezet azokról a szervezetekről, amelyek az általános müködési szabályoknál szigorúbb feltételeknek meg tudnak felelni. A jogalkotó ezen kívül részletekbe menően rendezi a díj megfizetésének és felosztásának kérdését is.

A kiadók szomszédos jogi státuszához való közelítését mutatják a kereskedelmi forgalomban nem kapható könyvek digitalizálása körében elfogadott kilépési szabályok. Mint láttuk, a magyar jog alapján a kilépést engedő közös jogkezelési helyzetekben a szomszédos jogi jogosult önállóan nem élhet ezzel a jogosultsággal (annak ellenére, hogy a gyakorlatban valószínűleg a szerző a zenemükiadóval kötött felhasználási szerződés alapján gyakorolja a kilépés jogát). Ezzel szemben a CPI kifejezetten biztosítja a kiadók számára is a kilépési jogot, igaz ugyan, együttesen a szerzővel. Ez logikusan következik egyébként abból a tényből is, hogy a kiadói szerződés alapján a kiadó megszerzi a vagyoni jogokat. 


\section{Következtetések}

A kötelező közös jogkezelés bevezetése kapcsán, csatlakozva Sylvie NÉRISSON álláspontjához, ${ }^{1130}$ el lehet mondani, hogy az egybeforrt az újabb jogok biztosításának kérdésével - és ez nem csak a francia szerzői jog kapcsán igaz álláspont. A szerzői jog fejlődése, mint láttuk, mindig is kéz a kézben járt a technikai fejlődéssel. A közös jogkezelés pedig ehhez az ívhez több ponton is kapcsolódik, és tölt be egyre jelentősebb szerepet. Ezt bizonyítja, hogy a törvény által elöírt közös jogkezelési esetkörök alá tartozó jogok pontos meghatározása is, amely arra törekszik, hogy egy bizonyos technológiai megoldáshoz köthető felhasználási módhoz (vezetékes továbbközvetítési jog, reprográfiai többszörözés joga, kereskedelmi forgalomban nem kapható könyvek digitalizálása), vagy később elismert joghoz (követő jog, bérleti és haszonkölcsönzési jog) kösse a közös jogkezelést.

A magyar kiterjesztett hatályú, kilépést engedő közös jogkezelési esetek azok, amelyek általában véve a klasszikusan közös jogkezelés körében gyakorolt eseteket határozzák meg. Ezek Franciaországban jellemzően önkéntes közös jogkezelés alatt állnak. Ez a szemléletmódbeli különbség jellemzi egyébként a törvény által elöírt közös jogkezelés dogmatikai megközelítését: míg Franciaországban elsősorban a szerzők rendelkezési jogát tekintik mindenek felett állónak, és a közös jogkezelést egy ebből fakadó jogtechnikai megoldásnak, addig Magyarországon ennek az elvnek a lenyomata nem olyan erős. Itthon úgy tünik, hogy inkább egyfajta felhasználásközpontú szemléletmód érvényesül. A magyar közös jogkezelési rendszer ugyanis a hatékony müködésnek (értsd ez alatt a minél egyszerübb engedélyszerzést) rendeli alá a rendelkezési jogot. Ez tükröződik a szigorú nyilvántartásba vételi és felügyeleti szabályokban, a tömérdek törvény által elöírt közös jogkezelési esetben, illetve a kiterjesztett hatály jogtechnikai megoldásának alkalmazásában.

A közös jogkezelés és a technológiai fejlődés összefonódása más megközelítésben is jellemző. Megfigyelhető, hogy bizonyos esetekben a jogalkotó inkább a szerzői jog díjigénnyé transzformálásáról dönt, ehhez kapcsolva a kötelező közös jogkezelés intézményét. Ezekben az esetekben a felhasználások tömegessége és

${ }^{1130}$ NÉRISSON (2013) p. 306. 
ellenőrizhetetlensége miatt gyakorlatilag nincsen más járható út a díjak kezelésére, mint a közös jogkezelés. Ez különösen a magáncélú többszörözés felhasználásánál jellemző, amely a tömeges méreteket öltött felhasználások miatt önmagában is számos megoldandó kérdést vet fel. Másfelől viszont sok esetben megmarad az az igény arra, hogy a szerzői jog alapvető jellemzőinek tiszteletben tartásával kifejezetten kizárólagos jogként kerüljenek meghatározásra az újabb jogok.

Felismerve viszont azt, hogy a jogosítás komplex folyamatának közös jogkezelők általi központosítása jobban megfelel a felhasználói igényeknek, illetve a szerzők számára is előnyökkel járó megoldásról van szó, a jogalkotó több esetben is egy többé-kevésbé kötelező közös jogkezelés elöírásáról rendelkezett. A kötelező közös jogkezelés így egyfajta egyensúlyozó, köztes szerepet is játszik a szerzői jog klasszikus engedélyezési joga, és a tisztán díjazáshoz való jog között. Ez különösen igaz abban az esetben, amikor a jogalkotó a kizárólagos jogok kilépést engedő módon utalta a közös jogkezelés körébe. Ez ugyanis lehetővé teszi a felhasználói és jogosulti oldal érdekeinek összehangolását, a szerzői jog alapvető elveinek lehető legteljesebb figyelembe vételével a jogkezelés hatékonyságának megoldásával.

A közös jogkezelés kilépést nem engedő formáját, mivel elismerten a kizárólagos engedélyezési jogok korlátjának minősül, a jogalkotó azokban az esetekben tette kötelezővé, amelyekben a nemzetközi vagy uniós jogi szerzői jogi jogforrások a jog gyakorlásának módjára nézve korlátozást tartalmaznak, vagy egyébként lehetővé teszik a jog korlátozását. Mivel Franciaországban a reprográfiai többszörözés joga nem díjigényként, hanem engedélyezési jogként került a CPI-be, a kötelező közös jogkezelés vizsgálata körében közvetlenül is szükségessé teszi a háromlépcsős tesztnek való megfelelés vizsgálatát. Ez utóbbi szempont egyébként a kilépést engedő, különösen a kiterjesztett hatályú közös jogkezelés esetében is indokolt, hiszen ezekben az esetekben a joggyakorlás módjának meghatározására nincsen közvetlenül a nemzetközi vagy uniós jogból eredő felhatalmazás.

Ezzel szemben az eleve díjigényként meghatározott, vagy díjigényre leszorított jogok gyakorlásánál a jogalkotó tágabb rendelkezési szabadsággal él(het) - amennyiben természetesen tiszteletben tartja a korlátozások bevezetésének általános szabályait. Mivel ezekben az esetekben az engedélyezési jog nem illeti meg a jogosultakat, gyakorlatilag szabadon közös jogkezelés körébe utalhatja a gyakorlásukat. Ez a 
megoldás egyébként többnyire indokolt is, hiszen (legalábbis a díjigényre szorítás) a tömeges felhasználások esetén jellemző. Előfordul azonban az is, hogy egyébként egyedileg is gyakorolható díjigény közös jogkezelés alá rendeléséről a jogalkotó a könnyebb tejesítés érdekében, pusztán gyakorlati szempontok érvényesítése miatt rendelkezik. Ebben a körben a korlátozások szempontjából azt érdemes figyelembe venni, hogy az összegek felosztása (illetve részben a díjak meghatározása) során milyen mértékben jelennek meg egyéb kulturális és szociális szempontok. Álláspontunk szerint ugyanis ezek aránya, illetve a felhasználás elöírásának módja, amennyiben túlmutat a közös jogkezelés természetéből adód kölcsönösségi, közösségi jellemzőkön, szerzői jogi korlátozásként tekinthetö. A könyvtári haszonkölcsönzési díjak szerzői jogi természete emiatt megkérdőjelezhető, hiszen a díj fizetésére sem a közvetett, sem pedig a közvetlen felhasználó nem köteles (ellentétben a magáncélú másolatokra tekintettel fizetett díjakkal), ráadásul Franciaországban ezek egy részét szociális célok megvalósítására kell fordítani.

A kötelező közös jogkezelés korlátozásokhoz való hasonlatosságát alátámasztja egyébként a jogkezelés körébe utalt jogok meghatározásának módja is. Akár a kizárólagos jogok, akár pedig a díjigényre szorított jogok meghatározását vesszük figyelembe, mindkét esetben elmondható a törekvés a minél szükebben, és minél pontosabban meghatározott jogokra. Bár a díjigények (kifejezetten a magáncélú másolásra tekintettel fizetett díjak) esetén a technológiai fejlődés miatt is igény mutatkozik a díj alapjának kiszélesítésére a díjjal terhelt hordozók körének kiszélesítésével (ezzel egyben kompenzálandó az analóg eszközök eladásának csökkenéséből eredő hátrányokat), az egyes felhasználási módok közötti különbségtétel a magáncélú másolat fogalmának egyre szükebbre vonását eredményezi.

A törvény által elöírt közös jogkezelési esetek tehát alapvetően a kizárólagos jog korlátozásával bevezetett olyan joggyakorlási módok, amelyek több esetben az egyedüli lehetséges megoldást jelentik a szerzők számára az engedélyezési jog gyakorlására, vagy a díjigény érvényesítésére. 


\section{Köszönetnyilvánítás}

A köszönet első helyen illeti meg két témavezetőmet, Dr. MEZEI Pétert, a Szegedi Tudományegyetem Állam- és Jogtudományi Karának docensét, stratégiai dékánhelyettest, valamint Prof. Antoine LATREILLE-t, az Université Paris-Sud Faculté Jean Monnet dékánját. Köszönöm nekik, hogy mindig szakítottak időt a kutatómunkám segítésére. A kutatáshoz nélkülözhetetlen segítséget kaptam Tuomas MYLLYTŐL, aki értékes forrásokat nyújtott rendelkezésemre. NÉMETH Lászlónak a dolgozat alapjául szolgáló tanulmányokhoz, HARKAI Istvánt, PETROVSZKI Klárát és BuJdOsó Villőt pedig a kézirathoz füzött értékes megjegyzéseiért illeti köszönet. BATÓ Szilviának hálás vagyok a kutatásmódszertani segítségért.

Doktoranduszi sorstársi közösségvállalásért külön hála illeti PoLLÁK Kittit, SZAKÁLY Zsuzsát és SzIGETI Tamarát, amiért nem fukarkodtak a baráti tanácsaikkal. Az Összehasonlító Jogi Intézet munkatársait, különösen ALMÁsI Ibolyát, BóKA Jánost, Samantha CHEESMANT és LELE Gabriellát köszönet illeti az íróasztalom fenntartásáért, és félévente az irodában töltött napi munka színesítéséért. Prof. BADÓ Attilának, az Összehasonlító Jogi Intézet vezetőjének külön hálás vagyok a téma befogadásááért és a kutatás feltételeinek biztosításáért. Külön köszönöm Anne-Céline RoQUE-nak és Rosine DE MATOSNAK a dolgozat francia összefoglalójának lektorálását.

A dolgozat ebben a formájában nem jöhetett volna létre a Francia Állam kettős témavezetésű doktori ösztöndíja nélkül, az adminisztrációban nyújtott segítségért különösen hálás vagyok a Campus France, illetve mindkét fogadóegyetem doktori iskolája munkatársainak.

Végezetül, de legföképpen hálás vagyok szeretteimnek, akik messzi földre elengedtek egy álom megvalósításáért. 


\section{Irodalomjegyzék}

A Szerzői Jogi Szakértő Testület tanulmányai a szerzői jog digitális világhoz való alkalmazkodásáról - A Szerzői Jogi Szakértö Testület UGC-munkacsoportjának beszámolója a felhasználók által generált tartalom szerzői jogi kérdéseivel kapcsolatban, ISZJSZ, 2014/4. p. 93-153.

Авотт, Frederick M. - COTTIER, Thomas - GURRY, Francis: International Intellectual Property in an Integrated World Economy, Aspen Publisher, USA, 2007

AlCARAS, Jean-Robert: La protection des droits peut-elle favoriser la crétation culturelle? Approche économique. In: BRUGUIÈRE, Jean-Michel (szerk.) Droit d'auteur et culture, Dalloz, 2007, p. 55-74.

AlFöLDY Dezső: A magyar szerzői jog különös tekintettel a M. Kir. Kuria gyakorlatára, Grill Károly Könyvkiadó, 1936. p. 57-58.

Allayaeys, Philippe: Hypothèses de forfait en droit d'auteur, Propr. intell. 2007/24. p. 269-278.

AlleAume, Christophe: La mise en balance du droit d'auteur, RIDC, 2010/2. p. 423445.

Alleaume, Christophe: Le droit de prêt ou l'Arlésienne du droit d'auteur, Légicom, 2001/24, p. 43-50.

Alleaume, Christophe: Le droit de prêt public (en France et au-delà), Propr. intell., 2004/12. p. 718-737.

Alleaume, Christophe: Le prêt des oeuvres de l'esprit, Thèse, Caen, 1997

Alma-DeletTRE, Sophie: La nature juridique des droits de propriété intellectuelle. In: Bruguière, Jean-Michel - Mallet-Poujol, Nathalie - Robin, Agnès: Propriété intellectuelle et droit commun, PUAM, 2007. p. 25-37.

AXHAMn, Johan - GuIBAUlt, Lucie: Solving Europeana's mass-digitization issues through extended collective licensing? NIR, 2011/6. p. 509-516.

AXHAMN, Johan: Exceptions, limitations and collective management of rights as vehicles for access to information. In: BELDIMAN, Dana (ed): Access To Information And Knowledge: 21st Century Challenges in Intellectual Property and Knowledge Governance, Edward Elgar Publishing, Cheltenham, 2013 p. 164186.

AzZI, Tristan: La loi applicable à la dévolution successorale du droit de suite (à propos de l'affaire Dalí), Propr. intell. 2012/44. p. 288-294.

AzZI, Tristan: Le „, business” de l'art. Le droit de suite, Propr. intell, 2011/38. p. 65-73.

BARRAUD, Boris: De l'imprimé au numérique - Le régime juridique des médias écrits à l'épreuve de leur dématérialisation, RLDI, 2012/85. p. 105-119.

BATTA János: Eredeti képzömüvészeti alkotás felhasználása a tulajdonjog átruházása útján, Magyar Jog, 1978/11, p. 996-1005.

BÉCOURT, Daniel: Commentaire de la loi $n^{\circ} 95-4$ du 3 janvier 1995 sur la reprographie, D., 1995a. p. 59.

BÉCOURT, Daniel: Les directives communautaires en droit d'auteur (1re partie), Petites affiches, 1995b/111. p. 8.BÉCOURT, Daniel: Les directives communautaires en droit d'auteur (2e partie), Petites affiches, 1995c/115. p. 4.

BÉCOURT, Daniel: Les directives communautaires en droit d'auteur (suite et fin), Petites affiches, 1995d/121, p. 4.

BELLIVIER, Florence: Rémunération des prêts en bibliothèque. Loi $n^{\circ}$ 2003-517 du 18 
juin 2003 relative à la rémunération au titre du prêt en bibliothèque et renforçant la protection sociale des auteurs (JO 19 juin 2003, p. 10241), RTD Civ, 2003, p. 558.

BÉNABOU, Valérie-Laure: De l'efficacité de l'exception en elle-même à sa confrontation aux mesures techniques, Propr. intell. 2007/25. p. 423-435.

BÉNABOU, Valérie-Laure: Droits d'auteur, droits voisins et droit communautaire, Bruylant, Bruxelles, 1998.

BÉNABOU, Valérie-Laure: La directive droit d'auteur, droits voisins et société de l'information: valse à trois temps avec l'acquis communautaire, Comm. com. électr., 2010/10. p. 8-11.

BÉNABOU, Valérie-Laure: La notion de compensation équitable dans l'arrêt Padawan ou quand la CJUE fait main basse sur les notions du droit d'auteur, Légipresse, 2011/280. p. 95-100.

BENHAMOU, Françoise - FARCHY, Joëlle: Droit d'auteur et copyright, Éditions la Découverte, Paris, 2009

Bensamoun, Alexandra: Essai sur le dialogue entre le législateur et le juge en droit d'auteur, PUAM, Aix-en-Provence, 2008

BÉRCESI Zoltán: A müholdas müsorsugárzás és a vezetékes müsortovábbitás szerzői jogi problémái az Európai Közösségben, Jogtudományi Közlöny, 1996/2. p. 49-59.

BÉRCESI Zoltán: Bérlet és haszonkölcsön az európai szerzői jogi jogharmonizáció fókuszában, Jogtudományi Közlöny, 1997/7-8. p. 337-342.

BERCOVITZ RODRÍGUEZ-CANO, Rodrigo: La communication au public dans la doctrine de la Cour de justice de l'Union européenne. In: BERnaUlt, Carine - ClaviER, Jean-Pierre - LuCAS-SCHLOETTER, Agnès - LuCAS, François-Xavier (ss la dir. de): Mélanges en l'honneur du professeur André Lucas, LexisNexis, Paris, 2014. p.35-46.

Bernault, Carine - Clavier, Jean-Pierre: Dictionnaire de droit de la propriété intellectuelle. Ellipses, Paris, 2e édition, 2015

BERNAULT, Carine: La gestion collective des droits des réalisateurs et des producteurs. In: TAFFOREAU, Patrick: Pratique de la propriété littéraire et artistique, LexisNexis, Paris, 2013, p. 463-473.

BERTRAND, André: La musique et le droit. De Bach à Internet. Litec, Paris, 2002

BINCTIN, Nicolas: La qualité à agir des SPRD pour les non-membres, Légipresse, 2009/261, II, p. 52.

BINCTIN, Nicolas: La rigueur risquée (Commentaire CJUE, 21 oct. 2010, aff. C467/08), Comm. com. électr. 2011/1. p. 7-10.

BINCTIN, Nicolas: Pour une application stricte de la rémunération pour copie privée commentaire sous CE, 10e et 9e ss-sect. réunies, 11 juillet 2008, no 298779, Syndicat de l'Industrie de matériels audiovisuels électroniques, Comm. com. électr, 2008, étude 21.

BINCTIN, Nicolas: Rémunération pour copie privé, J.Cl. Propriété littéraire et artistique, Fasc. 1510

BoDó Balázs: A szerzői jog kalózai. Typotex Kiadó, Budapest, 2011

BOIRON, Patrick: Le droit de reproduction par reprographie: les copies à des fins de commerce dix ans après la loi du 3 janvier 1995, Comm. comm. électr. 2004/12. p. $18-22$.

Bonadio, Enrico - CAntore, Carlo Maria: The ECJ Rules on the Private Copying Levy: Padawan SL v Sociedad General de Autores y Editores (SGAE) (C-467/08), EIPR, 2011/4. p. 260-263.

Boronkay Miklós - Boytha György - CsePely-KNORR Tamás - SzILÁGYi Pál: A szerzöi jogok közös kezelésének versenyjogi vonatkozásai. Különös tekintettel a 
technikai fejlödés által támasztott kihívásokra, PPKE-JÁK Versenyjogi Kutatóközpont, 2008 , (http://gvh.hu/data/cms1000526/GVH_kozos_jogkezelok_VKK4-2006.pdf)

BoYTHA György: Iparjogvédelem, szerzői jog. In: KIRÁLY Miklós (szerk.): Az Európai Közösség kereskedelmi joga, KJK Kerszöv, Budapest, 2003. p. 335-438.

BRUGUIÈRE, Jean-Michel, - FAUCHOUX, Vincent: Le livre numérique, RLDI, 2011/73. everzió

BRUGUIÈRE, Jean-Michel: La loi du ler mars 2012 relative à l'exploitation numérique des livres indisponibles du XXe siècle est constitutionnelle, Comm. com. électr. 2014/4. p. 9-11.

BRUGUIÈRE, Jean-Michel: La recevabilité de l'action des SPRD à agir en contrefaçon pour des créateurs non-membres, JCP E, 2009. p. 1471.

CARON, Christophe: „FAQ” autour de la rémunération pour copie privée à la mode luxembourgeoise, Comm. com. électr. 2013b/10. p. 23-24.

CARON, Christophe: A propos d'un contrat conclu sous l'empire des lois révolutionnaires, Comm. com. électr, 2005/7. p. 21.

CARon, Christophe: Ce que dit la loi sur les livres indisponibles, Comm. com. électr., 2012a/11. p. 26.

CARON, Christophe: Ce qu'est et ce que n'est pas la rémunération du droit de prêt, Comm. com. électr. 2011a/11. comm. 100.

CAROn, Christophe: Droit d'auteur et droits voisins, LexisNexis, Paris, 3e éd, 2013a

CARON, Christophe: La rémunération pour copie privée en droit communautaire, Comm. com. électr., $2011 \mathrm{~b} / 1$.

CARON, Christophe: Le droit contractuel dans la directive du 27 septembre 1993 relative à la radiodiffusion par satellite et la retransmission par câble ou le contrat malmené, Petites affiches, 1999/248., p. 6

CARON, Christophe: Le droit d'auteur de l'an 2440. Cauchemar s'il en fût jamais. In: Études à la mémoire du professeur Xavier Linant de Bellefonds, LexisNexis, 2007, p.105-116.

CARON, Christophe: Les exceptions au regard du fondement du droit d'auteut en droit français. In: LuCAS, André - SIRINELl, Pierre - BENSAMOUN, Alexandra: Les exceptions au droit d'auteur. État des lieux et perspectives dans l'Union européenne, Dalloz, 2012b, p. 19-25.

CARON, Christophe: Une cession des droits antérieure à la loi du 11 mars 1957 peutelle englober le droit d'exploitation numérique? Comm. com. électr., $2013 \mathrm{c} / 7$.

CARRE, Stephanie - VERCKEN, Gilles: Google et la fortune du droit d'auteur. In: Bernault, Carine - Clavier, Jean-Pierre - LuCAS-Schloetter, Agnès LuCAS, François-Xavier: Mélanges en l'honneur du professeur André Lucas, LexisNexis, Paris, 2014. p. 119-138.

CARRE, Stéphanie: Des exceptions d'usage privé: le cas de la copie privée. In: VIVANT, Michel: Les grands arrêts de la propriété intellectuelle, Dalloz, Paris, 2e éd, 2015. p. 298-314.

CARRE, Stéphanie: Le livre numérique un „OCNI” (Objet culturel non identifié), Comm. com. électr., 2005/10., p. 22-25.

CASTETS-RENARD, Céline: Clarification sur le périmètre de la cession légale du droit de reproduction, RLDI 2014/101. e-verzió

CASTEX, Lucien: Encadrer une bibliothèque numérique: de sa constitution à son exploitation, RLDI, 2010/66. p. 84-92. 
CHABERT, Cyril: Deux raisons de réexaminer la rémunération pour copie privée au regard des engagements internationaux français, Comm. com. électr., 2004/10. étude 36.

Collart-Dutilleul, François - Delebecque, Philippe: Contrats civils et commerciaux, Dalloz, Paris, 9e édition, 2011

Colombet, Claude: Grands principes du droit d'auteur et des droits voisins dans le monde. Approche de droit comparé, Litec, Unesco, Paris, 2e éd, 1992

Colombet, Claude: Propriété littéraire et artistique et droits voisins, Dalloz, Paris, 9e éd, 1999

COMTE, Henri: Une étape de l'Europe du droit d'auteur: La Directive du 19 novembre 1992 relative au prêt et à la location, RIDA, 1993/158. p. 3-73.

CORNU, Gérard: Vocabulaire juridique, Quadrige/PUF, Paris, 2007

COURTOIS, Georgie: L'impression 3D: chronique d'une révolution juridique annoncée, RLDI, 2013/99. p. 71-80.

CozIAn, Maurice - VIANDIER, Alain - DEBOISSY, Florence: Droit des sociétés, LexisNexis, Paris, 2014

DALEAU, Jeanne: Copie privée: contours de la notion de „compensation équitable”. CJUE 21 oct. 2010, C-467/08, Padawan. Dalloz actualité, 2010 november 15

DAvies, Gillian - Hung, Michèle E.: Music and Video Private Copying. An International Survey of the Problem and the Law, Sweet \& Maxwell, London, 1993

DE RIDDER, Frédérique: Droits d'auteur, droits voisins dans l'audiovisuel. Les sociétés de perception et de répartition, Éditions DIXIT, Paris, 1994

DEAZley, Ronan - KRETSCHMER, Martin - Bently, Lionel (szerk.): Privilege and Property: Essays on the History of Copyright. Open Book Publishers, 2010 (http://www.openbookpublishers.com/reader/26)

DERIEUX, Emmanuel: La notion de „publication” - Les insupportables incertitudes $d u$ droit, JCP G, 2010a/49. p. 2262-2263.

DERIEUX, Emmanuel: Le livre à l'ère numérique - Questions juridiques sans réponses, RLDI, 2010b/60., p. 80-101

DERIEUX, Emmanuel: Le régime juridique de l'exploitation numérique des livres indisponibles du XXe siècle, RLDI, 2012/87. p. 64.

DERIEUX, Emmanuel: Reproduction par reprographie et droit d'auteur: paralisme et réalités, Petites affiches, 1995/62. p. 28

Desbois, Henri: Le droit d'auteur en France, Dalloz, Paris, 3e éd, 1978

DESURMONT, Thierry: La transposition en France de la directive 2001/29/CE sur l'harmonisation de certains aspects du droit d'auteur et des droits voisins dans la société de l'information, RIDA, 2006/210, p. 111-183.

DIETZ, Adolf: La proposition de directive sur les sociétés de gestion collective du 11 juillet 2012 et la diversité culturelle - Une occasion ratée. In: BERNAULT, Carine - Clavier, Jean-Pierre - LuCAS-SCHLOETTER, Agnès - LuCAS, François-Xavier: Mélanges en l'honneur du professeur André Lucas, LexisNexis, Paris, 2014. p. 237-249.

DIETZ, Adolf: Le droit d'auteur dans la Communauté européene, Office des publications officielles des Communautés européennes, Luxembourg, 1976

DIETZ, Adolf: Legal regulation of collective management of copyright (collecting societies law) in Western and Eastern Europe, Journal of the Copyright Society of the U.S.A., 2001-2002/49. p. 897-916.

DIRINGER, Yvan: Gestion collective des droits d'auteur et droit de la concurrence. Pour une relecture à l'heure d'internet, PUAM, Aix-en-Provence, 2011 
DIRINGER, Yvan: La gestion collective des droits d'auteur aux États-Unis, un modèle concurrentiel en trompe l'oeil, RIDA, 2010/10. p. 4-279.

DREIER, Thomas: Limitations: The Centerpiece of Copyright in Distress - An Introduction, JIPITEC, 2010/1. p. 50-54.

DuCHEMIN, Jacques-Louis: Le droit de suite des artistes, Sirey, Paris, 1948

DUCHEMIN, Wladimir: La directive communautaire sur le droit de suite, RIDA, 2002/191, p. 3-131.

Dupuy, Pierre-Marie - Kerbrat, Yann: Droit international public, Dalloz, Paris, 12e éd, 2014

DUSOLliER, Sévérine: Droit d'auteur et protection des oeuvres dans l'univers numérique. Droits et exceptions à la lumière des dispositifs de verrouillage des oeuvres, Larcier, Bruxelles, 2007

EDElman, Bernard: Droits d'auteur et droits voisins. Loi $n^{\circ} 85-660$ du juillet 1985 relative aux droits d'auteur et aux droits des artistes-interprètes, des producteurs de phonogrammes et de vidéogrammes et des entreprises de communication audiovisuelle, Jurisprudence Générale Dalloz, Paris, 1987

EDELMAN, Bernard: Droits d'auteurs, droits voisins. Droit d'auteur et marché, Dalloz, Paris, 1993

EDELMAN, Bernard: La CJCE et la télédiffusion dans les chambres d'hôtel, Recueil Dalloz, 2001. p. 1094

EDELMAN, Bernard: Vers une définition du droit de communication au public, D. 2007. p. 1236

EFroni, Zohar - GeBert, Julia: The Google Books decision: The Authors' Guild v Google Inc, European Intellectual Propetry Review, 2011, 33(8) p. 532.

ÉMILE-ZOLA-Place, Emmanuel: L'exploitation numérique des livres indisponibles du XXe siècle: une gestion collective d'un genre nouveau, Légipresse, 2012/295. p. 355.

ESCARRA, Jean-Rault - HEPP, Jean-François: La doctrine française du droit d'auteur. Étude critique à propos de projets récents sur le Droit d'auteur et le Contrat d'édition, Éditions Bernard Grasset, Paris, 1937

FALUDI Gábor - GRAD-GYENGE Anikó: A nyilvánossághoz közvetitései (elöadási) jog értelmezése az Európai Bíróság gyakorlatában, ISZJSZ 2012/1. p. 77-93.

FALUDI Gábor - KABAI Eszter: A lényegtelenné vált CISAC-ügy margójára, ISZJSZ, 2014/1. p. 71-104.

FALUDI Gábor: A közös jogkezelö szervezetek felhasználási szerzödései. In: Liber Amicorum : Studia Gy. Boytha dedicata : ünnepi dolgozatok Boytha György tiszteletére, ELTE ÁJK, Budapest, 2004. p. 81-104.

FALUDI Gábor: A paródia a szerzői jogban. In: KESERÜ Barna Arnold - KÖHIDI Ákos (szerk.): Tanulmányok a 65 éves Lenkovics Barnabás tiszteletére, Eötvös József Könyv- és Lapkiadó Bt. Budapest, 2015. p. 94-120.

FALUDI Gábor: A szerzői jog átruházhatósága a magyar szerzői jogban, Magyar Jog, 1995/3. p. 146-156.

FALUDI Gábor: A szerzői jog és az internet viszonyának egyes kérdései. In: Acta conventus de iure civili Tomus II., Lectum, Szeged, 2008. p 9-27.

FALUDI Gábor: A szerzői közös jogkezelés mint szabályozott monopólium, Infokommunikáció és Jog, 2009a/4. p. 126-135.

FALUDI Gábor: A szerzői közös jogkezelés szabályozási környezetének változásai. In: Emlékkönyv Ficsor Mihály 70. születésnapja alkalmából barátaitól, Szent István Társulat, Budapest, 2009b, p. 64-92. 
FICSOR Mihály: La gestion collective du droit d'auteur et des droits voisins à la croisée des chemins: doit-elle rester volontaire, peut-elle être „étendue” ou rendue obligatoire? e-Bulletin du droit d'auteur, Octobre 2003b, (http://portal.unesco.org/culture/fr/files/14935/10718319981M._Ficsor_fr.pdf/M. + Ficsor+fr.pdf)

FICSOR, Mihály: Collective Management of Copyright and Related Rights, WIPO, Geneva, 2002

FICSOR, Mihály: Collective Management of Copyright in the International Environment, Zeitschrift für Urheber- und Medienrecht, 2003a/1. p. 3-15.

FICSOR, Mihály: Développement et objectif de la gestion collective des droits des auteurs, Le droit d'auteur, 1985/10. p. 296-309.

FICSOR, Mihály: Hungary. In: LINDNER, Brigitte - SHAPIRO, Ted: Copyright in the Information Society. A Guide to National Implementation of the European Directive, Edward Elgar, Cheltenham, UK, Northampton, MA, USA, 2011, p. 251-275.

FICSOR, Mihály: Le „,test des trois étapes”: pourquoi on ne signe pas la Déclaration de Munich? In: LuCAS, André - SiRINELli, Pierre - Bensamoun, Alexandra: Les exceptions au droit d'auteur. État des lieux et perspectives dans l'Union européenne, Dalloz, 2012a, p. 55-62.

FICSOR, Mihály: Short paper ont he three-step test for the application of exceptions and limitations int he field of copyright, 2012b (http://www.copyrightseesaw.net/archive/?sw_10_item=28)

FICSOR, Mihály: Svensson: Honest attempt at establishing due balance concerning the use of the hyperlinks - spolied by the erroneous ,new public" theory (slightly corrected version)

2014 (http://www.copyrightseesaw.net/archive/?sw_10_item=68)

FICSOR, Mihály: The Law of Copyright and the Internet. The 1996 WIPO Treaties, their Interpretation and Implementation, Oxford University Press, Oxford, 2002

FLORENSON, Paul: La gestion du droit d'auteur et des droits voisins en Europe, RIDA, 2003/196. p. 3-125.

FODOR Klaudia Franciska: A digitális magáncélú másolat kompenzációjának lehetöségei, ISZJSZ, 2009/4. p. 65-88.

FOUILLAND: L'apport de droits d'auteur à une société de gestion collective, Comm. com. électr. 2008, étude 2.

FRANÇON, André: Cours de propriété littéraire, artistique et industrielle, Les Cours de droit, Paris, 1999

FRANÇON, André: Loi du 27 mars 1997 de transposition de deux directives communautaires, RTD Com. 1997. p. 252.

FRANÇON, André: Reproduction par reprographie, utilisation collective, Gestion collective obligatoire. Copie privée sonore et audiovisuelle, qualité d'auteur, RTD Com, 1995, p. 121.

GALOPIN, Benoît: Conséquences de la nature constitutionnelle et européenne sur le droit d'auteur: retour sur quelques décisions récentes, RIDA, 2015/3, p. 174-235.

GALOPIN, Benoît: Les exceptions à usage public en droit d'auteur, LexisNexis, Paris, 2012

Gaubiac, Yves: Dimension de la copie privée dans le monde numérique de la communication, Comm. com. électr., 2008/6. étude 14.

GAUBIAC, Yves: Droit d'auteur en France. In: TAFFOREAU, Patrick (éd): La radiodiffusion par satellite et la retransmission par câble. Aspects de droit privé et de droit public. L'Harmattan, Paris, 2000. p. 23-28. 
GAUDEL, Denise: La distribution par câble et la diffusion par satellite des auvres de l'esprit. In: Droit d'auteur et droits voisins. La loi du 3 juillet 1985, Librairies Techniques, Paris, 1986, p. 67-86.

GAUDRAT, Philippe - SARDAIN, Frédéric: De la copie privée (et du cercle de famille) ou des limites au droit d'auteur, Comm. com. électr., 2005/11.p. 6-16.

GAUTIER, Pierre-Yves: Les exceptions au regard du droit de l'Union européenne. In: LuCAS, André - SiRinelli, Pierre - Bensamoun, Alexandra: Les exceptions au droit d'auteur. État des lieux et perspectives dans l'Union européenne, Dalloz, 2012, p. 37-42.

GAUTIER, Pierre-Yves: Propriété littéraire et artistique, PUF, Paris, 2012

GeIGER, Christophe - Hilty, Reto M. - Griffiths, Jonathan - SuthersanEn, Uma: Declaration. A Balanced Interpretation Of The „Three-Step Test” In Copyright Law, 2008 (http://www.ip.mpg.de/fileadmin/user_upload/declaration_three_step_test_final_e nglish1.pdf)

GeIGer, Christophe - MACrez, Franck - Bouvl, Adrien - CARre, Stéphanie HASSLER, Théo - SCHMIDT, Joanna: Quelles limites au droit d'auteur dans la société de l'information? Réponse au Livre vert sur ,"le droit d'auteur dans l'économie de la connaissance". Propr. intell. 2009/32. p. 232.

GEIGER, Chrsitophe: De la nature juridique des limites au droit d'auteur. Une analyse comparatiste à la lumière des droits fondamentaux, Propr. intell. 2004/13. p. 887.

GÉRA Eleonóra Erzsébet - CsATÁRI Bence: A Zeneszerzök Szövetkezetétöl az Artisjus Egyesületig (1907-2007): a zenei közös jogkezelés száz éve Magyarországon, Artisjus, Budapest, 2007

GeRVAIS, Daniel (szerk.): Collective Management of Copyright and Related Rights, Kluwer Law International, The Netherlands, 2010

GERVAIS, Daniel: Individual and Collective Management of Rights Online, In: AXHAMn, Johan (ed.): Copyright in a Borderless Online Environment. Norsteds juridik, Stockholm, 2012. p. 89-100.

GinsburG, Jane: A Tale of Two Copyright: Literary Property in Revolutionary France and America, RIDA, 147/1991. p. 124-289.

GINSBURG, Jane: L'avenir du droit d'auteur: un droit sans auteur? Comm. com. électr. 2009/5. p. 7-10.

GINSBURG, Jane - RICKETSON, Sam: International Copyright and Neighbouring Rights: The Berne Convention and Beyond (vol. 1-2.), Oxford University Press, Oxford, New York, 2006.

GiTTON, Antoine: La copie privée numérique: vers une licence d'édition privée, Légicom, 2001/25. p. 61-74.

Goldstein, Paul - Hugenholtz, Bernt: International Copyright. Principles, Law and Prectice, Oxford University Press, New York, 2010

Goldstein, Paul - Hugenholtz, Bernt: International Copyright. Princilpes, Law and Practice, Oxford University Press, New York, 2013

GONDOL Daniella: Honnan jövünk, kik vagyunk, hová megyünk? - Gondolatok a szerzői jogi törvény módositásáról, Infokommunikáció és Jog, 2009/3. p. 72-75.

GRAD-GYENGE Anikó - SARKADY Ildikó: Közös jogkezelés az audiovizuális médiában. Médiatudományi Intézet, 2014 (http://mtmi.hu/dokumentum/513/mk10_web.pdf)

GREFFE, Xavier: Économie de la propriété artistique, Economica, Paris, 2005

GROFFE, Julie: L'oeuvre orpheline saisie par le droit, entre impératif de protection et objectif de diffusion, RLDI, 2012/78. p. 112-118. 
Guibault, Lucie - WestKamp, Guido - Rieber-Mohn, Thomas - Hugenholtz, Bernt (et al.): Study on the Implementation and Effect in Member States' Laws of Directive 2001/29/EC on the Harmonisation of certain aspects of copyright and related rights in the information society, 2007 (http://www.ivir.nl/publications/guibault/Infosoc_report_2007.pdf)

GuiBault, Lucie: Copyright limitations and contracts. An Analysis of the Contractual Overridabilitiy of Limitations on Copyright, Kluwer Law International, The Hague, 2002

GuIBAUlT, Lucie: The Reprograpy Levies cross the European Union, IViR, 2003 (http://www.ivir.nl/publicaties/download/331)

GuiBault, Lucie: Why Cherry-Picking Never Leads to Harmonisation? The Case of the Limitations on Copyright under Directive 2001/29/EC, JIPITEC, 2010/1. p. 5566.

GYENGE Anikó: A képzömüvészeti alkotások szerzői jogi védelméröl - különös tekintettel a követö jogi szabályozás módositására. Infokommunikáció és Jog, 2005b/3. p. 86-94.

GYENGE Anikó: A kivételek és korlátozások céljai a szerzői monopoljogban. In: VALENTINY Pál - KISS Ferenc László - NAGY Csongor István (szerk.): Versenyés Szabályozás 2010, MTA KRTK Közgazdaság-tudományi Intézet, Budapest, 2011. p.

72-119.

(http://econ.core.hu/file/download/vesz2010/02_szerzoi_monopoljog.pdf)

GYENGE Anikó: A szerzői jog metamorfózisai és az editio princeps jogintézménye, Magyar Jog, 2003/11. p. 649-657.

GYENGE Anikó: A szerzői jogok korlátozásának általános szabályai: a három lépcsős teszt és értelmezése, Jogtudományi Közlöny, 2006/5. p. 171-185.

GYENGE Anikó: A szerzői mü ára - dijak az egyedi felhasználási szerzödésekben 1. rész, ISZJSZ, 2004/6. (http://www.sztnh.gov.hu/hu/kiadv/ipsz/200412/01-gyengeaniko.html)

GyenGE Anikó: A szerzői mü ára - dijak az egyedi felhasználási szerzödésekben 2. rész, ISZJSZ, 2005a/1. (http://www.sztnh.gov.hu/hu/kiadv/ipsz/200502/01gyenge-aniko.html)

GYENGE Anikó: Elárvult jog nevelöszülöt keres, Magyar Jog, 2009/3. p. 160-172.

GYENGE Anikó: Szerzői jogi korlátozások és a szerzői jog emberi jogi háttere, HVGOrac, Budapest, 2010

GYENGE Anikó: Újra az árva müvekröl, Infokommunikáció és Jog, 2011/45. p. 119124.

GYENGE Anikó: Viták a szerzői jogok közös kezelésének hatékony szabályozása körül. Infokommunikáció és Jog, 2008/5. p. 198

GYERTYÁNFY Péter - FALUDI Gábor - KABAI Eszter - SzINGER András - TóTH Péter Benjamin: Szerzői müvek, védjegyek és szellemi teljesitmények az interneten - a magyar jogi védelem I. rész, 2004/12. p. 705-715.

GYERTYÁNFY Péter - FALUDI Gábor - KABAI Eszter - SzINGER András - TóTH Péter Benjamin: Szerzői müvek, védjegyek és szellemi teljesitmények az interneten - a magyar jogi védelem. II. rész, Magyar Jog, 2005/3. p. 129-141.

GYERTYÁNFY Péter (szerk.): A szerzői jogi törvény magyarázata, Complex, Budapest, $2006 b$

GYERTYÁNFY Péter (szerk.): Nagykommentár a szerzői jogi törvényhez, Wolters Kluwer, Budapest, 2014

GYERTYÁNFY Péter: A magyar közös jogkezelés az Európai Unió követelményeinek tükrében (A jogosultak és a közös jogkezelö viszonya) In: Liber Amicorum : Studia 
Gy. Boytha dedicata : ünnepi dolgozatok Boytha György tiszteletére, ELTE ÁJK, Budapest, 2004 p. 133-161.

GYERTYÁNFY Péter: A szerzői és azzal szomszédos jogok közös kezelése II. Magyar Jog, 1997b/5. p. 257-265.

GYERTYÁNFY Péter: A szerzői és azzal szomszédos jogok közös kezelése, Magyar Jog, 1997a/3. p. 129-137.

GYERTYÁNFY Péter: A szerzői jogi jogharmonizáció eredménye az EU-ban, Jogtudományi Közlöny, 2002/6. p. 271-283

GYERTYÁNFY Péter: A szerzői vagyoni jogok újraszabályozásáról, Jogtudományi Közlöny, 1995/10. p. 451-466.

GYERTYÁNFY Péter: Jog nélkül kultúra sem terem - Kultúrpolitika és szerzői jog, Magyar Jog, 2006a/8. p. 449-454.

GYERTYÁNFY Péter: Meddig terjedjen még a szerzői jog? Jogtudományi Közlöny, 2001/9. p. 337-348.

GYERTYÁNFY Péter: Szerzői jogunk és az európai integráció I. rész, Magyar Jog, 1991a/6. p. 344-350.

GYERTYÁNFY Péter: Szerzői jogunk és az európai integráció II. rész, Magyar Jog, 1991b/9. p. 534-540.

GYERTYÁNFY Péter: Szerzői jogunk és az európai integráció III. rész, Magyar Jog, 1991c/10. p. 594-600.

GYERTYÁNFY Péter: Tévúton az európai zenei közös jogkezelés, ISZJSZ, 2009/6. p. 534.

GYERTYÁNFY, Péter: Why Is a European Directive on Collective Management Necessary? A Perspective from a New Member State of the EU, Journal of the Copyright Society of the U.S.A. 2005-2006/1-2., p. 71-101.

HAJDÚ Dóra: A kereskedelmi forgalomban nem kapható könyvek digitalizálása Franciaországban, Infokommunikáció és Jog, 2013/55. p. 53-59.

HAJDÚ Dóra: Az Európai Bíróság gyakorlata a magáncélú másolatra tekintettel fizetett dijak kérdésében, ISZJSZ, 2014a/6. p. 27-69.

HAJDÚ Dóra: Bevezetés a francia szerzői jog történetébe - A kezdetektöl a nagy francia forradalom idején elfogadott törvényekig, Jogtörténeti Szemle, 2014b/1. p. 50-58.

HELFER, Laurence R.: Collective Management of Copyrights and Human Rights: An Uneasy Alliance Revisited. In: GERVAIS, Daniel: Collective Management of Copyright and Related Rights, Kluwer Law International, The Netherlands, 2010 (2nd edition) p. 75-103.

Hugenholtz, Bernt: Why the Copyright Directive is Unimportant and Possibly Invalid, EIPR, 2000/22. (11.) p. 501-502.

Hugenholtz, P. Bernt: SatCab Revisited: The Past, Present and Future of the Satellite and Cable Directive, IrisPlus, 2009/8. p.13.

Hugenholtz, P. Bernt: The Story of the Tape Recorder, in: SHERMAN, Brad WiSEMAN, Leanne (ed): Copyright and the Challenge of the New, Kluwer Law International, The Netherlands, 2012. p. 179-196.

JANSSENS, Marie-Christine: The issue of exceptions: reshaping the keys to gates int he territory of literary, musical and artistic creation. In: DERCLAYE, Estelle (ed.): Research Handbook ont he Future of EU Copyright, Edward Elgar, Cheltenham UK, Northampton, MA, USA, 2009. p. 317-348.

JOUBERT, Claude: Les sociéétés de perception et de répartition des droits. In: Droit d'auteur et droits voisins. La loi du 3 juillet 1985. Librairies Techniques, Paris, 1986, p. 181-192. 
KARAPAPA, Stavroula: A copyright exception for private copying in the United Kingdom, EIPR 2013/3. p. 129-137.

KARAPAPA, Stavroula: Padawan v SGAE: a right to private copy? EIPR 2011/33(4). p. 252-259.

KARNELL, Gunnar: Extended collective license clauses and agreements in Nordic Copyright Law, Columbia Journal of Law and the Arts, 1985-86/10. p. 73-81.

KARNELL, Gunnar: Peculiar Features of Nordic Copyright Law, NIR, 1991/60. p. 1523.

KEREVER, André: Le droit d'auteur en Europe occidentale. In: Hommage à Henri Desbois. Études de propriété intellectuelle, Dalloz, 1974, p. 35-72.

KerJean, Benoît: Pratique contractuelle. Gestion des stocks et contrat d'édition: une liberté sous contrôle, Comm. com. électr. 2011/9.

Kézikönyv a szerzői jog érvényesitéséhez. Útmutató a gyakorlat számára. ProArt Szövetség a Szerzői Jogokért, 2. kiadás, 2013 (www.szerzoijogikezikonyv.hu)

KIKKIS, Ioannis: L'avancée du droit de prêt public en Europe suite à une harmonisation qui laisse à désirer. In: BERnAUlt, Carine - ClAVIER, Jean-Pierre - LuCASSCHLOETTER, Agnès - LuCAS, François-Xavier: Mélanges en l'honneur du professeur André Lucas, LexisNexis, Paris, 2014. p. 453-464.

KoliCZY, Janusz Piotr - ANTAS, Przemysław Dominik: Copyright levies imposed on production and import of reprographic equipement not due where analogous levies have been already paid in another EU Member State: Polish Court of Appeal Judgment in Wroclaw of February 21, 2012 (I ACa 11/12), EIPR, 2012/10. p. 732-737.

KolTAY Krisztina: Néhány gondolat a közös jogkezelö szervezetek dijmegállapitásáról, különös tekintettel a reprográfiai dijakra. In: Liber Amicorum : Studia Gy. Boytha dedicata : ünnepi dolgozatok Boytha György tiszteletére, ELTE ÁJK, Budapest, 2004. p. 235-245.

KReTSCHMER, Martin: Private Copying and Fair Compensation: An empirical study of copyright levies in Europe. A Report for the UK Intellectual Property Office (October 2011), (http://www.ipo.gov.uk/ipresearch-faircomp-full-201110.pdf)

KuR, Anette: Of Oceans, Islands and Inland Water - How Much Room for Exceptions and Limitations under the Three Step-Test? Max Planck Institute for Intellectual Property, Competition and Tax Law Research Paper Series No. 08-04, (http://papers.ssrn.com/sol3/papers.cfm?abstract_id=1317707)

La gestion collective en matière de reprograhpie, OMPI - IFFRO, 2005 (http://www.wipo.int/edocs/pubdocs/fr/copyright/924/wipo_pub_924.pdf)

LAmARQue, Jean - Négrin, Olivier - AYRAUlt, Ludovic: Droit fiscal général. LexisNexis, Paris, 3e éd, 2014

LÁNCHIDI, Péter: Collective Management of Music Rights and Competition Policy in the European Union, $\mathrm{PhD}$ értekezés, 2010 (http://ajk.pte.hu/files/file/doktoriiskola/lanchidi-peter/lanchidi-peter-vedes-ertekezes.pdf)

LAPOUSTERLE, Jean: L'influence des groupes de pression sur l'élaboration des normes. Illustration à partir du droit de la propriété littéraire et artistique, Dalloz, Paris, 2009

LATREILLE, Antoine: La copie privée démythifiée, RTD Com, 2004/3. p.403.

LATREILle, Antoine: Variations autour de la définition de l'acte de copie privée, Comm. com. électr, 2010/11. p. 7-9.

LE CAM, Stéphanie: La représentativité des sociétés de gestion collective. In: Bernault, Carine - Clavier, Jean-Pierre - LuCAS-Schloetter, Agnès - 
LuCAS, François-Xavier: Mélanges en l'honneur du professeur André Lucas, LexisNexis, Paris, 2014. p. 489-503.

LE Roy, Marc: Tout ce que vous avez toujours voulu savoir sur les droits d'exploitation d'une auvre cinématographique (sans jamais oser le demander)... RLDI, 2012/82. p. 52.

LeBoIs, Audrey: Droits patrimoniaux - Droit de location et de prêt, J. Cl. Propriété littéraire et artistique, Fasc. 1254.

LEGEZA Dénes: „Segitsük az árvákat” Útmutató az árva müvek egyes felhasználásaihoz, ISZJSZ, 2012/5. p. 23-58.

LEHMAnN, Michael: The EC Directive on the Harmonisation of Certain Aspects of Copyright and Related Rights in the Information Society - A Short Comment, ICC, 2003/5. p. 521.

LinANT DE BELlEFOnDS, Xavier: Droits d'auteur et droits voisins, Dalloz, Paris, 2004

Loi $n^{\circ} 2003-517$ du 18 juin 2003 relative à la rémunération au titre du prêt en bibliothèque et renforçant la protection sociale des auteurs (JO 19 juin 2003, p. 10241), RTD Civ, 2003, p. 558.

LuCAS, André - LuCAS, Henri-Jacques - LuCAS-SCHLOETTER, Agnès: Traité de la propriété littéraire et artistique, LexisNexis, Paris, 2012

LUCAS, André: Chroniques. Exceptions - Nature et champs d'application de la rémunération pour copie privée - Conditions de l'exception, Propr. intell. 2011/38. p. 81.

LUCAS, André: Droit d'auteur et numérique, Litec, Paris, 1998

LuCAS, André: Droit de la reproduction par reprographie (CPI, art. L.122-10 à L.12212) J.Cl. Propriété littéraire et artistique, Fasc. 1265

LUCAS, André: Droits des auteurs - Droits patrimoniaux - Exceptions au droit exclusif (CPI, art. L. 122-5 et L. 331-4), J.Cl. Propriété littéraire et artistique, Fasc. 1248.

LUCAS, André: Les dits et les mon-dits de la copie privée, Propr. intell. 2012/43. p. 232239.

LUCAS-SCHLOETTER, Agnès: La rémunération pour copie privée dans la tourmente (1er partie), Légipresse, 2013a/310.

LUCAS-SCHLOETTER, Agnès: La rémunération pour copie privée dans la tourmente (2e partie), Légipresse, $2013 \mathrm{~b} / 311$.

LUCAS-SCHLOETTER, Agnès: Les éditeurs peuvent-ils percevoir la rémunération pour copie privée? RIDA, 2015/1. p. 2-99.

MACREZ, Franck: L'exploitation numérique des livres indisponibles: que reste-t-il du droit d'auteur? Receuil Dalloz, n ${ }^{\circ} 12$ du 22/03/2012. p. 749.

MARÉCHAL, Camille: Arrêts CISAC: une leçon de droit et d'économie de la gestion collective, Comm. com. électr. 2013/12. p. 6-9.

MARINO, Laure: La (discutable) logique de la redevance pour copie privée, JCP G, 2010/50. note 1256 .

MasouyÉ, Claude: Guide de la Convention de Berne pour la protection des oeuvres littéraires et artistiques (Actes de Paris, 1971), OMPI, 1978 (http://www.wipo.int/edocs/pubdocs/fr/copyright/615/wipo_pub_615.pdf)

MEZEI Péter - HAJdú Dóra: Az ACI Adam BV és társai kontra Stichting de Thuiskopie és társa ügy. Az Európai Unió Bíróságának döntése a jogellenes forrásból történő másolatkészités után fizetendö jogdijak egyes kérdéseiről, Európai Jog, 2014/5. p. 33-47.

Mezei Péter: A jogkimerülés intézményének kialakulása és fejlődése az Egyesült Államokban, ISZJSZ, 2014c/2, p. 5-77. 
MEZEI Péter: A magáncélú szabad felhasználás a német szerzői jogban, Acta Juridica et Politica, Tomus LXX., Fasc. 10., Szeged, 2007

MEZEI Péter: A szerzői jog jövője (is) a tét - Gondolatok a Google Books könyvdigitalizálási projektről, ISZJSZ, 2011/5. p. 5-47.

MezEI Péter: A szerzői jog története a törvényi szabályozásig (1884: XVI. tc.) Jogelméleti Szemle, 2004/3. (http://jesz.ajk.elte.hu/mezei19.html)

MezeI Péter: A technológia és a szerzői jog szimbiózisa, Jogtudományi Közlöny, 2012a/5. p. 197-208.

MEZEI Péter: Elképzeltem: nem lenne jó. Kritikai észrevételek egy szerzői jogi abolicionalista tanulmány kapcsán. In: PoGÁcsÁs Anett (szerk.): Quaerendo et Creando. Ünnepi kötet Tattay Levente 70. születésnapja alkalmából, Szent István Társulat. Budapest, 2014a. p. 407-423.

Mezei Péter: Szabad felhasználás az osztrák jogrendszerben, Acta Juridica et Politica, Tomus LXVIII., Fasc. 15., Szeged, 2006

MEZEI Péter: The painter, the one horn cow and ole Hank Wilson's back lot - The future of library digitization in the European Union and Hungary, kézirat

MEZEI, Peter: The New Orphan Works Regulation of Hungary, IIC, 2014b/8. p. 940952.

MINERO, Gemma: Fair compensation for the private copying exception: private use versus professional use, EIPR. 2011/33(7).

MOINET, Jacques: Les différentes législations. In: Colloque international sur la copie privée dans le monde et la protection des auteurs, artistes-interprètes et producteurs, FDMS, 1987, p. 13-18.

MuNKÁCSI Péter: Müholdas müsorsugárzás és vezeték útján történő továbbközvetités az európai joggyakorlatban; gondolatok az "Egeda"-jogeset kapcsán, ISZJSZ, 2000/5. (http://www.sztnh.gov.hu/hu/kiadv/ipsz/200010/jogeset.htm?printable=1)

NÉRISSON, Sylvie: La directive 2014/26/UE du 26 février 2014 sur la gestion collective des droits d'auteur et des droits voisins: vol au-dessus de vaches sacrées intouchables, Propr. intell. 2014/51. p. 135-150.

NÉRISSON, Sylvie: La gestion collective des droits des auteurs en France et en Allemagne : Quelle légitimité? IRJS Editions, Paris, 2013

NORDEMANN, Wilhelm: Les problèmes actuels des sociétés d'exploitation des droits d'auteur au sein de la Communauté Européenne, RIDA, 1988/135, p. 30-67.

OchoA, Tyler: Copyright Duration: Theories and Practice. In: YU, Peter K. (ed): Intellectual Property and Information Wealth: Copyright and related rights, Greenwood Publishing Group, Portsmouth, 2007, p. 133-160.

PARDO, Asunción Esteve - LUCAS-SCHLOETTER, Agnès: Compensation for private copying in Europe: recent developments in France, Germany and Spain, EIPR, 2013/35. p. 463-471.

PARIS, Thomas: Le droit d'auteur: L'idéologie et le système, PUF, Paris, 2002

PFISTER, Laurent: Histoire du droit d'auteur, J.Cl Propriété littéraire et artistique, Fasc. 1110

PFISTER, Laurent: La propriété littéraire est-elle une propriété? Controverses sur la nature du droit d'auteur au XIXe siècle, RIDA, 2005/205, p. 117-209.

PIERRAT, Emmanuel: „Droit de prêt”: un état des lieux juridique en prélude à une intervention politique, Légipresse, 2000/173. p. 77-80.

PIRIOU, Florence-Marie: „, Oeuvres orphelines”: approche d'un nouveau statut juridique français et européen, Comm. com. électr., 2012a/7-8. étude 14.

PIRIOU, Florence-Marie: Le droit de prêt public en France. In: Le droit de prêt dans le monde. Droit d'auteur et politiques culturelles, Dalloz, 2008, p. 233-241. 
PIRIOU, Florence-Marie: Nouvelle querelle des anciennes et de modernes: la loi du ler mars 2012 relative à l'exploitation numérique des livres indisponibles du XXe siècle, Comm. com. électr., 2012b/10. p. 6.

PIRIOU, Florence-Marie: Rémunération légale au titre du prêt en bibliothèque: Projet de loi d'équilibre et de „paix culturelle”, Légipresse, 2003/202. p. 91-92.

PogÁCSÁs (2012) = PoGÁCSÁs Anett: A szerzöi jogi szabályozás (h)arcai, avagy mi is a szerepe a szerzői jogi védelemnek? Iustum Aequum Salutare 2012/3-4. p. 131137.

PogÁCsÁs Anett: A szerzö jelentősége és müvével való kapcsolata. Hova tovább szerzői jog? Iustum Aequum Salutare, 2014/1. p. 149-162.

Pollaud-Dulian, Frédéric: Attribution initiale des droits d'exploitation. Réalisateur. Producteur. Présomption de cession. Rémunération pour copie privée (CJUE, 9 février 2012, Martin Luksan c/ Petrus van der Let, $n^{\circ}$ C-277/10), RTDCom $2012 \mathrm{a} / 2$.

POLLAUD-DULIAN, Frédéric: Droit de reprographie - Utilisations commerciales - CFC - Droit de divulgation - Non-épuisement, RTD Com. 2014. p. 115.

Pollaud-Dulian, Frédéric: Droit de retransmission par câble. Directive CE du 27 septembre 1993, article 9, $\S 2$. Gestion collective obligatoire. Droit exclusif ou droit de perception. Incidence de la présomption légale de cession des droits au producteur de l'œuvres audiovisuelles. RTD Com. 2006. p. 603.

Pollaud-Dulian, Frédéric: L'exception de copie privée en France. In: LuCAS, André - SiRINElli, Pierre - Bensamoun, Alexandra: Les exceptions au droit d'auteur. État des lieux et perspectives dans l'Union européenne, Dalloz, 2012b, p. 79-94.

Pollaud-Dulian, Frédéric: Le droit d'auteur, Economica, Paris, 2005

Pollaud-Dulian, Frédéric: Le droit de destination. Le sort des exemplaires en droit privé, LGDJ, Paris, 1989

Pollaud-Dulian, Frédéric: Les droits exclusifs consacrés par la directive, Propr. intell. 2002/2, p. 7.-16.

Pollaud-Dulian, Frédéric: Livres indisponibles. Licence légale. Oeuvres orphelines. Numérisation. Bibliothèque, RTDCom, 2012c/2.

Pollaud-Dulian, Frédéric: Rémunération équitable. Copie privée. Directive CE $n^{\circ}$ 2001/29, RTDCom, 2010/4.

ReInbothe, Jörg - VON LEWINSKI, Silke: The EC Directive on Rental and Lending Rights and on Piracy, Sweet \& Maxwell, London, 1993

REINBOTHE, Jörg: A szerzői jog perspektívái Európában, ISZJSZ, 2002/1. (http://www.sztnh.gov.hu/kiadv/ipsz/200202/tanulmanyok.html)

RENEAUD, Fabrice: La loi du 18 juin 2003: Une nouvelle réglementation du prêt public des livres dans les bibliothèques, RIDA, 2004/199. p. 65-109.

RenouARD, Augustin-Charles: Traité des droits d'auteur, Paris, 1839

REVET, Thierry: Droit d'auteur et droits voisins: Loi n 97-283 du 27 mars 1997 portant transposition dans le code de la propriété intellectuelle des directives $d u$ Conseil des Communautés européennes $n^{\circ}$ 93/83 du 27 septembre 1993 et 93/98 du 29 octobre 1993, RTD Civ. 1997. p. 526.

RICOLFI, Marco: Individual and collective management of copyright in a digital environment. In: TORREMANS, Paul: Copyright Law. A Handbook of Contemporary Research, Edward Elgar, Cheltenham, UK, Northampton, MA USA, 2007. p. 286-287.

RIIS, Thomas - SchovsBO, Jens: Extended Collective Licenses and the Nordic Experience - It's a Hybrid but is it a VOLVO or a Lemon? Columbia Journal of Law and the Arts, 2009-2010/4. p. 471-495. 
RIIS, Thomas - SchovsBo, Jens: Extended collective licenses in action, IIC, 2012/43. p. 930-950.

RochicCIOLI, Elie-Pierre: Point de vue sur la législation applicable aux nouveaux médias, en France, dans le domaine des droits d'auteur, RIDA, 1991/148, p. 1757.

Rosén, Jan: A Copyright Act in the Melting Pot. A New Setting for Copyright Matters, Individuality and Collectivisation of Contracts - A Swedish Proposal. In: Scandinavian Studies in Law, 2010/56. p. 398.

Rosén, Jan: The Nordic Extended Collective Licensing Model as a Mechanism for Simplified Rights Clearence for Legitimate Online Services. In: AXHAMN, Johan (ed): Copyright in a Borderless Online Environment. Norsteds juridik, Stockholm, 2012. p. 65-85.

SÁr (2007) = SÁr Csaba: A szerzői jog kihívásai a XXI. században, ISZJSZ, 2007/2. p. 34-41.

SARKADY Ildikó - GRAD-GYENGE Anikó: A média-értéklánc szerzői jogi vonatkozásai, Médiatudományi Intézet, 2012 (http://mtmi.hu/dokumentum/341/Mediaerteklanc_szerzoi_jogi_vonatkozasai.pdf)

SCHMIDT, André: Les contrats de représentation des oeuvre dramatiques et musicales dans le cadre des sociétés d'auteurs en France, LGDJ, Paris, 1971

Senftleben, Martin: Copyright, Limitations and the Three-Step Test. An Analysis of the Three-Step Test in International and EC Copyright Law. Kluwer Law International, The Hague, 2004.

SENFTLEBEN, Martin: Ni flexibilité ni sécurité juridique. Les exception au regard du triple test. In: LuCAS, André - SIRINELLI, Pierre - BENSAMOUN, Alexandra: Les exceptions au droit d'auteur. État des lieux et perspectives dans l'Union européenne, Dalloz, 2012, p. 63-71.

SHAPIRO, Ted: Directive 2001/29/EC on Copyright in the Information Society. In: LINDNER, Brigitte - SHAPIRO, Ted: Copyright in the Information Society. A Guide to National Implementation of the European Directive, Edward Elgar, Cheltenham, UK, Northampton, MA, USA, 2011, p. 27-56.

SIIRIAINEN, Fabrice: La caractère exclusif du droit d'auteur à l'épreuve de la gestion collective, Thèse, Nice, 1999

SIIRIAINEN, Fabrice: La gestion collective du droit d'auteur en droit français. In: GeIGer, Christophe - Bouyssi-Ruch, Michèle - Hilty, Reto M.: Perspectives d'harmonisation $d u$ droit d'auteur en Europe. Rencontres franco-allemandes, Lexis-Nexis Litec, Paris, 2007, p. 443-453.

SIIRIAINEN, Fabrice: Théorie générale de la gestion collective. Logique du droit exclusif de la gestion collective, J.Cl. Propriété littéraire et artistique, Fasc. 1550

SiRINELl, Pierre: États des lieux. La situation en France. In: GEIGER, Christophe Bouyssi-Ruch, Michèle - Hilty, Reto M.: Perspectives d'harmonisation $d u$ droit d'auteur en Europe. Rencontres franco-allemandes, Lexis-Nexis Litec, Paris, 2007, p. 41-50.

SIRINELLI, Pierre: La directive ,société de l'information”: apport réel ou fictif au droit d'auteur? In: Commerce électronique et propriétés intellectuelles. IRPI, Litec, Paris, 2001. p. 79-96.

SPITZ, Brad: Droit de reprographie: l'exploitation commerciale des copies, RLDI, 2010/63. p. 19-23.

STROWEL, Alain: Google Books: quel futur pour l'accès aux livres? Une bibliothèque universelle en devenir ou une future galerie commerciale? Auteurs \& Média, 2010/1. p. 1-7. 
STROWEL, Alain: Peut-on tenir compte des copies faites à partir de sources illicites pour déterminer le montant de redevances? Commentaires sur quelques décisions récentes en France, aux Pays-Bas et état du droit en Belgique, Auteurs \& Média, 2009 , p. 56.

Strowel, Alain: The European „Extended Collective Licensing” Model, Columbia Journal of Law and the Arts, 2010-2011/34. p. 665-669.

SYNODINOU, Tatiana-Eleni: E-books, a new page in the history of copyright law? EIPR, 2013/35(4), p. 220-227.

SZINGER András: How the net was won and where is got us. In: Emlékkönyv Ficsor Mihály 70. születésnapja alkalmából barátaitól, Szent István Társulat, Budapest, 2009. p. 329.

TARR Péter: Beszerezhetetlenné vált, ismét kapható könyvek. Digitálisan pótolt „, hiánycikk-könyvek” a XX. századból, ISZJSZ, 2013/6. p. 108-134.

Tószegi Zsuzsanna: A könyvdigitalizálás egyes kérdéseiröl, (http://epa.oszk.hu/01200/01245/00033/tzs_0701.htm). A tanulmány eredetileg a Magyar Tudomány, 2006/11. számában (p. 1376-1384.) jelent meg.

TÓTH PÉTER BENJAMIN: A közös jogkezelö szervezet által érvényesithetö szankciók köre, különös tekintettel a további jogsértéstől való eltiltás igényére. In:: Liber Amicorum : Studia Gy. Boytha dedicata : ünnepi dolgozatok Boytha György tiszteletére, ELTE ÁJK, Budapest, 2004, p. 309-329.

TOURNIER, Jean-Loup: L'avenir des sociétés d'auteurs, RIDA, 1996/170. p. 97.

TOURNIER, Jean-Loup: Vivre de sa musique avec la Sacem, Éditions du Rocher, Paris, 2006

TREPPOZ, Edouard: L'adaptation des exceptions du droit d'auteur au numérique: vers une recherche d'alignement, Comm. com. électr. 2010/7-8. p. 6-10.

TriaIlle, Jean-Paul - Dusollier, Séverine - DEPREEUw, Sari - Hubin, Jean-Benoît COPPENS, François - DE FRANCQUEN, Amélie (et al.): Study on the Application of Directive 2001/29/EC on Copyright and Related Right sin the Information Society (the „InfoSoc Directive”), 2013 (http://ec.europa.eu/internal_market/copyright/docs/studies/131216_study_en.pdf)

TRUMPKE, Felix: The extended collective license - A matter of exclusivity? NIR 2012/3. p. 264-294.

UJHELYI Dávid: Válságjelek és megoldásaik a digitális szerzői jogban, ISZJSZ, 2013/6. p. 69-107.

VAn Eechoud, Mireille - Hugenholtz, P. Bernt - VAn Gompel, Stef - Guibault, Lucie - HeLBERGER, Natali: Harmonizing European Copyright Law. The Challanges of Better Lawmaking, Wolters Kluwer, The Netherlands, 2009

VAN LOON, Sophie: Levies for private copying when blank media are imported: who pays? Journal of Intellectual Property Law \& Practice, 2011/12.

VERCKEN, Gilles: La gestion collective dans la tourmente? L'exemple de la reprographie, RLDI, 2005/2. p. 47-54.

VERCKEN, Gilles: La pratique des clauses relatives à la gestion collective dans les contrats individuels portant sur les droits d'auteur, Légipresse, 2002/194. p. 103109.

VIDAL, Dominique: Droit des sociétés, LGDJ, Paris, 2010

VISEGRAD INVESTMENTS: Az üreshordozó díjrendszer vizsgálata. Készült a ProArt Szövetség a Szerzői Jogokért megbizásából. Az elemzést készítette ANTAL Dániel (http://hu.scribd.com/doc/180221026/Az-ures-hordozo-dijrendszer-vizsgalata2013) 
VIVAnt, Michel - Bruguière, Jean-Michel: Droit d'auteur et droits voisins, Dalloz, Paris, 2e éd, 2013

VON Lewinski, Silke - Walter, Michel: European Copyright Law. A Commentary, Oxford University Press, Oxford, 2010

VON LEWINSKI, Silke: A szerzői jogok közös jokezelésének magyar szabályai a nemzetközi jog és az európai jog tükrében, Jogtudományi Közlöny, 2004a/7-8. p. 247-255.

VON LEWINSKI, Silke: Copyright in a Borderless Online Environment: EU Cross-Border Licensing of Rights in. AXHAMN, Johan (ed.): Copyright in a Borderless Online Environment. Norsteds juridik, Stockholm, 2012. p. 101-118.

VON LEWINSKI, Silke: International Copyright Law and Policy, Oxford University Press, Oxford, 2008

VON LEWINSKI, Silke: La gestion collective obligatoire des droits exclusifs et sa compatibilité avec le droit international et le droit communautaire du droit d'auteur - Étude de cas, e- Bulltin du droit d'auteur, Janvier - mars 2004b (http://portal.unesco.org/culture/fr/files/19552/11515904971sve_f.pdf/sve_f.pdf)

WeSTKAMP, Guido: The Implementation of Directive 2001/29/EC in the Member States, 2007 (http://www.ivir.nl/publications/guibault/InfoSoc_Study_2007.pdf)

WIPO Guide to the Copyright and Related Right Treaties Administered by WIPO and Glossary of Copyright and Related Right Terms, 2003 (http://www.wipo.int/edocs/pubdocs/en/copyright/891/wipo_pub_891.pdf)

WIPO Intellectual Property Handbook, WIPO, 2nd edition, 2008

ZOLYNSKI, Célia: Méthode de transposition des directive communautaire. Étude à partir de l'exemple du droit d'auteur et des droits voisins. Dalloz, Paris, 2007

\section{Egyéb források}

AlbANEL, Christine: Pour un livre numérique créateur des valeurs, avril 2010 (http://www.ladocumentationfrancaise.fr/rapportspublics/104000189/index.shtml)

Artisjus Felosztási szabályzat (http://www.artisjus.hu/wpcontent/uploads/2015/06/felosztasi_szabalyzat_hatalyos.pdf)

Artisjus Füzetek Zenei jogdíjfelosztás - Érthetően című kötete (http://dalszerzo.hu/2015/05/06/zenei-jogdijfelosztas-erthetoen-megjelent/)

Artisjus Támogatási politika (http://www.artisjus.hu/wpcontent/uploads/2013/04/tamogatasi_politika_hatalyos.pdf)Magyar Reprográfiai Szövetség Szervezeti és Müködési Szabályzat (http://www.reprografia.hu/doc/SZMSZ.pdf)

Az ARTISJUS Magyar Szerzői Jogvédő Iroda Egyesület közleménye a hangfelvételen többszörözött, illetve $\square$ lmalkotásokba foglalt, videón vagy DVD-n többszörözött zenemüvekre megállapított mechanikai jogdíjakról (M15)

Az ARTISJUS Magyar Szerzői Jogvédő Iroda Egyesület közleménye a magáncélú másolásokra tekintettel megállapított üres hang- és képhordozó jogdíjakról (Ü14)

Az ARTISJUS Magyar Szerzői Jogvédő Iroda Egyesület közleménye az irodalmi és zenemüvek sugárzás útján, vezetékkel vagy egyéb módon a nyilvánossághoz 
történő közvetítéséért, kódoltan történő eredeztetéséért $\square$ zetendő szerzői jogdíjakról, valamint a felhasználás engedélyezésének egyéb feltételeiröl (R-TV 15)

Az ARTISJUS Magyar Szerzői Jogvédő Iroda Egyesület közleménye rádió- vagy televízió-müsorok egyidejü, változatlan, csonkítatlan továbbközvetítói, valamint kódoltan eredeztetett rádió- vagy televízió-müsorok kódoldás után vagy (át)kódoltan történő nyilvánossághoz közvetítésében közremüködők („,kábelszervezetek”) által $\square$ fizetendő szerzői jogdíjakról, valamint a felhasználás engedélyezésének egyéb feltételeiről (Kábel 15) (https://www.artisjus.hu/wpcontent/uploads/2015/06/aktualis_jogdijkozlemeny_kabel.pdf)

Az Európai Parlament 2014. február 27-i állásfoglalása a magáncélú többszörözési jogdíjakról (2013/2114(INI)), P7 TA(2014)0179

Az Európai Parlament 2015. július 9-i állásfoglalása az információs társadalomban a szerzői és szomszédos jogok egyes vonatkozásainak összehangolásáról szóló, 2001. május 22-i 2001/29/EK európai parlamenti és a tanácsi irányelv végrehajtásáról (http://www.europarl.europa.eu/sides/getDoc.do?pubRef=(2014/2256(INI)) //EP//NONSGML+TA+P8-TA-2015-0273+0+DOC+PDF+V0//HU).

EuROPEAN COPYRIGHT SOCEITY: Opinion on the The Reference to the CJEU in Case C572/13 Hewlett-Packard Belgium SPRL v. Reprobel SCRL (5 September 2015) (http://www.create.ac.uk/wp-content/uploads/2014/03/Opinion-in-Case-C572_13HP-Belgium-Reprobel-2015.pdf)

GAILlARD, Yann: La politique du livre face au défi du numérique, 25 février 2010 (http://www.senat.fr/rap/r09-338/r09-338.html)

Green paper on copyright and the challenge of technology - Copyright issues requiring immediate action, $\operatorname{COM}(88) 172$ final, 1988 (http://ec.europa.eu/greenpapers/pdf/green_paper_copyright_and_chanllenge_of_thecnology_com_(88)_17 2_final.pdf)

Internal draft: A Copyright Policy for Creativity and Innovation in the European Union (http://ipkitten.blogspot.hu/2014/06/super-kat-exclusive-heres-commissions.html)

Javaslat a szerzői és szomszédos jogokra vonatkozó közös jogkezelésről és a zenemüvek belső piacon történő online felhasználásának több területre kiterjedő hatályú engedélyezéséről szóló 2014/26/EU irányelv magyar jogba történő átültetésének koncepciójára (http://hu.scribd.com/doc/252881981/KJK-iranyelvatultetesi-koncepcioja\#scribd)

Javaslat: Az Európai Parlament és a Tanács irányelve a szerzői és szomszédos jogokra vonatkozó közös jogkezelésről és a zeneművek jogainak belső piacon történő online felhasználásra szóló, több területre érvényes engedélyezéséről, COM(2012) 372 final

KHIARI, Bariza: Rapport fait au nom au nom de la commission de la culture, de l'éducation et de la communication sur la proposition de loi de M. Jacques Legendre relative à l'exploitation numériquedes livres indisponiblesdu XXème siècle, rapport $\mathrm{n}^{\circ} 151$ du Sénat

La gestion collective des droits d'auteur et des droits voisins, Les documents de travail de Sénat, novembre 1997

Miniszteri indokolás a szellemi tulajdonra vonatkozó egyes törvények módosításáról szóló T/4859. számú javaslathoz

PATiNO, Bruno: Rapport sur le livre numérique, 30 juin 2008, (http://www.culture.gouv.fr/culture/actualites/conferen/albanel/rapportpatino.pdf) 
Projet de rapport sur la mise en œuvre de la directive 2001/29/CE du Parlement européen et du Conseil du 22 mai 2001 sur l'harmonisation de certains aspects du droit d'auteur et des droits voisins dans la société de l'information (2014/2256 (INI)) (http://www.europarl.europa.eu/sides/getDoc.do?pubRef=//EP//NONSGML+COMPARL+PE$546.580+02+\mathrm{DOC}+\mathrm{PDF}+\mathrm{V} 0 / / \mathrm{FR} \&$ language $=\mathrm{FR})$

Rapport au nom de la commission spéciale sur le projet de loi adopté par l'Assemblée nationale relatif aux droits d'auteur et aux droits des artistes-interprètes, des producteurs de phonogrammes et de vidéogrammes et des entreprises de communication audiovisuelle, doc. Sénat $n^{\circ} 212$

Répartition des redevances auteurs - éditeurs: Livres. 2013. http://www.cfcopies.com/images/stories/pdf/Auteurs-Editeurd/Photocopie/Noticerepartition-Livre.pdf

Répartition des redevances auteurs - éditeurs: Presse. 2013. http://www.cfcopies.com/images/stories/pdf/Auteurs-Editeurd/Photocopie/Noticerepartition-Presse.pdf

Report on the responses to the Public Consultation on the Review of the EU Copyright Rules (http://ec.europa.eu/internal_market/consultations/2013/copyrightrules/docs/contributions/consultation-report_en.pdf)

Stakeholder consultation on copyright levies in a converging world, june 2006. http://ec.europa.eu/internal_market/copyright/docs/levy_reform/stakeholder_cons ultation_en.pdf

STASSE, François: Rapport au ministre de la culture et de la communication sur l'accès aux œuvres numériques conservées par les bibliothèques publiques, avril 2005 (http://www.ladocumentationfrancaise.fr/rapports-publics/054000450/index.shtml

Szellemi Tulajdon Nemzeti Hivatala Részletes koncepció a szerzői és szomszédos jogokra vonatkozó közös jogkezelésröl és a zenemüvek belső piacon történő online felhasználásának több területre kiterjedő hatályú engedélyezéséről szóló 2014/26/EU irányelv átültetéséhez megalkotandó magyar jogi szabályozás főbb tartalmi kérdéseivel kapcsolatban, (http://www.sztnh.gov.hu/sites/default/files/20150710_kjk_ire_reszletes_atultetesi _koncepcio_konzultaciora_0.pdf)

TESSIER, Marc: Rapport sur la numérisation du patrimoine écrit, 12 janvier 2010 (http://www.ladocumentationfrancaise.fr/rapportspublics/104000016/index.shtml)

VITORINO, António: Recommendations resulting from the mediation on private copying and reprography levies, Brussels, 2013. (http://ec.europa.eu/internal_market/copyright/docs/levy_reform/130131_leviesvitorino-recommendations_en.pdf)

$\begin{array}{lllll} & \text { International } & \text { Survey on } & \end{array}$ (http://www.wipo.int/export/sites/www/freepublications/en/copyright/1037/wipo_ pub_1037_2013.pdf) 


\title{
Hivatkozott jogszabályok és jogesetek jegyzéke
}

\author{
Jogszabályok
}

Magyar jogszabályok

146/1996. (IX. 19.) Korm. rendelet a szerzői és szomszédos jogok közös kezeléséről 15/1982 (IX. 20.) MM rendelet

158/2000. (IX. 13.) Korm. rendelet a reprográfiára szolgáló készüékek körének meghatározásáról

1969. évi III. törvény a szerzői jogról

1975. évi 4. törvényerejű rendelet az irodalmi és a művészeti művek védelméről szóló 1886. szeptember 9-i Berni Egyezmény Párizsban, az 1971. évi július hó 24. napján felülvizsgált szövegének kihirdetéséröl

1993. évi XXIII. tv. a Nemzeti Kulturális Alapról

1997. évi CXL. törvény a muzeális intézményekről, a nyilvános könyvtári ellátásról és a közművelődésről

1998. évi IX. törvény az Általános Vám- és Kereskedelmi Egyezmény (GATT) keretében kialakított, a Kereskedelmi Világszervezetet létrehozó Marrakesh-i Egyezmény és mellékleteinek kihirdetéséröl

1999. évi LXXVI. törvény a szerzői jogról

2004. évi XLIX törvény a Szellemi Tulajdon Világszervezete 1996. december 20-án, Genfben aláírt Szerzői Jogi Szerződésének, valamint Előadásokról és Hangfelvételekről szóló Szerződésének kihirdetéséről

2011. évi CLXXIII. törvény a szellemi tulajdonra vonatkozó egyes törvények módosításáról

2011. évi CLXXV. tv. az egyesülési jogról, a közhasznú jogállásról, valamint a civil szervezetek müködéséről és támogatásáról

2011. évi CLXXXI. törvény a civil szervezetek bírósági nyilvántartásáról és az ezzel összefüggő eljárási szabályokról

2013. évi V. törvény a Polgári Törvénykönyvről

307/2011. (XII. 23.) Korm. rendelet a közös jogkezelő szervezetek nyilvántartására, felügyeletére, felügyeleti díjára, valamint e szervezetek nyilvántartásával, felügyeletével és díjszabásának jóváhagyásával kapcsolatos eljárásokban az elektronikus úton történő kapcsolattartásra vonatkozó részletes szabályokról

\section{Francia jogszabályok}

Arrêté du 21 mars 2013 portant agrément de la Société française des intérêts des auteurs de l'écrit

Code de la Propriété Intellectuelle 
Code général des impôts

Loi des 19 et 24 juillet 1793 relatif aux droit sde propriété des auteurs, compositeurs de musiques, peintres et dessinateurs.

Loi du 20 mai 1920 frappant d'un droit au profit des artistes les ventes publiques d'objet d'art.

Loi $\mathrm{n}^{\circ}$ 2000-719 du 1 août 2000 modifiant la loi $\mathrm{n}^{\circ}$ 86-1067 du 30 septembre 1986 relative à la liberté de communication

Loi ${ }^{\circ}$ 2001-624 du 17 juillet 2001 portant diverses dispositions d'ordre social, éducatif et culturel

Loi $\mathrm{n}^{\circ}$ 2006-961 du 1 août 2006 relative au droit d'auteur et aux droits voisins dans la société de l'information

Loi n 2011-1898 du 20 décembre 2011 relative à la rémunération pour copie privée.

Loi $n^{\circ} 2011-590$ du 26 mai 2011 relative au prix du livre numérique

Loi $n^{\circ}$ 2012-287 du 1er mars 2012 relative à l'exploitation numérique des livres indisponibles du XXe siècle.

Loi $\mathrm{n}^{\circ}$ 2012-287 du 1er mars 2012 relative à l'exploitation numérique des livres indisponibles du XXe siècle

Loi $\mathrm{n}^{\circ}$ 2015-195 du 20 février 2015 portant diverses dispositions d'adaptation au droit de l'Union européenne dans les domaines de la propriété littéraire et artistique et du patrimoine culturel.

Loi $\mathrm{n}^{\circ}$ 85-660 du 3 juillet 1985 relative aux droits d'auteur et aux droits des artistesinterprètes, des producteurs de phonogrammes et de vidéogrammes et des entreprises de communication audiovisuelle

Loi $\mathrm{n}^{\circ}$ 95-4 du 3 janvier 1995 sur la reprographie

Loi $n^{\circ}$ 97-283 du 27 mars 1997 portant transposition dans le code de la propriété intellectuelle des directives du Conseil des Communautés européennes $n^{\circ}$ s 93/83 du 27 septembre 1993 et 93/98 du 29 octobre 1993.

Loi n ${ }^{\circ} 57-298$ du 11 mars 1957 sur la propriété littéraire et artistique

Loi $n^{\circ} 2000-719$ du 1er août 2000 modifiant la loi n 86-1067 du 30 septembre 1986 relative à la liberté de communication

\section{EU és nemzetközi jogi jogforrások}

Az Európai Parlament és a Tanács 96/9/EK irányelve (1996. március 11.) az adatbázisok jogi védelméről

Az Európai Közösségek Tanács 89/552/EK irányelve a tagállamok törvényi, rendeleti vagy közigazgatási intézkedésekben megállapított, televíziós müsorszolgáltató tevékenységre vonatkozó egyes rendelkezéseinek összehangolásáról

Az Európai Parlament és a Tanács 2001/29/EK irányelve (2001. május 22.) az információs társadalomban a szerzői és szomszédos jogok egyes vonatkozásainak összehangolásáról

Az Európai Parlament és a Tanács 2001/84/EK irányelve (2001. szeptember 27.) az eredeti műalkotás szerzőjét megillető követő jogról

Az Európai Parlament és a Tanács 2009/24/EK irányelve (2009. április 23.) a számítógépi programok jogi védelméről (kodifikált változat) 
Az Európai Parlament és a Tanács 2011/77/EU irányelve (2011. szeptember 27.) a szerzői jog és egyes szomszédos jogok védelmi idejéröl szóló 2006/116/EK irányelv módosításáról

Az Európai Parlament és a Tanács 2012/28/EU irányelve az árva müvek egyes megengedett felhasználási módjairól

A Tanács 93/83/EGK irányelve (1993. szeptember 27.) a müholdas müsorsugárzásra és a vezetékes továbbközvetítésre alkalmazandó egyes szerzői és szomszédos jogi szabályok összehangolásáról

Az Európai Parlament és a Tanács 1215/2012/EU rendelete (2012. december 12.) a polgári és kereskedelmi ügyekben a joghatóságról, valamint a határozatok elismeréséről és végrehajtásáról

Az Európai Parlament és a Tanács 2006/115/EK irányelve (2006. december 12.) a bérleti jogról és a haszonkölcsönzési jogról, valamint a szellemi tulajdon területén a szerzői joggal szomszédos bizonyos jogokról (kodifikált változat)

Az Európai Parlament és a Tanács 2006/116/EK irányelve (2006. december 12.) a szerzői jog és egyes szomszédos jogok védelmi idejéről (kodifikált változat)

Az Európai Parlament és a Tanács 2014/26/EU irányelve (2014. február 26.) a szerzői és szomszédos jogokra vonatkozó közös jogkezelésről és a zenemüvek belső piacon történő online felhasználásának több területre kiterjedő hatályú engedélyezéséről

Az irodalmi és a müvészeti müvek védelméről szóló 1886. szeptember 9-i Berni Egyezmény Párizsban, az 1971. évi július hó 24. napján felülvizsgált szövege

Marrakesh Treaty to Facilitate Access to Published Works for Persons Who Are Bind, Visually Impaired, or Otherwise Print Disabled

\section{Jogesetek jegyzéke}

\section{Magyar bírósági döntések}

BH 1992.756.

BH 1993.158.

BH 2001.380.

Debreceni Ítélőtábla Pf.I.20.220/2010/4.

Fővárosi Bíróság 29.P.24.337/2009/22.

Fővárosi Bíróság P.20.497/2008/18.

Fővárosi Bíróság P.22.419/2006/25.

Fővárosi Ítélőtábla 8.Pf.20.304/2007/7.

Fővárosi Ítélőtábla 8.Pf.21.470/2011/4.

Győri Ítélőtábla Gf.I.20.007/2011/14.

Kúria Pf.IV.21.272/2012/7.

LB Pf.IV.721/1984/9.

\section{SZJSZT szakvélemények}


SZJSZT 01/2009/1.

SZJSZT 15/08.

SZJSZT 17/2006.

SZJSZT 18/2010.

SZJSZT 21/07/1.

SZJSZT 38/2000.

SZJSZT 43/07/01.

\section{Francia bírósági döntések}

C.cass. civ. 1re, 11 décembre 2013

C.cass. civ. 1re, 11 décembre 2013

CA Orléans, 8 févr. 1990, RIDA janv. 1991, p. 333, note Gaudel. Cass. 1re civ., 15 novembre 1991: Bull. civ. I, n 303, D. 1992, p. 361, note Edelman et 1993, somm. comm. 89, obs. Colombet

CA Paris 24 mars 2004

CA Paris 24 mars 2004

CA Paris 2e ch 27 mai 2011

CA Paris 2e ch 27 mai 2011

CA Paris, 12 sept. 2008, SAIF et al. c/ SARL Maïa Films et al. RTD Com, 2009, p.137, obs. F. Pollaud-Dulian, Comm. com. électr. 2008, étude 23, note P.-Y. Gautier, Légipresse 2008, ${ }^{\circ}$ 257, III, p. 238, note P. Boiron et E. Mirat; RLDI 2008/11, n 1429 , note B. Khalvdijan

CA Paris, 13e ch. 28 avril 2000, RIDA janv. 2001, p. 303. Comm. com. électr. 2001. comm. 36 note C. Caron.

CA Paris, 22 mars 2007, CCE 2007, $\mathrm{n}^{\mathrm{0}} 70$, note Caron

CA Paris, 4ch 22 avr. 2005, RIDA 1/2006, p. 374, JCP G 2005, II, 10126, note Geiger, Comm. com. électr. 2005, comm 98, note Caron, Propr. intell. 2005, p. 340, obs. A. Lucas et Sirinelli

CA Paris, 4e ch., 11 juin 1997: RIDA 1997/4, p. 255.

CA Paris, 4e ch., 1er juill. 1998: RIDA janv. 1999. p. 390.

CA Paris, 6 mars 1933: Gaz. Pal. 1933, p. 958; S. 1935, 1. p, note Gény

CA Paris, pôle 5, 4e ch. 3 juill. 2013, Comité prof. des galeries d'art: Propr. intell. 2014, $\mathrm{n}^{\mathrm{o}} 50$, p. 84 , note Lucas

CA Paris, pôle 5, 4e ch., 12 déc. 2012, D. 2013, act. 174.obs. Emile-Zola-Place

Cass. $1^{\text {re }}$ civ., 10 févr. 1987, SACEM, Bull. civ. I, p. 50.

Cass. 1re civ., 13 oct. 1993: JCP G 1993, IV, 2628; D. 1994, 138 note Edelman; D. 1994, somm. comm. (sommaire commenté) 93, obs. Colombet, arrêt cassé: Paris, 4e ch 28 janv. 1991, 28 janv. 1991, D. 1992, somm. 17, obs. Colombet

Cass. 1re civ., 28 juin 1988 : RIDA avr. 1989, p. 220

Cass. civ., 8 déc. 1913, SACD: Gaz. Pal. 1924, 1, p. 93.

Cass. crim., 12 mars 2013, $\mathrm{n}^{\circ}$ 12-85.163, F-D, Alexis M. et les Éditions du Cerf: JurisData $\mathrm{n}^{\circ}$ 2013-006702.

Cass. crim., 30 janv. 1978 : D. 1979, p. 583, note J. Le Calvez ; Gaz. Pal. 1978, 2, p. 466 ; RTD com. 1979, p. 456, obs. A. Françon

Cass. crim., 4 janv. 1991 : JurisData ${ }^{0}$ 1991-003606. 
CE 10e et 9e ss-sect, 17 déc. 2010, n ${ }^{\circ}$ 314308, Comm. com. électr. 2011, chron. 9, obs. P. Tafforau; Comm. com. électr. 2012, chron 4, obs. X Daverat

$\mathrm{CE} 10 \mathrm{e}$ et 9e ss-sect. réunies, 11 juillet 2008, Synd. de l'industrie des matériels audiovisuels électroniques c/ Sorecop et Copie France: Propr. intell. 2008, no 29, p. 428, obs. A. Lucas

CE 8 déc. 2000, n 202076 et 203626, Assoc. „Protection des ayants droit”, JurisData ${ }^{\circ}$ 2000-061506; Comm. com. électr. 2001, comm. 15, obs. Caron

CE 9e et 10e ss-sect., 17 juin 2011 n $^{\circ}$ 324816, Propr. intell. 2011, $\mathrm{n}^{\circ}$ 41, p. 401. obs. A. Lucas; D. 2012, p. 2836, P. Sirinelli ; RTDE 2011, p. 888, obs. D. Ritleng ; LPA 16 nov. 2011, $\mathrm{n}^{\circ}$ 228, p. 5, note A. Troianiello ; Gaz. Pal. 27 oct. 2011, jurispr. p. 3072, note L. Marino ; Comm. com. électr. 2012, chron. 9, obs. P. Tafforeau ; Comm. com. électr. 2012, chron. 4, obs. X. Daverat

CE, 10e et 9e ss-sect. 17 déc. 2010, n ${ }^{0}$ 310195: JurisData no 2010-024376, Comm. com. électr. 2011, chron. 9. obs. P. Tafferau; Comm. com. électr. 2012, chron. 4, obs. X. Daverat.

Civ 1re 27 novembre 2008, Propr. intell, 2009, n ${ }^{0} 31$, p. 170, obs. Bruguière

Civ. 1re 20 janv. 1969: Gaz. Pal. 1969. 1. 217.

Civ. 1re, 28 février 2006, Studio Canal et Sté Universal Pictures et al. c/ UFC Que Choisir et Perquin, dit „Mulholland Drive”, $\mathrm{n}^{\circ}$ 05-15.824

Civ. 1re, du 25 mai 2005, 02-17305

Conseil d'Etat, (10e et 9e sous-sect. réunies), 6 mai 2015, M. G. AQ. et a.

Crim. 18 décembre 2001. D. 2002. AJ 646, Légipresse $2002 \mathrm{n}^{0}$ 190, III, p. 62, CCE 2002, $\mathrm{n}^{\mathrm{O}} 37$, note Caron, RIDA avr. 2002, p. 377, obs. Kérever

Montpellier, 3e ch corr. 10 mars 2005 SACEM c/ Aurélien D: JCP G 2005, II, 10078, note Caron; JCP E 2005, no 1216, § 4, obs. Pignatari; JCP E 2006, no 1195, $\S 8$, obs. Vivant; D. 2005, jurispr. p. 1294, note Kessler; D. 2005, pan. p. 1488, obs. Sirinelli; Propr. intell. 2005, no 15, p. 165, obs. Sirinelli; RLDI 2005 mars, no 86 p. 21, obs. Costes; Rev. Lamy dr. aff. avr. 2005, no 5086, obs. Costes; Légipresse 2005, no 222, III, p. 120 note Wekstein; Comm. com. électr. 2005, comm. 77, note Caron.

Paris, 20 février. 1990: RIDA juill. 1990, p. 365. D. 1991. Somm. 100 obs, Colombet

Paris, 4e ch., 1er oct. 1990, D. 1990. IR. 235; RIDA 1991, n 149, 206, obs. Kéréver

Paris, 4e ch., 22 avr. 2005, et Paris 4e ch. 4 avr. 2007.

Paris, 8. oct. 1982, RIDA janv. 1983, p. 138. RTD Com. 1983. 434 obs. Françon.

T. com. Bobigny, 15 septembre 2005, CCE 2005, n ${ }^{\circ} 168$, note Caron

TGI Paris 3 e ch, 2e sect., 9 juillet 2010

TGI Paris 3 e ch, 2e sect., 9 juillet 2010

TGI Paris, 11 mai 2000, (RIDA avril $2001 \mathrm{n}^{\circ} 188$, p. 379)

TGI Paris, 17 janvier 1990. RIDA, avr. 1990,p. 231

TGI Paris, 1re ch., 1re sect, 17 janv. 1990: JurisData no 1990-046766; RIDA 1990 no 144, p. 231; JCP G 1990, I, 4378, obs. B. Edelman.

TGI Paris, 3e ch, 1 re sect. 16 sept. 2003 État fançais c/ Laing et al.,(nem közzétett)

TGI Paris, 3e ch, 1re sect. 16 sept. 2003, État fançais c/ Laing et al.,(inédit).

TGI Paris, 3e ch., 19 juin 1998: RIDA 1999/2, p. 410.

TGI Paris, 3e ch., 1er sect. 15 mai 2012, Propr. intell. 2012, n 44, p. 338, obs. A Lucas; RLDI, août/sept 2012, p. 28. obs. L Costes

TGI Paris, ord.réf. 6 août 2008, RIDA 2008, n² 217, p. 343. et p. 247. obs. Sirinelli, Propr. intell. 2008, n29, 427 obs. JM Bruguière

TGI Paris, réf. 10 juin 1997: D. Affaires 1997. 1156: D. 1998, 621 note Edelman; JCP 1997 II. 22974, obs. Olivier; Expertises, août 1997, p. 283. 
TGI Paris, réf., 5 mai 1997, Queneau: RIDA oct. 1997. p. 265; JCP 1997. II. 22906, note Olivier; Expertises, juin-juill. 1997, p. 219.

\section{Az Európai Unió Bíróságának döntései és fötanácsnoki indítványok}

A 7/82. sz. Gesellschaft zur Verwertung von Leistungsschutzrechten mbH (GVL) kontra az Európai Közösségek Bizottsága ügyben 1983. március 2-án hozott ítélet

A C-360/13. sz. Public Relations Association Agency-ügyben 2014. június 5-én hozott ítélet

A C-92/92. és C-326/92. sz. egyesített Phil Collins-ügyben 1993. október 20-án hozott ítélet

A C-271/10, Vereniging van Educatieve en Wetenschappelijke Auteurs (VEWA) c/ Belgische Staat ügyben 2011. június 30-án hozott ítélet

A C-403/08. sz. Football Association Premier League és társai ügyben 2011. október 4én hozott ítélet

A 127-73. sz BRT c/ SABAM et Fonior ügyben 1974. március 24-én hozott ítélet

A C-360/00. sz. Puccini II. ügyben 2002. június 6-án hozott ítélet

A C-245/00. SENA-ügyben 2003. február 6-án hozott ítélet

A C-169/05. sz. Uradex-ügyben 2006. június 1-jén hozott ítélet

A C-479/04. sz. Laserdisken-ügyben 2006. szeptember 12-én hozott ítélet

A C-456/06. sz. Peek and Cloppenburg-ügyben 2008. április 17-én hozott ítélet

A C-5/08. sz. Infopaq International ügyben 2009. július 16-án hozott ítélet

A C-518/08. sz. Fundación Gala-Salvador Dalí ügyben 2010. április 15-én hozott ítélet

A C-467/08. sz. Padawan-ügyben 2010. október 21-én hozott ítélet

A C-462/09. sz. Opus-ügyben 2011. június 16-án hozott ítélet

A C-145/10. sz. Painer-ügyben 2011. december 1-jén hozott ítélet

A C-302/10. sz. Infopaq International-ügyben 2012. január 17-én hozott végzés

A C-277/10. sz. Luksan-ügyben 2012. február 9-én hozott ítélet

A C-510/10. sz. DR és TV2 Danmark-ügyben 2012. április 26-án hozott ítélet

A C-607/11. sz. TVCatchup-ügyben 2013. március 7-én hozott ítélet

A C-457/11-C-460/11. sz. VG Wort egyesített ügyekben 2013. június 27-én hozott ítélet

A C-351/12. sz. OSA-ügyben 2014. február 27-én hozott ítélet

A C-435/12. sz. ACI Adam-ügyben 2014. április 10-én hozott ítélet

A C-117/13. sz. Eugen Ulmer-ügyben 2014. szeptember 11-én hozott ítélet

A C-117/13. sz. Ulmer ügyben 2014. szeptember 11-én hozott ítélet

A C-516/13 sz. Dimensione Direct Sales and Michele Labianca ügyben 2015. május 13-

án hozott ítélet

A C-572/13. sz. Reprobel-ügyben 2015. november 12-én hozott ítélet

A C-41/14. sz. Christie's France-ügyben 2015. február 26-án hozott ítélet

A C-463/12. sz. Copydan Båndkopi-ügyben 2015. március 5-én hozott ítélet

A C-521/11. sz. Amazon-ügyben 2013. július 11-én hozott ítélet

A C-572/13. sz. Reprobelel-ügyben 2015. június 11-én nyilvánosságra hozott főtanácsnoki indítvány

A C-467/08. sz. Padawan-ügyben ismertetett fötanácsnoki indítvány

A C-457/11-C-460/11. sz. VG Wort-ügyben ismertetett fötanácsnoki indítvány

A C-435/12. sz. ACI Adam-ügyben ismertetett fötanácsnoki indítvány

A C-462/09. sz. Opus-ügyben ismertetett főtanácsnoki indítvány 
A C-431/09. és C-432/09. sz. egyesített Airfield-ügyekben 2011. március 17-én ismertetett fötanácsnoki indítvány

\section{Egyéb döntések}

$124 / \mathrm{B} / 2004$. AB végzés

71/224/CEE Décision de la Commission du 2 juin 1971 relative à une procédure d'application de l'article 86 du traité CEE (IV/26760 — GEMA)

81/1030/EEC: Commission Decision of 29 October 1981 relating to a proceeding under Article 86 of the EEC Treaty (IV/29.839 - GVL), Official Journal L 370 , 28/12/1981 P. 0049 - 0059

Affaire COMP/C2/37.219 Banghalter \& Homem Christo v SACEM („Daft Punk”)

C.Cass. des Pays-Bas, 30 oct. 1981 (RIDA avr. 1982.)

Décision $\mathrm{n}^{\mathrm{o}} 13 \mathrm{du} 12$ janvier 2011 (Commission copie privée)

Décision $n^{0} 14$ du 9 février 2012 (Commission copie privée)

Décision $n^{0} 2013-370$ QPC du 28 février 2014.

Décision $\mathrm{n}^{\mathrm{0}} 7 \mathrm{du} 20$ juillet 2006 (Commission copie privée)

Décision $n^{0} 8$ du 9 juillet 2007 (Commission copie privée)

Décision $\mathrm{n}^{0} 9 \mathrm{du} 11$ décembre 2007 (Commission copie privée)

Sentencia del Juzgado de Primera Instancia ${ }^{\circ} 7$ de Alcalá de Henrares, juicio verbal número 726/2004, valamint Sentencia de la Audiencia Provincial de Málaga, Rollo 267/2006

SUISA (Swiss Society of Authors and Publishers) v. Rediffusion AG, Bundesgericht (Swiss Federal Supreme Court) [1982] ECC 481 (BGE 107 II 57) 20 January 1981

Tribunal fédéral suisse, 20 mars 1984 (RIDA 1985 janv)

WTO Panel DS160 - United States Section 110(5) Copyright Act 


\section{Tartalomjegyzék}

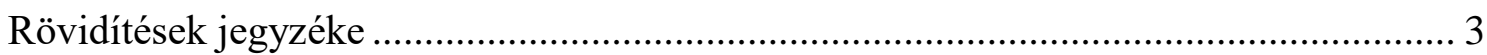

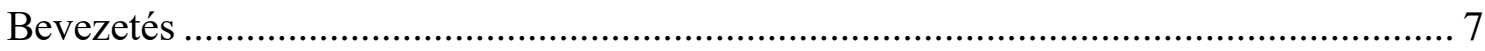

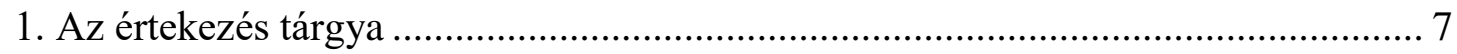

2. A vizsgálati módszer és az értekezés felépítése .................................................. 19

I. rész Fogalmi és elméleti keretek - a közös jogkezelés két eltérő felfogása................ 21

I. fejezet A szerzői jog korlátai, korlátozása …..................................................... 22

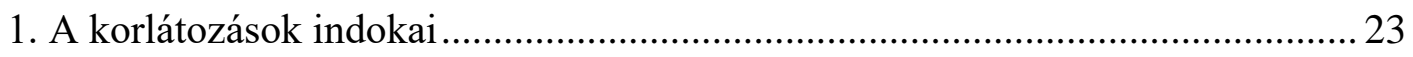

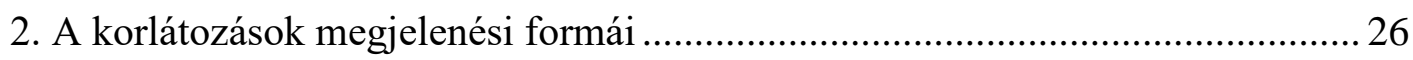

II. fejezet A közös jogkezelés fogalma és szervezeti háttere .................................... 34

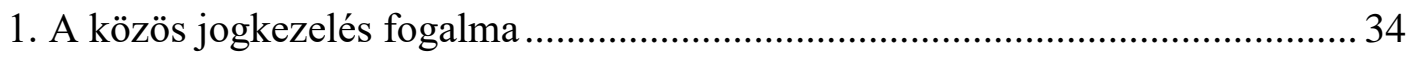

§1. A fogalom meghatározásának elutasítása .................................................. 34

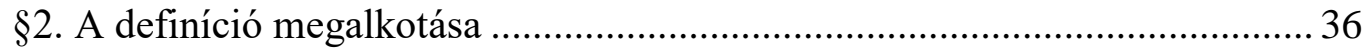

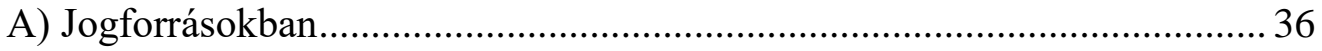

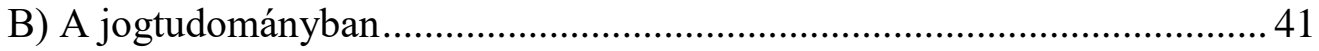

2. A közös jogkezelés szervezeti háttere ............................................................ 44

§1. A jogosultak önkorlátozása.................................................................. 46

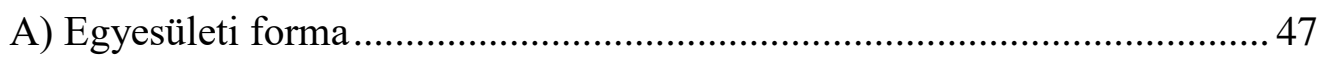

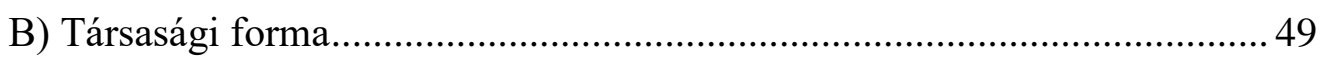

§2. A közös jogkezelési tevékenység korlátok közé szorítása...........................54

A) Állami beavatkozás az alapítás során .................................................. 54

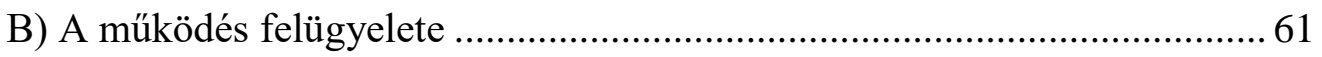

a) A müködés felügyeletének általános szabályai ................................... 61

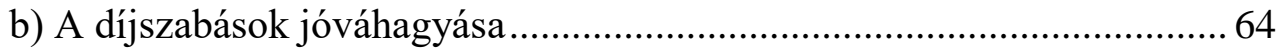

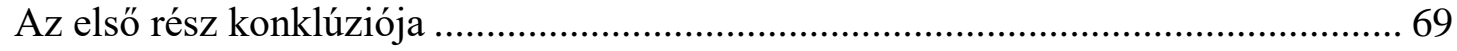


II. rész A törvény által elöírt közös jogkezelés, mint a kizárólagos jog korlátja ............. 71

I. fejezet A jog gyakorlásának korlátozása a közös jogkezelés előírásával ................ 73

1. A nyilvánossághoz közvetítés körébe tartozó egyes jogok közös kezelése ........ 75

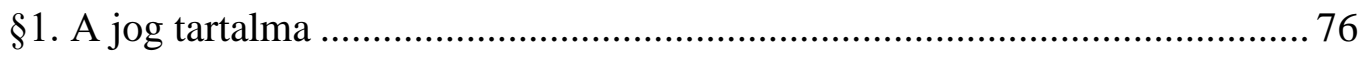

A) Nyilvános előadás, nyilvánossághoz közvetítés és ezekhez köthető egyéb

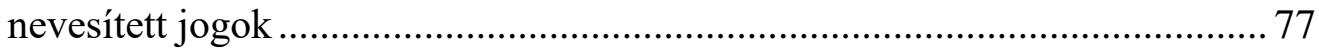

B) A vezetékes továbbközvetítési jog tartalmi elemei................................. 81

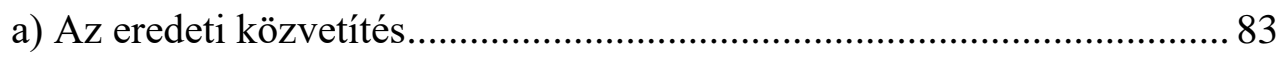

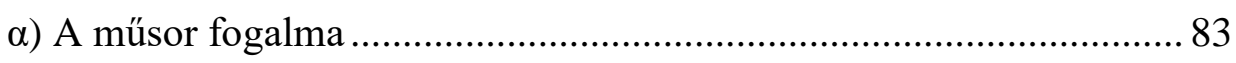

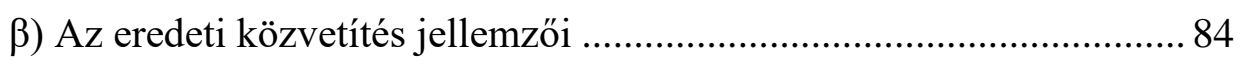

b) A továbbközvetítés jellemzői .......................................................... 85

a) A továbbközvetítés technikai megvalósulása..................................... 85

Egyidejü, változatlan és teljes.......................................................... 85

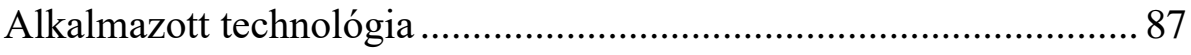

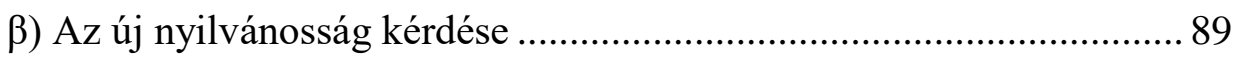

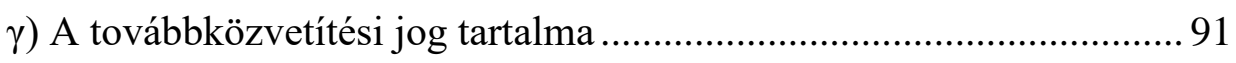

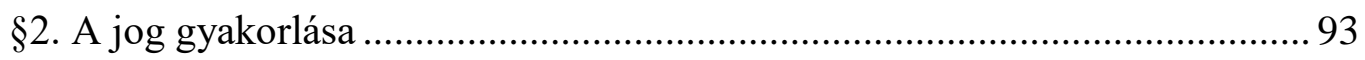

A) A vezetékes továbbközvetítéssel rokon jogok gyakorlása ......................94

B) A vezetékes továbbközvetítési jog gyakorlása ........................................ 95

a) A jogosultak képviselete.................................................................. 95

b) Az engedélyek megadása ............................................................... 97

c) A jogdíjak beszedése és felosztása ................................................... 99

d) Kivétel a kötelező közös jogkezelés alól ......................................... 100

2. A többszörözés jogával kapcsolatos közös jogkezelés.................................... 101

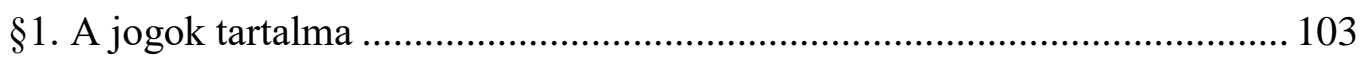

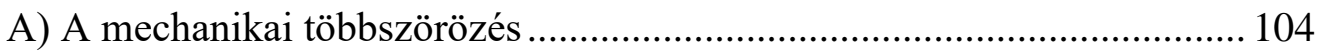

a) A mechanikai többszörözés fogalma .................................................... 104

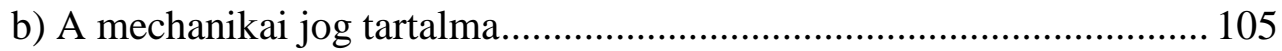

a) Az érintett jogok köre................................................................. 105

ß) Többszörözés vagy átdolgozás? .................................................... 107

B) A reprográfia útján megvalósuló többszörözés ..................................... 108 


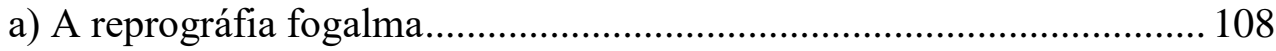

a) A papír vagy ehhez hasonló hordozó követelménye ........................ 108

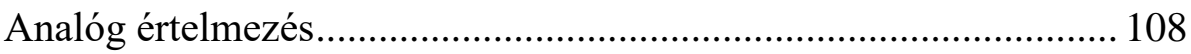

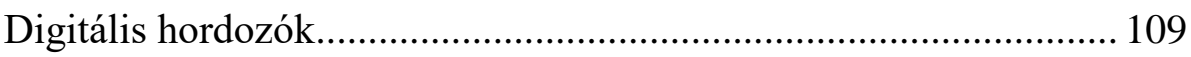

$\beta$ ) A fotómechanikai vagy azzal azonos hatással bíró eljárás................ 110

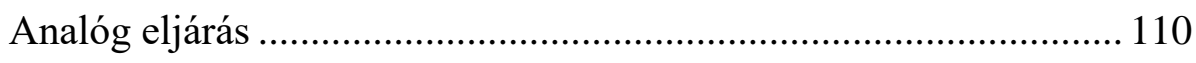

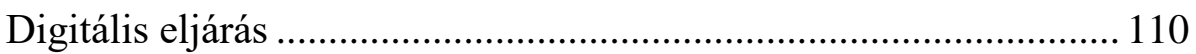

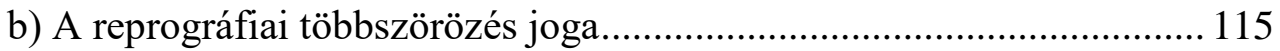

๔) A kizárólagos jog..................................................................... 115

ß) A kizárólagos jog viszonya a kivételekhez ..................................... 116

§2. A jogok gyakorlása ......................................................................... 119

A) A jog gyakorlásának átengedése....................................................... 119

a) A ,klasszikus” törvényi fordulat alkalmazása .................................... 120

a) A korábban hatályos szöveg ........................................................ 120

§) A jelenleg hatályos szöveg .......................................................... 120

b) A jog átszállása a közös jogkezelő szervezetre .................................. 121

a) Az átszállás természete............................................................. 121

ß) Az átszállás korlátai.................................................................... 123

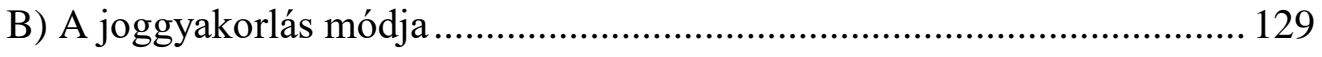

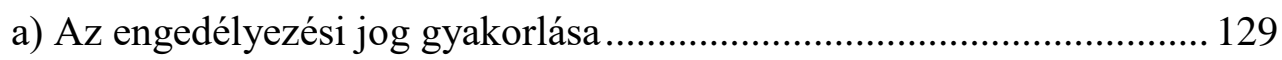

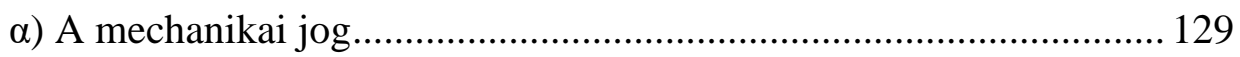

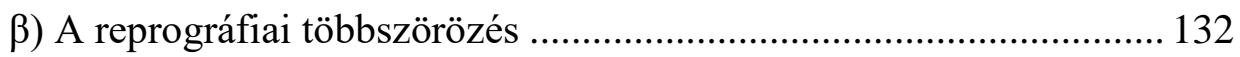

b) A jogdíjak beszedése és felosztása .................................................. 133

II. fejezet A kizárólagos jog díjigényre korlátozása révén bevezetett közös jogkezelés 137

1. Hasonló probléma, eltérő megoldás .............................................................. 138

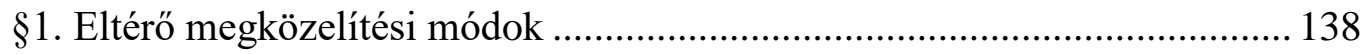

A) A felhasználás jellemzői .................................................................... 139

B) Az eltérő szabályozásból adódó különbségek .................................... 142

§2. A többszörözési jog korlátozása és a háromlépcsős teszt .......................... 145

A) A háromlépcsős teszt a különböző szintü jogforrásokban...................... 145

a) A teszt egyes szövegváltozatai ........................................................ 145

b) A teszt szerepének változása .............................................................. 147 
B) A teszt értelmezése

a) A teszt értelmezése nemzetközi és uniós szinten .............................. 149

๔) A WTO vitarendezési panel és a nemzetközi szakirodalom ............ 150

$\beta)$ Az ACI Adam-ügy és az uniós értelmezési keretek........................ 153

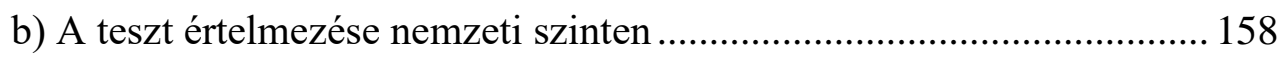

2. A magáncélú többszörözésre tekintettel fennálló díjigény közös jogkezelése.. 159

§1. A magáncélú többszörözés fogalmi elemei .............................................. 160

A) A többszörözést végző személy ......................................................... 161

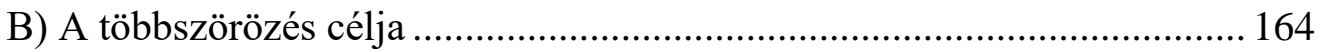

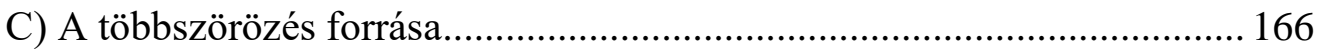

§2. A közös jogkezelés müködése ............................................................. 169

A) A felhasználásért fizetendő díj ........................................................... 170

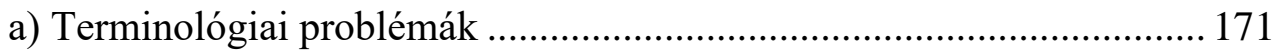

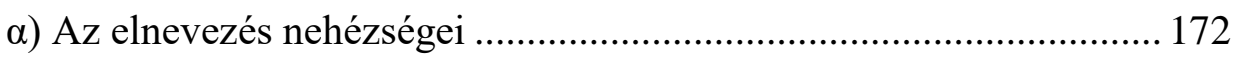

A méltányos díjazás az uniós jog önálló fogalma............................ 172

A díjazás eltérő használata........................................................... 174

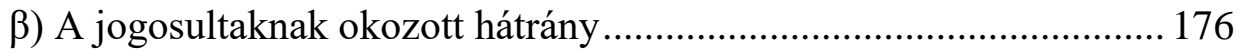

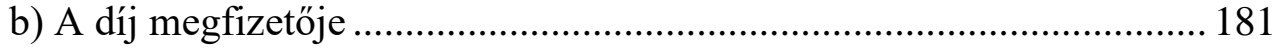

a) A hátrányt okozó személy ........................................................... 181

ß) A felhasználások szétválasztása .................................................. 186

Vállalkozások és természetes személyek általi felhasználás közötti

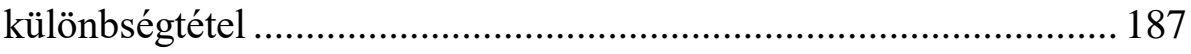

Megkülönböztetés a természetes személyek általi felhasználások

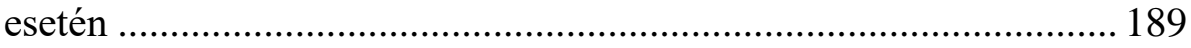

c) A díjazás meghatározásánál alkalmazandó egyéb szempontok............ 193

๔) A hatásos müszaki intézkedések szerepe a díj megállapításában..... 194

ß) A díjazással terhelhető hordozók................................................... 195

B) A díjak felosztása.......................................................................... 200

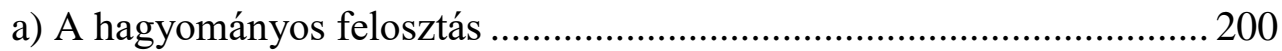

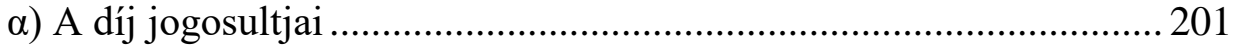

$\beta)$ A díjról való lemondás lehetősége ............................................... 208

b) A szociális és kulturális célok .............................................................. 209 
A második rész konklúziója 213

III. rész A törvény által elöírt közös jogkezelés, mint a joggyakorlás módja 216

I. fejezet Az engedélyezési jog gyakorlása kilépést engedö közös jogkezelés körében 218

1. Kilépést engedő közös jogkezelés: kötelező közös jogkezelés és az egyéni joggyakorlás között

§1. A közös jogkezelés tárgya: a kereskedelmi forgalomban nem kapható

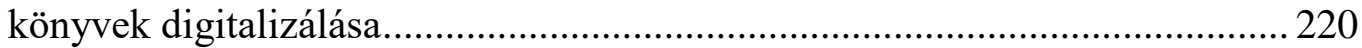

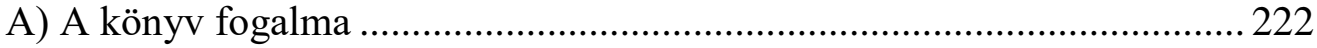

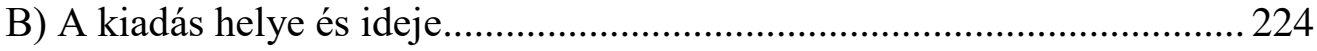

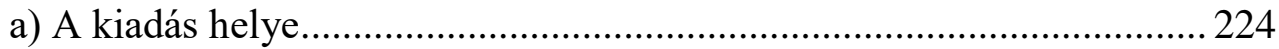

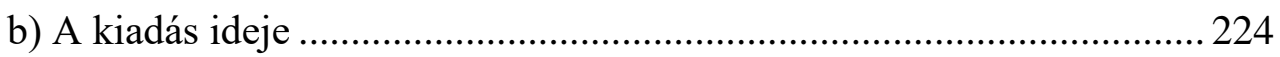

C) Kereskedelmi forgalomban nem kapható .............................................. 226

a) A könyv kereskedelmi forgalomban nem kapható ............................... 226

b) A mü nem képezi újabb kiadás tárgyát.............................................. 227

§2. A közös jogkezelés a gyakorlatban........................................................ 228

A) A közös jogkezelés müködése ........................................................ 229

a) A kilépési lehetőségek gyakorlása ..................................................... 229

a) Tiltakozás a nyilvántartásba vétel ellen........................................ 229

$\beta)$ Kilépés a közös jogkezelés alól................................................... 231

b) Az engedélyek megadása és a jogdíjak felosztása .............................. 233

๔) Az engedélyek megadása ............................................................... 233

ß) A jogdíjak beszedése és felosztása ............................................... 233

B) A nemzetközi és uniós jogi keretek, alkotmányossági kérdések ............. 235

2. Kilépést engedő, kiterjesztett hatályú közös jogkezelés: a rendelkezési jog

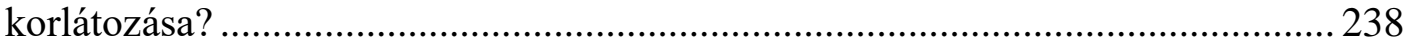

§1. A kiterjesztett közös jogkezelés szervezeti oldala .................................. 242

A) A reprezentativitás követelménye ..................................................... 242

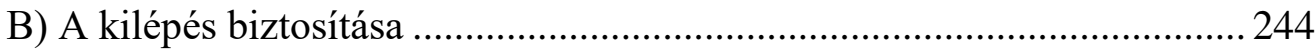

§2. Az engedélyezési jogok gyakorlása ................................................... 247

A) A felhasználási engedélyek megadása................................................. 247 
B) A nem tag jogosultak és a közös jogkezelő viszonya ............................ 248

II. fejezet Közös jogkezelés a hatékonyság szolgálatában.................................... 251

1. A bérlet és haszonkölcsönzési jog tekintetében fennálló díjigények közös kezelése.

$\S 1$. A bérlet és haszonkölcsönzési jog tartalma ............................................ 253

A) A vagyoni jogok meghatározása.......................................................... 253

a) A nyilvános haszonkölcsönzési jog jellemzöi .................................... 254

a) A haszonkölcsönzési jog tartalma ................................................. 254

A haszonkölcsönzési jog fogalma.................................................. 254

A haszonkölcsönzési jog közvetett tárgya és jogosultja ................... 258

ß) A haszonkölcsönzési jog rendszertani elhelyezése, egyéb jellemzői258

A haszonkölcsönzés a vagyoni jogok között .................................. 258

A haszonkölcsönzési jog szerepe.................................................. 260

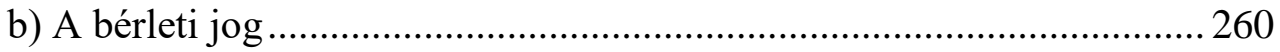

a) A bérleti jog tartalma................................................................... 261

$\beta)$ A bérbeadásra tekintettel a szerzőt megillető díjigény..................... 261

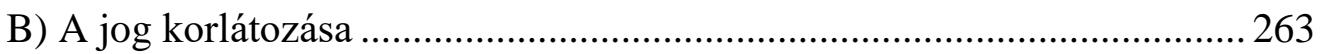

a) A nyilvános haszonkölcsönzési jog korlátozása ................................... 263

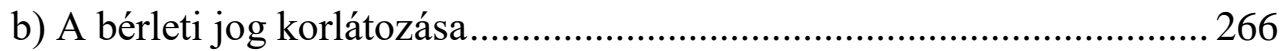

§2. A jog gyakorlásának módjai ................................................................... 266

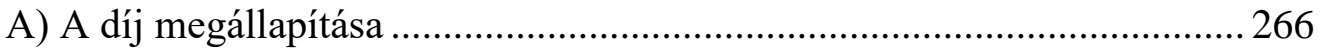

a) A díj megállapításának általános szempontjai .................................... 267

b) A díj megállapításának konkrét módozatai ........................................... 269

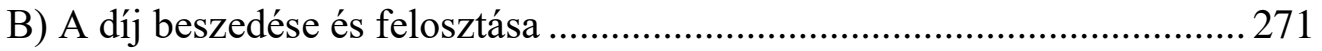

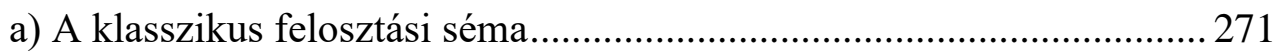

b) A felosztás során érvényesülő szociális és kulturális szempontok....... 272

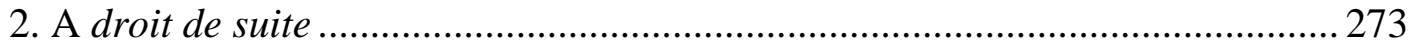

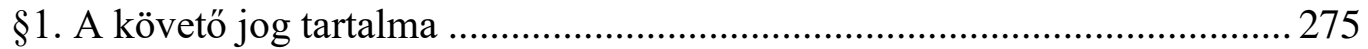

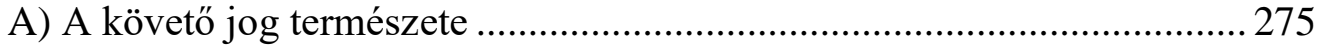

a) A részleges harmonizációból eredő kérdések .................................... 275

b) A követö jog dogmatikai elhelyezése .................................................. 276 
B) A követö jog tartalmi elemei ….......................................................... 278

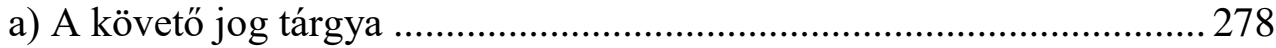

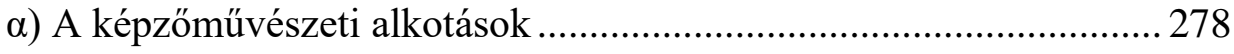

ß) Az eredetiség követelménye ........................................................ 280

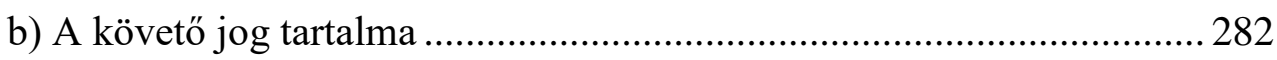

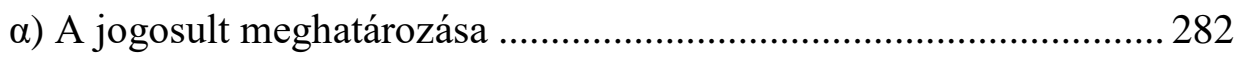

ß) A követő jog hatálya alá tartozó adásvételek .................................. 283

§2. A követő jogi díj érvényesítése .................................................................. 283

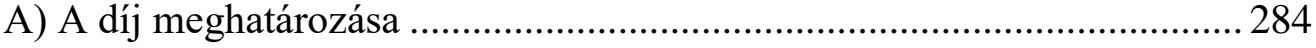

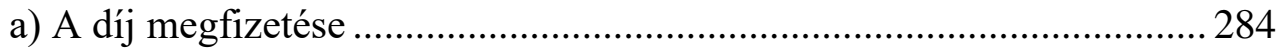

a) A díj fizetésére kötelezett ............................................................. 284

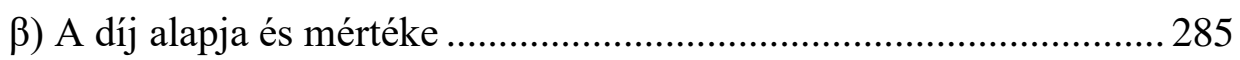

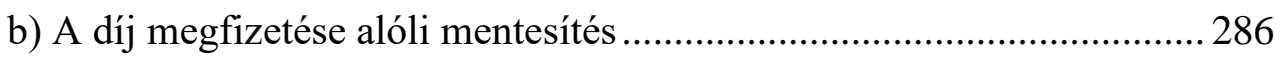

B) A díj beszedése és felosztása ............................................................ 287

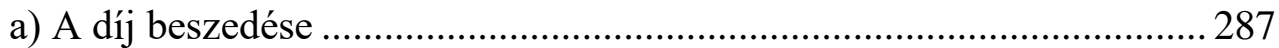

b) A közös jogkezelő szervezet eljárása a díj felosztása során................. 288

A harmadik rész konklúziója ............................................................................... 291

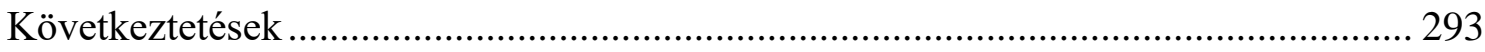

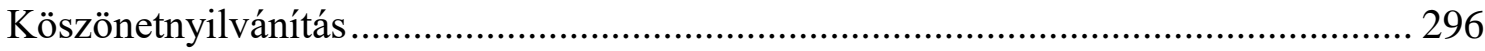

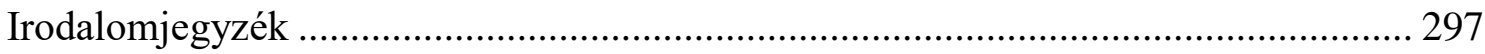

Hivatkozott jogszabályok és jogesetek jegyzéke ................................................. 315

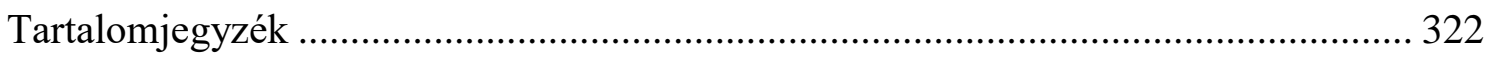

Függelék - Résumé substantiel de la thèse de doctorat ............................................. 329 
Függelék - Résumé substantiel de la thèse de doctorat 
La gestion collective des droits des auteurs : ses formes imposées par la loi hongroise et française

Résumé substantiel de la thèse de doctorat présentée par Mademoiselle Dóra HAJDÚ

en co-tutelle internationale de thèse dont le titre original est

A törvény által előírt közös jogkezelés a magyar és francia szerzői jogban

Co-directeurs de thèse

Péter MEZEI

Maître de conférences

Université de Szeged
Antoine LATREILLE

Professeur de droit privé

Université Paris-Saclay

Manuscrit clos le 30 novembre 2015 


\section{Sommaire}

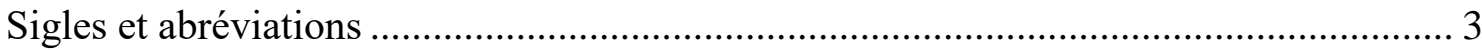

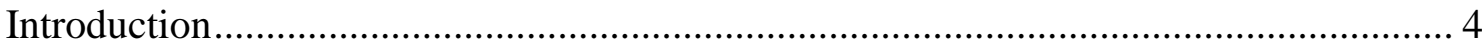

Première partie: Deux conceptions différentes de la gestion collective - Théories générales et notions de base .................................................................................... 7

Chapitre I. Les limitations aux droits d'auteur.......................................................... 7

Chapitre II. La définition de la gestion collective et la présentation de son mécanisme

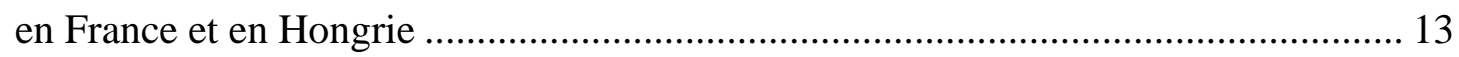

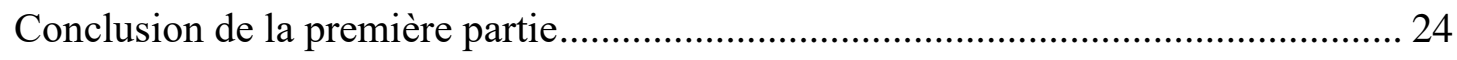

Deuxième partie : La gestion collective imposée par la loi : limitation au droit exclusif25 Chapitre I. L'encadrement de l'exercice des droits des auteurs par la gestion

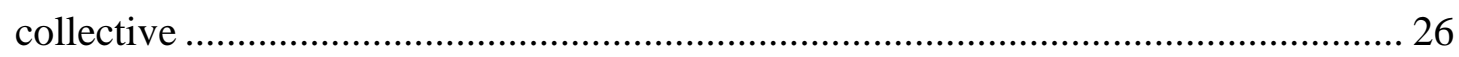

Chapitre II. La gestion collective liée à la limitation des droits exclusifs ................. 43

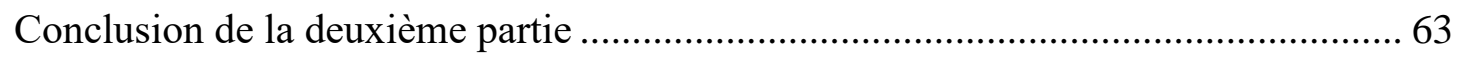

Troisième partie : La gestion collective imposée, garantie de l'exercice des droits ...... 65

Chapitre I. L'exercice du droit exclusif dans le cadre de la gestion collective assurant une sortie au titulaire du droit 66

Chapitre II. La gestion collective imposée au service de l'efficacité de l'exercice des droits

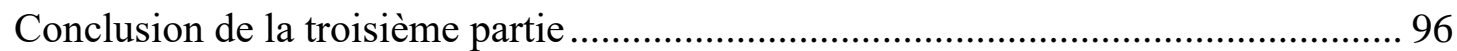

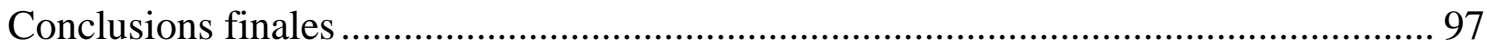

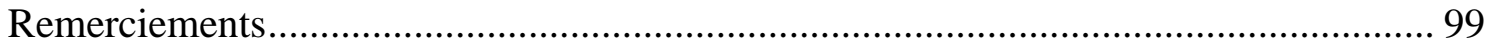

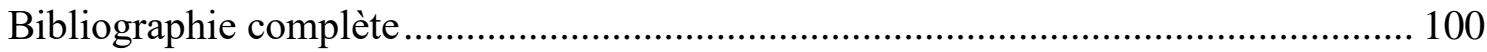

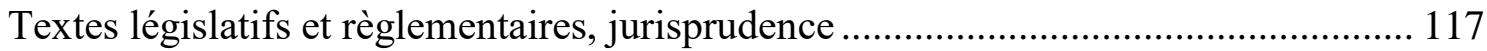




\section{Sigles et abréviations}

ADPIC

Art.

ARTISJUS

BNF

Bull. civ.

c/

CA

CCIP

CFC

CJUE

CMO

Comm. com. électr.

Convention de Berne

CPI

D.

Directive 2001/29

Directive 2001/84

Directive 2006/115

Directive 2014/26

Directive 93/83

Directive 96/9
Accord de l'OMC sur les aspects des droits de propriété intellectuelle qui touchent au commerce

Article

ARTISJUS Magyar Szerzői Jogvédő Iroda Egyesület (organisation de gestion collective hongroise représentant des auteurs des auvres littéraires et musicales)

Bibliothèque Nationale de France

Bulletin du droit civil

contre

Cour d'appel

Chambre de commerce et d'industrie de région Paris - Île-deFrance

Centre français d'exploitation du droit de copie

Cour de justice de l'Union européenne

Collective management organization

Communication, commerce électronique

Convention de Berne pour la protection des œuvres littéraires et artistiques (modifiée le 28 septembre 1979)

Code de la Propriété Intellectuelle

Recueil Dalloz

Directive 2001/29/CE du Parlement européen et du Conseil du 22 mai 2001 sur l'harmonisation de certains aspects du droit d'auteur et des droits voisins dans la société de l'information

Directive 2001/84/CE du Parlement européen et du Conseil du 27 septembre 2001 relative au droit de suite au profit de l'auteur d'une œuvre d'art originale

Directive 2006/115/CE du Parlement européen et du Conseil du 12 décembre 2006 relative au droit de location et de prêt et à certains droits voisins du droit d'auteur dans le domaine de la propriété intellectuelle (version codifiée)

Directive 2014/26/UE du Parlement européen et du Conseil du 26 février 2014 concernant la gestion collective du droit d'auteur et des droits voisins et l'octroi de licences multiterritoriales de droits sur des œuvres musicales en vue de leur utilisation en ligne dans le marché intérieur

Directive 93/83/CEE du Conseil du 27 septembre 1993 relative à la coordination de certaines règles du droit d'auteur et des droits voisins du droit d'auteur applicables à la radiodiffusion par satellite et à la retransmission par câble

Directive 96/9/CE du Parlement européen et du conseil du 11 mars 1996 concernant la protection juridique des bases des 
EIPR

EJI

Fasc.

FILMJUS

Gaz. Pal.

HUNGART

IIC

ISZJSZ

JCl.

JCP G

JIPITEC

loi DADVSI

NIR

OMC

OMPI

pma

Propr. intell.

PUAM

RIDA

RIDC

RLDI

RTD Com.

S.

SGDL

SOFIA

SPRD

szerk.

SZJSZT

Szjt.

SZTNH

TGI données

European Intellectual Property Review

Elöadómüvészi Jogvédő Iroda (organisation de gestion collective hongroise représentant des artistes-interprètes)

Fascicule

FILMJUS Filmszerzők és Elöállítók Szerzői Jogvédő Egyesülete (organisation de gestion collective hongroise représentant des auteurs et producteurs de films)

La Gazette du Palais

HUNGART Vizuális Müvészek Közös Jogkezelö Társasága Egyesület (organisation de gestion collective hongroise représentant des auteurs des arts visuels)

International Review of Intellectual Property and Competition Law

Iparjogvédelmi és Szerzői Jogi Szemle (Revue de la propriété Industrielle et du droit d'auteur)

JurisClasseur

La Semaine Juridique - Édition générale

Journal of Intellectual Property, Information Technology and Electronic Commerce Law

Loi $\mathrm{n}^{\circ} 2006-961 \mathrm{du} 1^{\mathrm{er}}$ août 2006 relative au droit d'auteur et aux droits voisins dans la société de l'information

Nordiskt Immateriellt Rättsskydd

Organisation Mondiale du Commerce

Organisation Mondiale de la Propriété Intellectuelle

post mortem auctoris

Propriétés intellectuelles

Presses universitaires d'Aix-Marseille

Revue internationale du droit d'auteur

Revue internationale de droit comparé

Revue Lamy droit de l'immatériel

Revue trimestrielle de droit commercial

Sirey

Société des Gens de Lettres

Société française des intérêts des auteurs de l'écrit

Société de perception et de répartition des droits

szerkesztette (édité par)

Szerzői Jogi Szakértő Testület (Conseil des experts en droit d'auteur)

A szerzői jogról szóló 1999. évi LXXVI. tv. (Loi numéro LXXVI de 1999 relative au droit d'auteur)

Szellemi Tulajdon Nemzeti Hivatala (Office National de la Propriété Intellectuelle)

Tribunal de Grande Instance 
UE

vs.

WIPO
Union européenne

Versus

World Intellectual Property Organization

Sauf indication contraire, les traductions sont celles de l'auteur. 


\section{Introduction}

Le droit d'auteur a toujours existé en cohabitation, voire en symbiose avec la technologie ${ }^{1}$. Il s'agit d'une véritable interconnexion de ces deux phénomènes qui garde le droit d'auteur en mouvement. Sujet des réformes ${ }^{2}$, le cœur historiquement établi du droit d'auteur reste intact, même au milieu de l'explosion que constitue l'évolution technologique. Notamment, son but principal est d'inciter la création et de garantir l'accès au résultat de cette activité, tout en assurant à l'auteur un revenu grâce à l'exploitation de ses œuvres par des utilisateurs professionnels. À cette fin, l'auteur est doté d'une série de droits exclusifs lui permettant d'exploiter ses propres créations et d'autoriser des tiers à les utiliser. De nos jours, la nature des utilisations est également transformée par l'apparition d'un vif intérêt manifesté par des non-professionnels pour profiter des productions originales ${ }^{3}$. Ce changement n'est pas uniquement intervenu à cause de l'évolution technologique, mais celle-ci est sans doute catalyseur de ce processus. L'histoire du droit d'auteur montre que la naissance de l'idée de la gestion collective est indépendante de la technologie ${ }^{4}$ puisqu'elle est liée avant tout à l'immatérialité essentielle des œuvres qui complique le contrôle et l'autorisation de leur exploitation. Pourtant, l'évolution technologique marque fortement son développement ultérieur, et l'incite à se renouveler de temps en temps.

Le mécanisme complexe, qu'est la gestion collective, a pour l'objectif de permettre l'exploitation licite des œuvres en y associant les auteurs. Elle peut ainsi être vue comme une forte contrepartie lors de la négociation des licences octroyées aux utilisateurs (avant tout professionnels), ainsi qu'un outil de suivi des utilisations grâce à la collecte et à la distribution des droits. Paradoxalement, la gestion collective constitue également une limitation, au sens large du terme, au monopole de l'auteur. Cette

\footnotetext{
${ }^{1}$ MEZEI (2012a). p. 197-208.

${ }^{2}$ La révision de la directive 29/2001/CE se trouve dans l'agenda des institutions européennes. Projet de rapport sur la mise en ouvre de la directive 2001/29/CE du Parlement européen et du Conseil du 22 mai 2001 sur l'harmonisation de certains aspects du droit d'auteur et des droits voisins dans la société de l'information (2014/2256 (INI)) (http://www.europarl.europa.eu/sides/getDoc.do?pubRef=//EP//NONSGML+COMPARL+PE-546.580+02+DOC+PDF+V0//FR\&language=FR)

${ }^{3} \mathrm{Vu}$ l'exemple de la copie privée ou le contenu généré par les utilisateurs, connu sous l'abréviation «UGC » (user generated content).

${ }^{4}$ HAjdu (2014b), DeAZley - Kretschmer - Bently (2010), Pfister, Laurent: Histoire du droit d'auteur, J.Cl Propriété littéraire et artistique, Fasc. 1110
} 
seconde caractéristique, est d'ailleurs beaucoup plus marquée lorsque la gestion collective résulte de dispositions législatives.

Notre thèse consiste donc en une réflexion sur l'ambiguïté de la gestion collective, laquelle se révèle plus particulièrement dans l'hypothèse où la gestion collective est exigée par la loi. Comme évoqué précédemment, cette technique de gestion est avant tout une limitation imposée au monopole de l'auteur en vue notamment de concilier ses intérêts avec ceux du public. Il y a lieu de mentionner cependant que l'introduction de la gestion collective par le législateur parfois peut se présenter comme le seul moyen d'exploitation des œuvres. Dans ce cas, la soumettre au régime propre des limitations aboutiraient à un résultat contraire à l'objectif visé.

L'intérêt de ce sujet, de cet angle de recherche particulier, tient également au fait que le législateur envisage la gestion collective comme une réponse à certaines questions du droit d'auteur contemporain, telles que l'utilisation des œuvres orphelines ou la numérisation des livres indisponibles. Il convient nécessairement alors de démontrer les particularités du régime afférent à la gestion collective et de la positionner au sein du droit d'auteur. Ceci a une importance particulière car la notion de gestion collective, telle qu'elle résulte de les lois françaises et hongroises n'est pas homogène. Elle englobe (i) la gestion collective obligatoire des droits exclusifs ainsi que (ii) la gestion collective des licences légales ou droits à rémunération, (iii) la gestion collective étendue et (iv) la gestion collective non étendue ouvrant un droit de sortie. Il convient de préciser que la gestion collective des droits voisins n'a qu'un rôle illustratif dans notre thèse, car ces droits ne représentent un caractère restrictif en comparaison au monopole complet de l'auteur. Ensuite, il convient de traiter non seulement de la structure et du fonctionnement de la gestion collective, mais également et avant tout des droits patrimoniaux, afin de pouvoir démontrer l'intérêt de les gérer par le biais du système de gestion collective.

La thèse est construite autour de l'analyse de la gestion collective régie par les lois françaises et hongroises, car ces deux pays disposent de systèmes juridiques différents au sein de la tradition civiliste. Ce travail illustre donc deux approches distinctes de la gestion collective imposée par la loi, ce qui a nécessité d'une part, l'étude de textes législatifs, de jurisprudences et de doctrines propres à ces deux pays, et d'autre part, l'analyse des textes régissant le droit d'auteur international et européen. 
Notre sujet ainsi délimité exige une approche méthodologique particulière puisque notre étude a été réalisée dans le cadre d'une co-tutelle internationale de thèse ce qui implique de respecter les règles procédurales en vigueur au sein des deux universités qui ont accueillies ces recherches. Cela a deux conséquences : la première tient à la langue employée lors de la rédaction de la présente thèse. Celle-ci a en effet écrite en hongrois, et ce document en français ne peut donc être vu que comme un résumé substantiel qui reprend les arguments majeurs développés dans les différents chapitres. Il ne s'agit donc pas d'une analyse profonde et complexe. La seconde réside dans une rupture volontaire avec la méthode cartésienne traditionnellement employée et le recours à une démonstration tripartite. Si ce découpage est scrupuleusement repris dans le présent résumé, la division en sous-sections des différentes parties n'est, en revanche, que suggérée. Pour permettre toutefois aux lecteurs francophones d'avoir une vue globale des développements présents dans le manuscrit rédigé en hongrois, une traduction complète de la table des matières est fournie avec une copie de la bibliographe complète.

Ainsi, avant d'étudier les questions de fond, nous avons trouvé utile de consacrer une première partie à la théorie générale de la gestion collective et aux limitations en droit d'auteur afin de déterminer si la gestion collective peut être vue comme une limitation apportée aux droits de l'auteur. Nous avons ensuite concentré notre attention sur la notion même de gestion collective imposée par la loi, de sorte à déterminer si elle peut être considérée comme une limitation au droit exclusif de l'auteur (deuxième partie) ou s'il s'agit simplement d'une garantie pour la mise en œuvre de ses droits (troisième partie). 


\section{Première partie : Deux conceptions différentes de la gestion collective - Théories générales et notions de base}

Notre thèse traite de la question de la gestion collective imposée par la loi dans l'optique des limitations aux droits d'auteur. Ainsi, nous trouvons nécessaire de commencer notre analyse par une brève explication de ces deux concepts. L'objectif de cette partie n'est cependant pas de détailler la théorie générale des limitations aux droits d'auteur ${ }^{5}$ ou celle de la gestion collective ${ }^{6}$, mais plutôt de donner un aperçu succinct des synergies entre ces deux notions et de mettre en relief le caractère limitatif du système de la gestion collective.

Nous employons le mot «limitations » au sens large du terme, de manière à englober toutes les dispositions qui ont pour effet de restreindre le monopole des auteurs, allant au-delà des exceptions et limitations énumérées par les lois. Dans un premier temps, nous nous attacherons à identifier les éléments qui nous permettent de considérer la gestion collective comme une limitation au droit d'auteur (Chapitre 1). Dans un second temps, nous nous intéressons aux deux approches différentes de la gestion collective : celle du législateur français, qui laisse une liberté contractuelle bien développée pour les auteurs, et celle du législateur hongrois, qui a établi un système rigoureux de surveillance et de contrôle (Chapitre 2).

\section{Chapitre I. Les limitations aux droits d'auteur}

D’une manière générale, les limitations aux droits patrimoniaux sont, avant tout, considérées comme des outils pour assurer une balance entre les intérêts de l'auteur et ceux de l'utilisateur ou de l'exploitant. Pour illustrer la nécessité de maintenir cette interconnexion entre les droits exclusifs et les limitations, Mihály FICSOR affirme que plus la protection est généreuse et garantit des droits étendus au profit de l'auteur, plus le droit d'auteur a besoin d'exceptions et de limitations définies de manière précise pour avoir des contrepoids au monopole trop étendu que détient

\footnotetext{
5 Voir: Gyenge (2010), SEnftleben (2004), Guibault (2002), LuCAS - SiRinelli - BEnSAMOUN (2012).

${ }^{6}$ La doctrine a traité d'une façon assez profonde cette question. Voir par exemple: SIIRIAINEN (1999). NERISSON (2013), DIRINGER (2011), BORONKAY - BOYTHA - CSEPELY-KNORR - SZILAGYI (2008), LANCHIDI (2010), GRAD-GYENGE - SARKADY (2014), FALUDI (2009a) p. 126-135.
} 
l'auteur sur son oeuvre (a contrario, les limitations trop larges exigent des droits exclusifs renforcés) ${ }^{7}$.

En conséquence, il nous semble que les limitations ne sont pas équivalentes aux exceptions aux droits d'auteur énumérées par les lois ${ }^{8}$, car elles concernent une catégorie plus vaste. Certes, la gestion collective ne figure ni dans l'article L. 122-5 du CPI, ni dans la Szjt., mais en pratique, elle peut engendrer des effets similaires aux exceptions mentionnées dans ces textes ${ }^{9}$. En effet, comme il sera démontré dans notre thèse, les limitations spéciales prévues par la Convention de Berne ont été parfois «transposées » dans les lois nationales comme des modalités de gestion collective obligatoire $^{10}$. Nous utilisons donc le terme «limitation » pour désigner une palette, dont les nuances s'étendent de l'élimination absolue du droit exclusif à la restriction moins sévère, qui porte simplement sur la pratique des droits ${ }^{11}$.

Afin de démontrer les similitudes entre la gestion collective et les limitations au droit d'auteur, nous analyserons en premier lieu les raisons d'être et les fondements desdites limitations (section 1), car des arguments similaires justifient souvent la gestion collective. Dans un second temps, nous étudierons brièvement la théorie des limitations afin d'y intégrer la gestion collective (section 2).

\section{Section 1. Les fondements des limitations}

Les limitations remplissent deux fonctions essentielles qui découlent logiquement de leur rôle qui consiste à concilier les intérêts des différents interlocuteurs de la création et de l'exploitation des œuvres. D'une part, elles permettent d'assurer l'intérêt public, notamment en fournissant et en garantissant l'accès général aux œuvres $^{12}$. D'autre part, les limitations déterminent les contours et l'étendue du droit d'auteur. Le droit d'auteur régit l'exploitation publique des œuvres, les limitations

\footnotetext{
${ }^{7}$ FICSOR (2002). p. 259.

${ }^{8}$ Art. L. 122-5 du CPI, de $\S 34$ à $\S 41$ de la Szjt.

${ }^{9}$ Alma-Delettre (2007) p. 36.

${ }^{10}$ Art. 11 bis (2) de la Convention de Berne. Voir en détail dans le Chapitre I de notre Deuxième partie.

${ }^{11}$ Pour une opinion contraire, GALOPIN (2012) p. 16.

${ }^{12}$ Par exemple l'exception pédagogique ou l'exception en faveur des personnes handicapées.
} 
jalonnent en effet la frontière entre la sphère publique et privée ${ }^{13}$, où le droit d'auteur n'est pas censé pénétrer ${ }^{14}$.

D’une manière plus précise, il peut être constaté que certaines limitations trouvent leurs origines dans les droits de l'homme. Ainsi, la libre citation au sein du droit d'auteur n'est que le reflet de la liberté d'expression. S'agissant de la gestion collective, celle-ci découle de la liberté d'association et de la liberté contractuelle. Il en découle que lorsque le législateur impose la gestion collective, il doit respecter ses caractères fondamentaux. A titre d'exemple, l'auteur non-membre de l'organisation de gestion collective devrait toujours bénéficier de garanties supplémentaires par rapport à celui qui a choisi d'y adhérer. Un deuxième volet des droits fondamentaux, certes plus indirect, est présent également par rapport à la gestion collective. La protection de la vie privée des utilisateurs et le droit à la culture expliquent respectivement la limitation du droit exclusif telle que le droit à une rémunération dans le cas de la copie privée et du prêt en bibliothèque, chacun administré par les organisations de gestion collective. Les raisonnements plus pragmatiques, comme la sauvegarde de la concurrence ou la protection de marché primaire des œuvres ${ }^{15}$ représentent un autre point commun entre la gestion collective et les limitations.

Pourtant, contrairement aux limitations qui justifient un intérêt bien fondé, parfois la gestion collective est établie pour des raisons pratiques. En effet, l'exploitation efficace du droit de reproduction par reprographie ou la rémunération pour copie privée serait être trop difficile, voire impossible, sans cette technique de gestion.

\section{Section 2. La mise en ouvre des limitations}

Comme il n'existe pas de définition communément acceptée des limitations dans les textes législatifs et règlementaires, il appartient alors à la doctrine de la créer. Trois expressions sont, en général, utilisées pour désigner le fait de restreindre le

\footnotetext{
${ }^{13}$ Par exemple l'exception de la copie privée.

${ }^{14}$ LINANT DE BELLEFONDS (2004) p. 203.

15 A cet égard, vu par exemple la directive 2009/24/EC sur la protection juridique des programmes d'ordinateurs.
} 
monopole de l'auteur : les limitations, les exceptions et, dans la loi hongroise, les «tilisations libres ${ }^{16}$.

Ce travail est d'autant plus délicat que, contrairement à la loi hongroise, le CPI ne contient aucune dénomination et ne fait que mentionner une liste d'exceptions précédées de la mention "l'auteur ne peut interdire » (art. L. 122-5 CPI). Il peut être d'autant plus complexe dans la mesure où le droit d'auteur international et européen ne fait que renvoyer aux termes «exceptions et limitations » sans définir de critères pour distinguer ces deux expressions. ${ }^{17}$ Dans un tel contexte, il n'est donc pas surprenant de retrouver une doctrine divisée et de lire dans le Guide des Traités sur le droit d'auteur et les droits connexes administrés par l'OMPI que «la seule chose que l'on puisse dire sans risque d'erreur est que l'expression "limitations et exceptions " couvre les utilisations libres sous toutes leurs formes, les licences non volontaires et, le cas échéant, d'autres limitations (par exemple, l'imposition d'un mécanisme de gestion collective obligatoire) $)^{18}$.

D'après Silke VON LEWINSKI, les exceptions sont des utilisations à titre gratuit et sans autorisation de l'auteur. Le professeur LEWINSKI fait également une sousdivision entre les catégories de limitations, en distinguant les licences légales et les licences obligatoires. Ces deux dernières catégories, bien qu'elles se trouvent en dehors du périmètre du droit exclusif de l'auteur d'autoriser ou interdire, assurent un revenu non négligeable à l'auteur ${ }^{19}$. Une théorie similaire à celle-ci a été établie par Mihály FICSOR, qui fait également la distinction selon la gratuité et l'absence ou non de l'autorisation ${ }^{20}$. Lucie GUIBAULT, en revanche, définit les expressions d'une manière renversée, en utilisant le terme limitation comme une définition neutre et large, qui englobe plusieurs catégories: les exceptions, les licences légales, les licences obligatoires et la gestion collective obligatoire ${ }^{21}$.

\footnotetext{
${ }^{16}$ Chapitre IV de la Szjt.: Utilisations libres et autres restrictions au droit d'auteur. D'après $\S 33$ (1) dans le cadre des utilisations libres, l'utilisation de l'oeuvre à titre gratuit et ne relève pas de l'autorisation de l'auteur. «A szabad felhasználás körében a felhasználás dijtalan, és ahhoz a szerzö engedélye nem szükséges. »

${ }_{17}$ Par exemple article 5 de la directive 2001/29/CE.

18 Guide des traités sur le droit d'auteur et les droits connexes administrés par l'OMPI (http://www.wipo.int/edocs/pubdocs/fr/copyright/891/wipo_pub_891.pdf), p. 288-289.

${ }^{19}$ VON LEWINSKI (2008) p. 152.

${ }^{20}$ FICSOR (2002) 5.04. , renforcé par FICSOR (2012b) p. 2.

${ }^{21}$ GUIBAULT (2002) p. 16-25.
} 
Comme il a déjà été mentionné, nous préférons utiliser le terme « limitation » dans un sens large car son emploi offre la possibilité d'envisager toutes les hypothèses en élargissant le champ de nos recherches. A ce premier avantage s'ajoute encore l'opportunité d'utiliser une terminologie plutôt neutre qui favorise un plus grand degré d'abstraction dans l'analyse, nous permettant ainsi de mettre en relief une hiérarchisation selon des modalités et l'étendue de leurs caractères respectifs. Il nous est dès lors possible de considérer que certaines limitations portent sur le cœur même du monopole de l'auteur. Il en existe des formes gratuites et sans autorisation qui pourraient être appelées «exceptions». Les licences légales appellent à une rémunération en contrepartie d'une autorisation octroyée non par l'auteur, mais directement par le législateur. A l'inverse, les licences obligatoires restreignent l'autonomie de l'auteur puisque c'est généralement une autorité qui les accorde à sa place $^{22}$. La gestion collective obligatoire des droits exclusifs est le moyen moins restrictif d'exercer son droit. En effet, le noyau dur du monopole reste intact, dans la mesure où il ne s'agit que d'imposer un mode de gestion à l'auteur. Sa forme allégée est la gestion collective présumée, qui laisse la liberté de sortir de ce même régime et de retourner à la gestion individuelle des droits. Enfin, la gestion collective volontaire peut être considérée comme une limitation, si l'adhésion de l'auteur à la société de gestion collective est le résultat d'une contrainte économique.

La pierre angulaire des limitations est, bien évidemment, la Convention de Berne, qui limite la marge de manœuvre des législateurs nationaux. La Convention détermine elle-même certaines utilisations, soit à titre gratuit, soit à titre onéreux, qui échappent du monopole de l'auteur ${ }^{23}$ ou circonscrit des hypothèses dans lesquelles les législateurs nationaux des Etats signataires peuvent introduire des limitations ${ }^{24}$. Le droit européen tend à s'approprier cette technique de régulation, comme le laisse entrevoir, par exemple, la directive 92/100 qui prévoit une limitation facultative du droit de prêt public $^{25}$. Cette technique est également utilisée, d'un point de vue plus général, dans la directive 29/2001 qui énumère une liste (quasiment) ${ }^{26}$ exhaustive des exceptions et

${ }^{22}$ Cette méthode est plus communément acceptée dans le droit de la propriété industrielle. L'autosation de l'utilisation des œuvres orphelines dans la loi hongroise pourrait être évoquée à titre d'exemple [§ 41/B (1) de la Szjt.].

${ }^{23}$ Art. 10 (1) de la Convention de Berne.

${ }^{24}$ Art. 10 (2) de la Convention de Berne sur les limitations aux fins pédagogiques.

${ }^{25}$ Art. 6 (1) de la directive 92/100/CE.

${ }^{26}$ L'article 5 (3) o) de la directive 2001/29/CE prévoit la possibilité d'introduire les exceptions ou limitations «lorsqu'il s'agit d'une utilisation dans certains autres cas de moindre importance pour 
limitations possibles sur le plan national. Les Etats membres pourraient, en conséquence, choisir de transposer en droit interne, des limitations et exceptions visées dans cette liste, bien que celles-ci ne soient pas conformes au droit communautaire.

Dans aucun de ces documents juridiques, la gestion collective n'apparaît en soi comme une «exception » ou une «limitation ». Néanmoins, elle est souvent rattachée aux exceptions et limitations existantes, car la perte du droit de l'auteur d'autoriser et d'interdire des utilisations dans le cas des licences légales est compensée par le versement d'une rémunération gérée par des sociétés de gestion collective. La gestion collective peut aussi constituer une barrière à l'exercice individuel des droits, or l'article 5 (2) de la Convention de Berne énonce que la jouissance et l'exercice des droits ne sont soumises à aucune formalité. Il convient de préciser alors que la gestion collective ne concerne pas la jouissance des droits exclusifs, elle est considérée comme un mode d'exploitation collective de ceux-ci qui n'empêche pas l'auteur de les exercer. Cette article est difficilement applicable alors au structure de la gestion collective. Il y a lieu d'ajouter toutefois que la gestion collective obligatoire est souvent introduite pour exploiter les droits exclusifs par rapport lesquels la Convention donne pouvoir aux Etats de régler leurs conditions de l'exercice. Ainsi, l'article 11bis (2) de la Convention prévoit cette possibilité par rapport au «droit de radiodiffusion et droits connexes ». Le droit de retransmission par câble est devenu un droit exclusif soumis au régime de la gestion collective obligatoire conformément aux dispositions de la directive $93 / 83 .{ }^{27}$ En outre, dans l'article 14ter (3) de la Convention prévoit, que «les modalités et les taux de la perception sont déterminés par chaque législation nationale ». Cette approche de la Convention de Berne a été reprise par la directive européenne relative au droit de suite, cette dernière laissant la faculté aux Etats membres d'introduire une gestion collective obligatoire dans leurs droits nationaux ${ }^{28}$.

Un deuxième aspect important à prendre en considération est celui du traitement national - surtout dans les cas non-harmonisés par le droit d'auteur européen/communautaire ou non prévus dans les conventions internationales - , car le

lesquels des exceptions ou limitations existent déjà dans la législation nationale, pour autant que cela ne concerne que des utilisations analogiques et n'affecte pas la libre circulation des marchandises et des services dans la Communauté, sans préjudice des autres exceptions et limitations prévues au présent article ». La doctrine internationale fait référence à cette disposition sous le nom de «grandfather clause $»$.

${ }^{27}$ Art. 9 de la directive 93/83.

${ }^{28}$ Art. 6 (2) de la directive 2001/84. 
non respect de ce principe peut restreindre l'exercice des droits. Plus spécifiquement, c'est en matière de gestion collective étendue qu'il y a une importance primordiale, car ce système repose sur l'autorisation globale des œuvres, y compris celles créées par des auteurs non-membres de l'organisation de gestion collective ${ }^{29}$.

Enfin, le test en trois étapes (également connu sous le nom de «triple test $)^{30}$ peut constituer un point de référence pour analyser la gestion collective. Au préalable, il convient de noter que le test est désormais utilisé comme un standard général pour la limitation des droits patrimoniaux. On peut ainsi retenir que l'utilisation est licite si elle (1) est réservée à certain cas spéciaux, (2) ne porte pas atteinte à l'exploitation normale de l'œuvre, (3) et ne cause pas de préjudice injustifié aux intérêts légitimes de l'auteur. Du point de vue de la gestion collective, l'application du test peut intervenir dans deux hypothèses. En premier lieu, lorsque le droit exclusif a été limité au droit de rémunération et sa gestion confiée aux organisations de gestion collective. En deuxième lieu, si le législateur national décide de mettre en place une gestion collective obligatoire ou présumée en l'absence d'autorisation explicite donnée par des textes internationaux.

\section{Chapitre II. La définition de la gestion collective et la présentation de son mécanisme en France et en Hongrie}

La gestion collective est un outil avant tout national : elle est fortement liée, non seulement au droit d'auteur, mais en outre, à la culture juridique d'un Etat. Ce n'est pas anodin s'il n'existe pas de convention internationale dédiée à la gestion collective : il est en effet difficile de s'accorder sur des principes communs, malgré des origines et des évolutions partagées par différents pays ${ }^{31}$. Le choix privilégié par le législateur en ce qui concerne l'encadrement juridique des statuts et le fonctionnement des organisations de gestion collective illustre son attitude envers le régime traditionnel qui repose sur l'autonomie des auteurs. L'intervention du législateur pour encadrer cette liberté peut être alors interprétée comme une limitation au monopole de l'auteur.

Afin de mettre en contexte la gestion collective des deux pays choisis dans notre thèse, nous aborderons en premier lieu les caractéristiques communes permettant

\footnotetext{
${ }^{29} \mathrm{Vu}$ en détail le Chapitre II de la Troisième partie de notre thèse.

${ }^{30}$ Le test sera étudié plus en détail dans le Chapitre II de la Deuxième partie.

${ }^{31}$ GYERTYÁNFY - FALUDI - KABAI - SZINGER - TÓTH (2004) p. 707. et COLOMBET (1992).
} 
la catégorisation de la gestion collective (section 1). Ensuite, nous analyserons la structure et le fonctionnement de la gestion collective sous l'angle de la restriction qu'elle apporte au monopole de l'auteur (section 2).

\section{Section 1. La définition de la gestion collective}

Les textes législatifs sont souvent réticents à définir la gestion collective (§1.), mais la doctrine pallie cette lacune en compilant les éléments distinctifs de cette notion $(\S 2$.

\section{\$1. Le rejet de la définition}

Bien que les travaux préparatoires en vue de définir la notion de gestion collective aient commencé à l'OMPI dans les années 1970 dans l'objectif de la signature d'une convention internationale, les négociations furent arrêtées, et aucune convention n'a pas été adoptée.

En effet, l'adoption d'une telle définition peut être problématique également au niveau national, comme le CPI l'illustre. Ainsi, bien que la France soit connue comme le pays où l'idée de la gestion collective s'est développée, on n'en trouve toutefois pas de définition dans le code. Bien plus, la loi n'utilise même pas l'expression «gestion collective », faisant référence aux «sociétés de répartition et de distribution des droits $»^{32}$. Cette dénomination, même si elle est exacte, restreint le champ d'activité des sociétés de gestion collective parce qu'elle ne prend pas en compte leur dimension d'intérêt général, c'est-à-dire leur fonction culturelle et sociale. Or, il s'agit d'un aspect qui, parmi d'autres, fait la distinction entre la gestion collective, dans son sens traditionnel, et la gestion commerciale des répertoires ${ }^{33}$. En revanche, l'absence de définition permet au législateur de conforter l'autonomie des auteurs et d'intervenir uniquement lorsque cela est nécessaire.

Une autre particularité du CPI est l'utilisation de termes similaires à SPRD, sans apporter davantage de précisions. Par exemple, s'agissant du contrat de représentations, la loi se réfère aux «organismes professionnels d'auteurs », qui correspondent aux sociétés de perception et de répartition des droits ${ }^{34}$. Néanmoins, en

\footnotetext{
${ }^{32}$ De l'article L.321-1 à l'article L. 321-13 du CPI.

${ }^{33}$ La directive 26/2014/UE reconnait cette distinction entre „les organismes de gestion collective” et „les entités de gestion indépendante". Vu ses articles 3 a) et 3 b).

${ }^{34}$ SCHMIDT (1971).
} 
ce qui concerne la qualité d'agir en justice pour défendre des intérêts des auteurs, le CPI semble faire une distinction entre les deux entités en les énumérant séparément ${ }^{35}$.

\section{\$2. L'expression de la définition}

$\mathrm{Au}$ regard du droit d'auteur français, la définition de la notion de «gestion collective » provient de la doctrine. Pourtant, avec la transposition de la directive 26/2014/UE ce statut quo tend à évoluer, compte tenu du fait que la directive en a défini les éléments constitutifs. La transposition obligatoire de cette directive repose également sur le législateur hongrois, nonobstant l'existence d'une définition dans la loi hongroise, dans la mesure où il est nécessaire de s'assurer que cette définition est en conformité avec le droit communautaire.

L'Union européenne a reconnu l'importance du droit d'auteur pour la constitution du marché intérieur tardivement, l'harmonisation des dispositions nationales ayant été initiée par les directives arrêtées dans les années $1990^{36}$. Au début de ce processus, le législateur a porté un intérêt faible pour la gestion collective, celle-ci n'apparaissant que de manière marginale dans le texte des directives. C'est alors la Cour de Justice de l'Union Européenne et la Commission qui se sont attelées à cette tâche, sous l'optique du droit de la concurrence ${ }^{37}$.

\footnotetext{
${ }^{35}$ Vu CPI article L. 331-2 et L. 331-24. NERISSON (2013) p. 356.

${ }^{36}$ GYERTYANFY (2002) p. 271-283.

${ }^{37}$ Les directives suivantes prévoient des articles relatifs à la gestion collective: directive 93/83/CEE article 1 (4) et article 13; directive 2006/15/CE article 5; directive 2001/84/CE article 6. Les principaux documents préparatoires et recommandations et avis non contraignants de la Commission (soft law) en matière d'harmonisation de la gestion collective sont les suivants: Livre Vert Le droit d'auteur et les droits voisins dans la Société de l'Information, COM (95) 382 final, le 09 juillet 1995 ; Follow-Up to the Green Paper on copyright and related rights in the Information Society, Communication from the Commission, 20 November 1996 ; Rapport du Parlement européen sur un cadre communautaire pour les sociétés de gestion collective du droit d'auteur, A5-0478/2003, le 11 décembre 2003 ; Proposition de résolution du Parlement européen sur un cadre communautaire pour les sociétés de gestion collective du droit d'auteur (2002/2274(INI)), le 11 décembre 2003 ; Communication de la Commission au Conseil, au Parlement européen et au Comité économique et social européen - La gestion du droit d'auteur et des droits voisins au sein du marché intérieur COM (2004) 261 final, 16 avril 2004 ; Commission Staff Working Document : Study on a Community Initiative on the Cross-border Collective Management of Copyright, 07/07/2005 ; Parlement européen Commission des affaires juridiques, Document de travail sur la recommandation de la Commission du 18 octobre 2005 relative à la gestion collective transfrontière du droit d'auteur et des droits voisins dans le domaine des services licites de musique en ligne, 23 août 2006 ; Rapport du Parlement européen sur la recommandation de la Commission du 18 octobre 2005 relative à la gestion collective transfrontière du droit d'auteur et des droits voisins dans le domaine des services licites de musique en ligne (2005/737/CE), A6-0053/2007 final ; 2005/737/CE Recommandation de la Commission du 18 mai 2005 relative à la gestion transfrontière du droit d'auteur et des droits voisins dans le domaine des services licites de musique en ligne; European Commission Monitoring of the 2005 Online Recommendation, Communication de la Commission au Parlement européen, au Conseil, au Comité économique et social européen et au Comité des régions sur les contenus créatifs en ligne dans le
} 
Néanmoins, chacune d'entre elles s'est évertuée à adopter une approche plutôt formelle de la gestion collective. Elles ne tentent pas, par exemple, de définir la gestion collective, faisant référence à toute organisation qui, selon le droit européen, exerce une activité de gestion des droits d'auteur.

Dans ce contexte, c'est donc la récente directive 2014/26/EU qui offre une définition complexe, reposant sur la détermination des éléments distinctifs des organismes de gestion collective. Il est en effet plus simple et faisable de déterminer les critères d'identification des organismes de gestion collective plutôt que d'énumérer une liste (exhaustive) de ses activités. La directive entend donc, par « organisme de gestion collective ", tout organisme dont le seul but ou le but principal consiste à gérer le droit d'auteur ou les droits voisins du droit d'auteur pour le compte de plusieurs titulaires de droits, au profit collectif de ces derniers, qui y est autorisé par la loi ou par voie de cession, de licence ou de tout autre accord contractuel, et qui remplit les deux critères suivants ou l'un d'entre eux: il est détenu ou contrôlé par ses membres ; il est à but non lucratif $^{38}$.

Bien que l'activité de «gestion collective_» n'ait pas été définie spécifiquement, ses principaux critères ressortent de ce texte. ${ }^{39}$ Il en découle qu'un organisme de gestion collective gère les droits patrimoniaux des titulaires de droits et cette activité est autorisée par la loi nationale ou par le consent contractuel de l'auteur conformément aux règles nationales, ou en vertu des accords de représentation réciproque conclu entre les organismes pour le bénéfice des titulaires de droits nonmembres. L'organisme arrête les tarifs applicables et les conditions d'utilisation des œuvres de son répertoire, ainsi que les modalités de distribution des sommes dues aux titulaires de droits, y compris les déductions concernant les frais de gestion et les utilisations pour la réalisation des services sociaux, culturels ou éducatifs, par les organes de démocratie interne. Étant donné que l'organisme octroi des licences et gère les redevances issues des licences légales ou non-volontaires, il contrôle l'utilisation des œuvres et exerce les actions en justice pour défendre l'intérêt des titulaires de droits. Toutefois, l'objectif de la directive étant d'harmoniser la gestion collective afin

marché unique, COM (2007) 836 final ; Résolution du Parlement européen du 25 septembre 2008 sur la gestion collective transfrontière du droit d'auteur et des droits voisins dans le domaine des services licites de musique en ligne, P6_TA(2008)0462.

${ }^{38}$ Art. 3 a) de la directive 26/2014.

${ }^{39}$ Art. 5 et suivants de la directive 2014/26. 
d'assurer son fonctionnement au sein du marché intérieur, la directive a laissé une certaine marge de manœuvre aux Etats membres en ce qui concerne les activités auxiliaires des organismes telles que l'assistance juridique aux membres ou la consultation lors de la préparation des lois sur le droit d'auteur ${ }^{40}$.

La Szjt. (contrairement au CPI) prévoit une définition de la gestion collective dans son $\S 85^{41}$ : «on entend par gestion collective la gestion des droits d'auteur ou droits voisins qui ne peuvent pas être gérés d'une façon individuelle en raison de la nature ou des circonstances de l'exploitation, réalisée par des organismes constitués à cette fin par des titulaires de droit, indépendamment du fait qu'une telle gestion soit autorisée par la loi ou repose sur la volonté autonome des auteurs. » Cette définition, plus stricte que celle proposée par le droit communautaire, peut soulever des difficultés lors de la transposition de la directive, car elle risque d'affaiblir des conditions d'agrément des organisations de gestion collective ${ }^{42}$. Le texte hongrois reste néanmoins flou. Son interprétation littéraire implique l'impossibilité d'exercer individuellement les droits patrimoniaux (soit des droits exclusifs soit des droits à rémunération) dans les cas prévus par la loi. Or, une disposition ainsi rédigée méconnaît le principe même du caractère volontaire de la gestion collective, qui se repose avant tout sur l'autonomie des auteurs, ainsi que l'esprit de la gestion collective étendue ${ }^{43}$ qui permet de retirer ses droits du répertoire des organismes de gestion collective ${ }^{44}$.

La loi hongroise spécifie également les principales caractéristiques de la gestion collective. Il s'agit notamment de : (1) l'établissement des barèmes et la définition des conditions d'utilisation des œuvres en vue de l'octroi de licences ou de la perception de rémunérations; (2) le contrôle de l'utilisation des œuvres et des prestations fournies par les auxiliaires désignés par le législateur et protégés par les droits voisins ; (3) la perception et la répartition des sommes dues, ou bien le transfert

\footnotetext{
${ }^{40}$ GYERTYANFY (2005-2006) p. 73-74.

${ }^{41}$ „Közös jogkezelés a felhasználás jellege, illetve körülményei miatt egyedileg nem gyakorolható szerzöi jogok és a szerzői joghoz kapcsolódó ilyen jogok érvényesitése a jogosultak által erre létrehozott szervezet útján, függetlenül attól, hogy azt a törvény írja elö vagy az a jogosultak elhatározásán alapul."

${ }^{42}$ Szellemi Tulajdon Nemzeti Hivatala Részletes koncepció a szerzői és szomszédos jogokra vonatkozó közös jogkezelésről és a zeneművek belső piacon történő online felhasználásának több területre kiterjedő hatályú engedélyezéséről szóló 2014/26/EU irányelv átültetéséhez megalkotandó magyar jogi szabályozás föbb tartalmi kérdéseivel kapcsolatban, (http://www.sztnh.gov.hu/sites/default/files/20150710_kjk_ire_reszletes_atultetesi_koncepcio_konzultaci ora_0.pdf), p. 4-6.

${ }^{43}$ Szjt. article 87 (3).

${ }^{44}$ Sens pareil: GRAD-GYENGE - SARKADY (2014) p. 115-116.
} 
des droits perçus à un organisme homologue en vue de leur répartition ; (4) l'action en contrefaçon $^{45}$. La loi de $2011^{46}$, portant modification des dispositions relatives à la gestion collective de Szjt. précise que les deux premières caractéristiques constituent le cœur de l'activité ${ }^{47}$.

En absence de définitions légales, la doctrine propose une notion générale pour la gestion collective. En France, celle du professeur SIRIIAINEN est communément acceptée et reprise pour décrire ce phénomène. A cet égard, «il s'agit de l'activité d'une personne morale qui a pour objet principal l'exercice des droits d'auteur et/ou des droits voisins de ses membres ou d'ayants droit, pour le compte de ceux-ci-c'està-dire dans un cadre fiduciaire. L'exercice de ces droits consiste, le cas échéant, dans la fixation des conditions et délivrance des autorisations d'exploitation, dans le contrôle, la perception et la répartition des rémunérations dues en contrepartie de l'exploitation des droits. Les membres des sociétés de gestion collective sont obligatoirement des auteurs, des artistes-interprètes, des producteurs de phonogrammes ou de vidéogrammes, des éditeurs, ou leurs ayants droit. La gestion collective poursuit également la promotion des intérêts moraux et matériels de ceux dont les droits sont ainsi exercés, notamment dans le cadre d'une action culturelle, voire sociale $e^{48} . »$

De notre côté, nous préférons utiliser des éléments similaires à ceux visés par le professeur SIIRIAINENEN de manière plus abstraite pour englober les régimes français et hongrois : c'est pourquoi nous optons pour le terme «organisme» ou «organisation» au lieu du terme «société », car ce dernier ne nous paraît pas applicable au contexte général de la gestion collective.

Grâce à ces différences, il est également possible de catégoriser les différentes formes existantes de gestion collective, ce qui nous permet d'avoir une opinion au sujet du respect de l'autonomie de l'auteur malgré la collectivisation de ses droits. Ces catégories peuvent être établies selon l'étendue de la collectivisation, le caractère volontaire ou obligatoire de la gestion collective, la prise en compte de la gestion

\footnotetext{
${ }^{45}$ Szjt. $\S 85$.

${ }^{46}$ 2011. évi CLXXIII. törvény a szellemi tulajdonra vonatkozó egyes törvények módosításáról.

${ }^{47}$ Szjt. $\$ 89$.

${ }^{48}$ SIIRIAINEN, Fabrice: Théorie générale de la gestion collective. Logique du droit exclusif de la gestion collective. JCl. Propriété littéraire et artistique, Fasc. 1550. point 10.
} 
collective étendue et enfin, l'ampleur de la liberté dont dispose l'organisme de gestion collective pour établir les conditions d'utilisation ${ }^{49}$.

\section{Section 2. Le mécanisme de la gestion collective}

La gestion collective est avant tout une expression de l'autonomie contractuelle des auteurs pour contrôler d'une façon efficace l'exploitation de leurs œuvres. Cette autonomie est, en revanche, encadrée par le législateur. La France et la Hongrie présentent deux approches différentes. Le droit français privilégie l'autorégulation des auteurs alors que le législateur hongrois a choisi de mettre en place une surveillance étendue de l'État sur le fonctionnement des organisations.

Il convient dès lors, de présenter ces deux approches de la gestion collective $(\S 1)$ de manière à aborder ensuite les différentes formes de contrôle de l'activité des organisations visées $(\S 2)$.

\section{\$1. Les formes associatives des organismes de gestion collective}

Même si les auteurs sont libres de créer des organismes de gestion collective, leur forme est définie par la loi : en Hongrie, ces organismes prennent la forme d'associations tandis qu' en France, ils sont constitués sous la forme de société civile.

La loi hongroise de $\mathrm{n}^{\circ}$ CLXXIII de $2011^{50}$ a redessiné le régime relatif au fonctionnement et au contrôle des organisations de gestion collective dans le but de libéraliser le marché. Cette réforme profonde a laissé intact les deux caractéristiques fondamentales du régime, à savoir, la forme juridique des organisations ${ }^{51}$ d'une part et leur immatriculation obligatoire auprès de $\mathrm{SZTNH}^{52}$. La forme légale de l'association sert avant tout à garantir l'autonomie des auteurs lors de la création et de l'opération de l'organisme et veille à ce que cette activité soit à but non-lucratif ${ }^{53}$. Ce choix correspond à la tradition civiliste hongroise qui attribue aux associations un rôle de promotion des activités culturelles ou sportives.

\footnotetext{
${ }^{49}$ FICSOR (1985) p. 299-300.

50 2011. évi CLXXIII. törvény a szellemi tulajdonra vonatkozó egyes törvények módosításáról.

${ }^{51} \S 91$ (1) de la Szjt.

$52 \S 86(1)$ de la Szjt.

53 La loi interdit explicitement à l'association de gestion collective de s'engager dans des activités commerciales. Seules certaines activités auxiliaires, telles que le bail des immeubles dont est l'association propriétaire, est autorisée, et les revenus provenant de cette activité doivent être utilisés afin de diminuer les frais de gestion [§ 89 (4) de la Szjt.].
} 
La loi édicte en outre certaines règles pour la constitution de l'association de gestion collective en raison de la particularité de son activité. L'adhésion à l'association est donc nécessairement non-discriminatoire, la demande d'un auteur candidat qui remplit les conditions d'adhésion déterminées par l'assemblée générale ne peut être refusée $^{54}$. Pour la gestion du portefeuille, une construction fiduciaire est mise en place. $\mathrm{Au}$ moment de l'adhésion, l'auteur donne mandat à l'association pour gérer ses droits pour son compte mais au propre nom de l'association. ${ }^{55}$ En effet, il ne s'agit pas d'une cession des droits exclusifs à l'association, car la loi hongroise pose le principe de l'incessibilité de ces droits et permet uniquement la cession de leurs exploitations. ${ }^{56}$ Le mandat vise uniquement à donner à l'association l'autorisation d'exploiter ces droits. L'auteur a également la possibilité de donner mandat à l'association sans y adhérer. L'inconvénient, dans ce cas, est que l'auteur perd toutes possibilités de s'exprimer dans les organes de démocratie interne (assemblée générale) de l'association.

En France, les «sociétés de perception et de répartition des droits» sont constituées sous forme de société civile, en raison des avantages que présentent une telle solution, similaires à ceux prodigués par le régime hongrois (autonomie et opération à but non-lucratif), et ceci tout en s'adaptant à la culture juridique française. Il est intéressant de noter d'ailleurs, que malgré les origines françaises de la gestion collective $^{57}$, aucune réglementation spécifique ne s'y référait jusqu'à l'adoption de la loi de 1985 qui a inséré les articles L. 321-1 à L. 321-13 dans le CPI.

Les sociétés d'auteurs peuvent comprendre des auteurs, des artistes-interprètes, des producteurs de phonogrammes et des vidéogrammes ${ }^{58}$. Les contrats conclus par les sociétés d'auteurs, constituées sous forme de société civile, sont par définition des contrats de droit civil, nonobstant la qualité de commerçant que certains de ses membres peuvent posséder. Le lien entre la société et ses membres soulève alors certaines questions théoriques. Il y existe, par exemple, plusieurs possibilités pour la société d'acquérir la qualité d'agir en justice au nom de ses membres, telles que la cession ou le

\footnotetext{
${ }_{55}^{54} \S 92(1)$ a) de la Szjt. $\mathrm{Vu}$ bulletin de d'adhésion de ARTISJUS http://artisjus.hu/_userfiles/file/szerzoknek/nyomtavanyok/belepesi_nyilatkozat_szerzoi.pdf. ${ }^{56} \S 16$ (1) de la Szjt.

${ }^{57}$ HAJDU (2014b) p.53-55 et surtout les références citées en notes de bas de page.

${ }^{58}$ Art. L. 321-1 du CPI.
} 
mandat, étant précisé que la distinction porte principalement sur l'étendue des droits exclusifs ainsi cédés.

En l'absence de forme et de dénomination uniforme dans les deux pays, nous préférons utiliser l'expression «organisation de gestion collective » pour décrire le mécanisme d'une manière générale et abstraite. Quand nous analyserons des questions spécifiques, nous utiliserons le vocable employé dans le pays concerné.

\section{\$2. L'encadrement de la gestion collective par le législateur hongrois et français}

Au-delà de la nature spéciale de l'activité exercée par les organisations de gestion collective, le nombre significatif de leurs membres ${ }^{59}$ justifie la nécessité d'une forte intervention de l'Etat lors de leur constitution et dans leur fonctionnement.

Le contrôle de l'Etat lors de la constitution se manifeste par la nécessité de remplir des critères supplémentaires par rapport à ceux exigés lors de la création des autres personnes morales de même forme juridique. En France, les critères spéciaux s'appliquent uniquement à la société souhaitant être agréée par le Ministre de la culture dans le but d'assurer la gestion collective obligatoire prévue par la loi. En revanche, en Hongrie, l'accord préalable donné par la SZTNH est une condition de validité pour la constitution de toutes les associations de gestion collective.

Actuellement, neuf associations hongroises sont immatriculées au registre des organisations de gestion collective tenue par la SZTNH. Parmi elles, l'association représentant les auteurs des œuvres musicales et littéraires a une place remarquable non seulement en raison de sa taille, mais également à cause de l'étendue de ses activités. La loi lui confie la perception des sommes dues aux autres bénéficiaires (typiquement, les titulaires de droits voisins) et le versement de ces sommes aux associations respectives de ces titulaires de droit. Les associations sont majoritairement constituées pour assurer la gestion des droits patrimoniaux qui sont soumis à la gestion collective obligatoire. Etant donné que ces dispositions couvrent les droits traditionnellement gérés collectivement, la gestion collective volontaire est reléguée en second plan.

En France, l'intérêt de l'agrément ministériel est de pallier l'absence de contrôle des auteurs par une surveillance administrative et judiciaire plus stricte afin de garantir la transparence et renforcer la crédibilité des sociétés de gestion collective. Les

\footnotetext{
${ }^{59}$ Paris, 20 février. 1990: RIDA juill. 1990, p. 365. D. 1991. Somm. 100 obs, Colombet
} 
critères posés servent surtout à confirmer l'aptitude de la société à la gestion des droits imposés par le législateur. La France a, d'ailleurs, développé une structure complexe de la gestion collective avec vingt-sept sociétés, parmi lesquelles certaines, souvent des entités crées par des SPRD et non directement par des auteurs, sont dotées de l'agrément ministériel. Toutefois, ces sociétés ne sont pas des entités distinctes et complètement indépendantes des «sociétés mères », dans la mesure où leurs personnels et les matériaux sont souvent communs à ces sociétés.

Ensuite, s'agissant des règles relatives au contrôle du fonctionnement, celles-ci garantissent la transparence des opérations réalisées par les organisations. ${ }^{60}$ Au-delà des règles générales, des dispositions spécifiques s'appliquent à l'approbation des «communications des droits ${ }^{61}$, qui constituent des conditions générales pour l'octroi des licences en Hongrie.

Ce contrôle général est effectué en France par la commission permanente des sociétés de gestion collective, et complété par la surveillance du Ministre de la culture. En Hongrie, c'est la SZTNH qui veille chaque année au respect des conditions d'immatriculation et que les statuts, les règlements intérieurs et les règles relatives à la répartition des droits soient conformes aux lois en vigueur ${ }^{62}$. L'autorité peut prendre plusieurs mesures pour restaurer le fonctionnement légitime des associations, pouvant aller jusqu'à la radiation de l'association registre. ${ }^{63}$

Une particularité du régime hongrois de la gestion collective consiste dans le fait de soumettre l'adoption des conditions générales d'affaire et des barèmes à une procédure de consultation menée avec les organismes représentant des utilisateurs ${ }^{64}$ et la notification de ces documents dans l'annexe du Journal Officiel hongrois après l'approbation du Ministre de la justice. Le législateur a mis en place cette procédure de manière à ce que les organisations de gestion collective n'abusent pas de leur position dominante, mais également, pour leur assurer une légitimité plus forte ${ }^{65}$. Toutefois, cette solution ne respecte pas l'autonomie des organisations (et donc celle des auteurs), car le

\footnotetext{
${ }^{60}$ C'est d'ailleurs l'un des principaux buts de la directive 2014/26.

61 Jogdíjközlemény.

$62 \S 92 / K(1)$ de la Szjt.

$63 \S 92 / K(6)$ de la Szjt.

64 Selon la loi, les utilisateurs importants ont le droit de déposer leurs commentaires lors de la consultation des lois. La procédure de consultation des tarifs relatifs à la rémunération pour copie privée révèle également la prise en compte des sondages concernant l'utilisation des supports audiovisuels.

${ }^{65}$ Györi Ítélőtábla Gf.I.20.007/2011/14.
} 
tarif afférent à l'utilisation des œuvres est librement négocié lors de l'exploitation individuelle des droits. L'approbation ministérielle des barèmes a des conséquences sur leur nature juridique : ces derniers sont considérés comme des conditions générales d'affaire $^{66}$, s'appliquant de la même façon à chaque utilisateur qui envisage de contracter avec l'association. Néanmoins, les barèmes n'ont pas la nature de texte législatif ou règlementaire, c'est-à-dire que le régime général de nullité des conditions générales d'affaire leur est applicable ${ }^{67}$. En France, c'est uniquement par rapport à la rémunération pour copie privée qu'une commission spéciale est chargée de déterminer le montant à payer. Le système français repose ainsi sur la coopération complète entre les sociétés de gestion collective et les utilisateurs lors de la négociation des conditions applicables aux licences. A notre sens, cette pratique correspond mieux à la vraie nature du droit d'auteur ${ }^{68}$.

\footnotetext{
${ }^{66} \mathrm{BH} 2001.380$.

${ }^{67}$ Un régime spécial est réservé aux cas où le débiteur demande la nullité d'une clause du contrat qui a été établie par la loi ou conformément aux dispositions législatives.

${ }^{68}$ DIETZ (2001-2002) p. 906-907.
} 


\section{Conclusion de la première partie}

L'objectif de cette première partie était de présenter la place occupée par la gestion collective au sein du droit d'auteur, et notamment son interconnexion avec les exceptions et limitations.

Le fait que la gestion collective repose essentiellement sur le volontariat et que l'autonomie des auteurs lors de la création et du fonctionnement de ces organisations soit garantie sont pourtant mis à mal par un contrôle rigoureux des institutions étatiques et un recours obligatoire à la gestion collective du fait du législateur. De ce point de vue, la Hongrie affiche une philosophie différente de celle de la France. Cette différence se manifeste clairement dans les nombreux cas de la gestion collective imposée par la loi hongroise, et au travers des règles strictes relatives au contrôle des associations. En revanche, le CPI tente d'embrasser l'idée selon laquelle la gestion collective, basée sur le volontariat, constitue une forme aboutie de cette modalité d'exploitation. Cette situation aboutit à un système complexe et moins transparent concernant la gestion des droits imposées par la loi. Cette tendance s'explique par le fait que le législateur fait bénéficier à la fois les auteurs et les titulaires des droits voisins de droits ainsi collectés et justifie la création de nouvelles sociétés. Une solution différente est celle favorisée par la loi hongroise, notamment une organisation est compétente pour la perception et la comptabilisation de certains droits et ensuite les transmets aux autres associations aux fins de distribution.

Le contrôle de l'Etat lors de la création et de l'opération est considéré comme une restriction à l'autonomie de l'auteur, car il s'agit d'une intervention dans le monopole de l'auteur, mais, bien évidemment, ces mesures sont nécessaires pour assurer le bon fonctionnement de ce mode de gestion. La gestion collective imposée par la loi apparaît comme un cas encore plus restrictif pour le monopole d'auteur et constitue une forme atypique de l'exploitation des droits. En France, l'idée de la gestion collective obligatoire est plutôt rejetée par rapport à sa version hongroise. En Hongrie, le caractère limitatif de la gestion collective obligatoire est présent dans de nombreux cas prévus par la loi, auxquels il convient d'ajouter une forte surveillance étatique. En résumé, le concept même de la gestion collective volontaire est mutilé du fait des dispositions législatives. 


\section{Deuxième partie : La gestion collective imposée par la loi : limitation au droit exclusif}

Nous entendons par gestion collective imposée par la loi tous les cas de gestion collective prévus par les textes législatifs, indépendamment de la volonté des titulaires de droit. La gestion collective obligatoire, parmi d'autres, fait partie de ce concept largement défini. Sa particularité réside dans l'exclusivité qui est offerte par ce mode de gestion : l'auteur ne peut, sous aucun prétexte, exploiter son œuvre selon la méthode individuelle. La gestion collective obligatoire peut parfois concerner des droits exclusifs, mais elle est; plus généralement, une forme communément acceptée de certains droits à rémunération, typiquement des licences légales.

De ce fait, la gestion collective obligatoire peut constituer une double limitation aux droits patrimoniaux. En premier lieu, elle est une restriction à l'exploitation des droits exclusifs, sans avoir, pour autant, un effet négatif sur l'existence même du droit. Pour l'auteur non-membre de l'organisation, la limitation est encore plus étendue, car il n'est pas représenté par les organes de démocratie interne de l'organisation, ce qui a l'avantage, pourtant, d'accroître la protection de ses intérêts de manière non-négligeable. En deuxième lieu, également considéré comme une limitation classique la restriction du droit exclusif en matière de licence légale est compensée par une rémunération soumise à la gestion collective. Dans cette hypothèse, la gestion collective n'est qu'une limitation indirecte, qui s'attache inséparablement à la transformation du droit exclusif en droit à rémunération.

Mode de gestion atypique, le législateur l'a introduit pour le droit de retransmission par câble et pour certains droits de reproduction (Chapitre I). La gestion de la rémunération pour copie privée est l'exemple courant de la gestion des licences légales (Chapitre II). 


\section{Chapitre I. L'encadrement de l'exercice des droits des auteurs par la gestion collective}

Le droit exclusif représente la liberté, pour un auteur, de décider s'il souhaite ou non exploiter son œuvre et, dans l'affirmative, sous quelles conditions. Cette faculté est bien évidemment mutilée lorsque le législateur décide, à la place de l'auteur, d'imposer la gestion collective comme moyen unique d'exploitation de certains droits exclusifs. Le niveau de restriction dépendra alors de la marge de manœuvre réservée à l'organisation : si le législateur prévoit des règles détaillées pour sa pratique (exemple : clauses de contrat d'exploitation, montant de la rémunération en contrepartie de la licence etc.), la gestion collective obligatoire devient similaire aux licences légales. Il convient d'analyser dès alors, à la fois le texte de loi et la pratique des organisations pour voir si la gestion collective imposée par le législateur représente une méthode particulière de l'exploitation des droits exclusifs ou une mutilation de ceux-ci.

Dans notre première section, nous parlerons du droit de retransmission par câble (section 1) pour pouvoir aborder, dans une seconde section, la gestion collective des droits de reproduction (section 2).

\section{Section 1. Les droits de représentation}

Le fait d'imposer la gestion collective en matière de droit de retransmission par câble est une possibilité prévue par la Convention de Berne ${ }^{69}$ et rendue obligatoire par la directive $93 / 83^{70}$. Les raisons ayant conduit à imposer la gestion collective dans pareil cas ne trouve pas uniquement sa source dans l'explication traditionnelle de la gestion collective, à savoir, le nombre considérable des utilisateurs. Le câblodistributeur, utilisateur secondaire de l'œuvre ne dispose pas de choix pour composer son programme, il retransmet tout simplement un programme préétabli et diffusé par un acteur distinct. Il convient alors de lui proposer une méthode simple pour obtenir des licences nécessaires à son activité.

L'harmonisation de la gestion du droit de représentation et plus particulièrement le droit de retransmission par câble au niveau européen résulte avant tout de l'évolution du droit de l'audiovisuel. L'adoption de la directive «télévision sans

\footnotetext{
${ }^{69}$ Art. 11 bis (2) de la Convention de Berne.
}

${ }^{70}$ Art. 9 (1) de la directive 93/83. 
frontières $»^{71}$ était une étape importante dans la création d'un marché unique des services audiovisuels. Le projet original, qui a tenté d'harmoniser tous les aspects de ce marché d'une manière transversale, a proposé alors un recours aux licences obligatoires du droit de retransmission par câble. Cette idée ayant été rejetée, les questions relatives au droit d'auteur ont été distinguées de ce projet pour donner naissance à la directive 93/83, qui a opté pour le respect de l'intégralité du droit exclusif et mis en place la gestion collective obligatoire ${ }^{72}$.

En Hongrie, d'autres droits exclusifs de la représentation sont également soumis à la gestion collective par la force de la loi. C'est notamment le cas du droit de la diffusion par voie hertzienne qui est également géré par le biais de la gestion collective obligatoire. En revanche, la gestion collective est seulement présumée et donc ouvre le droit d'en sortir concernant le droit de diffusion par satellite. Il convient d'étudier d'abord la complexité des droits de représentation $(\$ 1)$ pour pouvoir continuer ensuite étudier la mise en œuvre de ces droits (§2).

\section{\$1. Le contenu des droits}

Le droit de représentation est la forme typique de l'exploitation immatérielle de l'œuvre, c'est-à-dire de l'utilisation sans fixation sur un support physique ${ }^{73}$. Traditionnellement et historiquement, il s'agit de l'exécution de l'œuvre en présence d'un public en lieu et place de la représentation. L'évolution de la technologie permet désormais l'extension du droit de représentation à l'exploitation des œuvres réalisée par la diffusion des signaux à un public non-présent sur le lieu d'exécution. C'est alors l'entreprise de communication audiovisuelle qui assure l'infrastructure technologique de ces émissions, laquelle est d'ailleurs considérée comme utilisateur aux termes du droit d'auteur.

Cette évolution inévitable a nécessité la révision de la Convention de Berne afin d'assurer un droit exclusif à l'auteur d'autoriser de telles exploitations des œuvres

\footnotetext{
${ }^{71}$ Directive 89/552/CEE du Conseil du 3 octobre 1989 visant à la coordination de certaines dispositions législatives, réglementaires et administratives des États membres relatives à l'exercice d'activités de radiodiffusion télévisuelle.

${ }^{72}$ Cette solution est également avantageuse du point de vue du marché intérieur, car l'harmonisation complète assure sa cohérence. S'il existe des différences dans le niveau de protection, il y a un risque que les câblodistributeurs s'installent dans l'état membre où il est le plus bas. C'est la raison pour laquelle le législateur ne laissait aucune marge de manœuvre aux parlements nationaux, contrairement à la solution retenue par la Convention de Berne. BERCESI (1996) p. 52.

${ }^{73}$ Il n'est pas anodin que la première loi des 13-19 janvier 1791 relatif au droit d'auteur en France a traité de la représentation et de l'exécution publique des œuvres dramatiques et musicales.
} 
aux entreprises. L'article 11bis a été introduit lors de la révision intervenue en 1928, mais les dispositions actuelles n'ont été adoptées qu'à l'issue de la conférence diplomatique de Bruxelles en 1948. Cet article permet aux Etats signataires de la Convention de Berne de déterminer les modalités d'exploitation des droits exclusifs définis. Les modalités se manifestent en général dans la gestion collective imposée par le législateur.

La directive 93/83 a réduit cette faculté laissé aux Etats membres de l'UE, signataire de la Convention de Berne, en prévoyant l'introduction d'un régime obligatoire de la gestion collective relatif au droit de retransmission par câble.

\section{A) Exécution publique, communication au public et autres droits}

La Convention de Berne établit un liste des droits patrimoniaux qui forment le seuil de protection minimale en faveur des auteurs. Afin de protéger l'exécution publique des œuvres, elle énumère le droit de représentation publique, le droit de l'exécution publique, le droit de transmission publique et le droit de radiodiffusion ou communication publique par tout autre moyen. Les différents droits nationaux regroupent ces droits d'une manière différente selon leurs traditions juridiques.

La tradition française est de regrouper ces droits, soit sous le droit de représentation, soit sous le droit de reproduction. Le CPI, dans son article L. 122-2, propose alors une définition vague, selon laquelle « la représentation consiste dans la communication de l'œuvre au public par un procédé quelconque». La doctrine a nuancé cette définition neutre en proposant une liste d'exploitations identifiées en fonction de la technique utilisée pour leurs réalisations ${ }^{74}$.

La loi hongroise, pour sa part, suit une approche différente, et prévoit deux formes typiques de l'exploitation de l'œuvre en l'absence de fixation matérielle : la représentation publique concernant un public présent sur le lieu de l'exécution et la communication à un public absent. Dans cette dernière catégorie, le droit exclusif, et surtout son mode de gestion, dépendent de la réalisation technologique mise en œuvre. La diffusion par voie hertzienne, par exemple, relève de la gestion collective obligatoire, alors que la gestion collective du droit de la diffusion par satellite est uniquement présumée.

\footnotetext{
${ }^{74}$ LUCAS - LUCAS - LUCAS-SCHLOETTER (2012) p.284-299.
} 


\section{B) Le droit de retransmission par câble}

La Convention de Berne adopte une définition large et pose comme seule exigence que l'organisme de retransmission soit différent de celui à l'origine de diffusion. La directive 93/83 dans son article $1^{\text {er }}$ (3) énonce expressément le contenu et l'étendue du droit de retransmission par câble, préalable indispensable à l'harmonisation visée et à l'interprétation uniforme du droit au sein de l'Union européenne. Selon les dispositions de la directive, on entend par «retransmission par câble» «la retransmission simultanée, inchangée et intégrale par câble ou par un système de diffusion par ondes ultracourtes pour la réception par le public d'une transmission initiale à partir d'un autre État membre, sans fil ou avec fil, notamment par satellite, d'émissions de télévision ou de radio destinées à être captées par le public».

Afin de se conformer aux textes mentionnés ci-dessus, le CPI contient un article général relatif à la retransmission ${ }^{75}$ et un autre qui reprend mot-à-mot la lettre de la directive. ${ }^{76}$ Cette situation aboutit donc à la cohabitation de deux régimes parallèles du droit exclusif : l'un relatif à la retransmission transfrontalière au sein de l'Union Européenne qui relève de la gestion collective obligatoire, et l'autre, indépendant du premier, relatif aux autres retransmissions.

Le législateur hongrois a décidé d'introduire un régime uniforme de gestion collective obligatoire pour toutes les retransmissions, peu important l'origine du programme original. Cette solution est conforme à la fois à la Convention de Berne et à la directive $93 / 83$.

Le droit de retransmission par câble a été défini autour de deux caractéristiques déterminants, l'émission originale et la retransmission. De ce point de vue, il existe une différence terminologique remarquable entre la Convention de Berne, qui utilise la terminologie du droit d'auteur et fait référence aux œuvres, alors que la directive 93/83 utilise la terminologie du droit de l'audiovisuel et ne concerne que les émissions de télévision ou de radio. La mélange du droit d'auteur et du droit de l'audiovisuel n'est pas souhaitable à notre sens, car il risque de rendre plus difficile la détermination exacte des contours et de l'objet du droit de retransmission par câble. La loi hongroise

\footnotetext{
75 Art. L. 132-20 du CPI.

${ }^{76}$ Art. L. 132-20-1 du CPI.
} 
surmonte cette différence de terminologie et précise que le droit de retransmission par câble s'applique aux « œuvres diffusées dans une émission de télévision ou de radio » ${ }^{77}$.

L'émission originale doit répondre à trois conditions cumulatives. D'abord, elle doit provenir d'un Etat membre de l'Union européenne. Cette précision permet aux Etats membres de maintenir un régime différent pour les émissions strictement nationales et celles provenant d'un Etat tiers. L'application d'un régime différent en fonction de la source du programme est la solution retenue par le CPI. La loi hongroise, quant à elle prévoit un régime uniforme pour toutes les retransmissions, tout en respectant à la fois la Convention de Berne et la directive 93/83. Ensuite, l'émission originale doit être retransmise par une chaîne publique. Cette exigence est la répétition de la vocation générale du droit d'auteur : il n'est pas applicable aux utilisations non destinées au public. Enfin, le texte est rédigé d'une manière neutre concernant la technologie utilisée : l'émission pourrait-être réalisée par câble, par diffusion par voie hertzienne ou par satellite.

La retransmission est également soumise à conditions précisément établies. Si ces conditions ne sont pas réunies dans leur intégralité, l'utilisation perd son caractère privilégié, et on retourne aux règles générales de l'autorisation.

Ceci étant posé, la retransmission doit être simultanée, inchangée et intégrale en vertu de la directive 93/83. La retransmission est considérée simultanée avec l'émission originale, si les deux émissions se déroulent parallèlement. Un décalage minime qui résulte des caractéristiques physiques de la technologie utilisée est toutefois autorisé, si la retransmission est automatique. Avec l'intervention humaine, elle perd sa nature simultanée. La retransmission est inchangée si l'intégrité de l'émission originale reste intacte, et intégrale si la totalité de l'émission originale est soumise à la retransmission $^{78}$. Il en découle logiquement que les retransmissions retardées ${ }^{79}$ ou modifiées (par exemple en découpant ou remplaçant les publicités) ne constituent pas de retransmissions par câble au titre de la directive.

\footnotetext{
${ }^{77} \S 20$ (2) de la Szjt.

${ }^{78}$ VON LEWINSKI - WALTER (2010) p. 420.

${ }^{79}$ Le «channel sharing» par exemple ne correspond pas aux critères de la directive. HUGENHOLTZ (2009) p. 13.
} 
La Convention de Berne est indifférente aux mises en œuvre technologiques de la retransmission : celle-ci peut donc être réalisée soit par fil, soit sans fil ${ }^{80}$. Le champ d'application de la directive 93/83 et beaucoup plus restrictif et s'étend uniquement de la retransmission faite par câble ou microondes ${ }^{81}$. En conséquence, le simulcasting, qui relève de la transmission des signaux via internet, ne peut pas être considéré comme retransmission par câble en application de la directive 93/83 ${ }^{82}$. L'application de la directive a également été rejetée dans l'affaire EGEDA, portant sur la diffusion des émissions dans les chambres d'hôtel ${ }^{83}$, les conditions afférentes à la retransmission n'étant pas réunies.

En raison des différences existant entre le traité international et la directive communautaire, notamment sur la technologie utilisée, on peut s'interroger sur l'existence d'un conflit de normes. En théorie, le problème est résolu, car l'Union Européenne n'est pas partie signataire à la Convention de Berne. Pourtant, elle a signé le Traité ADPIC, qui reprend les dispositions de la Convention de Berne. La restriction concernant la technologie utilisée pour la réalisation de la retransmission pourrait être vue alors comme une violation du Traité ADPIC (et non de la Convention de Berne), dans la mesure où l'UE garantit moins de droits à l'auteur que prévu au niveau international. Pourtant, si on accepte que la gestion collective obligatoire est une limitation au droit d'auteur, la délimitation technologique du droit assure sa conformité au test en trois étapes, car dans toutes les autres hypothèses, l'auteur peut jouir l'intégralité de son monopole.

Il convient de mentionner un point, qui ne se trouve pas expressément dans la directive 93/83, alors qu'il est souvent au cœur du débat relatif à la retransmission par câble: il s'agit de savoir si la retransmission doit atteindre un nouveau public. La Convention de Berne ne prévoit pas cette condition ${ }^{84}$. La question est pourtant pertinente, car au niveau national, le public de la retransmission et celui de la diffusion

\footnotetext{
${ }^{80}$ Le simulcasting est ainsi considéré comme une retransmission selon la Convention de Berne.

${ }^{81}$ Il est intéressant de constater, à cet égard, que les États membres ont soit strictement suivi la directive, soit repris la formulation neutre de la Convention de Berne. DEPREEUW - TRIAILLE (2013) p. 228-232.

${ }^{82}$ Cette utilisation du coup relève du champ d'application de l'article 3 de la directive 29/2001/CEE. Vu l'affaire CJUE C-607/11 TV Catchup, 26.

${ }^{83}$ Affaire CJUE C-293/93 EGEDA, point 25. EDELMAN (2001) p. 1094.

${ }^{84}$ Sur l'interprétation de l'article 11bis de la Convention de Berne à cet égard : SUISA (Swiss Society of Authors and Publishers) v. Rediffusion AG, Bundesgericht (Swiss Federal Supreme Court) [1982] ECC 481 (BGE 107 II 57) 20 January 1981. Tribunal Fédéral suisse, 20 mars 1984 (RIDA 1985 janv).
} 
originale peuvent se chevaucher. En France, pourtant, l'encadrement géographique de la retransmission par câble implique qu'elle cible un nouveau public ${ }^{85}$.

Le SZJSZT a apporté une autre précision technique qui ne figurait pas dans la directive ou dans la Convention de Berne. Le signal lui-même, d'après les experts, peut être analogue ou numérique. Néanmoins, le décryptage des émissions cryptées ne constitue pas une retransmission, car le simple fait de décrypter n'est pas considéré comme une nouvelle utilisation puisqu'il fait partie intégrante de l'émission originale ${ }^{86}$.

\section{$\S .2$ L'exercice des droits}

Selon la Convention de Berne, «il appartient aux législations des pays de l'Union de régler les conditions d'exercice des droits mentionnés dans l'alinéa 1 de l'article 1 bis $»^{87}$. Ces conditions ne peuvent avoir qu'un effet strictement limité aux Etats qui les auront établies, et ne pourraient en aucun cas porter atteinte au droit moral de l'auteur, ni à son droit d'obtenir une rémunération équitable fixée. La convention prévoit alors la faculté pour les Etats d'imposer des limitations au droit de retransmission par câble sous certaines conditions. Cette possibilité se traduit souvent dans les textes nationaux par l'introduction des licences obligatoires ${ }^{88}$ ou, plus couramment, par la gestion collective obligatoire.

Dans ce contexte, la directive 93/83 oblige les Etats membres de l'UE à mettre en place un système de gestion collective obligatoire pour le droit de retransmission par câble défini par la directive. Il convient de rappeler que la loi hongroise applique le même régime pour la retransmission par câble et pour la diffusion des œuvres par voie hertzienne.

\section{A) Exercice obligatoire des droits de représentation par la gestion collective}

La loi hongroise prévoit un droit exclusif d'autorisation exercé uniquement par le biais de la gestion collective. L'association qui représente des auteurs d'œuvres littéraires et musicales est ainsi en charge de conclure les contrats avec les utilisateurs.

\footnotetext{
${ }^{85}$ Art. L. $132-201^{\circ} \mathrm{du}$ CPI.

${ }^{86}$ SZJSZT 38/2000.

${ }^{87}$ Art. 11 bis (2) de la Convention de Berne.

88 Dans ce cas, les conditions d'utilisation sont établies par un tiers. Le plus souvent, il s'agit d'une autorité qui attribue des licences d'utilisations au nom des auteurs.
} 
Les communications de droit ${ }^{89}$ et les conditions générales d'affaires, sont complétées par des clauses particulières relatives aux caractéristiques techniques de la diffusion. L'association dispose également de la faculté de négocier des conditions d'utilisation individualisées avec les utilisateurs importants.

\section{B) Exercice du droit de retransmission par câble}

A cause de la délimitation précise du champ d'application matériel de la directive, un Etat membre peut appliquer trois systèmes différents en fonction de la provenance de la retransmission, laquelle peut être extracommunautaire, intracommunautaire ou domestique. Nous nous concentrerons, pour notre part, principalement à l'exercice par les organisations de gestion collective du droit de retransmission intracommunautaire, comme la directive le prévoit.

En théorie, il existe deux méthodes pour assurer la représentation obligatoire des auteurs. Le première est d'obliger l'auteur à adhérer à l'organisation ou, à tout le moins, de lui donner un mandat exclusif de représentation. L'inconvénient de cette solution consiste dans la restriction apportée à la liberté contractuelle de l'auteur si l'organisation de gestion collective se trouve dans une situation de monopole. Si plusieurs organisations sont agréées à représenter l'auteur pour la gestion du droit de retransmission par câble, il est contraint de choisir parmi ces organisations. Le CPI a choisi cette méthode et prévoit, dans l'alinéa 2 de l'article L. 132-20-1 que si l'auteur n'a pas confié la gestion de son droit de retransmission par câble à l'une de ces sociétés, il désigne celle qu'il charge de l'exercer. L'auteur notifie par écrit cette désignation à la société concernée, qui ne peut la refuser. Le fait d'imposer la gestion collective de la sorte remet en question les principes mêmes du droit d'auteur français : l'exploitation individuelle des droits et le caractère de droit privé des sociétés de gestion collective ${ }^{90}$. Afin de contrebalancer l'absence de liberté de choisir ou non la gestion collective, le CPI prévoit des règles spéciales pour l'agrément de ces sociétés ${ }^{91}$.

\footnotetext{
${ }^{89}$ Az ARTISJUS Magyar Szerzői Jogvédő Iroda Egyesület közleménye az irodalmi és zeneművek sugárzás útján, vezetékkel vagy egyéb módon a nyilvánossághoz történő közvetítéséért, kódoltan történő eredeztetéséért $\square$ zetendő szerzői jogdíjakról, valamint a felhasználás engedélyezésének egyéb feltételeiről (R-TV 15). Disponible au https://www.artisjus.hu/wpcontent/uploads/2013/04/aktualis_jogdijkozlemeny_r_tv.pdf.

${ }^{90}$ FRANÇON (1997) p. 252.

${ }^{91}$ Art. R. 323-1 et suivants du CPI.
} 
La deuxième méthode consiste à étendre la gestion collective aux auteurs qui ne sont pas membres de organisation ou qui ne lui ont pas donné mandat de représentation $^{92}$. Dans ce cas-là, une présomption irréfragable assure le bon fonctionnement du régime. La directive 93/83 utilise cette technique et prévoit dans son article 9 (2) que «lorsque le titulaire n'a pas confié la gestion de ses droits à une société de gestion collective, la société de gestion collective qui gère des droits de la même catégorie est réputée être chargée de gérer ses droits». Si plusieurs organisations sont désignées pour gérer ces droits, l'auteur peut librement en choisir une. La loi hongroise adhère d'une manière générale à l'extension de la gestion collective $^{93}$; il n'est pas donc nécessaire de le préciser spécifiquement par rapport au droit de retransmission par câble.

Pour autoriser les utilisations, l'organisation de gestion collective conclut des contrats en son nom propre mais pour le compte des titulaires de droit. L'attribution des licences d'autorisation est automatique sous réserve du paiement des tarifs établis. En pratique, il existe également des convention cadres conclues avec les utilisateurs importants. En tout état de cause, les conditions d'utilisation sont les mêmes pour les catégories d'œuvres similaires. La directive 93/83 favorise aussi une médiation en cas de désaccord entre les organisations de gestion collective et les utilisateurs, afin de maintenir la nature contractuelle de l'exploitation et d'éviter des licences obligatoires. Dans les deux pays, les organisations peuvent ester en justice en cas de contrefaçon d'œuvres appartenant à leur portefeuille de gestion.

L'administration rigoureuse de chaque œuvre utilisée et la transmission des données permet une répartition exacte des droits. La loi hongroise édicte des seuils de répartition mais les associations peuvent prévoir des clés de répartition différentes ${ }^{94}$ en concluant un accord.

La directive elle-même énonce une exception au champ d'application de la gestion collective obligatoire s'agissant des droits exercés par un organisme de radiodiffusion à l'égard de ses propres émissions, peu important que les droits lui appartiennent ou qu'ils aient été transférés par d'autres titulaires du droit d'auteur et/ou

\footnotetext{
${ }^{92}$ De ce point de vue plutôt général, la gestion collective obligatoire peut être vue comme une forme de la gestion collective étendue privée de la possibilité de retirer des droits de la gestion.

9387 (1) de la Szjt.

${ }^{94} § 28$ (4) de la Szjt. Un tel accord n'était pas conclu relatif au droit de retransmission par câble.
} 
des droits voisins ${ }^{95}$. D'après Mihály FICSOR, cet article met en exergue le caractère exceptionnel de la gestion collective obligatoire, c'est-à-dire qu'elle est uniquement envisageable par le législateur lorsque il n'existe pas d'autre moyen pour l'exercice efficace des droits ${ }^{96}$.

\section{Section 2. La gestion collective des droits de reproduction}

Les droits de reproduction susceptible de faire l'objet de la gestion collective sont la reproduction mécanique des phonogrammes en Hongrie et la reproduction par reprographie en France.

La gestion collective du droit de reproduction mécanique en Hongrie ressort de l'article 13 (1) de la Convention de Berne, qui dispose que «chaque pays de l'Union peut, pour ce qui le concerne, établir des réserves et conditions relatives au droit exclusif de l'auteur d'une ouvre musicale et de l'auteur des paroles, dont l'enregistrement avec l'œuvre musicale a déjà été autorisé par ce dernier, d'autoriser l'enregistrement sonore de ladite cuvre musicale, avec, le cas échéant, les paroles ; mais toutes réserves et conditions de cette nature n'auront qu'un effet strictement limité au pays qui les aurait établies et ne pourront en aucun cas porter atteinte au droit qui appartient à l'auteur d'obtenir une rémunération équitable fixée, à défaut d'accord amiable, par l'autorité compétente ».

La loi du 3 janvier 1995 a introduit la gestion collective obligatoire de la reproduction par reprographie en France, bien avant l'adoption de la directive 2001/29 qui prévoit l'harmonisation transversale du droit de reproduction et précise, à l'article 5 (2) a), les conditions de sa limitation en raison de la reproduction par reprographie. La France n'a pas toutefois transposé cette disposition de la directive et conserve son système existant tout en respectant les dispositions de la Convention de Berne.

\section{\$1. Le contenu des droits}

Il convient d'analyser la notion et l'étendue des droits séparément pour le droit reproduction mécanique (A) et pour la reproduction par reprographie (B) car l'acte de reproduction se manifeste différemment dans les deux droits exclusifs.

\footnotetext{
${ }^{95}$ Art. 10 de la directive 93/83.

${ }^{96}$ FICSOR (2003b) p. 6-7.
} 


\section{A) Le droit de reproduction mécanique}

La reproduction mécanique, au sens large, englobe des méthodes utilisées pour reproduire les œuvres musicales. La loi hongroise réunit deux droits exclusifs autrement indépendants en définissant le droit mécanique comme l'enregistrement sonore et la distribution des œuvres musicales non dramatiques et de leurs paroles, ainsi que les extraits des œuvres musicales dramatiques (les «petits droits $»)^{97}$. Ces droits sont obligatoirement gérés par les organisations de gestion collective et l'auteur peut uniquement renoncer à la somme qui lui serait due après la distribution. Il en découle, $a$ contrario, que la reproduction et la distribution de l'œuvre dramatico-musicale sont toujours soumises à l'autorisation individuelle de l'auteur. D'après la pratique communément acceptée, les actes ou les morceaux importants d'une telle œuvre relèvent en revanche du régime de la gestion collective obligatoire. La reproduction devrait être identique à l'œuvre originale, car la loi est sans équivoque concernant l'adaptation : celle-ci relève toujours de l'accord individuel de l'auteur ${ }^{98}$.

Dans sa version originale, le droit de reproduction mécanique est apparu dans la loi hongroise comme une licence obligatoire. Afin d'être en conformité avec le droit d'auteur international ${ }^{99}$, le législateur hongrois a amendé le texte par une loi $\mathrm{n}^{\circ}$ CXII de $2008^{100}$ visant à transformer la licence obligatoire en gestion collective obligatoire. Selon le texte en vigueur avant la loi de 2009, la gestion collective obligatoire était applicable également à la reproduction et la distribution des œuvres multimédia, des vidéogrammes et bases de données numériques créées à partir des œuvres de petits droits. Le texte hongrois n'était alors pas conforme à la Convention de Berne, parce que le champ d'intervention de la gestion collective obligatoire était défini ${ }^{101}$ de manière trop large.

\footnotetext{
$97 \S 19$ (1) de la Szjt.

98 § 19 (2) de la Szjt., Fővárosi Bíróság P.22419/2006/25., SZJSZT 18/2010.

99 Art. 13 (1) de la Convention de Berne dispose ainsi: "chaque pays de l'Union peut, pour ce qui le concerne, établir des réserves et conditions relatives au droit exclusif de l'auteur d'une ouvre musicale et de l'auteur des paroles, dont l'enregistrement avec l'œuvre musicale a déjà été autorisé par ce dernier, d'autoriser l'enregistrement sonore de ladite ouvre musicale, avec, le cas échéant, les paroles ; mais toutes réserves et conditions de cette nature n'auront qu'un effet strictement limité au pays qui les aurait établies et ne pourront en aucun cas porter atteinte au droit qui appartient à l'auteur d'obtenir une rémunération équitable fixée, à défaut d'accord amiable, par l'autorité compétente ».

100 2008. évi CXII. törvény a szerzői jogról szóló 1999. évi LXXVI. törvény módosításáról.

${ }^{101}$ SZJSZT 01/2009/1. et SZJSZT 15/08.
} 


\section{B) La reproduction par reprographie}

Le recours à la gestion collective du droit exclusif de la reproduction par reprographie est justifié par le nombre élevé des utilisations des œuvres et par la possibilité relativement facile d'assurer le suivi de ces utilisations.

Dans le langage commun, on entend tout simplement par reprographie la reproduction des documents par une machine à photocopier. Le langage juridique, cependant, y inclut d'autres actes de reproduction. Ainsi, le CPI définit la reprographie comme une technique qui s'entend de la reproduction sous forme de copie sur papier ou support assimilé par une technique photographique ou d'effet équivalent permettant une lecture directe ${ }^{102}$. En conséquence, la reprographie suppose que la copie soit réalisée sur papier ou support assimilé, comme par exemple la toile. Il en découle également, que la reproduction réalisée sur des supports digitaux relève du régime distinct de la copie privée, et non celui du droit de la reproduction par reprographie. Les reproductions où la lisibilité de l'œuvre est indirecte, tel que l'écran de l'ordinateur, sont également exclues de la qualification de reprographie. La CJUE a retenu un argumentaire similaire dans l'affaire VG Wort, en affirmant que l'article 5 (2) a) de la directive 2001/29 «ne comprend pas de supports de reproduction non analogique, à savoir, notamment, numérique, dans la mesure où un substrat doit pouvoir servir de support à une représentation physique perceptible par les sens humains ${ }^{103}$. La reprographie, conformément au langage courant, concerne principalement alors les œuvres imprimées, telles que les écritures littéraires, artistiques et scientifiques ou les partitions de musique.

La copie devrait résulter de la photographie ou une technique d'effet équivalent permettant une lecture directe. Ce dernier élément a été ajouté au CPI afin de créer un texte flexible et moderne qui puisse être potentiellement appliqué à une variété de techniques non existantes au moment de l'adoption de la loi ${ }^{104}$. Il n'est pas surprenant que l'évolution du numérique ait provoqué de nouvelles interrogations à cet égard, notamment sur le fait de savoir si une technique qui enchaîne des étapes numériques et analogues, mais résulte d'une copie sur papier ou sur support assimilé (exemple : scan suivi d'une impression des documents numérisés) relève-t-elle de la reprographie? La

\footnotetext{
${ }^{102}$ Art. L. 122-10 du CPI.

103 Affaires jointes C-457/11 C-460/11, VG Wort, 67.

${ }^{104}$ BÉCOURT (1995a) p. 59.
} 
CJUE a répondu par l'affirmative à cette question dans l'affaire VG Wort ${ }^{105}$. Toutefois, il convient de préciser que l'impression à partir d'une source uniquement numérique n'est pas considérée comme une reprographie en raison des différences visuelles liées à la mise en page de l'écriture sur l'écran et sur le papier ${ }^{106}$.

La France a maintenu le droit exclusif de la reprographie, donc il ne s'agit pas de compensation équitable régie par la directive en contrepartie des utilisations. Il en résulte aussi que l'auteur peut interdire certaines utilisations ${ }^{107}$ telles que la reproduction intégrale des documents. En effet, seule la reprographie des extraits est autorisée dans la pratique des sociétés de gestion collective. Or, selon la logique du droit exclusif, contrairement à celle des limitations et exceptions, une autorisation globale pour la reproduction complète et totale de l'œuvre pourrait être envisageable ${ }^{108}$. La dernière conséquence inhérente au maintien du droit exclusif est la possibilité de reproduire des partitions, ce qui n'est pas licite selon l'article 5 (2) a) de la directive 2001/29.

Le maintien du droit exclusif nous invite à étudier les synergies entre le droit à la reproduction par reprographie et les exceptions du CPI y afférentes. Les établissements scolaires sont comptés parmi les utilisateurs les plus importants en matière de reprographie donc nous pourrons naturellement penser aux exceptions valorisées dans l'enseignement. Les documents, fascicules préparés par les enseignants sur la base de l'exception de la courte citation ou de l'analyse ne doivent pas relever nécessairement de l'autorisation, car ces documents atteignent rarement le seuil minimum de la protection. Le CPI détermine lui-même le rapport entre la reproduction par reprographie et l'exception pédagogique. Cette exception octroie une rémunération forfaitaire au profit de l'auteur, sans préjudice de la cession du droit de reproduction par reprographie. Son montant devrait être déterminé alors en fonction des droits déjà acquittés pour la reproduction par reprographie, ce qui ne s'est jamais produit en matière d'œuvres littéraires (contrairement aux œuvres audiovisuelles). L'exception de

\footnotetext{
${ }^{105}$ Affaire VG Wort, 70.

${ }^{106} \mathrm{http}: / /$ www.cfcopies.com/lexique/r

${ }^{107}$ LUCAS, André: Droit de la reproduction par reprographie (CPI, art. L.122-10 à L.122-12) J.Cl. Propriété littéraire et artistique, Fasc. 126513.

${ }^{108}$ C'est la raison principale pour laquelle André Lucas critique cette pratique des sociétés de gestion collective. Son argumentation ne prend pas en compte, à notre sens, que la reprographie est per se une utilisation secondaire. La limitation quantitative a alors pour finalité de protéger le marché primaire des œuvres en question. LuCAS, André: Droit de la reproduction par reprographie (CPI, art. L.122-10 à L.122-12) J.Cl. Propriété littéraire et artistique, Fasc. 126513.
} 
revue de presse, compte tenu de sa finalité, ne s'oppose pas à la reproduction par reprographie, qui sert un objectif différent.

\section{\$2. La mise en auvre des droits}

Dans les deux cas, il convient d'évoquer la cession des droits (A) avant de traiter des questions pratiques de leurs exploitations (B).

\section{A) Le transfert des droits}

Dans son libellé original, le § 19 (1) de la Szjt. prévoyait que le producteur de phonogramme, le producteur de l'œuvre multimédia et le producteur de base de données électroniques peut réclamer, en contrepartie d'une rémunération appropriée, de lui autoriser la reproduction sur phonogramme, vidéogramme, œuvre multimédia ou base de données électroniques, ainsi que la distribution des œuvres musicales avec ou sans parole et des extraits de l'œuvre dramatico-musicale déjà divulguée. Postérieurement à l'adoption de la loi de 2008, le texte est revenu à une tournure plus classique : l'auteur peut désormais uniquement exercer son droit par l'association de gestion collective. Le remplacement de licence obligatoire par la gestion collective obligatoire est plutôt symbolique, et démontre la volonté du législateur de respecter la cohérence du droit d'auteur.

La loi française a choisi un outil différent de celui retenu en matière de droit de retransmission par câble. Le CPI indique que la publication de l'œuvre emporte cession du droit de reproduction par reprographie à une société de gestion collective ${ }^{109} . \mathrm{La}$ cession est automatique, exclusive et forcée ${ }^{110}$, qualifiée parfois de cession légale ou contrat forcé ${ }^{11}$, et elle permet à la société agréée de conclure seule tout contrat avec les utilisateurs aux fins d'exploiter le droit ainsi cédé. Cependant, pour les stipulations autorisant les copies aux fins de vente, de location, de publicité ou de promotion, l'accord préalable de l'auteur ou de ses ayants droit est requis ${ }^{112}$. L'objectif de cette distinction est de préserver le marché primaire de l'œuvre et de laisser la faculté à l'auteur de décider l'utilisation commerciale de son œuvre. Toutefois, l'article du CPI n'est pas sans équivoque en ce qui concerne la mise en œuvre pratique de l'autorisation

\footnotetext{
${ }^{109}$ Art. L. 122-10 du CPI.

${ }^{110}$ DERIEUX (1995) p. 28.

${ }^{111}$ CARON (2013a) p. 284.

112 Art. L. 122-10. du CPI.
} 
préalable : s'agit-il d'une licence octroyée d'un commun accord par la société de gestion collective et le titulaire de droit ${ }^{113}$, ou une prérogative intacte, indépendante de la cession automatique du droit d'autoriser les utilisations non commerciales ${ }^{114}$ ?

La jurisprudence constante semble favoriser cette deuxième interprétation ${ }^{115}$, qui remet néanmoins en cause la validité des contrats conclus par un accord commun entre la société de gestion collective et le titulaire de droits ${ }^{116}$. La nature impérative de la gestion collective est renforcée par l'article L. 122-10 alinéa 4 du CPI, qui dispose que ces dispositions s'appliquent à toutes les œuvres protégées quelle que soit la date de leur publication, nonobstant toute stipulation contraire. La notion de publication, étant une notion assez vague ${ }^{117}$, plusieurs interprétations sont possibles. La Convention de Berne assimile la publication à l'édition ${ }^{118}$; cependant, la publication peut aussi signifier tout simplement la divulgation de l'œuvre ${ }^{119}$. Le CFC, société de gestion collective agréée pour la gestion du droit de reproduction par reprographie, adopte une conception stricte de la publication et propose des licences uniquement pour les œuvres éditées ${ }^{120}$. Ce choix emporte des conséquences non négligeables pour le titulaire du droit de reproduction par reprographie, puisque l'auteur jouit du droit exclusif et peut le céder à l'éditeur ${ }^{121}$ préalablement à l'édition, c'est-à-dire que l'éditeur bénéficie de la répartition des droits collectés et donne autorisation individuelle à l'utilisation commerciale du droit de reprographie.

\section{B) Les moyens utilisés dans la perspective de l'exercice des droits}

En ce qui concerne le droit mécanique, le contrat autorise la reproduction et la distribution des copies ainsi produites. L'association de gestion collective agréée hongroise, ARTISJUS, a élaboré deux méthodes pour proposer des licences aux

\footnotetext{
${ }^{113}$ LUCAS, André: Droit de la reproduction par reprographie (CPI, art. L.122-10 à L.122-12) J.Cl. Propriété littéraire et artistique, Fasc. 1265. 35., BOIRON (2004) p. 21.

${ }^{114}$ BOIRON (2004) p. 18-22. CARON (2013a) p. 245. VERCKEN (2005) p. 50-51.

${ }^{115}$ CA Paris 24 mars 2004, TGI Paris 3e ch, 2e sect., 9 juillet 2010, CA Paris 2e ch 27 mai 2011, C.cass. civ. 1re, 11 décembre 2013.

${ }^{116}$ VERCKEN (2005) p. 51.

117 DERIEUX (2010a).

118 Art. 3 (3) de la Convention de Berne : «Par «œuvres publiées», il faut entendre les ouvres éditées avec le consentement de leurs auteurs, quel que soit le mode de fabrication des exemplaires, pourvu que la mise à disposition de ces derniers ait été telle qu'elle satisfasse les besoins raisonnables du public, compte tenu de la nature de l'œuvre ».

${ }^{119}$ LUCAS, André: Droit de la reproduction par reprographie (CPI, art. L.122-10 à L.122-12) J.Cl.

Propriété littéraire et artistique, Fasc. 1265, 22.

${ }^{120}$ Contrat CFC 3.1.

${ }^{121}$ VERCKEN (2005) p. 52.
} 
utilisateurs. La première nécessite, au préalable, le versement d'une contrepartie pour chaque œuvre enregistrée, déterminée en fonction de nombre des copies effectuées. La deuxième méthode consiste dans la mise en place du protocole BIEM-IFPI, qui rend possible le paiement «en bloc et en aval». Ce type de contrat est proposé en général aux utilisateurs importants, qui remplissent des conditions strictes.

Bien qu'il s'agisse de gestion collective obligatoire, un outil permet toutefois à l'auteur d'en «sortir», et plus précisément, de ne pas faire entrer son œuvre dans ce mécanisme de gestion. Cet outil est l'édition à compte d'auteur qui assure l'exploitation directe de l'œuvre par son auteur sans l'intervention d'un producteur de phonogramme. Ainsi, si l'auteur décide d'exploiter son œuvre de cette manière, ${ }^{122}$ il est dispensé de demander l'autorisation de l'organisation de gestion collective et de payer les droits prévus à cet effet ${ }^{123}$. Toutefois, hormis cette hypothèse, la gestion collective reste obligatoire et l'utilisateur ne peut pas conclure de contrat directement avec l'auteur ${ }^{124}$.

Dans le cadre de l'exercice du droit exclusif de reproduction par reprographie le CPI clarifie le pouvoir de la SPRD agréée en matière de conclusion de contrats. La société établit les barèmes et les conditions d'utilisation des droits, et si nécessaire, elle peut également ester en justice.

Pour déterminer les droits à payer en contrepartie des licences accordées, quatre méthodes sont utilisées. Les tarifs peuvent en effet être arrêtés en fonction (i) de la capacité de l'appareil, (ii) du nombre des copies effectuées annuellement, (iii) du nombre d'élèves, étudiants ou employés de l'utilisateur ou (iv) une combinaison des méthodes susmentionnées ${ }^{125}$.

La France applique la troisième méthode, c'est à dire que le calcul de la rémunération est fonction du nombre de personnes qui bénéficient potentiellement des

\footnotetext{
${ }^{122}$ La jouissance et l'exploitation des droits patrimoniaux sont réservées à l'auteur qui peut décider de transmettre le droit d'exploitation à un tiers selon § 16 (1) de la Szjt.

${ }^{123}$ Naturellement, l'auteur ne bénéficiera pas des sommes versées. L'auteur, toutefois, est tenu de notifier l'édition à l'ARTISJUS avec le nombre des copies fabriquées, puisque le calcul des redevances pour copie privée dépend de ce chiffre. GYERTYANFY (2014) p. 168.

${ }^{124}$ Fövárosi Ítélötábla 8.Pf.21.470/2011/4.

${ }^{125}$ GUiBAULT (2003).
} 
copies. La Hongrie, pour sa part, a mis en place des grilles tarifaires en fonction de la capacité des machines ${ }^{126}$.

Le CFC n'autorise pas la copie intégrale de l'œuvre et applique la règle générale selon laquelle $10 \%$ d'un livre et $20 \%$ d'une revue sont librement «photocopiable ». Par ailleurs, la copie ainsi effectuée doit respecter la paternité de l'auteur sur son œuvre et faire mention des éléments bibliographiques. Il importe également de préciser que la copie a été autorisée par le CFC. D'ailleurs, pour permettre l'identification des ouvres concernées, l'utilisateur est tenu de communiquer les éléments bibliographiques du document concerné à la CFC. Le CPI ne prévoit aucun principe pour régir la distribution des droits : il appartient donc aux sociétés de gestion collective agréées d'en déterminer les règles ${ }^{127}$. La communication des œuvres concernées permet une distribution proportionnelle des sommes. Les droits distribués reflètent les spécificités des œuvres faisant l'objet de la photocopie : livres ou revues, illustrées ou non, selon les notifications des utilisateurs. En principe, le CFC verse les sommes dues à l'éditeur qui en assure le versement à l'auteur ${ }^{128}$, sauf stipulation contraire du contrat d'édition.

\footnotetext{
${ }^{126}$ Nous examinerons en détail les particularités de la rémunération pour reprographie dans le Chapitre II de la Deuxième partie car en Hongrie, la reprographie constitue une limitation au droit exclusif.

${ }^{127}$ CPI L. 122-12.

${ }^{128}$ VERCKEN (2005) p. 52-53.
} 


\section{Chapitre II. La gestion collective liée à la limitation des droits exclusifs}

La limitation des droits exclusifs à un simple droit à rémunération est une technique bien encadrée par le test en trois étapes, car le droit à rémunération ne répond pas à la logique principale du droit d'auteur qui est le droit exclusif de l'auteur. La licence légale, qui renvoie à l'hypothèse où l'autorisation d'utiliser l'œuvre découle directement de la loi et l'utilisateur est tenu de verser une rémunération en contrepartie, fait quand même partie intégrante du droit d'auteur. Le droit d'auteur continental la voit comme une forme spéciale des droits patrimoniaux qui implique la mise en place de garanties particulières en raison de la disparition du droit d'autoriser et d'interdire. Dans les deux pays concernés par notre thèse, la licence légale est complétée par la gestion collective obligatoire en raison de grand nombre des utilisations.

La copie privée est une illustration éclatante des licences légales (section 2), mais avant de l'étudier, il convient de mettre l'accent sur les différences entre la copie privée et la reproduction par reprographie, car celles-ci constituent deux solutions différentes au problème similaire de la reproduction abondante des œuvres (section 1).

\section{Section 1. Résolution différente d'un problème similaire}

Malgré les similitudes de la reproduction par reprographie et de la copie privée, tenant notamment au fait que ces notions sont déterminées par un nombre croissant et indéterminable d'utilisations, le législateur hongrois et français a choisi des solutions différentes $(\S 1)$. Afin de mieux comprendre l'intérêt de la copie privée, il convient également d'étudier en détail le test en trois étapes (\$2).

\section{\$1. Une technique différente pour restreindre les droits exclusifs}

L'idée de la rémunération pour copie privée a été développée en Allemagne dans les années 1960, comme réponse à la dispersion des magnétophones dans les foyers familiaux ${ }^{129}$. Cependant, l'exception de l'acte de copie privée gratuite était déjà connue en France au XIXème siècle ${ }^{130}$. La copie privée suppose, par définition, que l'œuvre ne soit pas communiquée au public. Elle se trouve en effet en dehors des périmètres du droit d'auteur. C'était grâce à l'augmentation exponentielle des copies facilement réalisables du fait des nouvelles inventions technologiques que le législateur

\footnotetext{
${ }^{129}$ HugenhOLTZ (2012) p. 182.

${ }^{130}$ RENOUARD (1839) p. 42.
} 
a décidé de compenser les auteurs pour ces actes privés. La Hongrie faisait partie des premiers pays qui ont adopté le principe d'une rémunération pour copie privée en 1982 ; la France a rejoint cette tendance un peu plus tard, en 1995. Cette solution consiste, principalement, à permettre, par l'intermédiaire de la loi, aux personnes privées, de disposer d'une autorisation d'utilisation et de prévoir une compensation pécuniaire forfaitaire en échange. Une telle solution n'était pas évidente à instituer au sein du droit d'auteur, car traditionnellement, il s'agit d'une utilisation privée. ${ }^{131}$ Ceci explique la considération de temps en temps des solutions fiscales ${ }^{132}$. C'est pourtant la généralisation des copies qui implique une réponse conforme au droit d'auteur.

La nature des utilisations explique également la différence entre reprographie et copie privée. Avant la révolution numérique, la photocopie était utilisée pour des raisons professionnelles, alors que les supports audiovisuels supposaient une utilisation dans un cadre privé ${ }^{133}$. La copie privée était, le plus souvent, réalisée à la maison, tandis que la photocopie s'effectuait dans un milieu professionnel, tel que la bibliothèque, un centre de photographie, un l'établissement scolaire et un lieu de travail. Il ne faut pas oublier qu'il s'agit de catégories fluctuantes, car la reprographie peut également servir à des usages professionnels et personnels, et des copies de documents non protégés par le droit d'auteur est aussi envisageable ${ }^{134}$. La copie privée sert en revanche principalement à l'utilisation personnelle de l'œuvre protégée, d'où l'idée de la séparer de la reprographie. L'avocat général VILLALON analyse les différences entre les deux modes d'utilisation dans les conclusions présentées au cours de l'affaire Reprobel ${ }^{135}$ concernant l'ère numérique et les appareils multifonctions. L'article 5 (2) a) de la directive 2001/29 ne mentionne pas le caractère privé de l'utilisation, contrairement aux dispositions relatives à la copie privée. La question se pose alors à savoir si les Etats membres devaient prendre en compte l'utilisation privée en fixant le montant de la compensation pour reproduction par reprographie ${ }^{136}$. L'avocat général affirme qu'une telle obligation ne s'impose pas aux Etats membres et qu'ils sont libres d'introduire une

\footnotetext{
${ }^{131}$ GAUDRAT - SARDAIN (2005) p. 10.

${ }^{132}$ Les premiers débats en France se sont déroulés autour du financement par une taxe parafiscale. LAPOUSTERLE (2009) p. 122. Plus récemment, l'Espagne s'est aussi tournée vers la compensation des auteurs par le budget central de l'Etat.

${ }^{133}$ De nos jours, avec l'émergence massive des appareils et supports numériques qui sont par définition polyvalents, cette différenciation stricte nous semble un peu obsolète.

${ }^{134}$ DAVIES - HUNG (1993) p. 8.

${ }^{135}$ Conclusions de l'avocat général du 11 juin 2015 dans l'affaire C-572/13, Reprobel.

${ }^{136}$ Conclusions de l'avocat général dans l'affaire Reprobel, considérant 34.
} 
telle possibilité dans leur système de redevance ${ }^{137}$. L'avocat général confirme ce faisant les écarts existants entre les deux régimes applicables, justifiés par les disparités de ces deux modes d'utilisation.

La théorie générale du droit d'auteur accepte désormais que la copie privée soit une exception ou limitation sous réserve de respecter les conditions définies par les textes législatifs y afférents ${ }^{138}$. L'application du test en trois étapes est nécessaire alors pour assurer la légitimité de ces utilisations.

\section{\$2. Limitations des droits exclusifs et le test en trois étapes}

Le test en trois étapes est devenu un outil communément accepté pour encadrer les exceptions et limitations du droit d'auteur, et pour assurer un équilibre entre le monopole de l'auteur et l'intérêt public d'accéder aux œuvres. Il a été introduit dans la Convention de Berne lors de sa révision de Stockholm en 1967, des dispositions concernant le droit de reproduction, qui ont été par la suite reprises (avec certaines modifications légères) par plusieurs sources de droit, tant au niveau international que national.

Dans sa version originale, le test est ainsi rédigé : «est réservée aux législations des pays de l'Union la faculté de permettre la reproduction desdites ouvres dans certains cas spéciaux, pourvu qu'une telle reproduction ne porte pas atteinte à l'exploitation normale de l'œuvre ni ne cause un préjudice injustifié aux intérêts légitimes de l'auteur ${ }^{139}$.

La directive 2001/29, pour sa part, contient l'article suivant : «les exceptions et limitations prévues aux paragraphes 1, 2, 3 et 4 ne sont applicables que dans certains cas spéciaux qui ne portent pas atteinte à l'exploitation normale de l'ouvre ou autre objet protégé ni ne causent un préjudice injustifié aux intérêts légitimes du titulaire du droit ${ }^{140}$.

Il semble que le CPI ait diminué le nombre des étapes à deux, en prévoyant que «les exceptions énumérées par le présent article ne peuvent porter atteinte à l'exploitation normale de l'œuvre ni causer un préjudice injustifié aux intérêts légitimes

\footnotetext{
${ }^{137}$ Conclusions de l'avocat général du 11 juin 2015 dans l'affaire C-572/13, considérants 52 et 53.

${ }^{138}$ Art. L. 122-5 $2^{\circ}$ du CPI, $\S 35$ de la Szjt., art. 5 (2) b) de la directive 2001/29.

139 Art. 9 (2) de la Convention de Berne.

${ }^{140}$ Art. 5 (5) de la directive 2001/29.
} 
de l'auteur ${ }^{141}{ }^{4}$. La loi hongroise, en revanche, a ajouté une condition supplémentaire et créé un test en quatre étapes par la formulation suivante: "l'utilisation dans les cadres des dispositions de l'utilisation libre est uniquement libre et non soumise au paiement des redevances, si elle ne porte pas atteinte à l'exploitation normale de l'cuvre, ni cause un préjudice injustifié aux intérêts légitimes de l'auteur, et elle est conforme aux règles de probité et n'est pas contraire aux finalités de l'utilisation libre ${ }^{142}$. Le test hongrois renforce alors la théorie selon laquelle le droit d'auteur relève du droit civil. Il semble que le test est complètement différent de sa version originale, mais il convient de noter que le quatrième étape, notamment la conformité de l'utilisation en question aux finalités de l'utilisation libre peut être interprétée comme équivalente à la condition de «certains cas spéciaux» telle qu'elle apparaît dans les autres documents. De manière synthétique, il ressort de ces quatre textes que les exceptions et limitations doivent (i) se restreindre à certains cas spéciaux, (ii) ne pas porter atteinte à l'exploitation normale de l'œuvre et (iii) ne causer aucun préjudice injustifié aux intérêts légitimes de l'auteur.

Le rôle du test et son interprétation varient en fonction du document juridique dans lequel il est inséré. A l'origine, la Convention de Berne avait prévu seulement des limitations au droit de reproduction. Les traités internationaux postérieurs, notamment le Traité ADPIC a élargi son champ d'application à tous les droits patrimoniaux ${ }^{143}$. Néanmoins, les principes du droit international public de l'interprétation des conventions internationales, font apparaître que le test en trois étapes, dans sa version ultérieure, ne s'applique pas à tous les droits patrimoniaux. Il pourrait être uniquement pris en compte pour la limitation du droit de location, le nouveau droit exclusif reconnu par le Traité ADPIC ${ }^{144}$. Il en est de même pour le Traité de l'OMPI sur le droit d'auteur, son article 10 incorporant du test s'applique exclusivement pour le droit de communication au public $^{145}$.

\footnotetext{
${ }^{141}$ Art. L. 122-5 du CPI.

${ }^{142} \S 33$ (2) de la «A felhasználás a szabad felhasználásra vonatkozó rendelkezések alapján is csak annyiban megengedett, illetve dijtalan, amennyiben nem sérelmes a mü rendes felhasználására és indokolatlanul nem kárositja a szerzö jogos érdekeit, továbbá amennyiben megfelel a tisztesség követelményeinek és nem irányul a szabad felhasználás rendeltetésével össze nem férö célra. »

${ }^{143}$ Art. 13 du Traité ADPIC.

144 GYENGE (2006) p. 174.

145 GYENGE (2006) p. 175.
} 
Incorporé dans les traités internationaux, le test sert à encadrer le législateur dans l'introduction les limitations aux droits exclusifs. La transposition de la directive 2001/29 dans les systèmes juridiques nationaux soulève la question si le texte communautaire a donné la possibilité aux juges du fond d'appliquer le test dans les litiges qui leur étaient soumis. Cette possibilité provoque un débat intellectuel sur la nature même du résultat découlant de l'application du test : s'agit-il d'une épreuve in abstacto ou in concreto ${ }^{146}$ ? Le fameux arrêt « Mulholland Drive » rendu par la Cour de cassation s'inscrit dans cette même lignée, la haute juridiction ayant fait usage de ce test, bien avant sa transposition en droit interne ${ }^{147}$.

Cette polémique influence aussi les méthodes d'interprétation du test, la recherche d'une interprétation générale est, au fur et à mesure, transformée en une interprétation concrète. En effet, hormis l'interprétation authentique qui en est faite par les juges ${ }^{148}$, c'est avant tout la doctrine qui a proposé des pistes pour mieux comprendre le fonctionnement du test. D'après la méthode traditionnelle élaborée par la doctrine, le test a vocation à interpréter graduellement, étape par étape, sans confondre leur ordre des éléments. En revanche, l'interprétation tout à fait novatrice ${ }^{149}$ et vivement critiquée met l'accent sur une application globale du texte, en considérant les différentes étapes comme un ensemble.

L'interprétation de l'article 5 (5) de la directive 2001/29 est présente dans une quinzaine arrêts de CJUE ${ }^{150}$. Parmi ces décisions, l'arrêt ACI Adam nous semble particulièrement important, puisqu'il a été rendu en matière de copie privée. Pour mémoire, il convient de rappeler que la directive contient une liste (quasiment)

\footnotetext{
${ }^{146}$ DUSOLLIER (2007) p. 438.

${ }^{147}$ Civ. 1re, 28 février 2006, Studio Canal et Sté Universal Pictures et al. c/ UFC Que Choisir et Perquin, dit « Mulholland Drive », $\mathrm{n}^{\circ}$ 05-15.824.

${ }^{148}$ Pourtant, il n'y a pas beaucoup d'affaires soulèvant les questions d'interprétation du test. Au niveau international, par exemple, une seule décision a été rendue : WTO Panel DS160 - United States Section 110(5) Copyright Act

${ }^{149}$ Nous faisons référence aux signataires de la Déclaration de München. GEIGER - HILTY - GRIFFITHS SUTHERSANEN (2008).

${ }^{150}$ CJUE 5 juin 2014, Public Relations Association Agency (C-360/13) ; CJUE 11 septembre 2014, Eugen Ulmer (C-117/13) ; CJUE 5 mars 2015, Copydan Båndkopi (C-463/12) ; CJUE10 avril 2014, ACI Adam (C-435/12) ; CJUE 27 février 2014, OSA (C-351/12) ; CJUE 27 juin 2013, VG Wort (du C-457/11 au C-460/11 affaires jointes); CJUE 26 avril 2012, DR et TV2 Danmark (C-510/10) ; CJUE 17 janvier 2012, Infopaq International (C-302/10) ; CJUE 9 février 2012, Luksan (C-277/10) ; CJUE $1^{\text {er }}$ décembre 2011, Painer (C-145/10) ; CJUE 16 juin 2011, Stichting de Thuiskopie (C-462/09) ; CJUE 21 octobre 2010, Padawan (C-467/08) ; CJUE 4 octobre 2011, Football Association Premier League et autres (C403/08) ; CJCE 16 juillet 2009, Infopaq International (C-5/08) CJCE 12 septembre 2006, Laserdisken (C479/04).
} 
complète des limitations et exceptions, laissant aux Etats membres toute liberté pour les transposer. Cette méthode d'harmonisation a abouti à un résultat opposé à celui poursuivi car elle a donné naissance à une disparité entre les législations nationales. C'est dans ces circonstances, que la CJUE a affirmé que le test en trois étapes se limite à préciser la portée des exceptions et des limitations prévues par la directive ${ }^{151}$. La Cour a précisé ensuite que l'article 5 (5) de la directive ne définit pas le contenu des différentes exceptions et limitations énoncées par cet article, mais n'intervient qu'au moment de l'application de celles-ci par les Etats membres ${ }^{152}$. La juridiction communautaire valide la fonction du test comme un outil imposant certaines exigences au législateur, et non au juge national. Toutefois, il convient de noter qu'en ce qui concerne l'exception de la reproduction temporaire, la CJUE a reconnu la conformité du texte de la directive au test en trois étapes ${ }^{153}$. Il est souhaitable de rappeler que dans l'arrêt ACI Adam, la Cour a omis de donner une interprétation de la première étape, et ceci pourrait être interprété comme étant un indice du fait qu'elle considère que la liste de la directive, pourtant exhaustive, se réfère à des cas particuliers. Ceci peut être traduit d'une telle manière que la première étape du test lie le législateur et les deux autres le juge. A notre sens, ce raisonnement n'est pas souhaitable, car il rend les contours du test encore plus abscons. En l'espèce, la Cour aurait dû vérifier si la directive fixe un cadre strict pour les actes de l'utilisateur dans le contexte de la copie privée ${ }^{154}$. De plus, dans d'autres affaires, la Cour avait donné une interprétation de la première étape ${ }^{155}$.

S'agissant de la deuxième étape, la CJUE en a fourni une analyse plus détaillée. Son argumentaire consiste à affirmer que si des reproductions faites par des personnes privées peuvent être réalisées à partir d'une source illicite, cela encouragerait la circulation des œuvres contrefaites ou piratées, diminuant ainsi nécessairement le volume des ventes ou des autres transactions légales relatives des œuvres protégées, de sorte qu'il serait porté atteinte à l'exploitation normale de celles-ci ${ }^{156}$. Pourtant, son argumentation n'est pas complète puisque la Cour ne précise pas le sens de l'œuvre

\footnotetext{
${ }^{151}$ CJUE C-351/12, considérant 40.

${ }^{152}$ CJUE C-435/12, considérant 25.

${ }^{153}$ CJUE C-302/10, considérant 56.

${ }^{154}$ MEZEI - HAJDU (2014) p. 41.

${ }^{155}$ Par exemple CJUE 5 juin 2014, Public Relations Association Agency (C-360/13), considérant 55. «A cet égard, il convient de rappeler, tout d'abord, que les copies sur écran et les copies en cache n'étant réalisées que dans le but de consulter des sites Internet, elles constituent, à ce titre, un cas spécial. » ${ }^{156}$ CJUE C-435/12, considérant 39.
} 
contrefaite ou piratée. Dans ces conditions, il est difficile pour un juge national de s'inspirer de cet arrêt.

S'agissant de la troisième étape, la Cour a uniquement déclaré que l'application de la législation nationale en question était susceptible d'entraîner un préjudice injustifié aux titulaires du droit d'auteur ${ }^{157}$. Il n'est pas surprenant que la CJUE soit restée laconique sur le sens qu'il fallait donner à cette étape. Nous pensons, pour notre part, que la Cour aurait dû s'exprimer sur les éléments de la compensation pour copie privée à cette occasion, conformément à la jurisprudence déjà rendue en la matière par ses soins.

L'interprétation du test au niveau national est également ambiguë. L'absence de la première étape dans le CPI donne lieu à deux interprétations. La première interprétation, in concreto, ajoute deux conditions générales aux éléments de validité des exceptions énumérées à l'article L. 122-5. Cette interprétation est délicate car elle laisse au juge le soin d'apprécier la légitimité des utilisations litigieuses au cas par cas. L'utilisateur n'est donc certain de la licéité de l'utilisation effectuée. L'autre interprétation favorise l'interprétation abstraite, en admettant que les exceptions prévues par le législateur sont désormais conformes au test en trois étapes ${ }^{158}$ et qu'il n'appartient pas au juge d'appliquer le test.

En l'absence d'interprétation jurisprudentielle de la version hongroise du test $^{159}$, c'est le SZJSZT qui a proposé des pistes de réflexion pour mieux comprendre le test. Le Conseil des experts en droit d'auteur a ainsi affirmé que le raisonnement social et juridique derrière la finalité poursuivie par la copie privée implique que celle-ci soit considérée comme un cas spécial, conformément à la première étape du test, car la copie privée ne saurait être considérée comme une exception. Dès lors, l'analyse des deux dernières étapes ne serait pas nécessaire ${ }^{160}$.

\footnotetext{
${ }^{157}$ CJUE C-351/12 (OSA), considérant 40.

${ }^{158}$ BENABOU (2007) p. 427-428.

159 A nos conaissances, seulement un arrêt fait référence au test en trois étapes, sans en donner l'interprétation. Debreceni Ítélőtábla Pf.I.20.220/2010/4.

${ }^{160}$ SZJSZT 17/2006. considérants 35 et 31.
} 


\section{Section 2. La gestion de la rémunération pour copie privée}

La loi hongroise a instauré une licence légale pour certains cas de l'exception de copie privée, puisque les paragraphes 20 (redevance des supports vierges) et 21 (redevance pour reprographie) de la Szjt. imposent de verser une rémunération forfaitaire en contrepartie de la création de certaines copies. Toutefois, cette rémunération forfaitaire n'est pas à la charge des utilisateurs mais du producteur, ou bien de celui qui les importe et, dans le cas de la reprographie, celui qui exploite des appareils concernés. Un système très similaire est en vigueur en France, lequel prévoit une rémunération pour la copie privée ${ }^{161}$. Nous étudierons parallèlement les deux régimes, et cette étude sera complétée par l'analyse de la rémunération pour reprographie en Hongrie.

\section{\$1. Les éléments constitutifs de la copie privée}

La doctrine résume en trois conditions cumulatives les exigences du CPI pour assurer la légitimité de la copie privée. La copie doit être (i) réalisée à partir d'une source licite, (ii) destinée à un usage individuel privé et non à une utilisation collective et enfin, (iii) l'usage poursuivi doit être celui du copiste. Ces conditions ressortent également de la loi hongroise, mais celle-ci met en avant également le fait que la copie devrait être réalisée par une personne physique et elle ne doit être utilisée, que ce soit directement ou indirectement, dans un but lucratif.

Une interrogation se pose en ce qui concerne la directive 29/2001, notamment en ce qui concerne la copie privée : à l'image de la compensation équitable pour copie privée ${ }^{162}$, la copie privée elle-même doit elle être considérée comme une notion du droit communautaire qui doit être interprétée de manière uniforme par les Etats membres ${ }^{163}$ ? A notre sens, la CJUE s'est orientée vers une telle interprétation dans l'arrêt ACI Adam, en exigeant que la source soit licite pour qualifier l'opération litigieuse de copie privée. Or, cette condition ne se trouve pas dans le texte de l'article 5 (2) b) de la directive.

La directive 2001/29 estime, par ailleurs, que l'auteur de la copie doit être une personne physique. Sa transposition par l'Etat hongrois a donc rendu nécessaire d'amender la loi hongroise, car initialement, cette dernière reconnaissait une exception

\footnotetext{
${ }^{161}$ Art. L. 311-1 du CPI.

${ }^{162}$ CJUE 21 octobre 2010, Padawan (C-467/08).

${ }^{163}$ LUCAS (2011) p. 93.
} 
de «copie personnelle» des personnes morales ${ }^{164}$. Une restriction spécifique concernant l'auteur de la copie résulte du texte de la loi hongroise, car les copies effectuées à l'aide d'un ordinateur ou sur un support numérique par une personne autre que celle qui l'utilise, sont exclues du champ de la copie privée ${ }^{165}$. Au regard de la loi hongroise, le copiste est l'utilisateur des copies numériques doivent être la même personne.

Le CPI ne contient pas de telles règles s'agissant de l'auteur de la copie. Cette notion a donc été précisée par la jurisprudence et la doctrine. Il en découle que le copiste, selon une définition pragmatique, est la personne qui effectue personnellement et directement les copies ${ }^{166}:$ il ne peut s'agir d'amis, d'un membre de la famille, ou d'une entreprise. Il doit disposer de l'œuvre protégée et aussi de l'appareil utilisé pour réaliser lesdites copies ${ }^{167}$. Selon une interprétation plutôt archaïque, ce rapport étroit entre le copiste et les copies suppose que les copies réalisés manuellement ${ }^{168}$, à notre avis, pourtant, il suffit de maîtriser personellement l'appareil.

La copie doit avoir pour finalité de servir à l'usage privé du copiste. D'un part, la directive 2001/29 précise ainsi qu'il ne peut s'agir de copies commerciales, que ce soit directement ou indirectement. La loi hongroise a imposé cette condition avant même la transposition de la directive, car il était exigé que les copies ne servent pas de gain ou ne permettent une augmentation des revenus, même de manière indirecte ${ }^{169}$. La copie privée doit remplir un but non lucratif ${ }^{170}$. D'autre part, selon la doctrine, l'usage privé s'apparente à une utilisation personnelle ou bien limitée au cercle familial ou amical du copiste au sens large, mais la finalité ultime de l'utilisation (enseignement, culture, divertissement etc.) est indifférente ${ }^{171}$. Nous critiquons ce concept vague de la doctrine, car selon notre opinion, le cercle familial au sens large est une notion floue susceptible d'être assimilée au public ${ }^{172}$.

\footnotetext{
${ }^{164}$ MEZEI (2006). MEZEI (2007). Dans certains cas précis, quelques institutions culturelles ou scolaires peuvent bénéficier d'une exception de copie libre, pour d'autres finalités que l'utilisation "privée ». Ces utilisations ne sont pas exemptées de la redevance des supports vierges.

$165 \S 35$ (3) de la Szjt.

${ }^{166}$ BERTRAND (2002) p. 62.

${ }^{167}$ LATREILLE (2004) p.403.

${ }^{168}$ DesBoIs (1978) p. 311.

${ }^{169} \S 18$ (1) de l'ancienne Szjt., « a szerzői jogról szóló 1969. évi III. törvény ».

${ }^{170}$ GYERTYANFY (2014) p. 253.

${ }^{171}$ GYERTYANFY (2014) p. 253

${ }^{172}$ Il appartiendrait au juge de déterminer ces limites en analysant les éléments en l'espèce.
} 
Le CPI dispose explicitement que la copie ne doit pas servir à des utilisations collectives, les copies faites pour la bénéfice des cercles privés ou d'associations (même occasionnelles) ne sont pas protégées par l'exception de copie privée. Le nombre des exemplaires copiés peut être utilisé pour identifier la nature collective ou privée des utilisations effectuées ${ }^{173}$. La doctrine française, avec un raisonnement similaire à celui de la doctrine hongroise, accepte, pour sa part, que les copies soient effectuées dans un dessein professionnel ${ }^{174}$.

Une troisième élément important pour la qualification de copie privée réside dans la légitimité de la source. La directive 2001/29 est muette sur cet point, et les Etats membres sont donc divisés : certains d'entre eux ont exigé que la source de la copie soit légitime lorsqu'ils ont été amenés à transposer la directive ${ }^{175}$ alors que d'autres ont refusé d'intégrer une telle condition en droit interne. La France a modifié le CPI en 2011 et ajouté la licéité de la source comme une condition de la légalité de la copie privée $^{176}$. En Hongrie, c'est le SZJSZT qui s'est exprimé sur cette question en l'absence de disposition législative. Il a ainsi affirmé que la légalité de la source est nécessaire pour la conformité de l'exception de copie privée à la première étape du test, c'est-àdire à l'exigence de «certain cas précis » ${ }^{177}$. Les arguments des partisans de la thèse adverses reposent avant tout sur la nécessité de garantir la fonctionnalité des redevances, et de protéger les utilisateurs individuels contre d'éventuelles poursuites. Ce débat au niveau européen semble désormais résolu, car la CJUE a déclaré que «si les Etats membres disposaient de la faculté d'adopter ou non une législation qui permet que des reproductions pour un usage privé soient également réalisées à partir d'une source illicite, il en résulterait, de toute évidence, une atteinte au bon fonctionnement du marché intérieur ${ }^{178}$.

La CJUE a clairement opté, ce faisant, de tendre vers une harmonisation plus complète du droit d'auteur, en essayant d'unifier les divers droits nationaux. Pourtant, il nous semble que les juges communautaires hésitent à emprunter la même voie, car ils ne

\footnotetext{
${ }^{173}$ Paris, 8. oct. 1982, RIDA janv. 1983, p. 138. RTD Com. 1983. 434 obs. Françon. BENSAMOUN (2008) p. 249-250.

${ }^{174}$ LATREILLE (2004) p. 403. En revanche, il existe des arrêts en jurisprudence qui en tire la conclusion opposée. Civ. 1re 20 janv. 1969: Gaz. Pal. 1969. 1. 217.

${ }^{175}$ WeSTKAMP (2007) p. 17.

${ }^{176}$ Loi n ${ }^{\circ} 2011-1898$ du 20 décembre 2011 relative à la rémunération pour copie privée.

177 SZJSZT 17/2006. considérant 36.

${ }^{178}$ CJUE C-435/12 considérant 35 .
} 
précisent pas ce qu'il faut entendre par «source illégale». Celle-ci peut en effet varier selon les législations nationales : les œuvres mises à disposition sans l'autorisation de l'auteur peuvent intégrer cette catégorie, mais des législations plus sévères peuvent également considérer que les sources dont le copiste n'est pas propriétaire, telle que les œuvres empruntées, constituent une «source illégale». Il y a lieu de noter, d'ailleurs, dans l'arrêt Copydån rendu par la CJUE, que la Cour a refusé de répondre à une question portant sur la source des copies privées litigieuses, au prétexte que cette notion ne faisait pas l'objet d'une harmonisation européenne.

\section{\$2. La mise en ouvre de la gestion collective}

La transposition de la directive 2001/29 a été effectuée d'une manière similaire dans les deux pays : les auteurs perçoivent une rémunération forfaitaire du fabriquant, de l'importateur, ou bien de la personne qui réalise une acquisition intracommunautaire, étant précisé que cette rémunération est gérée par les sociétés de gestion collective. Malgré ces similitudes, il existe des différences non-négligeables entre les législations hongroises et françaises, notamment en ce qui concerne la manière d'établir des tarifs. En Hongrie, cette tache relève de la compétence des organisations de gestion collective, alors qu'en France, elle a été attribuée à une commission spécialement désignée à cet effet ${ }^{179}$. La création de la commission, malgré la participation des représentants des personnes ayant intérêt dans la copie privée, laisse moins d'influance à l'auteur d'établir la rémunération qu'en Hongrie.

La jurisprudence de la CJUE a apporté des précisions sur plusieurs points qui constituent l'axe principal de notre analyse. Dans l'arrêt Padawan, la Cour a affirmé que la compensation équitable est une notion autonome du droit communautaire qui doit être interprétée d'une manière uniforme sur le territoire de l'UE ${ }^{180}$. Or, la CJUE n'a pas fourni de précisions quant à cette interprétation uniforme et a donc créé une insécurité juridique en reconnaissant aux États membres la faculté de déterminer la forme, les modalités de financement et de perception ainsi que le niveau de la compensation

\footnotetext{
${ }^{179}$ Art. L. 311-6 alinéa 1: «Les types de support, les taux de rémunération et les modalités de versement de celle-ci sont déterminés par une commission présidée par un représentant de l'État et composée, en outre, pour moitié, de personnes désignées par les organisations représentant les bénéficiaires du droit à rémunération, pour un quart, de personnes désignées par les organisations représentant les fabricants ou importateurs des supports mentionnés au premier alinéa du précédent article et, pour un quart, de personnes désignées par les organisations représentant des consommateurs 》.

${ }^{180}$ CJUE 21 octobre 2010, Padawan (C-467/08), considérant 33.
} 
équitable ${ }^{181}$. Paradoxalement, la Cour génère une confusion dans sa jurisprudence en précisant également que l'interprétation selon laquelle les Etats membres seraient libres de préciser les paramètres de manière incohérente et non harmonisée de la compensation équitable serait contraire à l'objectif de la directive 2001/29 ${ }^{182}$.

La CJUE a confirmé l'application des rémunérations forfaitaires en affirmant que la simple capacité des appareils et supports à réaliser des copies est suffisante pour ouvrir droit aux redevances pour copie privée, à condition qu'ils soient mis à la disposition des personnes physiques en tant qu'utilisateurs privés ${ }^{183}$. Au final, il est indifférent que les utilisateurs privés réalisent des copies privées sur ces supports. Néanmoins, la Cour a distingué entre les différents types d'utilisation, professionnelles et privées. Il nous semble néanmoins qu'avec l'affaire ACI Adam, la CJUE a partiellement rompu avec l'idée des forfaits et opté plutôt pour un système de compensation qui reflète davantage des critères juridiques et pratiques de la copie privée, car elle a apporté certaines précisions par rapport aux utilisations personnelles. Les droits français et hongrois reconnaissent aussi la nature forfaitaire de la rémunération ; la jurisprudence nationale précise toutefois que cette rémunération est déterminée en fonction de la capacité du support à faire des copies ${ }^{184}$. La Cour constitutionnelle hongroise met en avant la fonction générale de copie privée, c'est-àdire de balancer des intérêts des copistes et des titulaires de droit ${ }^{185}$. En revanche, le Conseil d'Etat, dans un arrêt rendu en $2008^{186}$ a considéré que la copie privée était une modalité particulière d'exploitation des droits des auteurs, dont le but était de compenser la perte des revenus.

La CJUE avec une interprétation contra legem a entièrement lié la compensation équitable à la notion de préjudice potentiel subi par les titulaires de droits $^{187}$, alors que il est uniquement une indicateur de son montant selon la considérant (35) de la directive 2001/29. La Cour, pourtant, n'as pas donné une explication plus détaillée de ce qu'il fallait entendre par «préjudice subi». Cette omission est

\footnotetext{
${ }^{181}$ CJUE 21 octobre 2010, Padawan (C-467/08), considérant 37.

${ }^{182}$ CJUE 21 octobre 2010, Padawan (C-467/08), considérant 36.

${ }^{183}$ CJUE 21 octobre 2010, Padawan (C-467/08), considérant 56.

${ }^{184}$ BH 1992.756. Crim. 18 décembre 2001. D. 2002. AJ 646, Légipresse $2002 \mathrm{n}^{\circ}$ 190, III, p. 62, CCE

2002, n ${ }^{\circ} 37$, note Caron, RIDA avr. 2002, p. 377, obs. Kérever.

185 124/B/2004. AB határozat III.2.1.

${ }^{186}$ Arrêt du 11 juillet 2008 du Conseil d'Etat.

${ }^{187}$ LUCAS-SCHLOETTER (2013a) p. 598.
} 
regrettable car cette notion peut être interprétée comme une simple perte économique, mais également renvoyer à la terminologie du droit de la responsabilité délictuelle, tributaire des traditions juridiques de chaque législation nationale. La Cour, dans des arrêts postérieurs à l'arrêt Padawan, a assoupli son interprétation stricte. A titre d'exemple, elle a précisé que la question de préjudice concernant la légitimité de la source relève du test en trois étapes. On peut même se poser la question de savoir le «préjudice subi » est identique à l'intérêt légal de l'auteur ${ }^{188}$.

Une particularité de la redevance pour copie privée est la distinction entre la personne qui cause la préjudice aux titulaires de droits et la personne qui est responsable du versement de la redevance, typiquement le producteur ou le distributeur des supports vierges ou autres appareils. Ce système se justifie, principalement, par les difficultés liées à l'identification de chaque utilisateur privé, et le montant minime du préjudice résultant d'une seule utilisation individuelle ${ }^{189}$. La CJUE a accepté l'existence d'un tel régime à condition que le montant de la redevance soit répercuté sur les utilisateurs privés ${ }^{190}$. La loi française de 2001 a bien précisé que le montant de la rémunération pour copie privée propre à chaque support est porté à la connaissance de l'acquéreur lors de la mise en vente des supports d'enregistrements ${ }^{191}$. Outre sa fonction pédagogique, cette notice explicative informe à l'utilisateur professionnel de demander l'exonération ou le remboursement des frais éventuellement générés ${ }^{192}$.

La CJUE a également précisé que le préjudice doit être rattaché au lieu de résidence de l'utilisateur privé. Cette précision a une importance particulière en ce qui concerne les acquisitions intracommunautaires dans la mesure où, dans un tel cas, il est nécessaire de déterminer le pays où la rémunération est due. La CJUE a ajouté également qu'une obligation de résultat impose aux Etats membres d'assurer la perception de ces redevances ${ }^{193}$. Afin d'éviter un double paiement, la Cour a pourtant approuvé la technique du remboursement dans l'arrêt Amazon ${ }^{194}$.

\footnotetext{
${ }^{188}$ LUCAS-SCHLOETTER (2015) p. 25.

${ }^{189}$ CJUE 21 octobre 2010, Padawan (C-467/08), considérant 46.

${ }^{190}$ CJUE 21 octobre 2010, Padawan (C-467/08), considérant 50.

${ }^{191}$ Art. L. 311-4-1 du CPI

${ }^{192}$ BinCTIN, Nicolas: Rémunération pour copie privée, J. Cl. Propriété littéraire et artistique, Fasc. 1510. 50.

${ }_{193}$ CJUE 16 juin 2011, Stichting de Thuiskopie (C-462/09), considérant 39.

${ }^{194}$ CJUE 11 juillet 2013, Amazon (C-521/11), considérenats 31-33.
} 
La rémunération pour copie privée peut uniquement servir à compenser des copies privées, toute utilisation professionnelle est ainsi exclue de l'assiette de la rémunération. ${ }^{195}$ On peut se demander alors si l'utilisateur privé pourrait demander l'exonération ou le remboursement des frais engagés s'il utilise le support d'enregistrement à des fins différentes de celle de la copie privée? A notre sens, le caractère forfaitaire de la rémunération exclut une telle possibilité.

La réalisation pratique de la séparation des utilisations privées et professionnelles rend nécessaire une révision systématique du régime existant de la copie privée. Deux solutions possibles sont envisageables : 1'exonération préalable ou le remboursement ultérieur des sommes. La loi hongroise, par exemple, prévoit des exonérations pour certaines utilisations professionnelles, telles que la mise en vente des supports aux fins d'exportation ou pour les appareils utilisés essentiellement dans les studios d'enregistrement. Les conditions générales d'affaire de l'association de gestion collective, qui prévoient des barèmes pour la perception de la redevance pour copie privée, ont donc été complétées postérieurement à l'arrêt Padawan puisqu'elles prévoient dorénavant des exemptions pour certaines utilisations professionnelles. Cet aspect est apparu en droit français lors de l'adoption de la loi de 2011 qui a inséré un article dans le CPI consacré au remboursement général : ainsi, lorsque les supports d'enregistrement sont acquis à des fins professionnelles et dont les conditions d'utilisation ne permettent pas de présumer un usage à des fins de copie privée, la réumération pour copie privée n'est pas due ${ }^{196}$.

Selon l'article 5 (2) b) de la directive 2001/29, l'application de mesures techniques de protection, visées à l'article $6^{197}$, doit être prise en considération lors de la mise en œuvre de la compensation équitable. Par rapport à l'interprétation de cette disposition la CJUE a précisé dans l'arrêt VG Wort : « eu égard au caractère volontaire de l'application de ces mesures techniques, même si une telle possibilité existe, le défaut d'application desdites mesures ne saurait entraîner la caducité de la compensation équitable. Néanmoins, il est loisible à l'Etat membre concerné de faire dépendre le

${ }^{195}$ Ce principe est d'ailleurs également appliqué pour la reproduction par reprographie. CJUE 12 novembre 2015, Hewlett-Packard Belgium (C-572/13), considérant 42.

${ }^{196}$ Art. L. 311-8. II. du CPI.

${ }^{197}$ Art. 6 (3) de la directive 2001/29. On entend par mesures techniques «toute technologie, dispositif ou composant qui, dans le cadre normal de son fonctionnement, est destiné à empêcher ou à limiter, en ce qui concerne les oeuvres ou autres objets protégés, les actes non autorisés par le titulaire d'un droit d'auteur ou d'un droit voisin du droit d'auteur prévu par la loi, ou du droit sui generis » 
niveau concret de la compensation due aux titulaires de droits de l'application ou non de telles mesures techniques, afin que ces derniers soient effectivement encouragés à les prendre et qu'ils contribuent ainsi volontairement à la correcte application de l'exception de copie privée ${ }^{198}$.

En principe, les Etats membres sont libres de déterminer les supports d'enregistrements soumis au paiement de la redevance pour copie privée. Cette assiette englobe des supports classiques, tels que les CDs, DVDs, ainsi que des supports multifonctionnels, comme des clés USB, des téléphones portables ou des tablettes tactiles. L'application de la rémunération sur cette dernière catégorie est toutefois délicate. En effet, ces supports sont polyvalents et pourraient être utilisés pour atteindre plusieurs objectifs, y compris l'acte de copie privée. Pourtant, la distinction des utilisations privées et professionnelles dans le cas des supports polyvalents suscite certaines difficultés, notamment en ce qui concerne la fixation des barèmes. La CJUE a déjà posé le principe selon lequel le fondement du paiement réside dans la capacité des supports à effectuer des copies. Les supports multifonctionnels peuvent alors être inclus dans l'assiette de base de calcul de la rémunération, sachant que leur caractère polyvalent doit être pris en compte lors de la fixation du montant exact de la rémunération à payer ${ }^{199}$. La haute juridiction hongroise a accepté un raisonnement similaire $^{200}$, alors que le Conseil d'Etat a annulé certaines décisions de la «commission copie privée » qui ont essayé d'élargir l'assiette de calcul en y incluant des supports multifonctions ou des appareils multimédia. D'après les juges administratifs, la «commission copie privée » a omis de prendre en compte la légalité de la source et a déterminé la redevance due uniquement sur la base de la capacité de stockage des supports concernés ${ }^{201}$. Afin de se conformer à la jurisprudence du Conseil d'Etat et de la CJUE, le législateur français a adopté la loi de 2011 de manière à instaurer de nouveaux principes pour régir le système de la rémunération pour copie privée.

\footnotetext{
${ }^{198}$ CJUE 27 juin 2013, VG Wort (du C-457/11 au C-460/11 affaires jointes) considérants 57-58.

${ }^{199}$ CJUE C-463/12 considérants 68-73.

${ }^{200}$ Kúria Pf.IV.21.272/2012/7. Fővárosi Bíróság P.20.497/2008/18.

${ }^{201}$ Décision $^{\circ} 8$ du 9 juillet 2007. CE, 10e et 9e ss-sect. 17 déc. 2010, no 310195: JurisData no 2010024376, Comm. com. électr. 2011, chron. 9. obs. P. Tafferau; Comm. com. électr. 2012, chron. 4, obs. X. Daverat. Kommentárját lásd: Strowel (2009) p. 56. Et aussi: Décision no 9 du 11 décembre 2007, Décision no 10 du 27 février 2008. CE 10e et 9e ss-sect, 17 déc. 2010, nº 314308, Comm. com. électr. 2011, chron. 9, obs. P. Tafforau; Comm. com. électr. 2012, chron 4, obs. X Daverat. CE et 9e ss-sect, 17 déc. 2010, $\mathrm{n}^{\mathrm{O}}$ 315832, Comm. com. électr. 2011, chron. 9, obs. P. Tafforeau; Comm. com. électr. 2012, chron. 4, obs. X. Daverat.
} 
Le cloud computing, une technologie de plus en plus répandue parmi les personnes privées pose des nouvelles questions par rapport à l'assiette de la rémunération. Cette technologie permet en effet aux utilisateurs de copier des œuvres protégées d'une part, et elle leur garantit un accès auxdites à partir de plusieurs appareils dédiés. Il convient de rappeler qu'il s'agit d'une technologie qui ne constitue pas en soi un appareil ou un support. L'idée envisagée est donc de mettre à la charge des serveurs qui stockent physiquement le contenu une rémunération au titre de copie privée. Toutefois, les appareils multimédia utilisés pour accéder aux fichiers stockés se trouvent, le plus souvent, dans «les nuages », et se voient déjà soumis à une rémunération pour copie privée. Il existe donc un risque de double paiement.

Il est opportun de mentionner également que des appareils multifonctionnels sont communément utilisés pour reproduire des œuvres par reprographie. L'avocat général ViLLALON a proposé quelques principes pour garantir la légitimité de telles utilisations. Tout d'abord, il faut qu'il y ait un lien nécessaire entre l'application de la rémunération forfaitaire sur les équipements et les appareils de reprographie et l'usage présumé de ces derniers à des fins de reproduction d'œuvres protégées ${ }^{202}$. Ensuite, le préjudice éventuellement causé par des copies devrait être évalué sur la base de critères objectifs et actualisés d'ordre statistique ${ }^{203}$. Enfin, il convient d'examiner si la rémunération forfaitaire doit, en tout état de cause, être assortie de la possibilité d'obtenir la restitution de la rémunération forfaitaire éventuellement indument versée. La CJUE a consacré une telle exigence de remboursement dans des conditions particulière, qui ne sont pas totalement assimilables à l'hypothèse étudiée ${ }^{204}$. Le régime existant en Hongrie ne correspond pas entièrement aux principes énoncés par l'avocat général, surtout en ce qui concerne le double critère d'actualité et d'objectivité de l'éventuel préjudice généré par les copies litigieuses. C'est le gouvernement hongrois qui a déterminé les appareils qui constituent l'assiette de la rémunération par décret tandis que les tarifs sont plafonnés dans la Szjt. Le régime manque alors d'une certaine flexibilité pour mettre à jour l'assiette et le montant de la rémunération.

La répartition de la rémunération ainsi collectée est assurée par les organisations de gestion collective. La particularité de la distribution est liée avant tout

\footnotetext{
${ }^{202}$ Conclusions de l'avocat général dans l'affaire CJUE C-572/13 considérant 83.

${ }^{203}$ Conclusions de l'avocat général dans l'affaire CJUE C-572/13 considérant 90.

${ }^{204}$ Concluisions de l'avocat général dans 11affaire CJUE C-572/13 considérants 96-97.
} 
à l'impossibilité de s'appuyer sur des statistiques exactes concernant l'utilisation des œuvres. Les organisations utilisent donc des méthodes «d'estimation» afin de se rapprocher du nombre d'utilisations effectivement réalisées. Ensuite, une partie des redevances pour copie privée sert aux objectifs culturels et sociaux déterminés afin de promouvoir la créativité et les créations artistiques.

La liberté dont bénéficie les sociétés de gestion collective dans la fixation des tarifs, est encadrée par la loi en ce qui concerne la répartition des sommes perçues. La loi hongroise énumère les catégories des titulaires de droits et le taux de répartition y afférent; elle laisse cependant la faculté aux organisations de gestion collective de conclure un accord qui définirait des taux de répartition différents. S'il est vrai que la gestion des sommes issues de la reproduction par reprographie a abouti à la conclusion d'un tel accord, tel n'est pas le cas pour les rémunérations liées aux supports vierges. Le CPI prévoit également des taux de répartition en recherchant une solution équitable entre les différents titulaires de droits. Concernant la rémunération des vidéogrammes et des œuvres enregistrées sur des supports différents, les titulaires de droits d'auteur et de droits voisins bénéficient de la rémunération dans les mêmes conditions. La loi hongroise, cependant, favorise visiblement les auteurs par rapport aux artistesinterprètes, aux producteurs de phonogrammes et de vidéogrammes et aux éditeurs. Le CPI favorise pour sa part les auteurs domestiques (ou au moins européens) dans la mesure où, sous réserve des conventions internationales, les sommes sont réparties entre les titulaires de droits pour les phonogrammes ou vidéogrammes enregistrés pour la première fois au sein de l'Union Européenne ${ }^{205}$. Il convient dès lors de distinguer le phonogramme et du vidéogramme : le premier est une séquence de sons alors que le second est une séquence d'images sonorisées ou non. Le CPI permet d'ailleurs aux auteurs des œuvres enregistrées sur d'autres supports de bénéficier de la rémunération pour copie privée à condition que la copie soit effectuée sur support numérique.

L'apparition de l'éditeur parmi les bénéficiaires de la copie privée pourrait être étonnante, car l'éditeur n'est pas doté d'un statut de titulaire de droits voisins. Néanmoins, le contrat d'édition lui garantit des prérogatives significatives, presque

${ }^{205}$ Art. L. 311-2 du CPI: "Sous réserve des conventions internationales, le droit à rémunération mentionné à l'article L. 214-1 et au premier alinéa de l'article L. 311-1 est réparti entre les auteurs, les artistes-interprètes, producteurs de phonogrammes ou de vidéogrammes pour les phonogrammes ou vidéogrammes fixés pour la première fois dans un Etat membre de la Communauté européenne». CHABERT (2004) 5. 
comparables à celles des titulaires de droits voisins ${ }^{206}$. En France, l'éditeur est titulaire de la rémunération pour copie privée pour les œuvres enregistrées sur des supports autres que le phonogramme et le vidéogramme; en Hongrie, il bénéficie de la rémunération pour reproduction par reprographie.

A notre sens, cette situation illustre la nature diffuse de la rémunération pour copie privée, et notamment, qu'elle sert également à soutenir l'activité culturelle et la création artistique. En faisant la promotion de telles valeurs, l'avocat général a démontré que les Etats membres pouvaient maintenir un système sui generis qui vise à compenser le préjudice subi par les éditeurs du fait de la copie privée, sans méconnaître le principe de la compensation équitable des auteurs ${ }^{207}$.

Afin de mieux défendre l'intérêt de l'auteur, il a souligné parallèlement que les éditeurs ne pouvaient pas être considérés comme des établissements culturels ou sociaux institués au bénéfice des auteurs, pour lesquels la gestion des sommes perçues a déjà été validée par la $\mathrm{CJUE}^{208}$. Pourtant, le droit d'auteur hongrois et français intègre complètement cette compensation dans le régime de rémunération pour copie privée. Dès lors, il ne peut s'agir d'un régime sui generis. Les conclusions de l'avocat général offriraient également aux Etats membres la possibilité d'introduire une redevance du droit d'auteur à des fins culturelles, ce qui n'est pas reconnu par la directive 2001/29 209 . C'était d'ailleurs la raison pour laquelle la CJUE n'a pas approuvé les arguments de l'avocat général, et a explicitement affirmé que les éditeurs ne bénéficiant pas de la compensation équitable en application de la directive, et ne pourraient pas en bénéficier sur la base d'un autre fondement.

Il convient d'analyser la situation du titulaire de droits qui renoncerait aux sommes qui lui sont dues. Selon la jurisprudence de la CJUE, cette possibilité ne lui est pas offerte, pas plus que celle de céder les sommes dues à un autre titulaire de droits ${ }^{210}$. La loi hongroise, dans des conditions très strictes, accorde cette faculté aux auteurs. La renonciation est uniquement possible néanmoins lorsque la répartition a été effectuée et

${ }^{206}$ Binctin, Nicolas: Rémunération pour copie privé, J. Cl. Propriété littéraire et artistique, Fasc. 1510, 23.

${ }^{207}$ Conclusions de l'avocat général dans l'affaire CJUE C-572/13 considérants 140-141.

${ }^{208}$ Conclusions de l'avocat général dans l'affaire CJUE C-572/13 considérants 130-131.

${ }^{209}$ European COPYRIGHT SOCEITY: Opinion on the The Reference to the CJEU in Case C-572/13 Hewlett-Packard Belgium SPRL v. Reprobel SCRL (5 September 2015) (http://www.create.ac.uk/wpcontent/uploads/2014/03/Opinion-in-Case-C572_13-HP-Belgium-Reprobel-2015.pdf), p. 5.

${ }^{210}$ CJUE 9 février 2012, Luksan (C-277/10), considérant 109. 
à hauteur de la somme exacte qui est due à l'auteur. La loi hongroise a instauré alors des garde-fous pour s'assurer que le titulaire de droits prenne une décision fondée et éclairée. Ce régime veille également à la protection des auteurs, mais reste plus souple que l'interprétation stricte de la CJUE. Selon notre opinion, l'essentiel est de garantir que l'auteur soit protégé contre les clauses qui prévoient une cession complète et globale de l'œuvre à l'éditeur ou au producteur de phonogramme. Etant donné que le CPI reste silencieux sur cette question, nous considérons que la rémunération pour copie privée est cessible.

La particularité de la rémunération pour copie privée consiste dans le fait qu'une partie de cette rémunération est consacrée à la réalisation d'objectifs culturels et sociaux, une pratique d'ailleurs validée par la CJUE sous réserve que les établissements culturels et sociaux les utilise aux bénéfices des ayants droit et que leur fonctionnement ne soit pas discriminatoire ${ }^{211}$. Il convient d'ajouter que l'utilisation culturelle ou sociale qui doit en être faite n'est pas définie par la loi, elle peut couvrir ainsi tout une série d'activités variées. Le CPI, pour sa part, se réfère à des activité qui relèvent du secteur culturel mais néglige les objectifs sociaux ${ }^{212}$. Selon le Conseil d'État, de telles utilisations doivent avoir un lien direct avec le soutien apporté à la création artistique ${ }^{213}$.

Le législateur hongrois a récemment amendé la Szjt. qui a désormais complètement redéfini l'utilisation des sommes à des fins culturelles et sociales. Selon les nouvelles dispositions législatives, $25 \%$ des sommes provenant de la copie privée sont destinées à une utilisation culturelle, et seul le Fond National de la Culture peut en faire usage. L'association de gestion collective compétente qui encaisse la rémunération se trouve obligée de transférer un quart de ce revenu net à cet organisme, qui est géré par le Ministre de la culture. D'un point de vue juridique, il est critiquable de confisquer des sommes qui ont intrinsèquement une nature privée pour les utiliser dans le cadre de la politique culturelle de l'Etat. L'autonomie des titulaires de droits nécessiterait la disposition complète des sommes versées. Il est également contestable que les «dispositions de transparence », prévues par la directive 2014/26 ou par la Szjt. ne

\footnotetext{
${ }^{211}$ CJUE 11 juillet 2013, Amazon (C-521/11), considérant 53.

${ }^{212}$ Art. L. 321-9 du CPI : «Ces sociétés utilisent à des actions d'aide à la création, à la diffusion du spectacle vivant et à des actions de formation des artistes (...) ».

${ }^{213}$ CE 8 déc. $2000, \mathrm{n}^{\circ} 202076$ et 203626, Assoc. «Protection des ayants droit», JurisData $\mathrm{n}^{\circ} 2000$ 061506; Comm. com. électr. 2001, comm. 15, obs. Caron.
} 
s'appliquent pas au FNC, ce qui est contraire aux principes même de la gestion collective.

Effectivement, une telle utilisation ne correspond pas nécessairement aux critères arrêtés par la CJUE dans l'arrêt Amazon. Les offres du FNC sont ouvertes uniquement pour des ressortissants hongrois ce qui constitue une violation du principe de non-discrimination. En outre, une partie des sommes n'est pas utilisée au profit des auteurs puisque le FNC en a fait usage pour créer son site internet et se doter de locaux $x^{214}$. Selon nous, le gouvernement hongrois devrait mettre à disposition au FNC de ressources financières distinctes pour le fonctionnement de ses infrastructures et de ses activités culturelles. La nécessité de veiller à ce que l'utilisation de la rémunération pour copie privée se fasse au profit des auteurs a d'ailleurs été confirmée par le juge hongrois dans un arrêt du FILMJUS. FILMJUS a conclu un accord avec une association littéraire. Conformément à ce contrat, FILMJUS a transféré une partie de sommes en provenance de la copie privée à l'association littéraire afin que celle-ci les utilise à des fins culturelles ou sociales au profit des auteurs. Or, l'association a utilisé $80 \%$ de cette somme pour couvrir ses frais professionnels. Le tribunal a rappelé dans cette décision que ce comportement constitue une faute grave qui justifiait la rupture immédiate du contrat par FILMJUS.

${ }^{214}$ A Cseh Tamás Program első évének eredményei - Sajtótájékoztató (http://online.nka.hu:81/NKA_belso/_temp/ckfinder/files/sajtoszoba/sajtanyag_150603.pdf) 


\section{Conclusion de la deuxième partie}

La gestion collective obligatoire est une forme de limitation aux droits exclusifs qui a été instaurée en conformité avec les dispositions du droit international et du communautaire en matière de droit d'auteur. Hormis le cas de la gestion collective obligatoire du droit de retransmission par câble qui découle directement de la directive communautaire, les autres hypothèses de gestion collective obligatoire constituent uniquement une faculté pour le législateur national en vue de restreindre le droit exclusif.

Paradoxalement, la gestion collective obligatoire nous semble être, parfois, le seul moyen efficace d'assurer l'exploitation normale des œuvres. Tel est le cas par exemple du droit exclusif de la reproduction par reprographie et de la retransmission par câble, conformément aux particularités de chaque mode d'exploitation. La gestion individuelle de ces droits est en effet quasiment impossible; toutefois, il y a lieu de mentionner que les garanties prévues par le législateur assurent le respect de l'autonomie et du monopole de l'auteur malgré la mise en place d'une gestion collective. Eu égard à ces deux droits exclusifs, la gestion collective ne méconnaît pas la logique du droit d'auteur. Elle peut même être considérée comme un bon compromis entre le maintien du droit exclusif et la prise en compte des particularités de chaque exploitation.

Dans certains cas la gestion collective est liée à la restriction du droit exclusif, qui se mue en un droit à rémunération, et ne constitue pas une limitation en soi. D'ailleurs, sans la gestion collective, le régime de la rémunération pour copie privée resterait lettre morte. La loi hongroise restreint pourtant la faculté des associations de gestion collective à disposer librement des sommes ainsi collectées, car un quart de la rémunération doit être transféré au FNC. A notre sens, cet intervention de l'Etat rend obsolète l'autonomie des auteurs en matière de répartition de la rémunération pour copie privée et pour reprographie.

Dans un contexte plus large, la copie privée constitue un point de départ à la discussion menée sur l'avenir du droit d'auteur. La théorie juridique impose l'interprétation stricte des exceptions et favorise le maintien du droit exclusif. C'est la raison pour laquelle il convient de distinguer les utilisations professionnelles des 
Deuxième partie : La gestion collective imposée par la loi : limitation au droit exclusif

utilisations privées, et d'identifier la source de la copie réalisée. La solution de cette problématique pourrait être d'instituer une gestion collective similaire à celle existant en droit français en matière de reproduction par reprographie pour les copies professionnelles. 
Troisième partie : La gestion collective imposée par la loi, garantie de l'exercice des droits

\section{Troisième partie : La gestion collective imposée, garantie de l'exercice des droits}

La recherche de l'efficacité est plus marquante dans certains cas qui, malgré leur imposition par la loi, ne sont pas forcément considérés comme une limitation au monopole. Le point commun d'un tel exercice des droits exclusifs est l'absence de base juridique du droit international ou communautaire, et également la possibilité pour l'auteur de renoncer à ce régime. C'est la raison pour laquelle il convient de les classer comme des cas de gestion collective présumée. Concernant le droit à rémunération, la recherche de l'efficacité se manifeste au travers du rôle plutôt administratif des organisations de gestion collective.

L'efficacité, naturellement, peut être analysée en deux axes, en fonction des intérêts de l'utilisateur et de l'auteur. L'efficacité de la gestion collective vis-à-vis de l'auteur est reconnue lorsque le titulaire du droit peut participer entièrement au fonctionnement de la société de gestion collective, y compris dans la détermination des conditions d'utilisation les droits à être répartis d'une manière individualisée. Bien évidemment, cette interprétation de l'efficacité nous renvoie aux règles de transparence $\mathrm{du}$ fonctionnement et de la protection de l'auteur non membre. En revanche, du point de vue de l'utilisateur, la gestion collective est considérée efficace si elle permet d'obtenir d'une manière simple les licences d'utilisation relatives à un répertoire large.

La prise en compte de ces facteurs a souvent amené le législateur à intervenir et définir certains cas de gestion collective où ce mode de gestion est présumé. La doctrine critique souvent cette solution en invoquant que la logique du droit d'auteur est complètement renversée. Contrairement à la gestion collective volontaire, où l'auteur peut décider d'adhérer à l'organisation de gestion collective, dans ces cas-là, la gestion collective est imposée, sauf opposition contraire (Chapitre 1). Eu égard aux droits à rémunération, les organisations sont privées d'une partie considérables de leurs prérogatives, et fonctionnent comme de simples administrateurs de droits (Chapitre 2). 
Troisième partie : La gestion collective imposée par la loi, garantie de l'exercice des droits

\section{Chapitre I. L'exercice du droit exclusif dans le cadre de la gestion collective assurant une sortie au titulaire du droit}

Ce type de gestion collective est une sorte d'hybride qui crée une transition entre la gestion individuelle (ou la gestion collective volontaire) et le régime de la gestion collective obligatoire. Elle permet à l'utilisateur d'obtenir des licences via un système de "one stop shop », et à l'auteur d'opter pour la gestion individuelle de l'exploitation de son monopole. Cette double exigence explique le besoin de dispositions législatives détaillées, qui encadrent les compétences de l'organisation de gestion collective et les modalités de sortie. Un exemple illustrant un tel régime est la numérisation des livres indisponibles prévue par le CPI (Section 1).

Parfois le mécanisme est lié à un effet étendu de la gestion collective. Cette idée, qui provient des pays nordiques est également connue dans le droit d'auteur hongrois, et assure une sécurité remarquable à l'utilisateur. Le principe du régime est l'extension de la portée de la licence aux œuvres alors que l'auteur n'est ni membre de l'organisation de gestion collective, ni son mandant ${ }^{215}$ (Section 2).

\section{Section 1. Gestion collective avec possibilité d'opt-out : mi-chemin entre la gestion collective traditionnelle et la gestion individuelle des droits}

Sans effet étendu, la gestion collective établie pour la numérisation des livres indisponibles est une réponse à une problématique limitée et spécifiée. Son objectif n'est pas de faciliter l'attribution des licences aux nombreuses utilisations des œuvres protégées, la gestion collective joue un rôle avant tout intermédiaire. Cette particularité explique l'absence de sa dénomination adaptée: elle s'appelle gestion collective obligatoire, gestion collective étendue ${ }^{216}$ ou gestion collective présumée ${ }^{217}$ dans la doctrine. A notre sens, c'est cette dernière dénomination qui décrit le mieux le noyau dur de ce régime, car il n'est pas obligatoire du fait de la possibilité d'opposition et il manque d'effet étendu. Le législateur hongrois semble désireux d'adopter une solution identique; dans les travaux préparatoires de la transposition de la directive 2014/26,

\footnotetext{
${ }^{215}$ RIIS - SCHOVSBO (2009-2010) p. 471-495.

${ }^{216}$ PIRIOU (2012b).

${ }^{217}$ ÉMILE-ZOLA-PlaCe (2012) p. 360.
} 
Troisième partie : La gestion collective imposée par la loi, garantie de l'exercice des droits

l'idée d'instaurer un régime spécifique est apparue ${ }^{218}$. Pourtant, nous n'étudierons pas ce texte, car il s'agit d'un projet non contraignant.

Dans ce contexte, nous analyserons dans un premier temps le champ d'application matériel $\mathrm{du}$ régime français $(\S 1$.$) et ensuite, nous traiterons \mathrm{du}$ fonctionnement de la gestion collective (§2.).

\section{\$1. La numérisation des livres indisponibles}

La numérisation des livres en général est un bel exemple pour démontrer les synergies entre les nouvelles technologies et le droit d'auteur, et plus spécifiquement la gestion collective. Différentes solutions sont envisageables en fonction du statut juridique des livres, soit des livres appartenant au domaine public ${ }^{219}$, soit des œuvres orphelines $^{220}$ ou encore des œuvres demeurant sous protection dont l'auteur est connu $^{221}$. La loi française qui porte sur la numérisation des livres indisponibles du XXème siècle trouve sa source d'inspiration alors dans tous ces précédents.

La nouvelle définition du livre indisponible se trouve dans l'article L.134-1 du CPI. Cet article énonce ainsi : " on entend par livre indisponible au sens du présent chapitre un livre publié en France avant le ler janvier 2001 qui ne fait plus l'objet d'une diffusion commerciale par un éditeur et qui ne fait pas actuellement l'objet d'une publication sous une forme imprimée ou numérique ». La notion de livre, élément clé de la disposition législative, est une notion controversée sur certains aspects : d'abord il s'agit d'une terminologie insolite dans la terminologie du droit d'auteur. Ensuite, la date et le lieu de la publication et les données les plus importantes sont bien délimitées par la loi.

Bien que les livres soient mentionnés dans l'article L. 112-2 du CPI, lequel énumère les œuvres protégées, ni le Code lui-même, ni la jurisprudence n'en donne

\footnotetext{
218 Javaslat a szerzői és szomszédos jogokra vonatkozó közös jogkezelésről és a zeneművek belső piacon történő online felhasználásának több területre kiterjedő hatályú engedélyezéséről szóló 2014/26/EU irányelv magyar jogba történő átültetésének koncepciójára (http://hu.scribd.com/doc/252881981/KJKiranyelv-atultetesi-koncepcioja\#scribd) p. 31-36.

${ }^{219} \mathrm{Vu}$ le projet Gallica de la BNF, le projet Gutenberg ou le projet Europeana.. MEZEI Péter: The painter, the one horn cow and ole Hank Wilson's back lot - The future of library digitization in the European Union and Hungary, manuscript.

${ }^{220}$ Art. 6 de la directive 2012/28/UE du Parlement européen et du Conseil du 25 octobre 2012 sur certaines utilisations autorisées des œuvres orphelines.

${ }^{221}$ MEZEI (2011) p. 8-10. EFRONI - GEBERT (2011) p. 532.
} 
Troisième partie : La gestion collective imposée par la loi, garantie de l'exercice des droits

aucune définition ${ }^{222}$. Certaines réglementations fiscales en proposent une définition, néanmoins leur application en matière de propriété intellectuelle reste incertaine vu que l'article L. 111-3 du CPI prévoit clairement l'indépendance de la propriété incorporelle de la propriété de l'objet matériel. La notion de «livre », en tant que tel, se réfère au support. Certains commentateurs soulignent alors que la terminologie utilisée par le législateur est par conséquent inadéquate.

Cependant, selon d'autres spécialistes en droit d'auteur, la terminologie utilisée reste claire en raison du but visé par le législateur. Celui-ci «a volontairement limité l'objet même du texte au livre et il n'a pas eu intention de l'étendre à l'œuvre en tant que telle $»^{223}$. La doctrine souligne également que même le CPI se réfère aux supports de l'œuvre tels que les phonogrammes et les vidéogrammes. Bien plus, une référence à la notion de livre se trouve dans la loi du 18 juin 2003 relative à la rémunération du prêt. Cette loi a inséré l'article L. 133-1 dans le CPI spécifiant que la rémunération du prêt est ouverte aux œuvres ayant fait l'objet d'un contrat d'édition en vue de leur diffusion sous forme de livre.

En effet, la définition la plus communément utilisée du livre est proposée par une instruction fiscale du 30 décembre 1971 actualisée par la circulaire du 12 mai 2005 afin d'appliquer le régime de la TVA réduite. Le livre y est ainsi défini : « un ensemble imprimé, illustré ou non, qui reproduit une ouvre de l'esprit d'un ou plusieurs auteurs en vue de l'enseignement, de la diffusion de la pensée et de la culture. Il doit se composer d'éléments assemblés ayant le même objet, ne pouvant pas être dissociés ni vendus séparément (ouvrages comprenant des disques, films ou diapositives par exemple). L'ensemble ne doit pas contenir plus du tiers de la surface totale en publicités et en blancs intégrés au texte ».

La notion de livre est par conséquent strictement liée à l'édition dans le cas des livres imprimés autant que dans celui des livres numériques. Pourtant, le but visé par le législateur réside dans la protection de la diversité culturelle et l'accès à la culture pour tous, incluant non seulement les documents édités mais aussi ceux que l'on pourrait quaifier d'inédits : mémoires, thèses, rapports, etc. ${ }^{224}$ Il semble que le législateur ait

\footnotetext{
${ }^{222}$ MACREZ (2012).

${ }^{223}$ PIRIOU (2012a).

${ }^{224}$ DERIEUX (2012).
} 
Troisième partie : La gestion collective imposée par la loi, garantie de l'exercice des droits

fortement méconnu son propre objectif reliant la mise à disposition numérique des œuvres à l'obligation d'édition. ${ }^{225}$

La date et le lieu de la publication constituent les éléments déterminants de l'édition des livres dont la loi apporte certaines précisions. D’une part, la loi exclut de son champ d'application des livres édités en dehors de la France. La coopération internationale des sociétés de gestion collective pourrait établir la possibilité de numériser les livres indisponibles édités à l'étranger, ainsi que les traductions éditées en France. Le dépôt légal ne correspond pas par conséquent à cette catégorie définie.

D'autre part, la loi fixe la date du $1^{\text {er }}$ janvier 2001 comme date ultime de la publication. Cette date a été choisie de manière discrétionnaire par le législateur en considérant qu'à partir du début du XXème siècle les contrats d'édition stipulent des clauses relatives à l'exploitation numérique des œuvres. Malheureusement, la loi ne définit pas le point de départ de ce délai. Bien que la loi porte la distinction «livres indisponibles $d u X X^{e}$ siècle » dans son intitulé, le chapitre inséré dans le CPI ne se réfère pas à un tel critère. Pour éviter les confusions, le décret d'application de la loi ${ }^{226}$ dispose que les titres des livres indisponibles doivent être effacés à l'expiration des durées de protections prévues par le $\mathrm{CPI}^{227}$.

Cette délimitation temporelle soulève la question de l'adaptation des contrats conclus avant l'entrée en vigueur de la loi du 11 mars 1957 à ce nouveau régime. En 2005, la Cour de cassation a reconnu dans l'affaire Collette ${ }^{228}$ le transfert absolu des droits sur le fondement des lois révolutionnaires en disposant ainsi : «la stipulation d'une vente pleine et entière, sans aucune réserve, de la propriété de l'ouvre littéraire transmet à l'acquéreur la pleine et absolue propriété de l'ouvre ainsi que l'ensemble des droits patrimoniaux d'auteur ». Le CPI clarifie cette anomalie en déclarant depuis 1992 que la clause d'une cession qui tend à conférer le droit d'exploiter l'œuvre sous une forme non prévisible ou non prévue à la date du contrat doit être expresse et stipuler une participation corrélative aux profits d'exploitation. ${ }^{229}$

\footnotetext{
225 Émile-ZOLA-PlaCe (2012) p. 357.

${ }^{226}$ Décret n ${ }^{\circ}$ 2013-182 du 27 février 2013 portant application des articles L134-1 à L134-9 du Code de la propriété intellectuelle relatif à l'exploitation numérique des livres indisponibles du XXème siècle.

${ }_{227}$ Art. R. 134-2 du CPI.

${ }^{228}$ C.cass., chambre civile 1, du 25 mai 2005.

${ }^{229}$ Art. L .131-6 du CPI.
} 
Troisième partie : La gestion collective imposée par la loi, garantie de l'exercice des droits

Notion-clé du régime, le critère de l'indisponibilité reste toutefois obscur car aucune définition n'en est donnée. Au sens de la loi un livre est indisponible lorsqu'il «ne fait plus l'objet d'une diffusion commercialel par un éditeur » et qu'il ne fait pas l'objet d'une "publication sous forme imprimée ou numérique ${ }^{230}$. En effet, il faut noter que le fait pour un livre de ne pas être disponible à la vente ou sur Internet par choix de l'éditeur ne signifie pas qu'il soit inaccessible: il peut être consulté en bibliothèque, faire l'objet de ventes en occasion, etc ${ }^{231}$.

Tout de même, cette notion d'indisponibilité est susceptible d'engendrer une confusion dans l'application de la loi. En effet, les dispositions propres au contrat d'édition obligent les éditeurs àd'assurer une exploitation permanente des œuvres imposées par l'article L.132-12. L'alinéa 2 de l'article L.132-17 du CPI prévoit, quant à lui, que « la résiliation a lieu de plein droit lorsque [...] l'éditeur n'a pas procédé [...], en cas d'épuisement, à [1] a réédition [de l'œuvre]».

Un livre est «épuisé » en matière d'édition, si l'éditeur ne satisfait pas dans les trois mois deux demandes de livraison d'exemplaires ${ }^{232}$, autrement dit «l'éditeur doit veiller à ce que l'ouvrage reste disponible $»^{233}$. Cet épuisement engendre la rupture totale du contrat. Dès lors, les éditeurs gardent généralement un minimum de livres en stock pour satisfaire les demandes ponctuelles ${ }^{234}$. En établisseant l'interprétation stricte de l'article L.132-17 du CPI, cette sanction est également applicable aux livres indisponibles par définition.

La loi ne propose aucune solution pour résoudre cette lacune. Elle tranche simplement le nœud gordien en disposant dans son article L.134-2 que l'inscription d'un livre dans la base de données ne préjuge pas de l'application des articles L.132 et L.132-17 du CPI. Pareille disposition se trouve également dans l'article L.134-4, II, alinéa 2. En résumé, la résiliation du contrat d'édition n'intervient pas lorsque le titre est considéré comme indisponible au sens de la nouvelle loi.

\footnotetext{
230 Art. L. 134-1 du CPI.

${ }^{231}$ Pollaud-Dulian (2012).

${ }^{232}$ Art. L. 132-17 du CPI.

${ }^{233}$ PIERRAT (2000) p. 65.

${ }^{234}$ PIRIOU (201).
} 
Troisième partie : La gestion collective imposée par la loi, garantie de l'exercice des droits

\section{\$2. La mise en auvre du régime de la gestion collective}

L'inscription de l'ouvrage au registre des livres indisponibles est le cœur du dispositif $^{235}$. Désignée pour mettre en œuvre ce régime, la BNF gère cette base de données, accessible au public via un site dédié à cet effet $^{236}$. Le second alinéa de ce même article permet à «toute personne » de demander à la BNF l'inscription du titre dans la base des données. C'est sur cette base de données que l'exploitation collective sera possible.

Le gouvernement a agréé la SOFIA parmi les sociétés de gestion collective intervenant dans le domaine de l'écrit pour assurer l'exploitation de ces œuvres. ${ }^{237}$ L'exploitation signifie la représentation numérique (exemple : diffusion en ligne) et de la reproduction numérique (exemple : téléchargement) mais pas la reproduction sur des supports papiers tels que l'impression à la demande ${ }^{238}$.

Avec l'idée de sortie (opt-out) empruntée au projet de Google Livres, ${ }^{239}$ deux possibilités s'ouvrent à l'auteur (ou ses ayants droits) ${ }^{240}$ ainsi qu'à l'éditeur : ils peuvent s'opposer à l'inscription des titres dans la base des données ou bien retirer le droit d'autoriser la reproduction et la représentation des œuvres sous forme numérique de la société de gestion collective.

En premier lieu, l'auteur et l'éditeur peuvent s'opposer à l'inscription de l'œuvre par écrit à la BNF dans un délai de six mois à compter de l'inscription dans la base des données. Le décret d'application précise que la base des données est enrichie de nouveaux titres le 21 mars de chaque année ${ }^{241}$. La période de six mois prend fin, par conséquent, le 21 septembre de chaque année.

Tandis que l'auteur peut pratiquer ce droit sans aucune condition, l'éditeur est tenu d'exploiter l'œuvre dans les deux ans suivant cette notification ${ }^{242}$. Dans les deux hypothèses, le livre concerné n'entre pas dans le régime de la gestion collective.

\footnotetext{
${ }^{235}$ Art. L. 134-2. du CPI.

${ }^{236}$ www.relire.fr.

${ }^{237}$ Arrêté du 21 mars 2013 portant agrément de la Société française des intérêts des auteurs de l'écrit.

${ }^{238}$ POLLAUD-DULIAN (2012).

${ }^{239}$ MACREZ(2012).

${ }^{240}$ Art. R. 134-5 du CPI.

${ }^{241}$ Art.. R. 134-1 du CPI.

${ }^{242}$ Art. L. 134-4 I et II du CPI.
} 
Troisième partie : La gestion collective imposée par la loi, garantie de l'exercice des droits

Une autre possibilité est également ouverte à l'auteur lorsqu'il considère que l'exploitation numérique est susceptible de nuire à son honneur ou à sa réputation. ${ }^{243}$ Contrairement aux autres possibilités d'opposition, celle-ci doit être envoyée par écrit à la société de gestion collective agréée. Comme ce droit peut être exercé après l'expiration du délai de six mois, il pourrait être considéré comme un cas de retrait. De plus, cette hypothèse fait une référence concrète à la protection des droits moraux tels que la Convention de Berne les formule ${ }^{244}$. Pourtant, si l'auteur exerce son droit d'opposition, il ne peut pas demander d'indemnisation ${ }^{245}$. La question se pose alors de savoir si le législateur a établi une nouvelle protection des droits moraux.

Le tableau suivant récapitule les informations les plus importantes concernant l'opposition à l'inscription des livres dans la base des données.

\begin{tabular}{|c|c|c|c|}
\hline & \multicolumn{3}{|c|}{ Opposition } \\
\hline Qui? & l'auteur & l'éditeur & l'auteur \\
\hline A qui? & $\mathrm{BNF}$ & $\mathrm{BNF}$ & Sofia \\
\hline Moyen? & par écrit & par écrit & par écrit \\
\hline Délai? & $\begin{array}{c}\text { six mois à compter } \\
\text { de l'inscription du } \\
\text { livre dans la base des } \\
\text { données }\end{array}$ & $\begin{array}{l}\text { six mois à compter de } \\
\text { l'inscription du livre } \\
\text { dans la base des } \\
\text { données }\end{array}$ & $\begin{array}{l}\text { après l'expiration du } \\
\text { délai de six mois à } \\
\text { compter de } \\
\text { l'inscription du livre } \\
\text { dans la base des } \\
\text { données }\end{array}$ \\
\hline Condition? & ---------- & $\begin{array}{c}\text { l'exploitation dans } \\
\text { les deux ans }\end{array}$ & $\begin{array}{c}\text { la reproduction ou la } \\
\text { représentation est } \\
\text { susceptible de nuire à } \\
\text { l'honneur ou la } \\
\text { réputation de l'auteur }\end{array}$ \\
\hline Conséquence? & $\begin{array}{l}\text { - mention faite dans } \\
\text { la base des données } \\
\text { - le livre concerné }\end{array}$ & $\begin{array}{l}\text { - mention faite dans } \\
\text { la base des données } \\
\text { - le livre concerné }\end{array}$ & $\begin{array}{l}\text { - le livre sort de la } \\
\text { gestion collective } \\
\text { - applicabilité des }\end{array}$ \\
\hline
\end{tabular}

${ }^{243}$ Art. L. 134-4 I du CPI.

${ }^{244}$ Art. 6bis de la Convention de Berne.

${ }^{245}$ Art. L. 134-4 I du CPI. 
Troisième partie : La gestion collective imposée par la loi, garantie de l'exercice des droits

\begin{tabular}{|l|c|c|c|}
\hline & n'entre pas dans la & n'entre pas dans la & sanctions de la \\
gestion collective & gestion collective & violation des droits \\
& & - l'éditeur est tenu & moraux ? \\
& d'exploiter l'œuvre & \\
& & concernée* & \\
\hline
\end{tabular}

Tableau $n^{\circ} 1$. L'opposition à l'inscription de l'œuvre dans la base des données

Le retrait de l'œuvre n'est possible postérieurement à son entrée en gestion collective. Le retrait est pratiqué alors par écrit à la Sofia. Conformément au droit de l'opposition, les auteurs semblent être titulaires d'un droit plus vague.

Toutefois, les auteurs peuvent à peine exercer ce droit car une condition stricte y est rattachée. L'auteur peut décider à tout moment de retirer de la Sofia ses droits lorsqu'il apporte la preuve qu'il est le seul titulaire de la reproduction et de la représentation numérique des œuvres ${ }^{246}$. Un cercle vicieux s'impose alors aux auteurs car cette preuve est quasiment impossible à apporter. Selon l'hypothèse établie par le législateur, les contrats conclus avant le $1^{\text {er }}$ janvier 2001 ne stipulent pas de clause relative à l'exploitation numérique des œuvres. Selon la règle générale d'interprétation des contrats, l'auteur conserve tous les droits qui n'y sont pas expressément mentionnés ${ }^{247}$. Toutefois, en évoquant ce principe d'interprétation, l'auteur n'apporte pas la preuve qu'il est le seul titulaire des droits mentionnés. Il peut uniquement le faire si le contrat le stipule expressément, étant précisé que les contrats anciens ne prévoyaient aucune disposition à ce sujet. Bref, "[1]e législateur a voulu favoriser l'éditeur en le présumant titulaire de droits qu'il n'exerce pourtant plus $»^{248}$.

L'auteur et l'éditeur peuvent décider conjointement à tout moment de retirer les droits concernés si l'éditeur s'engage à exploitater l'œuvre. Bien que Sofia en informe tous les utilisateurs, la durée de l'autorisation déjà délivrée à un tiers court toujours $^{249}$. Une concurrence est alors établie entre l'éditeur original et les nouveaux éditeurs, l'autorisation délivrée à l'éditeur original n'étant pas exclusive.

\footnotetext{
${ }^{246}$ Art. L. 134-6 alinéa 2 du CPI.

${ }^{247}$ Art. L.131-6 du CPI.

${ }^{248}$ PollaUd-Dulian (2012).

${ }^{249}$ Art. L. 134-6 du CPI.
} 
Troisième partie : La gestion collective imposée par la loi, garantie de l'exercice des droits

\begin{tabular}{|c|c|}
\hline & Retrait \\
\hline Qui? & Auteur \\
\hline A qui? & Sofia \\
\hline Moyen? & par écrit \\
\hline Délai? & à tout moment \\
\hline Condition? & l'auteur est le seul titulaire de la reproduction et la \\
& représentation numérique des cuvres \\
\hline Conséquence? & - mention dans la base des données \\
& - sortie de la gestion collective \\
\hline
\end{tabular}

Tableau $n^{\circ} 2$. Retrait à la Sofia des droits de reproduction et de représentation numérique

Le mécanisme de la gestion collective obligatoire n'intervient que dans l'hypothèse où ni l'auteur, ni l'éditeur, ne saisissent l'opportunité de sortir des droits. Le régime, par ce «droit de préférence», favorise clairement l'éditeur initial en lui assurant les possibilités les plus étendues d'obtenir des autorisations.

Outre les possibilités mentionnées prcédemment, la Sofia s'adresse en premier lieu à l'éditeur original en lui proposant une autorisation ${ }^{250}$. Lorsque ce dernier l'accepte, une autorisation exclusive lui est délivrée pour une durée de dix ans tacitement renouvelable ${ }^{251}$. La reproduction et la représentation des livres indisponibles sous une forme numérique sont autorisées à des tiers (tels que Google, Amazon, ou Fnac), moyennant une rémunération à titre non exclusif et pour une durée limitée à cinq ans renouvelable, lorsque l'éditeur initial n'accepte pas l'autorisation proposée par la Sofia $^{252}$. Il est important de souligner que l'utilisateur auquel la Sofia accorde une autorisation est considéré comme éditeur de livre numérique au sens de la loi en ce qui concerne le prix du livre numérique ${ }^{253}$.

En principe, l'exploitation des livres indisponibles n'est pas effectuée à titre gratuit. Christophe CARON a fait la remarque que «[c]'est une des raisons pour lesquelles une société de gestion collective occupe une place si centrale dans le

\footnotetext{
${ }^{250}$ Art. L. 134-5 alinéa 1er du CPI.

${ }^{251}$ Art. L. 134-5 alinea 3. du CPI.

${ }^{252}$ Art. L. 134-3 I. alinéa 2. du CPI

${ }^{253}$ Art. L.134-5 alinea 7 du CPI.
} 
Troisième partie : La gestion collective imposée par la loi, garantie de l'exercice des droits

dispositif mis en $e u v r e ~ »{ }^{254}$. La Sofia a alors l'obligation de répartir les sommes perçues de manière équitable entre les auteurs et les éditeurs initiaux ${ }^{255}$. Selon Frédéric POLLAUD-DULIAN, « il est à craindre que le partage se fasse à 50/50, alors même que l'éditeur n'exploitait plus l'œuvre et qu'il n'avait pas acquis les droits d'édition numérique de l'auteur ${ }^{256}$, car les «irrépartissables » sont dédiés à des fins culturelles et éducatives. Malgré la volonté du législateur d'assurer la protection des intérêts des auteurs, le bilan est plus favorable aux éditeurs.

Le droit international ou communautaire ne prévoit pas de limitation pour les nouvelles technologies. Il convient alors d'appliquer le test en trois étapes afin de démontrer la cohérence de régime en question avec l'ensemble du droit d'auteur. L'applicabilité du test en trois étapes dépend néanmoins de la réponse apportée à une question préalable : quelle version du test doit être prise en compte? Celui incorporé dans le CPI est exclu, car il s'applique uniquement aux exceptions prévues dans l'article L. 122-5 du CPI. Il nous reste alors à nous demander, si le droit communautaire ou international est applicable à la gestion collective présumée ? Si la gestion collective était considérée comme une exception ou limitation, le législateur aurait violé l'article 5 de la directive, qui ne connaist pas de tels cas. L'article 5 (5) de la directive 2001/29 est également difficilement applicable. Le Conseil d'Etat a formulé un renvoi préjudiciel à la CJUE avec la question suivante : «les dispositions de la directive s'opposent-elles à ce qu'une réglementation confie à des sociétés de perception et de répartition des droits agréées l'exercice du droit d'autoriser la reproduction et la représentation sous une forme numérique de "livres indisponibles », tout en permettant aux auteurs ou ayantsdroit de ces livres de s'opposer ou de mettre fin à cet exercice, dans les conditions qu'elle définit »? La CJUE va alors analyser pour la première fois la conformité de la gestion collective présumée à la directive. Le régime est conforme à la version du test qui se trouve dans les conventions internationales, car il s'agit d'un cas spécial, ne portant pas atteinte à l'exploitation normale de l'œuvre, et ne causant pas de préjudice injustifié aux intérêts de l'auteur. Le régime rend possible l'exploitation des œuvres commercialement inexploitées en posant un mode spécifique de l'exercice de certains droits patrimoniaux numériques.

\footnotetext{
${ }^{254}$ CARON (2012).

255 Art L. 134-3, III, $5^{\circ}$ du CPI.
}

${ }^{256}$ POLLAUD-DULIAN (2012). 
Troisième partie : La gestion collective imposée par la loi, garantie de l'exercice des droits

Le Conseil constitutionnel français a analysé le régime en utilisant les tests constitutionnels généralement acceptés, et tiré des conclusions similaires à celles que nous avons argumentées par rapport au test en trois étapes. Les juges ont précisé que le régime s'applique aux droits patrimoniaux bien déterminés et n'affecte pas les droits moraux (notamment le droit au respect du nom ou le droit à divulgation) et il est également dépourvu d'effet sur le droit d'auteur d'exploiter son œuvre sous autre forme que numérique ${ }^{257}$. Compte tenu du fait que les conditions de l'exploitation sont également bien précises et que l'auteur dispose de la possibilité de retirer son œuvre du régime de la gestion collective, le régime est conforme aux principes constitutionnels de la limitation du droit de propriété garanti par la Déclaration des droits de l'homme et du citoyen $^{258}$. Les dispositions ont pour objet de permettre la conservation et la mise à disposition du public sous forme numérique des ouvrages publiés en France et elles poursuivent alors un but d'intérêt général ${ }^{259}$. Le régime est conforme aux règles de limitations de la propriété telles que celles prévues par la jurisprudence du Conseil constitutionnel. A notre sens, cependant, en le comparant avec les autres droits exclusifs soumis à un régime de gestion collective obligatoire, les droits relevant de la numérisation des livres indisponibles du XXème siècle sont largement définis, sans distinguer entre les différents modes d'utilisation numérique.

\section{Section 2. La gestion collective étendue : restriction au droit exclusif?}

Pratique qui apparaît dans les années 1960 dans les pays nordiques avec pour principal objectif de faciliter l'obtention des licences des entreprises audiovisuelles, la gestion collective étendue offre la possibilité d'autoriser des utilisations à grande échelle. En l'absence de dispositions du droit international ou communautaire, les législateurs nationaux jouissent d'une liberté pour l'adopter en droit interne. Le considérant 18 de la directive 2001/29 prévoit également que la directive ne porte pas atteinte aux modalités qui existent dans les États membres en matière de gestion des droits, telles que les licences collectives étendues. Certains États membres ont déduit de ce texte que la gestion collective étendue constitue une modalité de l'exercice des droits et, comme celle-ci, elle est indépendante de la liste des exceptions et limitations

\footnotetext{
${ }^{257}$ Décision $n^{\text {o }} 2013-370$ QPC du 28 février 2014 considérant 15.

${ }^{258}$ Décision $n^{\circ} 2013-370$ QPC du 28 février 2014 considérant 17.

${ }^{259}$ Décision $\mathrm{n}^{\mathrm{o}} 2013-370$ QPC du 28 février 2014 considérant 14.
} 
Troisième partie : La gestion collective imposée par la loi, garantie de l'exercice des droits

énumérées dans l'article 5. En Hongrie, par exemple, la majorité des cas de gestion collective imposée par la loi tombent dans le domaine de la gestion collective étendue.

Pourtant, la doctrine exige traditionnellement de soumettre cette solution au test en trois étapes. ${ }^{260}$ La gestion collective étendue est ainsi un moyen efficace de gérer les utilisations secondaires, comme celles de l'enseignement, car dans ces cas, son intervention est plus naturelle et plus nécessaire. Pour assurer l'efficacité d'un tel régime, l'autre condition établie est la représentativité de l'organisation vis-à-vis des titulaires de droits domestiques et étrangers. Il est important aussi que le titulaire de droits dispose de la possibilité de retirer ses droits du régime sans se confronter à des difficultés injustifiées ${ }^{261}$.

Malgré ses avantages pratiques, cette solution pourrait être étrange dans certains droits nationaux. Le droit d'auteur français ne reconnait pas, par exemple, ce mécanisme ${ }^{262}$. La loi hongroise, en revanche, consacre des articles à ce régime depuis son adoption. La réforme la plus récente de la gestion collective en 2011 a proposé une réponse à la question de savoir quelle organisation est compétente pour délivrer des licences à effet étendu-si plusieurs associations sont agréées à exercer le même droit ?

L'effet étendu a une particularité dans le droit hongrois, car la loi est muette s'agissant de la délimitation de la gestion collective imposée. Le texte pourrait être également interprété de façon à ce que la gestion collective volontaire soit également dotée de cet effet $^{263}$. A notre sens, cette interprétation méconnait l'autonomie de l'auteur et ne correspond pas à l'esprit de la loi.

Ceci étant posé, il convient de traiter d'abord de la structure du régime (§1) pour pouvoir ensuite analyser le mécanisme de l'attribution des licences (§2).

\footnotetext{
${ }^{260}$ SHAPIRO (2011) p. 45.

${ }^{261}$ FICSOR (2011) p. 267

${ }^{262}$ Cependent, il convient de noter que l'article L. 132-25 alinéa 3 du CPI prévoit la règle suivante : « les accords relatifs à la rémunération des auteurs conclus entre les organismes professionnels d'auteurs ou les sociétés de perception et de répartition des droits mentionnées au titre II du livre III et les organisations représentatives d'un secteur d'activité peuvent être rendus obligatoires à l'ensemble des intéressés du secteur d'activité concerné par arrêté du ministre chargé de la culture ». La doctrine a vivement critiqué cette solution, voir BENABOU (2007) p. 430.

${ }^{263}$ GYERTYANFY (2014), p. 510-511.
} 
Troisième partie : La gestion collective imposée par la loi, garantie de l'exercice des droits

\section{\$1. Le structure de la gestion collective étendue}

La particularité de la gestion collective étendue est de créer une concurrence entre les différents modes de gestion, notamment la gestion individuelle et collective grâce à sa logique inverse, qui est la présomption de la gestion collective. Pour assurer un fonctionnement légitime de ce régime, deux éléments importants, la représentativité et le droit de sortie, déterminent la structure de la gestion collective étendue.

Dans le droit d'auteur hongrois, la représentativité est un critère de l'immatriculation générale des associations, qui est effectivement liée au nombre élevé de cas de gestion collective étendue. Le double critère impose que l'association de gestion collective représente la majorité des titulaires de droits dans son domaine d'activité et qu'elle soit ouverte. Plus spécifiquement ces statuts doivent laisser la faculté aux titulaires de droits domestiques et étrangers d'y adhérer librement ${ }^{264}$, ou doivent représenter la plupart de ces personnes par le biais d'accords de représentation réciproque. Afin de vérifier si la plupart des auteurs sont concernés, le législateur suggère de prendre en considération non seulement le nombre de membres de l'association, mais également l'importance du répertoire ainsi regroupé et la quantité de la rémunération perçue.

Le droit de sortie, autorisé directement par la Szjt., est considéré comme garant de la conformité à la Convention de Berne ${ }^{265}$. L'idée de garantir ce droit est d'offrir la possibilité de retourner à la gestion individuelle, cependant en pratique il n'aboutit pas à la gestion individuelle des droits ${ }^{266}$ en raison des difficultés liées à ce mode de gestion concernant les droits patrimoniaux en question. Etant donné que la loi n’oblige pas les auteurs à donner mandat à une autre association de gestion collective, ce sont souvent des sociétés de gestion indépendantes qui les assemblent et constituent un répertoire distinct. Sur les questions de fond, la sortie ne peut pas être réduite à certains modes d'exploitation ou certains droits spécifiques, elle forme une sortie absolue et globale des œuvres concernées.

\footnotetext{
${ }^{264}$ Le principe de non-discrimination doit être respecté, comme souligne les anciens arrêts de la Cour de Justice de l'Union européenne et les décisions de la Commission. Voir surtout l'affaire GVL: 81/1030/EEC : Commission Decision of 29 October 1981 relating to a proceeding under Article 86 of the EEC Treaty (IV/29.839 - GVL), Official Journal L 370 , 28/12/1981 P. 0049 - 0059. 55. Arrêt de la Cour du 2 mars 1983 Gesellschaft zur Verwertung von Leistungsschutzrechten mbH (GVL) contre Commission des Communautés européennes

${ }^{265}$ KARNELL (1985-86) p. 76.

${ }^{266}$ Pourtant, c'est cette possibilité qui est l'atout le plus important d'un tel régime. TRUMPKE (2012) p. 277.
} 
Troisième partie : La gestion collective imposée par la loi, garantie de l'exercice des droits

Parmi les droits concernés, on retrouve :

- le droit exclusif de l'auteur à l'exécution publique des œuvres nondramatiques musicales et littéraires ${ }^{267}$;

- le droit exclusif de l'auteur à la diffusion par satellite en parallèle à la diffusion par voie hertzienne de ses mêmes œuvres et leur transmission par câble ${ }^{268}$;

- les droits voisins du droit de communication au public et le droit exclusif de l'auteur relatif à cette exploitation concernant les œuvres non-dramatiques musicales ${ }^{269}$;

- les droits voisins et le droit exclusif de l'auteur relatifve à la fixation de l'exécution de l'œuvre non-dramatique musicale aux fins de sa rediffusion par satellite ou par voie hertzienne ${ }^{270}$.

Il s'agit de droits typiquement gérés par la voie de la gestion collective volontaire. Néanmoins, d'un certain point de vue, ce recours obligatoire imposé par la loi correspond mieux aux intérêts de l'auteur ${ }^{271}$, parce que le droit de sortie est défini par la loi et il est indépendant des dispositions des statuts des sociétés de gestion collective. Dans la jurisprudence communautaire, il est fait grief aux organisations de gestion collective l'exercice difficile de cette liberté ${ }^{272}$.

Le droit de sortie s'exerce individuellement, même dans le cas des œuvres collectives. Une interprétation contraire serait largement défavorable à l'auteur ${ }^{273}$. Ce droit est rattaché à la qualité d'auteur, ce qui veut dire que la personne cessionnaire de l'exercice des droits patrimoniaux ne peut pas l'exercer à la place de l'auteur, même si elle est titulaire d'un droit voisin. La sortie pourrait avoir une influence non négligeable

${ }^{267} \S 25$ (3) de la Szjt.

${ }^{268} \S 26(7)$ et $\S 27(2)-(3)$ de la Szjt.

$269 \$ 27$. (3) de la Szjt. et $\S 74$ (2) de la Szjt.

${ }^{270} \S 26(6)$ et $\S 74(2)$ de la Szjt.

${ }^{271}$ GYERTYANFY (2005-2006) p. 92.

${ }^{272}$ La fameuse affaire Daft Punk constitue un exemple classique. Affaire COMP/C2/37.219 Banghalter \& Homem Christo v SACEM ("Daft Punk"). Autres arrêts en ce même sens : 71/224/CEE Décision de la Commission du 2 juin 1971 relative à une procédure d'application de l'article 86 du traité CEE (IV/26760 - GEMA) ; CJCE 24 mars 1974, BRT c/ SABAM et Fonior (127-73) ; 71/224/CEE Décision de la Commission du 2 juin 1971 relative à une procédure d'application de l'article 86 du traité CEE (IV/26760 - GEMA).

${ }^{273}$ FALUDI (2004) p. 93. Les héritières de l'auteur, en revanche, compte tenu de leur qualité d'ayant droit, ne pourraient décider de la sortie que de façon conjointe. 
Troisième partie : La gestion collective imposée par la loi, garantie de l'exercice des droits

sur les structures globales de la gestion collective, car elle peut déboucher sur la dissolution de l'association si celle-ci ne répond plus aux critères de représentativité.

\section{\$2. L'exercice des droits exclusifs}

L'atout le plus important de la gestion collective étendue est effectivement l'extension du champ matériel des licences octroyées pour l'utilisation des œuvres des auteurs non adhérent ou non mandant de l'organisation de gestion collective. A tel point que le système hongrois se différencie du modèle nordique, car dans les pays scandinaves, c'est le contrat conclu avec l'utilisateur qui est doté de l'effet étendu. Or, dans le cas du régime hongrois, la loi présume cet effet globalement à la gestion collective imposée.

Afin de rendre efficace l'exercice indépendant des droits de l'organisme de gestion collective, le contrat doit préciser les œuvres faisant objet d'une sortie de ce régime. Elles constituent les limites de l'extension des droits, et il faut bien les préciser dans le contrat.

En contrepartie, l'utilisateur est tenu de déclarer les œuvres utilisées afin que l'organisme puisse procéder au calcul de distribution des droits.

Le rapport entre les titulaires de droits et l'association est complexe en ce qui concerne la gestion collective étendue. L'auteur non-membre, qui est par ailleurs couvert par l'effet étendu de la gestion collective, jouit d'une position faible car il ne participe pas au fonctionnement des institutions de la démocratie interne de l'association. Cependant, cet auteur subit des conséquences des décisions prises en son absence. Il faut lui garantir alors un traitement non-discriminatoire, ainsi que le droit de bénéficier de la répartition des droits collectés afin qu'il ne se trouve pas dans une situation défavorable. A cette fin, il est souhaitable d'instaurer la transparence du fonctionnement des organisations ${ }^{274}$. Dans le contrat, l'organisation se porte garant que le titulaire de droits (à moins qu'il ait exercé son droit de sortie) ne fasse pas valoir son droit à rémunération contre l'utilisateur qui s'est vu attribu une licence par l'organisation de gestion collective.

${ }^{274}$ AXHAMN - GUIBAULT (2011) p. 512-513. 
Troisième partie : La gestion collective imposée par la loi, garantie de l'exercice des droits

Chapitre II. La gestion collective imposée au service de l'efficacité de l'exercice des droits

Certains droits à rémunération sont déterminés indépendamment des droits exclusifs, sans pour autant consituer une limitation dans la mesure où il s'ait de moyens de rémunération efficaces des auteurs pour compenser les utilisations secondaires des œuvres. Leur exercice, par le biais des organisations de gestion collective, offre une solution simple et efficace, mais montre une version mutilée de la gestion collective en réduisant le rôle des organisations à un simple administrateur de la rémunération imposée par la loi. Pourtant, il ne s'agit pas de rémunération forfaitaire, car les utilisations sont déclarées et une répartition exacte des sommes est possible.

Les deux droits à rémunération analysés sont les dérivatifs du droit de distribution $^{275}$. Premièrement, c'est la rémunération pour prêt en bibliothèque, et en raison de leurs similitudes, le droit résiduel au titre de la cession du droit de location (Section 1). Deuxièmement, le droit de suite, pour lequel la directive prévoit la possibilité d'un régime obligatoire de gestion collective. C'est la solution choisie par le législateur hongrois, tandis que la loi française préfère la gestion collective volontaire (Section 2).

Section 1 La gestion collective de la rémunération pour prêt en bibliothèque et le droit résiduel au titre de la cession du droit de location

Le droit de prêt public et le droit de location, malgré leurs similitudes, constituent des droits distinct en raison du caractère onéreux de la location et la gratuité du prêt public.

Par ailleurs, le prêt public est un droit expressis verbis non reconnu par les traités internationaux. C'est avant tout parce que les utilisations réalisées au sein des bibliothèques sont intimement liées à leur statut de «protecteur de la culture », et il est certain qu'il n'est pas évident d'assimiler ce type de utilisations à celles typiques du droit d'auteur. Les premières tentatives ont, du coup, essayé d'établir un droit à

\footnotetext{
275 Droit non existant au sein du CPI, mais son contenu, à savoir le droit de l'auteur de contrôler l'exploitation des copies de l'œuvre, est reconnu par la jurisprudence.
} 
Troisième partie : La gestion collective imposée par la loi, garantie de l'exercice des droits

rémunération ${ }^{276}$, ce qui le rapproche du droit de location, en lui accordant son caractère de droit exclusif ${ }^{277}$. La directive 2006/115 a créé un nouveau droit au lieu d'harmoniser ceux qui existaient déjà, car c'était uniquement le Danemark qui avait imposé une rémunération pour le prêt public des œuvres cinématographiques et des logiciels ${ }^{278}$.

L’importance économique du droit de location est, cependant, évidente : le marché de location des cassettes vidéo et DVD fleurissait; de ce fait, les titulaires de droits ont souhaité bénéficier des profits découlant de cette activité. Le droit d'auteur international, et surtout le droit communautaire, ont donc élargi l'étendue des droits exclusifs pas à pas afin d'y inclure le droit de location.

Dans un premier temps, nous discuterons du contenu juridique de ces droits (§1) pour pouvoir ensuite analyser leur mise en œuvre par la gestion collective (§2).

\section{§1. Le contenu du droit de prêt public et le droit de location}

Le droit de prêt public se rattache, pour l'essentiel, aux prêts des bibliothèques et porte donc, en premier lieu, sur les œuvres littéraires éditées ou les phonogrammes. La France a reconnu ce droit par la transposition de la directive $92 / 100^{279}$ en $2003^{280}$; pour sa part, la Hongrie a imposé cette réglementation spécifique en $2008^{281}$.

Aucune des lois nationales ne définit cette notion et il convient alors de renvoyer aux principes du droit civil ${ }^{282}$. Le Code civil hongrois prévoit le prêt public comme un contrat par lequel une personne accorde à une autre l'utilisation temporaire d'une chose à titre gratuit. Du point de vue du droit d'auteur, le caractère public du prêt est également un élément constitutif de la définition, car le prêt entre deux personnes privées reste à l'extérieur du périmètre du droit d'auteur. Le CPI, pour sa part, apporte une précision concernant le droit de prêt dans son article L. 133-1 : «lorsqu'une ouvre a fait l'objet d'un contrat d'édition en vue de sa publication et de sa diffusion sous forme

\footnotetext{
${ }^{276}$ Green paper on copyright and the challenge of technology - Copyright issues requiring immediate action, $\quad \operatorname{COM}(88) \quad 172$ final, 1988 (http://ec.europa.eu/greenpapers/pdf/green_paper_copyright_and_chanllenge_of_thecnology_com_(88)_172_final.pdf), p. 153154.

${ }^{277}$ REINBOTHE - VON LEWINSKI (1993) p. 34.

${ }^{278}$ COMTE (1993) p.27.

${ }^{279}$ Version originale de la directive 2006/115.

${ }^{280}$ Loi $\mathrm{n}^{\circ}$ 2003-517 du 18 juin 2003 relative à la rémunération au titre du prêt en bibliothèque et renforçant la protection sociale des auteurs.

${ }^{281}$ A szerzői jogról szóló 1999. évi LXXVI. törvény módosításáról szóló 2008. évi CXII. tv.

${ }^{282} \mathrm{La}$ loi hongroise déclare spécifiquement son caractère civil et invite l'application du Code civil dans les questions où la loi sur le droit d'auteur est muette. $§ 3$ de la Szjt.
} 
Troisième partie : La gestion collective imposée par la loi, garantie de l'exercice des droits

de livre, l'auteur ne peut s'opposer au prêt d'exemplaires de cette édition par une bibliothèque accueillant du public. Ce prêt ouvre droit à rémunération au profit de l'auteur selon les modalités prévues à l'article L. 133-4. » Ainsi, le régime spécial n'est pas applicable aux articles ou revues de presse, ou encore aux phonogrammes. A notre sens, la jurisprudence ayant reconnu le droit de prêt, le prêt est possible selon les règles générales hormis la rémunération spécifique, qui ne s’applique pas.

La directive 2006/115 entend par «prêt » la mise à disposition des œuvres pour l'usage, pour un temps limité et pour un avantage économique ou commercial direct ou indirect, lorsqu'elle est effectuée par des établissements accessibles au public ${ }^{283}$. La consultation sur place des documents du coup ne pourrait pas être considérée comme tel. ${ }^{284}$ En sont également exclus le prêt entre bibliothèques et la mise à disposition de phonogrammes ou de films à des fins de représentation publique ou de radiodiffusion, et la mise à disposition à des fins d'exposition. Il appartient aux Etats membres de définir les établissements accessibles au public. En Hongrie c'est la loi n CXL de 1997 portant sur les bibliothèques publiques qui en a disposé ainsi. Les règles applicables englobent les bibliothèques nationales, départementales et locales, ainsi que les bibliothèques universitaires. Dans sa partie règlementaire, le CPI désigne également ces établissements $^{285}$. Cette liste est plus large puisqu'elle intègre, sous certaines conditions, des bibliothèques privées ${ }^{286}$. Le dernier élément distinctif de la notion définie par la directive réside dans l'absence d'avantage économique ou commercial direct ou indirect. Cependant, des frais d'inscriptions minimes ne dépassant pas la somme nécessaire pour couvrir les frais de fonctionnement de l'établissement, ils ne sont pas

\footnotetext{
283 § 2 (1) b) de la loi.

${ }^{284}$ Interprétation confirmée par le considérant 10 de la directive 2006/115.

${ }^{285}$ Art. R. 133-1 du CPI : «Les bibliothèques accueillant du public pour le prêt mentionnées aux articles L. 133-3_et L. 133-4_sont :

$1^{\circ}$ Les bibliothèques des collectivités territoriales désignées aux articles L. 310-1 à L. 310-6_et L. 320-1 à L. 320-4 du code du patrimoine ;

$2^{\circ}$ Les bibliothèques des établissements publics à caractère scientifique, culturel et professionnel et des autres établissements publics d'enseignement supérieur relevant du ministre chargé de l'enseignement supérieur ;

$3^{\circ}$ Les bibliothèques des comités d'entreprise ;

$4^{\circ}$ Toute autre bibliothèque ou organisme mettant un fonds documentaire à la disposition d'un public, dont plus de la moitié des exemplaires de livres acquis dans l'année est destinée à une activité organisée de prêt au bénéfice d'usagers inscrits individuels ou collectifs ».

${ }_{286}$ LEBOIS, Audrey: Droits patrimoniaux - Droit de location et de prêt, J. Cl. Propriété littéraire et artistique, Fasc. 1254. 21.
} 
Troisième partie : La gestion collective imposée par la loi, garantie de l'exercice des droits

assimilables à un avantage économique ou commercial ${ }^{287}$. Dépassant ces seuils, ladite exploitation pourrait être considérée comme une location ${ }^{288}$.

L'harmonisation communautaire exclut les œuvres des arts appliqués et les œuvres d'architecture de son champ d'application matériel, sinon toutes les catégories d'œuvres d'arts pourraient y prétendre. La France, toutefois, limite le régime de rémunération au prêt de livres publiés dans le cadre d'un contrat d'édition. Ne sont pas compris alors les éditions à compte d'auteur, les livres uniquement numériques ou les revues de presse. Cette interprétation limitative soulève la question de la transposition erronée de la directive ${ }^{289}$, le législateur n'ayant pas respecté le principe de conformité $^{290}$. En Hongrie, la loi ne contient pas de telles limitations.

Le droit de prêt est traditionnellement compris dans le droit de distribution, malgré la distinction érigée par les différentes directives ${ }^{291}$. La loi hongroise, ainsi catégorise expressément le droit de prêt sous le droit de distribution. Ne reconnaissant pas le droit de distribution, l'analyse théorique du droit de prêt reste difficile, la doctrine parfois le considère comme une notion étrange du droit d'auteur français ${ }^{292}$. Pourtant, depuis la parution de traité du droit d'auteur du professeur Henri DESBOIS ${ }^{293}$, la majorité des juristes acceptent son incorporation dans le droit de destination ${ }^{294}$.

L'adoption de la directive 2006/115 a profondément bouleversé la pratique établie du prêt en bibliothèque, car cette activité est tout d'un coup devenue une utilisation relevant de l'autorisation préalable de l'auteur. Cette pratique contractuelle est pourtant difficile à mettre en place, non seulement en raison du nombre des

\footnotetext{
${ }^{287}$ Directive 2006/115 considérant 11.

${ }^{288}$ GYERTYANFY (2014) p. 270-271.

289 ALLEAUME (2004) p.723.

${ }^{290}$ ZOLYNSKI (2007) p. 159.

${ }^{291}$ CJCE 17 avril 2008, Peek and Cloppenburg (C-456/06), considérant 41: «au sens de l'article 4, paragraphe 1, de la directive 2001/29, implique exclusivement un transfert de propriété de cet objet. Par conséquent, ni le simple fait d'accorder au public la possibilité d'usage des reproductions d'une ouvre protégée par le droit d'auteur ni l'exposition au public desdites reproductions sans même que la possibilité d'utiliser celles-ci soit accordée ne sauraient constituer une telle forme de distribution.» Pourtant, ce même article de la directive «permet à un titulaire du droit exclusif de distribution d'une œuvre protégée de s'opposer à une offre de vente ou à une publicité ciblée concernant l'original ou une copie de cette ouvre, quand bien même il ne serait pas établi que cette publicité a donné lieu à l'acquisition de l'objet protégé par un acheteur de l'Union, pour autant que ladite publicité incite les consommateurs de l'État membre dans lequel ladite ouvre est protégée par le droit d'auteur à en faire l'acquisition. » CJCE 17 avril 2008, Peek and Cloppenburg (C-456/06), considérant 35.

${ }^{292}$ ALLEAUME (2004) p.721.

${ }^{293}$ DESBOIS (1978) $\mathrm{n}^{\mathrm{O}} 288$.

${ }^{294}$ ALlEAUME (2001) p. 44.
} 
Troisième partie : La gestion collective imposée par la loi, garantie de l'exercice des droits

utilisations, mais également $\mathrm{du}$ fait même de la fonction des bibliothèques. Les bibliothèques sont traditionnellement vues comme les gardiens de la culture nationale, ce qui explique leurs financements par l'Etat. Le droit exclusif quand il se manifeste à interdit certaines utilisations, serai apte de rendre complètement impossible l'exercice du prêt ${ }^{295}$. Ensuite, les bibliothèques se confronteraient aux difficultés de payer les droits d'auteur sur leur budget modeste, tandis que le droit d'accès à la culture et à l'information prohibe d'imposer cette charge financière sur les lecteurs souhaitant consulter les œuvres. L'intention de la directive de reconnaître le droit exclusif à l'auteur n'est plus qu'un simple geste, une déclaration symbolique, mais difficile à mettre en place en pratique. Les raisons principales de procéder ainsi se trouvent d'abord dans le rapprochement du droit de prêt et de location : l'exclusion de l'une de ces deux prérogatives constituerait un désavantage pour les titulaires de droit. L'argument économique favorise l'établissement de droit exclusif, car le prêt en tant qu'utilisation secondaire pourrait se présenter comme une alternative à la vente des copies des œuvres littéraires.

Le droit de location, contrairement au droit de prêt, est à la fois prévu par les textes internationaux, et défini par la directive 2006/115 comme la mise à disposition des objets pour l'usage, pour un temps limité et pour un avantage économique ou commercial direct ou indirect. Le droit d'auteur hongrois le considère également comme une catégorie intégrante du droit de distribution ${ }^{296}$. Son champ d'application matériel est plus large que celui du droit de prêt, chaque catégorie des œuvres pouvant en faire l'objet. La directive 2006/115, dans le but de défendre les intérêts de l'auteur, établit un droit résiduel en sa faveur en cas de cession du droit de location ${ }^{297}$, combinant ainsi les avantages respectifs de deux systèmes de droit exclusif et droit à rémunération ${ }^{298}$. A notre sens, il ne s'agit pas de limitation du droit, car l'auteur peut céder son droit, ceci ne découlant pas automatiquement et directement de la loi, et surtout, malgré cette cession, il bénéficie d'une rémunération. Cette protection est d'ailleurs nécessaire en raison de la position relativement faible de l'auteur lors de la négociation du contrat (malgré sa prérogative issue du droit exclusif) ${ }^{299}$, qui ressort de la cession de l'exploitation du droit de location au producteur de phonogramme ou

\footnotetext{
${ }^{295}$ COMTE (1993) p. 35.

${ }^{296} § 23$ (2) de la Szjt.

297 Art. 5 (1) de la directive 2006/115.

298 BERCESI (1997) p. 341.

${ }^{299}$ GYENGE (2004) et GYENGE (2005a).
} 
Troisième partie : La gestion collective imposée par la loi, garantie de l'exercice des droits

vidéogramme. La protection de l'auteur nous semble encore plus pertinente, si on accepte la cession du droit de location à titre gratuit, solution par ailleurs confirmée par la jurisprudence française ${ }^{300}$. Il convient d'ajouter que, s'agissant des contrats de production audiovisuelle, la cession du droit de prêt est présumée dans les dispositions $\mathrm{du} \mathrm{CPI}^{301}$. Étant donné que l'auteur ne peut pas renoncer à ce droit résiduel, la cession gratuite du droit de location n'est pas possible car l'auteur est titulaire d'une rémunération équitable en toute hypothèse. La directive laisse une marge de manœuvre considérable aux Etats membres, car elle vise uniquement l'importance de la contribution apportée au film ou au phonogramme par l'auteur (ou titulaire du droit voisin). La rémunération équitable pourrait alors se manifester dans les droits nationaux comme une rémunération forfaitaire, mais également comme une rémunération proportionnée à l'utilisation $^{302}$.

Bien que la directive prévoie le droit exclusif, elle laisse la faculté aux États membres de le limiter et de l'introduire comme un droit à rémunération ${ }^{303}$. En raison du rattachement fort à la politique culturelle de l'Etat, la rémunération pour prêt en bibliothèque est encore moins harmonisée que celle pour la copie privée et montre des caractéristiques particulières à chaque pays ${ }^{304}$. Peu importe la solution adoptée par les législations nationales, le fait d'imposer la gestion collective nous semble opportun pour gérer soit le droit exclusif, soit le droit à rémunération pour prêt public. Pourtant, nous sommes favorables à la solution retenue par les Etats ${ }^{305}$, qui est le droit à rémunération, car le maintien du droit exclusif donnerait naissance aux problèmes divers de son exploitation.

La loi hongroise limite le droit de prêt sur deux points. Le premier porte sur l'utilisation libre du prêt entre bibliothèques, c'est-à-dire que le droit de prêt (et sa rémunération) ne couvre pas cette utilisation ${ }^{306}$. Le second concerne les bibliothèques nationales professionnelles puisque ces dernières bénéficient également de l'utilisation

\footnotetext{
${ }^{300}$ CA Paris, 4e ch., 1er juill. 1998: RIDA janv. 1999. p. 390.

301 Art. L. 132-24 du CPI.

${ }^{302}$ LEBOIS, Audrey: Droits patrimoniaux - Droit de location et de prêt, J. Cl. Propriété littéraire et artistique, Fasc. 1254. 52.

303 Art. 6 (1) de la directive 2006/115 : «les Etats membres peuvent déroger au droit exclusif prévu à l'article ler pour le prêt public, à condition que les auteurs au moins obtiennent une rémunération au titre de ce prêt $\gg$.

${ }^{304}$ Art. 6 (1) de la directive 2006/115 est ainsi libellé : « [les états membres] ont la faculté de fixer cette rémunération en tenant compte de leurs objectifs de promotion culturelle ».

${ }^{305} \mathrm{C}$ 'est un droit à la rémunération complété par la gestion collective. KIKKIS (2014) p. 463.

306 35.§ (4) de la Szjt. GYERTYANFY (2014) p. 193.
} 
Troisième partie : La gestion collective imposée par la loi, garantie de l'exercice des droits

libre $^{307}$. Il convient de préciser par ailleurs que la Szjt. ne restreint pas le droit exclusif à un simple droit à rémunération en ce qui concerne les œuvres enregistrées en phonogrammes et les œuvres cinématographiques.

La loi française ne rompt pas avec la rédaction traditionnelle des limitations et exceptions et prévoit que l'auteur ne peut pas interdire le prêt public de son œuvre. Dès lors, on considère, par déduction, que le droit de prêt existe, car le code lui-même ne contient aucune disposition en ce sens.

\section{\$2. L'exercice du droit}

Les organisations de gestion collective jouent un rôle réduit en ce qui concerne la détermination des prix, car ces derniers sont souvent fixés par la loi. La complexité $\mathrm{du}$ processus de modification des lois ne laisse aucune de marge de manœuvre afin de les ajuster avec flexibilité en fonction des utilisations réelles. Les organisations de gestion collective sont donc plutôt de simples administrateurs de droits, et non de véritables sociétés d'auteurs.

Pourtant, un souci important et délicat se pose, notamment pour déterminer qui est le débiteur de la rémunération. Trois solutions pourraient être envisagées pour le paiement : (i) par les bibliothèques, (ii) par les utilisateurs ou (iii) par subvention de l'Etat. Comme déjà démontrées, les deux premières solutions hypothétiques dans leurs formes pures sont difficilement réalisables pour des raisons plutôt politiques. Dans la plupart des cas, il s'agit alors d'aides d'Etat ou d'un régime mixte, qui peuvent ainsi servir à réaliser des objectifs culturels et sociaux. L'avantage de ce système est la définition des critères objectifs dans la loi pour la répartition des sommes ${ }^{308}$, dont le montant peut malheureusement varier en fonction de la volonté fiscale et peut être réduit à un seuil minimal ${ }^{309}$. L'interprétation grammaticale stricte de la directive aboutit à voir les auteurs uniquement comme des bénéficiaires de la rémunération, ce qui pourrait être discriminatoire vis-à-vis des autres titulaires de droits ${ }^{310}$. Néanmoins, il n'est pas interdit Etats membres d'appliquer des règles similaires aux titulaires de droits

307 § 39 de la Szjt. L'annexe 3 de loi CXV de 1997 prévoit la liste des bibliothèques nationales professionnelles.

${ }_{308} \mathrm{La}$ reconnaissance des critères objectifs ne rend pas forcément le régime «juste» et nondiscriminatoire. Surtout les pays nordiques ont favorisé les auteurs domestiques par la définition des critères.

309 D'après Fabrice RENEAUD, le montant faible de la rémunération justifie le recours à la gestion collective. RENEAUD (2004) p. 85.

${ }^{310}$ COMTE (1993) p. 37-39. 
Troisième partie : La gestion collective imposée par la loi, garantie de l'exercice des droits

voisins. En comparant la rédaction de la directive à celle du droit résiduel, il peut être constaté que ce droit à rémunération peut être l'objet d'une cession ${ }^{311}$. La jurisprudence de la CJUE a fait l'amalgame entre la rémunération pour copie privée et la rémunération pour prêt en bibliothèque ${ }^{312}$. Il est donc nécessaire d'appliquer mutatis mutandis les principes posés par la jurisprudence post-Padawan de la Cour ${ }^{313}$. Une certaine proportionnalité de la rémunération est alors requise, mais surtout, il faut éviter qu'elle soit symbolique. En respectant ces critères, l'évaluation d'une somme forfaitaire est sans doute possible. ${ }^{314}$

Concrètement, pour être conforme aux règles générales de notification des communications de droits, la loi hongroise exige que l'organisation de gestion collective adopte des barèmes et procède à leurs publications dans les limites de la proposition du Ministre de la culture dans la loi de finances ${ }^{315}$. C'est alors le Parlement hongrois qui attribue une somme aux fins de prêt en bibliothèque, mais formellement on parle des conditions générales d'affaire, car c'est l'association de gestion collective compétente qui répartit la rémunération parmi les auteurs. Naturellement, dans ce caslà, on ne parle pas de « collection des sommes » au sens strict du terme.

La rémunération en France repose sur deux piliers: le premier est la subvention étatique. Le montant de cette rémunération forfaitaire dépend du nombre de lecteurs inscrits dans les établissements, car l'Etat verse 1,50€ (1 euro auprès des bibliothèques universitaires) par lecteur aux titulaires de droit ${ }^{316}$. La doctrine considère ce pilier du régime comme le prix de la licence légale, qui a pour objectif de compenser l'auteur de la perte de son droit exclusif ${ }^{317}$.

Le deuxième pilier est une compensation au cas par cas, en fonction de chaque utilisation des œuvres protégées. Le législateur n'ayant pas voulu différencier le prêt de la consultation sur place ${ }^{318}$, il a décidé de lier la rémunération aux achats de livres. Néanmoins, afin de ne pas charger les bibliothèques, ce sont les fournisseurs de livres

\footnotetext{
${ }^{311}$ Il appartient à la CJUE d'interpréter le texte de la directive ; elle peut donc proposer une interprétation qui favorise l'incessibilité de ce droit.

${ }^{312}$ CJUE C-271/10 considérant 29.

${ }^{313}$ CARON (2011a).

${ }^{314}$ CJUE C-271/10 considérant 33.

315 § 23/A. (2) de la Szjt.

316 Art. R. 133-2. du CPI

317 ALLEAUME (2014) p. 724.

${ }^{318}$ On peut en douter si la rémunération ainsi établie remplit encore sa fonction originale.
} 
Troisième partie : La gestion collective imposée par la loi, garantie de l'exercice des droits

qui ont l'obligation de payer $6 \%$ du prix du livre comme rémunération pour prêt en bibliothèque ${ }^{319}$.

Deux aspects importants sont validés par rapport à la distribution des sommes ainsi reçues : les organisations de gestion collective les répartissent d'une manière plus ou moins proportionnelle parmi les titulaires de droits, et le cas échéant, elles les consacrent à la réalisation des objectifs culturels ou sociaux.

En Hongrie, à partir de 2011, l'association de gestion collective agréée requiert des informations de 20 bibliothèques choisies en fonction de leur taille, leur fonction et leur emplacement géographique. La base de la répartition est le nombre de prêts de l'œuvre ; dès lors, les bibliothèques sont tenues de fournir des informations à ce sujet.

Il nous semble qu'en France l'auteur ne peut pas renoncer à sa rémunération, ce qui emporte donc la nullité des contrats conclus en ce sens, même si, en général, dans les contrats d'édition, l'auteur cède à l'éditeur ses droits patrimoniaux relatifs à toute sorte d'utilisation $^{320}$. Cette interprétation nous semble pertinente, car la rémunération est majoritairement utilisée à des fins sociales et culturelles. La moitié des sommes perçues sont à distribuer parmi les auteurs et les éditeurs. La seconde moitié de la rémunération est destinée à être répartie parmi les auteurs qui ne bénéficieront pas de retraite complémentaire. L'ensemble de ce régime, avec les modes de financement et les méthodes de répartition, pourrait nous amener à remettre en question la nature juridique de la rémunération ${ }^{321}$. L'usage de ces sommes au bénéfice de l'auteur pour réaliser des objectifs sociaux est un but valide et légitime, reconnu par la CJUE en ce qui concerne la rémunération pour copie privée. Pourtant, les éditeurs n’ont pas le statut de titulaire de droits voisins.

\section{Section 2. Le droit de suite}

Le droit de suite, contrairement à la gestion collective étendue, est une invention française introduite dans le droit d'auteur en $1920^{322}$, qui reflète le problème frappant majoritairement l'artiste d'œuvres visuelles, à savoir la valorisation de son art

\footnotetext{
${ }^{319}$ Art. L. 133-3. du CPI.

${ }^{320}$ PIERRAT (2000) p. 79.

${ }^{321}$ CARON (2013a) p. 278

${ }^{322}$ Loi du 20 mai 1920 frappant d'un droit au profit des artistes les ventes publiques d'objet d'art. DUCHEMIN (1948).
} 
Troisième partie : La gestion collective imposée par la loi, garantie de l'exercice des droits

après sa mort. L'hypothèse rencontrée le plus souvent concerne la situation d'un auteur qui vit dans des circonstances modestes, voire miséreuses parce qu'il ne peut pas profiter de ses créations, alors que celles-ci peuvent devenir de grands succès des décennies après sa mort. Afin de compenser cette situation défavorable et de consacrer le respect et la réputation de l'auteur, les titulaires de ses droits (en général ses héritiers) bénéficient de profits issus de la revente de ses œuvres, qui est le mode d'exploitation le plus important. ${ }^{323}$

Suivant l'exemple français, les parties adhérentes à la Convention de Berne ont adopté l'article 14ter en 1948, et le législateur hongrois a également mis en place cette solution par le décret-loi de 1978. Le talon d'Achille de cette idée pourtant généreuse est son caractère optionnel. L'harmonisation mondiale reste illusoire, car plusieurs pays favorisent la protection de leur marché d'art par rapport à la protection des auteurs. L'Union Européenne, encore une fois, propose d'adopter une position commune sur ce sujet par l'adoption de la directive 2001/84 relatif au droit de suite.

\section{\$1. La nature du droit de suite}

János BATTA, juriste hongrois, a soutenu que le droit de suite constitue une forme de mise à disposition de l'œuvre au public, car ce dernier a tendance à s'élargir avec chaque revente ${ }^{324}$. Désormais, la position du droit d'auteur hongrois est changée, et la doctrine le considère parmi les droits patrimoniaux sous la forme d'un droit à rémunération $^{325}$ qui complète le droit de distribution une fois épuisé ${ }^{326}$. La doctrine française est divisée sur le point de savoir si on peut considérer le droit de suite comme un troisième pilier du droit d'auteur, au même titre que le droit de reproduction et le droit de représentation ${ }^{327}$.

Selon nous, le droit de suite est différent du droit exclusif d'autorisation et d'interdire pour plusieurs raisons. D'une part, l'épuisement du droit de distribution n'empêche pas l'auteur de s'opposer aux reventes de son œuvre d'art. D'autre part, l'auteur n'est pas libre de négocier le montant de la rémunération, car celui-ci est fixé par la loi. Enfin, il s'agit d'une exception de l'exception en ce sens que le droit de suite

\footnotetext{
${ }^{323}$ GYERTYANFY (2014) p. 422.

${ }^{324}$ BATTA (1978) p. 997.

${ }^{325}$ GYENGE (2005) p. 88

${ }^{326}$ GYERTYANFY (2014), p. 423.

${ }^{327}$ DeSBOIS (1978) p. 377. et POLLAUd-DULIAN (2005) p. 553-554.
} 
Troisième partie : La gestion collective imposée par la loi, garantie de l'exercice des droits

introduit dans le champ d'application du droit d'auteur un acte qui, normalement, se trouve en dehors de son périmètre ${ }^{328}$.

Le droit de suite porte sur les œuvres d'arts originales et les manuscrits originaux des écrivains ou des compositeurs, d'après la Convention de Berne ${ }^{329}$. Toutefois, même les commentateurs de la Convention ${ }^{330}$ reconnaissent que l'importance des manuscrits est faible; dès lors, traditionnellement, et surtout dans la directive 2001/84, ils sont dispensés de la portée de la directive ${ }^{331}$. Un autre argument est ensuite le rapport significatif entre l'œuvre et son support s'agissant des œuvres d'art, car le choix du support est également une manifestation de la liberté artistique. Compte tenu du fait que le droit de suite se rattache à l'apparence physique ${ }^{332}$, de ce point de vue, il est similaire à la rémunération pour copie privée.

La Convention de Berne ne propose pas de définition de l'œuvre d'art, mais traditionnellement les œuvres d'art graphiques et plastiques (peintures, dessins, sculptures etc.) en font partie ; en revanche, les œuvres d'architecture en sont exclues.

La directive 2001/4 ajoute à cette liste (et du coup intègre dans la catégorie des beaux-arts) certains objets qui marquent la limite entre les beaux-arts et les arts appliqués comme la tapisserie, les céramiques et la verrerie ${ }^{333}$. L'harmonisation ne s'étend pas aux œuvres d'art appliqué, les Etats membres jouissent alors de la liberté de légiférer à ce sujet. A cet égard, il est utile à mentionner que le droit d'auteur hongrois étend traditionnellement le champ d'application du droit de suite aux objets d'art ${ }^{334}$. La doctrine française reconnait également l'application du droit de suite sur les œuvres d'arts appliqués ${ }^{335}$. Il convient de noter également qu'aucune liste exhaustive des œuvres d'art ne peut être arrêtée car cela reviendrait à restreindre la créativité artistique. Il appartient alors au juge de décider d'appliquer les règles de droit de suite à l'espèce qui lui est soumise.

\footnotetext{
${ }^{328}$ En ce sens: MEZEI (2014c). p. 6-7.

${ }^{329}$ Art. 14ter de la Convention de Berne.

${ }^{330}$ MASOUYE (1978) p. 105-106.

${ }^{331}$ Considérant 19 de la directive 2001/84 : «Il est utile de préciser que l'harmonisation découlant de la présente directive ne s'applique pas aux manuscrits originaux des écrivains et des compositeurs ».

${ }^{332}$ COLOMBET (1999) p. 176-177.

${ }^{333}$ Art. 2 (1) de la directive 2001/84

$33470 \S$ (1) de la Szjt.

${ }^{335}$ CARON (2013a) p. 270
} 
Troisième partie : La gestion collective imposée par la loi, garantie de l'exercice des droits

Toutes les sources de droit s'entendent pour reconnaître que l'œuvre d'art se doit d'être une création originale pour pouvoir bénéficier de cette protection. Cette originalité ne peut être confondue toutefois avec le seuil minimal de la protection du droit d'auteur : il s'agit d'une catégorie supplémentaire. La Convention de Berne entend par originalité le fait que l'œuvre soit créée par les mains propres de l'auteur ${ }^{336}$. La directive européenne, et par conséquent, les droits nationaux hongrois et français utilisent une définition élargie. En ce sens, les exemplaires d'œuvres d'art couvertes par la présente directive, et qui ont été exécutés en quantité limitée par l'artiste lui-même ou sous sa responsabilité, sont considérés comme des œuvres d'art originales ${ }^{337}$. Il est possible de considérer, par exemple, comme tels les œuvres numérotées ou paraphées par l'auteur ${ }^{338}$. Les deux critères de l'originalité sont alors complémentaires et sont à l'application cumulative. Si l'œuvre d'art n'atteint pas le seuil minimum de protection en l'absence d'originalité, son auteur ne peut pas être titulaire du droit de suite. La situation est relativement claire si l'auteur a créé son œuvre lui-même ; la question de l'originalité peut cependant poser des difficultés quand l'œuvre est réalisée sous sa responsabilité ${ }^{339}$.

La Convention de Berne impose la réciprocité pour définir le bénéficiaire du droit de suite, qui peut nécessiter l'application des règles du droit international privé. Reprenant ce principe, les lois nationales posent certains principes de réciprocité pour déterminer si l'auteur ressortissant étranger (et surtout hors UE) pourrait bénéficier du droit de suite. Les héritiers de l'auteur, en leur qualité d'ayants droit, sont souvent titulaires du droit de suite; néanmoins, ils peuvent également être désignés par le testament de l'auteur défunt comme des créanciers du droit de suite. ${ }^{340}$

La directive précise les ventes ouvrant droit à la rémunération, telles que l'ensemble des actes de revente dans lesquels interviennent en tant que vendeurs, acheteurs ou intermédiaires, des professionnels du marché de l'art comme les salles de

\footnotetext{
${ }^{336}$ MASOUYE (1978) p. 106.

${ }^{337}$ Art. 1. (1)-(2) de la directive 2001/8, $\$ 70$ (2) de la Szjt, art. L. 122-8 alinea 2 du CPI. 338 § 70 (2) de la Szjt.

339 CA Orléans, 8 févr. 1990, RIDA janv. 1991, p. 333, note Gaudel. Cass. 1re civ., 15 novembre 1991: Bull. civ. I, no 303, D. 1992, p. 361, note Edelman et 1993, somm. comm. 89, obs. Colombet, Cass. 1re civ., 13 oct. 1993: JCP G 1993, IV, 2628; D. 1994, 138 note Edelman; D. 1994, somm. comm. (sommaire commenté) 93, obs. Colombet, arrêt cassé: Paris, 4e ch 28 janv. 1991, 28 janv. 1991, D. 1992, somm. 17, obs. Colombet.

${ }^{340}$ CJUE C-518/08 considérant 36.
} 
Troisième partie : La gestion collective imposée par la loi, garantie de l'exercice des droits

vente, les galeries d'art et, d'une manière générale, tout commerçant d'œuvres d'art ${ }^{341}$. A contrario, le régime du droit de suite ne s'applique pas aux actes de vente entre deux personnes privées ou à titre gratuit. Le droit hongrois élargit le concept de vente en soumettant au régime du droit de suite tous les actes de transfert de propriété de l'objet d'art à titre onéreux (exemple : l'échange). Il y a lieu de mentionner, à cet égard, que la qualité de commerçant d'art pourrait être attribuée à toute société dont l'activité s'étend au transfert régulier de propriété des objets d'art ${ }^{342}$.

\section{\$2. La pratique du droit de suite}

Le montant de la rémunération, les particularités de sa perception et de sa répartition sont déterminés par les législateurs nationaux, les auteurs n'ayant aucun rôle à cet égard ${ }^{343}$. La directive 2001/84 a institué une harmonisation complète sur ce point qui ne laisse pas beaucoup de liberté aux Etats membres.

La directive précise que le droit de suite est à la charge du vendeur. En principe, selon les lois françaises et hongroises, le débiteur de la rémunération est le commerçant professionnel. Le CPI précise par ailleurs que si les deux parties agissent en cette qualité, le droit de suite est à la charge du vendeur ${ }^{344}$. La question qui se pose est notamment de savoir si les parties peuvent contracter différemment et si la clause du contrat qui met à la charge de l'acheteur le paiement de la rémunération est valide. La CJUE a validé ${ }^{345}$ cette pratique contractuelle malgré le risque de distorsion de la concurrence inhérente à une telle pratique et de double paiement au profit du même bénéficiaire si l'acheteur s'engage dans la revente de l'œuvre ${ }^{346}$.

La base de calcul de la rémunération est le prix de vente des œuvres d'art hors taxe. Le législateur européen a choisi des montants de rémunération graduellement dégressifs, qui permettent de laisser une marge de manœuvre étroite aux États membres. Ainsi, il appartient aux États membres de déterminer le seuil minimal au-dessous duquel les actes de ventes sont exonérés du droit de suite et d'établir certains taux sur mesure

\footnotetext{
${ }^{341}$ Art. $1^{\text {er }}$ (2) de la directive 2001/84.

${ }^{342}$ GYERTYANFY (2014), p. 423.

${ }^{343}$ Art. 14ter (3) de la Convention de Berne.

344 § 70 (9) de la Szjt.

${ }^{345}$ CJUE C-41/14 considérant 32. Le juges du fond national s'est prononcé dans les deux sens. CA Paris, pôle 5, 4e ch., 12 déc. 2012, D. 2013, act. 174.obs. Emile-Zola-Place, CA Paris, pôle 5, 4e ch. 3 juill. 2013, Comité prof. des galeries d'art: Propr. intell. 2014, $\mathrm{n}^{\circ}$ 50, p. 84, note Lucas.

${ }^{346}$ AZZI (2011) p. 69.
} 
Troisième partie : La gestion collective imposée par la loi, garantie de l'exercice des droits

au regard des particularités de leurs marchés de l'art ${ }^{347}$. Cependant, la loi de 2011, en défavorisant les auteurs, a abaissé les taux applicables en Hongrie.

Un système d'exonération est également prévu en raison de l'objectif de la protection de la culture. En outre, pour les actes de revente effectués par des personnes privées à des musées sans but lucratif, et qui sont ouverts au public, le droit de suite n'est pas étendu ${ }^{348}$.

En raison de l'intervention forte du législateur, les organisations de gestion collective exercent plutôt un rôle d'administrateur dans la perception et la répartition des droits de suite. Les commerçants, en leur qualité de vendeurs, sont tenus d'acquitter les sommes dus au titre du droit de suite dans les trois mois et fournir les documentations permettant d'identifier les œuvres et de vérifier le calcul de montant des sommes $^{349}$

La directive 2001/84 a affirmé le principe, pour la première fois, de l'inaliénabilité des droits de suite, auquel l'auteur ne peut renoncer ${ }^{350}$. C'est une disposition protectrice des intérêts de l'auteur, car la possibilité d'y renoncer porterait atteinte au principe même du droit de suite.

L'organisation de gestion collective hongroise agréée à cet effet, la HUNGART, transmet au titulaire des droits les droits de suite perçus d'une manière déjà individualisée ${ }^{351}$. Selon sa pratique établie, elle transmet également toutes les informations complémentaires communiquées par les commerçants. Le juge a ainsi reconnu qu'en l'absence de dispositions législatives, il n'existe pas d'obligation de transmettre à la HUNGART des données complémentaires telles que la date de l'acte de la revente ou la date de perception de la rémunération, ni de les communiquer à l'auteur ${ }^{352}$.

En France, bien que la gestion du droit de suite par le biais des sociétés de gestion collective soit une option facultative, le CPI contient des articles spécifiques

\footnotetext{
${ }^{347}$ Art. 3 (3) et (4) de la directive 2001/84.

348 Directive 2001/84 considérant 18.

${ }^{349} \S 70$ (10) de la Szjt.

${ }^{350}$ Art. 1er (1) de la directive 2001/84.

${ }^{351}$ Il dispose de 30 jours suivant la perception. HUNGART Felosztási szabályzat 15.2. pont.

${ }^{352}$ Fővárosi Ítélőtábla 8.Pf.20.304/2007/7. sz. ítélet.
} 
Troisième partie : La gestion collective imposée par la loi, garantie de l'exercice des droits

relatifs à l'agrément des sociétés ${ }^{353}$. Le caractère facultatif de la gestion collective signifie également que le droit de suite est à payer directement à l'auteur. Ce n'est qu'en

l'absence de paiement que la société de gestion collective intervient afin de retrouver l'auteur ${ }^{354}$.

${ }^{353}$ Art. R. 122-7 du CPI : «I.-Le ministre chargé de la culture fixe par arrêté une liste de sociétés de perception et de répartition de droits aptes à informer les bénéficiaires du droit de suite et susceptibles à ce titre d'être avisées des ventes d'oeuvres originales graphiques ou plastiques dans les conditions fixées au II de l'article R. 122-9.

II.-Pour être inscrite sur la liste mentionnée au I du présent article, une société de perception et de répartition de droits doit à l'appui de sa demande:

$1^{\circ}$ Apporter la preuve de la diversité de ses associés et du nombre des ayants droit;

$2^{\circ}$ Justifier la qualification de ses gérants et mandataires sociaux, appréciée en fonction de leur expérience professionnelle dans le secteur des arts graphiques ou plastiques ou de la gestion d'organismes professionnels ;

$3^{\circ}$ Donner toutes informations relatives à son organisation administrative, à ses conditions d'installation et d'équipement et à sa capacité à informer les bénéficiaires du droit de suite, y compris à l'étranger.

Est radiée de la liste, par arrêté du ministre chargé de la culture, toute société qui en fait la demande ou, sous réserve d'avoir été mise à même de faire valoir ses observations dans un délai de deux mois, toute société qui ne remplit plus les conditions auxquelles est subordonnée l'inscription sur la liste.

III.-Les arrêtés du ministre chargé de la culture mentionnés au I et au II sont publiés au Journal officiel de la République française ».

${ }^{354}$ Art. R. 122-10 du CPI : "I.-Lorsqu'il est saisi d'une demande du bénéficiaire, le professionnel responsable du paiement du droit de suite lui verse le montant de celui-ci dans un délai qui ne peut excéder quatre mois à compter de la date de réception de la demande ou, si cette demande est reçue antérieurement à la vente, à compter de la date de cette vente.

Si l'oeuvre est due à la collaboration de plusieurs auteurs, le bénéficiaire en fait la déclaration et précise la répartition du droit de suite décidée entre les auteurs.

II.-S'il n'est saisi d'aucune demande, le professionnel responsable du paiement du droit de suite avise par lettre recommandée avec demande d'avis de réception, au plus tard trois mois après la fin du trimestre civil au cours duquel la vente a eu lieu, l'une des sociétés de perception et de répartition des droits mentionnées à l'article $R$. 122-6de la réalisation de la vente en lui indiquant la date de la vente, le nom de l'auteur de l'oeuvre et, le cas échéant, les informations relatives au bénéficiaire du droit de suite dont il dispose.

Lorsque une société de perception et de répartition des droits est avisée d'une vente ouvrant droit à la perception du droit de suite au profit d'un bénéficiaire mentionné à l'article R. 122-7, elle est tenue de l'en informer. Lorsque le bénéficiaire n'est pas identifié, la société de perception et de répartition des droits procède aux diligences utiles pour informer les personnes susceptibles de bénéficier du droit de suite, au besoin en faisant appel aux autres sociétés de perception et de répartition de droits mentionnées à l'article R. 122-6. A défaut d'avoir pu informer le bénéficiaire, elle procède aux mesures de publicité appropriées sous forme électronique ou par tout autre moyen adapté ». 
Troisième partie : La gestion collective imposée par la loi, garantie de l'exercice des droits

\section{Conclusion de la troisième partie}

Cette deuxième forme de gestion collective imposée par la loi fût introduite dans le droit d'auteur afin de faciliter l'administration des droits. Le législateur a ainsi essayé d'éviter qu'il s'agissait de la limitation des droits exclusifs, c'est la raison principale de l'introduction du droit d'opposition ou du droit de sortie. Il s'agit d'un renversement complet des principes du droit d'auteur.

Néanmoins, grâce à certaines garanties légales, le législateur a empêché les organisations de gestion collective d'abuser de leur position dominante et de bloquer la gestion individuelle dans leurs actes et règlements intérieurs. En effet, les éléments spécifiques du système hongrois de la gestion collective étendue permettent aux organisations de gestion collective d'être en conformité avec les conventions internationales et directives européennes portant sur le droit d'auteur. Le droit de sortie accordé aux éditeurs dans le cadre de la gestion collective en raison de la numérisation des livres indisponibles du XXème siècle montre également leur situation renforcée, semblable à celle des titulaires de droits voisins.

Le côté pragmatique est déterminant s'agissant de la gestion des droits à rémunération. La gestion de la rémunération pour le droit de prêt, même si elle se nourrit des sources financières de l'Etat, ne pourrait pas être organisée d'une manière efficace sans le principe et le savoir-faire de la gestion collective. En raison du rattachement de cette rémunération à la politique culturelle, les organisations de gestion collective assurent la réalisation des objectifs culturels nationaux.

Bien que sa finalité soit différente, le droit de suite a été conçu de manière similaire, car les titulaires de droits ne sont pas dotés de la liberté de déterminer le montant de la rémunération et ses modes de financement. A notre sens, ce mode de gestion se trouve à mi-chemin entre la gestion collective volontaire et obligatoire en France, en raison de l'agrément des sociétés de gestion collective et de l'application obligatoire du droit à rémunération. 


\section{Conclusions finales}

La gestion collective obligatoire est fortement liée à l'évolution technologique, c'est très souvent cette évolution qui a incité le législateur à imposer ce mode de gestion en réponse à une nouvelle technologie permettant la propagation et l'utilisation à plus grande échelle d'œuvres protégées (retransmission par câble, reproduction par reprographie, numérisation des livres indisponibles). La deuxième tendance consiste à la rendre obligatoire en ce qui concerne les droits récemment reconnus (droit de suite, droit de prêt en bibliothèque).

Pourtant, une différence d'approche émerge entre la France et la Hongrie. Dans le premier cas, l'autonomie de l'auteur est plus marquante, ce qui veut dire également que la gestion collective volontaire est considérée comme la forme le plus complète de la gestion collective. Alors qu'en Hongrie, ces mêmes droits sont souvent soumis à un régime de gestion collective imposé par la loi. De ce point de vue, le système de gestion collective hongrois favorise plutôt les utilisateurs.

La limitation des droits exclusifs en simple droit à rémunération est en relation avec le développement technologique ainsi que la recherche d'efficacité. En raison des utilisations nombreuses, le législateur a parfois décidé de limiter le droit exclusif à un simple droit à rémunération, et a rattaché la gestion collective à ce système, comme le démontre l'exemple tiré de la copie privée. Cette solution, en théorie, garantit une rémunération à l'auteur et assure en même temps une sécurité juridique aux utilisateurs. Cependant, il existe des domaines dans lesquels on a tenté de mieux respecter les principes du droit d'auteur et de maintenir le droit exclusif de l'auteur comme en matière de retransmission par câble, de reproduction par reprographie, de numérisation des livres indisponibles ou encore de gestion collective étendue. L'intervention des organisations de gestion collective demeure nécessaire, car le processus d'attribution des licences serait sinon trop complexe. En effet, la gestion collective des droits exclusifs imposée par le législateur est un moyen à mi-chemin entre la gestion individuelle traditionnelle et le simple droit à rémunération de concilier les intérêts des auteurs et ceux des utilisateurs tout en respectant les principes classiques du droit d'auteur. Cette recherche d'équilibre est encore plus visible s'agissant de la gestion 
collective étendue, qui offre un droit de sortie à l'auteur, parce qu'il a le choix de revenir à un exercice classique des droits.

La gestion collective obligatoire, sans droit de sortie, est uniquement prévue par les lois nationales quand les traités internationaux et le droit européen permettent la limitation du droit exclusif, ou rendent la gestion collective obligatoire. De ce point de vue, l'analyse du droit de la reproduction par reprographie est intéressante car, le législateur français n'a pas décidé de le transformer en droit à rémunération. L'application du test en trois étapes dans ce cas-là, ainsi qu'en matière de gestion collective présumée, est recommandée.

Une fois les droits exclusifs limités, le législateur dispose de plus de liberté pour soumettre les droits à rémunération à un régime de gestion collective obligatoire. Cette solution est souvent recherchée, car le grand nombre des utilisations combiné avec un simple droit à rémunération rend indispensable l'intervention d'un acteur intermédiaire. Le cas échéant, la gestion collective n'impose pas de limite en soi, mais ses règles de fonctionnement, et notamment l'utilisation des sommes à des fins culturelles et sociales, pourraient être défavorable aux auteurs. La nature juridique de la rémunération pour prêt en bibliothèque peut être discutée car ni l'utilisateur final, ni les bibliothèques, ne sont débiteurs de ce paiement alors que le système français prévoit qu'une partie des sommes ainsi perçues finance la retraite supplémentaire des auteurs.

Droit exclusif et droit à rémunération sont définis d'une manière précise et étroite, une fois leur gestion collective imposée. Malgré l'élargissement de l'assiette de calcul de la rémunération pour copie privée en raison du nombre croissant de nouveaux appareils, la somme distribuable a tendance à diminuer en raison de la restriction du champ de la notion de rémunération pour copie privée.

La gestion collective imposée par la loi est, en conclusion, un moyen d'exercer les droits patrimoniaux de l'auteur qui limite le droit exclusif et l'autonomie de celui-ci, mais qui peut être également, dans certains cas, le seul moyen efficace de l'exploiter des œuvres. 


\section{Remerciements}

Je remercie à mes deux directeurs de thèse, Monsieur le Professeur Antoine LATREILlE (Université Paris-Sud) et Monsieur Péter MEZEI (Université de Szeged), d'avoir enrichi mes connaissances et de m'avoir inspirée et guidée durant les années de recherche.

Je remercie à Madame Anne-Céline ROQUE, docteur en droit, et à Maître Rosine DE MATOS d'avoir assuré la relecture du résumé substantiel de la thèse. 


\section{Bibliographie complète}

A Szerzői Jogi Szakértő Testület tanulmányai a szerzői jog digitális világhoz való alkalmazkodásáról - A Szerzöi Jogi Szakértö Testület UGC-munkacsoportjának beszámolója a felhasználók által generált tartalom szerzői jogi kérdéseivel kapcsolatban, ISZJSZ, 2014/4. p. 93-153.

АвоTT, Frederick M. - COTTIER, Thomas - GURRY, Francis: International Intellectual Property in an Integrated World Economy, Aspen Publisher, USA, 2007

AlCARAS, Jean-Robert: La protection des droits peut-elle favoriser la crétation culturelle? Approche économique. In: BRUGUIERE, Jean-Michel (szerk.) Droit d'auteur et culture, Dalloz, 2007, p. 55-74.

ALFÖLDY Dezső: A magyar szerzői jog különös tekintettel a M. Kir. Kuria gyakorlatára, Grill Károly Könyvkiadó, 1936. p. 57-58.

Allayaeys, Philippe: Hypothèses de forfait en droit d'auteur, Propr. intell. 2007/24. p. 269278.

Alleaume, Christophe: La contractualisation des exceptions. La situation en France, Propr. intell. 2007/25. p. 436-442.

Alleaume, Christophe: La mise en balance du droit d'auteur, RIDC, 2010/2. p. 423-445.

AlleAume, Christophe: Le droit de prêt ou l'Arlésienne du droit d'auteur, Légicom, 2001/24, p. 43-50.

Alleaume, Christophe: Le droit de prêt public (en France et au-delà), Propr. intell., 2004/12. p. 718-737.

Alleaume, Christophe: Le prêt des oeuvres de l'esprit, Thèse, Caen, 1997

Alma-DElETtRe, Sophie: La nature juridique des droits de propriété intellectuelle. In: Bruguiere, Jean-Michel - MALlet-Poujol, Nathalie - RoBIN, Agnès: Propriété intellectuelle et droit commun, PUAM, 2007. p. 25-37.

AXHAMn, Johan - GUIBAULT, Lucie: Solving Europeana's mass-digitization issues through extended collective licensing? NIR, 2011/6. p. 509-516.

AXHAMN, Johan: Exceptions, limitations and collective management of rights as vehicles for access to information. In: BELDIMAN, Dana (ed): Access To Information And Knowledge: 21st Century Challenges in Intellectual Property and Knowledge Governance, Edward Elgar Publishing, Cheltenham, 2013 p. 164-186.

AzZI, Tristan: La loi applicable à la dévolution successorale du droit de suite (à propos de l'affaire Dalí), Propr. intell. 2012/44. p. 288-294.

AzZI, Tristan: Le „business” de l'art. Le droit de suite, Propr. intell, 2011/38. p. 65-73.

BARRAUD, Boris: De l'imprimé au numérique - Le régime juridique des médias écrits à l'épreuve de leur dématérialisation, RLDI, 2012/85. p. 105-119.

BATTA János: Eredeti képzőmüvészeti alkotás felhasználása a tulajdonjog átruházása útján, Magyar Jog, 1978/11, p. 996-1005.

BeCourt, Daniel: Commentaire de la loi $n^{\circ}$ 95-4 du 3 janvier 1995 sur la reprographie, D., 1995. p. 59.

BELLIVIER, Florence: Rémunération des prêts en bibliothèque. Loi $n^{\circ}$ 2003-517 du 18 juin 2003 relative à la rémunération au titre du prêt en bibliothèque et renforçant la protection sociale des auteurs (JO 19 juin 2003, p. 10241), RTD Civ, 2003, p. 558.

BenABOU, Valérie-Laure: De l'efficacité de l'exception en elle-même à sa confrontation aux mesures techniques, Propr. intell. 2007/25. p. 423-435. 
Benabou, Valérie-Laure: La directive droit d'auteur, droits voisins et société de l'information: valse à trois temps avec l'acquis communautaire, Comm. com. électr., 2010/10. p. 8-11.

BenABOU, Valérie-Laure: La notion de compensation équitable dans l'arrêt Padawan ou quand la CJUE fait main basse sur les notions du droit d'auteur, Légipresse, 2011/280. p. 95-100.

Benhamou, Françoise - FARCHY, Joëlle: Droit d'auteur et copyright, Éditions la Découverte, Paris, 2009

Bensamoun, Alexandra: Essai sur le dialogue entre le législateur et le juge en droit d'auteur, PUAM, Aix-en-Provence, 2008

BERCESI Zoltán: A müholdas müsorsugárzás és a vezetékes müsortovábbitás szerzői jogi problémái az Európai Közösségben, Jogtudományi Közlöny, 1996/2. p. 49-59.

BERCESI Zoltán: Bérlet és haszonkölcsön az európai szerzői jogi jogharmonizáció fókuszában, Jogtudományi Közlöny, 1997/7-8. p. 337-342.

BERCOVITZ RODRIGUEZ-CANO, Rodrigo: La communication au public dans la doctrine de la Cour de justice de l'Union européenne. In: BERnAUlt, Carine - ClAVIER, Jean-Pierre LuCAS-SchloetTer, Agnès - LuCAS, François-Xavier (ss la dir. de): Mélanges en l'honneur du professeur André Lucas, LexisNexis, Paris, 2014. p.35-46.

Bernault, Carine - Clavier, Jean-Pierre: Dictionnaire de droit de la propriété intellectuelle. Ellipses, Paris, 2e édition, 2015

BERnAUlt, Carine: La gestion collective des droits des réalisateurs et des producteurs. In: TAFFOREAU, Patrick: Pratique de la propriété littéraire et artistique, LexisNexis, Paris, 2013, p. 463-473.

BERTRAND, André: La musique et le droit. De Bach à Internet. Litec, Paris, 2002

BINCTIN, Nicolas: La qualité à agir des SPRD pour les non-membres, Légipresse, 2009/261, II, p. 52.

BinCTIN, Nicolas: La rigueur risquée (Commentaire CJUE, 21 oct. 2010, aff. C-467/08), Comm. com. électr. 2011/1. p. 7-10.

BINCTIN, Nicolas: Pour une application stricte de la rémunération pour copie privée commentaire sous CE, 10 e et 9 e ss-sect. réunies, 11 juillet 2008, no 298779, Syndicat de l'Industrie de matériels audiovisuels électroniques, Comm. com. électr, 2008, étude 21.

BInCTIN, Nicolas: Rémunération pour copie privé, J.Cl. Propriété littéraire et artistique, Fasc. 1510

BoDo Balázs: A szerzői jog kalózai. Typotex Kiadó, Budapest, 2011

BOIRON, Patrick: Le droit de reproduction par reprographie: les copies à des fins de commerce dix ans après la loi du 3 janvier 1995, Comm. comm. électr. 2004/12. p. 1822.

Bonadio, Enrico - CANTORE, Carlo Maria: The ECJ Rules on the Private Copying Levy: Padawan SL v Sociedad General de Autores y Editores (SGAE) (C-467/08), EIPR, 2011/4. p. 260-263.

BORONKAY Miklós - BoYTHA György - CSEPElY-KNORR Tamás - SzILÁGYI Pál: A szerzői jogok közös kezelésének versenyjogi vonatkozásai. Különös tekintettel a technikai fejlödés által támasztott kihívásokra, PPKE-JÁK Versenyjogi Kutatóközpont, 2008, (http://gvh.hu/data/cms1000526/GVH_kozos_jogkezelok_VKK4-2006.pdf)

BruguiERE, Jean-Michel, - FAUCHOUX, Vincent: Le livre numérique, RLDI, 2011/73. everzió

BRUGUIERE, Jean-Michel: La loi du ler mars 2012 relative à l'exploitation numérique des livres indisponibles du XXe siècle est constitutionnelle, Comm. com. électr. 2014/4. p. 9-11. 
BRUGUIERE, Jean-Michel: La recevabilité de l'action des SPRD à agir en contrefaçon pour des créateurs non-membres, JCP E, 2009. p. 1471.

CARON, Christophe: „FAQ” autour de la rémunération pour copie privée à la mode luxembourgeoise, Comm. com. électr. 2013b/10. p. 23-24.

CARON, Christophe: A propos d'un contrat conclu sous l'empire des lois révolutionnaires, Comm. com. électr, 2005/7. p. 21.

CARon, Christophe: Ce que dit la loi sur les livres indisponibles, Comm. com. électr., 2012a/11. p. 26.

CARON, Christophe: Ce qu'est et ce que n'est pas la rémunération du droit de prêt, Comm. com. électr. 2011a/11. comm. 100.

CARON, Christophe: Droit d'auteur et droits voisins, LexisNexis, Paris, 3e éd, 2013a

CARON, Christophe: La rémunération pour copie privée en droit communautaire, Comm. com. électr., 2011b/1.

CARON, Christophe: Le droit contractuel dans la directive du 27 septembre 1993 relative à la radiodiffusion par satellite et la retransmission par câble ou le contrat malmené, Petites affiches, 1999/248., p. 6

CARON, Christophe: Le droit d'auteur de l'an 2440. Cauchemar s'il en fût jamais. In: Études à la mémoire du professeur Xavier Linant de Bellefonds, LexisNexis, 2007, p.105-116.

CARON, Christophe: Les exceptions au regard du fondement du droit d'auteut en droit français. In: LUCAS, André - SIRINELLI, Pierre - BENSAMOUN, Alexandra: Les exceptions au droit d'auteur. État des lieux et perspectives dans l'Union européenne, Dalloz, 2012b, p. 19-25.

CARON, Christophe: Une cession des droits antérieure à la loi du 11 mars 1957 peut-elle englober le droit d'exploitation numérique? Comm. com. électr., 2013c/7.

CARre, Stephanie - VERCKEn, Gilles: Google et la fortune du droit d'auteur. In: BernaUlt, Carine - Clavier, Jean-Pierre - LuCAS-Schloetter, Agnès - LuCAS, FrançoisXavier: Mélanges en l'honneur du professeur André Lucas, LexisNexis, Paris, 2014. p. 119-138.

CARre, Stéphanie: Des exceptions d'usage privé: le cas de la copie privée. In: VIVANT, Michel: Les grands arrêts de la propriété intellectuelle, Dalloz, Paris, 2e éd, 2015. p. 298-314.

CARRE, Stéphanie: Le livre numérique un „OCNI” (Objet culturel non identifié), Comm. com. électr., 2005/10., p. 22-25.

CASTETS-RENARD, Céline: Clarification sur le périmètre de la cession légale du droit de reproduction, RLDI 2014/101. e-verzió

CASTEX, Lucien: Encadrer une bibliothèque numérique: de sa constitution à son exploitation, RLDI, 2010/66. p. 84-92.

CHABERT, Cyril: Deux raisons de réexaminer la rémunération pour copie privée au regard des engagements internationaux français, Comm. com. électr., 2004/10. étude 36.

Collart-Dutilleul, François - Delebecque, Philippe: Contrats civils et commerciaux, Dalloz, Paris, 9e édition, 2011

COLOMBET, Claude: Grands principes du droit d'auteur et des droits voisins dans le monde. Approche de droit comparé, Litec, Unesco, Paris, 2e éd, 1992

Colombet, Claude: Propriété littéraire et artistique et droits voisins, Dalloz, Paris, 9e éd, 1999

ComTe, Henri: Une étape de l'Europe du droit d'auteur: La Directive du 19 novembre 1992 relative au prêt et à la location, RIDA, 1993/158. p. 3-73.

CORNU, Gérard: Vocabulaire juridique, Quadrige/PUF, Paris, 2007

COURTOIS, Georgie: L'impression 3D: chronique d'une révolution juridique annoncée, RLDI, 2013/99. p. 71-80. 
Cozian, Maurice - Viandier, Alain - Deboissy, Florence: Droit des sociétés, LexisNexis, Paris, 2014

DALEAU, Jeanne: Copie privée: contours de la notion de „compensation équitable”. CJUE 21 oct. 2010, C-467/08, Padawan. Dalloz actualité, 2010 november 15

Davies, Gillian - Hung, Michèle E.: Music and Video Private Copying. An International Survey of the Problem and the Law, Sweet \& Maxwell, London, 1993

DE RIDDER, Frédérique: Droits d'auteur, droits voisins dans l'audiovisuel. Les sociétés de perception et de répartition, Éditions DIXIT, Paris, 1994

Deazley, Ronan - Kretschmer, Martin - Bently, Lionel (szerk.): Privilege and Property: Essays on the History of Copyright. Open Book Publishers, 2010 (http://www.openbookpublishers.com/reader/26)

DERIEUX, Emmanuel: La notion de „publication” - Les insupportables incertitudes du droit, JCP G, 2010a/49. p. 2262-2263.

DERIEUX, Emmanuel: Le livre à l'ère numérique - Questions juridiques sans réponses, RLDI, 2010b/60., p. 80-101

DERIEUX, Emmanuel: Le régime juridique de l'exploitation numérique des livres indisponibles du XXe siècle, RLDI, 2012/87. p. 64.

DERIEUX, Emmanuel: Reproduction par reprographie et droit d'auteur: paralisme et réalités, Petites affiches, 1995/62. p. 28

DesboIs, Henri: Le droit d'auteur en France, Dalloz, Paris, 3e éd, 1978

DESURMONT, Thierry: La transposition en France de la directive 2001/29/CE sur l'harmonisation de certains aspects $d u$ droit d'auteur et des droits voisins dans la société de l'information, RIDA, 2006/210, p. 111-183.

DIETZ, Adolf: La proposition de directive sur les sociétés de gestion collective du 11 juillet 2012 et la diversité culturelle - Une occasion ratée. In: BERNAULT, Carine - CLAVIER, Jean-Pierre - LuCAS-SchloetTER, Agnès - LuCAS, François-Xavier: Mélanges en l'honneur du professeur André Lucas, LexisNexis, Paris, 2014. p. 237-249.

DIETZ, Adolf: Le droit d'auteur dans la Communauté européene, Office des publications officielles des Communautés européennes, Luxembourg, 1976

DIETZ, Adolf: Legal regulation of collective management of copyright (collecting societies law) in Western and Eastern Europe, Journal of the Copyright Society of the U.S.A. , 2001-2002/49. p. 897-916.

DIRINGER, Yvan: Gestion collective des droits d'auteur et droit de la concurrence. Pour une relecture à l'heure d'internet, PUAM, Aix-en-Provence, 2011

DIRINGER, Yvan: La gestion collective des droits d'auteur aux États-Unis, un modèle concurrentiel en trompe l'oeil, RIDA, 2010/10. p. 4-279.

DREIER, Thomas: Limitations: The Centerpiece of Copyright in Distress - An Introduction, JIPITEC, 2010/1. p. 50-54.

DuCHEMIN, Jacques-Louis: Le droit de suite des artistes, Sirey, Paris, 1948

DUCHEMIN, Wladimir: La directive communautaire sur le droit de suite, RIDA, 2002/191, p. 3-131.

DupuY, Pierre-Marie - Kerbrat, Yann: Droit international public, Dalloz, Paris, 12e éd, 2014

DUSOLLIER, Sévérine: Droit d'auteur et protection des oeuvres dans l'univers numérique. Droits et exceptions à la lumière des dispositifs de verrouillage des oeuvres, Larcier, Bruxelles, 2007

EDELMAN, Bernard: Droits d'auteur et droits voisins. Loi $n^{\circ}$ 85-660 du juillet 1985 relative aux droits d'auteur et aux droits des artistes-interprètes, des producteurs de phonogrammes et de vidéogrammes et des entreprises de communication audiovisuelle, Jurisprudence Générale Dalloz, Paris, 1987 
EDElman, Bernard: Droits d'auteurs, droits voisins. Droit d'auteur et marché, Dalloz, Paris, 1993

EDELMAN, Bernard: La CJCE et la télédiffusion dans les chambres d'hôtel, Recueil Dalloz, 2001. p. 1094

EDELMAN, Bernard: Vers une définition du droit de communication au public, D. 2007. p. 1236

EFRONI, Zohar - GEBERT, Julia: The Google Books decision: The Authors' Guild v Google Inc, European Intellectual Propetry Review, 2011, 33(8) p. 532.

ÉMILE-Zola-Place, Emmanuel: L'exploitation numérique des livres indisponibles $d u$ XXe siècle: une gestion collective d'un genre nouveau, Légipresse, 2012/295. p. 355.

ESCARRA, Jean-Rault - HEPP, Jean-François: La doctrine française du droit d'auteur. Étude critique à propos de projets récents sur le Droit d'auteur et le Contrat d'édition, Éditions Bernard Grasset, Paris, 1937

FALUDI Gábor - GRAD-GYENGE Anikó: A nyilvánossághoz közvetítései (elöadási) jog értelmezése az Európai Bíróság gyakorlatában, ISZJSZ 2012/1. p. 77-93.

FALUDI Gábor - KABAI Eszter: A lényegtelenné vált CISAC-ügy margójára, ISZJSZ, 2014/1. p. 71-104.

FALUDI Gábor: A közös jogkezelö szervezetek felhasználási szerzödései. In: Liber Amicorum : Studia Gy. Boytha dedicata : ünnepi dolgozatok Boytha György tiszteletére, ELTE ÁJK, Budapest, 2004. p. 81-104.

FAludi Gábor: A paródia a szerzői jogban. In: KeSERÜ Barna Arnold - KöHIDI Ákos (szerk.): Tanulmányok a 65 éves Lenkovics Barnabás tiszteletére, Eötvös József Könyvés Lapkiadó Bt. Budapest, 2015. p. 94-120.

FALUDI Gábor: A szerzői jog átruházhatósága a magyar szerzői jogban, Magyar Jog, 1995/3. p. 146-156.

FALUDI Gábor: A szerzői jog és az internet viszonyának egyes kérdései. In: Acta conventus de iure civili Tomus II., Lectum, Szeged, 2008. p 9-27.

FALUDI Gábor: A szerzői közös jogkezelés mint szabályozott monopólium, Infokommunikáció és Jog, 2009a/4. p. 126-135.

FALUDI Gábor: A szerzöi közös jogkezelés szabályozási környezetének változásai. In: Emlékkönyv Ficsor Mihály 70. születésnapja alkalmából barátaitól, Szent István Társulat, Budapest, 2009b, p. 64-92.

FICSOR Mihály: La gestion collective du droit d'auteur et des droits voisins à la croisée des chemins: doit-elle rester volontaire, peut-elle être „étendue” ou rendue obligatoire? eBulletin du droit d'auteur, Octobre 2003b, (http://portal.unesco.org/culture/fr/files/14935/10718319981M._Ficsor_fr.pdf/M.+Ficso r+fr.pdf)

FICSOR, Mihály: Collective Management of Copyright and Related Rights, WIPO, Geneva, 2002

FICSOR, Mihály: Collective Management of Copyright in the International Environment, Zeitschrift für Urheber- und Medienrecht, 2003a/1. p. 3-15.

FICSOR, Mihály: Développement et objectif de la gestion collective des droits des auteurs, Le droit d'auteur, 1985/10. p. 296-309.

FICSOR, Mihály: Hungary. In: LINDNER, Brigitte - SHAPIRO, Ted: Copyright in the Information Society. A Guide to National Implementation of the European Directive, Edward Elgar, Cheltenham, UK, Northampton, MA, USA, 2011, p. 251-275.

FICSOR, Mihály: Le „test des trois étapes”: pourquoi on ne signe pas la Déclaration de Munich? In: LuCAS, André - SiRINELli, Pierre - Bensamoun, Alexandra: Les exceptions au droit d'auteur. État des lieux et perspectives dans l'Union européenne, Dalloz, 2012a, p. 55-62. 
FICSOR, Mihály: Short paper ont he three-step test for the application of exceptions and limitations int he field of copyright, 2012b (http://www.copyrightseesaw.net/archive/?sw_10_item=28)

FICSOR, Mihály: Svensson: Honest attempt at establishing due balance concerning the use of the hyperlinks - spolied by the erroneous ,new public” theory (slightly corrected version) 2014 (http://www.copyrightseesaw.net/archive/?sw_10_item=68)

FICSOR, Mihály: The Law of Copyright and the Internet. The 1996 WIPO Treaties, their Interpretation and Implementation, Oxford University Press, Oxford, 2002

FLORENSON, Paul: La gestion du droit d'auteur et des droits voisins en Europe, RIDA, 2003/196. p. 3-125.

FODOR Klaudia Franciska: A digitális magáncélú másolat kompenzációjának lehetőségei, ISZJSZ, 2009/4. p. 65-88.

FouILlAND: L'apport de droits d'auteur à une société de gestion collective, Comm. com. électr. 2008, étude 2.

FRANÇON, André: Cours de propriété littéraire, artistique et industrielle, Les Cours de droit, Paris, 1999

FRANÇON, André: Loi du 27 mars 1997 de transposition de deux directives communautaires, RTD Com. 1997. p. 252.

FRANÇON, André: Reproduction par reprographie, utilisation collective, Gestion collective obligatoire. Copie privée sonore et audiovisuelle, qualité d'auteur, RTD Com, 1995, p. 121.

GALOPIN, Benoît: Conséquences de la nature constitutionnelle et européenne sur le droit d'auteur: retour sur quelques décisions récentes, RIDA, 2015/3, p. 174-235.

GALOPIN, Benoît: Les exceptions à usage public en droit d'auteur, LexisNexis, Paris, 2012

GaUbiac, Yves: Dimension de la copie privée dans le monde numérique de la communication, Comm. com. électr., 2008/6. étude 14.

GAUBIAC, Yves: Droit d'auteur en France. In: TAFFOREAU, Patrick (éd): La radiodiffusion par satellite et la retransmission par câble. Aspects de droit privé et de droit public. L'Harmattan, Paris, 2000. p. 23-28.

GAUDEL, Denise: La distribution par câble et la diffusion par satellite des ouvres de l'esprit. In: Droit d'auteur et droits voisins. La loi du 3 juillet 1985, Librairies Techniques, Paris, 1986, p. 67-86.

GAUdRAT, Philippe - SARDAIn, Frédéric: De la copie privée (et du cercle de famille) ou des limites au droit d'auteur, Comm. com. électr., 2005/11.p. 6-16.

GAUTIER, Pierre-Yves: Les exceptions au regard du droit de l'Union européenne. In: LuCAS, André - SiRINELli, Pierre - BENSAMOUn, Alexandra: Les exceptions au droit d'auteur. État des lieux et perspectives dans l'Union européenne, Dalloz, 2012, p. 37-42.

GAUTIER, Pierre-Yves: Propriété littéraire et artistique, PUF, Paris, 2012

GeIGER, Christophe - HILTY, Reto M. - GRIFFITHS, Jonathan - SutHersanen, Uma: Declaration. A Balanced Interpretation Of The ,,Three-Step Test” In Copyright Law, 2008

(http://www.ip.mpg.de/fileadmin/user_upload/declaration_three_step_test_final_english 1.pdf)

GeIger, Christophe - MACrez, Franck - Bouvl, Adrien - CARre, Stéphanie - Hassler, Théo - SCHMIDT, Joanna: Quelles limites au droit d'auteur dans la société de l'information? Réponse au Livre vert sur ,"le droit d'auteur dans l'économie de la connaissance". Propr. intell. 2009/32. p. 232.

GEIGER, Chrsitophe: De la nature juridique des limites au droit d'auteur. Une analyse comparatiste à la lumière des droits fondamentaux, Propr. intell. 2004/13. p. 887. 
GERA Eleonóra Erzsébet - CSATARI Bence: A Zeneszerzök Szövetkezetétöl az Artisjus Egyesületig (1907-2007): a zenei közös jogkezelés száz éve Magyarországon, Artisjus, Budapest, 2007

GERVAIS, Daniel (szerk.): Collective Management of Copyright and Related Rights, Kluwer Law International, The Netherlands, 2010

GERVAIS, Daniel: Individual and Collective Management of Rights Online, In: AXHAMn, Johan (ed.): Copyright in a Borderless Online Environment. Norsteds juridik, Stockholm, 2012

GINSBURG, Jane: A Tale of Two Copyright: Literary Property in Revolutionary France and America, RIDA, 147/1991. p. 124-289.

GinsBURG, Jane: L'avenir du droit d'auteur: un droit sans auteur? Comm. com. électr. 2009/5. p. 7-10.

GitTon, Antoine: La copie privée numérique: vers une licence d'édition privée, Légicom, 2001/25. p. 61-74.

Goldstein, Paul - Hugenholtz, Bernt: International Copyright. Principles, Law and Prectice, Oxford University Press, New York, 2010

Goldstein, Paul - Hugenholtz, Bernt: International Copyright. Princilpes, Law and Practice, Oxford University Press, New York, 2013

Gondol Daniella: Honnan jövünk, kik vagyunk, hová megyünk? - Gondolatok a szerzői jogi törvény módositásáról, Infokommunikáció és Jog, 2009/3. p. 72-75.

GRAD-GYENGE Anikó - SARKADY Ildikó: Közös jogkezelés az audiovizuális médiában. Médiatudományi Intézet, 2014 (http://mtmi.hu/dokumentum/513/mk10_web.pdf)

GREFFE, Xavier: Économie de la propriété artistique, Economica, Paris, 2005

GROFFE, Julie: L'oeuvre orpheline saisie par le droit, entre impératif de protection et objectif de diffusion, RLDI, 2012/78. p. 112-118.

Guibault, Lucie - WestKamp, Guido - Rieber-Mohn, Thomas - Hugenholtz, Bernt (et al.): Study on the Implementation and Effect in Member States' Laws of Directive 2001/29/EC on the Harmonisation of certain aspects of copyright and related rights in the information society, 2007 (http://www.ivir.nl/publications/guibault/Infosoc_report_2007.pdf)

GuiBault, Lucie: Copyright limitations and contracts. An Analysis of the Contractual Overridabilitiy of Limitations on Copyright, Kluwer Law International, The Hague, 2002

GuIBAUlT, Lucie: The Reprograpy Levies cross the European Union, IViR, 2003 (http://www.ivir.nl/publicaties/download/331)

GuiBAulT, Lucie: Why Cherry-Picking Never Leads to Harmonisation? The Case of the Limitations on Copyright under Directive 2001/29/EC, JIPITEC, 2010/1. p. 55-66.

GYENGE Anikó: A képzőmüvészeti alkotások szerzöi jogi védelméröl - különös tekintettel a követö jogi szabályozás módositására, Infokommunikáció és Jog, 2005b/3. p. 86-94.

GYENGE Anikó: A kivételek és korlátozások céljai a szerzői monopoljogban. In: VALENTINY Pál - KISS Ferenc László - NAGY Csongor István (szerk.): Verseny és Szabályozás 2010, MTA KRTK Közgazdaság-tudományi Intézet, Budapest, 2011. p. 72-119. (http://econ.core.hu/file/download/vesz2010/02_szerzoi_monopoljog.pdf)

GYENGE Anikó: A szerzői jog metamorfózisai és az editio princeps jogintézménye, Magyar Jog, 2003/11. p. 649-657.

GYENGE Anikó: A szerzői jogok korlátozásának általános szabályai: a három lépcsős teszt és értelmezése, Jogtudományi Közlöny, 2006/5. p. 171-185.

GYENGE Anikó: A szerzöi mü ára - díjak az egyedi felhasználási szerzödésekben 1. rész, ISZJSZ, 2004/6. （http://www.sztnh.gov.hu/hu/kiadv/ipsz/200412/01-gyengeaniko.html) 
GyENGE Anikó: A szerzői mü ára - dijak az egyedi felhasználási szerzödésekben 2. rész, ISZJSZ, 2005a/1. (http://www.sztnh.gov.hu/hu/kiadv/ipsz/200502/01-gyengeaniko.html)

GYENGE Anikó: Elárvult jog nevelöszülöt keres, Magyar Jog, 2009/3. p. 160-172.

GYENGE Anikó: Szerzői jogi korlátozások és a szerzői jog emberi jogi háttere, HVG-Orac, Budapest, 2010

GYENGE Anikó: Újra az árva müvekről, Infokommunikáció és Jog, 2011/45. p. 119-124.

GYENGE Anikó: Viták a szerzöi jogok közös kezelésének hatékony szabályozása körül. Infokommunikáció és Jog, 2008/5. p. 198

GYERTYÁNFY Péter - FALUdi Gábor - KABAI Eszter - SzINGER András - TóTH Péter Benjamin: Szerzői müvek, védjegyek és szellemi teljesitmények az interneten - a magyar jogi védelem I. rész, 2004/12. p. 705-715.

GYERTYÁNFY Péter - FALUdi Gábor - KABAi Eszter - SzINGER András - TóTH Péter Benjamin: Szerzöi müvek, védjegyek és szellemi teljesítmények az interneten - a magyar jogi védelem. II. rész, Magyar Jog, 2005/3. p. 129-141.

GYERTYÁNFY Péter (szerk.): A szerzői jogi törvény magyarázata, Complex, Budapest, 2006b

GYERTYÁNFY Péter (szerk.): Nagykommentár a szerzői jogi törvényhez, Wolters Kluwer, Budapest, 2014

GYERTYÁNFY Péter: A magyar közös jogkezelés az Európai Unió követelményeinek tükrében (A jogosultak és a közös jogkezelö viszonya) In: Liber Amicorum : Studia Gy. Boytha dedicata : ünnepi dolgozatok Boytha György tiszteletére, ELTE ÁJK, Budapest, 2004 p. 133-161.

GYERTYÁNFY Péter: A szerzöi és azzal szomszédos jogok közös kezelése II. Magyar Jog, 1997b/5. p. 257-265.

GYERTYÁNFY Péter: A szerzöi és azzal szomszédos jogok közös kezelése, Magyar Jog, 1997a/3. p. 129-137.

GYERTYÁNFY Péter: A szerzői jogi jogharmonizáció eredménye az EU-ban, Jogtudományi Közlöny, 2002/6. p. 271-283

GYERTYÁNFY Péter: A szerzői vagyoni jogok újraszabályozásáról, Jogtudományi Közlöny, 1995/10. p. 451-466.

GYERTYÁNFY Péter: Jog nélkül kultúra sem terem - Kultúrpolitika és szerzői jog, Magyar Jog, 2006a/8. p. 449-454.

GYERTYÁNFY Péter: Meddig terjedjen még a szerzői jog? Jogtudományi Közlöny, 2001/9. p. 337-348.

GYERTYÁNFY Péter: Szerzöi jogunk és az európai integráció III. rész, Magyar Jog, 1991c/10. p. 594-600.

GYERTYÁNFY Péter: Tévúton az európai zenei közös jogkezelés, ISZJSZ, 2009/6. p. 5-34.

GYERTYÁNFY, Péter: Why Is a European Directive on Collective Management Necessary? A Perspective from a New Member State of the EU, Journal of the Copyright Society of the U.S.A. 2005-2006/1-2., p. 71-101.

HAJDÚ Dóra: A kereskedelmi forgalomban nem kapható könyvek digitalizálása Franciaországban, Infokommunikáció és Jog, 2013/55. p. 53-59.

HAJDÚ Dóra: Az Európai Bíróság gyakorlata a magáncélú másolatra tekintettel fizetett dijak kérdésében, ISZJSZ, 2014a/6. p. 27-69.

HAJDÚ Dóra: Bevezetés a francia szerzői jog történetébe - A kezdetektöl a nagy francia forradalom idején elfogadott törvényekig, Jogtörténeti Szemle, 2014b/1. p. 50-58.

HELFER, Laurence R.: Collective Management of Copyrights and Human Rights: An Uneasy Alliance Revisited. In: GERVAIS, Daniel: Collective Management of Copyright and Related Rights, Kluwer Law International, The Netherlands, 2010 (2nd edition) p. 75103. 
Hugenholtz, Bernt: Why the Copyright Directive is Unimportant and Possibly Invalid, EIPR, 2000/22. (11.) p. 501-502.

Hugenholtz, P. Bernt: SatCab Revisited: The Past, Present and Future of the Satellite and Cable Directive, IrisPlus, 2009/8. p.13.

Hugenholtz, P. Bernt: The Story of the Tape Recorder, in: SHERMAn, Brad - Wiseman, Leanne (ed): Copyright and the Challenge of the New, Kluwer Law International, The Netherlands, 2012. p. 179-196.

JANSSENS, Marie-Christine: The issue of exceptions: reshaping the keys to gates int he territory of literary, musical and artistic creation. In: DERClAYE, Estelle (ed.): Research Handbook ont he Future of EU Copyright, Edward Elgar, Cheltenham UK, Northampton, MA, USA, 2009. p. 317-348.

JOUBERT, Claude: Les sociéétés de perception et de répartition des droits. In: Droit d'auteur et droits voisins. La loi du 3 juillet 1985. Librairies Techniques, Paris, 1986, p. 181-192.

KARAPAPA, Stavroula: A copyright exception for private copying in the United Kingdom, EIPR 2013/3. p. 129-137.

KARAPAPA, Stavroula: Padawan v SGAE: a right to private copy? EIPR 2011/33(4). p. 252259.

KARNELL, Gunnar: Extended collective license clauses and agreements in Nordic Copyright Law, Columbia Journal of Law and the Arts, 1985-86/10. p. 73-81.

KARNELL, Gunnar: Peculiar Features of Nordic Copyright Law, NIR, 1991/60. p. 15-23.

KEREVER, André: Le droit d'auteur en Europe occidentale. In: Hommage à Henri Desbois. Études de propriété intellectuelle, Dalloz, 1974, p. 35-72.

KerJean, Benoît: Pratique contractuelle. Gestion des stocks et contrat d'édition: une liberté sous contrôle, Comm. com. électr. 2011/9.

Kézikönyv a szerzői jog érvényesitéséhez. Útmutató a gyakorlat számára. ProArt Szövetség a Szerzői Jogokért, 2. kiadás, 2013 (www.szerzoijogikezikonyv.hu)

KIKKIS, Ioannis: L'avancée du droit de prêt public en Europe suite à une harmonisation qui laisse à désirer. In: Bernault, Carine - ClaviER, Jean-Pierre - LuCAS-SCHLOETTER, Agnès - LuCAS, François-Xavier: Mélanges en l'honneur du professeur André Lucas, LexisNexis, Paris, 2014. p. 453-464.

Koliczy, Janusz Piotr - ANTAS, Przemysław Dominik: Copyright levies imposed on production and import of reprographic equipement not due where analogous levies have been already paid in another EU Member State: Polish Court of Appeal Judgment in Wroclaw of February 21, 2012 (I ACa 11/12), EIPR, 2012/10. p. 732-737.

Koltay Krisztina: Néhány gondolat a közös jogkezelő szervezetek díjmegállapításáról, különös tekintettel a reprográfiai dijakra. In: Liber Amicorum : Studia Gy. Boytha dedicata : ünnepi dolgozatok Boytha György tiszteletére, ELTE ÁJK, Budapest, 2004. p. 235-245.

Kretschmer, Martin: Private Copying and Fair Compensation: An empirical study of copyright levies in Europe. A Report for the UK Intellectual Property Office (October 2011), (http://www.ipo.gov.uk/ipresearch-faircomp-full-201110.pdf)

KuR, Anette: Of Oceans, Islands and Inland Water - How Much Room for Exceptions and Limitations under the Three Step-Test? Max Planck Institute for Intellectual Property, Competition and Tax Law Research Paper Series No. 08-04, (http://papers.ssrn.com/sol3/papers.cfm?abstract_id=1317707)

La gestion collective en matière de reprograhpie, OMPI - IFFRO, 2005 (http://www.wipo.int/edocs/pubdocs/fr/copyright/924/wipo_pub_924.pdf)

LAmArQue, Jean - Négrin, OliviER - AYrault, Ludovic: Droit fiscal général. LexisNexis, Paris, 3e éd, 2014 
LÁNCHIDI, Péter: Collective Management of Music Rights and Competition Policy in the European Union, PhD értekezés, $2010 \quad$ (http://ajk.pte.hu/files/file/doktoriiskola/lanchidi-peter/lanchidi-peter-vedes-ertekezes.pdf)

LAPOUSTERLE, Jean: L'influence des groupes de pression sur l'élaboration des normes. Illustration à partir du droit de la propriété littéraire et artistique, Dalloz, Paris, 2009

LATREILLE, Antoine: La copie privée démythifiée, RTD Com, 2004/3. p.403.

LATREILlE, Antoine: Variations autour de la définition de l'acte de copie privée, Comm. com. électr, 2010/11. p. 7-9.

LE CAM, Stéphanie: La représentativité des sociétés de gestion collective. In: BERNAULT, Carine - Clavier, Jean-Pierre - LuCAS-Schloetter, Agnès - LuCAS, FrançoisXavier: Mélanges en l'honneur du professeur André Lucas, LexisNexis, Paris, 2014. p. 489-503.

LE RoY, Marc: Tout ce que vous avez toujours voulu savoir sur les droits d'exploitation d'une cuvre cinématographique (sans jamais oser le demander)... RLDI, 2012/82. p. 52.

LEBoIS, Audrey: Droits patrimoniaux - Droit de location et de prêt, J. Cl. Propriété littéraire et artistique, Fasc. 1254.

LEGEZA Dénes: „Segitsük az árvákat” Útmutató az árva müvek egyes felhasználásaihoz, ISZJSZ, 2012/5. p. 23-58.

Lehmann, Michael: The EC Directive on the Harmonisation of Certain Aspects of Copyright and Related Rights in the Information Society - A Short Comment, ICC, 2003/5. p. 521.

LINANT DE BELlEFONDS, Xavier: Droits d'auteur et droits voisins, Dalloz, Paris, 2004

Loi $n^{\circ}$ 2003-517 du 18 juin 2003 relative à la rémunération au titre du prêt en bibliothèque et renforçant la protection sociale des auteurs (JO 19 juin 2003, p. 10241), RTD Civ, 2003, p. 558.

LuCAS, André - LuCAS, Henri-Jacques - LuCAS-SCHLOETTER, Agnès: Traité de la propriété littéraire et artistique, LexisNexis, Paris, 2012

LuCAS, André: Chroniques. Exceptions - Nature et champs d'application de la rémunération pour copie privée - Conditions de l'exception, Propr. intell. 2011/38. p. 81.

LuCAS, André: Droit d'auteur et numérique, Litec, Paris, 1998

LUCAS, André: Droit de la reproduction par reprographie (CPI, art. L.122-10 à L.122-12) J.Cl. Propriété littéraire et artistique, Fasc. 1265

LUCAS, André: Droits des auteurs - Droits patrimoniaux - Exceptions au droit exclusif (CPI, art. L. 122-5 et L. 331-4), J.Cl. Propriété littéraire et artistique, Fasc. 1248.

LUCAS, André: Les dits et les mon-dits de la copie privée, Propr. intell. 2012/43. p. 232-239.

LUCAS-SCHLOETTER, Agnès: La rémunération pour copie privée dans la tourmente (1er partie), Légipresse, 2013a/310.

LUCAS-SCHLOETTER, Agnès: La rémunération pour copie privée dans la tourmente (2e partie), Légipresse, 2013b/311.

LUCAS-SCHLOETTER, Agnès: Les éditeurs peuvent-ils percevoir la rémunération pour copie privée? RIDA, 2015/1. p. 2-99.

MACREZ, Franck: L'exploitation numérique des livres indisponibles: que reste-t-il du droit d'auteur? Receuil Dalloz, $\mathrm{n}^{\circ} 12$ du 22/03/2012. p. 749.

MARECHAL, Camille: Arrêts CISAC: une leçon de droit et d'économie de la gestion collective, Comm. com. électr. 2013/12. p. 6-9.

MARINO, Laure: La (discutable) logique de la redevance pour copie privée, JCP G, 2010/50. note 1256.

MAsouye, Claude: Guide de la Convention de Berne pour la protection des oeuvres littéraires $\begin{array}{lllll}\text { et artistiques (Actes de } & 1978\end{array}$ (http://www.wipo.int/edocs/pubdocs/fr/copyright/615/wipo_pub_615.pdf) 
MeZei Péter - HAJdu Dóra: Az ACI Adam BV és társai kontra Stichting de Thuiskopie és társa ügy. Az Európai Unió Bíróságának döntése a jogellenes forrásból történö másolatkészités után fizetendö jogdijak egyes kérdéseiről, Európai Jog, 2014/5. p. 3347.

MezeI Péter: A magáncélú szabad felhasználás a német szerzői jogban, Acta Juridica et Politica, Tomus LXX., Fasc. 10., Szeged, 2007

MEZEI Péter: A szerzői jog jövője (is) a tét - Gondolatok a Google Books könyvdigitalizálási projektröl, ISZJSZ, 2011/5. p. 5-47.

MEZEI Péter: A szerzői jog története a törvényi szabályozásig (1884: XVI. tc.) Jogelméleti Szemle, 2004/3. (http://jesz.ajk.elte.hu/mezei19.html)

MEZEI Péter: A technológia és a szerzöi jog szimbiózisa, Jogtudományi Közlöny, 2012a/5. p. 197-208.

MEZEI Péter: Elképzeltem: nem lenne jó. Kritikai észrevételek egy szerzői jogi abolicionalista tanulmány kapcsán. In: PoGÁCSÁs Anett (szerk.): Quaerendo et Creando. Ünnepi kötet Tattay Levente 70. születésnapja alkalmából, Szent István Társulat. Budapest, 2014a. p. 407-423.

MEZEI Péter: Szabad felhasználás az osztrák jogrendszerben, Acta Juridica et Politica, Tomus LXVIII., Fasc. 15., Szeged, 2006

MEZEI Péter: The painter, the one horn cow and ole Hank Wilson's back lot - The future of library digitization in the European Union and Hungary, kézirat

MEZEI, Peter: The New Orphan Works Regulation of Hungary, IIC, 2014b/8. p. 940-952.

MINERO, Gemma: Fair compensation for the private copying exception: private use versus professional use, EIPR. 2011/33(7).

MOINET, Jacques: Les différentes législations. In: Colloque international sur la copie privée dans le monde et la protection des auteurs, artistes-interprètes et producteurs, FDMS, 1987, p. 13-18.

MunKACSI Péter: Müholdas müsorsugárzás és vezeték útján történö továbbközvetités az európai joggyakorlatban; gondolatok az "Egeda"-jogeset kapcsán, ISZJSZ, 2000/5. (http://www.sztnh.gov.hu/hu/kiadv/ipsz/200010/jogeset.htm?printable=1)

NERISSON, Sylvie: La directive 2014/26/UE du 26 février 2014 sur la gestion collective des droits d'auteur et des droits voisins: vol au-dessus de vaches sacrées intouchables, Propr. intell. 2014/51. p. 135-150.

NERISSON, Sylvie: La gestion collective des droits des auteurs en France et en Allemagne : Quelle légitimité? IRJS Editions, Paris, 2013

NORDEMANN, Wilhelm: Les problèmes actuels des sociétés d'exploitation des droits d'auteur au sein de la Communauté Européenne, RIDA, 1988/135, p. 30-67.

OchOA, Tyler: Copyright Duration: Theories and Practice. In: YU, Peter K. (ed): Intellectual Property and Information Wealth: Copyright and related rights, Greenwood Publishing Group, Portsmouth, 2007, p. 133-160.

PARDO, Asunción Esteve - LUCAS-SCHLOETTER, Agnès: Compensation for private copying in Europe: recent developments in France, Germany and Spain, EIPR, 2013/35. p. 463471.

PARIS, Thomas: Le droit d'auteur: L'idéologie et le système, PUF, Paris, 2002

PFISTER, Laurent: Histoire du droit d'auteur, J.Cl Propriété littéraire et artistique, Fasc. 1110

PFISTER, Laurent: La propriété littéraire est-elle une propriété? Controverses sur la nature du droit d'auteur au XIXe siècle, RIDA, 2005/205, p. 117-209.

PIERRAT, Emmanuel: „Droit de prêt”: un état des lieux juridique en prélude à une intervention politique, Légipresse, 2000/173. p. 77-80.

PIRIOU, Florence-Marie: „Oeuvres orphelines”: approche d'un nouveau statut juridique français et européen, Comm. com. électr., 2012a/7-8. étude 14. 
PIRIOU, Florence-Marie: Le droit de prêt public en France. In: Le droit de prêt dans le monde. Droit d'auteur et politiques culturelles, Dalloz, 2008, p. 233-241.

PIRIOU, Florence-Marie: Nouvelle querelle des anciennes et de modernes: la loi du ler mars 2012 relative à l'exploitation numérique des livres indisponibles du XXe siècle, Comm. com. électr., 2012b/10. p. 6.

PIRIOU, Florence-Marie: Rémunération légale au titre du prêt en bibliothèque: Projet de loi d'équilibre et de „paix culturelle”, Légipresse, 2003/202. p. 91-92.

POGACSAS (2012) = POGACSAS Anett: A szerzöi jogi szabályozás (h)arcai, avagy mi is a szerepe a szerzői jogi védelemnek? Iustum Aequum Salutare 2012/3-4. p. 131-137.

PogACSAS Anett: A szerzö jelentősége és müvével való kapcsolata. Hova tovább szerzői jog? Iustum Aequum Salutare, 2014/1. p. 149-162.

Pollaud-Dulian, Frédéric: Attribution initiale des droits d'exploitation. Réalisateur. Producteur. Présomption de cession. Rémunération pour copie privée (CJUE, 9 février 2012, Martin Luksan c/ Petrus van der Let, $n^{\circ}$ C-277/10), RTDCom 2012a/2.

Pollaud-Dulian, Frédéric: Droit de reprographie - Utilisations commerciales - CFC Droit de divulgation - Non-épuisement, RTD Com. 2014. p. 115.

Pollaud-Dulian, Frédéric: Droit de retransmission par câble. Directive CE du 27 septembre 1993, article 9, § 2. Gestion collective obligatoire. Droit exclusif ou droit de perception. Incidence de la présomption légale de cession des droits au producteur de l'œuvres audiovisuelles. RTD Com. 2006. p. 603.

POllaud-Dulian, Frédéric: L'exception de copie privée en France. In: LuCAS, André SiRINELli, Pierre - BensAmoun, Alexandra: Les exceptions au droit d'auteur. État des lieux et perspectives dans l'Union européenne, Dalloz, 2012b, p. 79-94.

Pollaud-Dulian, Frédéric: Le droit d'auteur, Economica, Paris, 2005

POLlaUd-Dulian, Frédéric: Le droit de destination. Le sort des exemplaires en droit privé, LGDJ, Paris, 1989

Pollaud-Dulian, Frédéric: Les droits exclusifs consacrés par la directive, Propr. intell. 2002/2, p. 7.-16.

Pollaud-Dulian, Frédéric: Livres indisponibles. Licence légale. Oeuvres orphelines. Numérisation. Bibliothèque, RTDCom, 2012c/2.

Pollaud-Dulian, Frédéric: Rémunération équitable. Copie privée. Directive CE $n^{\circ}$ 2001/29, RTDCom, 2010/4.

REINBOTHE, Jörg - VON LEWINSKI, Silke: The EC Directive on Rental and Lending Rights and on Piracy, Sweet \& Maxwell, London, 1993

REINBOTHE, Jörg: A szerzői jog perspektívái Európában, ISZJSZ, 2002/1. (http://www.sztnh.gov.hu/kiadv/ipsz/200202/tanulmanyok.html)

RENEAUD, Fabrice: La loi du 18 juin 2003: Une nouvelle réglementation du prêt public des livres dans les bibliothèques, RIDA, 2004/199. p. 65-109.

RENOUARD, Augustin-Charles: Traité des droits d'auteur, Paris, 1839

REVET, Thierry: Droit d'auteur et droits voisins: Loi $n^{\circ}$ 97-283 du 27 mars 1997 portant transposition dans le code de la propriété intellectuelle des directives du Conseil des Communautés européennes $n^{\circ}$ 93/83 du 27 septembre 1993 et 93/98 du 29 octobre 1993, RTD Civ. 1997. p. 526.

RICOLFI, Marco: Individual and collective management of copyright in a digital environment. In: TORREMAns, Paul: Copyright Law. A Handbook of Contemporary Research, Edward Elgar, Cheltenham, UK, Northampton, MA USA, 2007. p. 286-287.

RIIS, Thomas - SchovsBo, Jens: Extended Collective Licenses and the Nordic Experience It's a Hybrid but is it a VOLVO or a Lemon? Columbia Journal of Law and the Arts, 2009-2010/4. p. 471-495. 
RIIS, Thomas - ScHOvsBO, Jens: Extended collective licenses in action, IIC, 2012/43. p. 930950.

RochICCIOLI, Elie-Pierre: Point de vue sur la législation applicable aux nouveaux médias, en France, dans le domaine des droits d'auteur, RIDA, 1991/148, p. 17-57.

Rosén, Jan: A Copyright Act in the Melting Pot. A New Setting for Copyright Matters, Individuality and Collectivisation of Contracts - A Swedish Proposal. In: Scandinavian Studies in Law, 2010/56. p. 398.

RosÉn, Jan: The Nordic Extended Collective Licensing Model as a Mechanism for Simplified Rights Clearence for Legitimate Online Services. In: AXHAMn, Johan (ed): Copyright in a Borderless Online Environment. Norsteds juridik, Stockholm, 2012. p. 65-85.

SÁr (2007) = SÁr Csaba: A szerzői jog kihivásai a XXI. században, ISZJSZ, 2007/2. p. 34-41.

SARKADY Ildikó - GRAD-GYENGE Anikó: A média-értéklánc szerzői jogi vonatkozásai, Médiatudományi Intézet,

(http://mtmi.hu/dokumentum/341/Mediaerteklanc_szerzoi_jogi_vonatkozasai.pdf)

SCHMIDT, André: Les contrats de représentation des oeuvre dramatiques et musicales dans le cadre des sociétés d'auteurs en France, LGDJ, Paris, 1971

SEnftLeben, Martin: Copyright, Limitations and the Three-Step Test. An Analysis of the Three-Step Test in International and EC Copyright Law. Kluwer Law International, The Hague, 2004.

SEnftleben, Martin: Ni flexibilité ni sécurité juridique. Les exception au regard du triple test. In: LuCAS, André - SiRINELli, Pierre - BENSAMOUn, Alexandra: Les exceptions au droit d'auteur. État des lieux et perspectives dans l'Union européenne, Dalloz, 2012, p. 63-71.

SHAPIRO, Ted: Directive 2001/29/EC on Copyright in the Information Society. In: LINDNER, Brigitte - SHAPIRO, Ted: Copyright in the Information Society. A Guide to National Implementation of the European Directive, Edward Elgar, Cheltenham, UK, Northampton, MA, USA, 2011, p. 27-56.

SIIRIAINEN, Fabrice: La caractère exclusif du droit d'auteur à l'épreuve de la gestion collective, Thèse, Nice, 1999

SIIRIAINEN, Fabrice: La gestion collective du droit d'auteur en droit français. In: GEIGER, Christophe - BouYsSI-RuCH, Michèle - HILTY, Reto M.: Perspectives d'harmonisation du droit d'auteur en Europe. Rencontres franco-allemandes, Lexis-Nexis Litec, Paris, 2007, p. 443-453.

SIIRIAINEN, Fabrice: Théorie générale de la gestion collective. Logique du droit exclusif de la gestion collective, J.Cl. Propriété littéraire et artistique, Fasc. 1550

SIRINELLI, Pierre: États des lieux. La situation en France. In: GEIGER, Christophe - BouYsSIRuch, Michèle - HiLty, Reto M.: Perspectives d'harmonisation du droit d'auteur en Europe. Rencontres franco-allemandes, Lexis-Nexis Litec, Paris, 2007, p. 41-50.

SIRINELLI, Pierre: La directive ,société de l'information": apport réel ou fictif au droit d'auteur? In: Commerce électronique et propriétés intellectuelles. IRPI, Litec, Paris, 2001. p. 79-96.

SPITZ, Brad: Droit de reprographie: l'exploitation commerciale des copies, RLDI, 2010/63. p. 19-23.

STROWEL, Alain: Google Books: quel futur pour l'accès aux livres? Une bibliothèque universelle en devenir ou une future galerie commerciale? Auteurs \& Média, 2010/1. p. $1-7$.

STROWEL, Alain: Peut-on tenir compte des copies faites à partir de sources illicites pour déterminer le montant de redevances? Commentaires sur quelques décisions récentes en France, aux Pays-Bas et état du droit en Belgique, Auteurs \& Média, 2009, p. 56. 
Strowel, Alain: The European „Extended Collective Licensing” Model, Columbia Journal of Law and the Arts, 2010-2011/34. p. 665-669.

SYNODINOU, Tatiana-Eleni: E-books, a new page in the history of copyright law? EIPR, 2013/35(4), p. 220-227.

SZINGER András: How the net was won and where is got us. In: Emlékkönyv Ficsor Mihály 70. születésnapja alkalmából barátaitól, Szent István Társulat, Budapest, 2009. p. 329.

TARR Péter: Beszerezhetetlenné vált, ismét kapható könyvek. Digitálisan pótolt „,hiánycikkkönyvek” a XX. századból, ISZJSZ, 2013/6. p. 108-134.

Tószegi Zsuzsanna: A könyvdigitalizálás egyes kérdéseiről, (http://epa.oszk.hu/01200/01245/00033/tzs_0701.htm). A tanulmány eredetileg a Magyar Tudomány, 2006/11. számában (p. 1376-1384.) jelent meg.

TÓTH PÉTER BENJAMIN: A közös jogkezelö szervezet által érvényesithetö szankciók köre, különös tekintettel a további jogsértéstöl való eltiltás igényére. In:: Liber Amicorum : Studia Gy. Boytha dedicata : ünnepi dolgozatok Boytha György tiszteletére, ELTE ÁJK, Budapest, 2004, p. 309-329.

TOURNIER, Jean-Loup: L'avenir des sociétés d'auteurs, RIDA, 1996/170. p. 97.

TOURNIER, Jean-Loup: Vivre de sa musique avec la Sacem, Éditions du Rocher, Paris, 2006

TREPPOZ, Edouard: L'adaptation des exceptions du droit d'auteur au numérique: vers une recherche d'alignement, Comm. com. électr. 2010/7-8. p. 6-10.

Triaille, Jean-Paul - Dusollier, Séverine - DePreeuw, Sari - Hubin, Jean-Benoît Coppens, François - DE FrANCQuen, Amélie (et al.): Study on the Application of Directive 2001/29/EC on Copyright and Related Right sin the Information Society (the „InfoSoc Directive”), 2013 (http://ec.europa.eu/internal_market/copyright/docs/studies/131216_study_en.pdf)

TRUMPKE, Felix: The extended collective license - A matter of exclusivity? NIR 2012/3. p. 264-294.

UJHELYI Dávid: Válságjelek és megoldásaik a digitális szerzői jogban, ISZJSZ, 2013/6. p. 69107.

VAN Eechoud, Mireille - Hugenholtz, P. Bernt - VAN Gompel, Stef - Guibault, Lucie HELBERGER, Natali: Harmonizing European Copyright Law. The Challanges of Better Lawmaking, Wolters Kluwer, The Netherlands, 2009

VAN LOON, Sophie: Levies for private copying when blank media are imported: who pays? Journal of Intellectual Property Law \& Practice, 2011/12.

VERCKEN, Gilles: La gestion collective dans la tourmente? L'exemple de la reprographie, RLDI, 2005/2. p. 47-54.

VERCKEN, Gilles: La pratique des clauses relatives à la gestion collective dans les contrats individuels portant sur les droits d'auteur, Légipresse, 2002/194. p. 103-109.

VIDAL, Dominique: Droit des sociétés, LGDJ, Paris, 2010

VISEGRAD InVESTMENTS: Az üreshordozó dijrendszer vizsgálata. Készült a ProArt Szövetség a Szerzői Jogokért megbizásából. Az elemzést készítette ANTAL Dániel (http://hu.scribd.com/doc/180221026/Az-ures-hordozo-dijrendszer-vizsgalata-2013)

Vivant, Michel - BruguIERE, Jean-Michel: Droit d'auteur et droits voisins, Dalloz, Paris, 2e éd, 2013

VON Lewinski, Silke - WALTER, Michel: European Copyright Law. A Commentary, Oxford University Press, Oxford, 2010

VON LEWINSKI, Silke: A szerzői jogok közös jokezelésének magyar szabályai a nemzetközi jog és az európai jog tükrében, Jogtudományi Közlöny, 2004a/7-8. p. 247-255.

VON LEWINSKI, Silke: Copyright in a Borderless Online Environment: EU Cross-Border Licensing of Rights in. AXHAMN, Johan (ed.): Copyright in a Borderless Online Environment. Norsteds juridik, Stockholm, 2012. p. 101-118. 
VON LEWINSKI, Silke: International Copyright Law and Policy, Oxford University Press, Oxford, 2008

VON LEWINSKI, Silke: La gestion collective obligatoire des droits exclusifs et sa compatibilité avec le droit international et le droit communautaire du droit d'auteur - Étude de cas, e- Bulltin du droit d'auteur, Janvier - mars 2004b (http://portal.unesco.org/culture/fr/files/19552/11515904971sve_f.pdf/sve_f.pdf)

WESTKAMP, Guido: The Implementation of Directive 2001/29/EC in the Member States, 2007 (http://www.ivir.nl/publications/guibault/InfoSoc_Study_2007.pdf)

WIPO Guide to the Copyright and Related Right Treaties Administered by WIPO and Glossary of Copyright and Related Right Terms, 2003 (http://www.wipo.int/edocs/pubdocs/en/copyright/891/wipo_pub_891.pdf)

WIPO Intellectual Property Handbook, WIPO, 2nd edition, 2008

ZOLYNSKI, Célia: Méthode de transposition des directive communautaire. Étude à partir de l'exemple du droit d'auteur et des droits voisins. Dalloz, Paris, 2007

\section{Sources diverses}

Albanel, Christine: Pour un livre numérique créateur des valeurs, avril 2010 (http://www.ladocumentationfrancaise.fr/rapports-publics/104000189/index.shtml)
Artisjus
Felosztási
szabályzat
(http://www.artisjus.hu/wpcontent/uploads/2015/06/felosztasi_szabalyzat_hatalyos.pdf)

Artisjus Füzetek Zenei jogdíjfelosztás - Érthetően címü kötete (http://dalszerzo.hu/2015/05/06/zenei-jogdijfelosztas-erthetoen-megjelent/)

Artisjus Támogatási politika (http://www.artisjus.hu/wpcontent/uploads/2013/04/tamogatasi_politika_hatalyos.pdf)Magyar Reprográfiai Szövetség Szervezeti és Müködési Szabályzat (http://www.reprografia.hu/doc/SZMSZ.pdf)

Az ARTISJUS Magyar Szerzői Jogvédő Iroda Egyesület közleménye a hangfelvételen többszörözött, illetve $\square$ lmalkotásokba foglalt, videón vagy DVD-n többszörözött zenemüvekre megállapított mechanikai jogdíjakról (M15)

Az ARTISJUS Magyar Szerzői Jogvédő Iroda Egyesület közleménye a magáncélú másolásokra tekintettel megállapított üres hang- és képhordozó jogdíjakról (Ü14)

Az ARTISJUS Magyar Szerzői Jogvédő Iroda Egyesület közleménye az irodalmi és zenemüvek sugárzás útján, vezetékkel vagy egyéb módon a nyilvánossághoz történő közvetítéséért, kódoltan történő eredeztetéséért $\square$ zetendő szerzői jogdíjakról, valamint a felhasználás engedélyezésének egyéb feltételeiröl (R-TV 15)

Az ARTISJUS Magyar Szerzői Jogvédő Iroda Egyesület közleménye rádió- vagy televíziómüsorok egyidejü, változatlan, csonkítatlan továbbközvetítői, valamint kódoltan eredeztetett rádió- vagy televízió-müsorok kódoldás után vagy (át)kódoltan történő nyilvánossághoz közvetítésében közremüködők („kábelszervezetek”) által $\square$ fizetendő szerzői jogdíjakról, valamint a felhasználás engedélyezésének egyéb feltételeiről (Kábel 15) content/uploads/2015/06/aktualis_jogdijkozlemeny_kabel.pdf)

(https://www.artisjus.hu/wp-

Az Európai Parlament 2014. február 27-i állásfoglalása a magáncélú többszörözési jogdíjakról (2013/2114(INI)), P7_TA(2014)0179 
Az Európai Parlament 2015. július 9-i állásfoglalása az információs társadalomban a szerzői és szomszédos jogok egyes vonatkozásainak összehangolásáról szóló, 2001. május 22-i 2001/29/EK európai parlamenti és a tanácsi irányelv végrehajtásáról (2014/2256(INI)) (http://www.europarl.europa.eu/sides/getDoc.do?pubRef=-//EP//NONSGML+TA+P8TA-2015-0273+0+DOC+PDF+V0//HU).

EuRopean COPYRIGHT SOCEITY: Opinion on the The Reference to the CJEU in Case C572/13 Hewlett-Packard Belgium SPRL v. Reprobel SCRL (5 September 2015) (http://www.create.ac.uk/wp-content/uploads/2014/03/Opinion-in-Case-C572_13-HPBelgium-Reprobel-2015.pdf)

GAILlARD, Yann: La politique du livre face au défi du numérique, 25 février 2010 (http://www.senat.fr/rap/r09-338/r09-338.html)

Green paper on copyright and the challenge of technology - Copyright issues requiring immediate action, $\operatorname{COM}(88) 172$ final, 1988 (http://ec.europa.eu/greenpapers/pdf/green_paper_copyright_and_chanllenge_of_thecnology_com_(88)_172_fina 1.pdf)

Internal draft: A Copyright Policy for Creativity and Innovation in the European Union (http://ipkitten.blogspot.hu/2014/06/super-kat-exclusive-heres-commissions.html)

Javaslat a szerzői és szomszédos jogokra vonatkozó közös jogkezelésről és a zenemüvek belső piacon történő online felhasználásának több területre kiterjedő hatályú engedélyezéséről szóló 2014/26/EU irányelv magyar jogba történő átültetésének koncepciójára (http://hu.scribd.com/doc/252881981/KJK-iranyelv-atultetesikoncepcioja\#scribd)

Javaslat: Az Európai Parlament és a Tanács irányelve a szerzői és szomszédos jogokra vonatkozó közös jogkezelésről és a zeneművek jogainak belső piacon történő online felhasználásra szóló, több területre érvényes engedélyezéséről, COM(2012) 372 final

KHIARI, Bariza: Rapport fait au nom au nom de la commission de la culture, de l'éducation et de la communication sur la proposition de loi de M. Jacques Legendre relative à l'exploitation numériquedes livres indisponiblesdu XXème siècle, rapport $\mathrm{n}^{\circ} 151 \mathrm{du}$ Sénat

La gestion collective des droits d'auteur et des droits voisins, Les documents de travail de Sénat, novembre 1997

Miniszteri indokolás a szellemi tulajdonra vonatkozó egyes törvények módosításáról szóló T/4859. számú javaslathoz

PATINO, Bruno: Rapport sur le livre numérique, 30 juin 2008, (http://www.culture.gouv.fr/culture/actualites/conferen/albanel/rapportpatino.pdf)

Projet de rapport sur la mise en ouvre de la directive 2001/29/CE du Parlement européen et du Conseil du 22 mai 2001 sur l'harmonisation de certains aspects du droit d'auteur et des droits voisins dans la société de l'information (2014/2256 (INI)) (http://www.europarl.europa.eu/sides/getDoc.do?pubRef=-

//EP//NONSGML+COMPARL+PE-546.580+02+DOC+PDF+V0//FR\&language=FR)

Rapport au nom de la commission spéciale sur le projet de loi adopté par l'Assemblée nationale relatif aux droits d'auteur et aux droits des artistes-interprètes, des producteurs de phonogrammes et de vidéogrammes et des entreprises de communication audiovisuelle, doc. Sénat $n^{\circ} 212$

Répartition des redevances auteurs - éditeurs: Livres. 2013. http://www.cfcopies.com/images/stories/pdf/Auteurs-Editeurd/Photocopie/Noticerepartition-Livre.pdf

Répartition des redevances auteurs - éditeurs: Presse. 2013. http://www.cfcopies.com/images/stories/pdf/Auteurs-Editeurd/Photocopie/Noticerepartition-Presse.pdf 
Report on the responses to the Public Consultation on the Review of the EU Copyright Rules (http://ec.europa.eu/internal_market/consultations/2013/copyrightrules/docs/contributions/consultation-report_en.pdf)

Stakeholder consultation on copyright levies in a converging world, june 2006. http://ec.europa.eu/internal_market/copyright/docs/levy_reform/stakeholder_consultatio n_en.pdf

STASSE, François: Rapport au ministre de la culture et de la communication sur l'accès aux œuvres numériques conservées par les bibliothèques publiques, avril 2005 (http://www.ladocumentationfrancaise.fr/rapports-publics/054000450/index.shtml

Szellemi Tulajdon Nemzeti Hivatala Részletes koncepció a szerzői és szomszédos jogokra vonatkozó közös jogkezelésröl és a zenemüvek belső piacon történő online felhasználásának több területre kiterjedő hatályú engedélyezéséről szóló 2014/26/EU irányelv átültetéséhez megalkotandó magyar jogi szabályozás főbb tartalmi kérdéseivel kapcsolatban,

(http://www.sztnh.gov.hu/sites/default/files/20150710_kjk_ire_reszletes_atultetesi_kon cepcio_konzultaciora_0.pdf)

TESSIER, Marc: Rapport sur la numérisation du patrimoine écrit, 12 janvier 2010 (http://www.ladocumentationfrancaise.fr/rapports-publics/104000016/index.shtml)

VITORINO, António: Recommendations resulting from the mediation on private copying and reprography levies,

Brussels, 2013. (http://ec.europa.eu/internal_market/copyright/docs/levy_reform/130131_leviesvitorino-recommendations_en.pdf)

WIPO International Survey on Private Copying, 2013 (http://www.wipo.int/export/sites/www/freepublications/en/copyright/1037/wipo_pub_1 037_2013.pdf) 


\section{Textes législatifs et réglementaires, jurisprudence}

\section{Textes législatifs et règlementaires hongrois}

146/1996. (IX. 19.) Korm. rendelet a szerzői és szomszédos jogok közös kezeléséröl 15/1982 (IX. 20.) MM rendelet

1969. évi III. törvény a szerzői jogról

1975. évi 4. törvényerejü rendelet az irodalmi és a művészeti művek védelméről szóló 1886. szeptember 9-i Berni Egyezmény Párizsban, az 1971. évi július hó 24. napján felülvizsgált szövegének kihirdetéséről

1993. évi XXIII. tv. a Nemzeti Kulturális Alapról

1997. évi CXL. törvény a muzeális intézményekről, a nyilvános könyvtári ellátásról és a közmüvelődésről

1998. évi IX. törvény az Általános Vám- és Kereskedelmi Egyezmény (GATT) keretében kialakított, a Kereskedelmi Világszervezetet létrehozó Marrakesh-i Egyezmény és mellékleteinek kihirdetéséröl

1999. évi LXXVI. törvény a szerzői jogról

2004. évi XLIX törvény a Szellemi Tulajdon Világszervezete 1996. december 20-án, Genfben aláírt Szerzői Jogi Szerződésének, valamint Előadásokról és Hangfelvételekről szóló Szerződésének kihirdetéséről

2011. évi CLXXIII. törvény a szellemi tulajdonra vonatkozó egyes törvények módosításáról

2011. évi CLXXV. tv. az egyesülési jogról, a közhasznú jogállásról, valamint a civil szervezetek müködéséről és támogatásáról

2011. évi CLXXXI. törvény a civil szervezetek bírósági nyilvántartásáról és az ezzel összefüggő eljárási szabályokról

2013. évi V. törvény a Polgári Törvénykönyvről

307/2011. (XII. 23.) Korm. rendelet a közös jogkezelő szervezetek nyilvántartására, felügyeletére, felügyeleti díjára, valamint e szervezetek nyilvántartásával, felügyeletével és díjszabásának jóváhagyásával kapcsolatos eljárásokban az elektronikus úton történő kapcsolattartásra vonatkozó részletes szabályokról

\section{Textes législatifs et règlementaires français}

Arrêté du 21 mars 2013 portant agrément de la Société française des intérêts des auteurs de l'écrit

Code de la Propriété Intellectuelle

Code général des impôts

Loi des 19 et 24 juillet 1793 relatif aux droit sde propriété des auteurs, compositeurs de musiques, peintres et dessinateurs.

Loi du 20 mai 1920 frappant d'un droit au profit des artistes les ventes publiques d'objet d'art.

Loi $\mathrm{n}^{\circ} 2000-719$ du 1 août 2000 modifiant la loi ${ }^{\circ}$ 86-1067 du 30 septembre 1986 relative à la liberté de communication

Loi $\mathrm{n}^{\circ}$ 2001-624 du 17 juillet 2001 portant diverses dispositions d'ordre social, éducatif et culturel

Loi $\mathrm{n}^{\circ}$ 2006-961 du 1 août 2006 relative au droit d'auteur et aux droits voisins dans la société de l'information

Loi n 2011-1898 du 20 décembre 2011 relative à la rémunération pour copie privée. 
Loi $\mathrm{n}^{\circ}$ 2011-590 du 26 mai 2011 relative au prix du livre numérique

Loi $\mathrm{n}^{\circ}$ 2012-287 du 1er mars 2012 relative à l'exploitation numérique des livres indisponibles du XXe siècle.

Loi $\mathrm{n}^{\circ}$ 2012-287 du 1er mars 2012 relative à l'exploitation numérique des livres indisponibles du XXe siècle

Loi $\mathrm{n}^{\circ}$ 2015-195 du 20 février 2015 portant diverses dispositions d'adaptation au droit de l'Union européenne dans les domaines de la propriété littéraire et artistique et du patrimoine culturel

Loi $\mathrm{n}^{\circ}$ 85-660 du 3 juillet 1985 relative aux droits d'auteur et aux droits des artistesinterprètes, des producteurs de phonogrammes et de vidéogrammes et des entreprises de communication audiovisuelle

Loi $\mathrm{n}^{\circ}$ 95-4 du 3 janvier 1995 sur la reprographie

Loi ${ }^{\circ}$ 97-283 du 27 mars 1997 portant transposition dans le code de la propriété intellectuelle des directives du Conseil des Communautés européennes $n^{\circ}$ s 93/83 du 27 septembre 1993 et 93/98 du 29 octobre 1993.

Loi n ${ }^{\circ} 57-298$ du 11 mars 1957 sur la propriété littéraire et artistique

Loi n ${ }^{\circ} 2000-719$ du 1er août 2000 modifiant la loi n 86-1067 du 30 septembre 1986 relative à la liberté de communication

\section{Sources de droit européens et internationaux}

Directive 96/9/CE du Parlament européen et du conseil, du 11 mars 1996, concernant la protection juridique des bases des données

La directive 89/552/CEE du Parlement européen et du Conseil du 3 octobre 1989 visant à la coordination de certaines dispositions législatives, réglementaires et administratives des États membres relatives à la fourniture de services de médias audiovisuels

Directive 2001/29/CE du Parlement européen et du Conseil du 22 mai 2001 sur l'harmonisation de certains aspects du droit d'auteur et des droits voisins dans la société de l'information

Directive 2001/84/CE du Parlement européen et du Conseil du 27 septembre 2001 relative au droit de suite au profit de l'auteur d'une œuvre d'art originale

Directive 2009/24/CE du Parlement européen et du Conseil du 23 avril 2009 concernant la protection juridique des programmes d'ordinateur (version codifiée)

Directive 2011/77/UE du Parlement européen et du Conseil du 27 septembre 2011 modifiant la directive 2006/116/CE relative à la durée de protection du droit d'auteur et de certains droits voisins

Directive 2012/28/UE du Parlement européen et du Conseil du 25 octobre 2012 sur certaines utilisations autorisées des œuvres orphelines

Directive 93/83/CEE du Conseil, du 27 septembre 1993, relative à la coordination de certaines règles du droit d'auteur et des droits voisins du droit d'auteur applicables à la radiodiffusion par satellite et à la retransmission par câble

Règlement (UE) no 1215/2012 du Parlement européen et du Conseil du 12 décembre 2012 concernant la compétence judiciaire, la reconnaissance et l'exécution des décisions en matière civile et commerciale

Directive 2006/115/CE du Parlement européen et du Conseil du 12 décembre 2006 relative au droit de location et de prêt et à certains droits voisins du droit d'auteur dans le domaine de la propriété intellectuelle (version codifiée) 
Directive 2006/116/CE du Parlement européen et du Conseil du 12 décembre 2006 relative à la durée de protection du droit d'auteur et de certains droits voisins (version codifiée)

Directive 2014/26/UE du Parlement européen et du Conseil du 26 février 2014 concernant la gestion collective du droit d'auteur et des droits voisins et l'octroi de licences multiterritoriales de droits sur des œuvres musicales en vue de leur utilisation en ligne dans le marché intérieur

Convention de Berne pour la protection des œuvres littéraires et artistiques (modifiée le 28 septembre 1979)

Marrakesh Treaty to Facilitate Access to Published Works for Persons Who Are Bind, Visually Impaired, or Otherwise Print Disabled

\section{Jurisprudence}

\section{Jurisprudene hongroise}

BH 1992.756.

BH 1993.158.

BH 2001.380.

Debreceni Ítélőtábla Pf.I.20.220/2010/4.

Fővárosi Bíróság 29.P.24.337/2009/22.

Fővárosi Bíróság P.20.497/2008/18.

Fővárosi Bíróság P.22.419/2006/25.

Fővárosi Ítélőtábla 8.Pf.20.304/2007/7.

Fővárosi Ítélőtábla 8.Pf.21.470/2011/4.

Győri Ítélőtábla Gf.I.20.007/2011/14.

Kúria Pf.IV.21.272/2012/7.

LB Pf.IV.721/1984/9.

\section{Les avis publiées de SZJSZT}

SZJSZT 01/2009/1.

SZJSZT 15/08.

SZJSZT 17/2006.

SZJSZT 18/2010.

SZJSZT 21/07/1.

SZJSZT 38/2000.

SZJSZT 43/07/01. 


\section{Jurisprudence française}

C.cass. civ. 1re, 11 décembre 2013

C.cass. civ. 1re, 11 décembre 2013

CA Orléans, 8 févr. 1990, RIDA janv. 1991, p. 333, note Gaudel. Cass. 1re civ., 15 novembre 1991: Bull. civ. I, $\mathrm{n}^{0}$ 303, D. 1992, p. 361, note Edelman et 1993, somm. comm. 89, obs. Colombet

CA Paris 24 mars 2004

CA Paris 24 mars 2004

CA Paris 2e ch 27 mai 2011

CA Paris 2e ch 27 mai 2011

CA Paris, 12 sept. 2008, SAIF et al. c/ SARL Maïa Films et al. RTD Com, 2009, p.137, obs. F. Pollaud-Dulian, Comm. com. électr. 2008, étude 23, note P.-Y. Gautier, Légipresse 2008, $\mathrm{n}^{\circ} 257$, III, p. 238, note P. Boiron et E. Mirat; RLDI 2008/11, $\mathrm{n}^{\circ} 1429$, note B. Khalvdijan

CA Paris, 13e ch. 28 avril 2000, RIDA janv. 2001, p. 303. Comm. com. électr. 2001. comm. 36 note C. Caron.

CA Paris, 22 mars 2007, CCE 2007, $\mathrm{n}^{\mathrm{0}}$ 70, note Caron

CA Paris, 4ch 22 avr. 2005, RIDA 1/2006, p. 374, JCP G 2005, II, 10126, note Geiger, Comm. com. électr. 2005, comm 98, note Caron, Propr. intell. 2005, p. 340, obs. A. Lucas et Sirinelli

CA Paris, 4e ch., 11 juin 1997: RIDA 1997/4, p. 255.

CA Paris, 4e ch., 1er juill. 1998: RIDA janv. 1999. p. 390.

CA Paris, 6 mars 1933: Gaz. Pal. 1933, p. 958; S. 1935, 1. p, note Gény

CA Paris, pôle 5, 4e ch. 3 juill. 2013, Comité prof. des galeries d'art: Propr. intell. 2014, ${ }^{\circ}$ 50, p. 84, note Lucas

CA Paris, pôle 5, 4e ch., 12 déc. 2012, D. 2013, act. 174.obs. Emile-Zola-Place

Cass. $1^{\text {re }}$ civ., 10 févr. 1987, SACEM, Bull. civ. I, p. 50.

Cass. 1re civ., 13 oct. 1993: JCP G 1993, IV, 2628; D. 1994, 138 note Edelman; D. 1994, somm. comm. (sommaire commenté) 93, obs. Colombet, arrêt cassé: Paris, 4e ch 28 janv. 1991, 28 janv. 1991, D. 1992, somm. 17, obs. Colombet

Cass. 1re civ., 28 juin 1988 : RIDA avr. 1989, p. 220

Cass. civ., 8 déc. 1913, SACD: Gaz. Pal. 1924, 1, p. 93.

Cass. crim., 12 mars 2013, ${ }^{\circ} 12-85.163$, F-D, Alexis M. et les Éditions du Cerf: JurisData ${ }^{\circ}$ 2013-006702.

Cass. crim., 30 janv. 1978 : D. 1979, p. 583, note J. Le Calvez ; Gaz. Pal. 1978, 2, p. 466 ; RTD com. 1979, p. 456, obs. A. Françon

Cass. crim., 4 janv. 1991 : JurisData $\mathrm{n}^{0}$ 1991-003606.

CE 10e et 9e ss-sect, 17 déc. 2010, n ${ }^{\circ}$ 314308, Comm. com. électr. 2011, chron. 9, obs. P. Tafforau; Comm. com. électr. 2012, chron 4, obs. X Daverat

CE 10e et 9e ss-sect. réunies, 11 juillet 2008, Synd. de l'industrie des matériels audiovisuels électroniques c/ Sorecop et Copie France: Propr. intell. 2008, no 29, p. 428, obs. A. Lucas

CE 8 déc. $2000, n^{\circ} 202076$ et 203626, Assoc. „Protection des ayants droit”, JurisData ${ }^{\circ}$ 2000-061506; Comm. com. électr. 2001, comm. 15, obs. Caron

CE 9e et 10e ss-sect., 17 juin $2011 \mathrm{n}^{\mathrm{o}}$ 324816, Propr. intell. 2011, $\mathrm{n}^{\mathrm{o}}$ 41, p. 401. obs. A. Lucas; D. 2012, p. 2836, P. Sirinelli ; RTDE 2011, p. 888, obs. D. Ritleng ; LPA 16 nov. 2011, n 228, p. 5, note A. Troianiello ; Gaz. Pal. 27 oct. 2011, jurispr. p. 3072, note L. Marino ; Comm. com. électr. 2012, chron. 9, obs. P. Tafforeau ; Comm. com. électr. 2012, chron. 4, obs. X. Daverat 
CE, 10e et 9e ss-sect. 17 déc. 2010, no 310195: JurisData no 2010-024376, Comm. com. électr. 2011, chron. 9. obs. P. Tafferau; Comm. com. électr. 2012, chron. 4, obs. X. Daverat. Civ 1re 27 novembre 2008, Propr. intell, 2009, n ${ }^{0} 31$, p. 170, obs. Bruguière

Civ. 1re 20 janv. 1969: Gaz. Pal. 1969. 1. 217.

Civ. 1re, 28 février 2006, Studio Canal et Sté Universal Pictures et al. c/ UFC Que Choisir et Perquin, dit „Mulholland Drive”, $\mathrm{n}^{\circ}$ 05-15.824

Civ. 1re, du 25 mai 2005, 02-17305

Conseil d'Etat, (10e et 9e sous-sect. réunies), 6 mai 2015, M. G. AQ. et a.

Crim. 18 décembre 2001. D. 2002. AJ 646, Légipresse $2002 \mathrm{n}^{\circ}$ 190, III, p. 62, CCE 2002, $\mathrm{n}^{\circ}$ 37, note Caron, RIDA avr. 2002, p. 377, obs. Kérever

Montpellier, 3e ch corr. 10 mars 2005 SACEM c/ Aurélien D: JCP G 2005, II, 10078, note Caron; JCP E 2005, no 1216, § 4, obs. Pignatari; JCP E 2006, no 1195, § 8, obs. Vivant; D. 2005, jurispr. p. 1294, note Kessler; D. 2005, pan. p. 1488, obs. Sirinelli; Propr. intell. 2005, no 15, p. 165, obs. Sirinelli; RLDI 2005 mars, no 86 p. 21, obs. Costes; Rev. Lamy dr. aff. avr. 2005, no 5086, obs. Costes; Légipresse 2005, no 222, III, p. 120 note Wekstein; Comm. com. électr. 2005, comm. 77, note Caron.

Paris, 20 février. 1990: RIDA juill. 1990, p. 365. D. 1991. Somm. 100 obs, Colombet

Paris, 4e ch., 1er oct. 1990, D. 1990. IR. 235; RIDA 1991, n 149, 206, obs. Kéréver

Paris, 4e ch., 22 avr. 2005, et Paris 4e ch. 4 avr. 2007.

Paris, 8. oct. 1982, RIDA janv. 1983, p. 138. RTD Com. 1983. 434 obs. Françon.

T. com. Bobigny, 15 septembre 2005, CCE 2005, $\mathrm{n}^{\mathrm{0}} 168$, note Caron

TGI Paris 3e ch, 2e sect., 9 juillet 2010

TGI Paris $3 e$ ch, 2e sect., 9 juillet 2010

TGI Paris, 11 mai 2000, (RIDA avril $2001 \mathrm{n}^{\mathrm{o}}$ 188, p. 379)

TGI Paris, 17 janvier 1990. RIDA, avr. 1990,p. 231

TGI Paris, 1re ch., 1re sect, 17 janv. 1990: JurisData no 1990-046766; RIDA 1990 no 144, p. 231; JCP G 1990, I, 4378, obs. B. Edelman.

TGI Paris, 3e ch, 1re sect. 16 sept. 2003 État fançais c/ Laing et al.,(nem közzétett)

TGI Paris, 3e ch, 1re sect. 16 sept. 2003, État fançais c/ Laing et al.,(inédit).

TGI Paris, 3e ch., 19 juin 1998: RIDA 1999/2, p. 410.

TGI Paris, 3e ch., 1er sect. 15 mai 2012, Propr. intell. 2012, $\mathrm{n}^{\mathrm{o}}$ 44, p. 338, obs. A Lucas; RLDI, août/sept 2012, p. 28. obs. L Costes

TGI Paris, ord.réf. 6 août 2008, RIDA 2008, n ${ }^{0}$ 217, p. 343. et p. 247. obs. Sirinelli, Propr. intell. 2008, n29, 427 obs. JM Bruguière

TGI Paris, réf. 10 juin 1997: D. Affaires 1997. 1156: D. 1998, 621 note Edelman; JCP 1997 II. 22974, obs. Olivier; Expertises, août 1997, p. 283.

TGI Paris, réf., 5 mai 1997, Queneau: RIDA oct. 1997. p. 265; JCP 1997. II. 22906, note

Olivier; Expertises, juin-juill. 1997, p. 219.

\section{Jurisprudence de la CJUE et opinions de l'avocat général}

CJCE 2 mars 1983 Gesellschaft zur Verwertung von Leistungsschutzrechten mbH (GVL) c/ Commission des Communautés européennes (7/82)

CJUE 5 juin 2014, Public Relations Association Agency (C-360/13)

CJCE 20 octobre 1993, Phil Collins [C-92/92 et C-326/92 (affaires jointes)]

CJUE 30 juin 2011, Vereniging van Educatieve en Wetenschappelijke Auteurs (VEWA) c/ Belgische Staat (C-271/10)

CJUE 4 octobre 2011, Football Association Premier League et autres (C-403/08) 
CJCE 24 mars 1974, BRT c/ SABAM et Fonior (127-73)

CJCE 6 juin, 2002 Puccini II (C-360/00)

CJCE 6 février 2003, SENA (C-245/00)

CJCE $1^{\text {er }}$ juin 2006, Uradex (C-169/05)

CJCE 12 septembre 2006, Laserdisken (C-479/04)

CJCE 17 avril 2008, Peek and Cloppenburg (C-456/06)

CJCE 16 juillet 2009, Infopaq International (C-5/08)

CJUE 15 avril 2010, Fundación Gala-Salvador Dalí (C-518/08)

CJUE 21 octobre 2010, Padawan (C-467/08)

CJUE 16 juin 2011, Stichting de Thuiskopie (C-462/09)

CJUE $1^{\text {er }}$ décembre 2011, Painer (C-145/10)

CJUE 17 janvier 2012, Infopaq International (C-302/10)

CJUE 9 février 2012, Luksan (C-277/10)

CJUE 26 avril 2012, DR és TV2 Danmark (C-510/10)

CJUE 7 mars 2013, TVCatchup (C-607/11)

CJUE 27 juin 2013, VG Wort (du C-457/11 au C-460/11 affaires jointes)

CJUE 27 février 2014, OSA (C-351/12)

CJUE10 avril 2014, ACI Adam (C-435/12)

CJUE 11 septembre 2014, Eugen Ulmer (C-117/13)

CJUE 13 mai 2015, Dimensione Direct Sales et Michele Labianca (C-516/13)

CJUE 26 février 2015, Christie's France (C-41/14)

CJUE 5 mars 2015, Copydan Båndkopi (C-463/12)

CJUE 12 novembre 2015, Hewlett-Packard Belgium (C-572/13)

CJUE 11 juillet 2013, Amazon (C-521/11)

Conclusions de l'avocat général dans l'affaire C-572/13, Hewlett-Packard Belgium

Conclusions de l'avocat général dans l'affaire C-467/08, Padawan

Conclusions de l'avocat général dans l'affaires jointes du C-457/11 au C-460/11, VG Wort

Conclusions de l'avocat général dans l'affaire C-435/12, ACI Adam

Conclusions de l'avocat général dans l'affaire C-462/09, Opus

\section{Jurisprudences diverses}

\section{4/B/2004. AB végzés}

71/224/CEE Décision de la Commission du 2 juin 1971 relative à une procédure d'application de l'article 86 du traité CEE (IV/26760 - GEMA)

Affaire COMP/C2/37.219 Banghalter \& Homem Christo v SACEM („Daft Punk”)

C.Cass. des Pays-Bas, 30 oct. 1981 (RIDA avr. 1982.)

Décision $\mathrm{n}^{\mathrm{o}} 13 \mathrm{du} 12$ janvier 2011 (Commission copie privée)

Décision $n^{0} 14$ du 9 février 2012 (Commission copie privée)

Décision $n^{0} 2013-370$ QPC du 28 février 2014.

Décision $\mathrm{n}^{\mathrm{O}} 7$ du 20 juillet 2006 (Commission copie privée)

Décision $n^{0} 8$ du 9 juillet 2007 (Commission copie privée)

Décision $\mathrm{n}^{\mathrm{O}} 9$ du 11 décembre 2007 (Commission copie privée)

Sentencia del Juzgado de Primera Instancia $n^{\circ} 7$ de Alcalá de Henrares, juicio verbal número 726/2004, valamint Sentencia de la Audiencia Provincial de Málaga, Rollo 267/2006

SUISA (Swiss Society of Authors and Publishers) v. Rediffusion AG, Bundesgericht (Swiss Federal Supreme Court) [1982] ECC 481 (BGE 107 II 57) 20 January 1981

Tribunal fédéral suisse, 20 mars 1984 (RIDA 1985 janv) 
WTO Panel DS160 - United States Section 110(5) Copyright Act 


\section{Table des matières complète de la thèse}

La pagination renvoie au numéro de page de la version complète de la thèse, rédigée en hongrois

Sigles et abréviations $\quad 4$

Introduction $\quad 7$

1. L'intérêt et le sujet de la thèse

2. Méthodologie et structure 19

Première Partie : Deux conceptions différentes de la gestion collective - Théories générales et notions de base $\quad 21$

Chapitre I. Les limitations aux droits d'auteur $\quad 22$

Section 1. Les fondements des limitations $\quad 23$

Section 2. La mise en œuvre des limitations $\quad 26$

Chapitre II. La définition de la gestion collective et présentation de son

mécanisme en France et en Hongrie $\quad 34$

Section 1. La définition de la gestion collective $\quad 34$

$\S 1$. Le rejet de la définition 34

§2. L'expression de la définition $\quad 36$

A) L'expression de la définition dans les textes législatifs 36

B) L'expression de la définition dans la doctrine $\quad 41$

Section 2. Le mécanisme de la gestion collective 44

$\S 1$. Les formes associatives des organismes de gestion collective $\quad 46$

A) L'association $\quad 47$

B) La société civile $\quad 49$

$\S 2$. L'encadrement de la gestion collective par le législateur hongrois et français $\quad 54$

A) L'encadrement de la création des organismes $\quad 54$

B) L'encadrement du fonctionnement des organismes 61

a) Règles générales du contrôle 61

b) L'approbation des barèmes 61

Conclusion de la premiere partie $\quad 69$

Deuxième partie : La gestion collective imposée par la loi : limitation au droit exclusif 71

Chapitre I. L'encadrement de l'exercice des droits des auteurs par la gestion

collective

$\begin{array}{ll}\text { Section 1. Les droits de représentation } & 75\end{array}$

$\S 1$. Le contenu des droits 76

A) Exécution publique, communication au public et autres droits $\quad 77$

B) Le droit de retransmission par câble $\quad 81$

a) La diffusion originale $\quad 83$

a) Définition du programme 83

$\beta$ ) Les caractéristiques de la diffusion originale $\quad 84$

b) La retransmission $\quad 85$

a) La mise en œuvre technologique de la retransmission $\quad 85$

Retransmission simultanée, intégrale et sans changement $\quad 85$

La technologie utilisée $\quad 87$

ß) Le principe du nouveau public $\quad 89$

$\gamma$ ) Le contenu du droit de retransmission par câble 
§2. L'exercice des droits

A) L'exercice obligatoire des droits de représentation par la gestion collective

B) L'exercice du droit de retransmission par câble 95

a) La représentation des auteurs $\quad 95$

b) L'octroi des licences $\quad 97$

c) La perception et répartition des droits $\quad 99$

d) L'exception de la gestion collective $\quad 100$

$\begin{array}{ll}\text { Section 2. La gestion collective des droits de reproduction } & 101\end{array}$

$\begin{array}{ll}\S 1 . \text { Le contenu des droits exclusifs } & 103\end{array}$

A) Le droit de la reproduction mécanique 104

a) La définition de la reproduction mécanique $\quad 104$

b) Les éléments du droit de la reproduction mécanique 105

$\alpha)$ Les droits exclusifs concernés 105

ß) Reproduction ou adaptation? 107

B) La reproduction par reprographie 108

a) La notion de reprographie $\quad 108$

$\alpha$ ) L'exigence du papier ou support assimilé $\quad 108$

Support analogue 108

Support numérique 109

$\beta)$ Une technique photographique ou d'effet équivalent permettant d'une lecture directe $\quad 110$

Technique analogue 110

Technique numérique 110

b) Le droit exclusif de reproduction par reprographie 115

$\alpha)$ Les éléments du droit exclusif $\quad 115$

$\beta)$ Le rapport du droit exclusif aux exceptions $\quad 116$

§2. La mise en œuvre des droits $\quad 119$

A) Le transfert des droits $\quad 119$

a) La disposition «classique » de la loi $\quad 120$

a) La disposition avant la loi de $2008 \quad 120$

$\beta)$ L'analyse de la disposition en vigueur $\quad 120$

b) La cession du droit à la société de gestion collective 121

a) La nature de la cession $\quad 121$

$\beta$ ) Les limites de la cession 123

B) Les moyens utilisés dans la perspective de l'exercice des droits $\quad 129$

a) La pratique d'attribuer des licences $\quad 129$

$\alpha)$ Le droit de reproduction mécanique $\quad 129$

$\beta)$ Le droit de reproduction par reprographie $\quad 132$

b) La perception et répartition des droits 133

$\begin{array}{ll}\text { Chapitre II. La gestion collective liée à la limitation des droits exclusifs } & 137\end{array}$

Section I. Résolution différente d'un problème similaire 138

$\S 1$. Une technique différente pour restreindre les droits exclusifs 138

A) Les caractéristiques de l'utilisation $\quad 139$

B) Une législation différente 142

§2. Limitations des droits exclusifs et le test en trois étapes 145

A) Le test dans les textes législatifs $\quad 145$

a) Les versions différentes du test $\quad 145$

b) L'évolution du rôle du test en trois étapes 147

B) L'interprétation du test en trois étapes 149 
a) L'interprétation au niveau international et communautaire

a) La décision à l'amiable de l'OMC et la doctrine internationale 150

$\beta$ ) L'arrêt ACI Adam et l'interprétation proposée par la Cour de Justice de l'Union Européenne

b) L'interprétation nationale du test

Section 2. La gestion collective de la rémunération pour copie privée 159

$\S 1$. Les éléments constitutifs de la copie privée 160

A) La notion du copiste $\quad 161$

B) L'objectif de la copie privée 164

C) La source de la reproduction 166

§2. La mise en œuvre de la gestion collective 169

A) La rémunération pour copie privée $\quad 170$

a) Questions de la terminologie appropriée 171

a) Les difficultés liées à la dénomination 172

La « compensation équitable », notion autonome de droit communautaire $\quad 172$

L'application du terme dans les États membres $\quad 174$

$\beta)$ Le préjudice causé aux titulaires des droits $\quad 176$

b) Le débiteur de la rémunération $\quad 181$

a) La personne qui cause préjudice aux titulaires des droits $\quad 181$

$\beta)$ La distinction entre les différentes modes d'utilisation 186

Une distinction entre professionnels et personnes privées 187

Une distinction entre les modes d'utilisation effectués par des personnes privées

c) Autres principes pour déterminer l'assiette de rémunération 193

a) Les mesures techniques de protection 194

$\beta)$ Les supports de la copie privée $\quad 195$

B) La répartition de la rémunération pour copie privée $\quad 200$

a) La répartition classique $\quad 200$

$\alpha)$ Les créanciers de la rémunération $\quad 201$

$\beta)$ La cession de la rémunération pour copie privée 208

b) L'utilisation de la rémunération aux fins sociales ou culturelles 209

Conclusion de la deuxième partie 213

Troisième partie : La gestion collective imposée, garantie de l'exercice des droits 216

Chapitre I. L'exercice du droit exclusif dans le cadre de la gestion collective assurant une sortie au titulaire du droit

Section 1. Gestion collective avec possibilité «d'opt-out»: mi-chemin

entre la gestion collective traditionnelle et la gestion individuelle des droits $\quad 219$

$\S 1$. La numérisation des livres indisponibles $\quad 220$

A) La définition de livre indisponible $\quad 222$

B) La date et lieu de l'édition $\quad 224$

a) Le lieu de l'édition $\quad 224$

b) La date de l'édition 224

C) Le critère de l'indisponibilité 226

a) Le livre est indisponible dans le commerce 226

b) Le livre ne fait pas l'objet d'une nouvelle édition 227

$\begin{array}{ll}\S 2 . \text { La pratique de la gestion collective } & 228\end{array}$

A) Le fonctionnement de la gestion collective $\quad 229$

a) Le droit de sortie $\quad 229$

a) Le droit de l'opposition $\quad 229$ 
B) Une sortie de la gestion collective 231

b) L'attribution des licences et la répartition des droits 233

a) L'attribution des licences 233

ß) La répartition des droits 233

B) Questions de constitutionnalité et la conformité au droit international 235

Section 2. La gestion collective étendue avec une droit de sortie : restriction $\begin{array}{ll}\text { au droit exclusif ? } & 238\end{array}$

$\S 1$. Le stucture de la gestion collective étendue 242

A) L'élément constitutif de représentativité 242

B) La mise en place une droit de sortie $\quad 244$

§2. L'exercice des droits exclusifs $\quad 247$

A) L'attribution des licences $\quad 247$

B) Le rapport de l'organisation de gestion collective avec les

$\begin{array}{ll}\text { auteurs non-membres } & 248\end{array}$

Chapitre II. La gestion collective imposée au service de l'efficacité de l'exercice des droits

Section 1. La gestion collective de la rémunération pour prêt en bibliothèque et le droit résiduel au titre de la cession du droit de location

$\S 1$. Le contenu du droit de prêt public et le droit de location 253

A) La définition des droits patrimoniaux 253

a) Les caractéristiques du droit de prêt 254

$\alpha$ ) Le contenu du droit de prêt 254

La notion du droit de prêt 254

L'objet et titulaire du droit de prêt 258

$\beta)$ Le droit de prêt comme droit patrimonial $\quad 258$

Le droit de prêt parmi des droits patrimoniaux $\quad 258$

Le rôle du droit de prêt $\quad 260$

b) Le droit de location $\quad 260$

$\alpha)$ Le contenu du droit de location $\quad 261$

$\beta)$ Le droit résiduel de l'auteur $\quad 261$

B) Les limitations imposées aux droits patrimoniaux 263

a) La limitation du droit de prêt 263

b) La limitation du droit de location 266

§2. Les moyens de l'exercice des droits 266

A) La détermination du montant de la rémunération 266

a) Les règles générales de la définition de rémunération 267

b) Les méthodes concrètes de la définition de rémunération $\quad 269$

B) La perception et la répartition de la rémunération 271

a) Le schéma classique de la répartition 271

b) L'utilisation de la rémunération aux fins sociales et culturelles $\quad 272$

$\begin{array}{ll}\text { Section 2. Le droit de suite } & 273\end{array}$

§1. La nature du droit de suite $\quad 275$

A) La nature juridique du droit de suite $\quad 275$

a) Les questions liées à la Convention de Berne 275

b) La théorie générale du droit de suite 276

B) Les éléments du droit de suite $\quad 278$

a) L'objet du droit de suite $\quad 278$

$\alpha)$ Les œuvres de l'art plastique et graphique $\quad 278$

$\beta)$ L'exigence de l'originalité 280 
b) Le contenu du droit de suite 282

a) Le titulaire du droit de suite 282

$\beta$ ) L'opération des ventes soumise au droit de suite 283

§2. La pratique du droit de suite 283

A) La détermination du somme de la rémunération 284

a) Le payement de la rémunération $\quad 284$

a) Le débiteur de la rémunération $\quad 284$

$\beta)$ L'assiette de la rémunération $\quad 285$

b) L'exonération du paymenet de la rémunération 286

B) La perception et la répartition de la rémunération 287

a) La perception de la rémunération 287

b) La pratique des organisations de gestion collective lors la répartition de la rémunération $\quad 288$

Conclusion de la troisième partie $\quad 291$

Conclusions finales $\quad 293$

Remerciements 296

Bibiliographie $\quad 297$

Textes législatifs et réglementaires $\quad 315$

Table des matières $\quad 322$

Annexe - Résumé substentiel de la thèse de doctorat 329 


\section{La gestion collective des droits des auteurs : ses formes imposées par la loi hongroise et française}

Dóra HAJDÚ

Le mécanisme complexe qu'est la gestion collective a pour objectif de permettre l'exploitation licite des œuvres en y associant les auteurs. Elle peut ainsi être vue comme une forte contrepartie lors de la négociation des licences octroyées aux utilisateurs (avant tout professionnels), ainsi qu'un outil de suivi des utilisations grâce à la collecte et à la distribution des droits. Paradoxalement, la gestion collective constitue également une limitation, au sens large du terme, au monopole de l'auteur. Cette seconde caractéristique est d'ailleurs beaucoup plus marquée lorsque la gestion collective résulte de dispositions législatives.

Notre thèse consiste donc en une réflexion sur l'ambiguïté de la gestion collective, laquelle se révèle particulièrement problématique dans les cas où la gestion collective est exigée par la loi. Cette technique de gestion est avant tout une limitation imposée au monopole de l'auteur en vue notamment de concilier ses intérêts avec ceux du public. Il y a lieu de mentionner cependant que l'introduction de la gestion collective par le législateur peut parfois s'avérer être le seul moyen d'exploitation des œuvres. Dans ce cas, la soumettre au régime propre des limitations aboutiraient à un résultat contraire à l'objectif visé.

L'intérêt de ce sujet, et de cet angle de recherche particulier, tient également au fait que le législateur envisage la gestion collective comme une réponse à certaines questions du droit d'auteur contemporain, telles que l'utilisation des œuvres orphelines ou la numérisation des livres indisponibles. Il convient alors de démontrer les particularités du régime afférent à la gestion collective et de la positionner au sein du droit d'auteur. Ceci revêt une importance particulière car la notion de gestion collective, telle qu'elle résulte des lois française et hongroise n'est pas homogène. Elle englobe (i) la gestion collective obligatoire des droits exclusifs ainsi que (ii) la gestion collective des licences légales ou droits à rémunération, (iii) la gestion collective étendue et (iv) la gestion collective non étendue ouvrant un droit de sortie. Ainsi, il convient de traiter non seulement de la structure et du fonctionnement de la gestion collective, mais également et avant tout des droits patrimoniaux, afin de pouvoir démontrer l'intérêt de les gérer par le biais du système de gestion collective. 
Cette thèse est construite autour de l'analyse de la gestion collective régie par la loi française et hongroise, car ces deux pays disposent de systèmes juridiques différents au sein de la tradition civiliste. Ce travail illustre donc deux approches distinctes de la gestion collective imposée par la loi, ce qui a nécessité d'une part, l'étude de textes législatifs, de jurisprudences et de doctrines propres à ces deux pays, et d'autre part, l'analyse des textes régissant le droit d'auteur international et européen.

Dans cette optique, la première partie est consacrée à la théorie générale de la gestion collective et aux limitations en droit d'auteur, et pose la question de la gestion collective comme limitation apportée aux droits de l'auteur. Nous concentrons ensuite notre attention sur la notion même de gestion collective imposée par la loi, de sorte à déterminer si la gestion collective peut être considérée comme une limitation au droit exclusif de l'auteur (deuxième partie) ou s'il s'agit simplement d'une garantie pour la mise en œuvre de ses droits (troisième partie).

Mots clés : gestion collective, gestion collective imposée, gestion collective obligatoire, limitations au droit d'auteur 


\title{
Collective rights management ordered by law in Hungarian and French copyright law
}

\author{
Dóra HAJDÚ
}

The complex mechanism of the collective management of copyrights seeks to facilitate lawful uses of protected works by associating the authors. It can therefore be seen as a strong asset when negotiating licenses granted to (mainly professional) users, and a useful mechanism for monitoring uses through the collection and distribution of license fees and levies. Paradoxically though, collective management imposes also a limitation on the exclusive rights of authors in the broad sense, because it restricts the exercise of economic rights. This latter feature is much more highlighted when the collective management proceeds from the initiative of the legislator.

Our thesis is a reflection on the ambiguity of collective management of copyrights ordered by law. The collective exploitation of economic rights is first and foremost a restriction on the exclusive rights of the authors meant to reconcile their interests with those of the public. It should be mentioned, however, that the introduction of collective management by law may sometimes prove the only means of exploitation of works. In this case, the submission of the solution to the special regime of limitations would lead to a result that is contrary to the objective of the collective management.

The aims of this specific research focus lies in the fact that the legislator is considering collective management as a response to some questions of today's copyright law, such as the use of orphan works or digital uses of out-of-commerce books. It is in that sense essential to analyse the details of collective management as ordered by law, and its place within the wider copyright system. This is particularly important because the concept of collective management, as it results from French and Hungarian laws, is not uniform. It includes (i) the mandatory collective management of exclusive rights, (ii) the collective management of statutory licenses or rights to remuneration, (iii) extended collective management, and (iv) the collective management with possibility of opting out. It also means that one should not only examine the collective rights-management system, but the economic rights licensed by the collective management organisations in order to demonstrate the reasons for introducing this mechanism as well. 
The present thesis thus provides a comparative analysis of collective management as stated in French and Hungarian copyright laws, as these two countries belong to different legal traditions within the civil law system. Our work sheds light on two distinct approaches to the collective management of copyrights ordered by law, through the study of legislative texts, jurisprudence, and doctrines specific to these two countries, as well as the analysis of the texts governing the international and European Union copyright law.

In this respect, the first part of our thesis is concentrates on the general theory of collective management and limitations in copyright, where we discuss whether collective management can be seen as a limitation placed on authors' economic rights. The two main parts of the thesis then focus on the concept of collective management ordered by law to examine whether collective management might be considered a limitation to the exclusive rights of authors (second part) or a simple guarantee for exploiting these rights (third part).

Keywords: collective rights management, collective rights management ordered by law, compulsory collective rights management, limitations to copyrights 